\title{
Foraminifera from the
}

Arctic Slope of Alaska

Part 3, Cretaceous Foraminifera

GEOLOGICAL SURVEY PROFESSIONAL PAPER 236-C

Prepared in cooperation with the U.S.

Department of the Navy, Office of Naval

Petroleum and Oil Shale Reserves

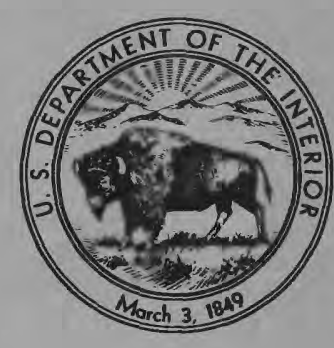




\section{Foraminifera from the}

Arctic Slope of Alaska

$B y$ HELEN TAPPAN

\section{Part 3, Cretaceous Foraminifera}

GEOLOGICAL SURVEY PROFESSIONAL PAPER 236-C

Description and illustrations of Cretaceous Foraminifera, ranging from Valanginian to Senonian in age, and the evidence they supply for correlation and interpretation of paleoecology and geologic history. Prepared in cooperation with the U.S.

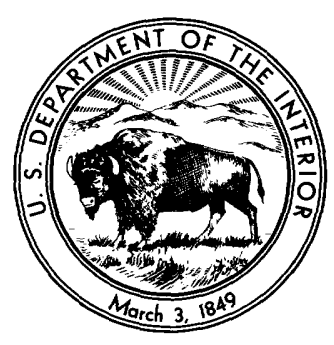
Department of the Navy, Office of Naval Petroleum and Oil Shale Reserves 


\section{UNITED STATES DEPARTMENT OF THE INTERIOR \\ STEWART L. UDALL, Secretary \\ GEOLOGIGAL SURVEY \\ Thomas B. Nolan, Director}

For sale by the Superintendent of Documents, U.S. Government Printing Office Washington 25, D.C. 


\title{
OUTLINE OF THE REPORT
}

\author{
General Introduction
}

Part 1. Triassic Foraminifera

2. Jurassic Foraminifera

3. Cretaceous Foraminifera

4. Pleistocene Foraminifera 



\section{CONTENTS}

Abstract

Introduction . . . . . . Stratigraphy of the Cretaceous of northern Alaska.....

Early Lower Cretaceous formations . . . . . . . . . Okpikruak formation Fortress Mountain formation Torok formation.... Topagoruk formation.......

Nanushuk group............. Tuktu formation Chandler formation Grandstand formation..... Ninuluk formation. ....... Kukpowruk formation Corwin formation

Colville group.

Seabee formation Schrader Bluff formation.................... Prince Creek formation

Ignek formation.

Foraminiferal studies in northern Alaska............

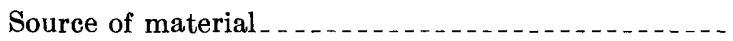

Areas of outcrop, and locality register......

1945 field season

Chandler River area.............

Colville River area

1946 field season...... Umiat area........................ Maybe Creek-Wolf Creek area ....... Kurupa-Oolamnagavik Rivers area... Sagavanirktok River area.........

1947 field season............ Colville River area Ipnavik, Etivluk and Kurupa Rivers area

Kigalik and Awuna Rivers area...... Utukok Rivers and Corwin-Cape Beaufort area........................... Upper Ikpikpuk River area..........Colville River area, between Ninuluk and Prince Creeks..............

Nanushuk and Anaktuvuk Rivers area

1948 field season Chandler River area............... Upper Colville River area............

1949 field season Carbon Creek and Titaluk anticlines. Kokolik and Kukpowruk Rivers area . Colville River area Kiruktagiak and Okokmilaga Rivers area..............................

1950 field season Siksikpuk and Nanushuk Rivers area Driftwood anticline-Utukok River region

1951-52 field season Chandler River area......... Awuna River area................

\begin{tabular}{|c|c|c|}
\hline Page & & Page \\
\hline 91 & Foraminiferal studies in northern Alaska-Continued & \\
\hline 91 & Source of material-Continued & \\
\hline 92 & Subsurface material & 107 \\
\hline 93 & Test wells and core tests. & 107 \\
\hline 93 & Arcon Point Barrow core test 1...... & 108 \\
\hline 93 & Avak test well 1. & 108 \\
\hline 93 & East Topagoruk test well $1 \ldots \ldots$ & 108 \\
\hline 93 & Fish Creek test well 1............... & 108 \\
\hline 94 & Gubik test well 1 & 109 \\
\hline 94 & Gubik test well 2 & 109 \\
\hline 95 & Oumalik core test 2 & 109 \\
\hline 95 & Oumalik core test 11 & 109 \\
\hline 95 & Oumalik test well 1 & 109 \\
\hline 95 & Sentinel Hill core test 1 & 109 \\
\hline 96 & Simpson core hole 3 & 109 \\
\hline 96 & Simpson core hole 8 & 109 \\
\hline 96 & Simpson core hole 10 & 109 \\
\hline 97 & Simpson core hole 11 & 109 \\
\hline 97 & Simpson core test 13 & 109 \\
\hline 97 & Simpson core test 25 & 109 \\
\hline 98 & Simpson core test 30 & 109 \\
\hline 98 & Simpson test well 1 & 109 \\
\hline 98 & Skull Cliff core test 1 & 109 \\
\hline 99 & South Barrow test well 1 & 109 \\
\hline 99 & South Barrow test well 2 & 109 \\
\hline 99 & South Barrow test well 3 & 109 \\
\hline 99 & South Barrow test well $4 \ldots$ & 110 \\
\hline 99 & Square Lake test well 1 & 110 \\
\hline 99 & Titaluk test well 1 & 110 \\
\hline 99 & Topagoruk test well 1 & 110 \\
\hline 99 & Umiat test well & 110 \\
\hline 99 & Umiat test well 2 & 110 \\
\hline \multirow[t]{2}{*}{99} & Umiat test well 3 & 110 \\
\hline & Umiat test well 8 & 110 \\
\hline 100 & Umiat test well 9 & 110 \\
\hline \multirow[t]{2}{*}{101} & Umiat test well 11 & 110 \\
\hline & Seismograph shot hole samples_......... & 110 \\
\hline 103 & 1946 shot holes. & 110 \\
\hline \multirow[t]{2}{*}{104} & 1948 shot holes. & 111 \\
\hline & 1949 shot holes. & 111 \\
\hline 104 & 1953 shot holes & 111 \\
\hline 105 & Foraminiferal evidence for correlation of the Cretace- & \\
\hline 105 & ous of Alaska & 111 \\
\hline 105 & Microfaunal zones & 111 \\
\hline 106 & Correlation with Canada & 113 \\
\hline 106 & Lower Cretaceous & 113 \\
\hline 106 & Upper Cretaceous & 113 \\
\hline 106 & Correlation with conterminous United States... & 115 \\
\hline \multirow[t]{2}{*}{106} & Lower Cretaceous & 115 \\
\hline & Upper Cretaceous & 116 \\
\hline 106 & Correlation with Europe & 116 \\
\hline 107 & Lower Cretaceous & 116 \\
\hline \multirow[t]{2}{*}{107} & Upper Cretaceous & 117 \\
\hline & Problems in taxonomy and the species concept & 118 \\
\hline 107 & Genetic and physiological criteria & 118 \\
\hline 107 & Morphological criteria & 118 \\
\hline 107 & Ecological criteria & 120 \\
\hline 107 & Evolutionary criteria & 121 \\
\hline
\end{tabular}


VI

Foraminiferal studies in northern Alaska-Continued

Biostratigraphical relations of the Cretaceous Foraminifera of Alaska . ............................

Limiting environmental factors. . . . . . . . .

Depth

Salinity

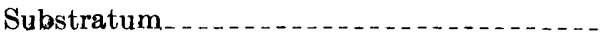

Food Supply

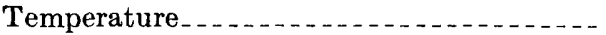

Turbulence and currents...........

Turbidity ..............................

Biofacies in the Cretaceous of Alaska.......

Inland facies-Fluviatile environment.....

Coastal facies-Supralittoral and littoral (intertidal) environment.............

Offshore facies-Inner sublittoral environment.

Offshore facies-Outer sublittoral environment.

Offshore facies-Open-sea environment

Systematic descriptions of Foraminifera

Rhizamminidae

Saccamminidae

Hyperamminidae

Ammodiscidae

Reophacidae

CONTENTS

\begin{tabular}{|c|c|c|}
\hline Page & $\begin{array}{l}\text { Foraminiferal studies in northern Alaska-Continued } \\
\text { Systematic descriptions of Foraminifera-Continued }\end{array}$ & Page \\
\hline 122 & Lituolidae & 133 \\
\hline 122 & Textulariidae & 139 \\
\hline 122 & Verneuilinidae & 142 \\
\hline 123 & Valvulinidae & $\mathbf{1 5 I}$ \\
\hline 123 & Trochamminidae & 152 \\
\hline 123 & Miliolidae & 157 \\
\hline 123 & Rzehakinidae & 157 \\
\hline 123 & Nodosariidae & 161 \\
\hline 124 & Glandulinidae. & 182 \\
\hline 124 & Polymorphinidae & 182 \\
\hline \multirow[t]{2}{*}{126} & Turrilinidae & 184 \\
\hline & Caucasinidae & 188 \\
\hline \multirow[t]{2}{*}{126} & Chilostomellidae. & 189 \\
\hline & Nonionidae & 190 \\
\hline \multirow[t]{2}{*}{127} & Alabaminidae & 190 \\
\hline & Eponididae & 191 \\
\hline \multirow{2}{*}{$\begin{array}{l}127 \\
127\end{array}$} & Conorboididae & 191 \\
\hline & Valvulineriidae & 194 \\
\hline 128 & Asterigerinidae & 195 \\
\hline 128 & Heterohelicidae & 196 \\
\hline 120 & Rotaliporidae & 196 \\
\hline 129 & Gavelinellidae. & 197 \\
\hline 129 & Anomalinidae & 199 \\
\hline 130 & References... & 200 \\
\hline 132 & Index $\ldots \ldots \ldots$. & 205 \\
\hline
\end{tabular}

\section{ILLUSTRATIONS}

[Plates 29-58 follow index]

Plate 29. Bathysiphon, Saccammina, Hyperamminoides, Glomospira, Glomospirella

30. Ammodiscus, Reophax, Haplophragmoides

31. Haplophragmoides

32. Ammobaculites, Verneuilinoides

33. Spiroplectammina, Textularia, Flabellammina, Uvigerinammina

34. Verneuilinoides, Siphotextularia, Gaudryina

35. Gaudryina, Gaudryinella

36. Gaudryina, Arenobulimina, Pseudoclavulina, Miliammina

37. Miliammina, Quinqueloculina, Psamminopelta

38. Trochammina

39. Trochammina

40. Lenticulina

41. Lenticulina, Saracenaria

42. Saracenaria, Marginulinopsis

43. Marginulinopsis, Marginulina

44. Marginulinopsis, Marginulina, Rectoglandulina, Lingulina

45. Nodosaria, Dentalina

46. Vaginulina, Astacolus, Vaginulinopsis

47. Vaginulinopsis, Citharina, Citharinella, Frondicularia, Oolina, Paleopolymorphina, Pyrulinoides, Globulina

48. Neobulimina, Praebulimina

49. Praebulimina, Caucasina, Lacosteina

50. Pallaimorphina, Nonionella
Plate 51. Eponides

52. Conorboides

53. Conorbina, Eurycheilostoma

54. Valvulineria, Eoeponidella

55. Heterohelix, Hedbergella, Globorotalites

56. Gavelinella

57. Gavelinella

58. Gavelinella, Anomalinoides

Figure 10. Cretaceous strata of northern Alaska.......

11. Index map of outcrop and seismic shothole samples, Colville River region............

12. Index map of outcrop and seismic shothole samples, between Canning and Colville Rivers _................................

13. Index map of outcrop samples, between Cape Lisburne and Carbon Creek............

14. Location of wells and core tests in Naval Petroleum Reserve 4................

15. Correlation of Alaskan and Canadian Cretaceous strata $\ldots \ldots$

16. Correlation of Cretaceous strata of Alaska with western interior and Gulf Coast of the United States.

17. Lithologic and faunal facies of the Nanushuk and Colville groups.

18. Depositional environments in northern Alaska during the Cretaceous
Page 


\title{
FORAMINIFERA FROM THE ARCTIC SLOPE OF ALASKA
}

\author{
By Helen 'Tappan ${ }^{1}$
}

\section{PART 3. GRETAGEOUS FORAMINIFERA}

\section{ABSTRACT}

A fauna of 155 species of Foraminifera was obtained from Cretaceous strata of northern Alaska, ranging in age from Early Cretaceous (Valanginian) to Late Cretaceous (Senonian). Material was obtained both from surface samples collected over a period of about seven years, and from cores and cuttings from the 76 wells and core tests drilled in Naval Petroleum Reserve No. 4 , in the Arctic Coastal Plain province of northern Alaska.

Fifty-eight genera are represented, belonging to 28 families, and the majority are long ranging and environmentally to1erant genera. Although only 58 of the species are agglutinated forms, representing a little over one-third of the number of species, they dominate the assemblages in numbers of specimens. The Lituolidae, Verneuilinidae, and Textulariidae characterize these assemblages. Another one-third of the species belong to the Nodosariidae, the remaining one-third of the species belong to the Turrilinidae Caucasinidae, and various rotaliform families and include the stratigraphically important forms. The Seabee formation, of Turonian age, contains the only planktonic Foraminifera found in the northern Alaska Cretaceous, a single species each of Heterohelix and Hedbergella.

The impoverished faunal assemblages are the result of an adverse depositional environment, and not due to subsequent destruction, such as by secondary weathering. The intertonguing marine and nearshore and nonmarine Cretaceous strata are each characterized by distinct microfaunal facies. The nonmarine formations contain charophyte oogonia, but no Foraminifera; brackish-water and intertidal deposits contain a few species of arenaceous Foraminifera, commonly represented by stunted specimens. The near-shore marine deposits consist largely of a turbidity facies throughout much of the northern Alaska Cretaceous, and the high turbidity and turbulence and resultant rapid deposition are the dominant controlling factors of the marine sedimentary environment. The species of agglutinated Foraminifera occur in the turbidity facies as large robust specimens, whereas some of these species were represented only by stunted specimens in the brackish environment. The agglutinated forms are commonly crushed and variously distorted in preservation. The rarer calcareous species and the extremely rare Radiolaria are represented in this facies by pyritic casts, an indication of their rapid burial. More offshore facies contain the calcareous and agglutinated species in approximately equal numbers, and in these sediments both the calcareous Foraminifera and the siliceous Radiolaria may occur as original shells, rather than as pyritic casts.

Both the faunal and lithologic facies cross time lines, so that similar assemblages appear in the same facies of different ages,

\footnotetext{
1 Mrs. Alfred R. Loeblich, Jr.
}

and different assemblages occur in contemporaneous beds of distinct facies. Even the generically similar faunal facies of the different formations are characterized by distinct species, however, and useful faunal zones can be recognized. Some of the more tolerant species also have sufficiently wide geographic range to be useful in interregional correlation, such as with Canada, and the Western Interior and Gulf Coast of the United States.

\section{INTRODUCTION}

This report is the third of a series describing the Foraminifera of northern Alaska. The material described was obtained during the field exploration and drilling program conducted by the U.S. Navy in Naval Petroleum Reserve No. 4, and adjacent areas of the Arctic Slope of Alaska. The U.S. Geological Survey cooperated with the U.S. Navy in the geological aspects of this program. A general discussion of these investigations, with an outline map showing the location of the Reserve, may be found in the first of this series (Tappan, $1951 \mathrm{c}$ ), which described the Triassic fauna. The second part (Tappan, 1955) described the Jurassic Foraminifera, and the present section covers the foraminiferal fauna of the Cretaceous. The Cretaceous sediments are near-shore sands and clays, commonly with intertonguing marine and nonmarine strata and those of the Lower Cretaceous are typically graywackes. This shallow, muddy-water depositional environment was an inhibiting factor in the faunal development, hence the faunal aspect is quite unlike that of equivalent strata of the Gulf Coast of the United States. In the latter area, a single sample may contain from 100 to 300 species of Foraminifera, whereas in Alaska about one-third of the samples were barren, the remainder containing from two to ten species or rarely as many as 20 species. Thus, the total fauna of 155 species represents a composite fauna of almost the entire Cretaceous section, from beds of Valanginian, Albian, Cenomanian, Turonian, and Senonian age, and many of these species, particularly of the Nodosariidae, are represented only by a few specimens in a single sample. Arenaceous species dominate the Lower Cretaceous faunas, but a few calcareous species become locally abundant in the cleaner Upper Cretaceous sediments. Planktonic assemblages are non-existent, except for a single Turonian zone, which con- 
tains two primitive species, both occurring only rarely. Considerably more than 2000 Cretaceous outcrop samples, and cuttings and cores from about 170,000 feet of well sections, and hundreds of samples from seismograph shot holes were examined over the past decade, in order to accumulate even these impoverished Cretaceous faunas. The poorly diversified character of the faunas combined with a considerable amount of distortion in preservation resulted in an extremely difficult problem of identification. In the early part of these studies, it was thought that a far greater number of species was represented, and only after considerable study was their total reduced to the present number. Many of the species, as illustrated on the accompanying plates, will seem at first glance to be too inclusive, but all gradations have been observed between the extremes, and no taxonomic or stratigraphic advantage could be seen to result from any further subdivision of the species. In spite of the specialized local environment, relative scarcity of specimens, and predominance of long-ranging arenaceous genera, the Foraminifera do show relationships to other faunas and the species can be used for both local correlations within the Reserve and long-range correlation with other areas of the world.

This study was made possible only by the full cooperation of the geologists of the U.S. Geological Survey engaged in studies of Naval Petroleum Reserve No. 4 during the past decade. Aid was given in obtaining material and information by Ralph L. Miller, George Gates, and George Gryc. Harlan R. Bergquist has cooperated in all phases of the micropaleontologic study, and I am indebted to him for many helpful discussions and suggestions on both stratigraphic and taxonomic problems. Thomas G. Payne also was of inestimable aid in the determination and understanding of the many facies changes in the sediments, and the resultant problems of correlation.

Lithologic studies of the well samples were made by Florence Rucker Collins, A. Samuel Keller, T. G. Roberts, and Florence Robinson, and in many instances subsurface formational contacts were based on these lithologic studies, where they did not coincide with the faunal or time boundaries.

Cretaceous outcrop material and stratigraphic information has been supplied by many of the Survey geologists during the period 1945 to 1952 , during the course of the geologic mapping program in northern Alaska. I am indebted for these samples to William L. Barksdale, Robert S. Bickel, William P. Brosgé, Robert M. Chapman, Robert I. Detterman, William A. Fischer, George Gryc, A. Samuel Keller, Charles A. Kirschner, Ernest H. Lathram, Marvin L. Mangus, William W.
Patton, Jr., Richard G. Ray, Hillard N. Reiser, Edward G. Sable, Karl Stefansson, Irvin L. Tailleur, Raymond M. Thompson, Robert F. Thurrell, Jr., Max L. Troyer, Edward J. Webber, Charles L. Whittington, and James H. Zumberge.

Samples were also made available from seismograph shot holes taken by crews of the United Geophysical Company. These samples supplied additional stratigraphic information in some areas where outcrops were poor, particularly in the Coastal plain region.

In the early stages of this study, microfossil samples were examined and picked by the writer and Alfred R. Loeblich, Jr. in Washington. Later all samples were prepared and picked in the Fairbanks laboratory and only the mounted slides supplied for study. These were prepared in Fairbanks by Tatiana Aschurkoff, Clyde Foster, William N. Lockwood, Octavia T. Pratt, Dorothy J. West, and Lucy Wiancko, under the direction of William N. Lockwood, Robert M. Chapman, Thomas G. Roberts, Arthur L. Bowsher, and Harlan Bergquist.

Acknowledgment is also made of the continued assistance of Alfred R. Loeblich, Jr., formerly with the U.S. National Museum, now with California Research Corp., La Habra, California, in early washing and picking of samples, in discussions of various taxonomic problems, in preparation of the illustrations and for helpful criticism throughout the study.

Illustrations of the fauna are shaded camera lucida drawings prepared by the writer and by Patricia Isham, scientific illustrator, Smithsonian Institution.

Cretaceous material from Canada, for comparative use, was supplied by R. T. D. Wickenden, of the Geological Survey of Canada, and Canadian foraminiferal types were loaned by C. R. Stelck, University of Alberta, Canada, and J. H. Wall, Research Council of Alberta. Type specimens of Canadian species described by A. Nauss were loaned by Stanford University, California.

\section{STRATIGRAPHY OF THE CRETACEOUS OF NORTHERN ALASKA}

Early work in the Cretaceous of northern Alaska was of reconnaissance nature as the relative inaccessibility of the area made field work difficult and hazardous. Early publications include those of Schrader (1902, 1904), Leffingwell (1919), and Smith and Mertie (1930). In 1945 the U.S. Geological Survey in cooperation with the U.S. Navy began geologic field studies of the Naval Petroleum Reserve and adjacent areas north of the Brooks Range. With the aid of bush pianes, helicopter, weasels, radio, etc., much more lengthy and detailed geologic work could be done. Use 
of aerial photographs aided in the mapping, and laboratory study of rock samples, micropaleontologic, and macropaleontologic studies aided in the understanding of the stratigraphic problems.

The near-shore, rapidly changing facies of the Cretaceous sediments made correlation difficult between the discontinuous outcrops; this was further complicated by the great amount of lithologic change from the more consolidated sediments near the Brooks Range to the loose sands and clays of the coastal plain. Macrofossils were sparse in part of the section, and truly diagnostic forms were only rarely obtained. The dominance of long-ranging arenaceous genera of Foraminifera prevented the full use of micropaleontology for correlation until after a considerable period of study.

New stratigraphic names were finally proposed after the facies and correlations had been largely worked out (Gryc, Patton and Payne, 1951; Gryc and others, 1956 ; Sable, 1956), and the present stratigraphic usage is shown in figure 10. As a basis for a biostratigraphic discussion, a brief summary of the Cretaceous formations follows, in ascending order. Megafossils listed were identified by $R$. W. Imlay and reported in the above-mentioned formational descriptions.

\section{EARIY LOWER CRETACEOUS FORMATIONS}

\section{OKPIKRUAK FORMATION}

Typically exposed along the Okpikruak River, this formation was named by Gryc, Patton and Payne (1951, p. 159). It is about 2,400 feet thick at the type locality, and is a fine-grained graywacke-type sandstone, dark clay and silt shale. The early Lower Cretaceous (Valanginian) pelecypod Buchia crassicollis (Keyserling) occurs throughout most of the formation, but the microfauna is extremely scarce, including only long-ranging species of such genera as Trochammina and Haplophragmoides.

\section{FORTRESS MOUNTAIN FORMATION}

In the southern half of the Arctic Foothills province this formation unconformably overlies the Okpikruak formation, the type section being along the Kiruktagiak River and on Castle Mountain, the name being from the nearby Fortress Mountain. Defined by Patton $(1956$, p. 219), it consists of graywacke-type conglomerates and sandstones intercalated with dark-gray clays and silts, and is approximately 10,000 feet in thickness in the type section. The rare macrofossils include Aucellina dowlingi McLearn, Beudanticeras sp., Lemuroceras sp. and Inoceramus sp., which indicate a late Early Cretaceous age. Foraminifera include long-ranging species of Bathysiphon, Glomo- spira, Haplophragmoides, a few Nodosariidae, and simple Discorbidea and Chilostomellidae. A few species limited to the Fortress Mountain formation and the equivalent Torok formation, include Gaudryina tailleuri (Tappan), Trochammina eileie Tappan, Vaginulinopsis pachynota ten Dam, Marginulina sulcifera (Reuss), and Conorbina sp. The first two of these are described from these strata and the Vaginulinopsis from the Hauterivian (Neocomian) of the Netherlands; the Marginulina ranges from Neocomian to Albian strata in Europe, and the Conorbina occurs in the Clearwater formation in Canada, which is equivalent in age to the Fortress Mountain.

\section{TOROK FORMATION}

The Torok formation was described by Gryc, Patton, and Payne (1951, p. 160), with the type locality on the Chandler River and its tributary, Torok Creek. Originally the formation was more inclusive, but it was restricted and redefined by Patton in 1956 (p. 222) when the equivalent conglomerates and sandstones of the southern part of the region were separated as the Fortress Mountain formation. The more northerly exposures of the redefined Torok formation are predominately shales, and exposures consist of small cutbanks along the creeks. The Torok formation is approximately 6,000 feet in thickness, and locally is much crumpled and faulted. The macrofossils in the Torok formation, like those of the equivalent Fortress Mountain formation, indicate a late Early Cretaceous age. In the type area the Torok formation has relatively few microfossils and these are predominantly agglutinated species. Farther west the Torok formation apparently is transgressive and includes younger beds, equivalent in age to the Topagoruk formation of the coastal plain, with the fauna characteristic of those deposits. The Torok formation in the subsurface of the coastal plain is of more off-shore character and has a well defined and diversified microfauna including numerous Nodosariidae, Polymorphinidae and Discorbidea in addition to the agglutinated species of Lituolidae, Textulariidae, Verneuilinidae, and Trochamminidae.

\section{TOPAGORUK FORMATION}

In the subsurface section, a silty shale unit overlies the Torok formation, and is laterally equivalent to the upper part of the outcropping Torok formation, the Tuktu formation, and part of Grandstand formation. Described as the Topagoruk member of the Umiat formation in 1951 (Gryc, Patton and Payne, p. 162) it was then regarded as including all marine Nanushuk beds above the Tuktu member. The Topagoruk was raised to formational rank by Robinson, Rucker, and 


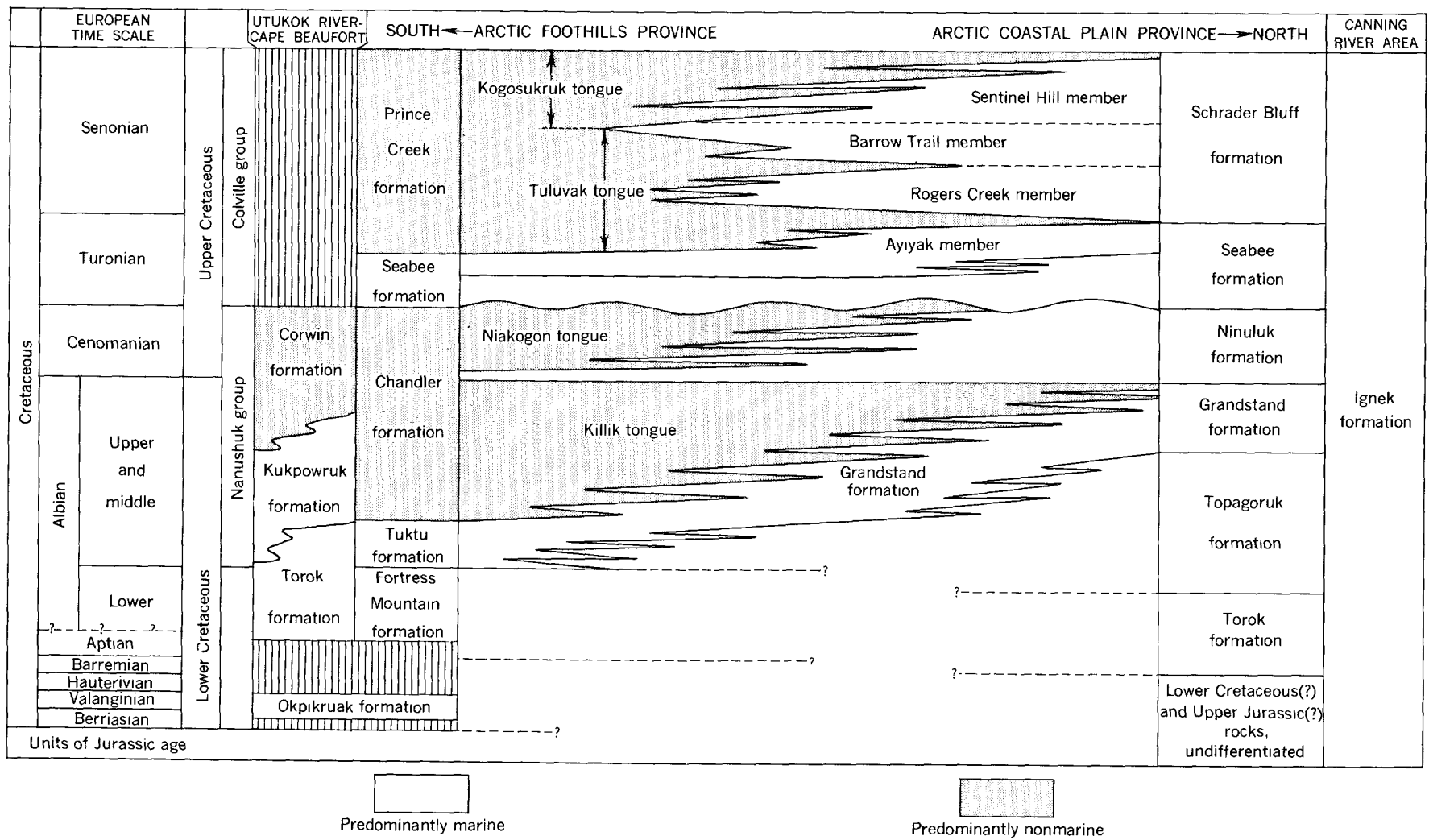

Figure 10.-Cretaceous strata of northern Alaska, and correlation with European time scale (modified after Gryc and others, 1956 ; Imlay and Reeside, 1954; Sable, 1956; Tappan, 1957).

Bergquist (1956, p. 229) and restricted to the lower series of fine marine clastics, whereas the later sandstones were placed in the Grandstand formation. As presently defined the Topagoruk formation is 2,550 feet thick in Topagoruk test well 1 , the type section. Megafossils include Cleoniceras, Inoceramus, and $\mathrm{Di}$ trupa, and the microfossils are those of the Verneuilinoides borealis faunal zone. This easily recognizable fauna is typically a shallow-water marine microfauna including Verneuilinoides borealis Tappan, Miliamina manitobensis Wickenden, Ammobaculites fragmentarius Cushman, Gavelinella stictata (Tappan), Conorboides umiatensis (Tappan), Eurycheilostoma grandstandensis Tappan, Gaudryina nanushukensis Tappan, Uvigerinammina manitobensis (Wickenden), and Spiroplectammina ammovitrea Tappan, in addition to rarer specimens of many species of Nodosariidae, typical of Albian strata in western Europe and Canada and the late Comanchean of the Gulf Coastal plain.

\section{NANUSHUK GROUP}

The Nanushuk series was defined by Schrader (1904, p. 79) and included strata of Early and Late Cretaceous age. It was redefined as the Nanushuk group by Gryc, Patton, and Payne (1951, p. 162) and restricted to include only the Lower Cretaceous strata, and some questionably Lower Cretaceous strata. As originally defined it included the marine Umiat formation, with Tuktu and Topagoruk members, intertonguing with the nonmarine Chandler formation, which included the Hatbox tongue and the Niakogon tongue. Most of these components of the group were redefined or renamed in 1956 (Gryc and others) as more surface and subsurface information became available. The Nanushuk group now includes the Tuktu, Grandstand, Ninuluk, and Chandler formations. It is equivalent in age to part of the Albian and Cenomanian stages of the European time scale, thus including parts of both the Lower Cretaceous and Upper Cretaceous.

\section{TUKTU FORMATION}

Described originally as a member of the Umiat formation (Gryc, Patton and Payne, 1951, p. 162) the Tuktu was elevated to formational status and redefined by Detterman (1956a, p. 233). The Tuktu formation forms a prominent south-facing escarpment along the southern edge of the Northern Foothills section, the type locality being at Tuktu Bluff on the Chandler River, where it is approximately 1,030 feet thick. Predominantly a fine-grained sandstone and siltstone, its locally abundant megafossils, including 
species of Inoceramus and Cleoniceras, indicate a middle Albian age. Tuktu formation microfossils are those of the Verneuilinoides borealis faunal zone (Bergquist, 1958a, p. 199). Due to downdip lithologic changes, the Tuktu formation is not generally recognized in the subsurface, where the Topagoruk formation is its age equivalent in part. The faunal zone is best developed in the subsurface sections, but the characteristic Haplophragmoides topagorukensis Tappan, Verneuilinoides borealis Tappan, Eurycheilostoma grandstandensis Tappan, Miliammina manitobensis Wickenden, Gavelinella stictata (Tappan), Gaudryina nanushukensis Tappan, and Gaudryina canadensis Cushman also occur in the surface Tuktu formation. Most of these species were described from the Alaskan section, but the Mitiammina and Gaudryina canadensis were originally described from Canada, where they occur in the basal Lloydminster shale of Alberta, and the Ashville beds of Manitoba. These Canadian strata are age equivalents of the later part of this faunal zone in Alaska.

\section{CHANDLER FORMATION}

The Chandler formation is exposed in the Northern Foothills section where it is about 4,700 feet in thickness. It was defined by Gryc, Patton, and Payne (1951, p. 164) as including the nonmarine portion of the Nanushuk group. It grades northward and eastward into the marine equivalents, the Topagoruk, Grandstand, and Ninuluk formations. Two of its major nonmarine tongues are named: the lower or Killik tongue (Detterman, 1956a, p. 237) was formerly known as the Hatbox tongue (Gryc, Patton, and Payne, 1951, p. 164). At the type locality on the Killik River the Killik tongue is 2,815 feet thick, and consists of thick-bedded, bluff-forming sandstones and conglomerates. Although the nonmarine beds do not contain microfossils, some marine or brackish-water interbeds occur locally which have the shallow-water microfauna of the Verneuilinoides boreatis zone, i.e., Haplophragmoides topagorukensis Tappan, Verneuilinoides borealis Tappan, Gaudryina canadensis Cushman, Ammobaculites fragmentarius Cushman, and various Rzehakinidae. The upper tongue (Niakogon) was named by Gryc, Patton and Payne (1951, p. 164) and redefined by Detterman (1956a, p. 240). Predominantly "salt and pepper" sandstones, with some conglomerates and siltstones, it is about 650 feet thick at the type locality on the Killik River, and grades northeastward into the marine Ninuluk formation. Some bentonites occur in the upper part. The equivalent Ninuluk formation contains Inoceramus athabaskensis McLearn, a late Cenomanian species which thus dates both the Ninuluk formation and the overlying Niakogon tongue of the Chandler formation as basal Late Cretaceous.

\section{GRANDSTAND FORMATION}

This formation is predominantly marine, with some lagoonal facies, and occurs typically where the Anaktuvuk River breaches the Grandstand anticline. The lower part contains thick sandstones, the upper part has some siltstones and shales as well. It totals approximately 1,700 feet in thickness, and contains Arctica dowling (McLearn), a long-ranging pelecypod. Microfossils are dominantly the arenaceous species of the Verneuitinoides borealis faunal zone. A slightly more offshore fauna occurs in the formation in the coastal plain wells (at Cape Simpson and Skull Cliff), and more of the calcareous Foraminifera are represented.

\section{NINULUK FORMATION}

This marine formation is approximately equivalent to the Niakogon tongue of the Chandler formation, with which it intertongues in the Killik River area. Described by Detterman (1956a, p. 241), the type locality is at Ninuluk Bluffs, 20 miles downstream from the junction of the Killik and Colville Rivers, where it consists of 656 feet of sandstones, siltstones, and clay shales. It conformably overlies the Killik tongue of the Chandler formation or the Grandstand formation, but there is a strong angular discordance with the overlying strata of the Colville group. Upper Cenomanian megafossils are found, including Inoceramus athabaskensis McLearn, I. dunveganensis McLearn, Panope dunveganensis Warren and Arctica dowlingi (McLearn). The microfossils are quite distinct from those of the Verneuitinoides borealis faunal zone, and include only agglutinated forms. The characteristic species are the Cenomanian Trochammina ribstonensis Wickenden, subspecies rutherfordi Stelck and Wall (which occurred rarely in the underlying Grandstand formation) and Gaudryina irenensis Stelck and Wall (which is also found in the later Cretaceous Seabee and Schrader Bluff formations). Long-ranging Saccammina lathrami Tappan, Miliammina ischnia Tappan and Siphotextularia? rayi Tappan also occur in this formation. However, the dominance of Gaudryina irenensis and Trochammina ribstonensis rutherfordi in the assemblage allow its recognition as a distinct faunal zone (Bergquist, 1958a, p. 199).

\section{KUKPOWRUK FORMATION}

In the western part of the northern Alaskan area, the formations of the Nanushuk group of the Colville River region become unrecognizable. In the Utukok 
region the Kukpowruk formation was described (Sable, 1956, p. 2637) as overlying the Torok formation. At the type locality on the Kukpowruk River it has a thickness of about 5,000 feet, but thins eastward and northward. It is equivalent to the uppermost Torok formation, the Tuktu formation, and part of the Grandstand formation of the Colville region. Megafossils indicate middle and upper? Albian age, the pelecypods being most abundant, i.e., species of Arctica, Entolium, Tancredia, and Camptonectes. Gastroplites is one of the ammonites which occur rarely. Microfossils include those characteristic of the Verneuilinoides borealis zone: Ammobaculites fragmentarius Cushman, A. wenonahae Tappan, Gaudryina canadensis Cushman, G. cushmani Tappan, Gaudryinella irregularis $\mathrm{T}$ a p pa $\mathrm{n}$, Uvigerinammina manitobensis (Wickenden), species of Trochammina, Mitiammina and Psamminopelta, Globulina exserta (Berthelin) Eurycheilostoma robinsonae Tappan, Pallaimorphina ruckerae Tappan, and Conorboides umiatensis (Tappan). Many of these species were described from Alaskan strata, others from Canada and some from the Gulf Coast Washita group, and the Albian of France. They indicate an Albian age for the Kukpowruk formation, and its equivalence to beds of the Nanushuk in the Colville River region.

\section{CORWIN FORMATION}

The Corwin series was defined by Schrader (1904, p. 72) and thought to be of Jurassic and Cretaceous age. It was later reduced to formational rank, but probably included beds now placed in the Torok formation, Nanushuk and Colville groups, thus comprising most of the Cretaceous system. It was further restricted and redefined by Sable $(1956$, p. 2641$)$, so that it includes only the predominantly nonmarine facies of the Nanushuk group, overlying and intertonguing with the Kukpowruk formation. It is about 15,500 feet thick at Corwin Bluff, 29 miles east of Cape Lisburne, and thins northeastward to about one third that amount on the lower Utukok River. Plant remains are common, microfossils relatively rare, including only charophyte oogonia and a few arenaceous Foraminifera such as Ammobaculites wenonahae Tappan, Gaudryinella irregularis Tappan, Uvigerinammina manitobensis (Wickenden), and Psamminopelta subcircularis Tappan.

\section{COLVILLE GROUP}

The Colville series was described by Schrader (1904, p. 81) from exposures along the Colville River, north of the junction with the Anaktuvuk River, and was thought to be of Tertiary age. Redefined by Gryc,
Patton, and Payne (1951, p. 164), it was reduced to group rank and includes the Seabee formation and the intertonguing nonmarine Prince Creek formation and marine Schrader Bluff formation. The total thickness was said to be about 5,200 feet, and beds of Turonian and Senonian age are included.

\section{SEABEE FORMATION}

Overlying the Nanushuk group unconformably, the Seabee was first defined as a member of the Schrader Bluff formation (Gryc, Patton, and Payne, 1951, p. 166) and later redefined as a formation (Whittington, 1956, p. 246). It is named for Seabee Creek, a tributary of the Colville River but as redefined the type section is in Umiat test well 11, where the formation has a thickness of almost 1,500 feet. Two members are described, the lower member consisting of a dark, fossiliferous marine clay, and the upper (Ayiyak member) consisting of a greenish-gray siltstone with some sandstone beds. The lower member contains a distinctive "paper shale" unit which contains thin beds of bentonite. Megafossils indicate an early Turonian age, and include Scaphites delicatulus Warren, Borissiakocerces sp., and Inoceramus labiatus Schlotheim. Minute fishbone fragments are also characteristic. Foraminifera are rare, but locally include Saccammina, $A$ mmodiscus, Haplophragmoides, Spiroplectammina, Gaudryina, Verneuilinoides, and Trochammina. A few specimens of Praebulimina seabeensis Tappan and Neobulimina albertensis (Stelck and Wall) also occur locally, and in the coastal plain wells occurs the only planktonic assemblage of the entire Cretaceous section. This very limited zone contains Heterohelix globulosa (Ehrenberg) and Hedbergella loetterlei (Nauss) in relative abundance, suggesting a correlation with the Favel formation of Manitoba and the middle part of the Lloydminster formation of Alberta.

The Ayiyak member, defined by Detterman (1956b, p. 253) includes beds earlier considered to be the Tuluga member of the Schrader Bluff formation (Gryc, Patton, and Payne, 1951, p. 166). Named from the Ayiyak River, it consists of about 360 feet of siltstones and shales. A "salt and pepper" sandstone near the base contains Inoceramus cf. I. lamarcki var. cuvievi Sowerby, which occurs from middle Turonian through the Coniacian. The contacts are well marked, the basal contact being at the top of the black paper shale, and the upper contact at the base of the nonmarine chert conglomerates of the Tuluvak tongue of the Prince Creek formation. The characteristic microfossils are Pseudoclavulina hastata (Cushman), Haplophragmoides rota Nauss, $H$. bonanzaensis Stelck and Wall, Textularia gravenori Stelck and Wall, Trocham- 
mina diagonis (Carsey), T. ribstonensis Wickenden, T. whittingtoni Tappan, and Arenobulimina tomula Tappan. It is designated the Pseudoclavulina-Arenobulimina faunal zone by Bergquist (1958b, p. 261).

\section{SCHRADER BLUFF FORMATION}

The Schrader Bluff formation was defined by Gryc, Patton, and Payne (1951, p. 164) from exposures of over 3,000 feet at Schrader Bluff on the Anaktuvuk River, just south of the junction with the Tuluga River. Originally the Seabee member (now formation) and Tuluga member (now Ayiyak member of the Seabee formation) were included, but as redefined by Whittington $(1956$, p. 249) the Schrader Bluff formation includes only the predominantly marine beds above and interfingering with the Tuluvak tongue of the Prince Creek formation. It now contains three members, the Rogers Creek, Barrow Trail, and Sentinel Hill, and is about 2,200 feet thick at Umiat, 1,900 feet at Schrader Bluff, and somewhat thinner in the coastal plain wells.

The Rogers Creek member (Whittington, 1956, p. 250) varies from about 600 to 700 feet in thickness, and consists of gray clay shale with interbeds of tuff, siltstone, sandstone, and bentonite. The type section is in Gubik test wells 1 and 2. Foraminifera included in these strata are Verneuilinoides fischeri Tappan, Spiroplectammina webberi Tappan, Trochammina diagonis (Carsey), Haplophragmoides rota Nauss, Praebulimina venusae (Nauss), $P$. cushmani (Sandidge), Neobulimina canadensis Cushman and Wickenden, Gavelinella tumida Brotzen, and Anomalinoides pinguis (Jennings), and indicate a Senonian age.

The Barrow Trail member (Whittington, 1956, p. 250) is named from Barrow Trail, near Umiat Mountain, where it is about 575 feet thick. It thickens northward to 700 to 900 feet at Schrader Bluff. Consisting of fine-grained sandstone, it has some interbeds of siltstone, bentonite, and tuff. Inoceramus, similar to I. lundbreckensis McLearn and I. cardissoides Goldfuss, indicate upper Santonian and lower Campanian age. Foraminifera are rarer than in the other members of the Schrader Bluff, but include species which range upward into the Sentinel Hill member. Many of these species occur in Senonian strata elsewhere in the United States, Canada, and Europe, including Neobulimina canadensis Cushman and Wickenden, Spiroplectammina mordenensis Wickenden, Gaudryina irenensis Stelck and Wall, Trochammina albertensis Wickenden, T. ribstonensis Wickenden, Praebulimina venusae (Nauss), and Anomalinoides talaria (Nauss), all described originally from Canada; Marginulina dorsata Cushman, Prciebulimina carseyae
(Plummer), and P. cushmani (Sandidge), all described from the Gulf Coast Upper Cretaceous; Gavelinella tumida Brotzen, Nodosaria lepida Reuss, N. fusula Reuss, all described from the European Senonian; and Lacosteina gouskovi Marie, originally described from the Senonian of North Africa.

The Sentinel Hill member was defined by Gryc, Patton, and Payne (1951, p. 166), and includes about 1,100 feet of clays, with abundant bentonites and tuffs. It is overlain by Quaternary deposits. Radiolaria are abundant (about 40 species) and Foraminifera are more diversified than in any other Upper Cretaceous strata of northern Alaska. In addition to those species mentioned above as occurring in the Rogers Creek and Barrow Trail members, nearly all of which are also present in the Sentinel Hill member, other important species include Caucasina vitrea (Cushman and Parker), Haplophragmoides bonanzaensis Stelck and Wall, Ammodiscus cretaceus (Reuss), Nonionella taylorensis Hofker, Anomalinoides solis (Nauss), Gavelinella ammonoides (Reuss), Eoeponidella linki Wickenden, and E. strombodes Tappan. Many of these also aid in correlation of the Alaskan strata with those elsewhere in America and Europe.

\section{PRINCE CREEK FORMATION}

The nonmarine equivalent of the Schrader Bluff formation, with which it intertongues, was named the Prince Creek formation by Gryc, Patton, and Payne (1951, p. 166). It consists of sandstone, conglomerate, shale, and coal, with a much greater proportion of bentonite and tuff than the Lower Cretaceous Chandler formation. Two major tongues were described, the Tuluvak tongue being the lower, and overlying the marine Seabee formation. It is about 1,200 feet thick at Tuluvak Bluffs on the Chandler River. Megafossils include a few fresh or brackish-water mollusks. Foraminifera are restricted to the intertonguing beds of the Schrader Bluff formation.

The Kogosukruk tongue is the nonmarine age equivalent of the marine Sentinel Hill member of the Schrader Bluff formation. It is named from the Kogosukruk River and consists of up to 2,340 feet of poorly consolidated, fine-textured clay, silt, and shale. Coal and bentonite beds are common, macrofossils very rare, consisting of fresh or brackish-water pelecypods and gastropods. Foraminifera are limited to marine interbeds of the Sentinel Hill member of the Schrader Bluff formation. It is overlain by a thin Quaternary mantle.

\section{IGNEK FORMATION}

The Ignek formation was described from the Canning River region by Leffingwell (1919, p. 103). The 
2,500 feet of black shales with some sandstones and coal beds were regarded as Jurassic in age, overlying the Kingak shale of Jurassic age. The type locality is in Ignek Valley, at the west end of the Sadlerochit Mountains. Not yet subdivided, the Ignek is still regarded as including some Jurassic strata (Payne and others, 1951), but also includes beds of Early Cretaceous Albian (Haplophragmoides gigas zone) and Late Cretaceous age, with Haplophragmoides rota Nauss, Verneuilinoides fischeri Tappan, Arenobulimina torula Tappan, and Anomalinoides solis (Nauss), suggesting that both Turonian and Senonian sediments are represented.

\section{FORAMINIFERAL STUDIES IN NORTHERN ALASKA}

Although exploration of Naval Petroleum Reserve 4 began in 1944, micropaleontologic studies were not begun until the drilling program commenced. At that time some of the well samples were sent to Dr. Joseph Cushman, for examination. With the expansion of the exploration program in late 1946 and 1947 a special studies group was organized under which the writer began the study of the Foraminifera from well and outcrop material. With greater expansion of the drilling program, micropaleontologic studies were expanded to include the Fairbanks office where Dr. Harlan Bergquist took over the examination of current well and outcrop material in 1949.

The writer then turned to the taxonomic aspects of the Alaskan Foraminifera. Various problems in both taxonomy and stratigraphy were studied jointly, however, as occasion demanded.

Little had been published on Alaskan Cretaceous Foraminifera in advance of the present series of articles, although considerable micropaleontologic work has been done on equivalent strata in Canada and the western interior of the United States.

Previous publications concerning the closely related Cretaceous strata of Canada, which include description or discussion of Foraminifera, are those by Cushman (1927, 1943, 1946), Cushman and Wickenden (1928), Henderson (1954), Mellon and Wall (1956), Nauss (1945, 1947), Stelck and Wall (1954, 1955), Stelck, Wall, Bahan, and Martin (1956), Stelck, Wall, and Wetter (1958), and Wickenden (1932a, b, 1945, 1948, 1949, 1951).

The study of the geology and paleontology of Naval Petroleum Reserve No. 4, has led to a number of reports which discuss the Cretaceous Foraminifera, by Bergquist (1956, 1958a-e, 1959a, b), Collins (1958a-c, 1959), Detterman (1956a, b), Robinson $(1956,1958 \mathrm{a}$, b, 1959a, b), Robinson, Rucker, and Bergquist (1956), Robinson and Collins (1959), and Whittington (1956).
Earlier articles by the present writer (Tappan, 1951a, b, 1957, 1960) discussed or described a few of the important index species in the Cretaceous strata.

The Cretaceous of the Western Interior of the United States is very similar in character to that of north Alaska, and certain of the Foraminifera are common to the two regions. Because of the difficulties encountered with these poorly diversified and poorly preserved faunas, it is probable that a number of additional species may be common to the two areas, but are not as yet recognized as such, having been described locally under distinct names. Only by comparison of large numbers of specimens from the various areas can the true specific relationships be determined. Nevertheless, the marked similarity in character of the Alaskan material and that of the western interior, is shown by the faunas described by Applin (1933), Bolin $(1952,1956)$, Carman (1929), Fox (1954), Loeblich and Tappan (1950), Loetterle (1937), Morrow (1934), Peterson, Gauger and Lankford (1953), Sko!nick (1958) and Young (1951).

\section{SOURCE OF MATERIAT}

\section{AREAS OF OUTCROP, AND LOCALITY REGISTER}

During the Navy's investigations in Naval Petroleum Reserve No. 4, field parties were sent into the various sections of the Reserve and adjoining areas over a period of 9 years (1945-1953).

In addition to samples from the Paleozoic, Triassic, and Jurassic a total of 1,535 outcrop samples of Early Cretaceous age and 553 outcrop samples of Late Cretaceous age were collected. Some of these samples were picked and examined by Harlan R. Bergquist and the staff at the Fairbanks laboratory and others by the present writer in the Washington, D.C., office.

Of the 1,535 Lower Cretaceous outcrop samples, 676 were barren, and 859 contained microfossils. Of the 553 Upper Cretaceous samples, 226 were barren and 327 contained microfossils.

The relatively high percentage of barren samples is due largely to the type of sediment. The poorly sorted, near-shore beds alternate and interfinger with nonmarine beds, and represent facies which in general are unfavorable to the development of a diversified microfauna. The samples which contain fossils commonly have only a very few specimens and very few species. Some samples had a few species in comparative abundance, but these in general had very little variety of fauna. In addition, the Early Cretaceous and Tertiary orogenies resulted in a greater amount of deformation nearer the Brooks Range, (now the areas of outcrop) and the resultant greater degree of 
consolidation also made more difficult the task of separating the specimens from the rocks.

Of the total 1,186 fossiliferous Cretaceous samples, about one-sixth are here recorded, as the following list includes only those samples from which types are described in the systematic portion of this paper. Many of the samples not recorded contained equally good faunas, however. The samples are listed below by years of collection, and under the year by region and collector. The first two numbers of each sample refer to the year of collection, the " $\mathrm{A}$ " following them refers to Alaska, and the next letter or letters refer to the collector, the remaining numbers apply to the horizon and locality. Due to the lack of geographic reference points other than rivers in northern Alaska, nearly all the field samples are located by latitude and longitude, and are plotted on the maps of figures 11-13, all being in the area of figure 11 unless otherwise noted.

\section{FIELD SEASON}

In 1945 three Survey field parties were in northern Alaska, one in the Chandler River area, one in the region of the Anaktuvuk River, and one in the Killik River area.

\section{Chandler River area}

45A Gr 170. Barrow Trail member of the Schrader Bluff formation, 800 to 900 feet above the base of the formation, on the Chandler River, between the Schrader anticline and Umiat, northern Alaska. Collected by George Gryc, 1945.

\section{Colville River area}

45A KR 121. Ninuluk(?) formation, stratigraphic position doubtful, may possibly be an interbed of the Grandstand formation, within the uppermost Killik tongue of the Chandler formation, on the Colville River, at approximately lat $69^{\circ} 04^{\prime} 15^{\prime \prime}$ N., long $153^{\circ} 41^{\prime} 30^{\prime \prime}$ W., northern Alaska. Collected by Charles E. Kirschner, 1945.

\section{FIELD SEASON}

In 1946, five field parties were in the Umiat area, Maybe Creek-Wolf Creek area, Meade River and coastal area, area of the Kurupa-Oolamnagavik Rivers, and the Sagavanirktok River and Colville River areas.

\section{Umiat area}

46A St 88. Ayiyak member of the Seabee formation, about 250 feet below the top of the formation, on the east side of a south-flowing branch of Seabee Creek, 0.9 mile northeast of Umiat test well 1 , lat $69^{\circ} 24^{\prime}$ N., long $152^{\circ} 18^{\prime}$ W., northern Alaska. Collected by Karl Stefansson, 1946.

\section{Maybe Creek-Wolf Creek area}

46A Fi 80A. Seabee formation, one mile east of Wolf Creek test well 2 , in the area of the Wolf Creek anticline, lat $69^{\circ} 24^{\prime}$ N., long $153^{\circ} 27^{\prime} \mathrm{W}$, northern Alaska. Collected by W. A. Fischer, 1946.

46A Ry 150A. Seabee formation, middle part, eastern end of the Wolf Creek anticline, on the axis, about $2 \frac{1}{2}$ miles east of Wolf Creek test well 1 , on Wolf Creek, lat $69^{\circ} 23^{\prime} 18^{\prime \prime}$
N., long $153^{\circ} 31^{\prime} 32^{\prime \prime}$ W., northern Alaska. Collected by $\mathbf{R}$. G. Ray, 1946.

\section{Kurupa-Oolamnagavik Rivers area}

46A Th 160. Grandstand formation interbed within the lower bed of the Killik tongue of the Chandler formation, on the Colville River, lat $68^{\circ} 55^{\prime}$ N., long $155^{\circ} 50^{\prime}$ W., northern Alaska. Collected by R. F. Thurrell, 1946.

46A Th 165. Grandstand formation interbed 40 feet below the top of the Killik tongue of the Chandler formation, at the east end of the Aupuk anticline, about 2 miles west of the confluence of Aupuk Creek with the Colville River, lat $69^{\circ} 06^{\prime}$ N., long $154^{\circ} 24^{\prime}$ W., northern Alaska. Collected by R. F. Thurrell, 1946.

Sagavanirktok River area (fig. 12)

46A Gr 98. Ignek formation, lower part. On the Ivishak River, lat $69^{\circ} 20^{\prime} 40^{\prime \prime}$ N., long $148^{\circ} 10^{\prime} 50^{\prime \prime}$ W., northern Alaska. Collected by George Gryc, 1946.

46A Gr 144. Barrow Trail member of the Schrader Bluff formation. On Toolik River, where it enters the East Kuparuk River, south of White Hills, lat $69^{\circ} 30^{\prime}$ N., long $149^{\circ} 15^{\prime} 30^{\prime \prime}$ W., northern Alaska. Collected by George Gryc, 1946.

46A L 66. Ignek formation, Upper Cretaceous part. Base of section exposed at the fork of the Ivishak and Sagavanirktok Rivers, approximately lat $69^{\circ} 30^{\prime} \mathrm{N}$., long $148^{\circ} 30^{\prime} \mathrm{W}$., northeastern Alaska. Collected by E. H. Lathram, 1946.

\section{FIELD SEASON}

The five field parties covered the (1) Colville River region, (2) the area of the Kigalik and Awuna Rivers, (3) the Utukok River and Corwin-Cape Beaufort areas, (4) the Titaluk and Ikpikpuk Rivers, Colville River between Ninuluk and Prince Creeks, and the Nanushuk River region, and (5) the area of the Shaviovik and Canning Rivers.

\section{Colville River area}

47A St 25. Sentinel Hill member of the Schrader Bluff formation, from 31 to 42 feet above the base, at station 65 , on the north bank of the Colville River, 8 miles ENE of Umiat, $7 \frac{1}{2}$ miles SW of the confluence of the Chandler and Colville Rivers, lat $69^{\circ} 25^{\prime}$ N., long $151^{\circ} 48^{\prime}$ W., northern Alaska. Collected by Karl Stefansson, 1947.

47A St 28. Sentinel Hill member of the Schrader Bluff formation. Same section as above, about 75 feet stratigraphically higher.

47A St 29. Sentinel Hill member of the Schrader Bluff formation, 120 feet above base. Same section as $47 \mathrm{~A}$ St 25 and $47 \mathrm{~A}$ St 28.

$47 \mathrm{~A}$ St 30. Sentinel Hill member of the Schrader Bluff formation. About 110 feet above base, and 30 feet below top of exposure in the same section as $47 \mathrm{~A}$ St 25, 28 and 29. Collected by Karl Stefansson, 1947.

47A St 32. Sentinel Hill member of the Schrader Bluff formation. Station 66, on the Colville River, about one mile downstream and ENE from preceding station (65), and approximately 120 feet higher stratigraphically, 15 miles S. $30^{\circ} \mathrm{W}$. of Sentinel Hill core test 1 , northern Alaska. Collected by Karl Stefansson, 1947.

47A St 38. Sentinel Hill member, Schrader Bluff formation. Station 69, on the Colville River at Schrader Bluff (type 


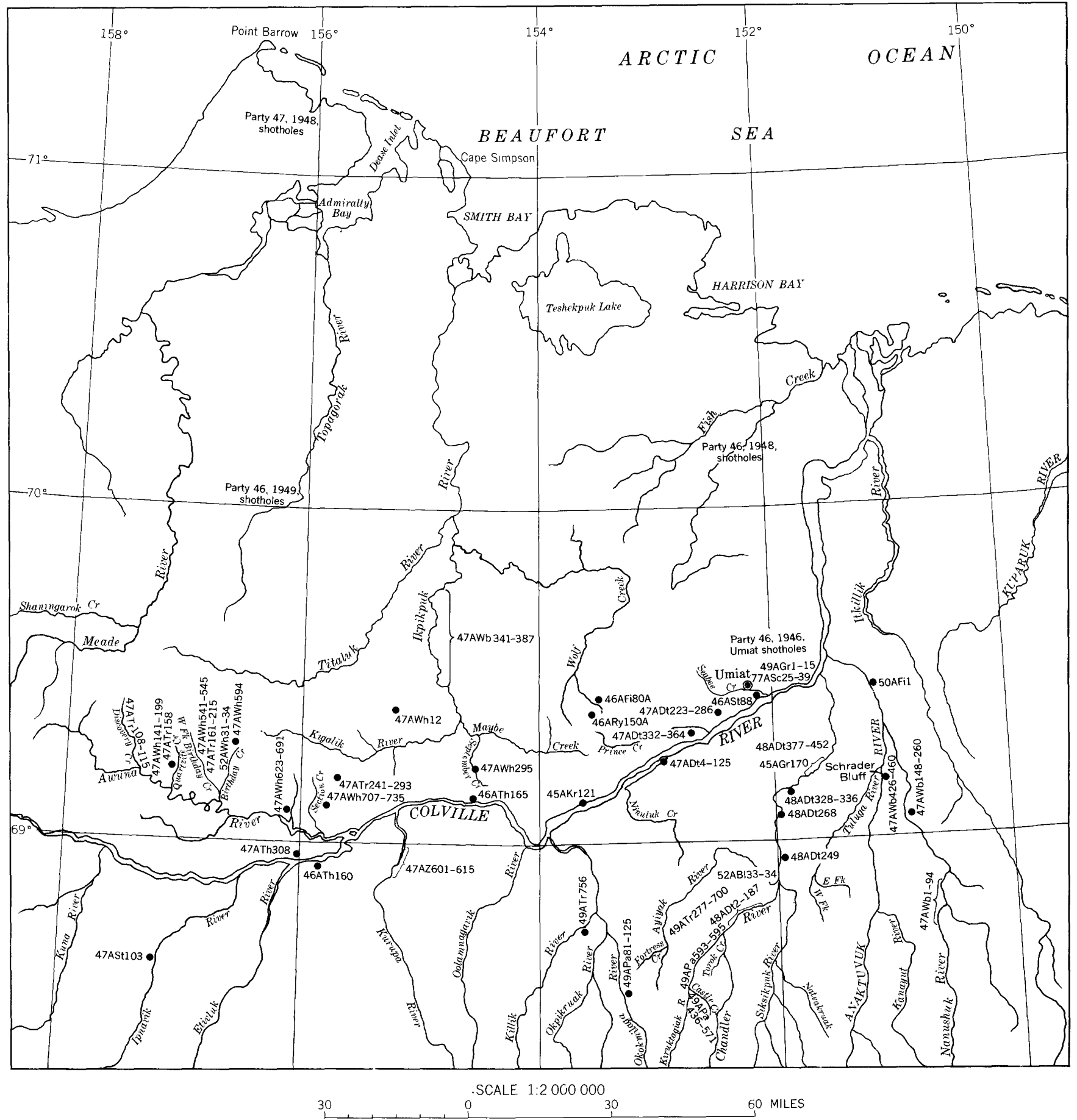

Frgure 11.-Location of outcrop and seismic shothole samples, from north of Brooks Range, region of Colville River and its tributaries, west to Meade River. For description of samples, see locality register under field number.

section of the formation), about 50 feet above the base of the upper tongue of the Sentinel Hill member, lat $69^{\circ} 30^{\prime}$ N., long $151^{\circ} 31^{\prime}$ W., 16 miles ENE of Umiat, northern Alaska.

47A St 39. Sentinel Hill member, Schrader Bluff formation. Same locality as above, 110 feet above base of upper tongue of the Sentinel Hill nember. Collected by Karl Stefansson, 1947.
Ipnavik, Etivluk and Kurupa Rivers area

47A St 103. Lower Cretaceous. Torok formation(?). On the Ipnavik River, lat $68^{\circ} 41^{\prime} \pm 5^{\prime \prime}$ N., long $157^{\circ} 08^{\prime}$ W., about 23 miles airline upstream from its confluence with the Colville River, northern Alaska. Collected by Karl Stefansson, 1947.

47 A Th 308. Torok formation, probably in upper part, 3 miles W. of the Etivluk River confluence, on the Colville River, 


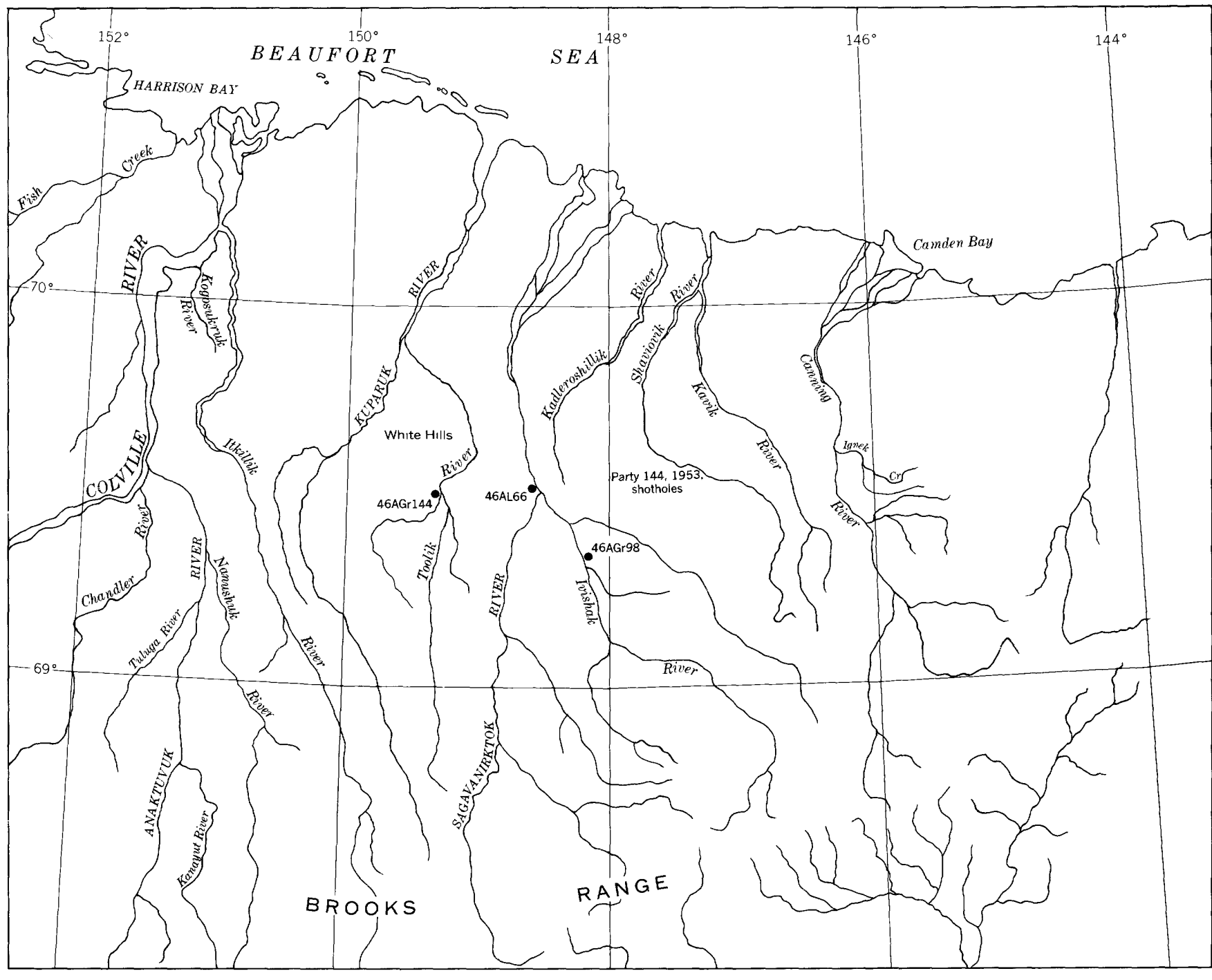

$30 \quad$ SCALE 1:2000000 60 MILES

FrguRE 12.-Location of outcrop and seismic shothole samples from north of Brooks Range, east of the Colville River system, and west of the Canning River. For description of samples, see locality register uncier field number.

lat $68^{\circ} 5 \mathrm{~g}^{\prime} \mathrm{N}$., long $156^{\circ} 08^{\prime} \mathrm{W}$., approximately 100 miles W. of Umiat, northern Alaska. Collected by Robert Thurrell, 1947.

47A Z 601. Tuktu formation. From 980 to 1,000 feet below the top, on the Kurupa River in a section from lat $68^{\circ} 53^{\prime}$ $30^{\prime \prime}$ N., long $155^{\circ} 05^{\prime} \mathrm{W}$., to lat $69^{\circ} 00^{\prime}$ N., long $155^{\circ} \mathrm{W}$., northern Alaska. Collected by J. H. Zumberge, 1947.

$47 \mathrm{~A} \mathrm{Z} \mathrm{603.} \mathrm{Tuktu} \mathrm{formation.} \mathrm{About} 60$ feet stratigraphically higher than $47 \mathrm{~A} \mathrm{Z} \mathrm{601,} \mathrm{and} \mathrm{farther} \mathrm{downstream,} \mathrm{on} \mathrm{the}$ east bank of the Kurupa River, northern Alaska.

$47 \mathrm{~A} \mathrm{Z} \mathrm{604.} \mathrm{Tuktu} \mathrm{formation.} \mathrm{About} 810$ feet below the top, and about 100 feet stratigraphically above $47 \mathrm{~A} \mathrm{Z} \mathrm{603}$, northern Alaska.

47A $\mathrm{Z}$ 606. Grandstand formation(?). Marine tongue within the lower part of the Chandler formation, about 500 feet stratigraphically above $47 \mathrm{~A} \mathrm{Z} \mathrm{604,} \mathrm{northern} \mathrm{Alaska.}$

47A $\mathrm{Z}$ 608. Grandstand formation, 500 feet stratigraphically above $47 \mathrm{~A} \mathrm{Z} \mathrm{606,} \mathrm{northern} \mathrm{Alaska.}$

47A $\mathrm{Z} \mathrm{615A}$. Grandstand formation, 3,850 feet below the top, and stratigraphically above $47 \mathrm{~A} \mathrm{Z}$ 608, northern Alaska. Collected by J. H. Zumberge, 1947.

Kigalik and Awuna Rivers area

47A Wh 12. Seabee formation, basal part. Weathered clay on divide between Bronx Creek and the Ikpikpuk River, $10 \frac{1}{2}$ miles NW of the confiuence of Maybe Creek and the Kigalik River, lat $69^{\circ} 25^{\prime}$ N., long $155^{\circ} 06^{\prime}$ W., northern Alaska. Collected by Charles Whittington, 1947.

$47 \mathrm{~A}$ Wh 141 . Corwin formation! One of several steeply dipping shale exposures along Quartzite Creek, Awuna River area, northern Alaska. Collected by C. L. Whittington, 1947.

47A Wh 160. Torok formation, upper part, 34-54 feet above the base of another exposure, on Quartzite Creek, lat $69^{\circ} 12^{\prime} 30^{\prime \prime}$ N., long $157^{\circ} 03^{\prime}$ W., Awuna River area, northern Alaska.

47A Wh 172. Torok formation, upper part, same section as $47 \mathrm{~A}$ Wh 160 , but 311 to 332 feet above the base of the exposure. Collected by C. L. Whittington, 1947. 
47A Wh 193. Torok formation, upper part. About 100 to 125 feet above the base of a 150 foot shale exposure, on the west bank of Quartzite Creek, 3.2 miles north of its confluence with the Awuna River, lat $69^{\circ} 13^{\prime}$ N., long $157^{\circ} 03^{\prime}$ W., northern Alaska. Collected by C. L. Whittington, 1947.

47A Wh 199. Torok formation, upper part. From 75 to 100 feet above the base of another section on Quartzite Creek at lat $69^{\circ} 13^{\prime} \mathrm{N}$., long $157^{\circ} 02^{\prime} 18^{\prime \prime}$ 'W., Awuna River area, northern Alaska. Collected by C. L. Whittington, 1947.

47A Wh 295. Seabee formation, 541 to 545 feet below top. On September Creek, a north-flowing tributary to Maybe Creek, lat $69^{\circ} 11^{\prime}$ N., long $154^{\circ} 34^{\prime}$ W., northern Alaska. Collected by C. L. Whittington, 1947.

47A Wh 541. Torok formation. Upper part, 40 foot section at the base of a 180 foot shale exposure, with northeast dips of $25^{\circ}$ to $60^{\circ}$, on the left bank of the west fork of Birthday Creek, east side of meander, 0.7 mile northwest of intersection of the fork with Birthday Creek, and 1.9 miles north of the intersection of Birthday Creek and Awuna River, lat $69^{\circ} 11^{\prime}$ N., long $156^{\circ} 41^{\prime}$ W., northern Alaska. Collected by C. L. Whittington, 1947.

47A Wh 542. Torok formation (upper part). Same locality as $47 \mathrm{~A}$ Wh 541 and just above it stratigraphically, 40 to 80 feet above base of exposure.

47A Wh 543. Torok formation (upper part). Same locality as $47 \mathrm{~A}$ Wh 542 , and just above it stratigraphically, 80 to 120 feet above base of exposure.

47A Wh 544. Torok formation (upper part). Same locality, just above 47A Wh 543 , and about 120 to 160 feet above base of exposure.

47A Wh 545. Torok formation (upper part). Same locality, just above 47A Wh 543, uppermost 20 feet of the 180 foot exposure. Collected by C. L. Whittington, 1947.

47A Wh 594. Corwin formation, 140 to 210 feet above the base. This is a residual soil, not a true outcrop. South flank of Kigalik anticline, lat $69^{\circ} 17^{\prime} 48^{\prime \prime}$ N., long $155^{\circ} 51^{\prime}$ W., Awuna River region, northern Alaska. Collected by C. L. Whittington, 1947.

47A Wh 623. Chandler formation. Residual soil of a marine zone within the predominantly nonmarine formation, above three coal beds, on the south flank of the Awuna syncline, lat $69^{\circ} 03^{\prime} 18^{\prime \prime}$ N., long $156^{\circ} 02^{\prime} 30^{\prime \prime}$ W., northern Alaska. Collected by C. L. Whittington, 1947.

47A Wh 630 . Corwin formation. In an exposure on the south flank of the Awuna anticline, from lat $69^{\circ} 06^{\prime} \mathrm{N}$., long $155^{\circ} 57^{\prime} \mathrm{W}$. to lat $69^{\circ} 02^{\prime} 48^{\prime \prime} \mathrm{N}$., long $156^{\circ} \mathrm{W}$., top of exposure. and 1,610 to 1,720 feet above the base of the formation, in northern Alaska. Collected by C. L. Whittington, 1947.

47A Wh 632. Corwin formation. Same locality as $47 \mathrm{~A}$ Wh 630 , but stratigraphically lower, from 1,560 to 1.610 feet above the base.

47A Wh 644. Corwin formation. Same locality, 1,000 to 1,030 feet above the base.

47A Wh 648. Corwin formation. Same locality, lower in section, from 875 to 905 feet above base.

47A Wh 654. Chandler formation. Residual soil of marine tongues within this formation, about 610 to 650 feet above the base, at the same locality as $47 \mathrm{~A}$ Wh $630-648$.

47A Wh 655. Chandler formation, residual soil of marine tongues, same locality, 580 to 610 feet above base.

47A Wh 656. Corwin formation, same locality, 540 to 580 feet above base of formation.
47A Wh 671. Corwin formation. Residual soil, same locality, lower stratigraphically, 25 to 50 feet above base of formation.

47A Wh 674A. Grandstand formation. Residual soil, same locality, 60 to 100 feet below the top of the formation.

47A Wh 688. Grandstand formation, residual soil, same locality, 660 to 720 feet below top of formation.

47A Wh 691. Grandstand formation, residual soil, 750 to $\mathbf{7 8 0}$ feet below the top, same locality.

47A Wh 707. Kukpowruk formation, about 660 feet below $47 \mathrm{~A} \mathrm{Wh} 691$, and 1,000 feet above the base of the formation. Residual soil from crest of divide, east of Section Creek and 3.0 miles $\mathrm{N} 20^{\circ} \mathrm{E}$ of the intersection of Section Creek with the Awuna River, lat $69^{\circ} 08^{\prime}$ N., long $156^{\circ} 00^{\prime}$ W., northern Alaska.

47A Wh 723. Kukpowruk formation, 2,220 to 2,260 feet below the top and 250 feet above the base of the formation, at the same locality.

47A Wh 735. Torok formation. Residual soil, 200 feet below top of formation, same locality. Collected by C. L. Whittington, 1947.

47A $\mathrm{Tr}$ 108. Grandstand formation. On Discovery Creek, north flank of the Awuna anticline, lat $69^{\circ} 14^{\prime} \mathrm{N}$., long $157^{\circ} 25^{\prime}$ W., northern Alaska. Collected by M. L. Troyer, 1947.

47A Tr 113. Kukpowruk formation, 70 to 100 feet below the top, on Discovery Creek, on the south flank of the Awuna anticline, Awuna River region, lat $69^{\circ} 14^{\prime} 36^{\prime \prime}$ N., long $157^{\circ}$ $27^{\prime}$ W., northern Alaska. Collected by M. L. Troyer, 1947.

47A $\operatorname{Tr} 115$. Kukpowruk formation. Same locality as $47 \mathrm{~A}$ Tr 113.

47A $\operatorname{Tr} 158$. Kukpowruk formation. East of Quartzite Creek, Awuna River region, northern Alaska. Collected by M. L. Troyer, 1947.

47A $\operatorname{Tr} 161$. Torok formation. North flank of Awuna anticline, west fork of Birthday Creek, Awuna River region, lat $69^{\circ} 11^{\prime} 42^{\prime \prime}$ N., long $156^{\circ} 45^{\prime}$ W., northern Alaska. Collected by M. L. Troyer, 1947.

47A $\operatorname{Tr} 166$. Torok formation. Upper part of a 50-foot section on the west fork of Birthday Creek, Awuna River region, lat $69^{\circ} 12^{\prime} 30^{\prime \prime}$ N., long $156^{\circ} 47^{\prime}$ W., northern Alaska. Collected by M. L. Troyer, 1947.

47A $\operatorname{Tr} 167$. Torok formation. Lower part of the 50-foot section, same locality as $47 \mathrm{~A} \operatorname{Tr} 166$, northern Alaska. Collected by M. L. Troyer, 1947.

$47 \mathrm{~A} \operatorname{Tr} 203$. Kukpowruk formation, 600 to 800 feet above the base. Cutbank exposure on left bank of Awuna River, extending from mouth of Birthday Creek downstream for about one-half mile, lat $69^{\circ} 10^{\prime}$ N., long $156^{\circ} 41^{\prime}$ W., northern Alaska. Collected by M. L. Troyer, 1947.

47A $\operatorname{Tr} 208$. Torok formation (upper part). Approximately 20 feet of shale, immediately underlying the basal sandstones of the Kukpowruk formation, in cutbank on abandoned meander of Birthday Creek, about 400 feet east of present stream course, one half mile $\mathrm{N} 25^{\circ} \mathrm{E}$ of intersection of Birthday Creek and Awuna River, lat $69^{\circ} 10^{\prime}$ N., long $156^{\circ} 40^{\prime}$ W., northern Alaska. Collected by M. L. Troyer, 1947.

47A $\operatorname{Tr} 212$. Torok formation (upper part), about 1,350 feet below the top. North flank of the Awuna anticline, on the left bank of Birthday Creek, 1.1 miles $\mathrm{N} 23^{\circ} \mathrm{E}$ of the intersection of Birthday Creek and Awuna River, lat 


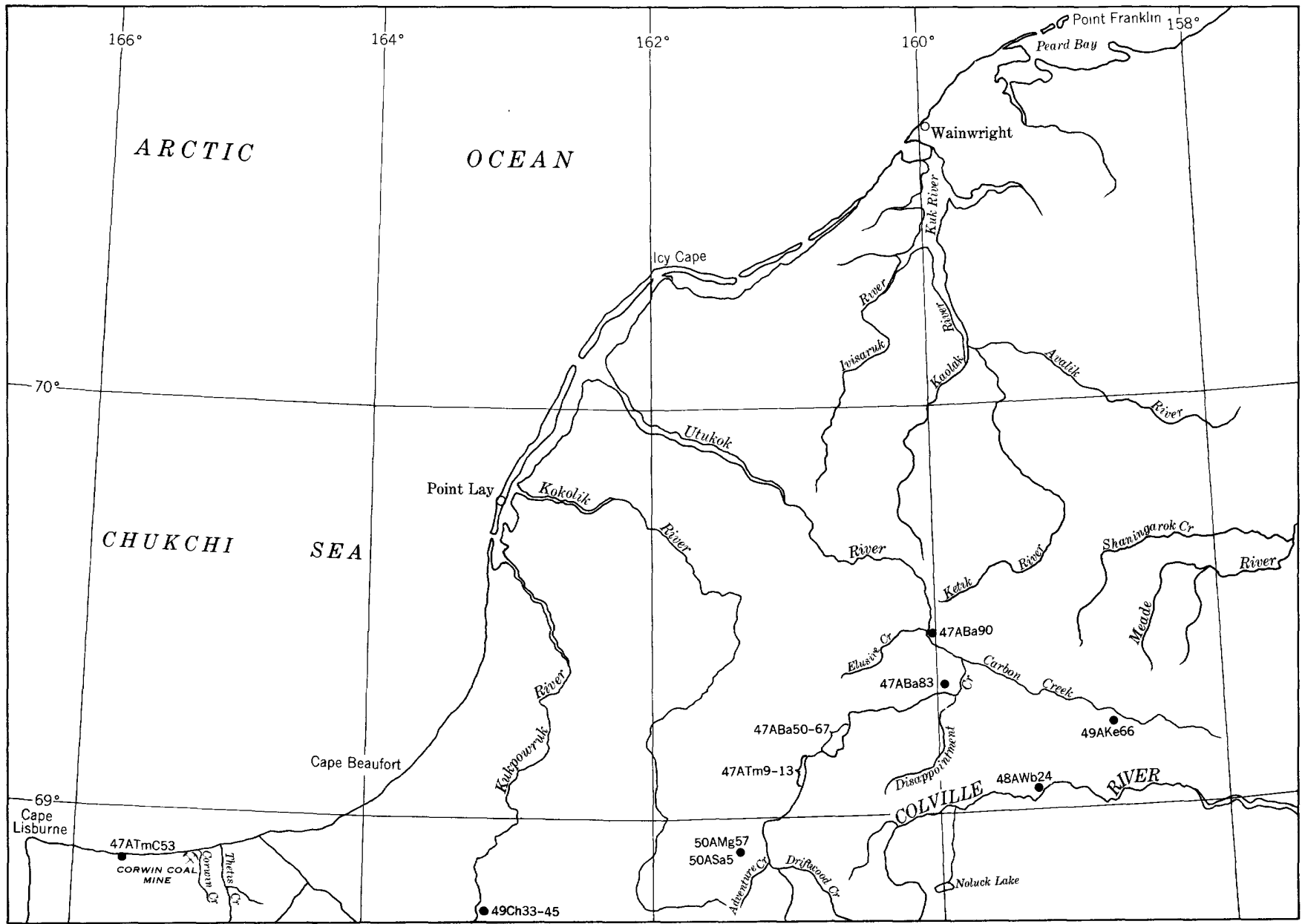

SCALE $1: 2000000$

30

60 MILES

Fraure 13.-Iocation of outcrop samples from north of Brooks Range, between Cape Lisburne and Carbon Creek. For description of samples, see locality register under field number.

$69^{\circ} 11^{\prime}$ N., long $156^{\circ} 40^{\prime}$ W., northern Alaska. Collected by M. L. Troyer, 1947.

47A Tr 215. Torok formation (upper part). About 1,400 feet below the top. Same locality as 47A Tr 212. Collected by M. L. Troyer, 1947.

47A $\operatorname{Tr} 241$. Chandler formation, marine tongue within the formation, on north flank of Awuna anticline, lat $69^{\circ} 12^{\prime} 18^{\prime \prime}$ N., long $155^{\circ} 47^{\prime}$ W., northern Alaska. Collected by M. L. Troyer, 1947.

47A Tr 253. Grandstand formation, 1,620 to 1,670 feet below the basal sandstones of the Chandler formation. On north flank Awuna anticline, lat $69^{\circ} 09^{\prime} 30^{\prime \prime}$ N., long $155^{\circ} 59^{\prime}$ W., northern Alaska. Collected by M. L. Troyer, 1947.

47A $\mathrm{Tr}$ 289. Grandstand formation, a 40-foot marine tongue about 200 feet above the basal sandstones of the Chandler formation, 1,800 feet stratigraphically above $47 \mathrm{~A} \operatorname{Tr} 253$, in the same locality.

47A $\operatorname{Tr} 293$. Chandler formation. Forty-foot section, including a marine tongue within the predominantly nonmarine formation 400 feet above its base, and 170 feet above sample $47 \mathrm{~A} \operatorname{Tr} 289$, at the same locality.
Utukok River and Corwin-Cape Beaufort area (fig. 13)

47A Ba 50. Kukpowruk formation (top). In a 3,700-foot section of intermittent exposures on the Utukok River, 1,400 feet below the top of the section and 2,050-2,130 feet above the Torok formation, 70 miles due east of Cape Beaufort, lat $69^{\circ} 07^{\prime} 30^{\prime \prime}$ N., long $160^{\circ} 54^{\prime} \mathrm{W}$., northern Alaska. Collected by W. L. Barksdale, 1947.

47A Ba 54. Corwin formation. About 640 feet below the top, in the same section as $47 \mathrm{~A} \mathrm{Ba} 50$, and about 760 feet higher stratigraphically.

47A Ba 67. Kukpowruk formation. Shale break, from 110 to 174 feet above the Torok formation, at base of 640-foot exposure on the north limb of a syncline, just north of the Utukok River and southwest of a small unnamed tributary, lat $69^{\circ} 14^{\prime} \mathrm{N}$., long $160^{\circ} 37^{\prime}$ W., 70 miles ENE of Cape Beaufort, northern Alaska. Collected by W. L. Barksdale, 1947.

47A Ba 83. Kukpowruk formation. From 903 to 1,043 feet above the Torok formation, and $\mathbf{7 8 0}$ feet below the top of the exposure, $2 \frac{1}{2}$ miles west of the confluence of Disappointment Creek with the Utukok River, lat $69^{\circ} 15^{\prime}$ N., 
long $159^{\circ} 57^{\prime}$ W., 70 miles east of Cape Beaufort, northern Alaska. Collected by W. L. Barksdale, 1947.

$47 \mathrm{~A} \mathrm{Ba} 90$. Kukpowruk formation, 550 feet below the top. On the Utukok River, about 65 miles upstream from its mouth, near the confluence of Elusive Creek, 10 miles east of the mouth of Carbon Creek, northern Alaska. Collected by W. L. Barksdale, 1947.

47A $\mathrm{Tm} 9$ Bed 6. Kukpowruk formation, about 1,100 feet above base, and about 700 feet below the top, on a high ridge, 5.2 miles west of the Utukok River, lat $69^{\circ} 07^{\prime} \mathrm{N}$., long $161^{\circ} 05^{\prime}$ W., northern Alaska. Collected by R. M. Thompson, 1947.

47 A $\operatorname{Tm} 10$, top 6 feet of bed 5. Kukpowruk formation, 79-229 feet above the Torok formation, 3,300 feet below the top exposed, in a 3,700-foot section of intermittent exposures along the Utukok River, lat $69^{\circ} 07^{\prime} 30^{\prime \prime}$ N., long $160^{\circ} 54^{\prime} \mathrm{W}$., northern Alaska. Collected by R. M. Thompson, 1947.

47A Tm 13. Kukpowruk formation. Sixty feet below the top and 858 to 860 feet above the Torok formation, in an exposure of about 1,000 feet. on the south limb of a syncline on the west bank of the Utukok River, lat $69^{\circ} 13^{\prime} \mathrm{N}$., long $160^{\circ} 38^{\prime}$ W., northern Alaska. Collected by R. M. Thompson, 1947.

47A Tm C-53. Kukpowruk formation or uppermost Torok formation, undifferentiated. Along the coast of the Arctic Ocean, about 16 miles east of Cape Lisburne, approximately lat $68^{\circ} 54^{\prime} \mathrm{N}$, long $165^{\circ} \pm 0^{\prime} \mathrm{W}$., northern Alaska. Collected by R. M. Thompson, 1947.

Upper Ikpikpuk River area

47A Wb 341. Ninuluk formation, about 140 feet below the top. On the east bank of the Ikpikpuk River, $61 / 2$ miles north of the confluence of Kigalik River and Maybe Creek, lat $69^{\circ} 26^{\prime}$ N., long $154^{\circ} 48^{\prime}$ W., northern Alaska. Collected by E. J. Webber, 1947.

47A Wb 352. Ninuluk formation, abont 50 feet below top, on west bank of Ikpikpuk River, 12 miles north of the confluence of Kigalik River and Maybe Creek, lat $69^{\circ} 30^{\prime} \mathrm{N}$., long $154^{\circ} 55^{\prime}$ W., northern Alaska. Collected by E. J. Webber, 1947 .

47A Wb 364. Ninuluk formation, near top. West bank of Ikpikpuk River, 181/2 miles north of confluence of Kigalik River and Maybe Creek, lat $69^{\circ} 36^{\prime}$ N., long $154^{\circ} 58^{\prime}$ W., northern Alaska. Collected by E. J. Webber, 1947.

$47 \mathrm{~A} \mathrm{~Wb} 368$. Ninuluk formation. About 80 feet below the top, in the same locality as $47 \mathrm{~A} \mathrm{~Wb} 364$.

$47 \mathrm{~A} \mathrm{~Wb} 387$. Ninuluk formation, near base. On the Ikpikpuk River, lat $69^{\circ} 44^{\prime}$ N., long $154^{\circ} 48^{\prime}$ W., northern Alaska. Collected by E. J. Webber, 1947.

Colville River area, between Ninuluk and Prince Creeks

47 A Dt 4 . Ninuluk formation. About 645 feet below the top, at the type locality of the formation. Ninuluk Bluffs on the Colville River, lat $69^{\circ} 08^{\prime}$ N., long $153^{\circ} 18^{\prime}$ W., northern Alaska. Coilected by R. L. Detterman, 1947.

47A Dt 7. Ninuluk formation, 516 feet below top. Same locality as $47 \mathrm{~A}$ Dt 4.

47A Dt 26. Ninuluk formation, 400 feet below top. Same locality.

47A Dt 58. Ninuluk formation, 200 feet below top. Same locality.

47A Dt 59. Ninuluk formation, 190 feet below top. Same locality.

47A Dt 61. Ninuluk formation, 185 feet below top. Same locality. Ail collected by R. L. Detterman, 1947.
47A Dt 78. Lower member, Seabee formation, 40 feet below the top of the 900 foot section exposed on the Colville River between Ninuluk Creek and Umiat Mountain, lat $69^{\circ} 13^{\prime} \mathrm{N}$., long $153^{\circ} 15^{\prime}$ W., 25 miles airline $\mathrm{S} 54^{\circ} \mathrm{W}$ of Umiat test well 1 , northern Alaska. Collected by R. L. Detterman, 1947.

47A Dt 80. Seabee formation, 20 feet above base, same locality as $47 \mathrm{~A}$ Dt 78. Collected by R. L. Detterman, 1947.

47A Dt 84. Lower member, Seabee formation, 70 feet above the base, 270 feet below the top, on the Colville River at Ninuluk Bluffs, lat $69^{\circ} 07^{\prime}$ N., long $153^{\circ} 18^{\prime}$ W., northern Alaska. Collected by R. L. Detterman, 1947.

47A $D$ t 96. Lower member, Seabee formation, 215 feet above the base, on the Colville River, lat $69^{\circ} 07^{\prime} \mathrm{N}$., long $153^{\circ} 18^{\prime}$ W., northern Alaska. Collected by R. L. Detterman, 1947.

$47 \mathrm{~A}$ Dt 125. Seabee formation, 210 feet above base. Same locality as $47 \mathrm{~A}$ Dt 78.

47A Dt 223. Torok formation, upper part. About 5 miles airline upstream from the mouth of Fossil Creek, a small, north-flowing tributary to the Colville River at approximately lat $69^{\circ} 19^{\prime} 30^{\prime \prime}$ N., long $152^{\circ} 28^{\prime}$ W., northern Alaska. Collected by R. L. Detterman, 1947.

47A Dt 227. Tuktu formation. Same locality as 47A Dt 223, and from 560 feet stratigraphically higher, and 1,000 feet below the top of the Tuktu formation.

47A Dt 228. Tuktu formation, 1,020 feet below the top, and 20 feet below $47 \mathrm{~A}$ Dt 227 at the same locality.

47A Dt 230. Tuktu formation, 860 feet below the top, same locality as $47 \mathrm{~A}$ Dt 228 , and 160 feet higher stratigraphically.

47A Dt 236. Tuktu formation, about 250 feet higher than $47 \mathrm{~A}$ Dt 230, at the same locality.

47A Dt 240. Tuktu formation, about 260 feet higher than $47 \mathrm{~A}$ Dt 236 , at the same locality.

47 A Dt 244. Tuktu formation. Same locality as 47A Dt 240, and 290 feet higher in the section.

47A Dt 256. Grandstand formation, 500 feet below top, same locality as $\mathbf{4 7} \mathrm{A}$ Dt 244 .

47A Dt 257. Grandstand formation, 530 feet below top, same locality as $47 \mathrm{~A}$ Dt 256. All collected by $R$. L. Detterman, 1947.

47A Dt 284. Sentinel Hill member of the Schrader Bluff formation. On the Colville River, 4 miles below the mouth of Fossil Creek, northern Alaska. Collected by R. L. Detterman, 1947.

47A Dt 286. Sentinel Hill member of the Schrader Bluff formation. Same locality as 47 A Dt 284 . Collected by R. L. Detterman, 1947.

47A Dt 332. Barrow Trail member of the Schrader Bluff formation, 330 feet above the base, in a cutbank on Prince Creek, from a section between 6 and 16 miles southwest of Uniat test well 1 , about lat $69^{\circ} 24^{\prime} 30^{\prime \prime}$ N., long $152^{\circ} 34^{\prime}$ W., northern Alaska. Collected by R. L. Detterman, 1947.

47A Dt 333. Barrow Trail member of the Schrader Bluff formation, 300 feet above the base, same locality as $47 \mathrm{~A} \mathrm{Dt}$ 332.

47A Dt 338. Barrow Trail member of the Schrader Bluff formation, about 20 feet below top of member, same locality as $47 \mathrm{~A}$ Dt 333 .

47A Dt 348. Sentinel Hill member of the Schrader Bluff formation, 120 feet below the top of the 440 foot member, same locality as $47 \mathrm{~A}$ Dt 338 .

47A Dt 358. Sentinel Hill member of the Schrader Bluff for- 
mation, 310 feet below the top, same locality as $47 \mathrm{~A}$ Dt 348.

47A Dt 360. Sentinel Hill member of the Schrader Bluff formation, 260 feet below the top, same locality as $47 \mathrm{~A} \mathrm{Dt}$ 358.

47A Dt 363. Sentinel Hill member of the Schrader Bluff formation, 160 feet above the base and 280 feet 1 elow the top, at the same locality as $47 \mathrm{~A}$ Dt 360 .

47A Dt 364. Sentinel Hill member of the Schrader Bluff formation, 280 feet above the base, same locality as $47 \mathrm{~A} \mathrm{Dt}$ 363. All collected by R. L. Detterman, 1947.

Nanushuk and Anaktuvuk Rivers area

$47 \mathrm{~A} \mathrm{~Wb} 1$. Ayiyak member of the Seabee formation, about 160 feet below top, on the Nanushuk River, lat $68^{\circ} 42^{\prime} 30^{\prime \prime}$ N., long $152^{\circ} 36^{\prime}$ W., northern Alaska. Collected by E. J. Webber, 1947.

$47 \mathrm{~A} \mathrm{~Wb} 35$. Ayiyak member of the Seabee formation, on the Nanushuk River, lat $68^{\circ} 45^{\prime}$ N., long $150^{\circ} 43^{\prime}$ W., northern Alaska. Collected by E. J. Webber, 1947.

$47 \mathrm{~A} \mathrm{~Wb} 94$. Tuktu formation, 150 to 200 feet below the top, on the Nanushuk River, lat $68^{\circ} 51^{\prime}$ N., long $150^{\circ} 31^{\prime} \mathrm{W}$. northern Alaska. Collected by E. J. Webber, 1947.

$47 \mathrm{~A}$ Wb 148 . Lower member, Seabee formation. From 10 feet above base, 1,375 feet below top, at the type locality, for about 3 miles along the Nanushuk River in a section from lat $69^{\circ} 03^{\prime} \mathrm{N}$., long $150^{\circ} 51^{\prime} \mathrm{W}$., to lat $69^{\circ} 04^{\prime} 30^{\prime \prime} \mathrm{N}$., long $151^{\circ} 49^{\prime}$ W., northern Alaska. Collected by E. J. Webber, 1947.

$47 \mathrm{~A} \mathrm{~Wb} 150$. Lower member, Seabee formation, 20 feet above base, same locality as $47 \mathrm{~A}$ Wb 148.

$47 \mathrm{~A} \mathrm{~Wb} 151$. Lower member, Seabee formation, 35 feet above base, same locality as $47 \mathrm{~A} \mathrm{~Wb} 150$.

$47 \mathrm{~A} \mathrm{~Wb} 155$. Lower member, Seabee formation, above $47 \mathrm{~A}$ $\mathrm{Wb} 151$ at the same locality.

$47 \mathrm{~A} \mathrm{~Wb} 172$. Lower member, Seabee formation, 95 feet above base, 1,290 feet below top, same locality.

$47 \mathrm{~A} \mathrm{~Wb} 213$. Lower member, Seabee formation, 340 feet above base, same locality.

$47 \mathrm{~A} \mathrm{~Wb} 255$. Lower member, Seabee formation, 100 feet below top, same locality.

$47 \mathrm{~A} \mathrm{~Wb} 258$. Lower member, Seabee formation, 60 feet below top, same locality.

$47 \mathrm{~A} \mathrm{~Wb} 259$. Lower member; Seabee formation, at contact with Ayiyak member, same locality.

$47 \mathrm{~A} \mathrm{~Wb} 260$. Ayiyak member of the Seabee formation, basal 10 feet, just above $47 \mathrm{~A} \mathrm{~Wb} 259$, at the same locality. All collected by E. J. Webber, 1947.

$47 \mathrm{~A} \mathrm{~Wb} 426$. Ayiyak member of the Seabee formation, 100 feet below the top, at Schrader Bluff on the Anaktuvlik River, lat $69^{\circ} 10^{\prime} 30^{\prime \prime}$ N., long $151^{\circ} 00^{\prime}$ W., northern Alaska. Collected by E. J. Webber, 1947.

$47 \mathrm{~A} \mathrm{~Wb} 428$. Ayivak member of the Seabee formation, 140 to 160 feet below the top, at the same locality as $47 \mathrm{~A} \mathrm{~Wb}$ 426 .

$47 \mathrm{~A} \mathrm{~Wb} 429$. Ayiyak member of the Seabee formation, 135 feet below the top, same locality.

$47 \mathrm{~A} \mathrm{~Wb} 431$. Ayiyak member of the Seabee formation, top of the member, same locality.

$47 \mathrm{~A} \mathrm{~Wb}$ 444. Rogers Creek member of the Schrader Bluff formation, 400 to $\mathbf{4 1 5}$ feet below the top. same locality.

$47 \mathrm{~A} \mathrm{~Wb} 447$. Tuluvak tongue, probably an interbed of the marine Rogers Creek member of the Schrader Bluff formation, 115 to 125 feet below top, same locality.
47A Wb 451. Rogers Creek member of the Schrader Bluff formation, about 550 feet below the top, same locality.

$47 \mathrm{~A} \mathrm{~Wb}$ 456. Rogers Creek member of the Schrader Bluff formation, 200 to 250 feet below the top, same locality.

47A Wb 460. Rogers Creek member of the Schrader Bluff formation, top of member, same locality, all samples collected by E. J. Webber, 1947.

\section{FIELD SEASON}

There were only three field parties during this year, and part of the area covered included Paleozoic rocks, hence a smaller number of Cretaceous samples were available.

\section{Chandler River area}

48A Dt 2. Torok formation, type locality, 125 to 160 feet below the top, at Tuktu Bluff on the Chandler River lat $68^{\circ}$ $43^{\prime}$ N., long $152^{\circ} 15^{\prime}$ W., northern Alaska. Collected by R. L. Detterman, 1948.

$48 \mathrm{~A}$ Dt 9. Torok formation, 450 feet below top, same locality. 48 A Dt 120. Torok formation, 4,300 feet below top, same locality.

48A Dt 121. Torok formation, 4,380 feet below top, same locality. Collected by R. L. Detterman, 1948.

$48 \mathrm{~A}$ Dt 187. Chandler formation, marine zone within the formation, 270 feet above base. On the Chandler River below Tuktu Bluff, lat $68^{\circ} 45^{\prime} 30^{\prime \prime}$ N., long $152^{\circ} 15^{\prime}$ W., northern Alaska. Collected by R. L. Detterman, 1948.

48A Dt 249. Grandstand formation. In an 800 foot section at Grandstand anticline, on the Chandler River, lat. $68^{\circ} 55^{\prime}$ N., long $151^{\circ} 50^{\prime}$ W., northern Alaska. Collected by $R$. L. Detterman, 1948.

48A Dt 268. Grandstand formation, 140 feet below top, on the Chandler River, between Niakogon syncline and Big Bend anticline, lat $69^{\circ} 04^{\prime}$ N., long $151^{\circ} 52^{\prime}$ W., northern Alaska. Collected by R. L. Detterman, 1948.

48A Dt 328. Grandstand formation, on the Chandler River, region of the Big Bend anticline, lat $69^{\circ} 07^{\prime} 30^{\prime \prime} \mathrm{N}$., long $151^{\circ} 45^{\prime}$ W., northern Alaska. Collected by R. L. Detterman, 1948.

48A Dt 336. Grandstand formation. On Trouble Creek, region of Big Bend anticline, lat $69^{\circ} 06^{\prime} 30^{\prime \prime}$ N., long $151^{\circ} 38^{\prime}$ W., northern Alaska. Collected by R. L. Detterman, 1948.

48A Dt 377. Rogers Creek nember of the Schrader Bluff formation. From 140 to 160 feet above base, near Schrader anticline, on the Chandler River, lat $69^{\circ} 10^{\prime} \mathrm{N}$.. long $151^{\circ} 27^{\prime}$ W., northern Alaska. Collected by R. L. Detterman, 1948.

48A Dt 378. Rogers Creek member of the Schrader Bluff formation, 120 to 140 feet above the base, same locality.

48A Dt 383. Rogers Creek member of the Schrader Bluff formation. Bed of this member within the Tuluvak tongue, 40 feet below top of the Tuluvak tongue, on the Chandler River, lat $69^{\circ} 11^{\prime} 45^{\prime \prime} \mathrm{N}$., long $151^{\circ} 28^{\prime} \mathrm{W}$, northern Alaska. Collected by R. L. Detterman, 1948.

48A Dt 392. Rogers Creek member of the Schrader Bluff formation. In a section going northward along the Chandler River, between Schrader anticline and Umiat, approximately 20 miles above the mouth of the Chandler River, northern Alaska. Collected by R. L. Detterman, 1948.

48A Dt 393. Rogers Creek member of the Schrader Bluff formation. Just below $48 \mathrm{~A}$ Dt 392 , at the same locality.

48A Dt 416. Barrow Trail member of the Schrader Bluff formation, 870 to 890 feet above the base, same locality. 
48A Dt 417. Barrow Trail member of the Schrader Bluff formation, 890 to 910 feet above base, same locality.

48A Dt 418. Barrow Trail member of the Schrader Bluff formation, 910 to 930 feet above the base, same locality.

48A Dt 421. Barrow Trail member of the Schrader Bluff formation, 980 to 990 feet above base, same locality.

48A Dt 422. Barrow Trail member of the Schrader Bluff formation, 990 to 1,010 feet above base of the formation, just above 48 A Dt 421 , same locality.

48A Dt 425. Barrow Trail member of the Schrader Bluff formation, 1,010 to 1,020 feet above base of formation, same locality.

48A Dt 426. Barrow Trail member of the Schrader Bluff formation, 1,020 to 1,030 feet above the base of the formation, all at the same locality. Collected by R. L. Detterman, 1948.

48A Dt 429. Barrow Trail member of the Schrader Bluff formation, at contact with overlying Sentinel Hill member, on the Chandler River, lat $69^{\circ} 13^{\prime} 45^{\prime \prime}$ N., long $151^{\circ} 24^{\prime} 30^{\prime \prime}$ W., northern Alaska. Collected by R. L. Detterman, 1948.

48A Dt 452. Sentinel Hill member of the Schrader Bluff formation. About 50 feet above base, on Chandler River, lat $69^{\circ} 17^{\prime}$ N., long $151^{\circ} 27^{\prime}$ W., northern Alaska. Collected by R. L. Detterman, 1948.

Upper Colville River area (fig. 13)

48A Wb 24. Torok formation (upper part). At junction of Reynard Creek and the Colville River, northeast of Noluk Lake, lat $69^{\circ} 06^{\prime} 30^{\prime \prime}$ N., long $159^{\circ} 27^{\prime}$ W., northern Alaska. Collected by E. J. Webber, 1948.

\section{FIELD SEASON}

Six parties were in the field during this season, some working on certain anticlines, some on areas of Paleozoic rocks. Of the Cretaceous samples available, a relatively greater percentage was from the older Lower Cretaceous strata.

Carbon Creek and Titaluk anticlines (fig. 13)

49A Ke 66. Kukpowruk formation, 1,130 feet above base. In the headwaters of Carbon Creek, a tributary to the Utukok River, on the south fiank of the Carbon Creek anticline, approximately 160 miles west of Umiat, northern Alaska. Collected by A. S. Keller, 1949.

Kokolik and Kukpowruk Rivers area (fig. 13)

49A Ch 33. Okpikruak formation. Stratigraphic position uncertain. In old meander bluffs 1,500 feet southwest of small lake on east side of Kukpowruk River, lat $68^{\circ} 44^{\prime} 10^{\prime \prime}$ N., long $163^{\circ} 06^{\prime} 45^{\prime \prime}$ W., northern Alaska. Collected by R. M. Chapman, 1949.

49A Ch 44. Torok formation, about 180 feet below top. In ravine in Kukpowruk Rirer basin, approximately lat $68^{\circ}$ $46^{\prime} 30^{\prime \prime}$ N., long $163^{\circ} 07^{\prime}$ W., northern Alaska.

$49 \mathrm{~A}$ Ch 45 . Torok formation. Same locality as $49 \mathrm{~A}$ Ch 44. Collected by R. M. Chapman, 1949.

Colville River area

49A Gr 1. Sentinel Hill member of the Schrader Bluff formation. A 7 foot bed of dark grey carbonaceous silt and shale, at base of 160 foot section on the Colville River, 9 miles ENE of Umiat, northern Alaska. This is at the same locality, but a slightly lower horizon than 47A St 25, listed above under 1947 field season. Collected by George Gryc, 1949.
49A Gr 15. Sentinel Hill member of the Schrader Bluff formation. Bottom one foot of a 60 foot claystone, which underlies an 8 foot sandstone at the top of the section. Schrader Bluff, on the west bank of the Colville River, 16 miles ENE of Umiat. This is from the same locality and horizon as $47 \mathrm{~A}$ St 39, listed above under the 1947 field season. Collected by George Gryc, 1949.

\section{Kiruktagiak and Okokmilaga Rivers area}

49A $\mathrm{Pa}$ 81. Fortress Mountain formation, lower part. On Fortress Creek, tributary to the Ayiyak River, north of Fortress Mountain, lat $68^{\circ} 35^{\prime} 25^{\prime \prime}$ N., long $153^{\circ} 11^{\prime}$ W., northern Alaska. Collected by W. W. Patton, Jr., 1949.

49A $\mathrm{Pa} 84$. Fortress Mountain formation. Samples $49 \mathrm{~A} \mathrm{~Pa}$ 83-94 are from along Fortress Creek for about one mile, on the west side of Fortress Mountain, $49 \mathrm{~A} \mathrm{~Pa} 84$ is at lat $68^{\circ} 35^{\prime} 20^{\prime \prime}$ N., long $153^{\circ} 11^{\prime} 30^{\prime \prime}$ W., northern Alaska. Collected by W. W. Patton, Jr., 1949.

49A $\mathrm{Pa} 90$. Fortress Mountain formation. Same locality as above sample, lat $68^{\circ} 35^{\prime} 10^{\prime \prime} \mathrm{N}$., long $153^{\circ} 10^{\prime} 30^{\prime \prime} \mathrm{W}$.

49A Pa 91. Fortress Mountain formation. Same locality as above; approximately lat $68^{\circ} 35^{\prime}$ N., long $153^{\circ} 10^{\prime}$ W., northern Alaska.

49A Pa 94. Fortress Mountain formation. Same locality as above, approximately lat $68^{\circ} 35^{\prime} \mathrm{N}$. long $153^{\circ} 10^{\prime} \mathrm{W}$., northern Alaska. Collected by W. W. Patton, Jr., 1949.

49A Pa 125. Fortress Mountain formation. On a small northfiowing tributary to Fortress Creek, northeast of Fortress Mountain, lat $68^{\circ} 30^{\prime}$ N., long $153^{\circ} 05^{\prime} 30^{\prime \prime}$ W., northern Alaska. Collected by W. W. Patton, Jr., 1949.

49A Pa 436. Fortress Mountain formation. On Castle Creek, a north-fiowing tributary to the Kiruktagiak River, 2.9 miles airline SSW of Castle Mountain, lat $68^{\circ} 32^{\prime} 30^{\prime \prime} \mathrm{N}$., long $152^{\circ} 51^{\prime} 30^{\prime \prime}$ W., northern Alaska. Collected by W. W. Patton, Jr., 1949.

49A Pa 468. Fortress Mountain formation. Along tributary to Castle Creek, $1 \frac{1 / 2}{2}$ miles SW of Castle Mountain, lat $68^{\circ} 33^{\prime} 40^{\prime \prime}$ N., long $151^{\circ} 51^{\prime}$ W., northern Alaska. Collected by W. W. Patton, Jr., 1949.

49A Pa 542. Torok formation. On Torok Creek, between Castle Mountain and Tuktu Bluff, lat $68^{\circ} 38^{\prime}$ N., long $152^{\circ} 37^{\prime}$ W., northern Alaska. Collected by W. W. Patton, Jr., 1949.

49A Pa 561. Fortress Mountain formation. On Castle Creek, $23 / 4$ miles SW of Castle Mountain, lat $68^{\circ} 33^{\prime} 15^{\prime \prime}$ N., long $152^{\circ} 52^{\prime} 30^{\prime \prime}$ W., northern Alaska. Collected by W. W. Patton, Jr., 1949.

49A Pa 564. Fortress Mountain formation. On Castle Creek, $2 \frac{1}{2}$ miles SW of Castle Mountain, lat $68^{\circ} 33^{\prime} 10^{\prime \prime}$ N., long $152^{\circ} 52^{\prime} 15^{\prime \prime}$ W., northern Alaska.

49A Pa 571. Fortress Mountain formation. On Castle Creek, $23 / 4$ miles SW of Castle Mountain, lat $68^{\circ} 32^{\prime} 45^{\prime \prime}$ N., long $152^{\circ} 51^{\prime} 30^{\prime \prime}$ W., northern Alaska.

49A Pa 593. Fortress Mountain formation, from 1,150 to 1,750 feet above base, on Kiruktagiak River, west of Castle Mountain, lat $68^{\circ} 35^{\prime}$ N., long $152^{\circ} 54^{\prime}$ W., northern Alaska.

49A $\mathrm{Pa} 594$. Fortress Mountain formation. Same locality as above, stratigraphically lower.

49A $\mathrm{Pa} 595$. Fortress Mountain formation (lower part). Same locality as above. Collected by W. W. Patton, Jr., 1949.

49A Tr 277. Fortress Mountain formation. Contorted shale unconformably underlying a conglomerate. On Fortress 
Creek, in farthest east cutbank of a series at the foot of Fortress Mountain (southwest end of the mountain), lat $68^{\circ} 34^{\prime} \mathrm{N}$., long $153^{\circ} 00^{\prime} 30^{\prime \prime} \mathrm{W}$. Collected by I. L. Tailleur, 1949.

49A $\operatorname{Tr} 291$. Fortress Mountain formation. Same locality as 49A $\operatorname{Tr} 277$, but from third cutbank downstream.

49A $\operatorname{Tr} 292$. Fortress Mountain formation. Same locality as $49 \mathrm{~A} \mathrm{~Pa} 91$, listed above.

49A $\operatorname{Tr} 562$. Fortress Mountain formation. In section from 5,500 to 6,000 feet above base, on Castle Creek, SSW of Castle Mountain, lat $68^{\circ} 32^{\prime} 05^{\prime \prime}$ N., long $152^{\circ} 49^{\prime}$ W., northern Alaska. Collected by I. L. Tailleur, 1949.

49A Tr 565. Fortress Mountain formation. Same locality as 49A $\operatorname{Tr} 562$, but stratigraphically lower.

49A $\operatorname{Tr} 575$. Fortress Mountain formation. From 7,400 feet above base, one mile SE of Castle Mountain, lat $68^{\circ} 33^{\prime} 35^{\prime \prime}$ N., long $152^{\circ} 45^{\prime}$ W., northern Alaska. Collected by I. L. Tailleur, 1949.

49A $\operatorname{Tr} 611$. Fortress Mountain formation. On the east fork of Torok Creek, east of Castle Mountain, lat $68^{\circ} 33^{\prime} 35^{\prime \prime} \mathrm{N}$., long $152^{\circ} 38^{\prime} 30^{\prime \prime}$ W., northern Alaska. Collected by I. L. Tailleur, 1949.

49A Tr 662. Fortress Mountain formation. From a cutbank on the east side of a small tributary that enters Kiruktagiak River from the south, about 1,000 feet upstream from their confluence, lat $68^{\circ} 37^{\prime} \mathrm{N}$., long $152^{\circ} 42^{\prime}$ W., northern Alaska, Collected by I. L. Tailleur, 1949.

49A $\operatorname{Tr} 685$. Torok formation. On the Kiruktagiak River, on the south limb of the Ayiyak anticlinorium, north of Castle Mountain, lat $68^{\circ} 39^{\prime} 15^{\prime \prime}$ N., long $152^{\circ} 43^{\prime}$ W., northern Alaska. Collected by I. L. Tailleur, 1949.

49A Tr 695. Torok formation. On the Kiruktagiak River, due north of Castle Mountain, lat $68^{\circ} 38^{\prime} 40^{\prime \prime}$ N., long $152^{\circ} 44^{\prime}$ W., northern Alaska. Collected by I. L. Tailleur, 1949.

49A $\mathrm{Tr} 700$. Torok formation. In a long cutbank on the southeast side of the Kiruktagiak River, lat $68^{\circ} 38^{\prime} 30^{\prime \prime}$ N., long $152^{\circ} 37^{\prime}$ W., northern Alaska. Collected by I. L. Tailleur, 1949.

49A Tr 756. Torok formation. On Okok Creek, a tributary to the Okpikruak River, above the Lemuroceras zone, lat $68^{\circ} 42^{\prime} 30^{\prime \prime}$ N., long $153^{\circ} 35^{\prime}$ W., northern Alaska. Collected by I. L. Tailleur, 1949.

\section{FIELD SEASON}

Seven field parties were operating, but relatively fewer samples were from strata covered in the present report.

\section{Siksikpuk and Nanushuk Rivers area}

$50 \mathrm{~A}$ Fi 1. Barrow Trail member of the Schrader Bluff formation. Near the axis of the Gubik anticline, on the Anaktuvuk River, about 28 miles ENE of Umiat, northern Alaska, Collected by W. A. Fischer, 1950.

Driftwood anticline-Utukok River region (fig. 13)

50A Mg 57. Torok formation (lower part). On Adventure Creek, a north-flowing tributary to the Utukok River, Driftwood anticline area, northern Alaska. Collected by M. D. Mangus, 1950.

$50 \mathrm{~A} \mathrm{Sa} \mathrm{5.} \mathrm{Torok} \mathrm{formation} \mathrm{(base} \mathrm{of} \mathrm{lower} \mathrm{part).} \mathrm{On} \mathrm{Adven-}$ ture Creek, on the south flank of the Driftwood anticline, northern Alaska. Collected by E. G. Sable, 1950.

\section{1-52 FIELD SEASON}

No samples collected by the 4 field parties in 1951, and only a few of those from the 1952 season, are recorded in the present report.

Chandler River area

52A Bl 33. Shale Wall member of the Seabee formation. From 500 feet above base, along the Ayiyak River, tributary to the Chandler River, west of Hawk anticline, northern Alaska. Collected by R. S. Bickel, 1952.

$52 \mathrm{~A} \mathrm{Bl} \mathrm{34.} \mathrm{Ayiyak} \mathrm{member} \mathrm{of} \mathrm{the} \mathrm{Seabee} \mathrm{formation} \mathrm{(base} \mathrm{of}$ member, at contact with the underlying Shale Wall member). Same locality as 52A Bl 33 . Collected by $R$. S. Bickel, 1952.

Awuna River area

52A Wh 31. Torok formation, upper part, 80 feet below top. In the middle of a steep, northward-dipping exposure of 180 feet, on the West Fork of Birthday Creek, tributary to the Awuna River, northern Alaska. This and the following samples (52A Wh 24 to 38 ) are from the same section as $47 \mathrm{~A}$ Wh $541-545$ and $47 \mathrm{~A} \mathrm{Tr} 218-219$, listed above under the 1947 field season. The present samples each comprise about 10 feet of section. Collected by Charles Whittington, 1947.

52A Wh 32. Torok formation, upper part, 70 feet below top. Same locality as above.

52A Wh 33. Torok formation, 60 feet below top. Same locality as above.

52A Wh 34. Torok formation, 50 feet below top. Same locality as above. Collected by Charles Whittington, 1947.

\section{SUBSURFACE MATERIAL \\ TEST WELIS AND CORE TESTS}

Over a period of 8 years, 35 test wells and 41 core tests were drilled in Naval Petroleum Reserve No. 4. Samples from nearly all of the 170,000 total footage were examined for microfossils, about two-thirds of the samples being fossiliferous. Wells included in the following register and plotted on figure 14 are those from which type specimens are here recorded, and all wells and core tests are given in alphabetical order. Because of the nature of the strata, there is considerable contamination from higher zones in the well samples, hence the percentage of fossiliferous samples is somewhat misleading, this relatively high percentage undoubtedly being due in part to the contamination factor. The foraminiferal fauna is in general restricted in character throughout much of the Cretaceous section, and in many of the wells the combination of progressively poorer faunas downward in the section, rapid facies changes in the near-shore sediments and high contamination rate of the samples made selection of contacts on a strictly faunal basis somewhat difficult. Most of the formations were described from the surface, and in some instances their onlapping character resulted in a different faunal facies being penetrated in the well sections, especially those of the coastal plain, than was present in the out- 


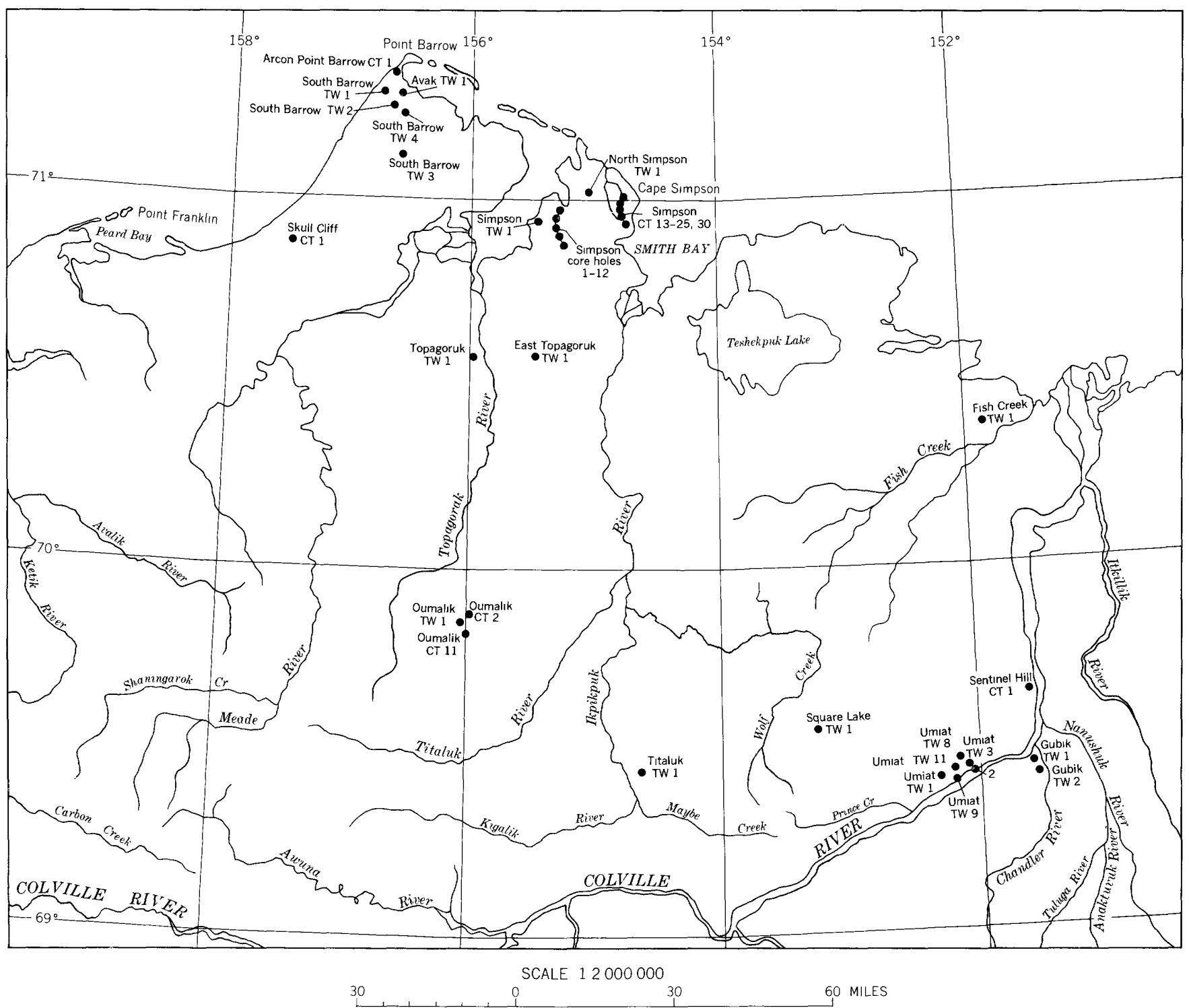

FigUre 14.-Location of the wells and core tests in Naval Petroleum Reserve No. 4, from which Foraminifera are here recorded.

crop. Thus the Verneuitinodes borealis faunal zone as defined by Bergquist (1958a, p. 199) may include the Grandstand, Topagoruk, Tuktu, and upper part of the Torok formations of various surface and subsurface areas. The formation contacts given below are thus in some cases faunally determined, and others have a lithologic basis.

Arcon Point Barrow core test 1.-North-northeast of Barrow Village, and southwest of Point Barrow, lat $71^{\circ} 19^{\prime} 30^{\prime \prime}$ N., long $156^{\circ} 40^{\prime}$ W., northern Alaska. This core test is within the Topagoruk formation, with a thin 70-foot Pleistocene surface covering, total depth $\mathbf{1 . 4 4 2}$ feet.

Avak test well 1.- Southeast of Barrow Village, due south of Point Barrow. lat $71^{\circ} 15^{\prime} 02^{\prime \prime}$ N., long $156^{\circ} 28^{\prime} 06^{\prime \prime}$ W., northern Alaska. Total depth 4,020 feet, with Pleistocene from 0 to 150 feet. 'Torok formation from 150 to 1.350 feet, Jurassic from 1,350 to 2,307 feet, and basement rocks from 2,307 to 4,020 feet.

East Topagoruk test well 1.-Between the Topagorak and Oumalik Rivers south southeast of Point Barrow, lat $\mathbf{7 0}^{\circ} 34^{\prime}$ 37.5' N., long $155^{\circ} 22^{\prime} 39^{\prime \prime}$ W., northern Alaska. The Pleistocene occurs to a depth of 90 feet, Seabee formation from 90 to 150 feet, Grandstand formation from 150 to 1,750 feet, Topagoruk formation from 1,750-3,589 feet, at the bottom of the well. Lithologic descriptions are given by Collins, 1958b, p. 301, and micropaleontology by Bergquist, 1958c. p. 313.

Fish Creek test well 1.-About 15 miles west of the mouth of the Colville River, lat $70^{\circ} 18^{\prime} 36^{\prime \prime}$ N., long $151^{\circ} 52^{\prime} 40^{\prime \prime}$ W., northern Alaska. This well penetrated Pleistocene (0-65 feet), Sentinel Hill member of the Schrader Bluff formation (65 to 600 feet), Barrow Trail member of the Schrader Bluff formation (600 to 835 feet), Rogers Creek member of the Schrader Bluff formation ( 835 to 1,435 feet), Tuluvak tongue of the Prince Creek formation (1,435 to 2,410 feet), Seabee formation 
(2,410 to 2,630 feet), Ninuluk formation $(2,630$ to 2,880 feet), Grandstand formation (2,880 to 3,720 feet), and Topagoruk formation $(3,720$ to 7,020 feet $)$, to the bottom of the well. Lithologic descriptions are given by Collins (in Robinson and Collins, 1959), p. 501.

Gubik test well 1.-On the east side of the Colville River, east of Umiat, lat $69^{\circ} 26^{\prime} 46^{\prime \prime}$ N., long $151^{\circ} 28^{\prime} 06^{\prime \prime}$ W., northern Alaska. Strata penetrated were Quaternary ( 0 to 67 feet), Schrader Bluff formation (67 to 890 feet; of this the section from 67 to 295 feet is of the Barrow Trail member, that from 295 to 890 feet is the Rogers Creek member). Tuluvak tongue of the Prince Creek formation ( 890 to 1,760 feet), Seabee formation (1,760 to 3,305 feet), Ninuluk formation and Killik tongue of the Chandler formation undifferentiated $(3,305$ to 3,735 feet), Grandstand formation (3,735 to 4,315 feet) and Topagoruk formation $(4,315$ to 6.000 feet, T. D. $)$. Lithologic descriptions are given by Robinson, $1958 \mathrm{a}$, p. 212, and micropaleontology by Bergquist, 1958 b, p. 259.

Gubik test well 2.-Near the confluence of the Chandler and Colville Rivers, east of Umiat, lat $69^{\circ} 25^{\prime} 10^{\prime \prime}$ N., long $151^{\circ} 27^{\prime}$

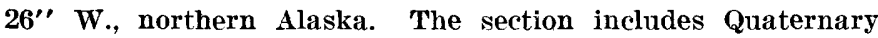
(0 to 110 feet), Schrader Bluff formation (110-1,135 feet; with Barrow Trail member from 110 to 555 feet, and Rogers Creek member from 555 to 1,135 feet), Tuluvak tongue of the Prince Creek formation $(1,135$ to 2,010 feet), Seabee formation (2,010 to 3,585 feet), Ninuluk formation and Killik tongue of the Chandler formation (3,585 to 4,025 feet), Grandstand formation (4,025 to 4,395 feet) and Topagoruk formation $(4,395$ to 4,620 feet, T. D.). Lithologic descriptions are given by Robinson, 1958a, p. 231, and micropaleontology by Bergquist, 1958 b, p. 260.

Oumalik core test 2.-At the apex of the anticline, lat $69^{\circ} 50^{\prime} \mathrm{N}$., long $156^{\circ} 00^{\prime} \mathrm{W}$., on the west bank of the Oumalik River, northern Alaska. The upper 40 feet are in the Quaternary, the remainder of the section in the Grandstand formation (40 to 190 feet, T. D.) Lithologic descriptions are given by Robinson, 1956, p. 12, and micropaleontology by Bergquist, 1956, p. 68.

Oumalik core test 11.-About 25 feet south of Oumalik test well 1 , lat $69^{\circ} 50^{\prime} 18^{\prime \prime}$ N., long $155^{\circ} 59^{\prime} 24^{\prime \prime}$ W., northern Alaska. The upper 14 feet are in the Quaternary; the remainder is in the Grandstand formation (14 to 303 feet, T. D.). Lithologic descriptions are given by Robinson, 1956, p. 16, and micropaleontology by Bergquist, 1956, p. 68.

Oumalik test well 1.-West of the Oumalik River, lat $69^{\circ}$ $50^{\prime} 18^{\prime \prime}$ N., long $155^{\circ} 59^{\prime} 36^{\prime \prime}$ W., northern Alaska. The upper 25 feet are Quaternary, from 25 to 2,825 feet is in the Grandstand formation, the Topagoruk formation is from 2.835 to 4,860 feet, Torok formation (4,860 to 10,880 feet), and undifferentiated Lower Cretaceous and Upper Jurassic is from 10,880 to 11,872 feet, T. D. Lithologic descriptions are given by Robinson, 1956, p. 25, and micropaleontology by Bergquist, 1956 , p. 65.

Sentinel Hill core test 1 . - On the west bank of the Colville River, lat $69^{\circ} 35^{\prime} 48^{\prime \prime}$ N., long $151^{\circ} 28^{\prime} 09^{\prime \prime}$ W., northwest of Umiat, northern Alaska. The entire section is in the Upper Cretaceous with the interfingering tongues of marine and nonmarine strata alternating. The nonmarine Kogosukruk tongue of the Prince Creek formation occurs from 9 to 469 feet, and again from 840 to 985 feet, and the marine Sentinel Hill member of the Schrader Bluff formation occurs from 469 to 840 feet, and again from 985 feet to 1,180 feet, T. D. Lithologic descriptions are given by Robinson (in Robinson and Collins, $1959)$, p. 486.

Simpson core hole 3.-East of Admiralty Bay, southwest of Cape Simpson at lat $70^{\circ} 55^{\prime} 27^{\prime \prime}$ N., long $155^{\circ} 16^{\prime} 55^{\prime \prime}$ W., northern Alaska. Pleistocene sands occurred to about 90 feet, the remainder of the section being in the Grandstand formation (90 to 340 feet, T. D.).

simpson core hole 8.- North of Simpson core hole 3 , lat $70^{\circ} 56^{\prime} 43^{\prime \prime}$ N., long $155^{\circ} 17^{\prime} 16^{\prime \prime}$ W., northern Alaska. The Pleistocene is approximately 120 feet in thickness, the remainder of the section is in the Grandstand formation (to T. D., 570).

Simpson core hole 10.-North of Simpson core hole 8, lat $70^{\circ} 57^{\prime} 34^{\prime \prime}$ N., long $155^{\circ} 17^{\prime} 27^{\prime \prime}$ W., northern Alaska. Pleistocene occurs to approximately 65 feet in depth, with the Grandstand formation from 65 to 490 feet, T. D.

Simpson core hole 11.-North of Simpson core holes 1-10, lat $70^{\circ} 58^{\prime} 49^{\prime \prime}$ N., long $155^{\circ} 17^{\prime} 32^{\prime \prime}$ W., northern Alaska. Pleistocene to a depth of 80 feet, with Schrader Bluff formation from 80 to 580 feet, T. D.

Simpson core test 13.-About 2 miles west of Cape Simpson, lat $70^{\circ} 58^{\prime} 05^{\prime \prime}$ N., long $154^{\circ} 38^{\prime} 43^{\prime \prime}$ W., northern Alaska. Pleistocene occurs to 85 feet in depth, Schrader Bluff formation to about 350 feet, Seabee formation to 710 feet, and Grandstand formation from 710 to 1,438 feet, T. D.

Simpson core test 25.--About $5 \frac{1 / 2}{2}$ miles southwest of Cape Simpson, lat $70^{\circ} 55^{\prime} 56.4^{\prime \prime}$ N., long $154^{\circ} 43^{\prime} 52.8^{\prime \prime}$ W., northern Alaska. The Pleistocene extends to 115 feet, Schrader Bluff formation from 115 to $\mathbf{5 0 0}$ feet, Seabee formation from $\mathbf{5 0 0}$ to 860 feet and Grandstand formation from 860 to 1,510 feet, T. D.

Simpson core test $30 .-$ Lat $70^{\circ} 55^{\prime} 49^{\prime \prime}$ N., long $154^{\circ} 40^{\prime} 41^{\prime \prime}$ W., northern Alaska. The Pleistocene occurs to 85 feet in depth, Seabee formation from 85 to 313 feet, and Grandstand formation from 313 to 693 feet, T. D.

Simpson test well 1.-West of Cape Simpson, lat $70^{\circ} 57^{\prime} 05^{\prime \prime}$ N., long $155^{\circ} 21^{\prime} 45^{\prime \prime}$ W., northern Alaska. The Pleistocene occurs to 120 feet, Grandstand formation from 120 to 1,000 feet, Topagoruk formation from 1,000 to 3,580 feet, Torok formation from 3,580 to 5,550 feet, Jurassic from 5,550 to 6,300 feet, Triassic from 6,300 to $6, \mathbf{0} 45$ feet, with basement argillite from 6,545 to 7,002 feet, T. D. Lithologic descriptions are given by Robinson, $1959 \mathrm{~b}$, p. 532 .

Skull Cliff core test 1.-About midway between Point Barrow and Point Franklin, southwest of Point Barrow, lat $70^{\circ} 55^{\prime}$ N., long $157^{\circ} 38^{\prime}$ W., northern Alaska. The Pleistocene occurs to a depth of 100 feet, and the Grandstand formation from 100 feet to 776 feet, T. D.

South Barrow test well 1.-Southwest of Point Barrow, lat $71^{\circ} 19^{\prime} 12.07^{\prime \prime}$ N., long $156^{\circ} 42^{\prime} 15.34^{\prime \prime}$ W., northern Alaska. The Pleistocene is about 40 feet thick, Topagoruk formation occurs from 40 to 2,847 feet, Torok formation from 2,847 to 3,410 feet and basement rocks from 3,410 to 3,553 feet, T. D.

South Barrow test well 2.-South-southwest of Point Barrow, lat $71^{\circ} 15^{\prime} 49^{\prime \prime}$ N., long $156^{\circ} 38^{\prime} 03^{\prime \prime}$ W., northern Alaska. Pleistocene occurs from 0 to 85 feet, Topagoruk formation from 85 to 1,980 feet, Torok formation from 1,980 to 2,320 feet, and Jurassic from 2,320 to 2,445 feet, basement complex from 2,445 to 2,505 feet, $\mathbf{T}$. $\mathbf{D}$.

South Barrow test well 3.-South of Point Barrow, lat $71^{\circ}$ $09^{\prime} 40^{\prime \prime}$ N., long $156^{\circ} 34^{\prime} 45^{\prime \prime}$ W., northern Alaska. The Quaternary extends to a depth of 20 feet, Topagoruk formation from 
20 to 1,340 feet, Torok formation from 1,340 to 1,645 feet, Jurassic from 1,645 to 2,547 feet, Triassic from 2,547 to 2,799 feet, and basement complex (late Paleozoic?) from 2,799 to 2,900 feet, T. D.

South Barrow test well 4.-South-southwest of Point Bar row and 447 feet N. $28^{\circ}$ E. of South Barrow test well 2, lat $71^{\circ} 15^{\prime} 55.24^{\prime \prime}$ N., long $156^{\circ} 37^{\prime} 44.89^{\prime \prime}$ W., northern Alaska. The Quaternary extends to $\mathbf{1 0 0}$ feet. Topagoruk formation from $\mathbf{1 0 0}$ to 1.988 feet, Torok formation from 1.988 to 2,328 feet and Jurassic from 2,328 to $2, \pi 38$ feet, T. D.

Square Lake test uell 1.-West-northwest of Umiat, lat $69^{\circ}$ $34^{\prime 2} 2^{\prime \prime}$ N., long $1.53^{\circ} 17^{\prime} 49^{\prime \prime}$ W., northern Alaska. The Quaternary extends to 30 feet, Schrader Bhuff formation (Rogers (reek nember) from 30 to 1,090 feet, Seabee formation from 1.090 to 1,883 feet, Ninuluk formation from 1,883 to 2.495 feet, and Grandstand and Topagoruk formations from 2,495 to 3,987 feet, T. D. Lithologic descriptions are given by Collins, 1959, p. 424 , and micropaleontology by Bergquist, 1959b, p. 479 .

Titaluk test uell 1.--East of the Ikpilppuk River, north of Maybe Creek and west of Prince Creek, lat $69^{\circ} 25^{\prime} 21^{\prime \prime}$ N., long $154^{\circ} 34^{\prime} 04^{\prime \prime}$ W., northern Alaska. The Ninuluk formation occurs to 1,400 feet. Killik tongue of the Chandler formation from 1,400 to 1.850 feet, and Grandstand and Topagoruk formations from 1,850 to 4,020 feet. T. D. Lithologic descriptions are given by Robinson, 1959 a, p. 381, and micropaleontology by Bergquist, 1959a, p. 417.

Topagoruk test well 1.-On the Topagorak River, south of Admiralty Bay, lat $70^{\circ} 37^{\prime} 30^{\prime \prime}$ N., long $155^{\circ} 53^{\prime} 36^{\prime \prime}$ W., northern Alaska. This deep test penetrated Quaternary ( 0 to 50 feet), Grandstand formation ( 50 to 1,350 feet) Topagoruk formation (1,350 to 3,900 feet), Torok formation (3,900 to 6.600 feet). Jurassic (6.600 to 8,640 feet) Triassic $(8,640$ to 9.380 feet), Permian (9.380 to 9,770 feet), redbeds (age? from 9.770 to 10,040 feet), and Devonian (10,040 to 10,503 feet. T. D.). Lithologic descriptions are given by Collins, 1958b, p. 267, and micropaleontology by Bergquist, 1958c, p. 312.

Tmiat test well 1.-West of Umiat, lat $69^{\circ} 23^{\prime} 52^{\prime \prime}$ N., long $152^{\circ} 19^{\prime} 45^{\prime \prime}$ W., northern Alaska. Strata penetrated included Seabee formation ( 0 to 915 feet), Ninuluk formation (915 to 1,010 feet). Killik tongue of the Chandler formation $(1,010$ to 1,305 feet, and again at 2,010 to 2,085 feet), Grandstand formation $(1,305$ to 2,010 feet and again at 2,085 to 2,850$)$, Topagoruk formation $(2,850$ to 5,650 feet $)$, and Torok formation $(5,650$ to 6,005 feet, T. D.). The repetition of section in the Killik tongue and in the Grandstand formation is due to a thrust fault at 2.010 feet. Lithologic descriptions are given by Collins, 1958a, p. 75, and micropaleontology by Bergquist, 1958 a, p. 200.

I'miat test well 2.--North of Umiat, lat $69^{\circ} 23^{\prime} 04^{\prime \prime} \mathrm{N}$., long $152^{\circ} 05^{\prime} 01^{\prime \prime}$ W., northern Alaska. Quaternary deposits extend to 80 feet, Killik tongue of the Chandler formation from 80 to 365 feet, Grandstand formation from 365 to 1,060 feet, Topagoruk formation $(1,060$ to 4,700 feet $)$. Torok formation $(4,700$ to 5.100 feet) and repeated Topagoruk formation $(5,100$ to 6,212 feet, T. D.). The Topagoruk is increased in thickness by repetition due to a thrust fault at 2,400 feet, and repeated in section also by a thrust fanlt at 5,100 feet. Iithologic descriptions are given by Collins. 1958a, p. 99, and micropaleontology by Bergquist, 1958a, p. 200.

Umiat test uell 3 (previously referred to as Umiat core test 1).-North of Umiat, lat $69^{\circ} 23^{\prime} 16^{\prime \prime}$ N., long $152^{\circ} 05^{\prime} 14^{\prime \prime}$ W., northern Alaska. No recovery of samples to a depth of 60 feet, where the Killik tongue of the Chandler formation was penetrated (60 to 225 feet), with the Grandstand formation occurring from 225 to 572 feet, T. D. Lithologic descriptions are given by Collins, $1958 \mathrm{a}$, p. 116, and micropaleontology by Bergquist, 1958a, p. 201.

Umiat test well 8. - North of Umiat, lat $69^{\circ} 23^{\prime} 59^{\prime \prime}$ N., long $152^{\circ} 06^{\prime} 56^{\prime \prime}$ W. northern Alaska. This well penetrated the Quaternary ( 0 to 20 feet), Seabee formation ( 20 to 60 feet), Ninuluk formation (60 to 170 feet), Killik tongue of the Chandler formation ( 170 to $\mathbf{3 5 0}$ feet), a thrust fault at $\mathbf{3 5 0}$ feet causing a repetition of section, with seabee formation again ( 350 to 445 feet), followed by Ninuluk formation ( 445 to 5.5 feet), Killik tongue of the Chandler formation (555 to 840 feet), and Grandstand formation ( 840 to 1,327 feet, T. D.). Lithologic descriptions are given by Collins, $1958 \mathrm{a}$, p. 148, and microplaleontology by Bergquist, 1958a, p. 202.

I'miat test uell 9.-Lat $69^{\circ} 23^{\prime} 14^{\prime \prime}$ N., long $152^{\circ} 10^{\prime} 11^{\prime \prime}$ W., northern Alaska. The Ninuluk formation occurs to 155 feet, Killik tongue of the Chandler formation from 155 to 425 feet, Grandstand formation from 425 to 1,090 feet, and Topagoruk formation from 1,090 to 1,257 feet, T. D. Lithologic descriptions are given by Collins, 1958a, p. 156, and micropaleontology by Bergquist, 1958a, p. 203.

Umiat test uell 11.-North of Umiat, lat $69^{\circ} 24^{\prime} 29^{\prime \prime}$ N., long $152^{\circ} 05^{\prime} 58^{\prime \prime}$ W., northern Alaska. Quaternary deposits extended to 22 feet, the Tuluvak tongue of the Prince Creek formation from 22 to 545 feet, the Seabee formation from 545 to 2,040 feet, Ninuluk formation from 2.040 to 2,160 feet, Killik tongue of the Chandler formation from 2,160 to 2,420 feet, Grandstand formation from 2,420 to 3,075 feet and Topagoruk formation from 3,075 to 3,303 feet, T. D. Lithologic descriptions are given by Collins, 1958a, p. 179, and micropaleontology by Bergquist, 1958a, p. 204.

\section{SEISMOGRAPH SHOT HOLE SAMPLES}

In addition to samples from the wells and from geologic field parties, a large quantity of material was made available from the shot holes of the rarious seismograph parties. Many of these shot holes in the coastal plain region were within the Quaternary cover, but in other areas they encountered Cretaceous strata. Of the thousands of such samples obtained, only those are here listed from which foraminiferal types are described, as was done in the case of outcrop and well material.

\section{Umiat area}

$$
1946 \text { SHOT HOLES (SEE FIG. 11) }
$$

Uniat party 46, line 1-46, shot hole 12.-Depth 155 to 180 feet. Lat $69^{\circ} 24^{\prime} \mathrm{N}$., long $152^{\circ} 05^{\prime} \mathrm{W}$., near Umiat, northern Alaska. Seabee formation, either from upper shale member or the Ayiyak member, probably the former, at least 650 feet below the top of the formation.

t'miat party 46, line 1-46, shot hole 13.-Lat $69^{\circ} 24^{\prime} 29.4^{\prime \prime} \mathrm{N}$., long $152^{\circ} 05^{\prime} 19.8^{\prime \prime}$ W., near Umiat, northern Alaska. Ayiyak member of the Seabee formation.

Umiat party 46, line 1-46, shot hole 14--North of Umiat, lat $69^{\circ} 24^{\prime} 45^{\prime \prime}$ N., long $152^{\circ} 05^{\prime} 30^{\prime \prime}$ W., northern Alaska. Rogers Creek member of the Schrader Bluff formation.

Umiat party 46, line 1-46, shot hole 15.-Depth 20 feet. About 7 miles NNE of Imiat, lat $69^{\circ} 25^{\prime}$ N., long $152^{\circ} 06^{\prime}$ W., northern Alaska. Rogers Creek member of the Schrader Bluff formation, about 200 feet below top of member.

Umiat party 46, line 1-46, shot hole 3\%.-Depth 65 feet. 
North-northwest of Umiat, lat $69^{\circ} 24^{\prime}$ N., long $152^{\circ} 11^{\prime}$ W., northern Alaska. Grandstand formation.

1948 SHOT HOLES (SEE FIG. 11)

Fish Creek area

Party 46, line 6-48, shot hole 15.-Lat $70^{\circ} 22^{\prime} 54^{\prime \prime}$ N., long $152^{\circ} 17^{\prime} 12^{\prime \prime}$ W., northern Alaska. Depth 70 feet. Probably Grandstand formation.

Party 46, line 10-48, shot hole 31.-Lat $70^{\circ} 21^{\prime} 12^{\prime \prime}$ N., long $152^{\circ} 19^{\prime} 36^{\prime \prime}$ W., northern Alaska. Depth 70 feet. Probably Grandstand formation.

Party 46, line 12-48, shot hole 12.-Depth 70 feet, Lat $70^{\circ}$ $20^{\prime} 06^{\prime \prime}$ N., long $152^{\circ} 05^{\prime} 30^{\prime \prime}$ W., northern Alaska. Grandstand formation.

Barrow area

Party 47, line 14-4-48, shot hole 35.-Lat $71^{\circ} 18^{\prime} 08^{\prime \prime}$ N., long $156^{\circ} 42^{\prime} 45^{\prime \prime}$ W., northern Alaska. Topagoruk formation.

Party 47, line 14-A-48, shot hole 37.-Depth 190 to 200 feet. Lat $71^{\circ} 17^{\prime} 54^{\prime \prime}$ N., long $156^{\circ} 43^{\prime} 21^{\prime \prime}$ W., northern Alaska. Topagoruk formation.

Party 47, line 14-4-48, shot hole 40.-Depth 160 to 170 feet. Lat $71^{\circ} 16^{\prime} 24^{\prime \prime}$ N., long $156^{\circ} 45^{\prime} 06^{\prime \prime}$ W., northern Alaska. Topagoruk formation.

Party 4\%, line 14-A-48, shot hole 43 and 43A.-Lat $71^{\circ} 16^{\prime} 39^{\prime \prime}$ N., long $156^{\circ} 45^{\prime} 06^{\prime \prime}$ W., northern Alaska. Topagoruk formation.

Party 4\%, line 14-A-48, shot hole 45.-Lat $71^{\circ} 16^{\prime} 20^{\prime \prime}$ N., long $156^{\circ} 45^{\prime} 07^{\prime \prime}$ W., northern Alaska. Topagoruk formation.

Party 47, line $27-48$, shot hole 2.-Lat $71^{\circ} 16^{\prime} 36^{\prime \prime}$ N., long $156^{\circ} 36^{\prime} 54^{\prime \prime}$ W., northern Alaska. Topagoruk formation.

Party 4\%, line $27-48$, shot hole 3.-Lat $71^{\circ} 16^{\prime} 30^{\prime \prime}$ N., long $156^{\circ} 37^{\prime}$ W., northern Alaska. Topagoruk formation.

Party 47, line 27-48, shot hole 8.-Lat $71^{\circ} 15^{\prime} 58^{\prime \prime}$ N., long $156^{\circ} 37^{\prime} 27^{\prime \prime}$ W., northern Alaska. Topagoruk formation.

$$
1949 \text { SHOT HOLES (SEE FIG. 11) }
$$

Topagorak River area

Party 46, line 43-49, shot hole 43.-Depth 60 feet. Grandstand formation. Lat $69^{\circ} 59^{\prime} 12^{\prime \prime} \mathrm{N}$., long $156^{\circ} 16^{\prime} 12^{\prime \prime}$ W., northern Alaska.

1953 SHOT HOLES (SEE FIG. 12)

Shaviovik River area

Party 144, line 4-53, shot hole 6.-Lat 69 $34^{\prime} 24^{\prime \prime}$ N., long $147^{\circ} 33^{\prime} 35^{\prime \prime} \mathrm{W}$., on the Shaviovik anticline, at the east end of the northern foothills of the Brooks Range, northern Alaska. Ignek formation.

Party 144, line 8-53, shot hole 4.-On Shaviovik anticline, lat $69^{\circ} 34^{\prime} 26^{\prime \prime} \mathrm{N}$., long $147^{\circ} 43^{\prime} 03^{\prime \prime}$ W., northern Alaska. Ignek formation.

\section{FORAMINIFERAT EVIDENCE FOR CORRELATION OF THE CRETACEOUS OF ATASKA}

Certain of the Alaskan Cretaceous strata have supplied megafossils useful for correlation, as mentioned in the stratigraphic discussion above. Foraminiferal evidence in general corroborates these correlations based on megafossils. Other strata have few or no diagnostic megafossils, however, and in certain of these strata microfossil evidence is available.

In the systematic portion of this paper, a brief ac- count of the geographic and geologic range is given with each of the specific descriptions, but a general summary of this stratigraphic evidence was considered advisable.

Of the 155 Cretaceous species here described, about one third were new in the Alaskan strata or not identifiable specifically. These were thus only of value in local correlation, in northern Alaska. However, the nearly 100 remaining species were first described in Canada, the United States, England, Germany, France, or Sweden. Some of these thus afford evidence as to the age of the Alaskan strata, as based on the European time scale. Other species may be locally restricted stratigraphically but indistinguishable morphologically from specimens of a different age in another region. For example Bathysiphon vitta Nauss is found in the lower Lea Park of Canada (of Senonian, Late Cretaceous age) but in Alaska occurs in older strata (Grandstand and Topagoruk formations of Albian or Early Cretaceous age). The species may have migrated from Alaska, and not appeared until later in Canada, but more probably is merely facies controlled locally and has a long range within the Cretaceous.

\section{MICROFAUNAL, ZONES}

A detailed zonation based on Foraminifera is generally possible in marine Cretaceous sediments. Many Cretaceous index genera have been used for such zonations in various areas of the world with excellent success. These zonations have been variously based on species of Rotalipora, Globotruncana, Schackoina, and various Heterohelicidae, among the planktonic Foraminifera, or on Bolivinoides, Neoflabellina or other specialized benthonic species, and have allowed local and regional correlations in considerable detail.

Unfortunately, none of the specialized Cretaceous genera occur in the north Alaskan sediments, over 90 per cent of the genera present ranging from Cretaceous to Recent. The half dozen more restricted genera include only the relatively unknown Lacosteina Marie, 1945, (previously known from North Africa), Uvigerinammina Majzon, 1943 (previously known from the Carpathian Mountains), Aeolostreptis Loeblich and Tappan, 1957, and Eurycheilostoma Loeblich and Tappan, 1957 (described from the Texas Cretaceous) in addition to those first described from the Alaskan strata (Psamminopelta Tappan, 1957; Pallaimorphina Tappan, 1957). The majority of the species occurring in Alaska are strongly facies controlled, the various facies being discussed below. As the facies cross the time lines, they are here given environmental classification. In addition to these faunal facies there are also microfaunal zones which are time indicators. 
These do not afford the detail for local zonation of the more usual Cretaceous markers, but are useful for general local and interregional correlation.

Five main microfossil zones can be recognized, roughly equivalent to the European stages, lower Albian, middle and upper Albian, Cenomanian, Turonian and Senonian. The older (pre-Albian) Alaskan strata contain too few Foraminifera for the recognition of a faunal zone.

Gaudryina tailleuri zone.-This lower Albian zone is characterized by Gaudryina tailleuri (Tappan), G. barrovensis Tappan, and Uvigerinammina athabascensis (Mellon and Wall), which are restricted to it, and Haplophragmoides topagorukensis Tappan and Trochammina eilete Tappan, which also range upward into the next younger zone. This faunal zone is represented in the Torok and Fortress Mountain formations (some 6,000 to 10,000 feet in thickness), and the species are usually relatively rare.

Verneuilinoides borealis zone.-This zone was described by Bergquist (1958a, p. 199). Verneuilinoides borealis Tappan occurs in many facies, coastal, nearshore and offshore, and in considerable abundance. Associated species include Ammobaculites fragmentarius Cushman, the two large and probably closely related species Haplophragmoides gigas Cushman and H. topagorukensis Tappan, Gaudryina nanushukensis Tappan, and Uvigerinammina manitobensis (Wickenden). In the coastal plain subsurface section, calcareous species occur in association with the arenaceous ones of this zone, including Eurycheilostoma robinsonae Tappan, E. grandstandensis Tappan, Pallaimorphina ruckerae Tappan, Conorboides umaitensis (Tappan), Globorotalites alaskensis Tappan, and Gavelinella stictata (Tappan). Rare specimens of various species of Nodosariidae and Buliminidae are found, but not in sufficient numbers to be characteristic. Middle and upper Albian formations represented by this faunal zone include the uppermost part of the Torok formation of the Awuna River region, and the Tuktu, Grandstand and Topagoruk formations, with a combined thickness of from 4,200 to 4,300 feet. Minor subzones can be recognized locally, as within the Umiat field, but these are closely related to the faunal and lithologic facies, and do not hold true over wide areas. These local facies-controlled horizons within the true faunal zones have been discussed in the series of reports on the various oil fields where they have been found useful (Bergquist, 1956, 1958a-c).

Gaudryina irenensis-Trochammina rutherfordi zone.-Also described by Bergquist (1958a, p. 199), this zone is characterized by the two species, G. irenensis Stelck and Wall, and Trochammina ribstonensis sub- species rutherfordi Stelck and Wall. It occurs in the Ninuluk formation of some 650 feet in thickness, almost exclusively of near-shore deposits, and is of Cenomanian age. Because of the regression which began in late Nanushuk time, no true offshore sediments representing this faunal zone are known in northern Alaska.

Pseudoclavulina hastata-Arenobulimina torula zone.-This zone was defined by Bergquist (1958b, p. 261) as being identified by Pseudoclavulina hastata (Cushman) and Arenobulimina torula Tappan, both species being limited to the upper 100 feet of the Ayiyak member of the Seabee formation, of Turonian age. A somewhat expanded definition is used here, and the entire 1,500 feet of the Seabee formation is included within the zone. Possibly a distinct zone or at least a subzone could be defined for the lower part of the Seabee formation, but there are no diagnostic species on which to base such a zone. The absence of the nominal zone markers may actually be a reflection of the black shale facies rather than a true zonal division, as all of the arenaceous Foraminifera which are found rarely in the lower member of the Seabee formation also range upward into the Ayiyak member. Locally a few calcareous species have been found, including Praebulimina seabeensis Tappan, and Neobulimina albertensis (Stelck and Wall), and the Cape Simpson wells penetrate a more offshore facies of the Seabee formation, which contains Heterohelix globulosa (Ehrenberg) and Hedbergella loetterlei (Nauss), the only planktonic Foraminifera found in the Cretaceous of northern Alaska. Even these are among the simplest and longer-ranging species of the planktonic forms, and both species range into younger strata elsewhere, although a zone of their relative abundance occurs in Turonian strata throughout the western interior and Canada correlative with the Seabee formation.

The typical Pseudoclavulina hastata-Arenobulimina torula zone of the Ayiyak member of the Seabee formation, contains, in addition to the zonal markers $P$. hastata (Cushman) and A. torula Tappan, the species Haplophragmoides rota Nauss, $H$. bonanzaensis Stelck and Wall, Textularia gravenori Stelck and Wall, Trochammina diagonis (Carsey), T. ribstonensis Wickenden, and $T$. whittingtoni Tappan, the last three also ranging upward into the next younger zone.

Trochammina ribstonensis-Neobulimina canadensis zone.-The Senonian Schrader Bluff formation contains a number of species which could be designated as zonal markers, but many of these do not occur widely enough to be useful in correlation. In Alaska, Trochammina ribstonensis Wickenden first appeared in the Seabee formation, but it is most characteristic of the present zone. Neobulimina canadensis Cushman and 
Wickenden is typical of the zone, and is associated with Haplophragmoides rota Nauss, Anomalinoides talaria (Nauss), A. solis (Nauss) and Praebulimina venusae (Nauss), all ranging throughout the Schrader Bluff formation of some 2,000 feet. The uppermost member, the Sentinel Hill, contains certain more restricted species which could possibly represent a subzone, such as Nonionella taylorensis Hofker, Eoeponidella linki Wickenden, E. strombodes Tappan, and Trochammina albertensis Wickenden, together with a distinctive radiolarian fauna of some 40 species.

These radiolarian faunas are probably equivalent in age to that reported from near the base of the Pierre shale in northwestern Manitoba (Rüst, 1892), but the latter contains a predominance of Dictyomitra, and is not as varied as the north Alaskan fauna. Unlike the radiolarian faunas of the Nanushuk group and the earlier Upper Cretaceous of Alaska, the Sentinel Hill assemblage is preserved as siliceous tests, rather than as pyritic replacements. This is a reflection of the less rapid sedimentation and more offshore environment of late Colville time. The Sentinel Hill fauna is similar to that described from California (Campbell and Clark, 1944) in having some very large species, and a large number of the Cyrtoidea, in lacking the Spyroidea, and in the abundance of the many jointed Stichocyrtoidea. It differs from the California assemblage in completely lacking the Saturnalis (ringbearing) group of radiolarians. The Distyomitra assemblage, such as that of Alaska, is typical of Mesozoic faunas, but is also characteristic of present-day cold-water faunas, and the climate may have had a limiting effect on the Alaskan Cretaceous assemblages. The Spumellaria in Alaska are represented by genera of the families Liosphaeridae, Stylosphaeridae, Sponguridae, Zygartidae and Spongodiscidae, and the Nasellaria are represented by the Archicorythidae, Lophosphaeridae, Theocorythidae and Stichocorythidae.

\section{CORRELATION WITH CANADA}

The table in figure 15 shows the correlations of Alaskan with Canadian strata. Foraminiferal evidence is here summarized.

\section{LOWER CRETACEOUS}

For the Okpikruak formation, very little information is available, as the extremely restricted fauna contains only long-ranging species, of no value in correlation. The placement in the table is based on the occurrence of megafossils, as noted in the stratigraphic section of this paper. An unconformity above the Okpikruak apparently represents late Neocomian and Aptian time.

The Torok formation and equivalent Fortress Moun- tain formation represent lower and middle Albian. The Torok, at least in certain outcrop areas, is apparently transitional and contains strata (and the fauna) of the lower part of the Nanushuk group, and Topagoruk formation in the subsurface. In many areas of the world foraminiferal species may range throughout the Albian, and very few are restricted to only one part of the Albian, except where due to local conditions of environment. Thus many of the species range throughout Torok, Topogoruk, and Nanushuk strata. A few are more restricted, however.

The lower part of the Torok formation (lower Albian) is equivalent to part of the Loon River and -the Clearwater formations in Canada, as shown by Gaudryina barrowensis Tappan and Conorbina sp., the later part of the Torok formation and the lower part of the Nanushuk group (middle Albian) have many species in common with the Clearwater, Loon River, Spirit River, Peace River, and Mannville formations of Canada, notably Uvigerinammina athabascensis (Mellon and Wall), Verneuilinoides borealis Tappan, Gaudryina barrowensis Tappan, G. canadensis Cushman, G. nanushukensis Tappan, Lenticulina bayrocki Mellon and Wall, Saracenaria grandstandensis Tappan, S. projectura Stelck and Wall, S. trollopei Mellon and Wall, MLarginulinopsis collinsi Mellon and Wall, M. reiseri Tappan, Globulina lacrima canadensis Mellon and Wall, Valvulineria loetterlei (Tappan), and Gavelinella stictata (Tappan). The Grandstand and Topagoruk formations are correlated with the Joli Fou and lower part of the Lloydminster formations of Alberta, and the Ashville formation of Manitoba, on the basis of the Haplophragmoides gigas CushmanH. topagorukensis Tappan group, Ammobaculites fragmentarius Cushman, Uvigerinammina manitobensis (Wickenden) and Miliammina manitobensis Wickenden.

\section{UPPER CRETACEOUS}

The Ninuluk formation contains Trochammina rainwateri Cushman and Applin (a Cenomanian species), Gaudryina irenensis Stelck and Wall and Trochammina ribstonensis rutherfordi Stelck and Wall, all characteristic of the Kaskapau formation of Alberta.

The most easily traced microfaunal zone in northern Alaska is that of the Seabee formation. This limited pelagic fauna containing Heterohelix globulosa (Ehrenberg), widely recorded as Guembelina, and Hedbergella loetterlei (Nauss), also recorded elsewhere as Globigerina loetterlei or $G$. cretacea, occurs in relative abundance at this level in equivalent strata through Canada, the western interior of the United States and into the Gulf Coastal area. Associated with the planktonic species in the Seabee formation are Pseudoclavu- 


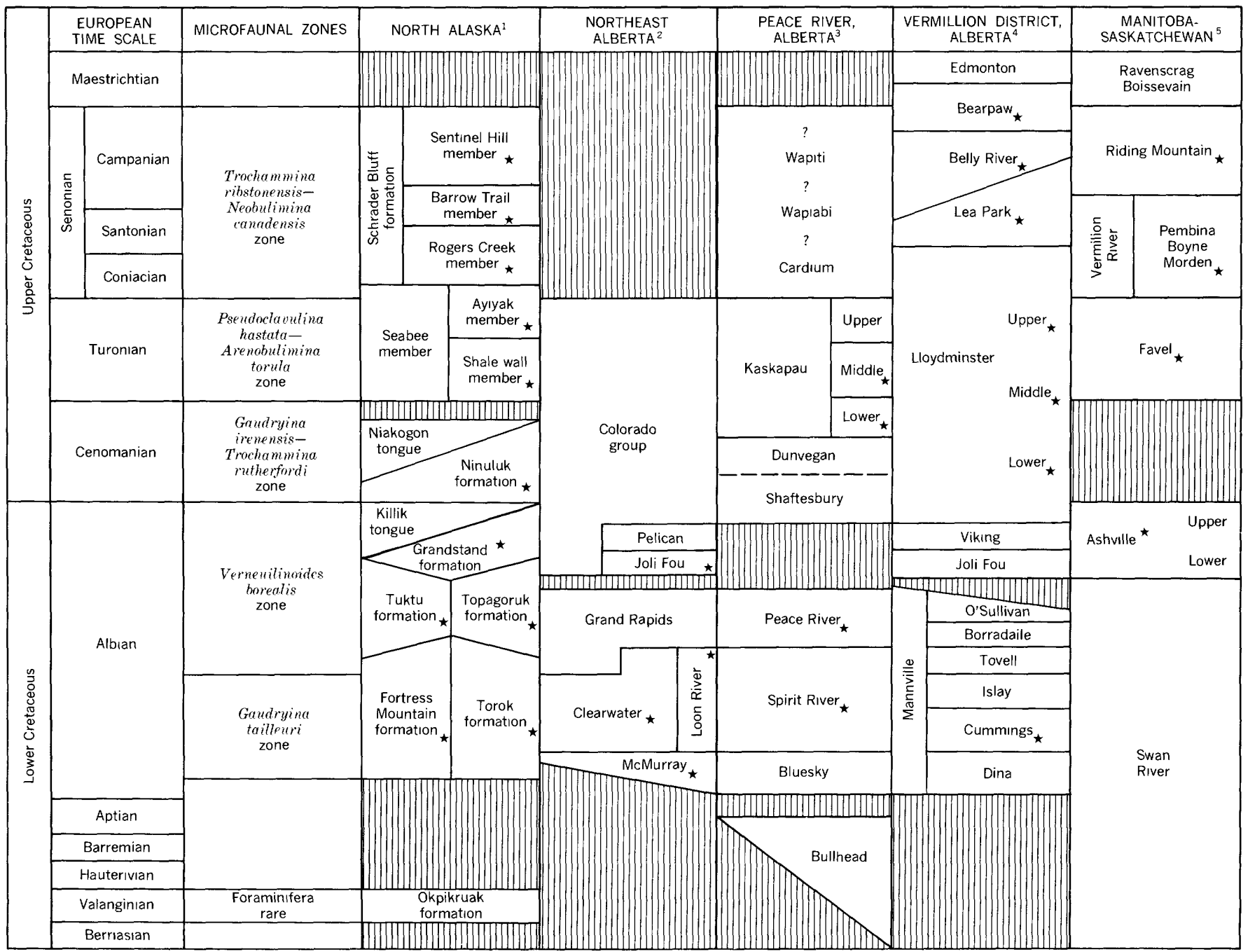

Frgune 15.-Correlation of the Cretaceous of northern Alaska and Canada, on the basis of foraminiferal zones. Formations starred contain foraminiferal species in common with equivalent strata in Alaska. Stratigraphy after (1) Gryc and others, 1956; (2, 3) Henderson, 1954; Stelck and Wall, 1954, 1955; Mellon and Wall, 1956 ; (4) Nauss, 1947; Stelck, Wall, Bahan, and Martin, 1956: (5) Wickenden, 1945.

lina hastata ('Cushman), Miliammina bisobscura Stelck and Wall, Neobulimina albertensis (Stelck and Wall), Textularia gravenori Stelck and Wall, Haplophragmoides bonanzaensis Stelck and Wall and Gaudryina irenensis Stelck and Wall. This assemblage of species occurs in Canada in the middle part of the Kaskapau and upper part of the Lloydminster formations of Alberta, and the Favel formation of Manitoba and Saskatchewan. Bentonites and dark shales are also characteristic of this part of the geologic column.

The Schrader Bluff formation has species typical of the Lea Park, Belly River, and the Bearpaw formations of Alberta, and the Vermilion River and Riding Mountain formations of Manitoba and Saskatchewan. Species found in the lower part of the Lea Park formation occur in the upper part of the Seabee forma- tion, and lower part of the Schrader Bluff formation (i.e., Trochammina ribstonensis Wickenden, Quinqueloculina sphaera Nauss). Trochammina albertensis Wickenden occurs in the Bearpaw formation of Alberta, and in the Sentinel Hill member of the Schrader Bluff formation in Alaska. Spiroplectammina mordenensis Wickenden occurs in the Vermilion River formation of Manitoba and in the Schrader Bluff formation of Alaska. Lea Park-Belly River formation species occur in the Sentinel Hill member of the Schrader Bluff formation, i.e., Ammodiscus cretaceus (Reuss), Haplophragmoides rota Nauss; Praebulimina venusae (Nauss), Neobulimina canadensis Cushman and Wickenden, Eoeponidella linki Wickenden, Anomalinoides solis (Nauss), and A.talarius (Nauss). Also widespread in this late Senonian zone (Campanian) 


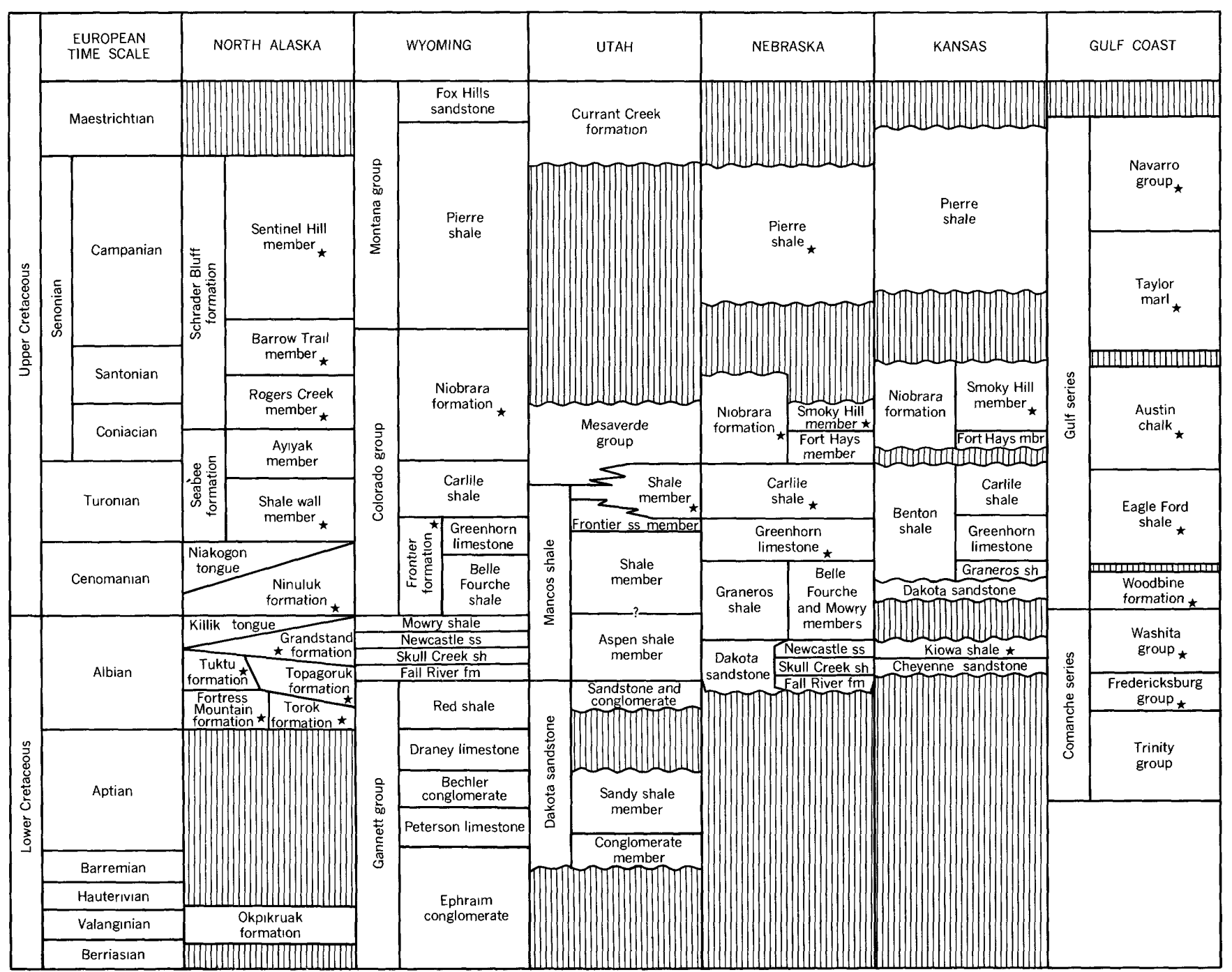

Figure 16.-Correlation of the Cretaceous strata of northern Alaska and the western interior and Gulf Coast of the United States. Formations starred contain foraminiferal species in common with equivalent strata in Alaska. Stratigraphy in part after Cobban and Reeside, 1952; Gryc and others, 1956.

are the very similar and undoubtedly closely related species Nonionella austinana Cushman and N. taylorensis Hofker (new name for $N$. cretacea Cushman) which in Alaska and Canada have a restricted vertical range. Characteristic of this Sentinel Hill microfauna is a radiolarian assemblage of about 40 species. This Sentinel Hill assemblage of Ammodiscus, Praebulimina, Eoeponidella, Nonionella and Anomalinoides with abundant Radiolaria occurs also in the Vanesti tongue of the Belly River formation in Alberta, and in the lower beds of the Riding Mountain formation of Manitoba.

CORRELATION WITH CONTERMINOUS UNITED STATES

Although there are fewer species to the south in common with the northern Alaska faunas, there are recognizable zones both in the western interior, where facies and sedimentary conditions were very similar, and to a lesser extent in the Gulf Coast where local conditions were quite different (fig. 16).

\section{LOWER CRETACEOUS}

An Albian arenaceous fauna was recently described (Skolnick, 1958) from the Skull Creek and Mowry shales of the Black Hills area. Genera represented are Haplophragmoides, Ammobaculites, Ammobaculoides, and Trochammina, and although referred to different species it is possible that a comparison of type material would show at least some of them to be conspecific with the similar-appearing forms in the Nanushuk. The benthonic arenaceous species are more likely to be geographically restricted however, and calcareous forms are extremely rare or absent in the western interior. 
The northernmost Lower Cretaceous calcareous fauna is that of the Kiowa shale of Kansas (Loeblich and Tappan, 1950). Here also over one-half the species present are agglutinated forms, Ammobaculites, Trochammina, Verneuilinoides, etc., none of which appear identical to the Alaskan material, although some of the species are also reported in the Black Hills area in the Skull Creek shale. However, calcareous forms are present which do have a wider geographic range, and Praebulimina nannina (Tappan) and Neobulimina cf. primitiva (Cushman) occur in the Kiowa shale as well as rarely in the Torok and Topagoruk formations of northern Alaska.

Farther south the Albian strata are of a more offshore nature and many calcareous species are present, including a number of planktonic species. Some of the benthonic Foraminifera show a correlation with the Alaskan section. Ammodiscus rotalarius Loeblich and Tappan occurs in the Walnut clay of Oklahoma (Fredericksburg group) and in the Torok formation and lower part of the Nanushuk group of Alaska. Globulina exserta (Berthelin), Neobulimina primitiva (Cushman) and $N$. subcretacea (Cushman) occur in the Goodland limestone (Fredericksburg group) of Texas, and $N$. primitiva also is in the Kiamichi formation, both of mid-Albian age and equivalent to the Torok formation and lower part of the Nanushuk group. The Washita group of Texas is of late midAlbian to early Cenomanian age, and the fauna includes about 15 species which are also present in the Nanushuk group of Alaska. These are Glomospirella gaultina (Berthelin), Reophax minuta Tappan, Spiroplectammina ammovitrea Tappan, Gaudryina cushmani Tappan, G. subcretacea Cushman, Gaudryinella irregularis Tappan, Dentalina strangulata Reuss, Astacolus perstriatus (Tappan), Citharinella ef. tarrantensis (Loeblich and Tappan), Frondicularia cushmani Loeblich and Tappan, F. ungeri Reuss, Oolina apiculata Reuss, Globulina exserta (Berthelin), and Praebulimina nannina (Tappan).

\section{UPPER CRETACEOUS}

Although there are fewer species of Foraminifera in the Upper Cretaceous of Alaska than in the Lower Cretaceous, some of those present are of importance in correlation, as they occur also in the western interior and Gulf Coast regions. Many of the Lower Cretaceous species were of long-ranging Nodosariidae, whereas the Upper Cretaceous fauna includes numerous bulimine and rotaliform species and even two planktonic species.

Trochammina rainwateri Cushman and Applin was described from the upper part of the Woodbine formation of Texas (Cenomanian age) and occurs in the
Ninuluk formation in Alaska. Reophax pepperensis Loeblich was originally described from the late Cenomanian Pepper shale member of the Woodbine formation of Texas, but occurs somewhat higher, in the Seabee formation, in Alaska. Its range may eventually be determined to be greater in Texas also. The Seabee fauna of abundant Heterohelix globulosa (Ehrenberg) and associated Hedbergella loetterlei (Nauss) (= "Globigerina cretacea" of authors) occurs in the Smoky Hill member of the Niobrara formation of Wyoming, Nebraska, and Kansas, the Carlile shale in Kansas, and the Frontier formation of Montana. Species found in the western interior and in the Schrader Bluff formation of northern Alaska are Dentalina basiplanata Cushman (Frontier formation of Utah), Ammodiscus cretaceus (Reuss) from the lower part of the Pierre shale in Nebraska, Praebulimina carseyae (Plummer) from the Pierre shale in South Dakota, and Gavelinella ammonoides (Reuss) from the Cody shale of Wyoming. Haplophragmoides gigas Cushman has been reported from the Carlile formation (Applin, 1933, p. 219) but as this is considerably younger than the type occurrence in Canada, or the range in Alaska, it seems possible that the Carlile species may belong either to $H$. rota Nauss or $H$. carlilensis Fox.

Schrader Bluff species occurring also in the Gulf Coast are: Neobulimina canadensis (Eagle Ford formation to Navarro group) : Marginulina dorsata Cushman from Annona chalk of Texas; Nodosaria fusula Reuss and Praebulimina carseyae (Plummer) from the Austin chalk and Taylor group of Texas; Caucasina vitrea (Cushman and Parker) from the Austin chalk of Texas and Selma chalk of Mississippi; Praebulimina cushmani (Sandidge) from the Austin chalk to Navarro group of Texas; and Trochammina diagonis (Carsey), Dentalina basiplanata Cushman, Nonionella taylorensis Hofker (formerly $N$. cretacea Cushman) and Anomalinoides pinguis (Jennings), all from the Taylor and Navarro groups in Texas. Nonionella taylorensis also has been reported from Tennessee and Anomalinoides pinquis from Cretaceous strata in New Jersey.

\section{CORRELATION WITH EUROPE LOWER CRETACEOUS}

No species in common with Europe were found in pre-Albian beds, but about 39 species of the Torok and Topagoruk formations and Nanushuk group are also found in the European Lower Cretaceous, all but five of them being representatives of the Nodosariidae. Because of the local environment the Nodosariidae are relatively rare in specimens in Alaska. Thirty-two of these appear in the Albian beds of France, England, 
Germany, Netherlands, and Czechoslovakia. A few species range downward also into Aptian or Neocomian strata or upward into the Cenomanian, as many of the Nodosariidae have relatively long geologic ranges. The relationships of the Alaskan formations and the European stages are shown in figure 10. The species and their Alaskan and known European ranges are given below:

Glomospirella gaultina (Berthelin) ; Torok, Topagoruk, Grandstand formations; Albian of France

Lenticulina ingenua (Berthelin) ; Torok formation; Albian of France

L. macrodisca (Reuss); Fortress Mountain, Topagortuk. Grandstand formations; Albian of France, north Germany, Bavaria, Czechoslovakia

L. polygona (Perner); Torok formation. Cenomanian of Czechoslovakia

L. erecta (Perner) ; Topagoruk, Grandstand formations; Cenomanian of Bohemia

Saracenaria spinosa Eichenberg; Topagoruk, Grandstand formations ; Aptian of Germany

S. valanginiana Bartenstein and Brand; Torok formation; Valanginian of Germany

Marginulinopsis jonesi (Reuss); Topagoruk, Grandstand formations; Albian of Germany; Hauterivian of England

Marginulina cephalotes (Reuss) ; Torok, Topagoruk, Grandstand formations; Albian of Germany, England, France, Netherlands

M. inepta (Reuss) ; Torok, Topagoruk formations; Albian of Germany, England, France

M. planiuscula (Reuss); Topagoruk, Grandstand formations; Neocomian of Germany, Albian of France

M. sulcifera (Reuss); Torok, Fortress Mountain formations; Albian of England, Germany

Rectoglandulina humilis (Roemer); Fortress Mountain, Topagoruk formations; Albian of England, France; Aptian of Germany

R. kirschneri Tappan; Torok, Topagoruk, Grandstand formations; Albian of England

Lingulina loryi (Berthelin); Fortress Mountain, Topagoruk formations; Albian of England, France, Netherlands; Valanginian of Germany

L. redivina Berthelin; Grandstand formation; Albian of France; Valanginian of Germany

Nodosaria ef. concinna Reuss; Torok formation; Albian of England, Germany, Netherlands

N. doliiformis Eichenberg; Torok formation; Albian of Germany

N. flexocarinata Khan; Grandstand formation; Albian of England

N. nana Reuss; Torok, Topagoruk formations; Albian of Germany

Dentalina distincta Reuss; Topagoruk formation; Albian of Germany

D. strangulata Reuss; Torok, Topagoruk, Grandstand formations; Albian of Germany, Netherlands; Hauterivian of England

Vaginulina exilis (Reuss) Torok, Topagoruk formations; Albian of Germany

V. cf. plana (Reuss) ; Torok formation; Albian of Germany
Astacolus incrassatus (Reuss) ; Torok, Topagoruk, Grandstand formations; Albian of Germany

A. perstriatus (Tappan); Torok, Topagoruk, Grandstand formations; Hauterivian of England

A. strombecki (Reuss) ; Torok, Grandstand formations; Albian of Germany

Vaginulinopsis grata (Reuss); Torok, Topagoruk, Grandstand formations; Aptian and Albian of Germany

V. muelleri (Reuss); Torok, Topagoruk, Grandstand formations ; Albian of Germany

V. pachynota ten Dam; Torok, Fortress Mountain formations; Hauterivian of Netherlands

V. schloenbachi (Reuss) ; Torok, Topagoruk formations; Neocomian to Albian of England and Germany

Citharina cf. acuminata (Reuss) ; Torok, Topagoruk formations; Upper Neocomian, Aptian, Albian of Germany

Frondicularia ampulla Hucke; Topagortik formation; Albian of Germany

F. cushmani Loeblich and Tappan; Grandstand, Topagoruk formations ; Hauterivian of Germany

F. ungeri Reuss; Grandstand formation; Albian of England, France, Germany

Oolina apiculata Reuss; Topagoruk formation; Albian of Germany, France, Netherlands

Paleopolymorphina gaultina (Berthelin); Grandstand formation; Albian of England, France

Globulina exserta (Berthelin) ; Torok, Topagoruk formations ; Albian of England, France

G. prisca Reuss; Topagoruk formation; Albian of Germany, England

Gavelinella intermedia (Berthelin) ; Torok, Topagoruk formations; Albian of England, France, Netherlands

\section{UPPER CRETACEOUS}

The Ninuluk formation contained no European species and the fauna found in the Seabee formation is largely restricted to North America, except for the two planktonic species. The latter have a relatively long reported geologic range, but these occurrences would need to be verified before they could be used for correlation. The stratigraphic value of the planktonic zone in western North America is based on the widespread floods of these species in the Turonian strata.

A number of the Schrader Bluff species are also reported from Europe or North Africa, most of them from the Senonian of Germany, England, France, Sweden or French Morocco. They are as follows:

Ammodiscus cretaceus (Reuss); Sentinel Hill member; Turonian of Bohemia

Lenticulina gryci Tappan; Sentinel Hill member; Senonian of France

Nodosaria fusula Reuss; Barrow Trail member; Upper Cretaceous of Germany

N. lepida Reuss; Rogers Creek and Barrow Trail members; Senonian of Germany

Praebulimina carseyae (Plummer) ; Schrader Bluff formation; Upper Cretaceous of England and Germany

Gavelinella ammonoides (Reuss); Sentinel Hill nember; Upper Cretaceous of Germany, Sweden

G. tumida Brotzen; Schrader Bluff formation; Senonian of Sweden 
Lacosteina gouskovi Marie; Sentinel Hill nember; Senonian of French Morocco

Nonionella taylorensis Hofker; Sentinel Hill member; Senonian of French Morocco

The correlation of Alaskan strata with Europe is thus less detailed than that with Canada and the United States. The Torok and Topagoruk formations and Nanushuk group contain many Albian species in common with Europe and the Schrader Bluff formation contains a number of European Senonian species. More detail in inter-continental correlation is not possible on the basis of the Alaskan Foraminifera as too many of these benthonic species are controlled more by local facies variation than by age, within these stages. The usual planktonic faunas characteristic of Cretaceous sediments in an offshore environment, on which detailed zonations and correlations are commonly based, are lacking in the Alaskan sequence.

\section{PROBLEMS IN TAXONOMY, AND THE SPECIES CONCEPT}

This study, based on a large number of samples, collected over some 400 miles from east to west and 200 miles from north to south, has emphasized a number of the problems with which a paleontologist must be concerned.

Paleontologists use most of the same methods and criteria as do neontologists (those who study living organisms), in determining the limits of species, and hence have the same problems in determining the amount of morphological variation to be allowed within a nominal species, facies versus time control of species and limitations enforced by the size and reliability of the population sample. In addition, the incomplete fossil records combined with the gradual evolution of species in time have supplied added hazards for the paleontologist, while at the same time denying him the physiological and genetic criteria used by the neontologist.

The isolated pocket of fossils with which the paleontologist usually has to deal-isolated by collection failure or by geological circumstances-needs then to be looked upon as the local and accidental remnant sample of a species whose former extension in time and space is indefinite or unknown. If the biometrical characters of the fossils as a group are adequate to describe that group, there is no difficulty in principle in recognizing that the group falls within the range of a known species, or is sufficiently different to be placed in a new species.-(George, 1956, p. 128).

Unfortunately, at times the material may not be adequate, yet must be studied, and in practice there may be resultant difficulties in recognizing the limitations of the species. In theory, the species may be the only true natural and objective taxonomic unit, yet as stated by Hatch (1941, p. 212), remains "a thing of mistiness and lack of definition. One can be fairly sure when one is getting pretty close to one but never certain that one is actually there."

\section{GENETIC AND PHYSIOLOGICAL CRITERIA}

A species is sometimes defined as representing an interbreeding population, and is referred to as a biospecies. This criterion of interbreeding can be used experimentally to prove or disprove the validity of recent species, but the paleontologist is limited to an interpretation of the fossil record. To belong to an interbreeding population, "a series of fossils must clearly have all been collected from the same geographical province and on the same stratigraphical horizon" (Sylvester-Bradley, 1956, p. 3). However, one should not immediately assume that isolated occurrences are of necessity distinct species, for there may be other reasons, such as the inadequacy of the fossil record, or lack of sufficient collections, which cause the apparent discontinuity.

Genetic criteria are not infallible with living populations, for there are some well known examples of inter-specific breeding resulting in hybrids, not all of which are infertile. A few instances of intergeneric hybrids are also known both in plants and animals. In practice these physiological criteria are not the primary basis for specific delimitation in neontology, regardless of the definition, except as the criteria are reflected in the morphology or ecology of the organisms. An example of such morphologic reflection of genetic criteria is shown by the dimorphism of the Foraminifera. The alteration of sexual and asexual generations is shown morphologically by the microspheric and megalospheric tests recognizable in many species. These different forms have sometimes been described as distinct species and only later been recognized to represent different stages of a single species. Two instances of this have occurred in the present Alaskan studies. The "species" Textularia topagorukensis and Spiroplectammina koveri are now believed to represent the megalospheric and microspheric generations, respectively, of a single species. Dorothia chandlerensis and Terneuilinoides tailleuri similarly are products of the reproductive dimorphism, and not two true species. These problems are discussed in more detail in the systematic portion of this paper.

\section{MORPHOLOGICAL CRITERIA}

A species may also be defined as a group of specimens which are combined on morphological grounds, sometimes known as a morphospecies. Paleontologic species are almost exclusively morphospecies, as contrasted with the biospecies (based on life criteria). 
Thomas (1956, p. 20) stated, "Paleontologists depend on the assumption that morphological differences or discontinuities, coupled with a degree of isolation in space or time of populations statistically demonstrated to be homogeneous, usually express genetic differences and discontinuities". However, paleontologic taxonomy is at different levels or grades of advancement in different fossil groups. There is not yet complete agreement, among the large number of specialists concerned with the economically important Foraminifera, as to the relative importance of the various morphologic characters, and a lengthy history of trial and error may be necessary before agreement is reached. In earlier years, all biserial Foraminifera were called Textularia, now only the agglutinated ones with simple interiomarginal apertures are placed therein and calcareous isomorphs are placed in many different genera, and a number of distinct families. Rhodes (1956, p. 35) stated, "One of the greatest problems of any morphological classification is that it is necessary to select a certain limited number of characters, some or all of which may have different taxonomic value". Shell form was originally used as a generic basis in Foraminifera but it is now regarded as less important than wall structure and composition, and the latter, together with the apertural shape and position, changes in growth pattern with age, etc. are all held to be valid bases for generic differentiation. Specific characters are in general those of ornamentation, size and relative proportions. Disagreement remains as to the relative importance of some of these morphologic features in classification and species delimitation.

Statistical methods are increasingly used with living populations, but this method is more difficult to use with fossil faunas. According to Newell (1956, p. $70)$, "wherever the original collection is small, a few morphological variants may be conspicuous. But if the sample is large, including tens or hundreds of specimens, the variants form a contemporaneous graded morphological series in which individual forms are not conspicuous except by relative abundance".

Statistical methods are excellent in helping to avoid too narrow limits for species, but as not all characters are equally measurable, statistical methods are not an alternative to traditional description, only supplementary to it. Joysey $(1956$, p. 88$)$ discusses the three statistic techniques used in paleontology. These include (1) frequency distributions (the variation in some character in the adult), (2) ratios (shape expressed as a ratio of two characters) and (3) relative growth (showing changes throughout the life of the individual). Difficulties with the first method, which is probably most often used, are that in some cases it may be difficult to determine the adult in fossil specimens and the greatest size variations in the population are those due to age. The young may live in a different environment than the adult of the same species, i.e., the young foraminifer may be planktonic, the adult benthonic. The force of mortality may vary for different ages and due to the environment this might fluctuate from place to place, so that the age distribution in the dead assemblage might differ considerably from that of the living population. Sorting after death may affect size distribution and chances of preservation may vary for different sizes, as a reflection of shape and shell thickness. Bias may also be introduced by the paleontologist, large specimens being more likely to be picked up than the smaller ones, or a certain size or shape may be favored by the collectors' preference or interest in a particular form. Size variations may also be due to environmental factors such as stunting in the brackish environment of much of the Alaskan near-shore deposits.

With the ratio statistical method, difficulties also arise. The ratios will change with age and "in animals that change shape during growth ratios are not a satisfactory basis for the comparison of samples". (Joysey, 1956, p. 91). Many of the Foraminifera change shape and growth pattern with age. In $A m$ mobaculites the early coiled series of chambers is followed by a linear series, with usually an immediate change in chamber size and shape coincident with the change in growth pattern. The same is true for Gaudryina in changing from a triserial to a biserial habit.

The statistical approach based on relative growth, where the presence of individuals of various ages is an advantage, is probably the most satisfactory for paleontologic use.

Even without the actual use of statistical analysis, an informal statistical approach should be helpful in studying foraminiferal species. Examination of large numbers of specimens of all different ages and sizes will show at a glance that many "end-forms" are only members of a completely graded population. Nevertheless many species of Foraminifera have been described with no indication of their abundance or the size of the population sample concerned. In one recent article a group of "species" is illustrated, all from a single sample, which obviously form a gradational sequence or natural population, even though referred to 5 species which were included in two genera!

The practice of setting too close limits on a species is also responsible for the host of new names described with each Cretaceous locality studied, throughout the Rocky Mountain chain. In certain instances the spe- 
cific distinctions in these graywacke type sediments are wholly features influenced by or due to the type of preservation, or due to the differing growth stages. One species was described as new because the holotype has "an extra whorl of chambers and its sutures are not as distinct"; for another "new" and "rare" species the possibility is admitted that it represents "the earlier chambers or ... the ancestral stage" of another one-specimen "species" from the same sample! Another species, a Trochammina. is based on having a "compressed final chamber with the thickened rim", a feature obviously due to crushing in fossilization.

Care must be taken not to use too close measurements for species delimitation. Although very strict limits in measurements are of great importance in certain of the larger Foraminifera, equal detail is worthless and misleading in the more primitive agglutinated forms, which are more notable for their wide variation. As stated by George $(1956$, p. 134), "The closer the similarity demanded between the morphotype (type specimen or holotype of a morphologically defined species) and its conspecific associates, the smaller the proportion of whole population that can be accommodated in the species; and the excluded individuals either remain anonymous, or are each allocated to its own equally narrowly defined species . . The more precise the taxonomy the fewer the individuals that become classified, or the greater the specific disintegration into which the original unitary population falls."

A glance at the accompanying plates will show the wide degree of variation that has been allowed many of the Alaskan species. In the early stages of this study many of these specimens were regarded as representing distinct species, and as many as 15 or 20 species of some genera were believed to occur. With the increasing amount of material available, the gradational forms became more evident, and the resultant species herein recognized are believed to represent actual populations. The wide morphological variation within certain species is due to other factors, geographic, chronologic and ecologic in nature. Size range and coarseness of particles in agglutinated tests are also greatly influenced by local environment. $A m$ mobaculites fragmentarius in a sandy sediment is coarsely agglutinated and the same species in a claystone has a finely agglutinated and smoothly finished wall. In more offshore sediments, specimens of Verneuilinoides boreatis will have twice the average size of those specimens in the very shallow or brackish water thin interbeds within the Chandler formation. Yet some "species" have been separated by one having "grains of considerably larger size than its cementing material", and the other having the grain size "not distinguishable from the matrix". More than one species of a genus in a single sample is suspect, unless there are sufficient numbers of each available to be certain of two populations.

Difficulties arise also with large quantities of material as well as with the "faunas" based on a single sample. A natural population or species thus may be recognized where abundant material is available, and it will nevertheless be difficult to determine whether or not it belongs to a species described elsewhere on a single specimen, without indication of the population characteristics.

Although local zonations have been based on such "restricted" species as mentioned above, they are useless for correlation, as such artificial zonations will not be recognizable elsewhere. Widespread naming of individual variants offers no advantage to the stratigrapher, and such narrow specific limits lead only to "holotype" species which have no "relatives", with the majority of the population left as a residue of unclassifiable forms. Whenever the "leftovers" or "transitional" specimens become a noticeable quantity in a fauna, paleontology has suffered from the description of too many species rather than too few, and the paleontologist has reason to doubt the validity of species as natural categories.

\section{ECOLOGICAL CRITERIA}

There is no doubt that environment has a great effect on the range of species, and thus it is unlikely that the same species will be found in two dissimilar environments, and not in those intervening or gradational ones. Geographic species or subspecies are difficult to recognize in fossil faunas, for the vagaries of fossilization and collection and differences in method of various specialists are sometimes of greater apparent effect than that of original location. Commonly also it is difficult to prove contemporaneity of even adjacent areas, and even more difficult with wider geographic range, so that it is impossible to know whether changes are geographically or stratigraphically controlled. The greater the range of material available, the fewer geographical subspecies will commonly be recognized, for "two geographical subspecies cannot come from the same locality, and two chronological subspecies cannot come from the same horizon", (SylvesterBradley, 1956, p. 3). When these similar species or subspecies are reported in association, it is very probable that some are invalid, and merely represent variants in a single population. Specimens from different localities, used as the basis for distinct species may be found to be completely intergradational when sufficient material is available, and each may represent only an 
extreme variant in one location. When material is available from only a limited area, apparent changes in faunal characters with time may be a result of migration rather than evolution.

In an offshore environment, where conditions are uniform over greater distances, unstable or delicate species may be present, and locally facies control may be less important than evolutionary factors. In such environments faunal zones are easily developed, and the zonation is a true time zonation. Closer to shore, the local facies exert an increasing influence, and the diversified and specialized forms disappear, their place being taken by the simpler, more tolerant species. Because of intertonguing facies along the coastline, a species may occur locally at one horizon, and in nearby areas where this time interval is represented by continental facies, the faunal zone may appear stratigraphically above or below, or both. As stated by Newell $(1956$, p. 70$)$, "The majority of biologic groups are so limited to particular stratigraphic facies that it seems clear that they favored a particular environment, gradually migrating from region to region with lateral shift in pliysical conditions of the environment. Usually, related but slightly different forms are found in adjacent regions".

In the relatively adverse environments of the north Alaskan Cretaceous seas, where rapid sedimentation formed inter-tonguing marine and brackish or freshwater deposits, only the extremely tolerant and simple species of Foraminifera lived. These not only had a high ecological valence (adaptability), and therefore greater facies range, but also were slower evolving and showed a greater amount of morphologic variation. More than usual restraint must therefore be used in creating new specific names under such circumstances.

It seems probable that many of the nominal species described from the isolated outcrops in Canada and in the western interior of the United States, belonging to certain arenaceous genera, e.g., Haplophragmoides, Ammobaculites or Trochammina, conld be proved conspecific, and a host of names suppressed as synonyms, if sufficient material could be obtained from intervening areas. From Albian to Senonian time there was probably a connecting seaway from Alaska to the Gulf Coast, as evidenced by a number of species common to these regions, but in the intervening areas different names have been given to "form species" in each isolated outcrop. Not enough material has yet been available in some of these regions to determine the true nature of the populations. Although a comparison of the faunal lists of these regions shows no basis for interregional correlation, as no species are reported in common, a comparison of the faunas themselves gives a far different impression, for the similarities are immediately evident.

Much greater attention must be given to foraminiferal populations and their ecological relationships, both in living assemblages and in fossil ones, in order to evaluate the species and the influence of ecology on their distribution. Ager (1956, p. 109) stated that "Geographical studies on the largest possible scale are essential to the true understanding of any fossil species, and are the most likely lines of attack for the accurate unravelling of any fossil lineage."

\section{EVOLUTIONARY CRITERIA}

In addition to the criteria discussed above, which are as important in neontology as in paleontology, another factor is present and of importance in fossil species. Because of the added dimension of time, the paleontologist is working with dynamic rather than static species. Termed chronospecies, they may show a gradual change in morphologic features with time. It has even been suggested that a complete paleontologic record would show all taxonomic distinctions to be as arbitrary as the division of a road by milestones, and each "species" to show a completely gradational transition to the next younger "species". (Haldane, 1956, p. 95). Even if this were true in theory, and not all evolutionists agree on such gradual evolutionary changes, in practice such uninterrupted sequences are non-existent, and vertical discontinuities are not exceptional, they are the rule. The problem is not that of too much available material, but generally the reverse. When material is available over a considerable stratigraphic range, the control by local facies becomes minimized. Species may evolve rapidly and become "advanced" in one character, while retaining other primitive characteristics, and a lineage may diverge, with the branches showing the evolution of a single character in opposing directions, eventually resulting in two unlike "species". The species Trochammina rutherfordi Stelck and Wall, and T. ribstonensis Wickenden were described from different stratigraphic levels in Canada, and in the type areas and levels the species can be readily distinguished. In northern Alaska, these two species appear in approximately the same stratigraphic relation as in Canada, but in addition similar forms occur in all the intervening strata, so that a complete gradation is shown between them. Although originally considered to be distinct species, their gradual transition in Alaskan strata suggests that one would be better considered as a stratigraphic subspecies, hence $T$. rutherfordi is here regarded as a subspecies of $T$. ribstonensis. 


\section{BIOSTRATIGRAPHICAL RELATIONS OF THE CRETA- CEOUS FORAMINIFERA OF ALASKA}

It is immediately apparent that the microfaunas of the Alaskan Cretaceous strata have a considerably different aspect than do those of Cretaceous strata in other well known areas of the United States and Europe. The dominance of arenaceous species in the outcropping strata of the foothills area results in a different faunal aspect than that shown by the equivalent subsurface material of the coastal plain. These very different assemblages made correlation difficult before intermediate control was established and the facies relationships better understood.

The paucity of faunas in the outcropping material is not due to secondary weathering as is commonly true of the west coast Cretaceous sediments (e.g. California), for in the Umiat area, where material was available from outcrops along the Colville River, from depths of 20 to 200 feet from seismic shotholes, and from the deeper subsurface of the Umiat wells, there was no appreciable difference in faunal character between the surface and subsurface. In fact, the same alternation of barren and fossiliferous zones was found, and a number of horizons (local "tops") could be recognized within the main faunal zones, and traced throughout the subsurface and to the nearby outcropping strata. The relative unimportance of the surface weathering was further emphasized by the collection of a series of samples in the Awuna River region, from weathered clays and residual soils. These samples contained identical arenaceous faunas to those of the fresher shales, and some of the specimens here illustrated were from these residual soils.

As surface weathering was thus proved to be of little local importance, another explanation was required for the faunal differences between the foothills outcrops and the coastal plain subsurface, and ecological control appeared highly probable. The arenaceous faunas certainly do not indicate abyssal depths, as do certain modern arenaceous assemblages, for in the foothills area the faunas are found in strata intercalated with coals and crossbedded sandstones.

A study of the faunas in the various areas in northern Alaska showed a close correlation with the local lithologic facies, for in the rapidly changing environments represented, the foraminiferal populations are facies controlled to a considerable degree.

In the open ocean, the only barriers to foraminiferal migration are those of temperature, and species tend to be widely dispersed. In shallow water, barriers include intervening oceanic depths, peninsulas of land, unfavorable sea bottom, suspended sediment and water freshening at river mouths, in addition to the temperature control. The range of individual species in the near-shore environments is thus smaller, and the number of species of each genus is larger. Geographic species and subspecies may replace each other in adjoining areas.

Because of the various types of barriers, many interrelated factors may affect the foraminiferal distribution, and the order or degree of their importance is difficult to determine. With progressively poorer living conditions, either in space or time, a notable reduction in faunal variety occurs. The closer the conditions approach the limiting values, the more striking are the common characters of the faunas. A typical turbidity controlled foraminiferal fauna consists of a few large and robust arenaceous species. A fauna limited by shallow water or reduced salinity is characterized by stunted forms of one or two species, which may be present in large numbers however, because of lessened competition.

\section{LIMITING ENVIRONMENTAL FACTORS}

The various influences limiting distribution, diversification, and quantities of marine organisms are well known. The following discussion is therefore limited to those influences which seem to be of controlling importance in the northern Alaskan Cretaceous assemblages.

\section{DEPTH}

The majority of the Alaskan Cretaceous sediments are relatively shallow-water deposits, as shown by the poorly sorted intertonguing marine and nonmarine beds and intercalated coals. The near-shore shallowto brackish-water deposits commonly contain only one or two species. However, because of the lessened competition these one or two species may become numerous in individuals, providing the food supply is sufficient. The complete elimination of a species is frequently preceded by the production of stunted forms, and these few species may be considerably smaller than in a more normal environment. Some interbeds of the Chandler formation have a fauna consisting of numerous stunted Verneuitinoides borealis and little else, and Ninuluk samples have an abundance of Trochammina and Gaudryina, with no associated fauna. It is quite possible that some of these beds may represent deposits in intertidal pools.

Abrupt changes occur in the ecological conditions within the tide pools, resulting in an impoverished food content. There also are greater temperature ranges, and the result is that in all latitudes populations of Foraminifera in the intertidal zone have few species in common with those living below tide level. 
A more diversified fauna occurs in the slightly deeper, more offshore deposits, although there are no true deep-water species, and no planktonic ones except in a limited area of the Seabee formation. As planktonic shells may be carried by ocean currents into many shallow water sediments, their absence suggests the possible lack of an open sea connection during much of the Cretaceous, or more probably, the presence of offshore currents so strong as to exclude them.

\section{SALINITY}

Stenohaline organisms are those which are affected by very slight changes in salinity. Euryhaline ones can withstand a considerable degree of variation.

In coastal areas of low salinity the numbers of species are correspondingly reduced, but the tolerant species show a decided increase in number of individuals. These species in the brackish waters are commonly cosmopolitan species (with a wide geographic range), and in spite of their large numbers they are usually smaller than normal in size (Myers and Cole, 1957 , p. 1076).

Those Foraminifera which secrete tests of calcite are in general stenohaline, as the ocean salts must be available for them, and a coastal environment where the oceanic waters are diluted by river influx may be lower in calcium carbonate as well as sodium chloride. It has been shown experimentally that when distilled water was added to the original sea water containing a culture of calcareous Foraminifera, to counteract evaporation, the calcareous tests tended to become transparent and "chitinous" rather than calcareous. Thus if some were to exist in the low salinity environment, the "chitinous" tests would be less likely to be preserved, resulting in a fossil arenaceous assemblage (Revelle and Fairbridge, 1957, p. 263).

Just as the calcareous Foraminifera are limited in a brackish environment so is the amount of cementing matrix in the aggultinated species of these remnant faunas. This results in a poorly cemented test, quite susceptible to crushing and distortion in various planes, and commonly rough textured. Such crushed and distorted specimens are characteristic of much of the Cretaceous fauna here described.

\section{SUBSTRATUM}

In a study of Recent Arctic Foraminifera (Loeblich and Tappan, 1953, p. 14) the character of the bottom was considered as the most important factor in the distribution of Foraminifera. The narrow beach area (sandy) is sparsely populated. The mud zone farther out also contains relatively few species, probably because of the lack of oxygen, due to its consumption by decaying organic matter. Where gravel and cobbles are mixed with the mud, the heterogeneous bottom allows a better supply of oxygen and the population increases. The offshore gravel zone has the most diversified fauna. Records showed that these zones were not static, but together with their characteristic populations had fluctuated over a distance of some miles in a few years. Where the mud zone encroached on the earlier gravel zone dredging brought up only dead shells. In the Cretaceous sediments, a parallel zonation is noted. For example the sandy marine interbeds in the Chandler formation, representing fossil beach areas, contain poor faunas of one or two species; the mud zone, represented by the shales in the foothills province also has an extremely limited arenaceous fauna. The Grandstand formation sandy clays and the pebble shales of the Torok formation of the Barrow-Simpson region show the most diversified fauna of this part of the section and contain numerous Nodosariidae, rotaliform genera, Turrilinidae, etc., in association with the arenaceous species.

\section{FOOD SUPPLY}

Foraminifera utilize microflora living on the seabottom for their food. Diatoms are probably the major food source but decaying animal tissue may also be used. Because they depend on the plants as food, the Foraminifera are indirectly influenced by the amount of light available, and grow most rapidly during the times of maximum plant growth, the spring, summer, and fall seasons in the Arctic regions. They remain relatively dormant during the winter months (Myers, 1943, p. 441). In addition to the seasonal variation, foraminiferal growth is greatest at a given time when food is most abundant and where feeding activities are not interrupted by the adverse conditions resulting from surf and tide changes (Myers, 1943, p. 443). Such interruptions in feeding activity in shallow, near-beach deposits, probably are a causative factor in the reduced size of the specimens found there.

\section{TEMPERATURE}

The temperature factor is important in the open sea, but apparently does not greatly influence zonation in shallow or partially enclosed basins, as the temperature variation is too small to be effective. The Foraminifera present in the northern Alaska Cretaceous sediments are not good indicators of temperature, for all belong to extremely tolerant genera. The presentday species of these genera or closely related ones occur in all latitudes.

\section{TURBULENCE AND CURRENTS}

These are the principle forces affecting the distribution of the northern Alaska Cretaceous Foraminifera. 
When surface sediments are thrown into suspension by turbulence, the lesser density and the shape of Foraminifera allow them to settle more slowly than quartz sands so that they rest at the surface. In muddy sediments they may be buried. If buried to a depth not exceeding 5 to 7 times the diameter of the test in sandy sediments they are able to escape. If buried more deeply, they die when the oxygen supply becomes insufficient ". . . a condition often made evident by the blue-black sulphides deposited on the walls of the tests or by the presence of iron pyrites within the tests" (Myers, 1943, p. 453). The presence of turbulence in the Cretaceous seas is evidenced by the number of pyrite casts of Foraminifera and Radiolaria in the sediments in the foothills area. According to Myers, "turbulence and current action in the sublittoral zone are responsible for the destruction of at least 80 percent of all individuals that survive beyond the juvenile stage. In tide pools . . a similar proportion of the population is also destroyed by these same agencies."

Currents may also strongly affect the faunal assemblage. In many shallow-water regions of the world, planktonic Foraminifera are washed in after death, and may even form a prominent part of the assemblage. Their complete absence in the Lower Cretaceous may be due to strong offshore currents. Turbidity currents are thought to be a major factor in the deposition of the Alaska Lower Cretaceous strata, and the strong currents responsible for the shelf building at this time may have prevented any influx of material not indigenous to the area.

During Seabee time, the adjacent coast was apparently lower and lesser amounts of sediment were carried into the depositional basin. The paper shales show that turbulence was not an important factor, and planktonic species were transported into the area for a limited time.

\section{TURBIDITY}

The depth to which light penetrates in the sea is limited by the turbidity, and as photosynthesis is reduced or eliminated in highly turbid water, the food supply of the Foraminifera, the microscopic plant life, is thereby limited. This has the greatest inhibiting effect on the calcareous species. Where large quantities of clay are discharged into the seas during heavy rains, the material may remain in suspension for days or even weeks. If this is silted out in such quantities as to cover the Foraminifera with a heavy film it will inhibit their occurrence. Stainforth (1952, p. 43) presented evidence that arenaceous foraminiferal assemblages dominated by large robust species are turbidity controlled. This type of fauna occurs in facies known to represent a considerable depth variation, and the most obvious common characteristic was the flysch nature of the sediments, suggesting turbidity of the depositional environment. Foraminiferal families characteristic of this type of environment, according to Stainforth $(1952$, p. 42$)$, are the Rhizamminidae, Reophacidae, Ammodiscidae, Lituolidae, Textulariidae, Verneuilinidae and Valvulinidae. Examples of all of these are dominant faunal elements in the Nanushuk group, and turbidity was undoubtedly one of the more important limiting environmental factors.

Turbidity currents have been proposed as a major depositional force for the fine grained Albian and younger Cretaceous sediments in Alaska (Payne and others, 1951, sheet 3), and an important element in the building of the continental shelf, then beginning in the Arctic region.

The turbidity controlled arenaceous faunas of moderately deep water differ from the stunted ones of the shallow water or intertidal environment. Typically large robust species occur in the Nanushuk sediments, such as the Haplophragmoides topagorukensis- $\boldsymbol{H}$. gigas group, Ammobaculites fragmentarius, A. wenonahae, Uvigerinammina manitobensis and Miliammina manitobensis. Uvigerinammina has been previously known only from the Carpathian flysch, from beds of probable Cenomanian to Paleocene age, and the genus is apparently restricted to this environment. It is associated with an arenaceous foraminiferal fauna in both hemispheres, with beds of tuff and flysch type sediments, and megafossils such as Inoceramus.

In the Upper Cretaceous large quantities of bentonite and tuffs indicate that ash falls were an important constituent of the turbidity. The high silica content of these sediments is also reflected by the relatively abundant radiolarian fauna in the Schrader Bluff formation. Scattered radiolarians occur as pyritic or glauconitic casts throughout much of the Cretaceous system, but siliceous tests occur only in the later part. The abundant supply of silica from volcanic deposits has been considered to be an important cause of an unusually large development of silica secreting organisms such as the Radiolaria (Bramlette, 1946). They are not considered necessarily indicative of deep water, but radiolarian deposits may also be formed at moderate depths, and near shorelines.

\section{BIOFACIES IN THE CRETACEOUS OF ALASKa}

Faunal facies, closely related to the lithologic facies, are recognizable for certain depositional environments. The faunal facies in the Cretaceous of Alaska are somewhat different from those in a normal depositional 
S.

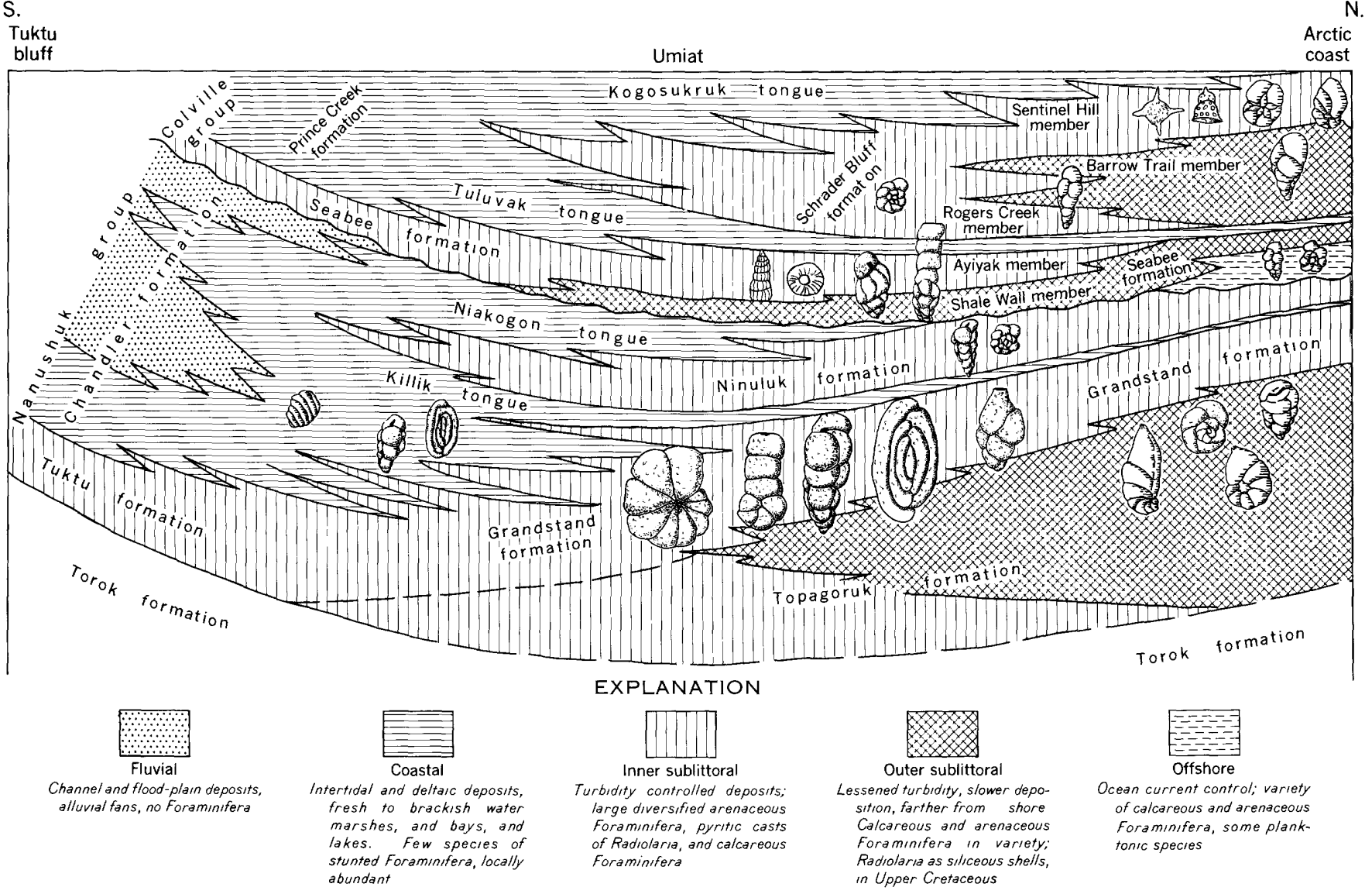

Figure 17.-Restored facies cross section of the Nanushuk and Colville groups, showing lithologic and faunal facies. Lithologic facies modified after Grye, Patton and Payne, 1951; Gryc and others, 1956.

environment, and are illustrated in figure 17. This is a restored facies cross section from Tuktu Bluffs on the Chandler River, north to the coast of the Arctic Ocean, near the mouth of the Colville River. The lithologic facies are based on a similar diagram from Gryc, Patton, and Payne (1951, p. 165), with the faunal facies superimposed. These facies zones are distinct from the faunal time zones used in correlation (such as the Verneuilinoides borealis zone), hence to avoid confusion are not given zonal names based on species, but on the type of depositional environment. These faunal facies cross time lines, and a given facies may contain one group of species in the early Nanushuk group, and a different group of species in the Colville group, although of similar environmental type. The facies indicate transgression of the sea in early Albian time, with gradual regression beginning with the Nanushuk group, so that offshore facies are covered by coastal deposits and these in turn by nonmarine sediments. A number of minor transgressions and regressions occurred, with a major regression at the close of the Nanushuk group deposition (end of
Cenomanian time). The unconformity is an angular one, and in some areas canyons were developed in the Nanushuk sediments before deposition of the Colville group began. With the Turonian transgression, a widespread inundation occurred, the resultant sediments being well bedded, and the fauna of offshore character.

The only planktonic assemblage of the north Alaskan Cretaceous occurs in the Turonian Seabee formation of the northern wells, suggesting the presence of an open sea connection, or perhaps stronger ocean currents toward shore with the lessened influx of sediments from the lowered adjacent land areas.

Regression began again in the Senonian, and the Early Cretaceous pattern of gradual emergence was repeated, with continuing broad fluctuations of the shoreline. Complete emergence was attained by the end of the Senonian and apparently no later sedimentation occurred over most of this area until Pleistocene time, although some Tertiary sediments are known in the eastern part of northern Alaska.

The major depositional environments, resulting in 


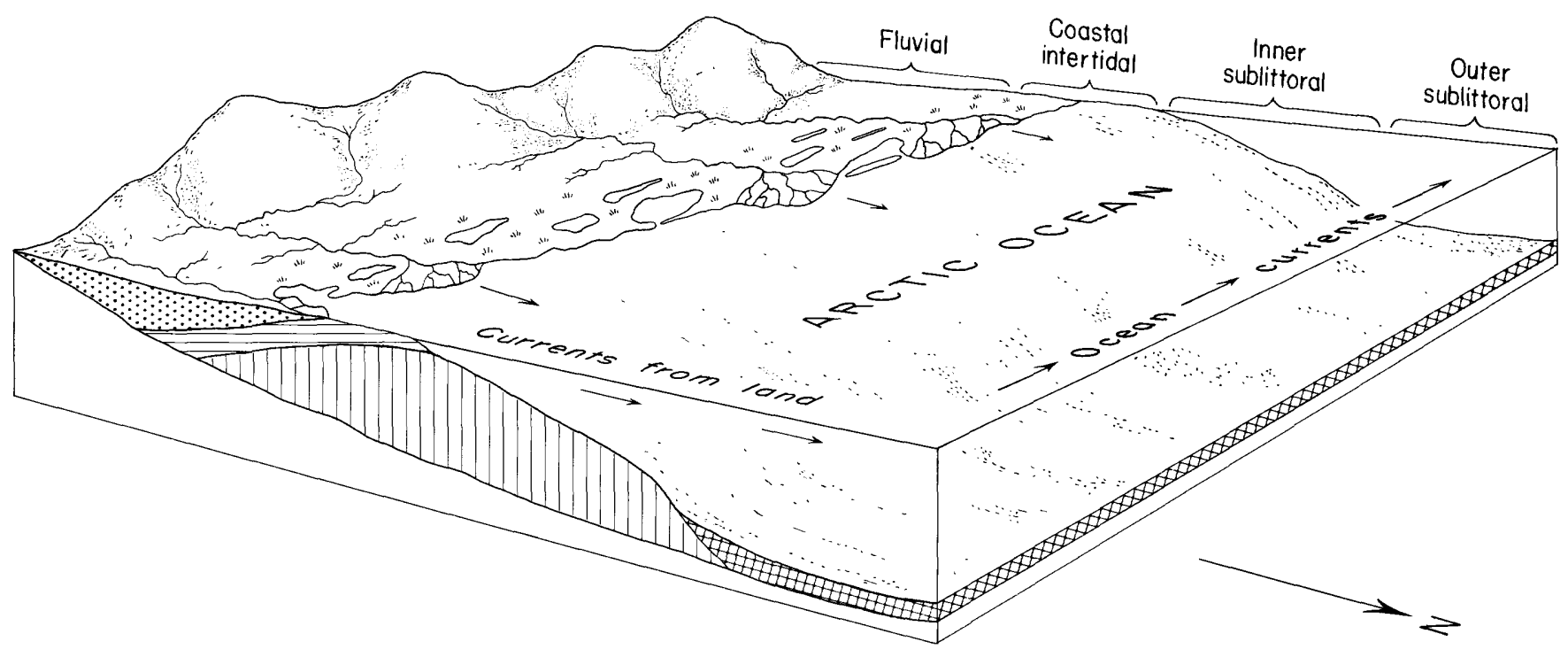

EXPLANATION
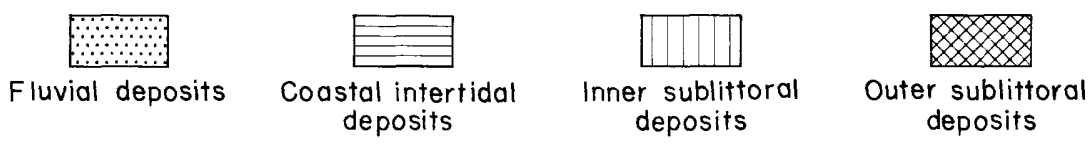

Figure 18.-Diagram showing depositional environments in northern Alaska during the Cretaceous. Minor fluctuations of the coastline and of the depositional environments resulted in the intertonguing lithologic and faunal facies shown in figure 17.

these lithologic and faunal facies are shown diagrammatically in figure 18 .

\section{INLAND FACIES-FLUVIATILE ENVIRONMENT}

Fluviatile sediments were deposited in channels and floodplains, and in alluvial fans. The well-washed sandstones and conglomerates of this facies are massive bedded, persistent, and show large-scale cross bedding. Faunal remains are absent. The inland portions of the Chandler formation are of this nature.

\section{COASTAL FACIES-SUPRALITTORAL AND IITTORAI (INTER-} TIDAL) ENVIRONMENT

The supralittoral (above high tide) and littoral (intertidal) deposits are lithologically gradational and differ only in faunal content. The supralittoral environment includes the fresh-water marshes, bays, lagoons, and lakes. Fresh-water pelecypods (Unio) occur, and the microfauna consists of fresh-water ostracodes and charophyte (algae) oogonia. Charophytes have been found in the outcropping Killik and Niakogon tongues of the Chandler formation, in cuttings in the Killik tongue in Umiat test well 1 , from $1,000-1,080$ feet, and in cuttings at 2,520 to 2,530 feet, within the Topagoruk formation in Simpson test well 1 , but probably as contamination from somewhat higher in the section.
The intertidal zone (littoral) includes the area of tidal pools and brackish water, and contains a microfauna of a few species of arenaceous Foraminifera. As is typical of a brackish environment these few species are generally stunted in size yet may become abundant in numbers. In beds of the Killik tongue and intertonguing Grandstand formation, this facies locally contains large numbers of Verneuitinoides borealis, Uvigerinammina manitobensis, Gaudryina canadensis, Miliammina manitobensis, or Saccammina lathrami, but seldom more than one or two of these species at a single locality. The same facies in the Ninuluk formation may contain Saccammina, Gaudryina irenensis, Trochammina ribstonensis rutherfordi, or T. rainvateri. In the later Cretaceous the intertidal zone is represented locally by the Rogers Creek or Barrow Trail members of the Schrader Bluff formation, or local tongues of the Prince Creek formation, such as in Umiat test well 11. Faunally it is again characterized by local abundance of one or two species, containing a similar assemblage of stunted specimens of Haplophragmoides rota, Verneuilinoides fischeri, Gaudryina irenensis or Trochammina ribstonensis. Lithologically this environment is represented by wellbedded shales, sandstone, and conglomerates deposited along the coast in barred basins, with interbedded rela- 
tively pure coal, bentonite, tuff, and ironstone deposits. Beach and bar deposits are also included here.

\section{OFFSHORE FACIES-INNER SUBLITTORAL ENVIRONMENT}

In the northern Alaska area, this environment is chracterized by high turbidity and considerable turbulence, with strong currents outward from the land. Turbidity is indicated by the poorly sorted sandstones with muddy matrix, grading northeastward into silty shale, the predominant facies, with pyroclastics mixed in the sediments rather than in distinct beds. Relatively high initial dips indicate the "progressive foreset deposition by turbidity currents that moved down the continental slope" (Payne, 1951, sheet 3) in early Nanushuk time. The later strata are more nearly horizontal and probably represent topset deposits on the shelf, near wave base. Thus the Grandstand formation is more sandy in character than the underlying Topagoruk. In the Oumalik and Umiat areas the Topagoruk and Grandstand formations are in this facies. Turbidity-controlled microfaunas consist of large arenaceous species, such as Haplophragmoides gigas, H. topagomkensis, Ammobaculites fragmentarius and $A$, wenonahae, robust Verneuitinoides borealis, Uvigerinammina manitobensis or Miliammina manitobensis. These species are geographically widespread also, ranging from Alaska through much of western Canada. There is a greater diversification of species than in the coastal facies. With the arenaceous species occur a number of pyritic replacements of radiolarians and calcareous foraminifers. The pyritic casts are indicative of rapid burial, such as might be expected in this environment.

Megafossils include various mollusks, such as Inoceramus and some cephalopods. Sediments of this type are typically developed in the Topagoruk and Grandstand formations and equivalent strata.

OFFSHORE FACIES-OUTER SUBLITTORAL ENVIRONMENT

Somewhat farther from shore, where turbulence and turbidity exerted less control, and deposition was less rapid, cleaner sands and better sorting are characteristic. Pyroclastics again occur in distinct beds. The faunal assemblage is mixed, with about equal numbers of calcareous and arenaceous species of Foraminifera and in much greater diversification of species. Because of the increased competition, individual species are less abundant than in the preceding zone, however. There is no sharp contrast between the two zones, but a gradual decrease in the turbidity allows a gradual increase in faunal variety. Calcareous spe- cies include representatives of the Nodosariidae, and various rotaliform Turrilinidae, Caucasinidae genera, the arenaceous species being largely those of the inner sublittoral environment in fewer numbers. Radiolarians are present as silicious tests (especially in the Schrader Bluff formation of the Fish Creek area) and a few occurrences of glauconitic replacements occur, but the pyritic casts are not characteristic of this environment. Representative strata include the Topagoruk and Grandstand formations in the coastal wells at Barrow and Cape Simpson, and the Schrader Bluff formation locally nearly as far south as Umiat in Sentinel Hill core test 1. The Seabee formation is largely in this facies, but seaward grades into the next faunal facies.

\section{OFFSHORE FACIES-OPEN-SEA ENVIRONMENT}

The Seabee formation characterizes this facies, with fine-grained, fissile, black and bituminous shales, thinbedded pyroclastics and dark-gray limestones. Megafossils include ammonites, Inoceramus, fish scales, and fishbone fragments. This facies is not indicative of deep water; a lessened influx of sediments from the land, because of pre-Turonian erosion, resulted in slower deposition. The faunal assemblages in the southern region are similar to those of the previously discussed offshore, outer sublittoral environment, including mixed calcareous and arenaceous assemblages. In addition, ocean currents were of proportionately greater influence, so that planktonic Foraminifera entered the region, and became locally abundant in the sediments now penetrated by wells near Cape Simpson. Although planktonic assemblages generally indicate an open sea connection, it is possible that they were excluded from the area by offshore currents and rapid sedimentation in the earlier Cretaceous, rather than by an absence of ocean connections. Some of the Albian arenaceous species appear identical from the Gulf Coast to Alaska, but the more delicate planktonic species common in the Gulf Coast region apparently were excluded by the turbidity-controlled deposition. Only during the brief Turonian sedimentation, with low-lying adjacent lands, did the planktonic Foraminifera migrate through the Rocky Mountain region into Canada and Alaska. In the western interior of the United States, planktonic faunas persisted (in the Niobrara, etc.) but by this time in Canada and Alaska they were again environmentally restricted, and the outward currents apparently prevented even the washing in of empty shells after death. 


\section{SYSTEMATIC DESCRIPTIONS OF FORAMINIFERA}

\section{Family RHIZAMMINIDAE Cushman, 1927}

Genus Bathysiphon Sars, 1872

Bathysiphon brosgei Tappan

Plate 29, figures 1-5

Bathysiphon brosgei Tappan, 1957, U.S. Natl. Mus. Bull. 215, p. 202, pl. 65, figures 1-5.

Test free, elongate, consisting of an undivided tubular chamber, commonly straight but rarely somewhat irregularly bent or curved; wall finely agglutinated, with considerable cement, rather smoothly finished, surface may have transverse growth wrinkles, irregularly spaced; aperture rounded at the open end of the tubular chamber.

Length of holotype $1.22 \mathrm{~mm}$, greatest breadth 0.31 $\mathrm{mm}$. Other specimens range from 0.34 to $1.66 \mathrm{~mm}$ in length and from 0.10 to $0.32 \mathrm{~mm}$ in breadth.

Remarks.-This species differs from the associated Bathysiphon vitta Nauss in being more slender, about one-third to one-fifth as broad, and in having a somewhat more roughened surface. It is similar in appearance to the figures of $B$ athsiphon alexanderi Cushman, but an examination of the type specimens of the latter shows them to be inorganic limonitic sticks, and not Foraminifera.

Bathysiphon brosgei occurs throughout the Colville and Nanushuk groups and the underlying Fortress Mountain formation.

It was named in honor of W. P. Brosgé, geologist, U.S. Geological Survey.

Types and occurrence.-Holotype (USNM P4216), figured paratypes (USNM P4217 a, b) and unfigured paratypes (USNM P4218) from a core at 2235-2245 feet, unfigured paratypes (USNM P4219) from a core at 1247-1267 feet, unfigured paratype (USNM P4220) from a core at 1197-1207 feet, all from the Topagoruk formation in Simpson test well 1.

Unfigured paratype (USNM P4221) from well cuttings at $3650-3660$ feet and unfigured paratype (USNM P4222) from well cuttings at 3930-3940 feet, both from the Topagoruk formation in Umiat test well 1.

Unfigured paratypes (USNM P4223) from well cuttings at 2640-2650 feet and figured paratypes (USNM P4224, a, b) from well cuttings at 2670-2680 feet; all from the Topagoruk formation in Umiat test well 2.

Unfigured paratypes (USNM P4225) from the Fortress Mountain formation, field sample 49A Pa 125.

Unfigured paratypes (USNM P5902) from field sample 47 A St 29, from the Sentinel Hill member of the Schrader Bluff formation.
Unfigured paratype (USNM P5903) from field sample 47A Dt 364, from the Sentinel Hill member of the Schrader Bluff formation.

Unfigured paratypes (USNM P5904) from a core at 1090 to 1100 feet, in the Sentinel Hill member of the Schrader Bluff formation, in Sentinel Hill core test 1.

Unfigured paratypes (USNM P5905) from field sample $46 \mathrm{~A} \mathrm{Gr} 98$, from the lower part of the Ignek formation.

\section{Bathysiphon vitta Nauss}

Plate 29, figures 6-8

Bathysiphon vitta Nauss, 1947, Jour. Paleontology, v. 21, no. 4, p. 334, pl. 48, fig. 4 .

Test an elongate tube, commonly compressed in preservation, with numerous transverse growth constrictions, but no internal partitions; wall finely agglutinated, with considerable cement and rather smoothly finished, characteristically white to gray in color; aperture at the slightly constricted open ends of the tubes.

Length of hypotype of fig. $6,2.56 \mathrm{~mm}$, breadth 0.44 $\mathrm{mm}$; length of hypotype of fig. $8,1.51 \mathrm{~mm}$, breadth $0.63 \mathrm{~mm}$; length of hypotype of fig. 7, $3.54 \mathrm{~mm}$.

Remarks.-Nauss recorded $B$. vitta from the lower half of the Lea Park shale, where it occurs with Epistomina fax Nauss, Anomalinoides solis (Nauss), Neobulimina canadensis Cushman and Wickenden, and Bolivina elkensis Nauss. The Alaskan specimens appear identical in appearance, but are from older beds. It is most abundant in the Grandstand and Topagoruk formations (Albian) and there are no unquestioned records of it in the Turonian and Senonian, Seabee and Schrader Bluff formations, which are the age equivalent of the Lea Park.

Types and occurrence.-Hypotype of fig. 7. (USNM P5906) from well cuttings at 2050 to 2060 feet, hypotype of fig. 8 (USNM P5907) and unfigured hypotypes (USNM P5908) from a core at 2235 to 2245 feet, unfigured hypotypes (USNM P5909) from a core at 1030 to 1040 feet, and unfigured hypotypes (USNM P5910) from a core at 2530 to 2535 feet, all from the Topagoruk formation in Simpson test well 1.

Unfigured hypotypes (USNM P5911) from well cuttings at 2380 to 2390 feet, in the Topagoruk formation, in South Barrow test well 1.

Figured hypotype (fig. 6) (USNM P5912) and unfigured hypotypes (USNM P5913) from field sample $47 \mathrm{~A}$ Th 308 , in the Torok formation.

Unfigured hypotypes (USNM P5914) from a core at 3240 to 3249 feet, in the Topagoruk formation, in Topagoruk test well 1. 
Unfigured hypotypes (USNM P5915) from a core at 599 to 609 feet, and unfigured hypotypes (USNM P5916) from a core at 1021 to 1031 feet, in the Topagoruk formation, in Arcon Point Barrow core test 1.

Unfigured hypotypes (USNM P5917) from the Fortress Mountain formation, field sample 49A Pa 125.

Unfigured hypotype (USNM P5918) from the upper part of the Torok formation (age equivalent of the Topagoruk formation of the subsurface), field sample 47A Wh 193.

Unfigured hypotypes (USNM P5919) from the Torok formation, field sample 48A Dt 9.

\section{Family SACCAMMINIDAE Brady, 1884 \\ Genus Saccammina Sars, 1869 \\ Saccammina lathrami Tappan \\ Plate 29, figures 9-12}

Saccammina lathrami Tappan, 1960, Am. Assoc. Petroleum

Geologists Bull., v. 44, no. 3, p. 289, pl. 1, figs. 1-2.

Test rounded to ovate in outline, flattened, with the flattened character commonly accentuated by additional compression in fossilization, which results in a central depression; wall finely agglutinated, with considerable cement, smoothly finished, white to gray in color; aperture rounded to ovate, at the end of a short, poorly defined rieck.

Length of holotype $0.63 \mathrm{~mm}$, breadth $0.44 \mathrm{~mm}$. Paratypes range from 0.18 to $0.67 \mathrm{~mm}$ in length.

Remarks.-This species resembles Pelosina complanata Franke, to which it had been provisionally referred in stratigraphic discussions of the northern Alaska material, but the present form is smaller, with a relatively larger although less distinctly defined neck. Both species consist of a single inflated chamber with short neck, and should be referred to Saccammina, as typical Pelosina consists of an elongate tapering chamber, and probably consisted of numerous such chambers in a linear arrangement.

Types and occurrence.-Holotype (USNM P5920) and figured paratype (USNM P5921) from a core at 900 to 910 feet in the Grandstand formation, in Simpson test well 1.

Paratype of fig. 9 (USNM P5922) from well cuttings at 2,200 to 2,210 feet, unfigured paratype (USNM P5923) from well cuttings at 2,290 to 2,300 feet, and paratype of fig. 12 (USNM P5924) from well cuttings at 2,520 to 2,530 feet, all from the Topagoruk formation in Umiat test well 2.

Unfigured paratypes (USNM P5925) from a core at 490 to 499 feet, and unfigured paratypes (USNM P5926) from a core at 499 to 509 feet, all from the Seabee formation, in Umiat test well 1.

Unfigured paratypes (USNM P5927) from the Torok formation, field sample 49A Tr 700 .
Unfigured paratypes (USNM P5928) from the Ninuluk formation, field sample $47 \mathrm{~A} \mathrm{Dt} 7$.

Unfigured paratypes (USNM P5929) from the Ninuluk formation, field sample 47A Dt 59.

Unfigured paratypes (USNM P5930) from the lower part of the Killik tongue, interbedded in the Grandstand formation, field sample 46A Th 160.

\section{Family HYPERAMMINIDAE Eimer and Fickert, 1899 \\ Genus Hyperamminoides Cushman and Waters, 1928 Hyperamminoides barksdalei Tappan \\ Plate 29, figures 21-27}

Hyperamminoides barksdalei Tappan, 1957, U.S. Natl. Mus. Bull. 215, p. 202, pl. 65, figs. 6-12.

Test free, flattened, elongate, somewhat flaring, consisting of an undivided tubular chamber with occasional growth wrinkles or constrictions but without internal partitions; wall finely arenaceous, smoothly finished; aperture a rounded opening at the somewhat constricted end of the chamber.

Length of holotype $0.55 \mathrm{~mm}$, breadth $0.26 \mathrm{~mm}$.

Paratypes range from 0.26 to $1.12 \mathrm{~mm}$ in length.

Remarks.-Hyperamminoides barksdalei Tappan differs from $H$. elegans (Cushman and Waters) in being less tapering and much smaller and in having less constricted transverse growth wrinkles. This species occurs in the Topagoruk and Grandstand formations. It was named in honor of W. L. Barksdale, geologist, formerly with the U.S. Geological Survey.

Types and occurrence.-Holotype (USNM P4386) from a core at 196-201 feet, unfigured paratypes (USNM P4387) from a core at 438-443 feet, all from the Grandstand formation, and unfigured paratypes (USNM P4388) from a core at 1302-1312 feet, all from Topagoruk formation, all from Simpson test well 1.

Figured paratype (USNM P4389) from well cuttings in the Topagoruk formation at 2110-2120 feet in South Barrow test well 1.

Figured paratype (USNM P4390) and unfigured paratypes (USNM P4391) from a core at 660-670 feet, in the Topagoruk formation, in South Barrow test well 2.

Unfigured paratypes (USNM P4392) from a core at 950-960 feet in the Topagoruk formation, in Arcon Point Barrow core test 1 .

Figured paratype (USNM P4226) from the Grandstand formation, in field sample 47A Dt 236.

Figured paratype (USNM P4227) from the lower part of the Topagoruk formation, field sample $47 \mathrm{~A}$ Wh 541.

Figured paratype (USNM P4228) from well cuttings at $1370-1380$ feet, figured paratype (USNM 
P4229) from well cuttings at 3300-3310 feet, and unfigured paratypes (USNM P4230) from well cuttings at 1290-1300 feet, all from the Topagoruk formation, Umiat test well 2.

Unfigured paratypes (USNM P4231) from the Grandstand formation, field sample 47A Tr 108.

\section{Family AMMODISCIDAE Reuss, 1862 \\ Genus Glomospira Rzehak, 1888 \\ Glomospira corona Cushman and Jarvis \\ Plate 29, figures $13-16$}

Glomospira charoides (Jones and Parker) var. corona Cushman and Jarvis, 1928, Cushman Lab. Foram. Research, Contr., vol. 4, p. 89, pl. 12, figs. 9-11; Cushman, 1946, U.S. Geol. Survey Prof. Paper 206, p. 19, pl. 2, figs. 1-3.

Test free, globular, consisting of a proloculus and spirally wound tubular non-septate second chamber, the extremely high spire resulting in the nearly globular test; spiral suture distinct and depressed; wall very finely agglutinated, with considerable cement, smoothly finished and white in color; aperture at the open end of the tube.

Greatest diameter of hypotypes ranges from 0.21 to $0.52 \mathrm{~mm}$.

Remarks.-Originally described from the Lizard Springs (Paleocene) formation of Trinidad, B.W.I., this long-ranged species occurs in the Nanushuk group of Alaska, and is easily distinguished by the regularly high spired and nearly globular test. It has also been widely recorded throughout the Cretaceous of the Gulf Coastal region.

Types and occurrence.-Hypotype of fig. 13 (USNM P5931) from a core in the Grandstand formation at 482 to 489 feet, in Umiat test well 2.

Hypotype of fig. 15 (USNM P5932) and unfigured hypotypes (USNM P5933) from a core at 3,374 to 3,376 feet, and unfigured hypotypes (USNM P5934) from well cuttings at 2,000 to 2,010 feet, all from the Topagoruk formation, in South Barrow test well 1.

Hypotype of fig. 16 (USNM P5935) and unfigured hypotypes (USNM P5936) from the Fortress Mountain formation, field sample $49 \mathrm{~A} \operatorname{Tr} 291$.

Unfigured hypotype (USNM P5937) from the Fortress Mountain formation, field sample 49A Tr 277.

Hypotype of fig. 14 (USNM P5938) from the Torok(?) formation, field sample 47A St 103.

\section{Genus Glomospirella Plummer, 1945 \\ Glomospirella gaultina (Berthelin) \\ Plate 29, figures $17-20$}

Ammodiscus gaultinus Berthelin, 1880, Géol. Soc. France, Mém., sér. 3, v. 1, no. 5, p. 19, pl. 1 (24), figs. 3a-b; Tappan, 1940, Jour. Paleontology, v. 14, no. 2, p. 95, pl. 14, figs. 6a-c; Tappan, 1943, Jour. Paleontology, v. 17, no. 5, p. 481, pl. 77, figs. 6a-b; Frizzell, 1954, Bur. Econ. Geol. Rept. Invest. No. 22, p. 58, pl. 1, figs. 17a-c.

Test free, consisting of a proloculus and spirally wound, non-septate tubular second chamber, the plane of spiralling changing with growth in the early stage, later more nearly planispiral; tubular chamber of nearly equal diameter throughout and forming $21 / 2$ to 5 volutions, with transverse growth constrictions; spiral suture distinct and depressed; wall finely arenaceous, with considerable cement, smoothly finished and commonly white in color; aperture at the open end of the tube.

Greatest diameter of specimen of fig. $18,0.57 \mathrm{~mm}$, greatest diameter of specimen of figure $17,0.34 \mathrm{~mm}$.

Remarks.-This species was originally described from the Albian of France, and occurs in beds of late Albian and early Cenomanian age (Washita group) in the Gulf Coastal Plain. It occurs throughout the Nanushuk group of Alaska.

Types and occurrence.-Hypotype of fig. 18 (USNM P5939) and unfigured hypotypes (USNM P5940) from a core at 743 to 753 feet in the Grandstand formation, and unfigured hypotypes (USNM P5941) from a core at 2,235 to 2,245 feet in the Topagoruk formation, in Simpson test well 1.

Hypotype of fig. 17 (USNM P5942) and unfigured hypotypes (USNM P5943) from a core at 3,173, to 3,181 feet, and unfigured hypotype (USNM P5944) from a core at 3,069 to 3,079 fee, all from the Topagoruk formation, in South Barrow test well 1.

Hypotypes of figs. 19, 20 (USNM P5945 a, b) and unfigured hypotypes (USNM P5946) from the Fortress Mountain formation, field sample 49A Tr 291.

Unfigured hypotype (USNM P5947) from well cuttings at 405 to 410 feet, unfigured hypotype (USNM P5948) from well cuttings at 550 to 560 feet, and unfigured hypotype (USNM P5949) from a core at 558 to 568 feet, all from the Topagoruk formation, in Arcon Point Barrow core test 1.

Unfigured hypotypes (USNM P5950) from the Fortress Mountain formation, field sample $49 \mathrm{~A} \mathrm{~Pa}$ 571.

Unfigured hypotype (USNM P5951) from well cuttings at 2120 to 2130 feet, in the Torok formation, in South Barrow test well 2.

Unfigured hypotype (USNM P5952) from a core at 3173 to 3181 feet, in the Torok formation, in South Barrow test well 4.

\section{Genus Ammodiscus Reuss, 1862 \\ Ammodiscus cretaceus (Reuss) \\ Plate 30, figures 1, 2}

Operculina cretacea Reuss, 1845, Verstein. böhmischen Kreideformation, Abt. 1, p. 35, pl. 13, figs. 64-65b. 
Ammodiscus cretaceus (Reuss). Cushman, 1946, U.S. Geol. Survey Prof. Paper 206, p. 17, pl. 1, fig. 35.

Test free, discoidal, consisting of a globular proloculus and planispirally wound, undivided, tubular second chainber of 8 to 10 volutions, increasing regularly in diameter and with occasional transverse growth constrictions, each whorl laterally overlapping the previous one for about one-half its thickness; spiral suture distinct and depressed; wall finely agglutinated, with calcareous cement soluble in acid, surface smoothly finished and polished in appearance, reddish in color; aperture at the open end of the tubular chamber, somewhat arched in outline, due to the lateral overlap of the chambers.

Hypotypes range in diameter from 0.44 to $1.0 \mathrm{~mm}$ and in thickness from 0.10 to $0.16 \mathrm{~mm}$.

Remarks.-Originally described as an Operculina from the Bohemian Plänermergel (Turonian), it has been widely recorded as Cornuspira cretacea and $A m$ modiscus cretaceus, both in Europe and North America, from strata ranging in age from Albian to Paleocene (Velasco shale of Mexico). According to Wickenden (1945, p. 50) it occurs commonly in the lower part of the Riding Mountain formation of Manitoba and Saskatchewan, Canada. The presence of numerous Radiolaria in the same formation strongly suggests a correlation with the Alaskan section. In northern Alaska, it occurs locally in the upper part of the Sentinel Hill member of the Schrader Bluff formation, which is also characterized by an abundance of Radiolaria.

Types and occurrence.-Figured hypotypes (USNM P5953 a, b) and unfigured hypotypes (USNM P5954) from field sample $47 \mathrm{~A}$ St 38 , in the upper part of the Sentinel Hill member of the Schrader Bluff formation.

\section{Ammodiscus mangusi (Tappan)}

Plate 30, figures 3, 4

Involutina mangusi Tappan, 1957, U.S. Natl. Mus. Bull. 215, p. 203 , pl. 65, figs. 13-14.

Test free, discoidal, consisting of proloculus and long undivided, planispiral, evolute second chamber, which is relatively thick and forms only a few whorls; specimens commonly compressed in preservation, surface granular in appearance; wall finely to moderately coarsely agglutinated; aperture at the open end of the tubular chamber.

Greatest diameter of holotype $0.49 \mathrm{~mm}$., thickness $0.06 \mathrm{~mm}$. Paratypes range from 0.36 to $0.68 \mathrm{~mm}$. in diameter.

Remarks.-Ammodiscus mangusi (Tappan) differs from Glomospirella gaultina (Berthelin) in being about one-half as large, in having a relatively thicker spiralling chamber, and in being more coarsely agglutinated. The present species is more evenly planispiral, rather than irregularly coiled in the early stages as in G. gaultina. The species is found in the Topagoruk and Grandstand formations and marine tongues in the equivalent Chandler formation. It was named in honor of M. D. Mangus, geologist, U. S. Geological Survey.

Types and occurrence.-Holotype (USNM P4232) and unfigured paratype (USNM P4233) from a core at 1080-1087 feet, unfigured paratype (USNM P4234) from a core at 1187-1197 feet, unfigured paratypes (USNM P4235) from a core at 1247-1267 feet, all from the Topagoruk formation, and unfigured paratype (USNM P4236) from a core at 673-683 feet, in the Grandstand formation, all from Simpson test well 1.

Unfigured paratypes (USNM P4237) from a core at 548-558 feet, in the Topagoruk formation, in Arcon Point Barrow core test 1.

Unfigured paratype (USNM P4238) from well cuttings at 1130-1140 feet and unfigured paratype (USNM P4239) from well cuttings at 1140-1150 feet, both from the Topagoruk formation in South Barrow test well 1 .

Paratype of figure 3 (USNM P4240) from field sample $47 \mathrm{~A}$ Wh 623 , residual soil of marine zone in Chandler formation.

Unfigured paratype (USNM P4241) from field sample $47 \mathrm{~A}$ Wh 688 , residual soil sample of the Grandstand formation.

\section{Ammodiscus rotalarius Loeblich and Tappan Plate 30, figures 5-8}

Ammodiscus rotalarius Loeblich and Tappan, 1949, Jour. Paleontology, v. 23 , no. 3 , p. 247 , pl. 46, fig. 1 ; Frizzell, 1954 , Bur. Econ. Geol. Rept. Invest. No. 22, p. 58, pl. 1, fig. 23.

Test free, discoidal; consisting of a proloculus and planispirally wound, gradually enlarging, undivided tubular second chamber; wall finely agglutinated, with considerable cement, probably siliceous, as the test is insoluble in acid, surface smoothly finished, color white, yellow, or brown; aperture at the open end of the tube.

Hypotypes range from 0.24 to $0.99 \mathrm{~mm}$. in greatest diameter; diameter of hypotype of figure 6 is 0.65 $\mathrm{mm}$., that of hypotype of figure $8,0.40 \mathrm{~mm}$.

Remarles.-Ammodiscus rotalarius was originally described from the Walnut clay of Oklahoma (middle Albian). In Alaska, it is found throughout the Nanushuk group and in the underlying Torok formation. It differs from the associated Glomospirella gaultina 
(Berthelin) in the completely planispiral test, more regularly enlarging tubular chamber, and less prominent transverse growth constrictions.

Types and occurrence.-Hypotype of figure 5 (USNM P5955) from well cuttings at 4,600 to 4,610 feet in the Topagoruk formation, in Umiat test well 1.

Hypotype of figure 8 (USNM P5956) and unfigured hypotype (USNM P5957) from a core at 1,432 to 1,442 feet, and unfigured hypotypes (USNM P5958) from a core at 651 to 666 feet, all from the Topagoruk formation, in Arcon Point Barrow core test 1.

Hypotype of figure 6 (USNM P5960) and unfigured hypotypes (USNM P5959) from the lower part of the Topagoruk formation, field sample 47A Wh 541 .

Unfigured hypotypes (USNM P5961) from field sample $47 \mathrm{~A} \mathrm{Wh} 544$, in the upper part of the Torok formation.

Unfigured hypotypes (USNM P5962) from a residual soil sample, in marine tongues within the Chandler formation, field sample 47A Wh 654 .

Unfigured hypotype (USNM P5963) from field sample $47 \mathrm{~A}$ Wh 707, in residual soil of the Kukpowruk formation.

Unfigured hypotype (USNM P5964) from field sample $47 \mathrm{~A} \mathrm{Wh} 735$, in the Torok formation, residual soil sample.

Hypotype of figure 7 (USNM P5965) and unfigured hypotypes (USNM P5966) from field sample $47 \mathrm{~A}$ $\operatorname{Tr} 203$, in the Kukpowruk formation.

Unfigured hypotype (USNM P5967) from field sample $47 \mathrm{~A} \operatorname{Tr} 208$, in the upper part of the Torok formation.

Unfigured hypotype (USNM P5968) from field sample $47 \mathrm{~A} \mathrm{Z} \mathrm{601,} \mathrm{in} \mathrm{the} \mathrm{Tuktu} \mathrm{formation.}$

Unfigured hypotypes (USNM P5969) from well cuttings at 1,060 to 1,070 feet, and (USNM P5970) from well cuttings at 2,070 to 2,080 feet, all from the Topagoruk formation, in South Barrow test well 1.

Unfigured hypotypes (USNM P5971) from well cuttings at 500 to 510 feet, hypotypes (USNM P5972) from 580 to 590 feet, and hypotypes (USNM P5973) from 1,020 to 1,030 feet, all from the Topagoruk formation, in South Barrow test well 2.

Unfigured hypotype (USNM P5974) from a core at 766 to 776 feet, in the Grandstand formation, in Skull Cliff core test 1 .

Unfigured hypotype (USNM P5975) from a core at 1,020 to 1,030 feet, unfigured hypotypes (USNM P5976) from a core at 1,070 to 1,080 feet, unfigured hypotypes (USNM P5977) from a core at 1,227 to 1,237 feet, unfigured hypotype (USNM P5978) from a core at 1,247 to 1,267 feet, unfigured hypotype (USNM P5979) from well cuttings at 3,560 to 3,565 feet, all from the Topagoruk formation, in Simpson test well 1.

\section{Ammodiscus species}

Plate 30, figure 9

Test free, small, discoidal, consisting of a proloculus and planispirally coiled, undivided, tubular second chamber; spiral suture somewhat obscure; wall finely agglutinated, surface rough; aperture at the open end of the tube.

Specimens range in greatest diameter from 0.19 to $0.44 \mathrm{~mm}$, and in thickness from 0.05 to $0.08 \mathrm{~mm}$.

Remarks.-This species differs from Ammodiscus cretaceus (Reuss) in the coarser grained test, thicker central region and indistinct spiral suture. It differs from $A$. rotalarius Loeblich and Tappan in being much smaller in size, about one-third as large, in having a spiral tubular chamber of considerably lesser diameter, and in having a less distinct spiral suture. It is found throughout the Schrader Bluff and Seabee formations.

Types and occurrence.-Figured specimen (USNM P5980) and unfigured specimen (USNM P5981) from field sample $47 \mathrm{~A}$ St 28 , in the Sentinel Hill member of the Schrader Bluff formation.

Unfigured specimen (USNM P5982) from field sample 47A Dt 333, from the Barrow Trail member of the Schrader Bluff formation.

Unfigured specimens (USNM P5983) from field sample $47 \mathrm{~A} \mathrm{Dt} 286$, in the Sentinel Hill member of the Schrader Bluff formation.

Unfigured specimens (USNM P5984) from field sample $46 \mathrm{~A} \mathrm{Gr} \mathrm{98,} \mathrm{in} \mathrm{the} \mathrm{lower} \mathrm{part} \mathrm{of} \mathrm{the} \mathrm{Ignek}$ formation.

Unfigured specimens (USNM P5985) from field sample $52 \mathrm{~A} \mathrm{Bl} \mathrm{33,} \mathrm{from} \mathrm{the} \mathrm{Shale} \mathrm{Wall} \mathrm{member} \mathrm{of}$ the Seabee formation.

\section{Family REOPHACIDAE Cushman, 1910 \\ Genus Reophax Montfort, 1808 \\ Reophax minuta Tappan \\ Plate 30, figure 10}

Reophax minuta Tappan, 1940, Jour. Paleontology, v. 14, no. 2, p. 94, pl. 14, figs. 4a-b; Tappan, 1943, Jour. Paleontology, v. 17 , no. 5, p. 480 , pl. 77 , figs. 4 a-b ; Frizzell, 1954, Bur. Econ. Geol. Rept. Invest. No. 22, p. 57, pl. 1, figs. 11 a, b.

Test free, tiny, narrow and elongate, consisting of a linear series of slightly inflated chambers, increasing gradually in size as added, and of nearly equal height and breadth; sutures distinct, horizontal and depressed; wall finely agglutinated; aperture terminal, rounded.

Length of figured hypotype $0.48 \mathrm{~mm}$, breadth 0.13 $\mathrm{mm}$. 
Remarks.-Reophax minuta was originally described from the Grayson formation of Texas, and occurs in beds of late Albian and early Cenomanian age in the Gulf Coastal area. It is quite rare in Alaska, occurring in the Topagoruk and Oumalik formations.

Types and occurrence.-Figured hypotype (USNM P5986) from well cuttings in the Torok formation, at 4,780 to 4,790 feet, and unfigured hypotype (USNM P5987) from well cuttings at 3,470 to 3,480 feet, in the Topagoruk formation, both in Simpson test well 1.

\section{Reophax pepperensis Loeblich}

Plate 30, figure 14

Rcophax pepperensis Loeblich, 1946, Jour. Paleontology, v. 20, no. 2, p. 133, pl. 22, figs. 1a, b; Frizzell, 1954, Bur. Econ. Geol. Rept. Invest. No. 22, p. 58, pl. 1, figs. 12a-b.

Test free, tiny, narrow, elongate, uniserial and rectilinear, moderately flaring; six to seven subcylindrical chambers, closely appressed, of slightly greater breadth than height; sutures distinct, slightly depressed; wall finely arenaceous; aperture rounded, terminal.

Hypotypes range in length from 0.24 to $0.49 \mathrm{~mm}$, and in breadth from 0.08 to $0.11 \mathrm{~mm}$.

Remarks.-This species was originally described from the Pepper shale member (Cenomanian) of Texas. It is found in slightly younger beds (Turonian) in Alaska, being restricted to the Seabee formation. It is characterized by the tiny size, and slightly tapering test.

Types and occurrence.-Figured hypotype (USNM P5988) and unfigured hypotypes (USNM P5989) from a core at 499 to 509 feet, unfigured hypotypes (USNM P5990) from a core at 457 to 467 feet, and unfigured hypotype (USNM P5991) from a core at 487 to 490 feet, all from the Seabee formation, in Umiat test well 1.

\section{Reophax troyeri Tappan}

Plate 30, figures 11-13

Reophax troyeri Tappan, 1960, Am. Assoc. Petroleum Geologists Bull., v. 44, no. 3, p. 291, pl. 1, figs. 10-12.

Test free, elongate, uniserial and rectilinear, microspheric forms slightly flaring, megalospheric forms with only slightly enlarging chambers, three to eight rounded chambers of nearly equal breadth and height, commonly only four to five, final chamber flask shaped and produced terminally to form a neck, all chambers commonly variously crushed and distorted in preservation; sutures distinct, depressed, horizontal; wall finely agglutinated, surface roughly finished; aperture terminal, rounded, at the end of a distinct neck.
Length of holotype $0.58 \mathrm{~mm}$, breadth $0.28 \mathrm{~mm}$. Other specimens range from 0.40 to $0.52 \mathrm{~mm}$ in length.

Remarks.-Reophax troyeri differs from Reophax texanus Cushman and Waters in being smaller, and in having a distinctly produced neck.

Types and occurrence.-Holotype (USNM P5992) from well cuttings at 1870 to 1880 feet, unfigured paratype (USNM P5993) from well cuttings at 1,500 to 1,510 feet, unfigured paratype (USNM P5994) from well cuttings at 2,340 to 2,350 feet, and unfigured paratype (USNM P5995) from well cuttings at 2,820 to 2,830 feet, all from the Topagoruk formation in South Barrow test well 1.

Paratype of figure 12 (USNM P5996) and unfigured paratype (USNM P5997) from well cuttings at 1,319 to 1,329 feet in the Topagoruk formation, in Arcon Point Barrow core test 1.

Figured paratype (USNM P5998) from well cuttings at 5,320 to 5,330 feet, in the Topagoruk formation, in Umiat test well 2.

Unfigured paratypes (USNM P5999) from a core at 2,535 to 2,540 feet in the Topagoruk formation, and unfigured paratype (USNM P6000) from well cuttings at 4,000 to 4,010 feet, probably contamination from the overlying Topagoruk formation although within the Torok formation, in Simpson test well 1.

Family LITUOLIDAE Lamarck, 1809

Genus Haplophragmoides Cushman, 1910

Haplophragmoides bonanzaensis Stelck and Wall

Plate 30, figures 16-19

Haplophragmoides bonanzaense Stelck and Wall, 1954, Research Council Alberta Rept. 68, p. 24, pl. 2, fig. 10.

Test free, small, robust, planispiral, biumbilicate, with relatively small umbilici, peripheral margin broadly rounded, peripheral outline lobulate; chambers inflated, cuneate in side view, with 6 to 8 per whorl, commonly only 6 ; sutures distinct, radial, depressed; wall finely agglutinated; aperture a low, interiomarginal, equatorial arch.

Greatest diameter of hypotype of figure 18, 0.45 $\mathrm{mm}$, thickness $0.23 \mathrm{~mm}$. Greatest diameter of hypotype of figure $16,0.15 \mathrm{~mm}$, and unfigured hypotypes range from 0.18 to $0.57 \mathrm{~mm}$ in diameter.

Remarks.-Haplophragmoides bonanzaensis Stelck and Wall differs from the associated $H$. rota Nauss in having commonly only 6 chambers per whorl, and a more inflated test with broadly rounded, rather than subacute, periphery. The present species is very close in appearance to $H$. linki Nauss, although somewhat smaller. $H$. linki, from the lower Lloydminster of Alberta, Canada (of late Albian age), was described as ranging from 0.35 to $0.95 \mathrm{~mm}$ in diameter. 
Haplophragmoides bonanzaensis was described from the "Central Kaskapau" (Turonian age) of Alberta, and the type specimen is $0.22 \mathrm{~mm}$ in diameter. In Alaska, this species occurs throughout the Seabee (Turonian) and Schrader Bluff (Senonian) formations. It shows a greater size range in the Alaskan sequence, as well as a less restricted vertical range.

Types and occurrence.-Hypotype of figure 18 (USNM P6004) from the middle part of the Seabee formation, field sample $46 \mathrm{~A} \mathrm{Ry} 150 \mathrm{~A}$.

Hypotype of figure 16 (USNM P6005) and unfigured hypotypes (USNM P6006) from a core at 1,150 to 1,160 feet in the Sentinel Hill member of the Schrader Bluff formation, in Sentinel Hill core test 1.

Unfigured hypotypes (USNM P6007) from field sample $47 \mathrm{~A} \mathrm{Dt} 84$, from the lower member of the Seabee formation.

Hypotypes of figures 17, 19 (USNM P6009 a, b) and unfigured hypotypes (USNM P6010) from field sample $47 \mathrm{~A} \mathrm{~Wb} 1$, from the Ayiyak member of the Seabee formation.

Unfigured hypotypes (USNM P6011) from field sample $47 \mathrm{~A} \mathrm{~Wb} 260$, from the Ayiyak member of the Seabee formation.

Unfigured hypotypes (USNM P6008) from field sample $47 \mathrm{~A} \mathrm{~Wb} 428$, from the Ayiyak member of the Seabee formation.

Unfigured hypotypes (USNM P6012) from field sample $47 \mathrm{~A} \mathrm{~Wb} 429$, from the Ayiyak member of the Seabee formation.

\section{Haplophragmoides gigas Cushman}

Plate 30, figure 15

Haplophragmoides gigas Cushman, 1927, Royal Soc. Canada Trans., 3rd ser., v. 21 , sec. 4 , p. 129 , pl. 1, fig. 5 ; Cushman, 1946, U.S. Geol. Survey Prof. Paper 206, p. 21, pl. 3, fig. 2; Nauss, 1947, Jour. Paleontology, v. 21, no. 4, p. 338, pl. 49, figs. 8a, b; Stelck, Wall, Bahan and Martin, 1956, Research Council Alberta, Rept. 75, p. 35, pl. 5, fig. 1.

Test large, compressed, planispiral, peripheral margin subacute, peripheral outline lobulate; nine to eleven chambers in the final whorl, somewhat inflated in the umbilical region; sutures distinct, depressed, radial, with a sinuate appearance; wall finely agglutinated, surface smoothly finished; aperture equatorial, a low interiomarginal arch.

Hypotypes range in diameter from 1.18 to $1.95 \mathrm{~mm}$ and in thickness from 0.33 to $0.94 \mathrm{~mm}$.

Remarks.-Haplophragmoides gigas is closest in appearance to $H$. rota Nauss but is about twice as large and more robust in appearance, and has more chambers per whorl.

This species is common in the middle to late Albian of Alberta, Saskatchewan and Manitoba, occurring in the Lloydminster shale, and the Joli Fou shale. It is regarded as a zone fossil by Nauss (1947, p. 330) Henderson $(1954$, p. 2275) and Stelck, Wall, Bahan and Martin (1956, p. 17). Although widespread in Canada, it does not extend far into Alaska, occurring very rarely only in the eastern part of the area studied. It is replaced in the north Alaskan region by the similar and possibly related Haplophragmoides topagorukensis Tappan.

Types and occurrence.-Figured hypotype (USNM P6001) and unfigured hypotypes (USNM P6002) from field sample $46 \mathrm{~A} \mathrm{Gr} 98$, in the lower part of the Ignek formation.

\section{Haplophragmoides rota Nauss \\ Plate 31, figures 16-18}

Haplophragmoides rota Nauss, 1947, Jour. Paleontology, v. 21, no. 4 , p. 339, pl. 49, figs. $1 \mathrm{a}-3 \mathrm{~b}$.

Test free, planispiral, laterally compressed, periphery subacute; 7 to 9 chambers in the final whorl, commonly 8 , with a small umbilicus on each side; sutures straight, radial, early ones may be somewhat obscure, later ones depressed; wall finely arenaceous to moderately coarsely grained, with considerable cement; aperture an interiomarginal equatorial arch.

Hypotypes range from 0.28 to $0.83 \mathrm{~mm}$ in diameter.

Remarks.-Haplophragmoides rota Nauss differs from $H$. bonanzaensis Stelck and Wall in being larger, in having more chambers per whorl, and in having a compressed rather than inflated and robust test. $H$. diversitatus Stelck and Wall differs in having a tendency to become trochoid, or more evolute on one side than the other.

This species was originally described from the Grizzly Bear shale of the Belly River group of Alberta, Canada. In Alaska it occurs in the Seabee and Schrader Bluff formations.

Types and occurrence.-Hypotype of figure 18 (USNM P6029) and unfigured hypotypes (USNM P6030) from field sample 46A St 88, in the Ayiyak (?) member of the Seabee formation.

Hypotype of figure 17 (USNM P6031) and unfigured hypotypes (USNM P6032) from field sample $48 \mathrm{~A} \mathrm{Dt} 378$, in the Rogers Creek member of the Schrader Bluff formation, and unfigured hypotype (USNM P6033) from field sample 48A Dt 422, from 990 to 1,010 feet above the base of the Rogers Creek member of the Schrader Bluff formation.

Unfigured hypotypes (USNM P6034) from Umiat seismograph party 46 , line $1-46$, shot hole 12 , at a depth of 155 to 180 feet, in the Seabee formation. 
Unfigured hypotypes (USNM P6035) from Umiat seismograph party, shot point 15 , at a depth of 20 feet, in the Rogers Creek member of the Schrader Bluff formation.

Unfigured hypotypes (USNM P6036) from a core at 470 to 475 feet in the Seabee formation, in Umiat test well 1.

Unfigured hypotypes (USNM P6037) from field sample $46 \mathrm{~A} \mathrm{Fi} 80 \mathrm{~A}$, in the Seabee formation.

Unfigured hypotypes (USNM P6038) from field sample $46 \mathrm{~A}$ Ry $150 \mathrm{~A}$, middle part of the Seabee formation.

Unfigured hypotypes (USNM P6039) from field sample $47 \mathrm{~A}$ St 32 , from the Sentinel Hill member of the Schrader Bluff formation, unfigured hypotypes (USNM P6040) from field sample 47A St 38, from 50 feet above the base of the upper part of the Sentinel Hill member of the Schrader Bluff formation, and unfigured hypotypes (USNM P6041) from field sample $47 \mathrm{~A} \mathrm{St} \mathrm{39,} \mathrm{from} 110$ feet above the base of the upper part of the Sentinel Hill member.

Unfigured hypotypes (USNM P6042) from field sample $47 \mathrm{~A}$ Wb 255, unfigured hypotypes (USNM P6043) from field sample $47 \mathrm{~A} \mathrm{~Wb} 259$, both from the lower member, Seabee formation, and unfigured hypotypes (USNM P6044) from field sample 47A Wb 260, from the Ayiyak member of the Seabee formation.

Figured hypotype (USNM P6045) and unfigured hypotypes (USNM P6046) from field sample 47A Wb 426, and unfigured hypotypes (USNM P6047) from field sample $47 \mathrm{~A} \mathrm{~Wb} 428$, all from the Ayiyak member of the Seabee formation, and unfigured hypotypes (USNM P6048) from field sample 47A Wb 456, from the Rogers Creek member of the Schrader Bluff formation.

Unfigured hypotypes (USNM P6049) from field sample $46 \mathrm{~A}$ Gr 98, from the Ignek formation.

Unfigured hypotypes (USNM P6050) from field

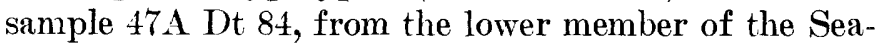
bee formation.

Unfigured hypotypes (USNM P6051) from field sample $47 \mathrm{~A}$ Dt 363 , from the Sentinel Hill member of the Schrader Bluff formation.

Unfigured hypotypes (USNM P6052) from a core at 709 to 719 feet, unfigured hypotypes (USNM P6053) from a core at 719 to 729 feet, unfigured hypotypes (USNM P6054) from a core at 764 to 765 feet, unfigured hypotypes (USNM P6055) from a core at 765 to 769 feet, and unfigured hypotypes (USNM P6056) from a core at 769 to 779 feet, in the Sentinel Hill member of the Schrader Bluff formation, in Sentinel Hill core test 1 .

\section{Haplophragmoides topagorukensis Tappan}

Plate 31, figures 1-15

Haplophragmoides topagorukensis Tappan, U.S. Natl. Mus. Bull. 215, p. 203, pl. 65, figs. 15-25.

Test free, planispiral and involute, occasional specimens partly evolute, biumbilicate, periphery rounded, 8 to 12 chambers in the final whorl, increasing gradually in size as added and slightly inflated; sutures straight and radial, somewhat thickened, moderately depressed; wall finely agglutinated, with variable amount of cement, test apparently not extremely rigid in original character, as most tests are distorted in preservation, those laterally crushed having the appearance of a more sharply angled periphery; surface generally smoothly finished, but those specimens from sandy strata commonly possessing a more roughened exterior; aperture an arch at the base of the final chamber face on the periphery.

Greatest diameter of holotype $0.62 \mathrm{~mm}$, thickness $0.08 \mathrm{~mm}$. Paratypes range from 0.31 to $1.87 \mathrm{~mm}$ in greatest diameter.

Remarks.-This is an extremely variable species in size; and because of the prevalence of distorted tests due to compression in preservation, it is variable in apparent relative thickness and angularity of periphery. However, as there are specimens crushed in different directions as well as some pyrite-filled tests which are less distorted, it is possible to determine the true characters. It is found in the Grandstand, Topagoruk, Torok and Fortress Mountain formations, and in marine zones within the Chandler formation.

The species differs from $H$. collyra Nauss in having more numerous chambers in the final whorl and a less lobulate periphery. It is distinguished from Haplophragmoides eggeri Cushman in being about twice as large and in having about double the number of chambers in the final whorl.

It occurs at approximately the same stratigraphic position as does Haplophragmoides gigas Cushman in Canada, in beds of middle and upper Albian age. Although similar to $H$. gigas in size, and possibly related to it, the present species lacks the distinctly sinuate sutures and the raised umbilical margins, which are characteristic of the Canadian form.

Types and occurrence.-Holotype (USNM P4242) and unfigured paratypes (USNM P4243) from the Topagoruk formation in a core at 1,322-1,330 feet; figured paratype (USNM P6013) and unfigured paratypes (USNM P6014) from a core at 201 to 206 feet, unfigured paratypes (USNM P6015) from a core at 196 to 201 feet, and unfigured paratypes (USNM 
P6016) from a core at 206 to 211 feet, unfigured paratypes (USNM P4244) from a core at 303-308 feet, unfigured paratypes (USNM P4245) from a core at 443444 feet, figured paratypes (USNM P4246 a, b) and unfigured paratypes (USNM P4247) from a core at 533-543 feet, unfigured paratypes (USNM P4248) from a core at 565-578 feet, unfigured paratypes (USNM P4249) from a core at 578-588 feet, and unfigured paratypes (USNM P4250) from a core at 713723 feet, all from the Grandstand formation, and unfigured paratypes (USNM P6017) from a core at 1,050 to 1,060 feet, unfigured paratypes (USNM P4251) from a core at 1,227-1,237 feet, figured paratype (USNM P4252) and unfigured paratypes (USNM P4253) from a core at 1,247-1,267 feet, figured paratype (USNM P4254) and unfigured paratypes (USNM P4255) from well cuttings at 1,730-1,740 feet, unfigured paratypes (USNM P4256) from well cuttings at 1,830-1,840 feet, figured paratype (USNM P4257) and unfigured paratypes (USNM P4258) from a core at 2,235-2,245 feet, unfigured paratypes (USNM P4259) from a core at 2,739-2,749 feet, unfigured paratypes (USNM P4260) from well cuttings at 2,7602,770 feet and unfigured paratypes (USNM P4261) from well cuttings at 2,880-2,890 feet, all from the Topagoruk formation; all from Simpson test well 1.

Unfigured paratypes (USNM P6003) from a core at 1339 to 1348 feet, in the Torok formation, in Avak test well 1.

Unfigured paratypes (USNM P4262) from well cuttings at 1180 to 1190 feet, and (USNM P4263) from well cuttings at 1370 to 1380 feet, all from the Topagoruk formation, figured paratype (USNM P6018) and unfigured paratypes (USNM P6019) from a core at 3,226-3,237 feet, and unfigured paratypes (USNM $\mathrm{P} 6020$ ) from a core at 3,333 to 3,341 feet, all from the Torok formation, in South Barrow test well 1.

Unfigured paratypes (USNM P4269) from a core in the Grandstand formation at 264 feet, in Skull Cliff core test 1 .

Figured paratype (USNM P4270) from a core in the Topagoruk formation at 3,776-3,786 feet, in Fish Creek test well 1.

Unfigured paratypes (USNM P4271) from a core at 1,615-1,625 feet and unfigured paratypes (USNM $\mathrm{P} 4272$ ) from a core at 1,625-1,635 feet, unfigured paratypes (USNM P4273) from a core at 2,347-2,357 feet, and unfigured paratypes (USNM P4274) from a core at 2,365-2,370 feet, all from the Grandstand formation, and figured paratype (USNM P4275) from well cuttings at $3,660-3,670$ feet and unfigured paratypes (USNM P4276) from well cuttings at 4,110-4,120 feet, all from the Topagoruk formation in Umiat test well 1.
Figured paratype (USNM P4277) and unfigured paratypes (USNM P4278) from cuttings at 2,4002,410 feet and figured paratype (USNM P4279) from cuttings at $2,950-2,960$ feet, all from the Topagoruk formation, in Umiat test well 2.

Figured paratype (USNM P4288) and unfigured paratype (USNM P4289) from a core at 529-532 feet, in the Grandstand formation, in Umiat test well 3.

Unfigured paratypes (USNM P4280) from the upper part of the Torok formation, field sample 47A Dt 223. Unfigured paratypes (USNM P4281) from field sample 47A Dt 227, unfigured paratypes (USNM P4282) from field sample 47A Dt 236, and unfigured paratypes (USNM P4283) from field sample 47A Dt 244 , all in the Grandstand formation.

Figured paratype (USNM P6023) and unfigured paratypes (USNM P6024) from field sample 47A Tr 167 , in the Torok formation, and unfigured paratypes (USNM P4286) from a marine tongue within the Chandler formation, field sample 47A Tr 241.

Unfigured paratypes (USNM P4285) from field sample 48A Dt 268, and unfigured paratypes (USNM P4284) from field sample $48 \mathrm{~A}$ Dt 336 , all from the Grandstand formation.

Figured paratype (USNM P6025) and unfigured paratypes (USNM P6026) from field sample $49 \mathrm{~A} \mathrm{~Pa}$ 125, and unfigured paratypes (USNM P6027) from field sample $49 \mathrm{~A} \mathrm{~Pa} \mathrm{84,} \mathrm{all} \mathrm{from} \mathrm{the} \mathrm{Fortress} \mathrm{Moun-}$ tain formation, and unfigured paratypes (USNM P4486) from the Torok formation, field sample 49A $\mathrm{Pa} 542$.

Unfigured paratypes (USNM P6028) from the Torok formation, field sample 49A $\operatorname{Tr} 695$.

Unfigured paratype (USNM P4287) from well cuttings at 250-260 feet in the Grandstand formation, in Simpson core test 8 .

\section{Genus Ammobaculites Cushman, 1910 \\ Ammobaculites fragmentarius Cushman \\ Plate 32, figures 8-11}

Ammobaculites fragmentaria Cushman, 1927, Royal Soc. Canada Trans., 3rd ser., v. 21, sec. 4. p. 130, pl. 1, fig. 8 ; Nauss, 1947, Jour. Paleontology, v. 21, no. 4, p. 331 (range chart).

Ammobaculites coprolithiforme (Schwager) Cushman, 1927, Royal Soc. Canada Trans. 3rd ser., v. 21, sec. 4, p. 130, pl. 1, figs. 6-7.

Ammobaculites coprolithiformis (Schwager) Wickenden, 1932, Jour. Paleontology, v. 6, no. 2, p. 204, pl. 29, fig. 2.

Reophax texana Cushman and Waters, Wickenden, 1932 (not Cushman and Waters, 1927), Ibid., p. 204, pl. 29, fig. 1 .

Ammobaculites humei Nauss, 1947, Jour. Paleontology, v. 21, no. 4 , p. 333 , pl. 48 , fig. 1 ; Mellon and Wall, 1935, Research Council of Alberta, Rept. 72, p. 15, pl. 1, fig. 18.

Ammobaculites tyrrelli Nauss, 1947, Jour. Paleontology, v. 21, no. 4 , p. 333 , pl. 48 , fig. 2 . 
Not Ammobaculites tyrrelli Nauss, Tappan, 1951, Cushman Found. Foram. Research, Contr., v. 2, pt. 1, p. 3, pl. 1, figs. 12-14; Tappan, 1951, in Payne et al, U.S. Geol. Survey Oil and Gas Invest. Map OM-126, sheet 3, fig. 21 (11).

Not Ammobaculites coprolithiformis (Schwager) Cushman, 1946, U.S. Geol. Survey Prof. Paper 206, p. 22, pl. 3, figs. 7-9; Frizzell, 195t, Bur. Econ. Geol. Rept. Invest. 22, p. 61, pl. 2, figs. 15a-b.

Not Ammobaculites fragmentarius Cushman, Cushman, 1946, U.S. Geol. Survey Prof. Paper 206, p. 23, pl. 3, figs. 10-16; Frizzell, 1954, Bur. Econ. Geol. Rept. Invest. 22, p. 62, pl. 2 , figs. $16-18$

Test free, elongate and subcylindrical, with close coiled early portion of about five inflated chambers, later part of two to five, rarely more, slightly inflated uniserial chambers of somewhat greater breadth than height, and of circular section; sutures distinct, radial and depressed in the early coil, horizontal and slightly constricted in the uniserial portion; wall finely to medium coarsely arenaceous; aperture terminal, rounded.

Hypotypes range from 0.44 to $0.94 \mathrm{~mm}$ in length and from 0.21 to $0.29 \mathrm{~mm}$ in breadth.

Remarks.-Ammobaculites fragmentarius is quite variable in some characters, such as the wall texture, for in sandy strata it may be extremely coarse textured, and have little apparent cement. In silty or shaly beds it is finer grained and may have a smoothly finished surface, as do many other associated arenaceous species. The flaring character mentioned by Cushman in the original description is less prominent than is suggested by the illustration, and is not shown in the paratypes in the Cushman Collection. However, in many Alaskan specimens the later chambers may be crushed in the preservation, and thus simulate a flaring test. The names $A$. fragmentarius, $A$. humei and $A$. tyrrelli have all been applied to only minor variations in the size and shape or texture, which do not hold valid when large numbers of specimens are examined. Furthermore, the almost identical recorded ranges of these "species" tend to support the conclusion that they represent only a single species.

Cushman (1927) described this and other species from the Cretaceous in Canadian wells, considering all to be of Late Cretaceous age. Some of the wells were later shown to be in Lower Cretaceous beds, according to Cushman $(1946$, p. 34) who stated that Gaudryina canadensis was "definitely Lower Cretaceous". However, specimens of Ammobaculites coprolithiforme and A. fragmentarius from the same horizon and well were still regarded as of Late Cretaceous age in the 1946 publication. Cushman recorded the smoothly finished specimens as $A$. coprolithiforme (Schwager) and the coarsely agglutinated forms as a new species, $A$. frag- mentarius, the latter differing "in its greater proportion of uncoiled chambers, the tapering test and the peculiar flaky structure of the wall." His holotype appears almost identical with the hypotype of $A$. coprolithiforme, except for having one additional chamber, the somewhat coarser texture, and the slight flaring probably resulting from crushing.

This species was first recognized as a useful zonal marker by Wickenden (1932b) who recorded it as $A$. coprolithiformis, and broken specimens as Reophax texana Cushman and Waters. Wickenden's hypotypes of $R$. texana, in the Cushman Collection at the U.S. National Museum, are definitely Ammobaculites, and the sutures of the early coil can be seen when the specimens are dampened. Because the coil and the later uniserial chambers are of approximately equal diameter and the sutures may be obscure unless the specimens are dampened, it is not difficult to understand this misinterpretation. Wickenden recorded both "Reophax texana" and "Ammobaculites coprolithiformis" from the same horizon, the former from 330450 feet below the top of the "Alberta shale", with the upper range about 70 to 100 feet above the Clavulina zone, and the Ammobaculites from 340 to 450 feet below the top, usually appearing about 70 feet above the Clavulina zone, and becoming very abundant in that zone.

Nauss (1945) described as the Lloydminster formation, strata in Alberta, Canada, in which the present species occurred, as he stated that the name Alberta shale was incorrectly applied here. Recognizing that they differed from A. coprolithiformis Schwager, he described the finer-textured specimens as $A$. tyrrelli Nauss, and the specimens with clear angular quartz grains and little cement in the wall he described as A. humei Nauss. The holotypes of the two "species" were from different formations, $A$. tyrrelli from the basal Lloydminster, and $A$. humei from the Cummings member of the underlying Mannville formation. However, the distribution table given by Nauss shows nearly identical ranges for the two "species," as well as for A. fragmentarius Cushman.

Tappan (1951a, 1951b) recorded A. tyrrelli as one of the index species for the Alaskan Cretaceous, considering it to be distinct from $A$. fragmentarius. However, the Alaskan specimens figured were of the larger and broader species later described as $A$. wenonahae Tappan, which is commonly associated with $A$. fragmentarius. One of the hypotypes of $A$. tyrrelli recorded by Tappan, but not figured (USNM 106488), does belong to the present species.

Mellon and Wall (1956) recorded this species from the basal Clearwater formation of the Athabasca re- 
gion of Alberta, Canada, using the name A. humei, as their specimens were "coarsely arenaceous".

Suites of specimens from the many thousands of well and outcrop samples studied from northern Alaska as well as the comparison of the types of these "species" definitely show that Ammobaculites fragmentarius, humei and tyrrelli are all conspecific. As the name fragmentarius has priority, it should henceforth be used for both the coarsely and finely textured specimens.

Gulf Coast Upper Cretaceous specimens referred to A. coprolithiformis and $A$. fragmentarius are not the same species as the older Canadian form. The Gulf Coast strata of this age do not have a similar form, and apparently $A$. fragmentarius is a northern species only.

A. fragmentarius is found in the Grandstand, Topagoruk and Kukpowruk formations in northern Alaska. It occurs in the Mannville and Lower Lloydminster formations of the Vermilion district, in the Clearwater formation of the Athabasca River region and the Loon River and lower Peace River formation of the Peace River area, all of Alberta, Canada. The Ammobaculites sp. recorded by Wickenden $(1945, \mathrm{p} .22)$ from the Asheville formation of Manitoba probably belongs to either this species or to $A$. wenonahae Tappan.

Types and occurrence.-Figured hypotypes (USNM P6057 a, b) and unfigured hypotypes (USNM P6058), from a core at 469 feet, figured hypotype (USNM P6059) and unfigured hypotype (USNM P6060) from a core at $470-475$ feet, all in the Grandstand formation, and unfigured hypotypes (USNM P6061) from a core at 1,850-1,855 feet in the Topagoruk formation, all from Umiat test well 2 .

Figured hypotype (USNM P6062) and unfigured hypotype (USNM No. 106488; originally recorded as 4 mmobaculites tyrrelli Nauss by Tappan, 1951) from the Topagoruk formation in a core at $558-568$ feet in Arcon Point Barrow core test 1.

Unfigured hypotypes (USNM P6063) from a core at 3,237 to 3,250 feet, in the Torok formation, in South Barrow test well 1.

Unfigured hypotype (USNM P6064) from well cuttings at $4,330-4,340$ feet in the Topagoruk formation in Umiat test well 1.

Unfigured hypotypes (USNM P606) from field sample 47A $\operatorname{Tr} 203$, in the Kukpowruk formation.

\section{Ammobaculites wenonahae Tappan}

Plate 32, figures 1-7

Ammobaculites wenonahae Tappan, 1960, Am. Assoc. Petroleum Geologists Bull., v. 44, no. 3, p. 291, pl. 1, figs. 3-6.

Ammobaculites tyrrelli Nauss. Tappan, 1951 (not Nauss, 1947), Cushman Found. Foram. Research, Contr., vol. 2, pt. 1, p. 3, pl. 1, figs. 12-14; Tappan, 1951, in Payne et al, U.S. Geol. Surv., Oil and Gas Invest. Map OM-126, Sheet 3, fig. 21 (11).

Test free, elongate, slightly compressed, early portion close-coiled, with five to seven chambers in the coil and a large umbilicus, later portion uniserial with nearly parallel sides, early uniserial portion of equal or less breadth than the coil, peripheral margin broadly rounded; chambers numerous, inflated in the coil, ranging from subround to low and broad in the uniserial portion, uniserial chambers increasing very little in diameter as added, although secondary compression may result in a flaring appearance; sutures distinct, except in the most coarsely agglutinated specimens, straight and depressed; wall arenaceous, texture varying with the type of enclosing sediments, from very coarsely grained and roughly finished to fine grained with considerable cement and smoothly finished; aperture terminal, rounded, at the end of a short neck, which may not always be preserved. Length of holotype $1.27 \mathrm{~mm}$, greatest breadth of coil $0.47 \mathrm{~mm}$, greatest breadth of uniserial portion $0.52 \mathrm{~mm}$, thickness $0.26 \mathrm{~mm}$. Paratypes range between 0.47 and 1.27 $\mathrm{mm}$ in length.

Remarks.-This species differs from Ammobaculites coprolithiformis (Schwager) in having nearly parallel sides in the uniserial portion; the chambers increase very little in height as added and the earliest uniserial portion is of nearly the same breadth as the coil. In A. coprolithiformis the earliest uniserial chambers are much narrower than the coil, the later portion flaring rapidly and the chambers increase more rapidly in height.

The present species differs from the associated but rarer Ammobaculites fragmentarius Cushman in being two to three times as large, and the chambers proportionately broader, lower and more closely appressed. Ammobaculites fragmentarius is widely recorded from Canada, but the present larger species is apparently a more geographically restricted form. It is more abundant in Alaska than is A. fragmentarius and it occupies a distinct stratigraphic zone within the Grandstand formation of northern Alaska. The top occurrence in wells can be used as a reference plane with considerable accuracy within a limited area.

Types and occurrence.-Holotype (USNM 106127a), figured paratype (USNM 106127b) and unfigured paratypes (USNM 106128), all formerly considered (Tappan, 1951) to represent $A$. tyrrelli Nauss, from a core at $532-547$ feet, in the Grandstand formation (formerly Umiat formation), in Umiat test well 3 (originally considered as Umiat core test 1). 
Figured paratype (USNM 106129) figured by Tappan (1951) as $A$. tyrrelli, from cuttings at $3,570-3,580$ feet, in the Topagoruk formation (formerly considered to be the Umiat formation), in Umiat test well 1. Additional figured paratypes (USNM P6066) from well cuttings at 3,560-3,570 feet, and (USNM P6067) from well cuttings at 5,580-5,590 feet, both from the Topagoruk formation, and unfigured paratypes (USNM P6068) from a core at 1,615 to 1,625 feet in the Grandstand formation, unfigured paratypes (USNM P6069) from a core at $1,635-1,645$ feet in the Grandstand formation, unfigured paratype (USNM P6070) from well cuttings at 3,930-3,940 feet in the Topagoruk formation and unfigured paratype (USNM P6071) from well cuttings at 4,840-4,850 feet in the Topagoruk formation, all from Umiat test well 1.

Figured paratype (USNM P6072) and unfigured paratypes (USNM P6073) from a core at 543-545 feet in the Grandstand formation, unfigured paratype (USNM P6074) from a core at 1,020-1,030 feet, unfigured paratypes (USNM P6075) from a core at 1,040-1,050 feet, unfigured paratypes (USNM P6076) from a core at 1,050-1,060 feet, unfigured paratypes (USNM 106486, formerly recorded by Tappan, 1951, as hypotypes of $A$ tyrrelli) from a core at 1,080-1,087 feet, and unfigured paratype (USNM P6077) from well cuttings at 1,560-1,570 feet, all from the Topagoruk formation; all from Simpson test well 1.

Unfigured paratypes (USNM 106130, formerly recorded by Tappan, 1951, as hypotypes of A. tyrrelli) from a core at 990-992 feet, in the Grandstand formation (formerly Umiat formation), and unfigured paratype (USNM P6078) from well cuttings at 2,680-2,690 feet in the Topagoruk formation, all from Umiat test well 2 .

Unfigured paratypes (USNM 106487, formerly recorded by Tappan, 1951, as hypotypes of $A$. tyrrelli) from cuttings at 250-260 feet in the Grandstand formation (formerly Umiat formation) in Simpson Core Hole 8.

Unfigured paratypes (USNM P6079) from a core at 2307-2317 feet in the Torok formation in South Barrow Test Well 2.

Unfigured paratypes (USNM P6080) from a core at 1625 to 1639 feet, in the Torok formation in South Barrow Test Well 3.

Unfigured paratypes (USNM P6081) from a core at 2340-2350 feet in the Torok formation in South Barrow Test Well 4.

Figured paratype (USNM P6082) and unfigured paratypes (USNM P6083) from field sample $47 \mathrm{ADt}$ 227, unfigured paratypes (USNM P6084) from field sample $47 \mathrm{ADt} 230$, and unfigured paratype (USNM
P6085) from field sample 47 ADt 236, all from the Grandstand formation.

Figured paratype (USNM P6086) from field sample $47 \mathrm{ATm} 13$, bed 6 , in the Kukpowruk formation.

Unfigured paratype (USNM P6087) from field sample $47 \mathrm{~A} \operatorname{Tr} 115$, from the Kukpowruk formation, and unfigured paratypes (USNM P6088) from field sample $47 \mathrm{ATr} 167$, from the Torok formation.

Unfigured paratypes (USNM P6089) from field sample 47AWh 141, in the Corwin formation, unfigured paratypes (USNM P6090) from field sample 47 AWh 172, in the upper part of the Torok formation, unfigured paratype (USNM P6091) from field sample $47 \mathrm{AWh} 632$, in the Corwin formation, and unfigured paratypes (USNM P6092) from field sample $47 \mathrm{AWh}$ 723 in the Kukpowruk formation.

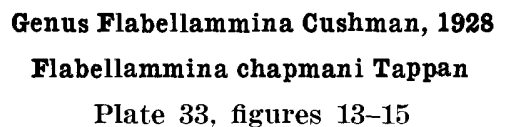

Flabellammina chapmani Tappan, 1960, Am. Assoc. Petroleum Geologists Bull., v. 44, no. 3, p. 292, pl. 1, figs. 13-14.

Test free, elongate, compressed, with nearly parallel sides; early portion in a flat planispiral coil of few chambers, later with three to four uniserial chambers, low and gently arched, somewhat produced at the apertural end; sutures slightly depressed but may be obscured by the coarse texture of the wall, radial in the coil, arched in the rectilinear portion; wall relatively coarsely agglutinated, roughly finished; aperture terminal, elongate, on a short blunt neck.

Length of holotype $0.65 \mathrm{~mm}$, breadth $0.31 \mathrm{~mm}$, thickness $0.08 \mathrm{~mm}$. Paratypes range from 0.89 to $1.55 \mathrm{~mm}$ in length.

Remarks.-Flabellammina chapmani, resembles $F$. rugosa Alexander and Smith in the nearly parallel sides and produced final chamber, but is about onehalf as large and less coarsely agglutinated, and the final chamber has a more distinctly produced neck.

The present species is extremely rare, having been observed in only two localities.

Types and occurrence.-Holotype (USNM P4355) from the Seabee formation, field sample $47 \mathrm{~A} \mathrm{~Wb} 155$.

Figured paratypes (ITSM P6093 a-b) and unfigured paratypes (USNM P6094) from field sample 47 A Wb 456, from the Rogers Creek member of the Schrader Bluff formation.

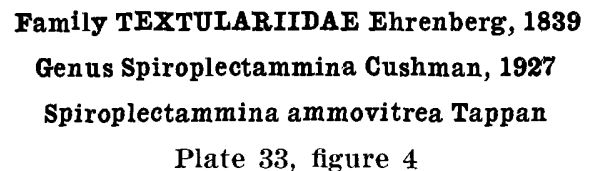

Spiroplectammina ammovitrea Tappan, 1940, Jour. Paleontology, vol. 14, no. 2 , p. 97 , pl. 14, figs. 13a-b; Tappan, 
1943, Jour. Paleontology, v. 17, no. 5. p. 484, pl. 77, figs. 23 a-c; Frizzell, 1954, Bur. Econ. Geol., Rejt. Invest. 22, p. 66 , pl. 4 , figs. $22 \mathrm{a}-\mathrm{b}$.

Test free, small, elongate, slightly compressed, sides nearly parallel, early portion forming a relatively large planispiral coil of about five chambers, followed by a biserial stage of three to five pair of chambers of nearly equal breadth and height, the biserial stage having a breadth approximately equal that of the coil; sutures radial in the coil, horizontal in the biserial portion, slightly depressed; wall finely arenaceous, smoothly finished; aperture a low interiomarginal arch at the inner margin of the final chamber.

Length of figured hypotype $0.44 \mathrm{~mm}$, breadth $0.16^{\circ}$ $\mathrm{mm}$. Unfigured hypotype is $0.36 \mathrm{~mm}$ in length.

Remarks.-This species was originally described from the Grayson formation of Texas, and was later recorded from the Duck Creek formation there, having a known geologic range of mid-Albian to basal Cenomanian. It is rare in Alaska, occurring in the Topagoruk formation.

Spiroplectammina ammovitrea differs from $S$. scotti Cushman and Alexander in having higher chambers, and horizontal sutures, instead of low and broad chambers and oblique sutures.

Types and occurrence.-Figured hypotype (USNM P6095) from well cuttings at 5850 to 5860 feet, within the Torok shale section, but probably contamination from the overlying Topagoruk formation, from Umiat test well 2.

Unfigured hypotype (USNM P6096) from well cuttings at 3930 to 3940 feet in the Topagoruk formation, in Umiat test well 1.

\section{Spiroplectammina mordenensis Wickenden}

Plate 33, figure 6

Spiroplectammina mordencnsis Wickenden, 1932, Royal Soc. Canada, Trans. ser. 3, v. 26 , sec. 4 , p. 86 , pl. 1 , figs. $4 a-b$; Cushman, 1946, U.S. Geol. Survey Prof. Paper 206, p. 28 , pl. 6, fig. 4; Tappan, 1951. Cushman Found. Foram. Research. Contr. vol. 2 , pt. 1, p. 5. pl. 1. figs. 20a-b; Tappan, 1951, in Payne and others, U.S. Geol. Survey Oil and Gas Invest. Map OM-126, sheet 3, fig. 21 (5).

Test free, small, with early planispiral portion comparatively large, comprising one-third to one-fourth the length of the test and of diameter equal to or greater than the breadth of the biserial portion which follows, biserial portion gradually increasing in breadth, periphery rounded; chambers distinct, about six in the coil, followed by six to eight closely appressed, biserially arranged chambers, the final pair of chambers being much higher than the preceding ones; sutures straight, flush with the surface in the planispiral portion, distinet, straight and slightly de- pressed in the biserial portion; wall finely arenaceous, with considerable cement, surface smoothly finished; aperture at the base of the inner margin of the final chamber. Length of figured hypotype $0.31 \mathrm{~mm}$, greatest breadth of coil $0.16 \mathrm{~mm}$, greatest breadth of biserial portion $0.18 \mathrm{~mm}$, greatest thickness $0.13 \mathrm{~mm}$. Other specimens range from 0.31 to $0.47 \mathrm{~mm}$ in length.

Remarks.-Wickenden (1932) described this species from the Morden member of the Vermilion River formation of Manitoba. In northern Alaska it occurs rarely in the Sentinel Hill and Barrow Trail members of the Cpper Cretaceous Schrader Bluff formation of the Colville Group. It has not been recorded elsewhere.

Types and occurrence,-Figured hypotype (USNM no. 106501) from beds of the Barrow Trail member of the Schrader Bluff formation interfingered with the Tuluvak formation, from a seismograph shot hole, Umiat Shot Point 15, at a depth of 20 feet.

Unfigured hypotype (USNM P6099) from field sample 48 A Dt 452 , in the Sentinel Hill member of the Schrader Bluff formation.

\section{Spiroplectammina webberi Tappan \\ Plate 33, figures 1-3}

spiroplectammina rebberi Tappan, 1957, U.S. Natl. Mus. Bull. 215 , p. 205 , pl. 66, figs. 3-5.

Test free, small, elongate, base rounded with early portion planispiral, later biserial with sides gradually flaring; chambers increasing gradually in size, about three or four pair of biserial chambers, of nearly equal height and breadth; sutures slightly depressed, nearly horizontal in the biserial portion; wall agglutinated, of fine to medium grains, roughly finished; aperture at the base of the inner margin of the chamber.

Length of holotype $0.46 \mathrm{~mm}$, breadth $0.17 \mathrm{~mm}$, thickness $0.07 \mathrm{~mm}$.

Paratypes range from 0.26 to $0.88 \mathrm{~mm}$ in length.

Remanks.-This species differs from $S$. mordenensis Wickenden in being larger and more compressed, in having a relatively smaller coil, higher biserial chanbers, and a more flaring test. It occurs throughout the Colville group, from the Seabee formation to the Sentinel Hill member of the Schrader Bluff formation.

The species was named in honor of $\mathrm{E}$. J. Webber, geologist, formerly with the U.S. Geological Survey.

Types and orcurrence.-Holotype (USNM P4348) and unfigured paratypes (USNM P4349) from the lower member of the Seabee formation, from field sample $47 \mathrm{~A} \mathrm{~Wb} 150$, and unfigured paratypes (USNM P4350) from the Seabee formation (field sample 47A Wb 155). 
Unfigured paratypes (USNM P4351) from the Sentinel Hill member of the Schrader Bluff formation (field sample 47 A St 25).

Figured paratypes (USNM P4352 a, b) and unfigured paratypes (USNM P4353) from a core at 1110-1120 feet, in the Sentinel Hill member of the Schrader Bluff formation, in Sentinel Hill core test 1.

Unfigured paratypes (USNM P 4354) from a core at 490-499 feet, in the Seabee formation, in Umiat test well 1.

Unfigured paratypes (USNM P 6100) from field sample 48 A Dt 378 from the Rogers Creek member of the Schrader Bluff formation and unfigured paratype (USNM P6101) from field sample 48 A Dt 383, from the Rogers Creek member of the Schrader Bluff formation.

\section{Spiroplectammina species}

Plate 33, figure 5

Test free, small, short, rounded in section, flaring only slightly from the rounded base; relatively large initial coil of about four chambers followed by about four pair of broad, low, biserially arranged chambers; sutures slightly depressed, radial in the coil, slightly oblique in the biserial portion, forming an angle with the horizontal of up to 30 degrees; wall finely agglutinated, surface smoothly finished; aperture an interiomarginal arch at the inner margin of the final chamber.

Length of figured hypotype $0.44 \mathrm{~mm}$, breadth 0.23 , thickness $0.16 \mathrm{~mm}$.

Remarks.-This species differs from spiroplectammina alexanderi Lalicker in having more nearly parallel sides, and in being about twice as large. It differs from Textularia topagorukensis (Tappan) in having a large coil and only very slightly flared test which is not greatly compressed. In Alaska it occurs rarely in the Topagoruk formation.

Types and occurrence.-Figured hypotype (USNM P6103) from well cuttings at 1,960 to 1,970 feet in the Topagoruk formation and unfigured hypotype (USNM P6104) from well cuttings at 2,380-2,390 feet, probably as contamination from the overlying Torok or Topagoruk formations in South Barrow test well 2.

Unfigured hypotype (USNM P6102) from a core in the Topagoruk formation at 1,570 to 1,580 feet, in Simpson test well 1.

\section{Genus Textularia Defrance, 1824 \\ Textularia gravenori Stelck and Wall \\ Plate 33, figures 16,17}

Textularia gravenori Stelck and Wall, 1955, Research Council Alberta, Rept. 70, p. 55, pl. 2, fig. 36.

Test, free, tiny, narrow and tapering; chambers numerous, up to nine pair, low and biserially ar- ranged; sutures distinct, slightly depressed and oblique; wall finely arenaceous, surface granular in appearance; aperture a low arch at the inner margin of the final chamber.

Hypotypes range in length from 0.26 to $0.37 \mathrm{~mm}$, and in breadth from 0.10 to $0.15 \mathrm{~mm}$.

Remarks.-Textularia gravenori was originally described as occurring only in a seven-foot interval above the Howard Creek sand, in the lower part of the "Central" Kaskapau formation (Turonian), in the Spirit River area of western Alberta, Canada.

The species occurs in approximately the same stratigraphic position in Alaska, being restricted to the Seabee formation (Turonian).

Types and occurrence.-Figured hypotypes (USNM $\mathrm{P} 6105 \mathrm{a}-\mathrm{b})$ from a depth of 5 feet, and unfigured hypotypes (USNM P6106) from a depth of 20 feet, all from the Ayiyak nember of the Seabee formation in Umiat seismograph shot point 13.

Unfigured hypotypes (USNM P 6107) from a core at 499 to 509 feet in the Seabee formation, in Umiat test well 1.

\section{Textularia topagorukensis Tappan}

Plate 33, figures 7-11

Textularia topagorukensis Tappan, 1957, I.S. Natl. Mus. Bull. 215, p. 205, pl. 66, figs. 8-9.

Spiroplectammina koveri Tapuan, 1957, U.S. Natl. Mus. Bull. 215 , p. 205 , pl. 66 , figs. $1,2$.

Test free, tiny, elongate, early chambers in a planispiral coil in the relatively rare microspheric generation, all chambers of the megalospheric form and later chambers of the microspheric ones biserially arranged, increasing gradually in breadth as added, but increasing more rapidly in relative height, from five to six pairs of biserial chambers; sutures distinct, depressed, slightly oblique; wall finely agglutinated, rather smoothly finished, commonly crushed and distorted in preservation; aperture a low arch at the base of the final chamber.

Length of holotype of Textularia topagorukensis $0.46 \mathrm{~mm}$, breadth $0.17 \mathrm{~mm}$, thickness $0.07 \mathrm{~mm}$. Paratypes range from 0.23 to $0.60 \mathrm{~mm}$ in length. The holotype of spiroplectammina koveri (now regarded as belonging to the present species) is $0.49 \mathrm{~mm}$. in length, $0.18 \mathrm{~mm}$. in greatest breadth and $0.06 \mathrm{~mm}$. in thickness.

Remarks.-Originally this species was described as wholly biserial, and those specimens with early coil were regarded as a relatively rare species of Spiroplectammina. The exact coincidence of occurrence and the difficulty in separating the forms in any way other than the presence or absence of the early coil has led to the conclusion that they merely represent two generations of a single species. 
Textularia topagorukensis differs from $T$. rollaensis Stelck and Wall in the lower and more numerous chambers, more horizontal sutures, and more nearly parallel sides. It is found in the Torok and Topagoruk formations, rarely in the Tuktu formation, and rarely in the Grandstand formation in the subsurface section.

Types and occurrence.-Holotype (USNM P4296) and unfigured paratypes (USNM P4297) of T. topagomukensis, and holotype (USNM P4290) and unfigured paratypes (USNM P4291) of Spiroplectammina koveri (now considered to belong to T. topagorukensis), all from a core at 459 to 469 feet, and figured paratype (USNM P4302) from well cuttings at 17201730 feet, all in the Topagoruk formation, in South Barrow test well 2.

Unfigured paratypes of $S$. koveri, now regarded as T. topagorukensis (USNM P4294), from the Topagoruk formation in a core at 1030-1040 feet, and unfigured paratypes (USNM P4298) of T. topagorukensis from a core at 2235-2245 feet, and unfigured paratypes (USNM P4299) from a core at 2939-2949 feet, all from the Topagoruk formation, in Simpson test well 1.

Unfigured paratypes (USNM P4303) of T. topagorukensis and unfigured paratypes (USNM P6098) of $S$. koveri, all from a core at 256-264 feet, in the Grandstand formation, in Skull Cliff core test 1.

Figured paratype (USNM P4292) and unfigured paratypes (USNM P4293) of S. koveri (now regarded as T. topagomkensis), from a core in the Topagoruk formation at 1342-1352 feet in Arcon Point Barrow core test 1 .

Figured paratype of $S$. koveri (now regarded as $T$. topagorukensis) (USNM P 6097) from field sample 47 A $\operatorname{Tr} 215$, from the upper part of the Torok formation.

Unfigured paratype of $S$. koveri (now regarded as T. topagomikensis) (USNM P4295) from seismograph party 47 , line $27-48$, shot hole 8 , at $190-200$ feet in the Grandstand formation.

Unfigured paratypes of $T$. topagorukensis (USNM P4300) from a core at 1600-1610 feet, in the Topagoruk formation, in South Barrow test well 1.

\section{Genus Siphotextularia Finlay, 1939 \\ Siphotextularia? rayi Tappan \\ Plate 34, figures 19-22}

Siphotextularia? rayi Tappan, 1957, U.S. Natl. Mus. Bull. 215, p. 206, pl. 66, figs. 6-7.

Test free, biserial, somewhat flaring; chambers inflated, relatively high, and increasing rapidly in size; sutures distinct, depressed, horizontal; wall finely agglutinated, smoothly finished, white; aperture a slit in the terminal face of the final chamber, not extending to the base of the chamber.

Length of holotype $0.55 \mathrm{~mm}$, breadth $0.31 \mathrm{~mm}$, thickness $0.08 \mathrm{~mm}$. Paratypes range from 0.44 to $0.60 \mathrm{~mm}$ in length.

Remarks.-Siphotextularia? rayi differs from $S$. washitensis Loeblich and Tappan in being larger, with higher and more inflated chambers and more nearly horizontal sutures. It is not a typical Siphotextularia in that it is not quadrangular in section, but seems closest to that genus in the terminal apertural character, although the aperture is not produced on a neck. It occurs in the Grandstand and Topagoruk formations.

The specific name is in honor of R. G. Ray, geologist, U.S. Geological Survey.

Types and occurrence.-Holotype (USNM P4304) and unfigured paratypes (USNM P 4305) from a core at 660-670 feet, in the Topagoruk formation, in South Barrow test well 2.

Figured paratype (USNM P4306) from well cuttings at $857-867$ feet, and unfigured paratypes (USNM $\mathrm{P} 4307$ ) from well cuttings at 1086-1091 feet, all in the Topagoruk formation, in Arcon Point Barrow core test 1 .

Unfigured paratypes (USNM P4308) from a core at 2235-2245 feet, in the Topagoruk formation, in Simpson test well 1.

Unfigured paratype (USNM P4309) from seismograph party 47 , shot hole 35 , line $14 \mathrm{~A}-48$, at a depth of 110-120 feet, in the Grandstand formation.

Figured paratype (USNM P6108) from field sample 47 A Wh 541, from the lower part of the Topagoruk formation.

Unfigured paratype (USNM P6109) from field sample $47 \mathrm{~A}$ Wh 160, in the upper part of the Torok formation.

Unfigured paratype (USNM P6110) from field sample $47 \mathrm{~A} \mathrm{~Wb} 372$ in the Ninuluk formation.

Unfigured paratype (USNM P6121 from field sample $47 \mathrm{~A} \operatorname{Tr} 212$ in the Torok formation.

Figured paratype (USNM P6122) from field sample $47 \mathrm{~A} \operatorname{Tr} 115$, in the Kukpowruk formation.

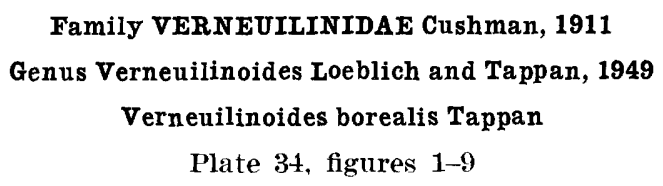

T'erneuilinoides? sp. Mellon and Wall, 1956, Research Council Alberta, Rept. 72, p. 28, pl. 1, figs. 13, 14.

Verneuilinoides borealis Tappan, 1957, I.S. Natl. Mus. Bull. 215 , p. 206, pl. 66, figs. $10-18$.

Test free, elongate, triserial, axis commonly slightly twisted, rounded in section, broadly flaring, rarely 
more elongate and less flaring in the later portion; chambers increasing rapidly in size, normally inflated, but in many specimens the tests are crushed in preserration; sutures distinct, depressed; wall commonly finely agglutinated, or may be relatively coarse grained, probably reflecting the character of the local depositional enrironment; aperture a low arch at the base of the final chamber.

Length of holotype $0.49 \mathrm{~mm}$, breadth $0.18 \mathrm{~mm}$. Paratypes range in length from 0.26 to $1.17 \mathrm{~mm}$.

Remarks.-This species is extremely variable in size, degree of flaring, coarseness of texture, and type of preservation. Commonly the specimens are crushed and distorted, but more rarely specimens are filled with pyrite, which preserves the original form and inflation of the chambers. It is one of the most abundant species in the northern Alaska strata. It differs from Terneuilinoides perplexa var. gleddiei Stelck and Wall in being considerably larger and more flaring.

$V$. boreatis occurs in the Grandstand and Topagoruk formations, in equivalent marine zones in the Chandler formation, and in the upper part of the surface Torok formation. It was recorded as Ternevilinoides sp. (Mellon and Wall, 1956) from the basal Clearwater formation and upper part of the McMurray formation in Alberta, Canada, where it "occurs commonly to abundantly".

Types and occurrence.-Holotype (USNM 106131), figured paratype (USNM 106132), and unfigured paratypes (USNM 106133), all from a core at 1810-1816 feet; unfigured paratypes (USNM P4310) from a core at 1635-1645 feet; unfigured paratypes (USNM P4311) from a core at 1693-1703 feet; unfigured paratypes (USNM P4312) from a core at 2365-2370 feet, all from the Grandstand formation, and unfigured paratypes (USNM P4313) from well cuttings at 3890 3900 feet and unfigured paratype (USNM P4314) from well cuttings at $4860-4870$ feet, all from the Topagoruk formation, in Umiat test well 1.

Unfigured paratypes (USNM P4315) from a core at 469 feet and unfigured paratypes (USNM 106135) from a core at 785-788 feet, all from the Grandstand formation, in Umiat test well 2.

Unfigured paratypes (USNM 106134) from a core at 361-366 feet, in the Grandstand formation, in Uiniat test well 3.

Unfigured paratypes (USNM P4316) from field sample $48 \mathrm{~A}$ Dt 328 , in a marine zone interfingered with the Chandler formation.

Figured paratype (USNM P4317) and unfigured paratypes (USNM P4318) from a core at 461-466 feet, in the Grandstand formation, in Skull Cliff core test 1.
Figured paratype (USNM P4319) and unfigured paratypes (USNM P4320) from a core at 308-318 feet and unfigured paratypes (USNM P4321) from a core at 533-5 43 feet; all in the Grandstand formation, and unfigured paratypes (USNM P4322) from a core at 2,275-2,285 feet in the Topagoruk formation, all from Simpson test well 1.

Unfigured paratype (USNM P4323) from a core at 231.5 to 233 feet, in the Grandstand formation, in Simpson core test 3 .

Unfigured paratypes (USNM P432t) from a core at $342-352$ feet, in the Grandstand formation, in Simpson core test 8 .

Unfigured paratypes (USNM P4325) from well cuttings at 150-160 feet; figured paratype (USNM $P+326$ ) and unfigured paratypes (USNM P4327) from well cuttings at 170-180 feet; and unfigured paratypes (CSNM P4328) from well cuttings at 180-190 feet, all from the Grandstand formation, in Oumalik core test 2.

Figured paratypes (USNM P4329 a-d) and unfigured paratypes (USNM P4330) from field sample 6 A Th 165, Grandstand formation.

Unfigured paratypes (USNM P4331) from the Grandstand formation (field sample 47A Dt 240).

Unfigured paratypes (USNM P4332) from field sample 48A Dt 2, upper part of the Torok formation (equivalent to the Topagoruk formation in the subsurface).

Unfigured paratypes (USNM P4333) from field sample $47 \mathrm{~A} \operatorname{Tr} 167$, in the Topagoruk formation.

Unfigured paratypes (USNM P4334) from 180 to 230 feet above the base of the Grandstand formation, field sample $47 \mathrm{~A} \operatorname{Tr} 289$.

Unfigured paratypes (USNM P4335) from an outcrop 3,850 feet below the top of the Grandstand formation (field sample $47 \mathrm{~A} \mathrm{Z} 615 \mathrm{~A}$ ).

Unfigured paratypes (USNM P4336) from field sample $48 \mathrm{~A}$ Dt 187 , in marine zone of the Chandler formation.

Infigured paratypes (USNM P4337) from well cuttings at $450-460$ feet, in the Topagoruk formation, in South Barrow test well 2.

\section{Verneuilinoides fischeri Tappan}

Plate 32, figures $12-17$

Verneuilinoides fischeri Tappan, 1957, U.S. Natl. Mus. Bull. 215, p. 207, pl. 66, figs. 23-28.

Test large, free, flaring at the base, but comparatively narrow and elongate, sides nearly parallel in the later portion; chambers numerous, inflated, triserially arranged, increasing in proportional height as added; sutures distinct, depressed; wall finely agglutinated, 
surface smoothly finished; aperture loop shaped, at the base of the inner face of the final chamber.

Length of holotype $1.30 \mathrm{~mm}$, breadth $0.39 \mathrm{~mm}$. Paratypes range from 0.36 to $1.77 \mathrm{~mm}$ in length.

Remarks.-This species occurs in the Seabee and Schrader Bluff formations of Turonian to Campanian age, and in their equivalent zones in the Ignek formation.

Terneuitinoides fischeri differs from Tremeuilina parallela Cushman from the Craie Blanche of France, in being longer, narrower and more tapering, in haying relatively higher chambers, and in lacking the triangular section of true Terneuitina. Terneuitina bearpawensis (Wickenden) has more inflated and higher chambers and a more twisted test. Terneuitinoides boreatis Tappan is smaller, with a broader, flaring, and more twisted test, and relatively lower chambers.

The species is named in honor of W. A. Fischer, geologist, U.S. Geological Survey, who collected some of the material containing this species.

Types and occurrence.-Holotype (USNM P4356), figured paratypes (USNM P 4357 a, b), and unfigured paratypes (ISNM P4358) from the Upper Cretaceous part of the Ignek formation, field sample $46 \mathrm{~A} \mathrm{~L} 66$.

Figured paratype (USNM P4359) from a core at 571-574 feet, unfigured paratype (USNM P4360) from a core at 500-510 feet, unfigured paratypes (USNM P4361) from a core at 589-602 feet, unfigured paratypes (USNM P4362) from a core at 602-604 feet, and unfigured paratypes (USNM P 4363 ) from a core at 829-839 feet, all from the Sentinel Hill member of the Schrader Bluff formation, in Sentinel Hill core test 1 .

Unfigured paratypes (USNM P4364) from a core at 1351 feet, in a marine zone of the Prince Creek formation, in Gubik test well 2.

Figured paratype (USNM P4340) and unfigured paratypes (USNM P 4341) from field sample $46 . \mathrm{A}$ Fi $80 \mathrm{~A}$, in the Seabee formation.

Figured paratype (USNM P4342) and unfigured paratypes (USNM P4343) from field sample $46 \mathrm{~A}$ Gr 98, lower part of the Ignek formation.

Unfigured paratypes (USNM P4346) from field sample $47 \mathrm{~A}$ St 25 , from 2570 feet below the top of the Sentinel Hill member of the Schrader Bluff formation.

Unfigured paratypes (USNM P4347) from a core at 614-624 feet in the Seabee formation in Umiat test well 1.

Unfigured paratypes (ISNM P6111) from field sample 46A Ry $150 \mathrm{~A}$, in the Seabee formation.

\section{Genus Uvigerinammina Majzon, 1943}

The following two species were both originally placed in Tritaxia Reuss, 1860, but did not fit well into this generic assignment. The present genus differs from Tritaxia in the trochoid rather than strictly triserial chamber arrangement and rounded rather than triangular test. The chambers increase rapidly in size, and although there are usually three per whorl they are not in series as in Tritaxia. Eren in the type species in the Carpathian Mountains there is a tendency to a biserial arrangement, which is also noted in both the Canadian-Alaskan species. There is no change in apertural position with growth, as the aperture is terminal in all growth stages in livigerinammina. The genus is reported from the Upper Cretaceous and Paleogene sediments of the Carpathian area (formerly Czechoslowakia, now in the T.S.S.R.). It also occurs at the "base of the variegated Ipper Cretaceous marls" of Albian? and Cenomanian age (Geroch, 1957). Specimens from both regions have been supplied by $\mathbf{S}$. Geroch, for comparison with the Canadian and Alaskan forms. Interestingly, the genus occurs in the flysch sediments from tuffaceous beds with an arenaceous foraminiferal assemblage, in the Carpathian region, and is characteristic of the same lithologic and faumal facies in both Canada and Alaska.

Uvigerinammina athabascensis (Mellon and Wall)

Plate 33, figure 12

Tritaxia athabascensis Mellon and Wall, 1956, Research Council Alberta, Rept. 72, p. 27, pl. 1, figs. 16, 17.

Test free, elongate, flaring, apparently biserial, but tests almost invariably compressed and crushed in preservation, later portion loosely biserial; chambers few in number, increasing rapidly in size as added, and inflated, although most specimens have been crushed and distorted in rarying planes in the process of fossilization; sutures slightly depressed, nearly horizontal; wall of fine quartz grains, conmonly white to gray in color; smoothly finished; aperture terminal, circular, at the end of a short neck, with a distinct lip.

Hypotypes range from 0.33 to $0.83 \mathrm{~mm}$ in length, and from 0.28 to $0.37 \mathrm{~mm}$ in breadth.

Remarks.-This species differs from $U$. manitobensis (Wickenden) in being larger, more flaring from the pointed base, and in having more numerous and more closely appressed chambers. Originally described from the basal Clearwater formation of Alberta, Canada, it was also said to occur in the middle and upper part of the Clearwater formation. It occurs at the same stratigraphic level in Alaska, in the Torok formation. This species may possibly be ancestral to the some- 
what younger Uvigerinammina munitobensis (Wickenden).

Types and occurrence.-Figured hypotype (USNM P6783) and unfigured hypotype (USNM P6784) from a core at 2030 to 2040 feet in the Torok formation, in South Barrow test well 2.

Unfigured hypotypes (USNM P6785) from a core at 3036 to 3046 feet, and unfigured hypotypes (USNM P6786) from a core at 3346 to 3349 feet, all from the Torok formation, in South Barrow test well 1.

Unfigured hypotypes (USNM P6787) from a core at 2340 to 2350 feet in the Torok formation, in South Barrow tast well 4 .

\section{Uvigerinammina manitobensis (Wickenden) \\ Plate 33, figures 18-23}

Tritaxia manitobensis Wickenden, 1932, Royal Soc. Canada, Trans. ser. 3, v. 26, sec. 4, p. 87 , pl. 1. fig. 10 ; Cushman, 1937, Cushman Lab. Foram. Research. Spec. Publ. 7, p. 27, pl. 4. fig. 7 ; Cushman, 1946, U.S. Geol. Survey Prof. Paper 206, p. 31, pl. 7, fig. 8; Tappan. 1951, Cushman Found. Foram. Research, Contr. vol. 2, pt. 1, p. 3, pl. 1, figs. 15-17; Tappan, 1951, in Payne and others, U.S. Geol. Survey Oil and Gas Invest. May OM-126, sheet 3, fig. 21 (9).

Test free, robust, loosely triserial, flaring very little from the rounded base; chambers few in number, distinct, rounded, inflated, increasing rapidly in size, early ones closely appressed, later more loosely arranged; sutures distinct, depressed; wall finely arenaceous, surface smoothly finished; aperture terminal, rounded, at the end of a distinct neck. Length ranges between 0.29 and $0.81 \mathrm{~mm}$, breadth ranges between 0.23 and $0: 47 \mathrm{~mm}$.

Remarks.-This species seems to have had a chitinous base to the arenaceous test, for the specimens are almost invariably crushed, compressed and distorted in varions ways, although other species in the same beds may show no distortion. The necklike extension of the final chamber, rounded terminal aperture and large irregular chambers serve to make this species one of the most easily recognized in the Cretaceous section. It is characteristic of the Tuktu, Topagoruk and Grandstand formations of northern Alaska, and was originally described from the upper shale member of the Ashville formation of Kirk, in Manitoba.

Types and occurrence.-Figured hypotypes (USNM 106489a--b) from field sample 47A Dt 227, formerly recorded as from the Tuktu member of the Umiat formation, but now considered to be the Tuktu formation.

Unfigured hypotypes (USNM P6226) from a core at 673 to 683 feet, unfigured hypotypes (USNM P6227) from a core at 723 to 733 feet, unfigured hypotype (USNM no. 106491) from a core at 733 to 743 feet, unfigured hypotypes (USNM P6228) from a core at 743 to 753 feet, all from the Grandstand formation, and figured hypotype (USNM no. 106490) from a core at 1080 to 1087 feet, unfigured hypotypes (TSNM $\mathrm{P} 6229$ ) from a core at 1570 to 1580 feet, figured hypotype (USNM P6230) from a core at 2024 to 2026 feet, unfigured hypotypes (USNM P6231) from a core at 2235 to 2245 feet, and unfigured hypotype (USNM no. 106492) from a core at 3350 to 3360 feet, all from the Topagoruk formation, all from Simpson test well 1.

Unfigured hypotypes (USNM no. 106493) from well cuttings at 1150 to 1160 feet, and unfigured hypotype (USNM no. 106494) from well cuttings at 1830 to 1840 feet, all from the Topagoruk formation, in South Barrow test well 1.

Unfigured hypotypes (USNM no. 106495) from a core at 459 to 469 feet in the Topagoruk formation, in South Barrow test well 2.

Hypotype (USNM 106496) from cuttings at 892902 feet, in the Topagoruk formation, in Arcon Point Barrow core test 1.

Unifgured hypotypes (USNM no. 106497) from a core at 256 to 264 feet and unfigured hypotypes (USNM P6232) from a core at 264 feet, all from the Grandstand formation in Skull Cliff core test 1.

Figured hypotypes (USNM P6233 a, b) and unfigured hypotypes (USNM P6234) from field sample $47 \mathrm{~A} \operatorname{Tr} 166$, and unfigured hypotypes (USNM P6235) from field sample $47 \mathrm{~A} \operatorname{Tr} 167$, both from the upper part of the Torok formation.

Unfigured hypotype (USNM P6236) from field sample $47 \mathrm{~A} \mathrm{Z} 603$, from $900-920$ feet below the top of the Tuktu formation. Unfigured hypotypes (USNM P6237) from field sample $47 \mathrm{~A} Z 606$, in a marine tongue within the lower part of the Chandler formation.

Unfigured hypotypes (USNM P6238) from field sample $47 \mathrm{~A} \mathrm{Ba} \mathrm{54}$, in the Corwin formation.

Unfigured hypotypes (USNM P6239) from field sample 49A Ke 66, in the Kukpowruk formation.

Unfigured hypotype (USNM P6240) from seismograph party 47 test hole, line $14 \mathrm{~A}-48$, shot point 43 .

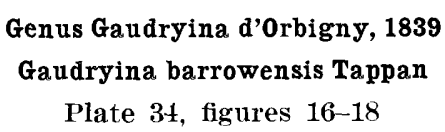

Gaudryina barrowensis Tappan, 1960, Am. Assoc. Petroleum Geologists Bull., v. 44, no. 3, p. 292, pl. 1, figs. 7-9.

Perneuitina sp. A. Wickenden, 1951, Canada Dept. Mines Tech. Surveys, Geol. Survey Canada, Paper 51-16, p. 35, pl. 1A, fig. 8 .

Test free, narrow, elongate, flaring rapidly in the initial portion, later with nearly parallel sides, tri- 
serial and triangular in section, with subacute angles and somewhat excavated sides, commonly specimens show only this triserial development, but adult welldeveloped specimens also show a short biserial stage; chambers broad, low and closely appressed; sutures distinct, depressed, horizontal to slightly oblique; wall finely agglutinated, surface smoothly finished; aperture a low arch at the inner margin of the final chamber.

Length of holotype $0.81 \mathrm{~mm}$, breadth $0.23 \mathrm{~mm}$. Paratypes range from 0.28 to $0.99 \mathrm{~mm}$ in length.

Remarks.-The species recorded as Verneuilina sp. A. from the upper part of the Loon River formation of Alberta, Canada, appears very similar to the present species, which occupies a correlative stratigraphic position in Alaska.

Guadryina barrowensis differs from the younger $G$. nanushukensis Tappan in being smaller, with lower, less inflated and more closely appressed chambers, sharper and more acute angles and more excavated sides. $G$. alexanderi Cushman is also larger and more flaring.

Types and occurrence.-Holotype (USNM P6131) from a core at 3155-3163 feet, unfigured paratype (USNM P6132) from a core at 3217-3226 feet, and unfigured paratype (USNM P6133) from a core at 3349-3355 feet, all in the Torok formation, in South Barrow Test well 1.

Figured paratype (USNM P6134) and unfigured paratypes (USNM P6135) from a core at 2161-2171 feet, unfigured paratype (USNM 106122) from a core at 2000-2010 feet (formerly an unfigured paratype of Gaudryina nanushukensis Tappan), unfigured paratype (USNM P6136) from a core at 2138-2140 feet, unfigured paratype (USNM P6137) from a core at 2153-2161 feet, unfigured paratypes (USNM P6138) from a core at 2171-2178 feet, unfigured paratype (USNM P6139) from a core at 2198-2208 feet, and unfigured paratype (USNM P6140) from a core at 2297-2307 feet, all from the Torok formation, in South Barrow Test well 2.

Figured paratype (USNM P6141) and unfigured paratypes (USNM P6142) from a core at 2320-2329 feet, and unfigured paratypes (USNM P-6143) from a core at 2329-2340 feet, all from the Torok formation, in South Barrow test well 4.

\section{Gaudryina canadensis Cushman \\ Plate 35, figures 1-7}

Bigenerina angulata Cushman, 1927, Royal Soc. Canada, Trans. 3rd ser., v. 21, sec. 4 , 1). 131, pl. 1, fig. 10.

Gaudryina canadensis Cushman. 1943 (for Gaudryina angulata (Cushman), 1927: not Gaudryina triangularis Cushman var. angulata Cushman, 1924), Cushman Lab. Foram. Re- search, Contr. v. 19, pt. 2, p. 28, pl. 6, figs. 7, 8; Cushman, 1946, Cushman Lab. Foram. Research, Spec. Publ. 7A, p. 9. pl. 1, fig. 22; Cushman, 1946, U.S. Geol. Survey Prof. Paper 206, p. 34, pl. 6. fig. 24.

Gaudryina hectori Nauss, 1947, Jour. Paleontology, v. 21, no. 4, p. 335 , pl. 48 , figs. $6 a-b$.

Gaudryina sp. A. Wickenden, 1951, Canada Dept. Mines and Tech. Survey, Geol. Survey Canada. Paper 51-16, p. 36, pl. 1 A, fig. 9.

Test free, narrow, elongate, twisted, rounded in section, early triserial portion forming about one-third the length of the test, followed by a well-developed, twisted biserial portion, commonly more or less compressed, and occasional specimens may be crushed and distorted; chambers numerous, of approximately equal breadth and height, appearing cuneate, inflated, or by compression may be somewhat collapsed centrally; sutures oblique, distinct and depressed in well preserved specimens, less distinct in the crushed or distorted specimens; wall finely agglutinated, surface smoothly finished to slightly granular in appearance; aperture a relatively high arch extending up the face of the final chamber.

Hypotypes range in length from 0.18 to $0.86 \mathrm{~mm}$, and in breadth from 0.10 to $0.23 \mathrm{~mm}$.

Remarks.-Gaudryina canadensis is characterized by the rounded section, relatively long and narrow test, inflated chambers and constricted sutures. In Alaska it occurs most commonly in the Ninuluk formation (Cenomanian), and more rarely in the underlying Topagoruk and Grandstand formations (upper Albian). Rarely it is also found in the Oumalik formation.

This species was originally described as Bigenerina angulata Cushman, on the basis of crushed specimens for which the generic diagnosis was difficult. It was thought to be of Late Cretaceous age. Later, Cushman stated that additional material proved the species to be of Early Cretaceous age, and to belong to Gaudryina. As the specific name angulata was already preoccupied for Gaudryina, Cushman proposed the new name canadensis to replace it. Meanwhile Nauss described the present species as Gaudryina hectori, occurring in the basal Lloydminster formation of Alberta, Canada. He also recorded "Bigenerina" angulata in a table, as occurring in both the Lloydminster and the Cummings member of the Mannville formation but did not illustrate that species.

Gaudryina sp. A, recorded by Wickenden (1951) from the Loon River formation of the Peace River area of Alberta probably belongs to the present species. In discussion of Alaskan stratigraphy by Detterman (1956a) the present species was referred to G. hectori Nauss. 
Types and occurrence.-Figured hypotypes (USNM P6144 a, b) and unfigured hypotypes (USNM P6145) from a core at 1,693 to 1,703 feet, figured hypotypes (USNM P6146 a, b) and unfigured hypotypes (USNM P6147) from a core at 1,810 to 1,816 feet, all from the Grandstand formation (Albian), and unfigured hypotype (USNM P6148) from well cuttings at 5060 to 5070 feet, in the Topagoruk formation (Albian) in Umiat test well 1.

Unfigured hypotypes (USNM P6149) from a core at 472 to 481 feet in Umiat test well 3 , in the Grandstand formation.

Unfigured hypotypes (USNM P6150) from a core at 848 to 858 feet, in the Grandstand formation, in Umiat test well 9.

Figured hypotype (USNM P6151) from a core at 1,297 to 1,302 feet, figured hypotype (USNM P6152) and unfigured hypotypes (USNM P6153) from a core at 2,535 to 2,540 feet, all from the Topagoruk formation in Simpson test well 1.

Unfigured hypotypes (USNM P6154) from a core at 577 to 588 feet, in the Grandstand formation, in Simpson core test 30 .

Unfigured hypotypes (USNM P6157) from field sample 45A Kr 121, from the Killik tongue, probably interbedded with the Grandstand formation.

Figured hypotype (USNM P6158) and unfigured hypotypes (USNM P6159) from field sample $47 \mathrm{~A} \mathrm{~Wb}$ 94, in the Tuktu formation.

Unfigured hypotypes (USNM P6164) from field sample 47A Tm 13, bed 12, in the Kukpowruk formation.

\section{Gaudryina cushmani Tappan}

Plate 34. figure 10

Gaudryina cushmani Tappan, 1940. Jour. Paleontology, vol. 14, no. 2. p. 99, pl. 15, figs. 6a-b : Cushman, 1946, Cushman Lab. Foram. Research, Spec. Publ. 7A, p. 8, pl. 1. figs. 18a-b ; Frizzell, 1954, Bureau Econ. Geol. Rept. Invest. 22, p. 70 , pl. 5 , figs. $19 \mathrm{a}-\mathrm{b}$.

Test free, conical, the later biserial portion flaring rapidly from the tiny triserial base; chambers numerous, broad and low, increasing in proportionate breadth as added; sutures distinct, slightly depressed, nearly horizontal; wall finely arenaceous, surface smoothly finished; aperture a low arch at the inner margin of the final chamber, in the somewhat excavated upper surface.

Length of figured hypotype $0.39 \mathrm{~mm}$, breadth 0.34 $\mathrm{mm}$.

Remarks.-This species was originally described from the lower Grayson formation of Texas (basal Cenomanian). The Alaskan specimens are slightly older, being from the Topagoruk formation of middle or upper Albian age. Because of the very small triserial portion, the species may have elsewhere been confused with Textularin. such as T'. conica d'Orbigny, and may thus in reality have a more extensive range than is recorded.

Types and occurrence.-Figured hypotype (USNM P6165) from field sample $47 \mathrm{~A}$ Wh 160 , in the upper part of the Torok formation (Topagoruk formation equivalent).

Unfigured hypotype (USNM P6166) from a core at 4087 to 4097 feet in the Topagoruk formation, in Umiat test well 2.

Cinfigured hypotypes (USNM P6167) from field sample $47 \mathrm{~A} \mathrm{Tr} 115$, in the Kukpowruk formation.

\section{Gaudryina irenensis Stelck and Wall}

Plate 35, figures 17-21

Gaudryina irenensis Stelck and Wall, 1955, Alberta Research Council, Rept. 70, p. 42, pl. 2, figs. 4, 5 .

Gaudryina cf. G. hectori Nauss. Stelck. Wall, and Wetter, 1958, Alberta Research Council, Geol. Div., Bull, 2, p. 26, pl. 3, figs. 23,24 .

Test free, elongate, compressed, consisting of a short triserial stage followed by a well developed flaring biserial stage; chambers of somewhat greater breadth than height, very slightly inflated in the later portion; sutures indistinct in early portion, somewhat depressed, in adult stage slightly oblique; wall agglutinated, finely to relatively coarsely grained, surface rough, with very little cement; aperture an interiomarginal slit extending about one-half the distance up the apertural face of the final chamber.

Hypotypes range in length from 0.28 to $0.50 \mathrm{~mm}$ and in breadth from 0.08 to $0.26 \mathrm{~mm}$.

Remarks.-Guadryina irenensis was originally described from the Kaskapau formation, below the horizon of the Pouce Coupe sand in Alberta, Canada. In Alaska it occurs in the Ninuluk and Seabee formation and more rarely in the overlying Schrader Bluff formation. Stelck, Wall, and Wetter (1958) recorded as $G$. hectori. a similar and probably conspecific form from the St. John shale of British Columbia.

Types and occurrence.-Figured hypotype (USNM P6189) and unfigured hypotypes (USNM P6190) from field sample $47 \mathrm{~A} \mathrm{~Wb} 155$, from the Seabee formation.

Unfigured hypotype (USNM P6191) from field sample $47 \mathrm{~A} \mathrm{~Wb} 151$, in the lower member of the Seabee formation.

Unfigured hypotypes (USNM P6192) from field sample $47 \mathrm{~A} \mathrm{~Wb} 451$, in the Rogers Creek member of the Schrader Bluff formation.

Figured hypotype (USNM P6193) and unfigured hypotypes (ITSM P6194) from field sample 47A Dt 
80 , from 20 feet above the base of the Seabee formation.

Unfigured hypotypes (USNM P6195) from the Sentinel Hill member of the Schrader Bluff formation, field sample $47 \mathrm{~A}$ Dt 364

Unfigured hypotypes (USNM P6196) from the Rogers Creek member of the Schrader Bluff formation, field sample 48A Dt 378; unfigured hypotypes (USNM P6197) from field sample 48A Dt 383, from the Rogers Creek member of the Schrader Bluff formation; unfigured hypotype (USNM P6198) from field sample 48A Dt 417, in the Barrow Trail member of the Schrader Bluff formation, and unfigured hypotype (USNM P6199) from field sample 48A Dt 421, in the Barrow Trail member of the Schrader Bluff formation.

Unfigured hypotype (USNM P6200) from field sample $46 \mathrm{~A} \mathrm{Fi} 80 \mathrm{~A}$, in the Seabee formation.

Unfigured hypotype (USNM P4345) from field sample $46 \mathrm{~A}$ Ry $150 \mathrm{~A}$, from the middle part of the Seabee formation.

Unfigured hypotypes (USNM P6201) from a core at 490 to 499 feet, and unfigured hypotypes (USNM P6202) from a core at 499 to 509 feet, in the Seabee formation in Umiat test well 1.

Unfigured hypotype (USNM P6203) from field sample $47 \mathrm{~A}$ Wh 295 , from the Seabee formation.

Figured hypotypes (USNM P6160a-c) and unfigured hypotypes (USNM P6161) from field sample $47 \mathrm{a} \mathrm{Wb} 341$, from 130 to 150 feet below the top of the formation, unfigured hypotypes (USNM P6155) from field sample 47A Dt 58, unfigured hypotypes (USNM P6156) from field sample 47A Dt 61, unfigured hypotypes (USNM P6162) from field sample 47A Wb 364, at the top of the formation, and unfigured hypotypes (USNM P6163) from field sample 47A Wb 387 , all from the Ninuluk formation.

\section{Gaudryina nanushukensis Tappan \\ Plate 34, figures 11-15}

Gaudryina sp. B. Wickenden, 1951, Canada Dept. Mines and Tech. Surv., Geol. Survey Canada, Paper 51-16, p. 44, pl. 1B, fig. 7.

Gaudryina nanushukensis Tappan, 1951. Cushman Found. Foram. Research, Contr., v. 2, pt. 1, p. 2, pl. 1. figs. 8a-11; Tappan, 1951, in Payne and others, U.S. Geol. Survey Oil and Gas Invest. Map, OM-126, sheet 3, fig. 21 (12a-b).

Test free, elongate, robust, early triserial portion flaring from the pointed to somewhat rounded base, with the third angle somewhat lower than the other two, many tests developing only the triserial stage, later portion of mature specimens becoming biserial through the loss of the series of chambers forming the lowest of the three angles of the triserial stage, angles rounded, sides slightly excavated; chambers numerous, low and broad, final chambers comparatively somewhat higher; sutures distinct, very slightly depressed, straight across the angles; wall finely arenaceous, with considerable cement, surface rather smoothly finished, and commonly with black mineral grains outlining the sutures and covering parts of the surface; aperture a low arch at the base of the face of the final chamber.

Length of holotype $0.91 \mathrm{~mm}$, greatest breadth 0.36 $\mathrm{mm}$, thickness through triserial portion $0.26 \mathrm{~mm}$, thickness through biserial portion $0.17 \mathrm{~mm}$. Other specimens range between 0.39 and $1.12 \mathrm{~mm}$ in length.

Remarks.-This species is similar in appearance to Gaudryina alexanderi Cushman, from the Lower Cretaceous of Texas, and is of about the same stratigraphic position, but is somewhat smaller, has less excavated sides and more rounded angles, and the biserial stage is not as well developed. It may represent a northern offshoot of the Gulf Coast species.

The species recorded by Wickenden (1951) as Gaudryina sp. B, from the "middle shale member" of the Peace River formation of Alberta, Canada, is apparently the same as the Gaudryina namushukensis of Alaska. Wickenden also noted the rounded angles, reduced biserial stage, and the white fine-grained arenaceous wall, "with a very thin coating of black carbon over some parts, especially near the sutures."

In Alaska, this species is characteristic of the Grandstand and Topagoruk formations in the subsurface, and has been found in the upper part of the Torok and Tuktu formations in outcrops.

Very similar species occur in beds of Lower Cretaceous age throughout the world. Gaudryina alexanderi Cushman and $G$. subcretacea Cushman occur in the Washita group of the Gulf Coast (mid-Albian age) and G. namushukensis Tappan, G. subcretacea Cushman, and $G$. barrovensis Tappan all occur in the Alaskan Lower Cretaceous, Gaudryina sp. B. of Wickenden (1951), from the Canadian Peace River area is here considered identical with $G$. nanushukensis and "Tritaxia D-4 of Hecht (1938) from the Aptian of Germany" may be an ancestral type.

Types and occurrence.-Holotype (USNM no. 106120 ) and figured paratypes (USNM $106124 \mathrm{a}-\mathrm{b}$ ) from well cuttings at 2720 to 2730 feet, originally described as from the upper Tuktu member of the Umiat formation, Nanushuk group, now placed within the Topagoruk formation of the Nanushuk group (Gryc et al., 1956); unfigured hypotypes (USNM P6168) from a core at 2145 to 2150 feet, figured paratype (USNM 106121) from cuttings at 2400 to 2410 feet, unfigured hypotypes (USNM P6169) from a core at 3000 to 3007 feet, unfigured hypotype (USNM 106503) 
from cuttings at 3050 to 3060 feet, and unfigured hypotypes (USNM P6170) from cuttings at 4310 to 4320 feet, all from the Topagoruk formation, in Umiat test well 2.

Unfigured hypotypes (USNM P6171) from well cuttings at 3680 to 3690 feet, unfigured hypotypes (USNM P6172) from well cuttings at 3810 to 3820 feet, unfigured hypotype (USNM P6173) from well cuttings at 3850 to 3860 feet, unfigured hypotype (USNM P6174) from well cuttings at 3970 to 3980 feet, unfigured hypotype (USNM P6175) from well cuttings at 4600 to 4610 feet, unfigured hypotypes (USNM P6176) from well cuttings at 4700 to 4710 feet, unfigured hypotypes (USNM P6177) from well cuttings at 4770 to 4780 feet, unfigured hypotypes (USNM P6178) from well cuttings at 5540 to 5545 feet, and unfigured hypotype (USNM P6179) from well cuttings at 5670 to 5680 feet, all from the Topagoruk formation in Umiat test well 1.

Unfigured hypotypes (USNM P6180) from a core at 543 to 545 feet and unfigured hypotypes (USNM P6181) from well cuttings at 1810 to 1820 feet, from the Grandstand formation in Simpson test well 1.

Unfigured hypotype (USNM P6182) from well cuttings at 666 to 676 feet in the Topagoruk formation, in Arcon Point Barrow core test 1.

Figured hypotype (USNM P6183) and unfigured hypotypes (USNM P6184) from field sample 47A Dt 223, and unfigured hypotype (USNM P6185) from field sample $47 \mathrm{~A} \mathrm{Dt} 227$, both in the Tuktu formation.

Unfigured hypotype (USNM P6186) from field sample 47A Z 604, in the Tuktu formation, 810 feet below the top of the formation.

Unfigured paratypes (USNM 106123) from field sample 47A Wh 543, and unfigured hypotypes (USNM P6187) from field sample 47A Wh 542, from the upper part of the Torok formation, equivalent to the subsurface Topagoruk formation.

Unfigured hypotypes (USNM P6188) from field sample 52A Wh 31, in the upper part of the Torok formation.

Unfigured hypotypes (USNM P6789) from a core at 2113 to 2122 feet, in the Topagoruk formation, in East Topagoruk test well 1.

\section{Gaudryina subcretacea Cushman}

Plate 36, figures 5, 6

Gaudryina suberetacea Cushman, 1936, Cushman Lab. Foram. Research. Spec. Publ. 6, p. 5, pl. 1, figs. 11 a, b; Tappan, 1945, Jour. Paleontology, v. 17, no. 5, p. 490, pl. 78, figs. 28-29 ; Frizzell, 1954. Bur. Econ. Geol. Rept. Invest. 22, p. 71 , pl. 5 , figs. $22 \mathrm{a}, \mathrm{b}$.

Test free, slightly flaring, sharply triangular in section although the sides are generally unequal in breadth, sides excavated, chambers generally triserially arranged throughout, but occasional specimens show one or 2 biserial pairs, increasing rapidly in size in the early development, later low and broad; sutures straight but oblique, inclined at about a $30^{\circ}$ angle with the horizontal, very slightly depressed to somewhat obscure; wall finely agglutinated, white to brown in color; aperture an interiomarginal arch in the final chamber face.

Length of hypotype of figure $6,1.20 \mathrm{~mm}$, breadth $0.50 \mathrm{~mm}$. Other hypotypes range from 0.49 to 1.15 $\mathrm{mm}$ in length.

Remarks.--This species differs from the somewhat younger $G$. nanushukensis in having sharply angled sides, less inflated chambers and a more flared test. Originally described from the Duck Creek formation of Texas, the species occurs in Alaska in the Torok and Topagoruk formations.

Types and occurrence.-Figured hypotype (USNM P6204) from well cuttings at 2,520-2,530 feet, figured hypotype (USNM P6205) from well cuttings at 2,700-2,710 feet; unfigured hypotype (USNM P6206) from well cuttings at $2,440-2,445$ feet; unfigured hypotype (USNM P6207) from well cuttings at 2,960-2,970 feet and unfigured hypotype (USNM P6208) from well cuttings at 3,010-3,020 feet, all from the Topagoruk formation in Simpson Test well 1.

Unfigured hypotypes (USNM P6788) from the Torok formation, in a core at 1004 to 1013 feet, in Avak test well 1.

\section{Gaudryina tailleuri (Tappan)}

Plate 35, figures 8-16

Verneuilinoides tailleuri Tappan, 1957, U.S. Natl. Mus. Bull. 215, p. 208, pl. 66, figs. 19-22.

Dorothia chandlerensis Tappan, 1957, U.S. Natl. Mus. Bull. 215, p. 209, pl. 66, figs. 29-30.

Test free, relatively narrow, elongate, sides nearly parallel; chambers numerous, low, triserially arranged and somewhat inflated at the base, occasional specimens consisting entirely of the triserial stage, later portion in well developed specimens becoming biserial, with up to 7 or 8 pairs of biserial, somewhat compressed chambers, all of nearly equal size and relatively low and broad; sutures may be somewhat obscure in the early portion, later ones distinct, depressed and horizontal; wall finely agglutinated, may be somewhat roughly finished; aperture an arch at the base of the final chamber.

Length of holotype $0.58 \mathrm{~mm}$, breadth $0.18 \mathrm{~mm}$. Paratypes range from 0.34 to $0.99 \mathrm{~mm}$ in length.

Remarks.-Gaudryina tailleuri differs from Verneuilinoides borealis Tappan in being smaller and 
narrower, with nearly parallel sides, and in having lower, more numerous, and more closely appressed chambers and nearly horizontal sutures, and in well developed specimens showing a distinct biserial stage. It differs from Tritaxia spiritensis prolongata Stelck and Wall in lacking the terminal aperture and in having lower and more closely appressed chambers, and a biserial development.

Specimens of this species were formerly regarded (Tappan, 1957) as representing two species and genera. Those described as Verneuilinoides tailleuri were somewhat shorter, and had only a triserial development. The rarer specimens which had a distinct biserial stage were thought to belong to Dorothia because of a somewhat bulbous base, although the sutures were admittedly "obscure in the early portion". Additional material has now shown these two forms to be conspecific, possibly representing the megalospheric and microspheric generations, and has proven the base to be only triserial and the later portion biserial thus requiring the generic assignment to Gaudryina.

Gaudryina tailleuri occurs in the Torok and Fortress Mountain formations. It was named in honor of I. L. Tailleur, geologist, U.S. Geological Survey, who collected some of the outcrop material containing this species.

Types and occurrence.-Holotype (USNM P4367), figured paratype (USNM P4368), and unfigured paratypes (USNM P4369) from field sample 49A Tr 565, and figured paratype (USNM P4365) and unfigured paratype (USNM P4366) from field sample $49 \mathrm{~A} \operatorname{Tr} 662$, all from the Fortress Mountain formation.

Figured paratype (USNM P6763) from a core at 2329 to 2340 feet, in the Torok formation, in South Barrow test well 4.

Figured paratype (USNM P6112) and unfigured paratypes (USNM P6113) from a core at 5305 to 5308 feet, and figured paratype of Dorothia chandlerensis (now regarded as G. tailleuri) (USNM P4404) from well cuttings at 5150-5160 feet, all in the Torok formation, all in Simpson test well 1.

Unfigured paratype (USNM P6114) from a core at 3133 to 3144 feet, unfigured paratype (USNM P6115) from a core at 3155 to 3163 feet, unfigured paratypes (USNM P6116) from a core at 3164 to 3173 feet, unfigured paratypes (USNM P6117) from a core at 3226 to 3227 feet, figured paratype (USNM P6118) and unfigured paratype (USNM P6119) from a core at 3237 to 3250 feet, all from the Torok formation in South Barrow test well 1.

Unfigured paratype (USNM P6120) from a core at
2258 to 2270 feet in the Torok formation, in South Barrow test well 2.

Unfigured paratype (USNM P4370) from field sample 49A Pa 84, unfigured paratype (USNM P4371) from field sample $49 \mathrm{~A} \mathrm{~Pa} 436$, unfigured paratype (USNM P4372) from field sample 49A Pa 571, and figured paratype (USNM P4373) and unfigured paratypes (USNM P4374) from field sample 49A Pa 594, all from the Fortress Mountain formation.

Holotype (USNM P4401) and unfigured paratypes (USNM P4402) of Dorothia chandlerensis Tappan, from field sample 48A Dt 120, and unfigured paratype of $D$. chandlerensis (USNM P4403) from field sample 48 A Dt 121, all from the Torok formation.

Unfigured paratypes of Dorothia chandlerensis Tappan (USNM P4405) from field sample 49A Tr 685 and unfigured paratype (USNM P4406) from field sample $49 \mathrm{~A} \operatorname{Tr} 756$, both from the Torok formation, are now considered to belong to Gaudryina tailleuri (Tappan).

\section{Genus Gaudryinella Plummer, 1931 \\ Gaudryinella irregularis Tappan \\ Plate 35, figures 22-24}

Gaudryinella irregularis Tappan, 1943, Jour. Paleontology, v. 17, no. 5, p. 490 , pl. 78, figs. 31, 32 ; Frizzell, 1954, Bur. Econ. Geol. Rept. Invest. 22, p. 72, pl. 5, fig. 21.

Test free, small, narrow, elongate; chambers few in number, loosely triserial, nearly globular in shape and not closely appressed; sutures distinct, depressed; wall finely agglutinated, smoothly finished; aperture terminal, rounded.

Hypotypes range in length from 0.23 to $0.42 \mathrm{~mm}$, and in breadth from 0.11 to $0.18 \mathrm{~mm}$.

Remarks.--Originally described from the Duck Creek formation, Lower Cretaceous Washita group of Texas, of mid-Albian age, this species occurs in Alaska in beds of approximately equivalent age, from the lower part of the Torok, the Corwin, Kukpowruk, Grandstand and Topagoruk formations.

Types and occurrence.-Figured hypotype (USNM 6209) from well cuttings within the Torok formation, but probable contamination from the overlying Topagoruk formation, at 4840 to 4850 feet in Umiat test well 2.

Unfigured hypotype (USNM P6210) from a core at 472 to 481 feet, in the Grandstand formation, in Umiat test well 3.

Unfigured hypotype (USNM P6211) from a core at 3341 to 3346 feet in the Torok formation, in South Barrow test well 1.

Figured hypotype (USNM P6212) from well cuttings at 2310 to 2320 feet, and unfigured hypotypes 
(USNM P6213) from a core at 2138 to 2148 feet in the Torok formation, in South Barrow test well 2.

Figured hypotype (USNM P6214) and unfigured hypotypes (USNM P6215) from a core in the Torok formation, at 1388 to 1396 feet, in South Barrow test well 3.

Unfigured hypotypes (USNM P6216) from a core at 2320 to 2329 feet, in the Torok formation, in South Barrow test well 4.

Unfigured hypotypes (USNM P6217) from a core at 443 to 444 feet, in the Grandstand formation, in Simpson test well 1.

Unfigured hypotypes (USNM P6218) from a core at 231 to 233 feet in the Grandstand formation, in Simpson core hole 3.

Unfigured hypotypes (USNM P6790) from a core at 572 to 592 feet, unfigured hypotypes (USNM P6791) from a core at 1004 to 1013 feet, unfigured hypotypes (USNM P6219) from a core at 1314 to 1329 feet, and unfigured hypotype (USNM P6220) from a core at 1339 to 1349 feet, all in the Torok formation, in Avak test well 1.

Unfigured hypotypes (USNM P6221) from the Kukpowruk formation, field sample 47A Tr 113.

Unfigured hypotypes (USNM P6222) from field sample $47 \mathrm{~A}$ Wh 594, unfigured hypotypes (USNM P6223) from field sample 47A Wh 644, and unfigured hypotypes (USNM P6224) from field sample 47A Wh 656 , all from the Corwin formation.

Unfigured hypotypes (USNM P6225) from field sample $50 \mathrm{~A} \mathrm{Mg} \mathrm{57,} \mathrm{in} \mathrm{the} \mathrm{lower} \mathrm{part} \mathrm{of} \mathrm{the} \mathrm{Torok}$ formation.

\section{Genus Pseudoclavulina Cushman, 1936 \\ Pseudoclavulina hastata (Cushman) \\ Plate 36, figures 10,11}

Bigenerina hastata Cushman, 1927, Royal Soc. Canada, Trans. 3rd ser., v. 21, sec. IV, p. 131, pl. 1, flg. 9; Cushman, 1946, U.S. Geol. Survey, Prof. Paper 206, p. 30, pl. 6, fig. 25.

Test free, robust, elongate, of medium size; early chambers triserially arranged, small, low and increasing rapidly in breadth, resulting in a flared base to the test, later chambers uniserial, cylindrical, closely appressed, about twice as broad as high, and all uniserial chambers of nearly equal breadth from the triserial portion to the aperture; sutures nearly flush to slightly constricted, horizontal in the later stage; wall finely agghutinated, with considerable cement and smoothly finished; aperture terminal, rounded.

Hypotypes range from 0.34 to $0.86 \mathrm{~mm}$ in length and from 0.16 to $0.29 \mathrm{~mm}$ in breadth.

Remarks.-This species was originally described from the Canadian Cretaceous as a Bigenerina. Ex- amination of the holotype and paratypes in the Cushman Collection at the U.S. National Museum shows a distinctly triserial rather than biserial base, the third series of chambers in the holotype appearing on the side opposite to that figured originally. The triserial base followed by a cylindrical uniserial portion with terminal aperture, definitely places the species in the genus Pseudoclavulina Cushman, 1936.

The original reference listed the horizon only as Upper Cretaceous. In Alaska, Pseudoclavulina $h a-$ stata occurs in the Ayiyak member of the Seabee formation. Inoceramus lamarcki var. cuvieri Sowerby, which also occurs in this member, ranges from mid-Turonian through the Coniacian (lowest Senonian).

Types and occurrence.-Figured hypotypes (USNM P6241 a, b) and unfigured hypotypes (USNM P6242) from field sample $47 \mathrm{~A} \mathrm{~Wb} 428$, from 140 to 160 feet below the top of the Ayiyak member of the Seabee formation, and unfigured hypotypes (USNM P6243) from field sample $47 \mathrm{~A} \mathrm{~Wb} 429$, from 135 feet below the top of the member, and unfigured hypotype (USNM P6244) from field sample 47A Wb 431, from the Ayiyak member of the Seabee formation.

Unfigured hypotype (USNM P6245) from the Rogers Creek member of the Schrader Bluff formation, field sample $47 \mathrm{~A} \mathrm{~Wb} 444$.

Unfigured hypotypes (USNM P6246) from the base of the Ayiyak member of the Seabee formation, field sample 52A Bl 34.

Unfigured hypotypes (USNM P6247) from the Ayiyak member of the Seabee formation, Umiat Seismograph shot hole 13 , at a depth of 5 feet.

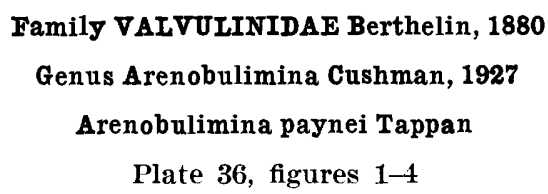

Arenobulimina paynei Tappan, 1957, U.S. Natl. Mus. Bull. 215, p. 208 , pl. 67 , figs. $1-4$.

Test free, flaring, early portion triserial, later with four chambers to a whorl; chambers much inflated, although some specimens have been crushed in preservation, increasing rapidly in size; sutures distinct and much constricted; wall finely agglutinated, but some of the paratypes are represented only by pyritic casts, a common method of preservation in these strata; aperture a low arch at the inner margin of the final chamber.

Length of holotype $0.36 \mathrm{~mm}$, breadth $0.21 \mathrm{~mm}$. Paratypes range in length from 0.18 to $0.55 \mathrm{~mm}$.

Remarks.-This species differs from Arenobulimina chapmani Cushman, from the Gault of England, in 
being more flaring, about one-third as large, and with more inflated and fewer chambers to each whorl. It occurs in the Grandstand and Topagoruk formations.

This species was named in honor of T. G. Payne, geologist formerly with the U.S. Geological Survey, in recognition of his work on the stratigraphy of the Cretaceous strata of Alaska.

Types and occurrence.--Holotype (USNM P4375) from well cuttings at $4140-4150$ feet, unfigured paratype (USNM P4376) from well cuttings at $4150-4160$ feet, unfigured paratypes (UTSNM P4377) from well cuttings at $3160-3170$ feet, unfigured paratypes (USNM P4378) from well cuttings at $4460-4470$ feet, all from the Topagoruk formation, in Umiat test well 1.

Figured paratype (USNM P4379) and unfigured paratypes (USNM P4380) from a core at 602-609 feet, in the Grandstand formation, unfigured paratypes (USNM P4381) from well cuttings at 1560-1570 feet, unfigured paratype (USNM P4382) from well cuttings at 2850-2860 feet, unfigured paratype (USNM P4383) from well cuttings at $2900-2910$ feet, figured paratypes (USNM P4384 a, b) from well cuttings at 2980-2990 feet, and unfigured paratype (USNM P4385) from well cuttings at $4580-4590$ feet, all from the Topagoruk formation, in Umiat test well 2.

\section{Arenobulimina torula Tappan}

Plate 36, figures 7-9

Arenobulimina torula Tappan, 1957, U.S. Natl. Mus. Bull. 215, p. 209 , pl. 37 , figs. 5-7.

Test free, elongate, flaring from the pointed base, rounded in section; chambers numerous, low and triserial in the early portion, later becoming higher and narrower with four chambers to a whorl, the chambers lying somewhat obliquely; sutures distinct, flush, oblique, somewhat darker in color than the remainder of the test; wall finely arenaceous, surface smoothly finished, specimens commonly crushed in various ways in preservation; aperture an arch at the base of the inner face of the final chamber.

Length of holotype $0.62 \mathrm{~mm}$, breadth $0.36 \mathrm{~mm}$. Paratypes range from 0.16 to $0.68 \mathrm{~mm}$ in length.

Remarks.-Arenobulimina tomla differs from $A$. chapmani Cushman in being slightly larger, and in having broader, lower, and more inflated chambers, and in being more finely arenaceous with a more smoothly finished surface.

This species occurs in the Ayiyak member of the Seabee formation and in the Ignek formation.

Types and occurrence.-Holotype (USNM P4393) from the Ignek formation, on the Shaviovik anticline, seismograph party 144 , line $4-53$, shot point 6 , at a depth of 50-100 feet.

Unfigured paratype (USNM P4394) from a depth of 50-100 feet, and unfigured paratypes (USNM P4395) from a depth of 100-150 feet, all from the Ignek formation, in seismograph party 144 , line $8-53$, shot point 4.

Figured paratypes (USNM P4396 a, b) and unfigured paratypes (USNM P4397) from the Ignek formation (field sample 46A L 66).

Unfigured paratypes (USNM P4398) from the Ayiyak member of the Seabee formation (field sample $47 \mathrm{~A} \mathrm{~Wb} 35)$.

Unfigured paratypes (USNM P4399) from the Ayiyak member of the Seabee formation, in Umiat seismograph shot point 13 , at a depth of 25 feet.

Unfigured paratypes (USNM P4400) from the Seabee formation, at 561-571 feet, in Umiat test well 11.

\section{Family TROCHAMMINIDAE Schwager, 1877 \\ Genus Trochammina Parker and Jones, 1859 \\ Trochammina albertensis Wickenden \\ Plate 39, figures 13, 14}

Trochammina albertensis Wickenden, 1932, Royal Soc. Canada Trans., 3rd ser., v. 26, sec. 4 , p. 90 , pl. 1, figs. 9a-c; Cushman, 1946, U.S. Geol. Survey Prof. Paper 206, p. 50, pl. 15, fig. 7 .

Test free, trochospirally coiled, concavo-convex, with subacute periphery; all chambers visible on the convex spiral side where they appear crescentic, only the five or six chambers of the final whorl visible on the concave umbilical side, chambers increasing rapidly in size; sutures distinct, oblique and gently curved on the spiral side, nearly radial on the umbilical side; wall finely arenaceous, roughly finished; aperture indistinct in the material available.

Hypotypes range in diameter from 0.28 to $0.45 \mathrm{~mm}$, and in thickness from 0.08 to $0.16 \mathrm{~mm}$.

Remarks.-Trochammina albertensis resembles $T$. ribstonensis Wickenden in the relatively high spired test, which may be secondarily crushed, but differs in being twice as large, in having a concave umbilical side and crescentic-appearing chambers on the spiral side, and in the chambers increasing more rapidly in size. The present species resembles an arenaceous isomorph of Rosalina.

This species was originally described from the Bearpaw formation of Alberta, and has not previously been recorded elsewhere. In Alaska the species is rare, occurring only in the Barrow Trail and Sentinel Hill members of the Schrader Bluff formation.

Types and occurrence.-Figured hypotypes (USNM $\mathrm{P} 4516 \mathrm{a}-\mathrm{b}$ ) and unfigured hypotypes (USNM P6248) 
in a core at 819 to 829 feet and hypotypes (USNM P6149) from a core at 500-510 feet from the Sentinel Hill member of the Schrader Bluff formation, in Sentinel Hill core test 1.

Unfigured hypotypes (USNM P6250) from field sample $48 \mathrm{~A}$ Di 429 , at the top of Barrow Trail member of the Schrader Bluff formation.

\section{Trochammina diagonis (Carsey)}

Plate 38, figures 1-4

Haplophragmoides diagonis Carsey, 1926, Univ. Texas Bull. 2612, p. 22, pl. 3 , fig. 1.

Trochammina diagonis (Carsey) Cushman, 1927, Royal Soc. Canada Trans., 3rd ser., v. 21, sec. 4, p. 132; Cushman, 1946, U.S. Geol. Sarv. Prof. Paper 206, p. 49, pi. 15, figs. 1-3; Frizzell, 1954, Bur. Econ. Geol. Rept. Invest. 22, p. 79, pl. 7, fig. 14 .

Test free, of medium to large size, trochospirally coiled, commonly somewhat deformed by compression, periphery rounded; eight to ten chambers in the final whorl, increasing gradually in size; sutures radial, may be rather indistinct, but commonly slightly depressed; wall moderately coarsely arenaceous, surface roughly finished; aperture indistinct in the material available.

Hypotypes range from 0.36 to $0.91 \mathrm{~mm}$ in diameter.

Remarks.-Trochammina diagonis differs from the associated Trochammina whittingtoni in the larger size, less compressed but typically deformed test, and more coarsely arenaceous wall. It differs from Trochammina stefanssoni in being more coarsely arenaceous and roughly finished, and in lacking the prominent and elevated spire on the spiral side. It ranges throughout the Colville group of northern Alaska.

Types and occurrence.-Figured hypotypes (USNM P6251a, b) and unfigured hypotypes (USNM P6252) from the Shale Wall member of the Seabee formation, field sample $47 \mathrm{~A}$ Dt 84 .

Unfigured hypotype (USNM P6253) from the Seabee formation, field sample $47 \mathrm{~A} \mathrm{Dt} 80$.

Unfigured hypotypes (USNM P6254) from the Sentinel Hill member of the Schrader Bluff formation, field sampie $47 \mathrm{~A}$ St 29.

Unfigured hypotypes (USNM P6255) from the Seabee formation in a core at 519-529 feet in Umiat test well 1.

Figured hypotypes (CSNM P6256a, b) from the Ayiyak member of the Seabee formation, Umiat Seismograph Shot Point 13, at a depth of 5 feet.

\section{Trochammina eilete Tappan \\ Piate 38, figures 9,10}

Trochammina eilete Tappan, 1957, U.S. Natl. Mus. Bull. 215, p. 213 , pl. 68 , figs. $1,2$.
Test free, discoidal, trochoid but with a flattened spire, periphery rounded; chambers numerous, about 10 to 14 in the final whorl of adult specimens, of greater height than breadth and appearing cuneate in side view; sutures distinct, thickened, somewhat depressed, radiate; wall finely agglutinated, with considerable cement, surface smoothly finished; aperture a low arch at the base of the final chamber face, against the periphery of the previous whorl.

Greatest diameter of holotype $0.52 \mathrm{~mm}$, thickness $0.17 \mathrm{~mm}$. Paratypes range from 0.21 to $0.68 \mathrm{~mm}$ in diameter.

Remarks.-Trochammina eilete differs from $T$. sablei Tappan, from the Jurassic, in being about twice as large, in having many more chambers per whorl, and in the chambers being wedge shaped rather than inflated and subglobular. This species is characteristic of the Torok formation and the equivalent Fortress Mountain formation.

Types and occurrence.-Holotype (USNM P4483) and unfigured paratypes (USNM P4484) from field sample $49 \mathrm{~A}$ Ch 45 and unfigured paratypes (USNM P4485) from field sample $49 \mathrm{~A} \mathrm{Ch} 44$, both from the Torok formation.

Figured paratype (USNM P4487) and unfigured paratype (USNM P4488) from the Fortress Mountain formation, field sample $49 \mathrm{~A} \mathrm{~Pa} 593$.

Unfigured paratypes (USNM P4489) from 5500 to 6000 feet above the base of the Fortress Mountain formation, field sample $49 \mathrm{~A} \operatorname{Tr} 562$.

Unfigured paratypes (USNM P4482) from the Torok formation, field sample 49A Tr 695 .

Unfigured paratype (USNM P6792) from a core at 1019 to 1024 feet in the Torok formation, in Avak test well 1.

\section{Trochammina rainwateri Cushman and Applin}

Plate 39, figures 7-12

Trochammina rainwateri Cushman and Applin, 1946, Cushman Lab. Foram. Research, Contr., v. 22, pt. 3, p. 75, pl. 13, fig. 9.

Trochammina webbi Stelck and Wall, 1954, Research Council Alberta, Rept. 68, p. 33, pl. 2, fig. 11.

Test free, small, low trochospiral, peripheral margin rounded, peripheral outline lobulate; the inflated chambers increasing rapidly in size, all whorls visible on the spiral side, only the commonly 4 to 5 of the final whorl visible around the small umbilicus of the umbilical side; sutures distinct, slightly curved and depressed; wall finely agglutinated but somewhat roughened in appearance; aperture indistinct in the specimens available.

Hypotypes range from 0.23 to $0.50 \mathrm{~mm}$ in diameter. Remarks.-Trochammina rainwateri Cushman and 
Applin was described originally from the upper part of the Woodbine sand, Cenomanian age, of northern Texas. Trochammina webbi Stelck and Wall was described from central Kaskapau formation (Lower Turonian) of Alberta, Canada, but is very similar in size, shape, and other characteristics, differing only in being more compressed, which was recognized by the authors to be due to the type of preservation. In Alaska, in well material in the northern coastal plain, specimens of this species resemble those of Texas in being less compressed. In the outcrop and well material of the foothills of the Brooks Range, the greater amount of compression and folding of the strata has resulted in compressed tests of the Foraminifera, so that this species more closely resembles those specimens of Canada. The species also is found slightly lower stratigraphically in Alaska, although this may be due solely to the lack of published information on the older Canadian horizons.

Trochammina rainwateri differs from $T$. ribstonensis Wickenden in the larger size, fewer chambers per whorl, and more rapid increase in chamber size. It also lacks the protruding ropelike early whorls characteristic of $T$. ribstonensis Wickenden.

Types and occurrence.-Figured hypotype (USNM P6257) and unfigured hypotypes (USNM P6258) from a core at 2,739 to 2,749 feet, unfigured hypotypes (USNM P6259) from a core at 2,275 to 2,285 feet, and unfigured hypotypes (USNM P6260) from well cuttings at 2,310 to 2,320 feet, all from the Topagoruk shale in Simpson test well 1.

Figured hypotype (USNM P6261) and unfigured hypotype (USNM P6262) from a core at 231.5 to 233 feet, in the Grandstand formation, in Simpson core test 3 .

Figured hypotypes (USNM P6263a,b) from a core at 4,433 to 4,443 feet in the Topagoruk formation, in Umiat test well 2.

Unfigured hypotypes (USNM P6264, 6265) from a core at 532 to 547 feet in the Grandstand formation, in Umiat test well 3.

Figured hypotype (USNM P6266) and unfigured hypotypes (USNM P6267) from a core at 14 to 24 feet in the Grandstand formation, in Oumalik core test 11.

Figured hypotype (USNM P6268) and unfigured hypotypes (USNM P6269) from the Tuktu formation, field sample $47 \mathrm{~A} \mathrm{~Wb} 94$.

Unfigured hypotypes (USNM P6270) from the Ninuluk formation, field sample $47 \mathrm{~A} \mathrm{Dt} 4$, and unfigured hypotypes (USNM P6271) from the Ninuluk formation, field sample $47 \mathrm{~A}$ Dt 61.
Unfigured hypotypes (USNM P6272) from the Kukpowruk formation, field sample 47A Tm 9.

Unfigured hypotypes (USNM P6273) from the Okpikruak formation, field sample 49A Ch 33.

\section{Trochammina ribstonensis Wickenden}

Plate 39, figures 15-17

Trochammina ribstonensis Wickenden, 1932, Royal Soc. Canada Trans., 3rd ser., v. 26, sec. 4, p. 90, pl. 1, figs. 12a-c; Cushman, 1946, U.S. Geol. Survey Prof. Paper 206, p. 50, pl. 15, fig. 9; Nauss, 1947, Jour. Paleontology, v. 21, no. 4, p. 340 , pl. 49 , figs. $6 a-c$.

Test free, small, trochospiral, forming a low cone; chambers subglobular, all of the $2 \frac{1}{2}$ whorls visible on the spiral side, only the 5 to 7 of the final whorl visible on the umbilical side, sutures very slightly oblique, distinct and depressed, the arrangement of chambers and sutures giving the appearance of a coil of rope; wall finely arenaceous, smoothly finished; aperture a low interiomarginal extraumbilical arch, rarely visible due to the poor preservation of the material.

Hypotypes range from 0.13 to $0.36 \mathrm{~mm}$ in diameter. Remarks.-Trochammina ribstonensis is easily distinguished from associated species by its small size, almost globular chambers, and low conical form. It is commonly found with a pyrite filling, thus preserving the original chamber form.

It was originally described from the subsurface in Canada, from beds probably equivalent to the Lea Park. According to Nauss (1947, p. 340) it is restricted to the lower 40 feet of the Lea Park shale in the Vermilion area of Alberta, Canada. A similar form was described as Trochammina rutherfordi Stelck and Wall, from somewhat older beds in Canada. Although specimens from their respective type localities can be distinguished, as can those of the extremes of range in Alaska, there seems also to be a vertical gradation, so that it is difficult to separate the youngest $T$. rutherfordi from the older specimens of T. ribstonensis.

It seems probable, therefore, that $T$. mutherfordi was ancestral to $T$. ribstonensis, and that the two intergrade stratigraphically. Trochammina rutherfordi is therefore here regarded as a stratigraphical subspecies of $T$. ribstonensis.

Types and occurrences.-Figured hypotype (USNM P6286) from the Barrow Trail member of the Schrader Bluff formation, field sample 47A Dt 332; unfigured hypotypes (USNM P6287) from the Sentinel Hill member of the Schrader Bluff formation, field sample 47A Dt 286; and unfigured hypotypes (USNM P6288) from the Barrow Trail member of the Schrader Bluff formation, field sample 47A Dt 333. 
Figured hypotype (USNM P6289) and unfigured hypotypes (USNM P6290) from a core at 1482-1492 feet in the Tuluvak tongue, in Gubik test well 2.

Figured hypotype (USNM P6291) from field sample $46 \mathrm{~A} \mathrm{Fi} 80 \mathrm{~A}$, in the Seabee formation.

Unfigured hypotypes (USNM P6292) from a core at 500 to 510 feet, unfigured hypotype (USNM P6293) from a core at 587 to 589 feet, unfigured hypotype (USNM P6294) from a core at 589-602 feet, and unfigured hypotype (USNM P6295) from a core at 824 to 829 feet, all from the Sentinel Hill member of the Schrader Bluff formation, in Sentinel Hill core test 1.

Unfigured hypotypes (USNM P6314) from the Ayiyak member of the Seabee formation, field sample $47 \mathrm{~A} \mathrm{~Wb} 1$ and unfigured hypotypes (USNM P6285) from field sample $47 \mathrm{~A} \mathrm{~Wb} 447$, within the Tuluvak tongue, but probably a bed of the marine Rogers Creek member of the Schrader Bluff formation.

Trochammina ribstonensis Wickenden, subspecies rutherfordi Stelck and Wall

Plate 39, figures $18-20$

Trochammina rutherfordi Stelck and Wall, 1955, Research Council Alberta Rept. 70, p. 56, pl. 1, figs. 11, 12, 14, 16, ( ?15) , pl, 3, figs. 20, 21, 36, 37.

Trochammina sp. cf. T. rutherfordi Stelck and Wall. Stelck, Wall, and Wetter, 1958. Research Council Alberta, Geol. Div. Bull. 2, p. 33, pl. 4, figs. 6-10.

Trochammina rutherfordi variety 2 Stelck and Wall. Stelck, Wall, and Wetter, 1958, Ibid., p. 34, pl. 4, figs. 1-5.

Test free, small, low trochospiral to compressed; chambers of approximately equal breadth and height, about 2 whorls visible on the spiral side, with only the 5 to 7 chambers of the final whorl visible on the umbilical side, chambers increasing rapidly in thickness; sutures slightly oblique on the spiral side and radial on the umbilical side, slightly depressed in well preserved specimens, but obscure in specimens with greatest distortion; wall finely arenaceous; aperture a low, interiomarginal extraumbilical arch, visible only in the best preserved specimens.

Hypotypes range from 0.15 to $0.36 \mathrm{~mm}$ in diameter.

Remarks.-The types of Trochammina rutherfordi Stelck and Wall are very similar in appearance to the somewhat younger $T$. ribstonensis Wickenden (s.s.) both having globular chambers and a low conical test, and somewhat more numerous chambers in the earlier whorls. T. rutherfordi is here regarded as a subspecies of the younger $T$. ribstonensis Wickenden. As mentioned under the discussion of the latter species, specimens from the extremes of their geologic range can be easily distinguished, but near the Upper Cretaceous-Lower Cretaceous contact specimens may be gradational in character, and it is difficult to separate them. Even the slight difference in their geologic ages in the type area may be more apparent than real, for additional material may eventually prove the species to have a continuous range in Canada as it does in Alaska.

Although it does not appear in all samples, the present species is common where found, and has a known range from the Grandstand to the Ninuluk formation in Alaska. Specimens from Umiat test well 2 and Oumalik core test 2 are only questionably referred to this species, as they are represented only by pyritic casts.

Stelck and Wall described T. mutherfordi as having two varieties (Stelck and Wall, 1955; Stelck, Wall and Wetter, 1958). Variety 1 was described as differing in having more curved sutures and 8 instead of $6 \frac{1}{2}$ chambers in the final whorl. Variety 2 differed in being larger $(0.3 \mathrm{~mm}$ in diameter rather than $0.2 \mathrm{~mm}$ as in the holotype) and in having 4 whorls instead of three. Trochammina sp. cf. T. rutherfordi of Stelck, Wall, and Wetter (1958), from the "upper St. John shale" was described as differing in being more coarsely arenaceous, although occurring with typical specimens.

Inasmuch as these arenaceous forms are commonly distorted in preservation, and their larger "variety 2" also had an additional whorl of chambers, it seems very probable that all are merely individual variations within the single subspecies. The coarseness of grain size also varies considerably with the availability of material. The Alaskan specimens show a wide range in size, form and height of spire, largely due to the stage of growth reached and the amount of distortion suffered in preservation.

Trochammina memurrayensis Mellon and Wall, from the uppermost McMurray formation of Alberta, Canada, may be ancestral to the present subspecies. It is somewhat older than any of the Alaskan specimens, but quite similar in general appearance to the older representatives of $T$. ribstonensis subsp. rutherfordi. Trochammina mcmurrayensis has fewer chambers per whorl, and does not have the characteristic "ropy" appearance of the present species. Preservation is commonly poor in all of these forms and the extremely low spire of T. memurrayensis may be in part due to compression in preservation.

Types and occurrence.-Figured hypotype (USNM P6296) and unfigured hypotypes (USNM P6297) from the Ninuluk formation, field sample $47 \mathrm{~A} \mathrm{Dt} 58$; unfigured hypotypes (USNM P6298) from the Ninuluk formation, field sample $47 \mathrm{~A}$ Dt 26 ; unfigured hypotypes (USNM P6299) from the Ninuluk formation, field sample $47 \mathrm{~A}$ Dt 61. 
Figured hypotypes (USNM P6300a, b) and unfigured hypotypes (USNM P6301) from the Ninuluk formation, field sample $47 \mathrm{~A} \mathrm{~Wb} 364$; unfigured hypotypes (USNM P6302) from the Ninuluk formation, field sample 47A Wb 341; unfigured hypotypes (USNM P6303) from the Ninuluk formation, field sample 47A Wb 352; unfigured hypotypes (ISNM P6304) from the Ninuluk formation, field sample $47 \mathrm{~A} \mathrm{~Wb} 368$; and unfigured hypotypes (USNM P6305) from the Ninuluk formation, field sample $47 \mathrm{~A} \mathrm{~Wb} 387$.

Unfigured hypotypes (USNM P6306) from the Ninuluk (?) formation, field sample 45A Kr 121.

Unfigured hypotypes (USNM P6307) from the Kukpowruk formation, field sample 47A Tr 158.

Unfigured hypotypes (USNM P6308) from the Grandstand formation, field sample 48A Dt 249.

Unfigured hypotypes (USNM P6309) from the Grandstand formation in a core at $470-475$ feet in Umiat test well 2.

Unfigured hypotypes (USNM P6310) from cuttings at 150-160 feet, unfigured hypotype (USNM P6311) from cuttings at 160-170 feet, and unfigured hypotype (USNM P6312) from enttings at 170-180 feet, all in the Grandstand formation, in Oumalik core test 2.

Unfigured hypotypes (USNM P6313) from a core at $2670-2676$ feet in the Grandstand formation, in Titaluk test well 1.

\section{Trochammina stefanssoni Tappan}

Plate 38, figures 11-14

Trochammina stefanssoni Tappan, 1957, U.S. Natl. Mus. Bull. 215 , p. 214, pl. 67 , figs. $30-33$.

Test free, trochoid, low spired, periphery rounded; all chambers of the approximateiy two whorls visible dorsally, only the nine of the final whorl visible on the umbilicate ventral side, chambers increasing rapidly in size, early ones subglobular, later cuneate in side view; sutures distinct, depressed, radial; wall very finely arenaceous, with considerable cement and smoothly finished, all specimens crushed and distorted in preservation; aperture an arch at the base of the final chamber face, against the previous whorl on the periphery.

Greatest diameter of holotype $0.55 \mathrm{~mm}$. Paratypes range from 0.31 to $0.62 \mathrm{~mm}$ in diameter.

Remarks.-Trochammina stefanssoni differs from $T$. diagonis (Carsey) in having more chambers to each whorl and in the chambers being cuneate rather than rounded and inflated. It is also more finely arenaceous and more smoothly finished.

This species has been found only in the Sentinel Hill and Barrow Trail members of the Schrader Bluff for- mation (Upper Cretaceous). The species was named for Karl Stefansson, geologist, formerly of the U. S. Geological Survey.

Types and occurrences.-Holotype (USNM P4490) and unfigured paratypes (USNM P4491) from a core at $475-476$ feet, figured paratypes (USNM P4492a-c) and unfigured paratypes (USNM P4493) from a core at $478-480$ feet, and unfigured paratypes (USNM P4494) from a core at 579-589 feet, unfigured paratypes (USNM P627t) from 602-604 feet, and unfigured paratypes (USNM P6275) from a core at 829 to 839 feet, all from the Sentinel Hill member of the Schrader Bluff formation, in Sentinel Hill core test 1.

Unfigured paratype (USNM P6276) from field sample 50A Fi 1, in the Barrow Trail member of the Schrader Bluff formation.

\section{Trochammina umiatensis Tappan}

Plate 38, figures 5-8

Trochammina umiatensis Tappan, 1957, U.S. Natl. Mus. Bull. 215, p. 214, pl. 67, figs. 27-29.

Test free, trochoid, relatively high spired, periphery lobulate and rounded; chambers inflated and subglobular, few in number, increasing rapidly in size, only four or rarely five in each whorl; sutures distinct, depressed, radial; wall finely to coarsely agglutinated, roughly finished; aperture ventral, a slit at the base of the final chamber face.

Greatest diameter of holotype $0.68 \mathrm{~mm}$, thickness $0.29 \mathrm{~mm}$. Paratypes range from 0.29 to $0.81 \mathrm{~mm}$ in diameter.

Remarks.-Trochammina umiatensis differs from $T$. globigeriniformis (Parker and Jones) in having more chambers per whorl, commonly four instead of the three of T. globigeriniformis, in being nearly three times as large, and in having a better developed and higher spire and a greater increase in chamber size.

Types and occurrence.-Holotype (USNM P4499) from well cuttings at $735-740$ feet, in the Grandstand formation, in Umiat test well 2.

Unfigured paratypes (USNM P4500) from a core at 1,615-1,625 feet and unfigured paratype (USNM P4501) from a core at 1,625-1,635 feet, both from the Grandstand formation, and figured paratype (USNM P6021) from cuttings at 3,400-3,410 feet, in the Topagoruk formation, in Umiat test well 1.

Figured paratypes (USNM P4502 a, b) from a core at 1,130-1,133 feet, unfigured paratypes (USNM $\mathrm{P} 4503)$ from a core at 1,183-1,186 feet, and unfigured paratypes (USNM P4504) from well cuttings at 1,190 1,195 feet, all from the Grandstand formation, in Umiat test well 8. 


\section{Trochammina whittingtoni Tappan}

Plate 39, figures 1-6

Trochammina whittingtoni Tappan, 1957, U.S. Natl. Mus. Bull. 215 , p. 214, pl. 68, figs. 3-6.

Test free, trochoid, much compressed; chambers numerous, increasing gradually in size, eight or nine in the final whorl; sutures slightly depressed, radial; wall finely agglutinated, probably with a "chitinous" base as all specimens are laterally crushed in preservation and of a brownish color, with chambers collapsed centrally; aperture obscured by the lateral compression of the test.

Greatest diameter of holotype $0.49 \mathrm{~mm}$. Paratypes range from 0.26 to $0.73 \mathrm{~mm}$ in diameter.

Remarks.-This species differs from $T$. diagonis Carsey in being smaller, and in having a characteristic brownish color and fine-grained, smoothly finished wall, with its usual lateral compression. It occurs in the Seabee and Schrader Bluff formations of the Upper Cretaceous. The specific name is in honor of $\mathrm{C}$. L. Whittington, geologist, U.S. Geological Survey.

Types and occurrences.-Holotype (USNM P4505), figured paratype (USNM P4506), and unfigured paratypes (USNM P4507) all from the Seabee formation, field sample $47 \mathrm{~A}$ Wh 295.

Figured paratype (USNM P4508) and unfigured paratypes (USNM P4509) taken 20 feet above the base of the Seabee formation (field sample $47 \mathrm{~A} \mathrm{Dt}$ 80 ), and unfigured paratypes (USNM P4510) taken 210 feet above the base of the Seabee formation (field sample $47 \mathrm{~A}$ Dt 125).

Unfigured paratypes (USNM P4511) taken 140-160 feet above the base of the Ayiyak member of the Seabee formation, field sample 48A Dt 377 , and unfigured paratypes (USNM P4512), from the Barrow Trail member, taken 990-1010 feet above the base of the Schrader Bluff formation, field sample 48A Dt 422.

Unfigured paratypes (USNM P4513) taken 2,460 feet below the top of the Sentinel Hill member of the Schrader Bluff formation, field sample 47A St 30.

Figured paratype (USNM P4514) and unfigured paratypes (USNM P4515) from a core at 609-615 feet, all from the Sentinel Hill member of the Schrader Bluff formation, in Sentinel Hill core test 1.

Unfigured paratypes (USNM P4517) from a core at 499-509 feet and unfigured paratypes (USNM P4518) from a core at 519-529 feet, all from the Seabee formation in Umiat test well 1.

Figured paratype (USNM P6277) and unfigured paratypes (USNM P6278) from the Ayiyak member of the Seabee formation, field sample $47 \mathrm{~A} \mathrm{~Wb} 260$; unfigured paratypes (USNM P6279) from field sam- ple $47 \mathrm{~A} \mathrm{~Wb} 148$, and unfigured paratypes (USNM $\mathrm{P} 6280$ ) from field sample $47 \mathrm{~A} \mathrm{~Wb} 150$, both samples from the lower member of the Seabee formation, and unfigured paratypes (USNM P4519) from 1,290 feet below the top of the Seabee formation, field sample $47 \mathrm{~A} \mathrm{~Wb} 172$.

Figured paratype (USNM P6281) and unfigured paratypes (USNM P6282) from the basal part of the Seabee formation, field sample $47 \mathrm{~A}$ Wh 12.

Unfigured paratypes (USNM P6283) from field sample $47 \mathrm{~A}$ Dt 84 and unfigured paratypes (USNM P6284) from field sample 47A Dt 96, both samples from the lower member of the Seabee formation.

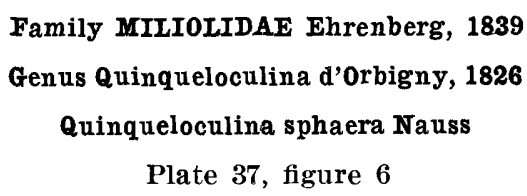

Quinqueloculina sphaera Nauss, 1947, Jour. Paleontology, v. 21, no. 4 , p. 340 , pl. 48 , figs. $14 a-c$.

Test free, small, robust, ovate to nearly circular in outline, rounded in section; chambers arranged in a quinqueloculine pattern, each a half coil in length, of equal diameter throughout; sutures distinct, flush with the surface; wall calcareous, porcellanous, surface smooth, occasional specimens represented only by pyritic internal casts; aperture terminal on the final chamber, an arched slit.

Length of figured hypotype $0.24 \mathrm{~mm}$, breadth 0.19 $\mathrm{mm}$.

Remarks.-This species was described from the lower Lea Park shale of Alberta, Canada. In Alaska it occurs rarely in the Schrader Bluff formation.

Types and occurrence.-Figured hypotype (USNM P6315) from field sample 48A Dt 425, in the Barrow Trail member of the Schrader Bluff formation.

Unfigured hypotype (USNM P6316) from well cuttings at 835 to 845 feet, in the Schrader Bluff formation, in Gubik test well 1.

Unfigured hypotypes (USNM P6512) from a core at 1030 to 1040 feet, in the Seabee formation, in Umiat test well 11.

\section{Family RZEHAKINIDAE Cushman, 1933 \\ Genus Psamminopelta Tappan, 1957 \\ Psamminopelta bowsheri Tappan \\ Plate 37, figures 11-22}

Psamminopelta bowsheri Tappan, 1957, U.S. Natl. Mus. Bull. 215, p. 211, pl. 67, figs. 11-18, 22-24.

Test free, ovate in outline, flattened, consisting of long, narrow and tubular planispirally arranged chambers, each a half coil in length, and only very slightly 
overlapping earlier coils; sutures depressed; wall finely agglutinated, smoothly finished, with siliceous cement, insoluble in acid, commonly crushed and flattened in preservation; aperture at the open end of the tubular chamber, commonly appearing elongate because of compression of the test, without a tooth.

Length of holotype $0.83 \mathrm{~mm}$, breadth $0.57 \mathrm{~mm}$, thickness $0.05 \mathrm{~mm}$. Paratypes range from 0.29 to $0.91 \mathrm{~mm}$ in length.

Remarks.-Psamminopelta bowsheri differs from Massilina texasensis Cushman in the narrower chambers, planispiral coiling, relatively broader test, and the agglutinated wall, which is insoluble in acid.

It occurs in the Grandstand, Topagoruk, Tuktu, and upper part of the Torok formations and in marine zones of the equivalent Chandler formation.

The species was named in honor of A. L. Bowsher, geologist, U.S. Geological Survey.

Types and occurrence.-Holotype (USNM P4424) from a core at 256-264 feet, in the Grandstand formation, in Skull Cliff core test 1.

Unfigured paratypes (USNM P4425) from a core at 438-443 feet, in the Grandstand formation, figured paratype (USNM P4426) from a core at 1020-1030 feet, and unfigured paratypes (USNM P 4427 ) from a core at 1247-1267 feet, all from the Topagoruk formation, in Simpson test well 1.

Unfigured paratype (USNM P4428) from well cuttings at $470-480$ feet, in the Grandstand formation, in Simpson core test 10 .

Unfigured paratypes (USNM P4468) from a core at 1424-1434 feet, figured paratype (USNM P4429) from a core at 1615-1620 feet, and figured paratypes (USNM P4430 a-c) and unfigured paratypes (USNM P4431) from a core at 1810-1816 feet, all from the Grandstand formation, and unfigured paratypes (USNM P4432) from well cuttings at 3970-3980 feet, in the Topagoruk formation, and unfigured paratype (USNM P4433) from well cuttings at $4790-4800$ feet, in the Topagoruk formation, in Umiat test well 1.

Figured paratype (USNM P4434) from residual soil of the Grandstand formation (field sample 47A Wh 688), unfigured paratypes (USNM P4435) from residual soil of marine zone in the Chandler formation (field sample $47 \mathrm{~A}$ Wh 648), figured paratype (USNM P4436) and unfigured paratype (USNM P4437) from field sample $47 \mathrm{~A}$ Wh 654 , a residual soil sample of marine tongues taken $610-650$ feet above the base of the Chandler formation, and unfigured paratype (USNM P4438) from residual soil of a marine zone in the Chandler formation (field sample $47 \mathrm{~A} \mathrm{Wh} 671)$.
Unfigured paratypes (USNM P4439) from a marine zone in the Chandler formation, field sample $48 \mathrm{~A}$ Dt 249.

Figured paratype (USNM P6367) from field sample $47 \mathrm{~A}$ Wh 160, figured paratype (USNM P4443) and unfigured paratypes (USNM P4444) from field sample $47 \mathrm{~A}$ Wh 199, all in the upper part of the Torok formation, equivalent to the Topagoruk formation of the subsurface.

Unfigured paratypes (USNM P4447) from field sample 47A Ba 50, in the Kukpowruk formation.

Unfigured paratypes (USNM P4448) from a core at $472-481$ feet in the Grandstand formation, in Umiat test well 3 .

Unfigured paratype (USNM P4449) from well cuttings at 1090-1100 feet and unfigured paratype (USNM P 4450) from well cuttings at 1180-1190 feet, from the Topagoruk formation, in South Barrow test well 1.

Unfigured paratype (USNM P4451) from well cuttings at $750-760$ feet, in the Topagoruk formation, in South Barrow test well 2.

Figured paratype (USNM P4462) and unfigured paratypes (USNM P4463) from field sample 47A $\mathrm{Tr}$ 253, in the Kukpowruk formation.

Unfigured paratypes (USNM P4464) from field sample $47 \mathrm{~A}$ Wh 594 , residual soil sample of the Grandstand formation.

Unfigured paratype (USNM P4465), from seismograph party 47 test hole, line $14 \mathrm{~A}-48$, shot hole 45 , at a depth of 110-120 feet, in the Grandstand formation.

Unfigured paratype (USNM P4466) from the Grandstand formation, field sample 47A Dt 227 .

Unfigured paratype (USNM P4467) from 81 feet below the top of the Tuktu formation (field sample 47A Z 604) and unfigured paratypes (USNM P4445) from the Grandstand formation, 70 feet above the Tuktu formation (field sample 47A $Z$ 608).

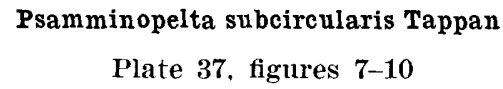

Psamminopelta subcircularis Tappan, U.S. Natl. Mus. Bull. 215, p. 213, pl. 67, figs. 8-10.

Test free, discoidal, planispiral, each chamber a half coil in length, chambers very narrow and elongate, nearly circular in section; sutures distinct, depressed; wall finely agglutinated, smoothly finished; aperture at the end of the last tubular chamber, no tooth visible.

Length of holotype $0.31 \mathrm{~mm}$, greatest breadth 0.26 $\mathrm{mm}$, thickness $0.04 \mathrm{~mm}$. Paratypes range from 0.18 to $0.34 \mathrm{~mm}$ in length. 
Remarks.-Psammminopelta subcircularis differs from Mitiammina manitobensis Wickenden in being much smaller, about one fourth as large, in being discoidal rather than fusuline in shape, and in lacking the quinqueloculine development of Mitiammina. Psamminopelta bowsheri Tappan is about 3 times as large, with much broader chambers. The present species somewhat resembles Massitina glutinosa Cushman and Cahill, but is about one-half as large, with narrower chambers and more nearly circular outline, planispiral development, and arenaceous wall, insoluble in acid.

It occurs in the Corwin, Grandstand, Topagoruk, Tuktu and upper part of the Torok formations.

Types and occurrence.-Holotype (USNM P4452) and figured paratype (USNM P4453) from a core at 361-366 feet in the Grandstand formation, in Umiat test well 3.

Figured paratype (USNM P6317) and unfigured paratypes (USNM P6318) from a core at 365-375 feet, figured paratype (USNM P4454) and unfigured paratype (USNM P4455) from a core at 499-509 feet, unfigured paratype (USNM P4456) from a core at 522-524 feet, unfigured paratypes (USNM P4457) from a core at 770-780 feet, all from the Grandstand formation, and unfigured paratype (USNM P4458) from well cuttings at 4010-4020 feet, in the Topagoruk formation, in Umiat test well 2.

Unfigured paratypes (USNM P4459) from a core at 1424-1434 feet, unfigured paratypes (USNM P4460) from a core at 1693-1703 feet, and unfigured paratypes (USNM P4461) from a core at 1713-1723 feet, and unfigured paratype (USNM P6319) from well cuttings at 2090-2095 feet, all from the Grandstand formation, in Umiat test well 1.

Unfigured paratype (USNM P6320) from the Grandstand formation, field sample 48A Dt 249.

Unfigured paratypes (USNM P6321) from the Grandstand formation, field sample 47A Dt 256.

Unfigured paratype (USNM P6322) from the Corwin formation, field sample $47 \mathrm{~A}$ Wh 630 .

\section{Genus Miliammina Heron-Allen and Earland, 1930 \\ Miliammina awunensis Tappan \\ Plate 36, figures $20-24$}

Miliammina aধunensis Tappan, 1957, U.S. Natl. Mus. Bull. 215, p. 210, pl. 67, figs. 19-21.

Test free, elongate, flattened, ovate in outline, quinqueloculine in plan; chambers narrow, elongate, each a half coil in length, of equal diameter throughout length; sutures distinct, depressed; wall finely agglutinated, surface smoothly finished; aperture a simple opening at the end of the tubular chamber.
Length of holotype $0.44 \mathrm{~mm}$, breadth $0.26 \mathrm{~mm}$. Paratypes range from 0.23 to $0.65 \mathrm{~mm}$ in length.

Remarks.-Specimens of this species are commonly distorted in preservation and may be crushed at varying angles, so that the test may assume variable outlines.

Miliammina awunensis differs from $M$. manitobensis Wickenden in having narrower chambers, of even diameter throughout, and in being more finely agglutinated and smoothly finished. It differs from $M$. valdensis Bartenstein and Brand in being somewhat larger with thicker chambers.

It occurs in the Grandstand, Tuktu, Topagoruk and the upper part of the Torok formations and in marine zones of the equivalent Chandler formation.

Types and occurrence.-Holotype (USNM P4407) from residual soil of brackish or marine tongues in the Chandler formation (field sample 47A Wh 623).

Unfigured paratypes (USNM P4408) from field sample $47 \mathrm{~A}$ Wh 688 , in residual soil of the Grandstand formation.

Figured paratype (USNM P4409) and unfigured paratypes (USNM P4410) from field sample 47A Wh 655 , from residual soil of marine or brackish tongues in the Chandler formation.

Unfigured paratypes (USNM P4411) from field sample 47A Tr 293, from a marine zone in the Chandler formation.

Unfigured paratypes (USNM P4412) from field sample $47 \mathrm{~A} \mathrm{Tm} \mathrm{13,} \mathrm{bed} \mathrm{12,} \mathrm{in} \mathrm{the} \mathrm{Kukpowruk} \mathrm{forma-}$ tion.

Unfigured paratypes (USNM P4413) from field sample $47 \mathrm{~A} \mathrm{Z} \mathrm{604,} \mathrm{in} \mathrm{the} \mathrm{Grandstand} \mathrm{formation.}$

Unfigured paratype (USNM P4414) from the Grandstand formation in a core at 432-439 feet, in Umiat test well 3.

Figured paratype (USNM P4415) and unfigured paratypes (USNM P4416) from a core at 256-264 feet and unfigured paratypes (USNM P6323) from well cuttings at 375 to 380 feet, both in the Grandstand formation in Skull Cliff core test 1.

Figured paratype (USNM P6324) from well cuttings at 3110 to 3120 feet in the Topagoruk formation in Umiat test well 2.

Figured paratype (USNM P6325) and unfigured paratypes (USNM P6326) from the upper part of the Torok formation, field sample 47A Wh 199.

Unfigured paratypes (USNM P4417) from a core at $443-444$ feet, in the Grandstand formation, in Simpson test well 1 .

Unfigured paratypes (USNM P4418) from a core at 459-469 feet, in the Topagoruk formation, in South Barrow test well 2. 
Unfigured paratypes (USNM P6327) from the Grandstand formation, field sample 47A Dt 257.

Unfigured paratypes (USNM P6328) from the Grandstand formation, field sample 47A Z 608 .

\section{Miliammina bisobscura Stelck and Wall}

Plate 36, figure 19

MIiliammina bisobscura Stelck and Wall, 1954, Research Council Alberta, Rept. 68, p. 29, pl. 1, fig. 1.

Test free, ovate, of medium size, quinqueloculine in plan; chambers narrow and elongate, each a half coil in length and of equal diameter throughout; sutures depressed; wall finely agglutinated, smoothly finished; aperture at the open end of the final chamber.

Hypotypes range in length from 0.23 to $0.53 \mathrm{~mm}$ and in breadth from 0.08 to $0.26 \mathrm{~mm}$.

Remarks.-This species is similar in appearance to the somewhat older Miliammina ischnia Tappan, but is larger and comparatively broader, and has an ovate outline rather than parallel sides. It is smaller than Miliammina manitobensis Wickenden, and has a more finely textured wall.

Mitiammina bisobscura was originally described from the Kaskapau shales (base of Inoceramus labiatus zone, lower Turonian) of British Columbia, Canada. In Alaska it occurs in the Seabee and Schrader Bluff formations, of Turonian and Senonian age.

Types and occurrence.-Figured hypotype (USNM P6329) and unfigured hypotypes (USNM P6330) from a core in the Seabee formation at 490 to 499 feet, in Umiat test well 1.

Unfigured hypotypes (USNM P6331) from the Sentinel Hill member of the Schrader Bluff formation, field sample $47 \mathrm{~A}$ Dt 284.

Unfigured hypotype (USNM P6332) from the lower member of the Seabee formation, field sample $47 \mathrm{~A} \mathrm{~Wb} 258$.

Unfigured hypotypes (USNM P6333) from residual soil of the basal part of the Seabee formation, field sample 47A Wh 12.

Unfigured hypotype (USNM P6334) from the Ayiyak member of the Seabee formation, field sample $52 \mathrm{~A} \mathrm{Bl} 34$.

\section{Miliammina ischnia Tappan}

Plate 37, figures 1-5

Miliammina ischnia Tappan, 1957, U.S. Natl. Mus. Bull. 215, p. 211, pl. 67, figs. $25,26$.

Test free, small, narrow, elongate, sides subparallel, quinqueloculine in section; chambers narrow, elongate, a half coil in length; sutures distinct, depressed; wall finely agglutinated, surface smoothly finished; aperture at the open end of the final chamber.

Length of holotype $0.36 \mathrm{~mm}$, breadth $0.10 \mathrm{~mm}$.
Remarks.-Mitiammina ischnia differs from $M$. manitobensis Wickenden in being smaller and comparatively narrower and more elongate. It differs from Miliammina awunensis Tappan in being narrower with nearly parallel sides, rather than ovate in outline, M. sproulei Nauss is broader and more ovate in outline than Miliammina ischnia.

Miliotina gramen Friedberg is similar in general appearance, but is two to three times as large.

This species is found in the Grandstand and Topagoruk formations.

Types and occurrence.-Holotype (USNM P4419) and unfigured paratypes (USNM P4420) from a core at 1910-1920 feet, and figured paratype (USNM P4421) and unfigured paratypes (USNM P4422) from a core at 1693-1703 feet, both from the Grandstand formation, in Umiat test well 1.

Unfigured paratypes (USNM P4423) from a core at $432-439$ feet, in the Grandstand formation, in Umiat test well 3.

Figured paratypes (USNM P6335a-c) and unfigured paratypes (USNM P6336) from a core at 785788 feet in the Grandstand formation, in Umiat test well 2.

Unfigured paratypes (USNM P6337) from a core at 577 to 588 feet in the Grandstand formation, in Simpson core test 30 .

Unfigured paratype (USNM P6338) from well cuttings at 1710 to 1720 feet in the Topagoruk formation in South Barrow test well 1.

Unfigured paratypes (USNM P6339) from residual soil of a marine interbed in the Chandler formation, field sample $47 \mathrm{~A}$ Wh 655 .

\section{Miliammina manitobensis Wickenden \\ Plate 36, figures 12-18}

Miliammina manitobensis Wickenden, 1932, Royal Soc. Canada, Trans. 3rd ser., v. 26, sec. 4, p. 90, pl. 1, figs. 11a-c.

Test free, large, ovate in outline, the relatively thick chambers each a half coil in length and added in a quinqueloculine plan; sutures distinct, depressed; wall finely to coarsely agglutinated, insoluble in acid; aperture a simple rounded opening at the end of the final chamber, slightly produced on a short neck, without a tooth.

Hypotypes range from 0.34 to $1.30 \mathrm{~mm}$ in length.

Remarks.-This species was originally described from the Ashville beds of Manitoba, and was recorded by Nauss (1947) from the middle Lloydminster shale of the Vermilion area of Alberta, Canada. In Alaska it occurs in the Topagoruk and Grandstand formations, and in the upper part of the Torok formation of the foothills region. 
Types and occurrence.-Figured hypotypes (USNM $\mathrm{P} 6342 \mathrm{a}, \mathrm{b})$ and unfigured hypotypes (USNM P6343) from a core at 196 to 201 feet, unfigured hypotypes (USNM P6344) from a core at 206 to 211 feet, unfigured hypotypes (USNM P6345) from a core at 293 to 303 feet, unfigured hypotypes (USNM P6346) from a core at 613 to 623 feet, all from the Grandstand formation; and unfigured hypotypes (USNM P6347) from a core at 1010 to 1020 feet, unfigured hypotypes (USNM P6348) from a core at 1020 to 1030 feet, figured hypotype (USNM P6349) from a core at 1287 to 1297 feet, unfigured hypotypes (USNM P6350) from a core at 1302 to 1312 feet, and figured hypotype (USNM P6351) from well cuttings at 2430 to 2440 feet, all from the Topagoruk formation, in Simpson test well 1.

Figured hypotype (USNM P6352) and unfigured hypotype (USNM P6353) from a core at 264 feet, and unfigured hypotype (USNM P6354) from a core at 256 to 264 feet, all in the Grandstand formation, in Skull Cliff core test 1.

Figured hypotype (USNM P6355) from cuttings at 5180 to 5190 feet, unfigured hypotype (USNM P6356) from cuttings at 3650 to 3660 feet, and unfigured hypotype (USNM P6357) from cuttings at 4490 to 4500 feet, all in the Topagoruk formation, in Umiat test well 1.

Figured hypotype (USNM P6358) and unfigured hypotypes (USNM P6359) from cuttings at 1340 to 1350 feet in the Topagoruk formation, and unfigured hypotypes (USNM P6360) from a core at 470 to 475 feet, and unfigured hypotype (USNM P6361) from a core at 990 to 992 feet, all in the Grandstand formation in Umiat test well 2.

Unfigured hypotype (USNM P6362) from a core at 472 to 481 feet in the Grandstand formation in Umiat test well 3 .

Unfigured hypotype (USNM P6363) from a core at 548 to 558 feet in the Topagoruk formation in Arcon Point Barrow core test 1.

Unfigured hypotype (USNM P6364) from cuttings at 1700 to 1710 feet in the Topagoruk formation in South Barrow test well 1.

Unfigured hypotype (USNM P6365) from cuttings at 250 to 260 feet in the Grandstand formation, in Simpson core hole 8 .

Unfigured hypotype (USNM P6366) from cuttings at 330 to 340 feet in the Grandstand formation, in Simpson core hole 10.

Unfigured hypotype (USNM P6368) from field sample $47 \mathrm{~A}$ Wh 199 , in the upper part of the Torok formation; unfigured hypotypes (USNM P6369) from field sample $47 \mathrm{~A}$ Wh $674 \mathrm{~A}$, and unfigured hypotypes
(USNM P6370) from field sample 47A Wh 691, all from residual soils of the Grandstand formation.

Unfigured hypotypes (USNM P6371) from field sample $47 \mathrm{~A} \operatorname{Tr} 167$, from the Torok formation.

Unfigured hypotypes (USNM P6372) from field sample $47 \mathrm{~A}$ Tm C-53, in the undifferentiated Kukpowruk and upper part of the Torok formations.

Unfigured hypotype (USNM P6373) from field sample $46 \mathrm{~A}$ Th 165 , in an interbed of the Grandstand formation, within the Killik formation.

Unfigured hypotype (USNM P6374) from a depth of 110 to 120 feet in seismograph test hole, party 47, line 14-A-48, shot point $43 \mathbf{A}$, in the Grandstand formation.

\section{Family NODOSARIIDAE Ehrenberg, 1839 \\ Genus Lenticulina Lamarck, 1804 \\ Lenticulina bayrocki Mellon and Wall}

Plate 40, figures 2, 3

Lenticulina bayrocki Mellon and Wall, 1956, Research Council Alberta Rept. 72, p. 19, pl. 2, figs. 7, 8; Stelck, Wall, Bahan and Martin, 1956, Ibid., Rept. 75, p. 42, pl. 3, figs. 17, 18.

Test free, lenticular, robust, planispiral, biumbonate, periphery subacute; chambers broad and low, 7 to 9 in the final whorl; sutures distinct, curved, thickened; wall calcareous, perforate, surface smooth; aperture at the peripheral angle, radiate.

Hypotypes range from 0.58 to $1.31 \mathrm{~mm}$ in diameter.

Remarks.-This species was described from the basal Clearwater formation (lower Albian) of Alberta, Canada, and has been recorded also from the middle and upper parts of the Clearwater formation. Lenticulina sp. Wickenden, 1951, from the Loon River formation and Peace River formation, Peace River area of Alberta, is reported (Mellon and Wall, 1956, p. 19) to be the same as the present species. In Alaska, it occurs rarely in the Grandstand, Topagoruk and Torok formations.

It resembles Lenticulina secans (Reuss) from the Gault (Albian) of Germany but is thicker and more robust, with less pronounced umbonal bosses.

Types and occurrence.-Figured hypotype (USNM P6411) from the Grandstand formation, in a core at 2733 to 2743 feet, and figured hypotype (USNM P6412) from the Topagoruk formation in cuttings at 5070 to 5080 feet, both from Umiat test well 1 .

Unfigured hypotype (USNM P6413) from cuttings at 600 to 610 feet in the Topagoruk formation in South Barrow test well 1.

Unfigured hypotype (USNM P6114) from cuttings at 5360 to 5370 feet, in the Torok formation, in Simpson test well 1. 


\section{Lenticulina erecta (Perner)}

Plate 40, figures 13,14

Cristellaria erecta Perner, 1892, Česká Akad. Císaře Františka Josefa, Pal. Bohemiae, Praha, Czechoslovakia, Trída 2, Nr. 1, pp. 39, 63, pl. 4; figs. 12-13.

Test free, large, lenticular, biumbonate, chambers relatively numerous, low, about 12 per whorl, periphery weakly keeled; sutures gently curved; wall calcareous, surface smooth; aperture at the peripheral angle, radiate.

Hypotypes range from 0.45 to $1.31 \mathrm{~mm}$ in diameter. Remarks.-This species was originally described from the Cenomanian of Bohemia. In Alaska it occurs in the Grandstand and Topagoruk formations.

Types and occurrence.-Figured hypotype (USNM P6375) from a core at 1277 to 1287 feet, unfigured hypotype (USNM P6376) from a core at 1287 to 1297 feet, unfigured hypotype (USNM P6377) from cuttings at 2860-2870 feet, and unfigured hypotype (USNM P6378) from cuttings at 3110 to 3120 feet, all in the Topagoruk formation, in Simpson test well 1.

Figured hypotype (USNM P6379) from cuttings at 2890 to 2900 feet and unfigured hypotype (USNM P6380) from cuttings at 4570 to 4580 feet, both in the Topagoruk formation and unfigured hypotype (USNM P6381) from a core at 572 to 582 feet in the Grandstand formation, all in Umiat test well 2.

Unfigured hypotypes (USNM P6382) from cuttings at 3000 to 3010 feet in the Topagoruk formation, in South Barrow test well 1.

Unfigured hypotype (USNM P6383) from a depth of 70 feet in seismograph test hole 12 , line $12-48$, party 46 , in the Grandstand formation.

\section{Lenticulina gryci Tappan \\ Plate 40 , figure 4}

Lenticulina gryci Tappan, 1960, Am. Assoc. Petroleum Geologists Bull., v. 44, no. 3, p. 292, pl. 1, fig. 15.

Lenticulina frankei Marie, 1941 (not Lenticulina frankei Eichenberg, 1933) Mém. Mus. Natl. Hist. Nat., Paris, New Ser., v. 12, fasc. 1 , p. 100 , pl. 9, figs. $105 \mathrm{a}$, b.

Test free, small, planispiral, lenticular, robust, biumbonate, periphery angled; about 10 chambers in the final whorl; sutures gently curved, flush; wall calcareous, surface smooth; aperture radiate, at the peripheral angle.

Hypotypes range from 0.55 to $0.60 \mathrm{~mm}$ in diameter. Remarks.-Originally described from the Senonian, Craíe à Belemnitella mucronate, this species occurs rarely in beds of similar age in Alaska, in the Schrader Bluff formation.

Types and occurrence.-Figured hypotype (USNM P6409) from the Sentinel Hill member of the Schrader Bluff formation, field sample $49 \mathrm{~A}$ Gr 1 .
Unfigured hypotype (USNM P6410) from a core at 1110 to 1120 feet in the Sentinel Hill member, Schrader Bluff formation, in Sentinel Hill core test 1.

\section{Lenticulina ingenua (Berthelin)}

Plate 41 , figures 1,2

Cristellaria ingenua Berthelin, 1880, Soc. Géol. France, Mém. ser. 3, v. 1, no. 5, p. 54, pl. 3, figs. 20-21.

Test free, compressed, lenticular, planispiral, periphery keeled; proloculus large and spherical, chambers increasing gradually in size, with later chambers showing a tendency to uncoil; sutures distinct, somewhat thickened, gently curved; wall calcareous, hyaline, surface smooth; aperture radiate, at the peripheral angle.

Greatest diameter of hypotype 0.49 to $0.86 \mathrm{~mm}$.

Remarks.-This species was originally described from the Lower Cretaceous (Albian) of France. In Alaska it occurs in the Torok formation. It is characterized by the compressed test, peripheral keel, relatively large proloculus and tendency to uncoil.

Types and occurrence.-Figured hypotype (USNM P6384) from well cuttings at 3290 to 3300 feet, figured hypotype (USNM P6422) from a core at 3133 to 3144 feet, and unfigured hypotype (USNM P6421) from cuttings at 3050 to 3060 feet, in the Torok formation, in South Barrow test well 1.

\section{Lenticulina macrodisca (Reuss)}

Plate 40, figures $5-8$

Cristellaria (Cristellaria) macrodisca Reuss, 1863, K. Akad. Wiss. Wien., Math.-Naturw. Cl., Sitzber., Wien., v. 46, Abt. 1 (1862) p. 78, pl. 9, figs. 5a, b.

Test free, lenticular, robust, planispiral; with relatively large globular proloculus followed by gradually enlarging chambers, about 7 to 9 in the final whorl of larger specimens; sutures gently curved, somewhat thickened, flush; wall calcareous, hyaline, surface smooth; aperture radiate at the peripheral angle of the final chamber which is somewhat produced to form a short neck-like extension.

Greatest diameter ranges from 0.23 to $1.07 \mathrm{~mm}$.

Remarks.-This species was originally described from the Lower Cretaceous, upper Hils and middle Gault, of northern Germany, and has been recorded in Albian strata of France, Czechoslovakia and Bavaria.

The most notable characteristic is the extremely large proloculus which is generally visible at the center of the test.

In Alaska, it occurs in the Grandstand, Topagoruk and Fortress Mountain formations.

Types and occurrence.-Figured hypotype (USNM P6385) and unfigured hypotype (USNM P6386) from 
a core at 1080 to 1087 feet, unfigured hypotype (USNM P6387) from a core at 1247 to 1267 feet, and unfigured hypotypes (USNM P6388) from a core at 1967 to 1977 feet, all in the Topagoruk formation; unfigured hypotype (USNM P6389) from a core at 201-206 feet, unfigured hypotype (USNM P6390) from a core at 211-221 feet, unfigured hypotype (USNM P6391) from a core at 433-438 feet, unfigured hypotype (USNM P6392) from a core at 438 to 443 feet, and unfigured hypotype (USNM P6393) from a core at 533 to 543 feet, all in the Grandstand formation; all from Simpson test well 1.

Figured hypotype (USNM P6394) and unfigured hypotype (USNM P6395) from a core at 667 to 686 feet in the Topagoruk formation in Arcon Point Barrow core test 1 .

Figured hypotype (USNM P6396) from cuttings at 3210 to 3220 feet in the Topagoruk formation, and unfigured hypotypes (USNM P6397) from a core at 1625 to 1635 feet in the Grandstand formation, all in Umiat test well 1.

Figured hypotype (USNM P6398) from cuttings at 2860 tu 2870 feet in the Topagoruk formation, in Umiat test well 2.

Unfigured hypotype (USNM P6399) from a core at 472 to 481 feet in the Grandstand formation in Umiat test well 3 .

Unfigured hypotype (USNM P6400) from a core at 1200 to 1210 feet, in the Topagoruk formation, in South Barrow test well 1.

Unfigured hypotype (USNM P6401) from cuttings at 350 to 360 feet, and unfigured hypotype (USNM P6402) from cuttings at 520 to 530 feet, all in the Topagoruk formation in South Barrow test well 2.

Unfigured hypotype (USNM P6403) from 370 to 380 feet in the Grandstand formation in Simpson core hole 8 .

Unfigured hypotype (USNM P6404) from seismograph shot hole 43 at 60 feet, in the Topagoruk formation, Party 46, line 43-49; and unfigured hypotype (USNM P6405) from test hole 8 at 170 to 180 feet, in the Topagoruk formation, party 47 , line $27-48$.

Unfigured hypotype (USNM P6406) from field sample 49A $\mathrm{Pa} 571$, and unfigured hypotype (USNM P6407) from field sample $49 \mathrm{~A}$ Tr 291 , both in the Fortress Mountain formation.

\section{Lenticulina polygona (Perner)}

Plate 40, figure 1

Cristellaria polygona Perner, 1892, Česká Akad. Císaře Františka Josefa, Pal. Bohemiae, Praha, v. 2, no. 1, pp. 39, 63, pl. 5, figs. 3-4.

Test free, lenticular, sloping sharply from the thickened umbonal regions to the subacute periphery, peripheral outline polygonal, with the angles at the sutures, and the outer chamber margins flattened between the sutures, about 7 to 9 chambers per whorl; sutures oblique but nearly straight, slightly thickened; wall calcareous, hyaline, surface smooth; aperture radiate, at the peripheral angle.

Greatest diameter of figured hypotype $0.58 \mathrm{~mm}$.

Remarks.-This species was originally described from the Cenomanian of Czechoslovakia. In Alaska it appears somewhat lower in the section, in the Torok formation. The Alaskan figured specimen is somewhat smaller than the holotype, but also has the lower limit in number of chambers as originally defined by Perner, and thus may represent a young specimen, rather than an adult. It is rare in Alaska.

Type and occurrence.-Figured hypotype (USNM P6408) from the Torok formation, in cuttings at 2110 to 2120 feet in South Barrow test well 2.

\section{Ienticulina topagorukensis Tappan}

Plate 40, figures 9-12

Lenticulina topagorukensis Tappan, 1960, Am. Assoc. Petroleum Geologists Bull., v. 44, no. 3, p. 292, pl. 1, figs. 16-19.

Test free, small, planispiral and involute, sides flattened, with small umbonal bosses, periphery subrounded; chambers 6 to 7 in the final whorl, enlarging gradually as added; sutures distinct, gently curved, depressed; wall calcareous, perforate, surface smooth; aperture at the peripheral angle, slightly produced, but this slight neck commonly broken, leaving a rounded hole in most specimens observed.

Greatest diameter of holotype $0.37 \mathrm{~mm}$; paratypes range from 0.16 to $0.52 \mathrm{~mm}$ in diameter.

Remarks.-This species is similar to Robulus isidis (Schwager) of Loetterle (1937), but has a more robust test and lacks a peripheral keel. Cristellaria isidis Schwager is from the Eocene of Egypt, and has more straight and radial sutures than the present species and is a much larger and more compressed form.

This species occurs in the Topagoruk and Torok formations in Alaska.

Types and occurrence.-Holotype (USNM P6415) from cuttings at 4280 to 4290 feet, and figured paratype (USNM P6416) from cuttings at 2660 to 2670 feet, all in the Topagoruk formation, in Umiat test well 2.

Figured paratype (USNM P6417) from cuttings at 3670 to 3680 feet in the Topagoruk formation in Umiat test well 1.

Figured paratype (USNM P6418) and unfigured paratype (USNM P6419) from a core at 3069 to 3079 feet, and unfigured paratype (USNM P6420) from 
a core at 3105 to 3115 feet, all in the Torok formation in South Barrow test well 1.

\section{Genus Saracenaria Defrance, 1824}

Saracenaria dutroi Tappan

Plate 41 , figures $15-17$

Saracenaria dutroi Tappan, 1947, U.S. Natl. Mus. Bull. 215, p. 216, pl. 68, figs. 14-i6.

Test free, early portion coiled, later uncoiling and rectilinear, triangular in section, periphery acute but without a keel; chambers increasing rapidly in size from the globular proloculus, becoming increasingly broader but enlarging very littie in height, with considerable overlap, so that final chamber is about half again as high as the penultimate, sides of chambers flattened or slightly depressed centrally, apertural face flattened; sutures distinct, gently curved in the early portion, more nearly straight, but oblique in the later portion, highest at the dorsal angle, wall calcareous, hyaline, finely perforate, surface smooth; aperture terminal at the dorsal angle, radiate, and slightly produced.

Length of holotype $0.78 \mathrm{~mm}$, greatest breadth of side $0.31 \mathrm{~mm}$, breadth of face $0.26 \mathrm{~mm}$. Paratypes range from 0.26 to $0.73 \mathrm{~mm}$ in length.

Remarks.-Saracenaria dutroi differs from S. saratogana Howe and Wallace in being relatively narrower, with fewer and higher chambers, a more enrolled base, and more acutely angled margins.

It occurs in the Grandstand and Topagoruk formations of northern Alaska.

The specific name is in honor of J. T. Dutro, Jr., geologist, U.S. Geological Survey.

Types and occurrence.-Holotype (USNM P4533) from well cuttings at 1940-1950 feet, from the Topagoruk formation; unfigured paratypes (USNM P4534) from a core at 438-443 feet, unfigured paratype (USNM P4535) from a core at 493-503 feet, unfigured paratypes (USNM P4536) from a core at 543545 feet, all from the Grandstand formation; figured paratype (USNM P4537) from a core at 1080-1087 feet, unfigured paratype (USNM P4538) from well cuttings at 2300-2310 feet, and unfigured paratype (USNM P4539) from well cuttings at 2460-2470 feet, all from the Topagoruk formation, all from Simpson test well 1.

Figured paratype (USNM P4540) from well cuttings at 1392-1397 feet, in the Topagoruk formation, in Arcon Point Barrow core test 1.

Unfigured paratype (USNM P6517) from a core at 1738 to 1748 feet, in the Grandstand formation, in East Topagoruk test well 1.
Saracenaria grandstandensis Tappan

Plate 41 , figures $3-5$

Saracenaria grandstandensis Tappan, 1960, Am. Assoc. Petroleum Geologists Bull., v. 44, no. 3, p. 292, pl. 2, figs. 8-10. Saracenaria sp. C. Stelck and Wall, 1956 (in Stelck, Wall, Bahan and Martin), Research Council Alberta Rept. 75, p. 52, pl. 3, figs. 30,31 .

Test free, elongate; early chambers added on a curved axis, but without a distinct coil, later uncoiled and rectilinear, chambers very low and broad, later ones distinctly triangular in section, with rounded angles; sutures distinct, nearly straight to slightly curved, strongly oblique; wall calcareous, finely perforate, surface smooth; aperture radiate, at the peripheral angle, somewhat produced.

Length of holotype $0.76 \mathrm{~mm}$, breadth $0.33 \mathrm{~mm}$; paratypes range from 0.31 to $0.78 \mathrm{~mm}$ in length.

Remarks.-Saracenaria grandstandensis n. sp., differs from S. trollopei Mellon and Wall in the absence of an early coil, the very low, broad chambers and straight but strongly oblique sutures.

Saracenaria sp. C. of Stelck and Wall is apparently identical with the Alaskan species, and was recorded from the Clearwater formation of Alberta, Canada. In Alaska, this species is characteristic of the Grandstand formation, and more rarely occurs in the underlying Topagoruk formation.

Types and occurrence.-Holotype (USNM P6442) from a core at 283 to 293 feet, figured paratype (USNM P6443) from a core at 438 to 443 feet, figured paratype (USNM P6444) from a core at 523 to 533 feet, all from the Grandstand formation, and unfigured paratype (USNM P6445) from cuttings at 2390 to 2395 feet, and unfigured paratype (USNM P6446) from cuttings at 2450 to 2460 feet, both in the Topagoruk formation; all from Simpson test well 1.

Unfigured paratype (USNM P6447) from a core at 520 to 529 feet in the Grandstand formation, in Umiat test well 3 .

\section{Saracenaria projectura Stelck and Wall}

Plate 41 , figures $9-14$

Saracenaria sp. Mellon and Wall, 1956 (part), Research Council Alberta, Rept. 72, p. 26, pl. 2, figs. 18, 19 (not figs. 20-25).

Saracenaria projectura Stelck and Wall, 1956, Ibid., Rept. 75, p. 50, pl. 3, figs. 22-25.

Test free, early portion coiled, later chambers tending to uncoil, so that the final chamber may not reach the coil on the inner margin; chambers triangular in section with rounded angles, about twice as broad as high; sutures distinct, depressed, slightly curved; wall 
calcareous, finely perforate, surface smooth; aperture at the dorsal angle, radiate, somewhat produced.

Hypotypes range from 0.26 to $0.50 \mathrm{~mm}$ in length.

Remarks.-Saracenaria projectura differs from $S$. trollopei Mellon and Wall in being smaller, with a more pronounced coil and somewhat more compressed test.

This species was described from the Clearwater formation of Alberta, Canada. In Alaska it occurs in the Grandstand, Topagoruk, Torok and Fortress Mountain formations.

Types and occurrence.-Figured hypotype (USNM P6423a, b) and unfigured hypotypes (USNM P6424) from a core at 3069 to 3079 feet, figured hypotype (USNM P6425) from a core at 3079 to 3088 feet, unfigured hypotypes (USNM P6426) from a core at $3094 \frac{1}{2}$ to 3105 feet, figured hypotype (USNM P6427) and unfigured hypotypes (USNM P6428) from a core at 3115 to 3125 feet, unfigured hypotypes (USNM P6429) from a core at 3125 to 3133 feet, unfigured hypotypes (USNM P6430) from a core at 3355 to 3360 feet, and unfigured hypotype (USNM P6431) from a core at 3374 to 3376 feet, all in the Torok formation, in South Barrow test well 1.

Unfigured hypotype (USNM P6432) from a core at 578 to 588 feet, and unfigured hypotype (USNM P6433) from a core at 613 to 623 feet, both from the Grandstand formation, in Simpson test well 1.

Figured hypotype (USNM P6434) from a core at 532 to 547 feet in the Grandstand formation, in Umiat test well 3.

Unfigured hypotype (USNM P6435) from cuttings at 1850 to 1860 feet, in the Topagoruk formation, in Umiat test well 2.

Unfigured hypotype (USNM P6436) from field sample $49 \mathrm{~A} \mathrm{~Pa} 595$ in the Fortress Mountain formation.

Unfigured hypotypes (USNM P6437) from the Grandstand formation, Seismograph Party 47 test hole, line $14 \mathrm{~A}-48$, shot hole 37 at 190 to 200 feet.

\section{Saracenaria spinosa Eichenberg}

Plate 41, figures 18, 19

Saracenaria spinosa Eichenberg, 1935, Mitt. Roemer-Museum, Hildesheim, no. 37, teil 1, folge 4, p. 10, pl. IV, figs. 5a-d.

Test free, small, early portion coiled, later few chambers tending to uncoil, chambers increasing in relative breadth as added, triangular in section and strongly tricarinate, with prominent keel along the outer margin, and at each margin of the apertural face; sutures distinct, strongly curved, flush on the sides, somewhat depressed on the face; wall calcareous, finely perforate, smooth except for the keels; aperture radiate, somewhat produced, at the peripheral angle. Hypotypes range from 0.26 to $0.40 \mathrm{~mm}$ in length. Remarks.-This species was originally described from the Aptian of northern Germany. In Alaska, it appears in the Grandstand and Topagoruk formations of somewhat younger (Albian) age.

Saracenaria spinosa differs from $S$. dutroi Tappan in the shorter and broader test, less enrolled early portion, and in the pronounced marginal keels.

Types and occurrence.-Figured hypotype (USNM P6448) and unfigured hypotype (USNM P6449) from a core at 308 to 318 feet, and unfigured hypotype (USNM P6450) from a core at 358 to 368 feet, all in the Grandstand formation, in Simpson test well 1.

Figured hypotype (USNM P6451) from a core at 4698 to 4708 feet in the Topagoruk formation, Fish Creek test well 1.

\section{Saracenaria trollopei Mellon and Wall}

Plate 41 , figures $6-8$

Saracenaria trollopei Mellon and Wall, 1956, Research Council Alberta, Rept. 72, p. 25, pl. 2, figs. 26, 27.

Test free, relatively large, robust, early portion coiled, later uncoiling but with only a few chambers which fail to reach back to the early coil; chambers few in number, increasing rapidly in size, triangular in section, with rounded angles; sutures distinct, slightly curved, depressed; wall calcareous, perforate, surface smooth; aperture radiate, at the peripheral angle.

Hypotypes range from 0.33 to $0.70 \mathrm{~mm}$ in length.

Remarks.-Originally described from the Clearwater formation of Alberta, the species was also reported to be present in the Moosebar formation of British Columbia, Canada. In Alaska, it occurs in the Topagoruk and Torok formations.

Saracenaria trollopei Mellon and Wall differs from S. oligostegia (Reuss) in showing a greater tendency to uncoil and in being somewhat larger with less depressed sutures. It is somewhat similar to Lenticulina (Saracenaria) bronnii (Roemer) of Bartenstein and Brand, but Roemer's species is more elongate, narrow and compressed, with a lanceolate rather than triangular section.

Types and occurrence.-Figured hypotype (USNM P6438) from well cuttings at 2050-2060 feet, figured hypotype (USNM P6439) and unfigured hypotype (USNM P6440) from a core at 2040-2052 feet, in the Torok formation, in South Barrow test well 2.

Figured hypotype (USNM P6441) from well cuttings at $4430-4440$ feet in the Topagoruk formation in Umiat test well 1. 
Saracenaria valanginiana Bartenstein and Brand

Plate 42, figures 7,8

Lenticulina (Saracenaria) valanginiana Bartenstein and Brand, 1951, Abh. Senckenberg Naturf. Gesell. no. 485, p. 291, pl. 13, figs. 364-365.

Test free, elongate, early portion coiled, later uncoiling; chambers increasing in relative breadth as added, triangular in section, with narrow keels on each of the three angles; sutures distinct, slightly curved, somewhat depressed; wall calcareous, finely perforate, surface ornamented with the three keels at the angles and a few very fine low ribs on the sides and on the lower part of the apertural face; aperture radiate, at the peripheral angle.

Hypotypes range from 0.33 to $0.52 \mathrm{~mm}$ in length.

Remarks.-This species was originally described from the Valendis (Valanginian) of northwestern Germany. In Alaska it occurs in the Torok formation.

It differs from $S$. spinosa Eichenberg in having lower and less prominent marginal keels and in having fine ribs on both the sides and face of the test.

Types and occurrence.-Figured hypotype (USNM P6452) from a core at 2040 to 2050 feet in the Torok formation, in South Barrow test well 2.

Figured hypotype (USNM P6453) from a core at 3125 to 3133 feet, unfigured hypotype (USNM P6454) from a core at 3036 to 3046 feet and unfigured hypotype (USNM P6455) from cuttings at 3230 to 3240 feet, all in the Torok formation, in South Barrow test well 1.

\section{Saracenaria species}

Plate 42, figure 9

Test free, early portion close coiled, later chambers broad and low, uncoiling and becoming distinctly triangular in section, with face and two sides of approximately equal breadth, and angles sharp and keeled; sutures curved, slightly depressed; wall calcareous, finely perforate, sides of test ornamented with about 5 low longitudinal ribs but apertural face smooth and unornamented, aperture radiate, at the peripheral angle.

Length of figured specimen $0.47 \mathrm{~mm}$.

Remarks.-The specimen illustrated resembles Saracenaria valanginiana Bartenstein and Brand, which occurs in somewhat older Cretaceous beds in Alaska, but differs in having coarser surface ribs on the sides, and in lacking any ornamentation on the apertural face of the chambers. As only a single specimen was found, it is not described specifically.

Type and occurrence.-Figured specimen (USNM P6456) from cuttings at 1970 to 1980 feet, in the Topagoruk formation, in Simpson test well 1.

\section{Genus Marginulinopsis Silvestri, 1904}

Marginulinopsis chandlerensis Tappan

Plate 44, figures 1-3

Marginulinopsis chandlerensis Tappan, 1960, Am. Assoc. Petroleum Geologists Bull., v. 44, no. 3, p. 293, pl. 2, figs. 5-7.

Test free, large, robust, ovate in section, early portion close coiled as in Lenticulina, with 6 or 7 chambers in the coil, later with a few uncoiled chambers of a breadth twice their height; sutures distinct, slightly curved; wall calcareous, surface smooth; aperture radiate, at the peripheral angle.

Length of holotype $0.73 \mathrm{~mm}$, breadth 0.44 , thickness $0.36 \mathrm{~mm}$; paratypes range from 0.34 to $0.44 \mathrm{~mm}$ in length.

Remarks.-Marginulinopsis chandlerensis differs from the associated Marginulina dorsata Cushman, in having a large, and more enrolled early portion, in being broader and more compressed, and in lacking the apiculate proloculus and produced neck of $M$. dorsata.

Types and occurrence--Holotype (USNM P6538) and figured paratype (USNM P6539) from field sample 48A Dt 425, unfigured paratype (USNM P6540) from field sample $48 \mathrm{~A}$ Dt 426 , and unfigured paratype (USNM P6541) from field sample 48A Dt 418, all from the Barrow Trail member of the Schrader Bluff formation.

Figured paratype (USNM P6542) from field sample 47A Dt 358, from the Sentinel Hill member of the Schrader Bluff formation.

Unfigured paratype (USNM P6543) from field sample 47A St 30, from the Sentinel Hill member of the Schrader Bluff formation.

\section{Marginulinopsis collinsi Mellon and Wall}

\section{Plate 42 , figures $10-15$}

Marginulinopsis collinsi Mellon and Wall, 1956, Research Council Alberta, Rept. 72, p. 20, pl. 2. figs. 1-4; Stelck, Wall. Bahan, and Martin ; 1956, Ibid., Rept. 75, p. 44, pl. 1, fig. 3 ; pl. 3, figs. 19, 20 (not pl. 2, figs. 21, 22).

Test free, robust, early portion curved to enrolled and tending toward the character of Marginulinopsis, later uncoiled and becoming straight, chambers slightly compressed laterally, enlarging rapidly in the coiled or curved portion, more gradually in the straight portion, of slightly greater breadth than height; sutures distinct, gently curved in early portion, slightly oblique in later portion, partially obscured by the surface ribs; wall calcareous, finely perforate, surface omamented with 9 to 12 longitudinal, continuous and elevated costae; aperture radiate, somewhat produced at the peripheral angle.

Length ranges from 0.26 to $0.88 \mathrm{~mm}$. 
Remarks.--There are many similar ribbed species in the Cretaceous. The present species differs from Marginulina acuticostata Reuss in the more numerous ribs (9 to 12 instead of 6 ), and in the less acuminate and produced final chamber. Marginulina robusta Reuss differs in being relatively shorter and with fewer but more elevated ribs. Marginulinopsis jonesi (Reuss) differs in having more numerous but less elevated ribs.

Types and occurrence.-Figured hypotype (USNM P6460) from cuttings at 1190-1200 feet in the Topagoruk formation, figured hypotype (USNM P6461) from a core at 3155 to 3163 feet, and unfigured hypotype (USNM P6462) from a core at 3226 to 3237 feet, both in the Torok formation, in South Barrow test well 1.

Figured hypotype (USNM P6463) from a core at 1277 to 1287 feet, figured hypotype (USNM P6464) from cuttings at 2120 to 2130 feet, and unfigured hypotype (USNM P6465) from cuttings at 3420 to 3430 feet, all in the Topagoruk formation; and unfigured hypotype (USNM P6466) from a core at 533 to 543 feet in the Grandstand formation, all from Simpson test well 1.

Figured hypotype (USNM P6467) from a core at 4610 to 4620 feet, in the Topagoruk formation, in Umiat test well 2 .

Figured hypotype (USNM P6468) from a depth of 160 to 170 feet in the Grandstand formation in shot hole 40, Seimograph Party 47, line 14-A-48.

\section{Marginulinopsis jonesi (Reuss)}

Plate 42, figures 1-6

Cristellaria (Marginulina) jonesi Reuss, 1863, K. Akad. Wiss. Wien., Math.-Naturw. Cl., Sitzber., v. 46, Abt. 1, p. 61, pl. 5, fig. 19.

Lenticulina (Marginulinopsis) robusta jonesi (Reuss). Bartenstein, 1956, Senckenb. leth., v. 37, nos. 5, 6, p. 515, pl. 2, fig. 55.

Test free, robust, elongate, early portion coiled, with about three to six rapidly enlarging chambers, later uncoiled with two to four rectilinear chambers of greater breadth than height; sutures radial in the early portion, straight but slightly oblique in the uncoiled portion, and somewhat obscured by the numerous very low and evenly spaced longitudinal ribs; wall calcareous, finely perforate, ornamented by the longitudinal ribs; aperture radiate, at the peripheral angle.

Hypotypes range from 0.28 to $0.89 \mathrm{~mm}$ in length.

Remarks.-Marginulinopsis jonesi differs from $M$. collinsi Mellon and Wall in having more numerous but less elevated ribs, and in having a shorter more robust test. It differs from $M$. umiatensis Tappan in having a more regular increase in chamber size, better developed uncoiled stage but less prominent early coil.

Types and occurrence.-Figured hypotype (USNM P6469) and unfigured hypotype (USNM P6498) from a core at 471 feet in the Grandstand formation, in Umiat test well 2.

Unfigured hypotype (USNM P6470) from a core at 578 to 588 feet, and unfigured hypotype (USNM P6471) from a core at 613 to 623 feet, both in the Grandstand formation; and figured hypotype (USNM P6472) from cuttings at 1870 to 1880 feet in the Topagoruk formation, and figured hypotype (USNM P6473) from cuttings at 4020 to 4030 feet, probably contamination from the Topagoruk formation, all in Simpson test well 1.

Figured hypotype (USNM P6474) from cuttings at 790 to 800 feet, in the Topagoruk formation, in South Barrow test well 1.

Figured hypotype (USNM P6475 a, b) from field sample $47 \mathrm{~A}$ Wh 541 , in the Topagoruk formation.

\section{Marginulinopsis reiseri Tappan}

Plate 43, figures 1-4

Marginulinopsis reiseri Tappan, 1960, Am. Assoc. Petroleum Geologists Bull., v. 44, no. 3, p. 293, pl. 2, figs. 1-2. Saracenaria trollopei var. Mellon and Wall, 1956, Research Council Alberta Rept. 72, p. 28, pl. 2, figs. 28-29.

Test free, robust, early portion coiled, but consisting of only a few rapidly enlarging chambers, later uncoiling with chamber breadth approximately twice their height, chambers somewhat inflated; sutures distinct, slightly depressed, gently curved, radial in the early portion, oblique in the uncoiled portion; wall calcareous, finely perforate, surface smooth; aperture radiate, at the peripheral angle.

Length of holotype $0.97 \mathrm{~mm}$, greatest breadth 0.49 $\mathrm{mm}$, thickness $0.49 \mathrm{~mm}$; paratypes range from 0.29 to $0.96 \mathrm{~mm}$ in length.

Remarks.-The specimens referred to Saracenaria trollopei var. by Mellon and Wall appear identical with this species. They differ from the typical Saracenaria trollopei in having a rounded or ovate rather than triangular section, and a more uncoiled test. In Alaska, the present species occurs stratigraphically above Saracenaria trollopei Mellon and Wall. Planularia bronni Roemer, from the Hils of Germany, is somewhat similar but is a more delicate, compressed species and has a narrower and more arcuate test, and a less pronounced early coil.

Types and occurrence.-Holotype (USNM P6476) from cuttings at 1770 to 1780 feet, in the Topagoruk formation, unfigured paratype (USNM P6477) from a core at 283 to 293 feet and unfigured paratype (USNM P6478) from a core at 503 to 513 feet, both in 
the Grandstand formation; unfigured paratype (USNM P6479) from cuttings at 1750 to 1760 feet, unfigured paratype (USNM P6480) from cuttings at 1940 to 1950 feet, unfigured paratypes (USNM P6481) from cuttings at 1950 to 1960 feet, all in the Topagoruk formation, unfigured paratype (USNM P6482) from cuttings at 4960 to 4970 feet and figured paratype (USNM P6483) from cuttings at 5200 to 5210 feet, both within the Torok formation section, but probably contamination from the overlying Topagoruk formation, all in Simpson test well 1.

Figured paratype (USNM P6484) and unfigured paratypes (USNM P6485) from a core at 471 feet, in the Grandstand formation; figured paratype (USNM P6486) from cuttings at 1400 to 1410 feet, and unfigured paratype (USNM P6487) from cuttings at 2880 to 2890 feet, from the Topagoruk formation, all in Umiat test well 2.

Unfigured paratype (USNM P6488) from cuttings at 2280 to 2285 feet, in the Grandstand formation, in Umiat test well 1.

Unfigured paratype (USNM P6489) from a core at 256 to 264 feet, and unfigured paratype (USNM $\mathrm{P} 6490$ ) from a core at 481 to 486 feet, both in the Grandstand formation, in Skull Cliff core test 1.

\section{Marginulinopsis umiatensis Tappan}

Plate 43 , figures 5-7

Marginulinopsis umiatensis Tappan, 1951, Cushman Found. Foram. Research, Contr., v. 2, pt. 1, p. 2, pl. 1, figs. 6-7b ; Tappan, 1951, in Payne and others. U.S. Geol. Survey Oil and Gas Invest. Map OM-126, sheet 3, fig. 21 (13).

Test free, small, robust, slightly longer than broad, thickness as great as breadth, early portion close coiled, later chambers becoming uniserial, periphery broadly rounded; four to six inflated chambers in the coiled portion, increasing rapidly in size, uniserial development poor, commonly consisting of a single terminal chamber; sutures distinct, depressed, straight; wall calcareous, hyaline, ornamented by numerous fine costae, about eight visible in side view, costae disappearing at about the midline of the final chamber, the terminal portion of the chamber being smooth; aperture terminal, rounded. Length of holotype $0.31 \mathrm{~mm}$, greatest breadth of coil $0.29 \mathrm{~mm}$, greatest thickness $0.23 \mathrm{~mm}$. Other specimens are up to $0.49 \mathrm{~mm}$ in length.

Remarks.-This species is very similar in appearance to Marginulina trinitatensis Cushman, from the Upper Cretaceous of Trinidad, but is about one-half as large, the test is comparatively thicker and lacks the peripheral keel, sutures are more depressed in the early portion and the costae are less elevated, and the terminal neck is lacking.
Types and occurrence.-Holotype (USNM 106125) from a core at 2,408 to 2,418 feet, and figured paratype (USNM 106126) from cuttings at 2,530 to 2,540 feet, originally considered as the upper Tuktu member of the Umiat formation, but now considered to belong to the Topagoruk formation, Nanushuk group, in Umiat test well 2.

Figured paratype (USNM P6457) from a core at 1050 to 1060 feet in the Topagoruk formation, in Simpson test well 1.

Unfigured paratype (USNM P6458) from cuttings at 3890 to 3900 feet in Umiat test well 1.

Unfigured paratype (USNM P6459) from field sample $47 \mathrm{~A} \mathrm{Wh} 545$, in the upper part of the Torok formation.

\section{Genus Marginulina d’Orbigny, 1826 \\ Marginulina cephalotes (Reuss) \\ Plate 43 , figures $14-17$}

Cristellaria cephalotes Reuss, 1863, Sitz. K. Akad. Wiss., math.nat. classe, v. 46 , p. 67 , pl. 7, figs. 5-6.

Vaginulinopsis cephalotes (Reuss), ten Dam, 1950, Mèm. Soc. Geol. France, n. ser., v. 29 , no. 4 , mèm. 63 , p. 39, pl. 3 , fig. 9.

Test free, early portion consisting of about 4 to 5 chambers in a partial coil, later portion uncoiled with two to four chambers which do not extend back to the enrolled portion, chambers somewhat inflated at the ventral side, slightly compressed, and suggesting a keel on the dorsal margin; sutures distinct, slightly curved, radial in the early part, oblique in the uncoiled portion of the test; wall calcareous, finely perforate, surface smooth; aperture radiate, produced on a distinct neck at the dorsal angle.

Hypotypes range from 0.40 to $0.73 \mathrm{~mm}$ in length.

Remurks.-Marginulina cephalotes (Reuss) difiers from Marginulinopsis reiseri Tappan in its much smaller size, and more slender test and in having a distinct apertural neck.

Types and occurrence.-Figured hypotype (USNM P6518) from well cuttings at 1500 to 1510 feet, figured hypotype (USNM P6519) and unfigured hypotype (USNM P6520) from a core at 1600 to 1610 feet, and figured hypotype (USNM P6521) from a core at 3105 to 3115 feet, all in the Torok formation, in South Barrow test well 1.

Unfigured hypotype (USNM P6522) from well cuttings at 1860 to 1870 feet in the Topagoruk formation, in Simpson test well 1.

Unfigured hypotype (USNM P6523) from a core at 1100 to 1110 feet, in the Grandstand formation, in East Topagoruk test well 1.

Figured hypotype (USNM P6524) from field sample $49 \mathrm{~A} \mathrm{~Pa} 91$, in the Fortress Mountain formation. 


\section{Marginulina dorsata Cushman}

Plate 44, figures 4, 5

Marginulina dorsata Cushman, 1937, Cushman Lab. Foram. Research, Contr., v. 13, p. 94, pl. 13, figs. 16-18; Cushman, 1946, U.S. Geol. Survey Prof. Paper 206, p. 60, pl. 20, figs. 29-31; Frizzell, 1954, Bur. Econ. Geol. Rept. Invest. 22, p. 84 , pl. 8 , figs. 44,45 .

Test free, large, robust, subcylindrical, with somewhat arcuate axis; early chambers increasing rapidly in size from the apiculate proloculus, all chambers low and closely appressed, coiling shown only by the slightly bent axis of the early portion, later chambers nearly rectilinear; sutures flush, slightly oblique; wall calcareous, hyaline, surface smooth; aperture terminal, somewhat produced on a neck at the dorsal angle, radiate.

Length of hypotypes ranges from 0.53 to $1.09 \mathrm{~mm}$, breadth from 0.31 to $0.34 \mathrm{~mm}$.

Remarks.-This species was originally described from the Annona chalk of Texas, and specimens from Alaska are typical.

Types and occurrence.-Figured hypotypes (USNM P6499 a, b) and unfigured hypotypes (USNM P6500) from field sample $47 \mathrm{AWb} 460$, in the Rogers Creek member of the Schrader Bluff formation.

\section{Marginulina gatesi Tappan}

Plate 43, figures 12, 13

Marginulina gatesi Tappan, 1957, U.S. Natl. Mus. Bull. 215, p. 215 , pl. 68 , figs. 7,8 .

Test free, robust, early portion with a curved axis, but not a distinct coil, later uncoiled and rectilinear, rounded in section; chambers few in number, those of the curved early portion increasing very rapidly in size as added, later three or four chambers uncoiled and of more nearly equal size, considerably overlapping, inflated, final chamber about twice the height of the penultimate one; sutures distinct, somewhat constricted, radial in the early portion, nearly horizontal in the uncoiled part of the test; wall calcareous, finely perforate, surface ornamented, with about 12 low and widely spaced vertical ribs; aperture radiate, terminal on the final chamber, eccentric, somewhat closer to the dorsal angle and slightly produced.

Length of holotype $0.52 \mathrm{~mm}$, breadth $0.26 \mathrm{~mm}$. Paratypes range from 0.36 to $0.68 \mathrm{~mm}$ in length.

Remarks.-Marginutina gatesi differs from $M$. radiata Terquem in having fewer and wider spaced ribs and in these being vertical rather than crossing the chambers obliquely. The present species is also much more robust.

It occurs in the Grandstand and Topagoruk formations.
The specific name is in honor of G. L. Gates, U.S. Geological Survey.

Types and occurrence-Holotype (USNM P4522) and unfigured paratypes (USNM P4523) from a core at 273-283 feet, unfigured paratypes (USNM P4524) from a core at 238-256 feet, unfigured paratypes (USNM P4525) from a core at 293-303 feet, unfigured paratype (USNM P4526) from a core at 338348 feet, figured paratype (USNM P4527) and unfigured paratypes (USNM P4528) from a core at 523-533 feet, unfigured paratypes (USNM P4529) from a core at 900-910 feet, all from the Grandstand formation; and unfigured paratype (USNM P4530) from a core at 1080-1087 feet, in the Topagoruk formation, all from Simpson test well 1.

Unfigured paratype (USNM P4531) from well cuttings at $410-420$ feet, in the Grandstand formation, in Simpson core test 10 .

Unfigured paratype (USNM P4532) from the Grandstand formation, field sample 47A Dt 228.

\section{Marginulina inepta (Reuss) \\ Plate 44 , figures 6,7}

Dentalina inepta Reuss, 1846 (not Marginulina inepta Nengeboren, 1851) Sitz. Akad. Wiss. Math.-Nat., Cl., v. 46, pt. 1, p. 40, pl. 2, fig. 13 .

Dentalina paupercula (Reuss) Berthelin, 1880 (not Reuss, 1845), Soc. géol. France, ser. 3, v. 1, no. 5, p. 43, pl. 2, fig. 17.

Nodosaria (Dentalina) paupercula Reuss. Chapman, 1893 (not Reuss, 1845), Royal Micr. Soc. Jour., p. 593, pl. 9, fig. 14 (not fig. 13).

'Test free, elongate, robust, with slightly curved axis; chambers relatively few in number, inflated, of nearly equal breadth and height, enlarging rapidly in the early portion of the microspheric specimens, more gradually in the megalospheric specimens, the rounded proloculus apiculate where the surface ribs converge; sutures slightly constricted, horizontal; wall calcareous, perforate, surface with about 16 or more longitudinal costae which are low, but continuous across chambers and sutures; aperture terminal, rounded, bordered with a distinct lip.

Hypotypes range from 0.37 to $0.76 \mathrm{~mm}$ in length.

Remarks.-This species was originally described from the Lower Cretaceous of Germany. In France and England it was later considered to be equivalent to Nodosaria paupercula Reuss 1845, an Upper Cretaceous species. $N$. paupercula is a true Nodosaria, with nearly equal-sized, subglobular chambers and strongly constricted sutures. The Lower Cretaceous species has more closely appressed chambers which show a gradual increase in size as added, a more robust test, slightly arcuate axis, and excentric aperture. 
Although originally placed in Dentatina, this species is here placed in Marginulina because of the excentric aperture and horizontal sutures. It cannot be placed in Nodosaria because of the excentric aperture and slightly curved axis.

Types and occurrence.-Figured hypotype (USNM $\mathrm{P} 6$ 719) from a core at 3069 to 3079 feet, in the Torok formation, in South Barrow test well 1.

Figured hypotype (USNM P6720) from a core at 1152 to 1162 feet, in the Topagoruk formation, in Arcon Point Barrow core test 1.

Unfigured hypotype (USNM P6721) from a core at 1050 to 1060 feet, in the Topagoruk formation, in Simpson test well 1 .

\section{Marginulina planiuscula (Reuss) \\ Plate 43, figures 8-11}

Cristellaria planiuscula Reuss, 1862, Sitz. k. Akad. Wiss. math.nat. classe, v. 46, p. 71, pl. 7, fig. 51; Berthelin, 1880, Mém. Soc. Geol. France, sér. 3, v. 1, no. 5, p. 53, pl. 3, fig. 25.

Test free, small, robust, consisting of 5 to 6 chambers in a slightly coiled arrangement from the ovate proloculus, the later one to four chambers uncoiling; chambers relatively low and broad, final chamber about twice as broad as high; sutures distinct, flush, curved, early ones radial, later sutures oblique in the uncoiled portion of the test; wall calcareous, finely perforate, surface smooth; aperture radiate, somewhat produced, at the peripheral angle.

Hypotypes range from 0.23 to $0.67 \mathrm{~mm}$ in length, and from 0.15 to $0.29 \mathrm{~mm}$ in breadth.

Remarks.-Originally described from the Neocomian of northern Germany, and later reported from the Albian of France, this species occurs in the Grandstand and Topagoruk formations in northern Alaska. It is characterized by the small size, broad low chambers and slightly coiled axis.

The form in the German Valendian referred to Lenticulina (Taginulinopsis) cf. planiuscula (Reuss) by Bartenstein and Brand (1951, p. 287), and that referred to Cristellaria planiuscula Reuss (Chapman, 1894, p. 654) from the Gault of England, are more compressed laterally than the present species.

Types and occurrence.-Figured hypotypes (USNM P6525 a, b) and unfigured hypotypes (USNM P6526) from a core at 533 to $5 \pm 3$ feet, figured hypotype (USNM P6527) from a core at 308 to 318 feet, unfigured hypotype (USNM P6528) from a core at 181 to 191 feet, unfigured hypotypes (USNM P6529) from a core at 201 to 206 feet, unfigured hypotypes (USNM P6530) from a core at 206 to 211 feet, unfigured hypotypes (USNM P6531) from a core at 273 to 283 feet, unfigured hypotype (USNM P6532) from a core at 338 to 348 feet, and unfigured hypotypes (USNM P6533) from a core at 523 to 533 feet, all from the Grandstand formation, in Simpson test well 1.

Figured hypotype (USNM P6534) from well cuttings at 390 to 400 feet in the Grandstand formation, in Simpson core hole 8.

Unfigured hypotype (USNM P6535) from a core at 446 to 456 feet, and unfigured hypotypes (USNM P6536) from a core at 586 to 596 feet, all from the Grandstand formation in Skull Cliff core test 1.

Unfigured hypotypes (USNM P6537) from a core at 2154 to 2164 feet in the Topagoruk formation, in East Topagoruk test well 1.

\section{Marginulina sulcifera (Reuss) \\ Plate 43, figures 18, 19}

Cristellaria sulcifera Reuss, 1862, Sitz. k. Akad. Wiss. math.nat. classe, v. 46 , p. 74 , pl. 8 , fig. 8 ; Chapman, 1894 , Royal Micr. Soc. Jour., p. 650, pl. 10, fig. 2.

Test free, small, delicate, early portion coiled, later portion uncoiled but arcuate; chambers subglobular, seldom more than five in number; sutures distinct, constricted, slightly oblique; wall calcareous, hyaline, surface ornamented with eight longitudinal ribs which are interrupted at the sutures, but are prominent at the mid portion of each chamber; aperture terminal, radiate, somewhat produced at the peripheral angle.

Hypotypes range from 0.31 to $0.44 \mathrm{~mm}$ in length.

Remarks.-This species was originally described from the "Minimusthon" (Gault) of northern Germany, and has also been reported from the Gault of Folkestone, England. It occurs in the Torok and Fortress Mountain formations in Alaska, equivalent in age to its lower range in Europe. It differs from the younger Marginutina gatesi Tappan in being much smaller, relatively more slender and more arcuate, and in having fewer and less continuous ribs.

Types and occurrence.-Figured hypotype (USNM P6544) from well cuttings at 4650 to 4660 feet in the Torok formation in Simpson test well 1.

Unfigured hypotype (USNM P6545) from a core at 2030 to 2040 feet in the Torok formation, in South Barrow test well 2.

Figured hypotype (USNM P6546) from field sample 49ATr 292, in the Fortress Mountain formation.

\section{Genus Rectoglandulina Loeblich and Tappan, 1955 \\ Rectoglandulina humilis (Roemer) \\ Plate 41, figures 8-10}

Nodosaria humilis Roemer, 1841, Verstein. norddeutsch. Kreidegebirges, Hannover, Hahuschen Hofbuchhandlung, p. 95, pl. 15, fig. 6 . 
Glandulina mutabilis Reuss, 1863 (part) Sitz. k. Akad. Wiss. Math.-Nat. Classe, v. 46, p. 58, pl. 5, figs. 9-11 (not figs. $7,8)$.

Nodosaria (Glandulina) humilis Roemer. Chapman, 1893, Royal Micr. Soc. Jour., p. 585, pl. 8, fig. 18.

Glandulina humilis Roemer. Eichenberg, 1934, Niedersächs geol. Ver. zu Hannover, $26 \mathrm{Jb}$., p. 174, pl. 16, fig. 9.

Pseudoglandulina humilis (Römer). Noth, 1951, Jb. Geol. Bundusanst., Sond. 3, Wien., p. 59, pl. 2, fig. 35 ; Bartenstein, 1956, Senckenb. Leth., v. 37 , nos. 5,6 , p. 521, pl. 2, figs. 45,54 .

Test free, rectilinear, relatively large and robust; the 5 to 7 closely appressed, much overlapping chambers rapidly enlarging from the subglobular proloculus; sutures distinct, horizontal, slightly constricted; wall calcareous, finely perforate, surface smooth; aperture terminal, radiate.

Hypotypes range from 0.39 to $0.97 \mathrm{~mm}$ in length and from 0.28 to $0.54 \mathrm{~mm}$ in breadth.

Remarks.-This species was originally described by Roemer (1841) from the Hilsthon of northern Germany. Later, Reuss (1863) included it in the synonymy of his species Glandutina mutabitis, although Roemer's name had over 20 years priority. Chapman (1893) separated Reuss's figures 9 and 11 as $N$. humilis, restricting the name $N$. (Glandulina) mutabilis to the more elongate specimens, Reuss's figs. 7, 8, and 10 .

This species occurs in the Albian of Germany, France and England.

Types and occurrence.-Figured hypotype (USNM $\mathrm{P} 6623)$ from the Topagoruk formation in well cuttings, at 2650 to 2660 feet, in Simpson test well 1.

Figured hypotype (USNM P6624) from a core at 706 to 716 feet, in the Grandstand formation, in Skull Cliff core test 1 .

Figured hypotype (USNM P6625) from well cuttings at 4870 to 4880 feet in the Topagoruk formation, in UTmiat test well 1.

Unfigured hypotype (USNM P6626) from field sample $49 \mathrm{~A} \operatorname{Tr} 291$, in the Fortress Mountain formation.

\section{Rectoglandulina kirschneri Tappan \\ Plate 44, figures $13-18$}

Nodosaria Jonesi Reuss, 1863 (not N. jonesi Richter, 1861), Akad. Wiss. Wien., Sitz., Bd. 46, p. 89, pl. 12, fig. 6 .

Nodosaria radicula Linné var. Jonesi Reuss. Chapman, 1893, Royal Micr. Soc. Jour., p. 586, pl. 8, fig. 22.

Rectoglandulina kirschneri Tappan, 1957, U.S. Natl. Mus. Bull. 215 , p. 216 , pl. 68 , figs. 17,18 .

Test free, elongate, rectilinear, circular in section, chambers increasing gradually in size from the conical proloculus, early chambers closely appressed and overlapping, later more inflated and with less overlap, final chamber turbinate in appearance; sutures distinct, depressed, horizontal; wall calcareous, hyaline, finely perforate, surface smooth; aperture terminal, radiate, slightly produced on a neck.

Length of holotype $0.52 \mathrm{~mm}$, breadth $0.23 \mathrm{~mm}$. Paratypes range from 0.34 to $0.94 \mathrm{~mm}$ in length.

Remarks.-This species somewhat resembles Glandulina elongata Reuss, 1860, from the Upper Cretaceous (not $G$. elongata Bornemann, 1855), in general appearance but is about one-third as large and has a conical instead of a rounded proloculus. Pseudonodosaria cleamuaterensis Mellon and Wall, 1956, is similar but has a rounded proloculus.

Nodosaria jonesi Reuss, 1863, was described from the Gault of Folkestone, England, but the name is a homonym of $N$. jonesi Richter, from the Permian of Germany. Alaskan specimens, like the English ones, are characterized by the apiculate proloculus.

The species occurs in the Grandstand, Topagoruk, and Torok formations, and was named in honor of $\mathrm{C}$. A. Kirschner, geologist, formerly with U.S. Geological Survey.

Types and occurrence-Holotype (USNM P4546) from a core at 1152-1162 feet, and figured paratype (USNM P6611) from a core at 651 to 666 feet, both in the Topagoruk formation, in Arcon Point Barrow core test 1 .

Figured paratype (USNM P6610) from a core at 196 to 201 feet and unfigured paratype (USNM P4547) from a core at 555-565 feet, both in the Grandstand formation, and figured paratype (USNM P4548) from well cuttings at $4870-4880$ feet, in the Torok formation, all from Simpson test well 1.

Figured paratype (USNM P4549) from a core at 1625-1630 feet, in the Grandstand formation, in Umiat test well 1.

Figured paratype (USNM P6603) from a core at 2030 to 2040 feet, and unfigured paratype (USNM P6604) from a core at 2130 to 2140 feet, both in the Torok formation in South Barrow test well 2.

Unfigured paratype (USNM P6605) from a core at 3046 to 3069 feet, in the Torok formation, in South Barrow test well 1.

Unfigured paratype (USNM P6606) from a core at 2390 to 2399 feet, in the Topagoruk formation in Topagoruk test well 1.

Unfigured paratype (USNM P6609) from a core at 2145 to 2150 feet, in the Topagoruk formation, in Umiat test well 2.

\section{Rectoglandulina netrona Tappan}

Plate 44, figures 11,12

Rectoglandulina netrona Tappan, 1960, Am. Assoc. Petroleum Geologists Bull., v. 44, no. 3, p. 293, pl. 2, figs. 11-12.

Test free, small, spindle shaped, chambers enlarging gradually from the rounded proloculus; chambers few 
in number, three or four, the final chamber widest near its base, sloping sharply to the aperture; sutures distinct, straight and horizontal, flush with the surface; wall calcareous, finely perforate, surface'smooth; aperture terminal, radiate, somewhat produced.

Length of holotype $0.36 \mathrm{~mm}$, breadth $0.16 \mathrm{~mm}$. Paratypes range from 0.21 to $0.36 \mathrm{~mm}$ in length.

Remarks.-Rectoglandulina netrona, new species, differs from Pseudoglandulina acuta Le Roy, from the late Tertiary of Borneo, in being more slender, and in having fewer chambers, with a somewhat lesser degree of overlap. It differs from $R$. kirschneri Tappan and $R$. humilis (Roemer) in being smaller and spindle shaped, rather than elongate, in the greater degree of chamber overlap, and flush rather than constricted sutures.

Types and occurrence.-Holotype (USNM P6627) from a core at 1340 to 1350 feet and figured paratype (USNM P6628) from a core at 1330 to 1340 feet, both from the Topagoruk formation; and unfigured paratype (USNM P6629) from a core at 368 to 378 feet, in the Grandstand formation, all in Simpson test well 1.

Unfigured paratype (USNM P6630) from a core at 667 to 686 feet, in the Topagoruk formation, in Arcon Point Barrow Core test 1.

\section{Genus Lingulina d'Orbigny, 1826 \\ Lingulina loryi (Berthelin) \\ Plate 44, figures 19-21}

Frondicularia Loryi Berthelin, 1880, Soc. Geol. France, Mèm., no. 5 , ser. 3 , v. 1 , p. 60 , pl. 4 , fig. 5 ; Chapman, 1894 , Royal Micr. Soc. Jour., p. 154, pl. 3, fig. 5 .

Lingulina loreyi (Berthelin), ten Dam, 1950, Soc. Geol. France, Mèm., no. 63, n. ser., v. 29, fasc. 4 , p. 30, pl. 2, fig. 20.

Frondicularia loryi Berthelin: Bartenstein and Brand, 1951, Senckenb. Naturf. Gesell. Abh., no. 485, p. 303, pl. 8, figs. $202,203$.

Test free, small, flattened, with rounded margins, ovate to elongate in outline; globular proloculus followed by a few strongly arched uniserial chambers which extend back at each margin of the test, only two to five chambers observed in the Alaskan specimens; sutures strongly but regularly arched at the center of the two faces of the test, very slightly depressed; wall calcareous, finely perforate, surface smooth; aperture a terminal slit.

Length of hypotypes ranges from 0.26 to $0.33 \mathrm{~mm}$.

Remarks.-The Alaskan specimens agree closely with the types from the Albian of France, but somewhat more elongate specimens are reported from the Albian of the Netherlands, with up to 7 chambers in the test. It has also been recorded from the Gault of England and the upper Valendian of Germany.
This species was considered to be transitional between the genera Lingulina and Frondicularia by both Berthelin and Chapman, and considered as Frondicularia because of the strongly arched chambers. The original figure given by Berthelin showed the oval to slit-like aperture of Lingulina, rather than the radiate one of Frondicularia, hence the species was later transferred to Lingulina.

Types and occurrence.-Figured hypotype (USNM P6612) from well cuttings at 2200 to 2210 feet and figured hypotype (USNM P6613) from a core at 2235 to 2245 feet, both in the Topagoruk formation, in Simpson test well 1.

Figured hypotype (USNM P6614) from field sample 49ATr 292, in the Fortress Mountain formation.

\section{Lingulina rediviva Berthelin \\ Plate 44 , figure 22}

Lingulina rediviva Berthelin, 1880, Soc. Geol. France, Mèm., no. 5, ser. 3, v. 1, p. 65, pl. 4, fig. 7 .

?Lingulina sp. 3 Bartenstein and Brand, 1951, Senckenb. Naturf. Gesell., Abh., no. 485, p. 301, pl. 8, fig. 193.

Test free, narrow, elongate, tapering, very slightly compressed; up to 5 uniserial chambers, increasing rapidly in breadth from the globular proloculus in the early portion, later increasing very slowly, closely appressed, with considerable overlap of earlier chambers; sutures straight and horizontal, flush; wall calcareous, finely perforate, surface smooth; aperture a terminal slit.

Hypotypes range from 0.33 to $0.45 \mathrm{~mm}$ in length.

Remarks.-This species is characterized by the strongly overlapping chambers and horizontal sutures, characters which suggest the genus Rectoglandulina, but the aperture is slitlike, rather than radiate as in Rectoglandulina. It was described from the Albian of France, and also occurs in the Valendian of northern Germany. It is rare in Alaska.

Types and occurrence.-Figured hypotype (USNM P6615) from a core at 196 to 201 feet in the Grandstand formation in Simpson test well 1.

Unfigured hypotype (USNM P6616) from a core at $26 \pm$ feet, in the Grandstand formation, in Skull Cliff core test 1 .

\section{Genus Nodosaria Lamarck, 1812 \\ Nodosaria cf. concinna Reuss \\ Plate 45, figures 5, 6}

?.Nodosaria concinna Reuss, 1860 , K. Akad. Wiss. Wien., Math.Naturw., Cl., Sitz., v. 40, p. 178, pl. 1, fig. 3.

Nodosaria calamorpha Reuss. Burrows, Sherborn and Bailey, 1890 (not Nodosaria (Nodosaria) calomorpha Reuss, 1866), Royal Micr. Soc. Jour., p. 556, pl. 9, fig. 21.

Dentalina cf. soluta Reuss. Eichenberg, 1934, Niedersächs. geol. Ver. zu Hannover, Jb. 26, pt. 1, folge 3, p. 164, pl. 10, 
fig. 14; Eichenberg, 1935, Mitteil. Roemer-Mus., No. 37, pt. 1, folge 4, p. 14, pl. 1, fig. 4; ten Dam, 1950, Soc. Geol. France, n. ser., mèm. 63, p. 29, pl. 2, fig. 18.

Dentalina soluta Reuss. Eichenberg, 1935, Mitteil. RoemerMus., no. 37, pt. 1, folge 4, p. 14, pl. 1, fig. 3; Bartenstein and Brand, 1951, Senckenberg. Naturf. Gesell. Abh. 485, p. 309 , pl. 9 , fig. 237.

Dentalina calomorpha (Reuss). Eichenberg, 1935, Mitteil. Roemer-Mus., no. 37, 1t. 1, folge 4, p. 15, pl. 1, fig. 7.

Nodosaria sp. Noth, 1951, Geol. Bundensanst. Jb., Sond. 3, p. 55 , pl. 2, figs. $21,22$.

Test free, consisting of a few rectilinear, subglobular chambers of nearly equal size; sutures strongly constricted; wall calcareous, finely perforate, surface smooth; aperture terminal, rounded, somewhat produced.

Fragmental hypotypes range from 0.29 to $0.49 \mathrm{~mm}$ in length.

Remarks.-This species occurs widely in the Lower Cretaceous strata of England, Germany and the Netherlands, and has been variously referred to Nodosaria concinna Reuss, $N$. calomorpha Reuss and Dentatina soluta Reuss. Dentalina soluta Reuss, 1851, is an Eocene species with more constricted sutures, an apical spine and a more arcuate test than the present species.

Nodosaria calomorpha Reuss, 1866 is an Oligocene species, with an apical spine, more elongate chambers and more constricted sutures than the present species, and from the original figures appears to belong to Nodosarella. This species may belong to $N$. concinna Reuss, described from the Upper Cretaceous of Germany, but the original figures show an apical proloculus and a nore elongate final chamber. It is possible that the Lower Cretaceous species here discussed is distinct, but Alaskan specimens are too fragmental to warrant description of a new species.

Types and occurrence.--Figured hypotype (USNM $\mathrm{P} 6710)$ from a core at 1980 to 1990 feet, and figured hypotype (USNM P6711) from a core at 2010 to 2020 feet, both in the Torok formation, in South Barrow test well 1.

\section{Nodosaria doliiformis Eichenberg}

Plate 45, figures 13,14

Nodosaria (Dentalina) doliiformis Eichenberg, 1933, Niedersächs. Geol. Ver. Jb. 25. Hannover, 1. 7, pl. 7, figs. 6 a, b.

Test free, narrow, elongate, tapering very slightly from the subconical proloculus; chambers cylindrical, early ones relatively low, but later chambers becoming higher than broad; sutures straight, horizontal, flush with the surface; wall calcareous, perforate, surface smooth; aperture terminal, rounded.

Length of hypotype of figure $14,0.54 \mathrm{~mm}$, breadth $0.13 \mathrm{~mm}$. Other hypotypes range from 0.60 to 0.70 $\mathrm{mm}$ in length.
Remarks.-This species was originally described from the Albian of northern Germany. Alaskan specimens are similar to the holotype, but may represent microspheric specimens, as the early chambers are lower, with a greater degree of overlap. The later development is typical. The species could be placed in Dentalina, as it is slightly asymmetrical, but is here referred to Nodosaria, because of the horizontal sutures, rounded section and almost complete symmetry. It is rare in both Germany and Alaska.

Types and occurrence.-Hypotype of fig. 13 (USNM P6641) from a core at 3069 to 3079 feet, hypotype of fig. 14 (USNM P6640) from a core at 3341 to 3346 feet, and unfigured hypotype (USNM P6642) from a core at 3036 to 3046 feet, all in the Torok formation, in South Barrow test well 1.

\section{Nodosaria flexocarinata Khan \\ Plate 45, figures 3,4}

Nodosaria fontannesi (Berthelin) var. flexocarinata Khan, 1950, Royal Micr. Soc. London, Jour. ser. 3, v. 70, pt. 3, p. 269 , pl. 1, figs. $6-8$.

Test free, elongate, cylindrical to slightly tapering; chambers few in number, closely appressed, proloculus subconical and apiculate; sutures horizontal, nearly flush, somewhat obscured by the costae; wall calcareous, perforate, surface with numerous low, continuous costae, which may twist somewhat near the base; and which may increase by intercalation at about the middle of the test; aperture terminal, rounded, with a surrounding lip.

Hypotypes range from 0.24 to $0.91 \mathrm{~mm}$ in length.

Remarks.-This species was originally described from the Gault (Lower Cretaceous) of England. Alaskan specimens appear typical.

This species is similar to Nodosaria graysonensis Tappan, from the Lower Cretaceous of the Gulf Coastal region, but has more regular costae, and is not as slender and elongate.

Types and occurrence.-Figured hypotype (USNM P6722) from a core at 416 to $4231 / 2$ feet, in the Grandstand formation, in Skull Cliff core test 1.

Figured hypotype (ITSNM P6723) from cuttings above 969 feet in depth, and unfigured hypotypes (USNM P6724) from a core at 1234 to 1245 feet in the Grandstand formation, in Simpson core test 25.

\section{Nodosaria fusula Reuss \\ Plate 45, figure 2}

Nodosaria (Nodosaria) fusula Reuss, 1875, in Geinitz, Paleontogr., Beitrag. Naturg. v. 20, pt. 2, p. 82, pl. 20, fig. 9.

Nodosaria fusula Reuss. Franke, 1928, Preuss. Geol. Landesanst., Abh., n. ser. v. 111, p. 49, pl. 4, fig. 3; Cushman, 1946, U.S. Geol. Survey Prof. Paper 206, p. 71, pl. 26, 
fig. 5; Frizzell, 1954, Bur. Econ. Geol. Rept. Invest. 22, p. 90, pl. 10, fig. 15 .

Test free, narrow, elongate, chambers increasing gradually in relative height as added, from the apiculate base, final chamber produced at the aperture; sutures horizontal, partially obscured by the costae; wall calcareous, finely perforate, surface with about 8 fine continuous costae extending the length of the test; aperture terminal, radiate.

Length of figured hypotype $0.21 \mathrm{~mm}$.

Remarks.-This species which occurs in Germany and in the American Gulf Coast Upper Cretaceous, is extremely rare in Alaska, only a few juvenile specimens having been observed.

Types and occurrence.-Figured hypotype (USNM P6706) from the Barrow Trail member of the Schrader Bluff formation, field sample $45 \mathrm{AGr} 170$.

Unfigured hypotype (USNM P6725) from a core at 1468 to 1478 feet, in the Seabee formation, in Square Lake test well 1.

\section{Nodosaria lepida Reuss}

Plate 45 , figures 7,8

Nodosaria lepida Reuss, 1860, K. Akad. Wiss. Wien., Math.Naturw. Cl., Sitz., v. 40, p. 178, pl. 1, fig. 2.

Test free, rectilinear, robust, consisting of a relatively few rounded uniserial chambers, enlarging gradually; sutures distinct, constricted; wall calcareous, finely perforate, surface smooth; aperture terminal.

Length of fragmental hypotypes ranges from 0.31 to $0.58 \mathrm{~mm}$.

Remarks.-This species was described from the Senonian (Upper Cretaceous) of Germany. Alaskan specimens are rare and commonly fragmental.

Types and occurrence.-Figured hypotypes (USNM P6712 a, b) from the Rogers Creek member of the Schrader Bluff formation, field sample $47 \mathrm{AWb} 460$.

Unfigured hypotype (USNM P6713) from the Barrow Trail member of the Schrader Bluff formation, field sample $48 \mathrm{ADt} 416$.

\section{Nodosaria nana Reuss \\ Plate 45, figure 1}

Nodosaria nana Reuss, 1860, K. Akad. Wiss. Wien., Math.Naturw. Cl., Sitz., v. 40, p. 179, pl. 1, fig. 6; Noth, 1951, Geol. Bundesanst. Jb., Sond. 3, p. 55, pl. 2, fig. 29.

not Nodosaria (Dentalina) nana Reuss, 1863, K. Akad. Wiss. Wien., Math.-Naturw. Cl., Sitz., v. 46, pt. 1, p. 39, pl. 2, figs. $10,18$.

Test free, rectilinear, short and stout, consisting of 3 or 4 gradually enlarging subglobular chambers, proloculus with a small apical spine, final chamber moderately produced at the apertural end; sutures dis- tinct, constricted, horizontal; wall calcareous, finely perforate, surface ornamented with 10 to 12 continuous elevated costae, crossing the sutures and chambers alike; aperture terminal, radiate, at the end of a short neck.

Hypotypes range from 0.36 to $0.65 \mathrm{~mm}$ in length.

Remarks.-This species was originally described from the Gault (Lower Cretaceous) of Germany. Apparently it is rare wherever found. It differs from $N$. fontannesi (Berthelin) in the much larger size, subglobular chambers and more numerous, but less flangelike costae. It differs from $N$. flexocarinata in the shorter, more robust test, subglobular chambers, and fewer, more regular and more elevated costae.

Types and occurrence.-Figured hypotype (USNM P6708) from well cuttings at 3910 to 3920 feet, and unfigured hypotype (USNM P6709) from well cuttings at 4250 to 4260 feet, both in the Torok formation, but possibly contamination from the overlying 'Topagoruk formation, in Simpson test well 1.

\section{Genus Dentalina d'Orbigṇy, 1826 \\ Dentalina basiplanata Cushman \\ Plate 45, figure 17}

Dentalina basiplanata Cushman, 1938, Cushman Lab. Foram. Research, Contr., v. 14, pt. 2, p. 38, pl. 6, figs. 6-8; Cushman, 1946, U.S. Geol. Survey Prof. Paper 206, p. 68, pl. 24, figs. 1-6; Peterson, 1953, in Peterson, Gauger and Lankford, Utah Geol. Miner. Survey, Bull. 47 (Contr. Micropaleon. 1), p. 35, pl. 1, figs. 22, 23.

Test relatively large, elongate, arcuate, slightly tapering; chambers distinct, low and broad in the early portion, later becoming relatively higher and less closely appressed, final chamber of greater height than breadth and tapering toward the aperture; sutures distinct, nearly straight and horizontal, flush with the surface in the early portion, moderately constricted in the later portion; wall calcareous, finely perforate, surface smooth; aperture terminal, radiate, slightly produced.

Length of figured hypotype $1.35 \mathrm{~mm}$, breadth 0.26 $\mathrm{mm}$. Other hypotypes range from 0.45 to $0.91 \mathrm{~mm}$ in length.

Remarks.-This species has been recorded from the Navarro and Taylor groups of Texas, and equivalent strata throughout the Gulf Coast, and occurs in the somewhat older Frontier formation of Utah.

Types and occurrence.-Figured hypotype (USNM P6633) from the Rogers Creek member of the Schrader Bluff formation, field sample $47 \mathrm{AWb} 456$.

Unfigured hypotypes (USNM P6634) from the Sentinel Hill member of the Schrader Bluff formation, field sample $47 \mathrm{ASt} 32$. 
Unfigured hypotype (USNM P6635) from the Rogers Creek member of the Schrader Bluff formation, field sample 48ADt 393.

\section{Dentalina? dettermani Tappan}

Plate 45, figures 9-12, 22

Dentalina? dettermani Tappan, 1957, U.S. Natl. Mus. Bull. 215, p. 215 , pl. 68 , figs. $9-12$.

Test free, consisting of inflated, somewhat elongate or ovate chambers, much constricted to a slender tubular neck at each end, and probably originally consisting of a number of these chambers uniserially arranged, and in an arcuate series, as the chambers may be slightly asymmetrical, with the apertural neck eccentric; sutures at the end of the greatly constricted necks, but chambers of all specimens observed have been broken apart at these constrictions; wall calcareous, finely perforate, hyaline, surface smooth to finely hispid; aperture at the end of the tubular neck, rounded.

Length of chamber of holotype $0.65 \mathrm{~mm}$, breadth $0.34 \mathrm{~mm}$. Paratypes range in chamber length from 0.29 to $0.55 \mathrm{~mm}$.

Remarks.-The generic placement of this species was questioned, as no complete tests have been found, undoubtedly because of the fragile nature of the connecting necks between the inflated chambers. The asymmetry of the single chambers, their size range, and the invariable presence of a broken neck at one or both ends strongly suggest that these chambers represent an elongate, fragile Dentalina, whose chambers were isolated in preservation.

Superficially D.? dettermani resembles Lagena hauteriviana Bartenstein and Brand, but it differs in the presence of a connecting neck at both ends of the inflated ovate chambers, their asymmetrical and more elongate outline, and the greater range in size, the smaller specimens possibly representing earlier formed chambers.

It occurs in the Grandstand, Topagoruk, and Fortress Mountain formations.

The species was named in honor of R. L. Detterman, geologist, U.S. Geological Survey.

Types and occurrence.-Holotype (USNM P4556), figured paratype (USNM P4557), and unfigured paratypes (USNM P4558), all from a core at 543-545 feet, in the Grandștand formation and figured paratype (USNM P6701) from well cuttings at 1,830 to 1,840 feet, in the Topagoruk formation in Simpson test well 1.

Figured paratype (USNM P4559) from well cuttings at 5,730-5,740 feet and unfigured paratypes (USNM P4560) from well cuttings at 4,310-4,320 feet, all from the Topagoruk formation, in Umiat test well 2 .

Figured paratype (USNM P4561) from the Fortress Mountain formation, field sample $49 \mathrm{~A} \mathrm{~Pa} 94$.

Unfigured paratype (USNM P6499) from a core at 3,066 to 3,076 feet, in the Torok formation, in East Topagoruk test well-1.

\section{Dentalina distincta Reuss}

Plate 45 , figure 18

Dentalina distincta Reuss, 1860, K. Akad. Wiss. Wien., Math.Naturw. Cl. Sitz., v. 40, p. 184, pl. 2, fig. 5.

Test free, small, very slightly arcuate, elongate, consisting of 3 to 4 uniserial subglobular chambers, enlarging gradually from the globular, apiculate proloculus, final chamber of somewhat greater relative height; sutures distinct, constricted, slightly oblique; wall calcareous, finely perforate, surface smooth; aperture terminal, excentric, radiate, somewhat produced on a short neck.

Length of figured hypotype $0.38 \mathrm{~mm}$.

Remarks.-This rare species was originally described from the upper part of the Gault (Lower Cretaceous) of Germany. The holotype had 4 chambers and was somewhat larger than the Alaskan specimen, but is alike in all other characters.

Types and occurrence.-Figured hypotype (USNM P6707) from a core at 667-686 feet, in the Topagoruk formation, Arcon Point Barrow core test 1.

Dentalina praecommunis Tappan

Plate 45, figures 15, 16

Dentalina praecommunis Tappan, 1960, Am. Assoc. Petroleum Geologists Bull., v. 44, no. 3, p. 295, pl. 2, figs. 3-4.

Test free, elongate, slightly arcuate, increasing gradually in size from the conical proloculus; chambers low and broad in the early portion, becoming progressively higher as added, final chamber about 1/1/2 times as high as its breadth; sutures distinct, flush, oblique in the early stages, becoming less oblique and nearly horizontal in the later portion; wall calcareous, finely perforate, surface smooth; aperture terminal, somewhat produced, radiate.

Holotype is $1.13 \mathrm{~mm}$ in length and $0.25 \mathrm{~mm}$ in breadth. Paratypes range from 0.52 to $1.73 \mathrm{~mm}$ in length.

Remarks.-Dentalina communis d'Orbigny was originally described from the Recent of the Adriatic Sea. Similar forms have been referred to this species from many different geologic periods. Upper Cretaceous specimens have been made the basis for the genus Enantiodentalina Marie, 1941, as the early chambers appear to alternate in a pseudobiserial manner. The Lower Cretaceous specimens referred to Dentalina 
communis do not show this alternating character, hence are not the same as the species in the Upper Cretaceous. Dentalina praecommunis differs from the typical Recent species, Dentalina communis d'Orbigny in being smaller, relatively broader, and less elongate, with less inflated chambers.

Other Lower Cretaceous references to Dentalina communis do not belong to the present species. Specimens so referred by Carsey (1926, pl. 7, fig. 5), Plummer (1931, pl. 11, fig. 4), Tappan (1940, pl. 16, fig. 1; 1943, pl. 79, figs. 28, 29), Lozo (1944, pl. 4, fig. 9), and Noth $(1951$, pl. 4, fig. 17$)$ are a more slender and tapering species than is D. praecommunis. That of Eichenberg (1933, pl. 19, fig. 3, pl. 21, fig. 7) has more inflated chambers. The specimen in the Gault of Folkestone referred to D. communis by Chapman (1893, pl. 9 , fig. 1) has more oblique sutures and a rounded rather than apiculate base.

Dentalina praecommunis differs from $D$. nana Reuss from the Lower Cretaceous of Germany, in being more arcuate, in having a subconical rather than a globular proloculus, with low early chambers and higher later chambers, whereas those of $D$. nana are of more nearly equal height throughout.

The present species differs from Dentalina siliqua (Reuss) of the German Lower Cretaceous, in having more numerous, broader and lower chambers, increasing in relative height as added.

Types and occurrence.-Holotype (USNM P6715) from well cuttings at 405 to 410 feet, in the Topagoruk formation, in Arcon Point Barrow core test 1.

Figured paratype (USNM P6716) from well cuttings at 2260 to 2270 feet, in the Topagoruk formation, in Simpson test well 1.

Unfigured paratype (USNM P6717) from a core at 3976 to 3986 feet, in the Topagoruk formation, in Fish Creek test well 1.

Unfigured paratype (USNM P6718) from a core at 2164 to 2174 feet, in the Topagoruk formation, in East Topagoruk test well 1 .

\section{Dentalina strangulata Reuss \\ Plate 45, figures 20-21}

Dentalina strangulata Reuss, 1860, K. Akad. Wiss. Wien., Math.-Naturw. Cl., Sitz., v. 40, v. 185, pl. 2, fig. 6; Eichenberg, 1934, Niedersächs. Geol. Ver. zu Hannover, Jb. 26, pt. 1 , no. 3 , p. 163 , pl. 10, fig. 6 .

Nodosaria filiformis d'Orbigny. Carsey, 1926 (not d'Orbigny, 1826), Texas Univ. Bull. 2612, p. 33, pl. 7, fig. 8 .

Dentalina sp. Tappan, 1940. Jour. Paleontology, v. 14, no. 2. p. 102, pl. 16, fig. 4; Tappan, 1943, Jour. Paleontology, v. 17 , no. 5 , p. 496 , pl. 79 , fig. 27.

Dentalina ef. soluta Reuss. ten Dam, 1950 (not Reuss, 1851), Mém. Soc. Geol. France, n. ser., vol. 29, no. 4, mém. 63, p. 29 , pl. 2 , fig. 18 .
Nodosaria cf. regularis Terquem. Bartenstein, 1956 (not Terquem, 1862), Senckenb. leth., v. 37, nos. 5, 6, p. 521, pl. 3, fig. 66 .

Test free, consisting of elongate-ovate chambers with much constricted sutures, commonly represented only by two chambered fragments; wall calcareous, finely perforate, surface smooth; aperture radiate, terminal.

Hypotypes range from 0.29 to $0.55 \mathrm{~mm}$ in length (two-chambered specimens).

Remarks.-These fragmental tests have been variously referred to many species of Nodosaria and Dentalina. Owing to the degree of constriction at the sutures, they commonly appear only as one or two chambered fragments. The species was originally described from the upper Gault (Albian) of Germany, the type specimen of 4 chambers being $1.09 \mathrm{~mm}$ in length. It differs from Nodosaria filiformis d'Orbigny of the Pliocene of Italy, in being much smaller, and in having narrower and more elongated chambers.

Dentalina soluta Reuss, from the Eocene of Germany, has more inflated chambers and an apiculate proloculus, but is otherwise similar in appearance. Nodosaria regularis Terquem, from the Lias (Lower Jurassic) of France, has nearly spherical chambers, and is considerably smaller.

Dentalina monile Cornuel, 1848, from the Neocomian (Lower Cretaceous) of France, may belong to the present species also, although the type is much more complete than usual, consisting of 9 chambers and attaining a length of $1.5 \mathrm{~mm}$. Although Cornuel's species antedates that of Reuss, it is a homonym of Nodosaria monile Hagenow, 1842 [= Dentalina, according to Franke (1928, p. 31) and Marie (1941, p. 89 ) ] hence the next available name is $D$. strangulata Reuss.

Nodosuria loeblichae ten Dam, from the Neocomian of the Netherlands, is also similar, but is about twice as large, and characterized by a roughened wall surface.

Types and occurrence.-Figured hypotype (USNM P6699) from a core at 538 to 542 feet, in the Grandstand formation, in Umiat test well 3.

Figured hypotype (USNM P6700) in a core at 3382 to $33821 / 2$ feet, in the Torok formation, in South Barrow test well 1 .

\section{Dentalina species}

Plate 45 , figure 19

Test free, small, rectilinear, consisting of a globular proloculus, followed by a few broad, low, somewhat inflated chambers, final chamber of approximately equal breadth and height; sutures distinet, constricted, slightly oblique; wall calcareous, finely perforate, sur- 
face smooth; aperture terminal, radiate, at the dorsal margin, slightly produced on a neck.

Figured specimen is $0.40 \mathrm{~mm}$ in length.

Remarks.--This specimen is similar to Dentalina discrepans Reuss, from the Senonian (Upper Cretaceous) of Germany, differing in the more closely appressed chambers, relatively lower final chamber, and globular, rather than apiculate proloculus. The Lower Cretaceous $D$. distincta Reuss differs in having an apiculate proloculus and less closely appressed chambers.

Types and occurrence.--Figured specimen (USNM P6705) from the Rogers Creek member of the Schrader Bluff formation at a depth of 20 feet, in seismograph shot hole, Umiat shot point 15 , party 46 , line $1-46$.

\section{Genus Vaginulina d'Orbigny, 1826 \\ Vaginulina exilis (Reuss)}

Plate 46, figures 1-3

Cristellaria exilis Reuss, 1863, Sitz. K. Akad. Wiss., Math.Nat. Classe, v. 46, p. 66, pl. 6, fig. 19.

Test free, small, narrow, elongate; ovate proloculus followed by about 5 relatively low chambers which become proportionately higher as added; sutures slightly depressed, oblique; wall calcareous, perforate, surface smooth; aperture radiate at the dorsal angle.

Length of hypotypes ranges from 0.26 to $0.42 \mathrm{~mm}$.

Remarks.-This species is rare in Alaska, the majority of specimens being juveniles, and thus appearing relatively broader than the original types. They are similar to the young stage of development in the German specimens, however, and are regarded as conspecific. The single Alaskan fragment of a more typical adult specimen is broken at the base.

Types and occurrence-Figured hypotype (USNM $\mathrm{P} 6548$ ) from a core at 3133 to 3144 feet, in the Torok formation, in South Barrow test well 1.

Figure hypotype (USNM P6549) from a core at 1030 to 1040 feet in the Topagoruk formation, and unfigured hypotype (USNM P6550) from a core at 723 to 733 feet, in the Grandstand formation, both in Simpson test well 1.

Figured hypotype (USNM P6551) from well cuttings at 3910 to 3920 feet, in the Topagoruk formation, in Umiat test well 2.

\section{Vaginulina cf. plana (Reuss) \\ Plate 46, figure 11}

?Cristellaria plana Reuss, 1863, Sitz. K. Akad. Wiss., math.-nat. classe, v. 46 , p. 72 , pl. 8 , fig. 3 .

Test free, small, compressed, sides flat, the only specimen observed in the Alaskan material consisting of a globular proloculus and three additional chambers, in a somewhat arcuate series; chambers somewhat cuneate in outline, of greatest height at the dorsal margin; sutures distinct, slightly depressed, sinuate, and strongly oblique; wall calcareous, perforate, surface smooth; aperture radiate, produced at the dorsal angle.

Length of figured specimen $0.41 \mathrm{~mm}$, breadth 0.2 $\mathrm{mm}$, thickness $0.09 \mathrm{~mm}$.

Remarks.-The original illustration of this species from Germany shows a more ovate proloculus, and chambers of more equal height throughout their breadth. Cristellaria protosphaera Reuss is similar to the present form but has a narrower test and regularly curved sutures instead of the somewhat sinuate sutures of the specimen here figured.

Type and occurrence.-Figured specimen (USNM $\mathrm{P} 6547$ ) from a core at 3341 to 3346 feet, in the Torok formation, in South Barrow test well 1.

\section{Vaginulina schraderensis Tappan \\ Plate 46 , figures 4,5}

Taginulina schraderensis Tappan, 1906, Am. Assoc. Petroleum Geologists Bull., v. 44, no. 3, p. 295, pl. 2, figs. 13-14.

Test free, narrow, elongate, nearly rectilinear or with slightly arcuate early portion; chambers of somewhat greater breadth than height, increasing moderately in diameter in the early stage, later increasing very little in size as added; sutures distinct, slightly depressed, oblique; wall calcareous, finely perforate, surface smooth; aperture radiate, at the dorsal angle.

Length of holotype $0.65 \mathrm{~mm}$, paratypes range from 0.29 to $0.74 \mathrm{~mm}$ in length.

Remarks. - This species differs from Marginulina elonguta d'Orbigny, from the Upper Cretaceous of France, in being straighter and more tapering, with higher chambers, more oblique sutures, and more produced aperture. It differs from Vaginutina angusta Reuss in being narrower and less curved dorsally. Marginutina glabra d'Orbigny from the Pliocene of Italy is more tapered and more enrolled at the base.

Types and occurience.-Holotype (USNM P6617) and figured paratype (USNM P6618) from the Rogers Creek member of the Schrader Bluff formation, Umiat Seismograph party 46, line 1-46, shot point 15, at a depth of 20 feet.

Unfigured paratype (USNM P6619) from the Barrow Trail member of the Schrader Bluff formation, field sample $45 \mathrm{AGr} 170$.

Unfigured paratype (USNM P6620) from the Barrow Trail member of the Schrader Bluff formation, field sample 47ADt 338. 
Unfigured paratypes (USNM P6621) from the Sentinel Hill member of the Schrader Bluff formation, field sample 47ASt 32.

Unfigured paratype (USNM P6622) from the Rogers Creek member of the Schrader Bluff formation, field sample 48ADt 392.

\section{Genus Astacolus Montfort, 1808 \\ Astacolus incrassatus (Reuss) \\ Plate 46, figures $8-10$}

Vaginulina incrassata Reuss, 1863, Sitz. K. Akad. Wiss., math.nat. classe, v. 46 , p. 52 , pl. 4 , fig. 9 .

Test free, small, subovate in outline, sides flattened, with greatest thickness of test at the ventral margin near the coil; chambers few in number, commonly only six or seven in the adult, the early chambers in a coil, and increasing rapidly in breadth but relatively slowly in height, the later uncoiling chambers continuing to reach back toward the proloculus at the inner margin of the coil; sutures distinct, curved, thickened, crossed by a few longitudinal costae; wall calcareous, finely perforate, margins of test carinate, sides with about 4 longitudinal costae, which vary somewhat in degree of development in the different specimens seen, ranging from continuous ribs to short costae projecting only slightly from the thickened sutures, and not continuing across the chambers; aperture radiate, at the dorsal angle.

Hypotypes range from 0.31 to $0.78 \mathrm{~mm}$ in length. Remarks.--Vaginulina vandenbroecki Berthelin, from the French Albian, is very similar to the present species, but has discontinuous and oblique ribs, which are not straight and evenly spaced, and the sides of the test are flatter.

Types and occurrence.-Figured hypotype (USNM P6555) from well cuttings at 3440 to 3450 feet, in the Topagoruk'formation, in Umiat test well 2.

Figured hypotype (USNM P6557) from well cuttings at 540 to 550 feet, in the Topagoruk formation, and figured hypotype (USNM P6556) from well cuttings at 3180 to 3190 feet, in the Torok formation, in South Barrow test well 1.

Unfigured hypotype (USNM P6561) from a core at 1247 to 1267 feet, and unfigured hypotype (USNM P6562) from well cuttings at 2380 to 2390 feet, both in the Topagoruk formation, in Simpson test well 1.

Unfigured hypotype (USNM P6563) from seismograph shot hole 37 , party 47 , line 14-48, at a depth of 160 to 170 feet, in the Grandstand formation.

\section{Astacolus perstriatus (Tappan)}

Plate 46, figures 16,17

Taginulina complanata (Reuss) var. perstriata Tappan, 1940, Jour. Paleontology, v. 14, no. 2, p. 108, pl. 16, fig. 25; Tap- pan, 1943, Jour. Paleontology, v. 17, no. 5, p. 499, pl. 80, fig. 14; Bartenstein, 1956, Senckenb. Leth., v. 37, nos. 5, 6, p. 518, pI. 2, figs. 35-37.

Citharina complanata (Reuss) var. perstriata (Tappan). Frizzell, 1954, Bureau Econ. Geol. Rept. Invest. 22, p. 94, pl. 11, fig. 3 .

Test free, of medium size, compressed, but thickest at the ventral margin, early portion coiled, later tending to uncoil, but with chambers extending back nearly to the coil on the inner margin; chambers few in number, cuneate in early portion, of somewhat more equal height in later portion, increasing very little in size in the uncoiling portion of the test; sutures radial in the early coil, gently curved and strongly oblique in the later portion, partially obscured by the longitudinal costae; wall calcareous, finely perforate, surface with a relatively few oblique costae, which are continuous across the sutures; aperture radiate, at the peripheral angle.

Hypotypes range from 0.49 to $0.62 \mathrm{~mm}$ in length.

Remarks.-The oblique costae and more compressed test separate this species from the associated Astacolus incrassatus (Reuss). It was originally described from the Grayson formation (Cenomanian) of Texas, and also occurs in the Duck Creek formation (Albian) of Texas.

Types and occurrence.-Figured hypotype (USNM P6552) from well cuttings at 2120 to 2130 feet, in the Torok formation, in South Barrow test well 2.

Figured hypotype (USNM P6553) from well cuttings at 4540 to 4550 feet, in the Topagoruk formation, in Umiat test well 2.

Unfigured hypotype (USNM P6554) from a core at 523 to 533 feet, in the Grandstand formation, in Simpson test well 1.

\section{Astacolus strombecki (Reuss)}

Plate 46 , figures 14,15

Cristellaria strombecki Reuss, 1863, Sitz. K. Akad. Wiss. Math.Nat. Classe, v. 46 , p. 68, pl. 7 , fig. 7 .

Test free, small, elongate-ovate in outline, compressed; the 9 or 10 chambers in a slightly coiled arrangement, very low, increasing rapidly in breadth, and extending far backward on the inner margin, nearly to the proloculus; sutures distinct, slightly curved, strongly oblique, flush to slightly depressed; wall calcareous, finely perforate, surface smooth; aperture at the peripheral angle, probably radiate, but not well preserved in the Alaskan specimens observed.

Hypotypes range from 0.41 to $0.50 \mathrm{~mm}$ in length.

Remarks. - This species is somewhat similar to Astacolus complanatus (Reuss) but has flush or depressed rather than elevated sutures. Astacolus laevigatus (Reuss) is similar but has much higher chambers. 
Types and occurrence.-Figured hypotype (USNM P6558) from a core at 538 to 542 feet, in the Grandstand formation, in Umiat test well 3.

Figured hypotype (USNM P6559) from a core at 3125 to 3133 feet, in the Torok formation, in South Barrow test well 1.

Unfigured hypotype (USNM P6560) from a core at 2030 to 2040 feet, in the Torok formation, in South Barrow test well 2 .

\section{Genus Vaginulinopsis Silvestri, 1904 \\ Vaginulinopsis grata (Reuss) \\ Plate 46, figures 6,7}

Cristellaria grata Reuss, 1863. Sitz. K. Akad. Wiss. Math.Nat. Classe, v. 46 , p. 70, pl. 7, fig. 14 .

Robulus (?Astacolus) gratus Reuss. Eichenberg, 1935, Mitt.

Roemer-Mus., Hildesheim, no. 37, p. 5, pl. 3, fig. 9.

Test free, small, compressed, elongate ovate in outline, periphery rounded; early chambers forming a coil of approximately one volution, later chambers tending to uncoil, but commonly extending back nearly to the coil on the ventral margin, early chambers cuneate, of nearly equal breadth and height, later chambers of increased proportional width, with final chambers about twice as broad as high; sutures distinct, very gently curved, slightly thickened, flush with the surface; wall calcareous, finely perforate, surface smooth; aperture radiate, at the dorsal angle.

Hypotypes range from 0.29 to $0.75 \mathrm{~mm}$ in length.

Remarks. - This is one of the nodosariids which has been referred to various genera, because of the inconsistency of shape in different specimens. Young specimens with very little uncoiling resemble Lenticulina, others tend to uncoil slightly, but with overhanging chambers as in Astacolus, and well developed specimens are sufficiently uncoiled as to be referred to Vaginulinopsis. The latter generic designation is here used as it seems to be best indicative of the adult character's. The species was originally described from the Albian of northern Germany, and has also been recorded from the Aptian there.

Types and occurrence.-Figured hypotype (USNM P6590) and unfigured hypotype (USNM P6591) from a core at 1167 to 1177 feet, in the Topagoruk formation; unfigured hypotype (USNM P6592) from a core at 166 to 176 feet, unfigured hypotype (USNM P6593) from a core at 293 to 303 feet, unfigured hypotype (USNM P6594) from a core at 308 to 318 feet, and unfigured hypotypes (USNM P6595) from a core at 970 to 980 feet, all from the Grandstand formation; unfigured hypotypes (USNM P6596) from a core at 1137 to 1147 feet, and unfigured hypotype (USNM P6597) from well cuttings at 2450 to 2460 feet, all from the Topagoruk formation; all from Simpson test well 1.

Figured hypotype (USNM P6598) from a core at 651 to 666 feet, in the Topagoruk formation, in Arcon Point Barrow core test 1.

Unfigured hypotype (USNM P6599) from well cuttings at 1620 to 1630 feet, in the Topagoruk formation, in South Barrow test well 1.

Unfigured hypotype (USNM P6600) from well cuttings at 2330 to 2340 feet, and unfigured hypotype (USNM P6601) from well cuttings at 2440 to 2450 feet, both in the Torok formation, in South Barrow test well 2 .

Unfigured hypotype (USNM P6602) from a core at $6101 / 2$ to 614 feet, in the Grandstand formation, Skull Cliff core test 1.

\section{Vaginulinopsis muelleri (Reuss) \\ Plate 47 , figures $1-5$}

Marginulina mülleri Reuss, 1863, Sitz. K. Akad. Wiss., Math.Nat. Classe, v. 46 , p. 61 , pl. 6 , fig. 1 .

Test free, elongate, slightly compressed, early portion coiled with 6 to 8 chambers in the coil, final 2 or 3 chambers uncoiled, but extending somewhat toward the coil at their inner margin; sutures distinct, curved, slightly depressed; wall calcareous, finely perforate, surface ornamented with low, narrow and evenly spaced ribs; aperture radiate, at the peripheral angle.

Hypotypes range from 0.26 to $0.60 \mathrm{~mm}$ in length.

Remarks. - This species differs from the somewhat similar associated ribbed species, Marginulinopsis collinsi Mellon and Wall, in the much finer and more closely spaced ribs, and the flattened test.

Types and occurrence.-Figured hypotype (USNM P6564) and unfigured hypotype (USNM P6565) from a core at 523 to 533 feet, and unfigured hypotype (USNM P6566) from a core at 543 to 545 feet, all in the Grandstand formation; figured hypotype (USNM P6567) from a core at 1040 to 1050 feet, figured hypotype (CSNM P6568) and unfigured hypotype (USNM P6569) from a core at 1322 to 1330 feet, figured hypotype (USNM P6570) and unfigured hypotype (USNM P6571) from a core at 1350 to 1360 feet, unfigured hypotype (USNM P6572) from a core at 1127 to 1137 feet, unfigured hypotype (USNM P6573) from a core at 1187 to 1197 feet, and unfigured hypotypes (USNM P6574) from a core at 1302 to 1312 feet, all in the Topagoruk formation; all from Simpson test well 1.

Figured hypotype (USNM P6575) from cuttings at 2100 to 2110 feet, unfigured hypotype (USNM P6576) from a core at 2020 to 2030 feet, and unfigured hypotype (USNM P6577) from a core at 2060 to 2070 
feet, all from the Torok formation, in South Barrow test well 2.

Unfigured hypotype (USNM P6578) from a core at 3125 to 3133 feet, and unfigured hypotype (USNM P6579) from a core at 3144 to 3153 feet, both in the Torok formation, in South Barrow test well 1.

Unfigured hypotype (USNM P6580) from well cuttings at 405 to 410 feet, and unfigured hypotype (USNM P6581) from a core at 651 to 661 feet, both in the Topagoruk formation, in Arcon Point Barrow core test 1 .

\section{Vaginulinopsis pachynota ten Dam \\ Plate 47 , figure 6}

Vaginulinopsis pachynota ten Dam, 1946, Jour. Paleontology, v. 20 , no. 6 , p. 575 , pl. 88 , figs. 5,6 .

Lenticulina (Taginulinopsis) pachynota (ten Dam) Bartenstein, 1956, Senckenb. leth., v. 37, nos. 5, 6, p. 516, pl. 2, fig. 55 .

Test free, compressed, ovate in outline, periphery subangled; the few, broad and low chambers forming a partial coil, the earliest ones increasing rapidly in breadth; sutures distinct, gently curved, slightly depressed, oblique and extending back toward the coil at the inner margin; wall calcareous, finely perforate, surface smooth; aperture radiate, at the peripheral angle.

Hypotypes range from 0.44 to $0.62 \mathrm{~mm}$ in length.

Remarks.-This species was originally described from the middle Neocomian (Hauterivian) of the Netherlands. The Alaskan specimens are somewhat younger geologically, but appear quite typical.

Types and occur rence.--Figured hypotype (USNM P6582) from the upper part of the Torok formation, field sample 47AWh 199.

Unfigured hypotype (USNM P6583) from the Fortress Mountain formation, field sample $49 \mathrm{APa} 571$.

Unfigured hypotype (USNM P6584) from a core at 3155 to 3163 feet, in the Torok formation, in South Barrow test well 1.

\section{Vaginulinopsis schloenbachi (Reuss)}

Plate 46, figures 12,13

Cristcllaria schloenbachi Reuss, 1863, Sitz. K. Akad. Wiss. Math.-Nat. Classe, v. 46, p. 65, pl. 6, figs. 14, 15; Chapman, 1894, Royal Micr. Soc. Jour., p. 649, pl. 9, fig. 9.

Lenticulina (Astacolus) schlönbachii (Reuss). Bartenstein and Brand, 1951, Abh. Senckenb. Naturf. Gesell. no. 485, p. 286, pl. 5, figs. 12ł, 125.

Test free, small, narrow, elongate, slightly compressed, periphery rounded; early portion in a close coil consisting of about 5 low, cuneate chambers, later 2 or 3 chambers in a rectilinear arrangement, and of much greater relative height; sutures distinct, depressed, gently curved and radiate in the early coil, oblique but nearly straight in the uncoiled portion wall calcareous, finely perforate, surface smooth; ape. ture terminal, radiate, slightly produced on a short neck at the dorsal margin.

Hypotypes range in length from 0.34 to $0.57 \mathrm{~mm}$.

Remarks.-Originally described from the Hilsthon of northern Germany, this species has been recorded from Valendian (Neocomian) through the Albian, in western Europe.

Types and occurrence.-Figured hypotype (USNM P6585) from a core at 2235 to 2245 feet, figured hypotype (USNM P6586) from well cuttings at 3240 to 3250 feet, unfigured hypotype (USNM P6587) from a core at 1360 to 1370 feet, unfigured hypotype (USNM P6588) from well cuttings at 3550 to 3560 feet, all in the Topagoruk formation, in Simpson test well 1.

Unfigured hypotype (USNM P6589) from a core at 3125 to 3133 feet, in the Torok formation, in South Barrow test well 1.

\section{Genus Citharina d'Orbigny, 1839 \\ Citharina cf. accuminata (Reuss) \\ Plate 47, figures 7,8}

?Vaginulina acuminata Reuss, 1863, Sitz. K. Akad. Wiss., Math.-Nat. Classe, v. 46, p. 49, pl. 4, fig. 1; Eichenberg, 1933, Niedersächs, geol. Ver. Hannover, Jb. 25, p. 187, pl. 23, fig. 11; Eichenberg, 1935, Mitt. Roemer-Museum, Hildesheim, no. 37 , p. 26 , pl. 5, fig. 2.

?Citharina acuminata (Reuss). Bartenstein and Brand, 1951, Abh. Senckenb. Naturf. Gesell, no. 485, p. 298.

Test free, flattened, elongate, slender, tapering slightly to the base; with numerous broad and very low, oblique chambers in an almost straight series; sutures nearly straight and strongly oblique, much obscured by the closely spaced longitudinal ribs; wall calcareous, finely perforate, ornamented with the 8 to 10 narrow continuous ribs extending the length of each of the flattened sides of the test; aperture at the dorsal angle, radiate, and somewhat produced to give the distinctive neck.

Length of larger hypotype fragment $1.18 \mathrm{~mm}$.

Remarks.-This species is quite rare in Alaska, only the two figured specimens having been observed. As both are only fragments, the specific identification is questioned, although the fragments are similar in all characters to the German species. Citharina angustissima (Reuss) is similar, but narrower, with less broad chambers and Citharina rudocostata Bartenstein and Brand is a wider and more flaring species.

Citharina acuminata was originally described from the upper Hilsthon of Germany, probably of Aptian age, and has also been recorded from strata of Barremian and upper Hauterivian age. 
Types and occurrence.-Figured hypotype (USNM P6607) from well cuttings at 3530 to 3540 feet, in the Topagoruk formation, in Simpson test well 1.

Figured hypotype (USNM P6608) from a core at 2040 to 2050 feet, in the Torok formation, in South Barrow test well 2.

\section{Genus Citharinella Marie, 1938}

Citharinella of. tarrantensis (Loeblich and Tappan)

Plate 47, figure 15

?Palmula tarrantensis Loeblich and Tappan, 1941, Bull. Am. Paleontology, v. 26 , no. 99 , p. 13 , pl. 2, figs. 8-12. Citharinella tarrantensis (Loeblich and Tappan). Loeblich and Tappan, 1957, U.S. Natl. Mus. Bull. 215, p. 225, pl. 72, figs. 14-16.

Test free, compressed, palmate, proloculus and second chamber paired, later chambers symmetrical, broad, low and equitant, strongly angled at the midline; sutures distinct, slightly depressed, acutely angled; wall calcareous, finely perforate, surface with a few low, discontinuous ribs; aperture terminal, radiate.

Length of figured hypotype $0.47 \mathrm{~mm}$, breadth 0.33 $\mathrm{mm}$.

Remarks.-The specimen here figured is similar to Citharinella tarrantensis from the Lower Cretaceous of the Gulf Coast, but lacks the apical spine on the proloculus and has a broader base. The preservation may account for the lack of the apical spine, and as only a single specimen was found in Alaska, it is tentatively referred to the Gulf Coast species.

Frondicularia pseudoconcinna Bartenstein and Brand is similar to the present form, but is a true Frondicularia with globular, projecting proloculus and completely symmetrical test.

Frondicularia perovata Chapman has more numerous ribs, a globular proloculus, and is also completely symmetrical. Frondicularia microdisca dichotomiana Bartenstein and Brand differs in being much larger, with sides more flaring, and has fewer, more scattered ribs and complete symmetry.

Type and occurrence.-Figured specimen (USNM P6714) from a core at 348-358 feet, in the Grandstand formation, in Simpson test well 1.

\section{Genus Frondicularia Defrance, 1826 \\ Frondicularia ampulla Hucke}

Plate 47, figures 11, 12

Frondicularia ampulla Hucke, 1904, Dentsch. Geol. Ges. Zeitschr., v. 56, p. 168, pl. 23, fig. 10.

Test free, flattened, palmate; proloculus spherical, followed by a few uniserial equitant chambers, the Alaskan specimens observed being juvenile specimens of only two chambers; sutures slightly depressed; wall calcareous, perforate, surface with closely spaced low vertical costae; aperture terminal, radiate.

Hypotypes 0.40 to $0.42 \mathrm{~mm}$ in length. The original type was $0.47 \mathrm{~mm}$ in length and $0.13 \mathrm{~mm}$ in breadth.

Remarks.-This species was originally described from the upper part of the Gault (Lower Cretaceous) of Germany. Alaskan specimens observed have a larger proloculus than the type specimen, and are probably megalospheric. This species is commonly slightly asymmetrical, almost transitional to Citharina.

Types and occurrence.-Figured hypotype (USNM P6726) from cuttings at 1480 to 1490 feet in the Topagoruk formation, in South Barrow test well 1.

Figured hypotype (USNM P6727) from cuttings at 1715 to 1725 feet, in the Topagoruk formation, in Umiat test well 2.

\section{Frondicularia cushmani Loeblich and Tappan \\ Plate 47 , figures 9,10}

Frondicularia cushmani Loeblich and Tappan, 1941, Bull. Am. Paleontology, v. 26, no. 99, p. 14, pl. 3, fig. 4; Frizzell, 1954, Bur. Econ. Geol. Rept. Invest. 22, p. 98, pl. 12, fig. 27.

Frondicularia cordai Reuss. Eichenberg, 1934 (not Reuss, 1881) Neidersächs. Geol. Ver. zu Hannover, 26 Jb., pt. 1, no. 3 , p. 180 , pl. 16 , fig. 7 .

Test free, flattened, broad; spherical proloculus followed by numerous broad, low, strongly equitant uniserial chambers, which extend back on each side nearly to the base, all chambers of nearly equal height, but increasing rapidly in breadth due to the great amount of lateral overlap; sutures distinct, thickened, flush; wall calcareous, finely perforate, surface ornamented by numerous, low longitudinal ribs which are prominent across the chambers, but die out at the sutures; aperture terminal, produced on a short neck, radiate.

Hypotypes range from 0.39 to $0.71 \mathrm{~mm}$ in length.

Remarks.-This species was originally described from the Pawpaw formation, Washita group, of Texas. It differs from Frondicularia guestphalica Reuss of the Gault of Germany in having a spherical rather than lanceolate proloculus.

Frondiculariu cushmani was originally described as having a single longitudinal rib on the proloculus, whereas the Alaskan specimens have lateral ribs as well. In view of the amount of variability in degree of development of such ribs in most species of this genus, the Alaskan forms are here regarded as belonging to the same species.

Frondicularia cordai Reuss, from the Upper Cretaceous of Bohemia, is also similar to the present species, but the original description mentions costae only on the proloculus, although they are shown in the figured specimen. It has a somewhat more lanceolate outline, 
with more acutely angled equitant chambers, and is a larger species than is $F$. cushmani. The specimen referred to $F$. cordai by Chapman (1894, pl. 4, fig. 6) should be referred to $F$. guestphalica Reuss; that placed in $F$. corda $i$ by Eichenberg, 1934, pl. 16, fig. 7 has a spherical proloculus with ribs as do the Alaskan specimens of $F$. cushmani, and belongs to the present species.

Types and occurrence.-Figured hypotype (USNM P6702) from a core at 433 to 438 feet, in the Grandstand formation and figured hypotype (USNM P6703) from cuttings at 4550 to 4560 feet, in the Topagoruk formation, both in Simpson test well 1 .

\section{Frondicularia ungeri Reuss}

Plate 47 , figure 13

Frondicularia ungeri Reuss, 1863, Akad. Wiss. Wien., Sitz., v. 46, p. 54, pl. 4, fig. 11; Berthelin, 1880, Soc. Géol. France, mém. ser. 3, v. 1, mém. 5, p. 61, pl. 4, fig. 4; Chapman, 1894, Royal Micr. Soc. Jour., p. 157, pl. 3, fig. 16; Chapman, 1899, Ann. Mag. Nat. Hist. ser. 7, vol. 3, p. 302; Eichenberg, 1933, Niedersächs geol. Ver., Jb. 25, Folge 1 p. 8, pl. 6, fig. 1; Loeblich and Tappan, 1941, Bull. Am. Paleontology, v. 26, no. 99, p. 16, pl. 3, figs. 5-7; Tappan, 1943, Jour. Paleontology, v. 17, no. 5, p. 502 ; Frizzell, 1954, Bur. Econ. Geol. Rept. Inv. 22, p. 99, pl. 13, fig. 1.

Test free, elongate-palmate, much compressed, proloculus globular, followed by gradually broadening, acutely angled, low equitant chambers, which are all of nearly equal height; sutures distinct, arching at about a $60^{\circ}$ angle from the horizontal; wall calcareous, finely perforate, surface smooth; aperture terminal, slightly produced.

Length of figured hypotype $1.78 \mathrm{~mm}$, breadth 1.13 mm.

Remarks.-This species is represented in the Alaskan material by a single specimen which was split longitudinally, so that only half remains, embedded in a rock fragment.

Types and occurrence.-Figured hypotype (USNM P6704) from a core at 4269 feet, in the Grandstand formation, in Gubik test well 1.

\section{Frondicularia species \\ Plate 47 , figure 14}

This somewhat asymmetrical fragment is of a smooth walled Frondicularia with somewhat thickened sutures, and equitant chambers of moderate breadth.

Length of figured specimen $0.33 \mathrm{~mm}$, breadth 0.25 $\mathrm{mm}$.

Type and occurrence.-Figured specimen (USNM P6728) from a core at 3164 to 3173 feet in the Torok formation, in South Barrow test well 1.

\section{GLANDULINIDAE, Reuss, 1860 \\ Genus Oolina d'Orbigny, 1839 \\ Oolina apiculata Reuss \\ Plate 47 , figure 16}

Oolina apiculata Reuss, 1850, Haidinger's Nat. Abh., v. 4, p. 22, pl. 1, fig. 1.

Lagena apiculata (Reuss). Reuss, 1863, Sitz. K. Akad. Wiss., Math.-Nat. Classe, v. 46, p. 319, pl. 1, figs. 4-8, 10-11 ; Burrows, Sherborn and Bailey, 1890, Royal Micr. Soc. Jour., p. 555, pl. 9, figs. 6, 7, 9-11; Chapman, 1893, Royal Micr. Soc. Jour., p. 581, pl. 8, figs. 2, 3 ; Eichenberg, 1934, Niedersächs geol. Vèr., Jb. 26, p. 182, pl. 12, fig. 12; Tappan, 1940, Jour. Paleontologv, v. 14, no. 2, p. 111, pl. 17, fig. 15; Tappan, 1943, Jour. Paleontology, v. 17, no. 5, p. 503, pl. 80, fig. 31; ten Dam, 1950, Soc. Geol. France, Mém. n. ser., v. 29, fasc. 4, mém. 63, p. 40; Frizzell, 1954, Bur. Econ. Geol. Rept. Invest. 22, p. 102, pl. 14, fig. 5, 6.

Test free, small, globose, unilocular, with a briefly apiculate base; chamber slightly longer than wide; wall calcareous, finely perforate, surface smooth; aperture terminal, somewhat produced, rounded.

Length of hypotypes ranges from 0.28 to $0.36 \mathrm{~mm}$.

Remarks.-Originally described from the Cretaceous of Germany, this species occurs widely in the Albian strata of northern Germany, France, the Netherlands, and the American Gulf Coast. As are most of the Nodosariidae, it is rare in northern Alaska strata.

Types and occurrence.-Figured hypotype (USNM P6631) from well cuttings at 6,110 to 6,120 feet, probably as contamination from the overlying Torok or Topagoruk formations, in Simpson test well 1.

Unfigured hypotypes (USNM P6632) from well cuttings at 3,210 to 3,220 feet in the Topagoruk formation, in Umiat test well 1.

\section{Family POIYMORPHINIDAE d'Orbigny, 1839 \\ Genus Paleopolymorphina Cushman and Ozawa, 1930 \\ Paleopolymorphina gaultina (Berthelin) \\ Plate 47, figure 17}

Polymorphina gaultina Berthelin, 1880, Soc. Geol. France, Mém. ser. 3, v. 1, mém. 5, p. 58, pl. 4, fig. 19.

Palcopolymorphina gaultina (Berthelin). Cushman and Ozawa, 1930, U.S. Natl. Mus. Proc., v. 77, art. 6, p. 112, pl. 28, fig. 6.

Test free, tiny, compressed; chambers few, arranged biserially, embracing, the final pair occupying much of the test; sutures distinct, oblique, flush; wall calcareous, perforate, surface smooth; aperture terminal, radiate.

Length of figured hypotype $0.26 \mathrm{~mm}$, breadth 0.21 $\mathrm{mm}$.

Remarks.-Originally described from the Albian (Lower Cretaceous) of France, this species has also been recorded from the equivalent Gault of England. It is extremely rare in northern Alaska. 
A similar species, Paleopolymorphina ozawai Tappan, occurs in the Lower Cretaceous Washita group of the Gulf Coastal region, but it differs from the present species in being more slender and elongate, with narrower and more inflated chambers, and constricted sutures.

Types and occurrence.-Figured hypotype (USNM P6679) from a core at 1910 to 1913 feet, in the Grandstand formation, in Umiat test well 1.

\section{Genus Pyrulinoides Marie, 1941 \\ Pyrulinoides thurrelli Tappan}

Plate 47 , figure 24

Pyrulinoides thurrelli Tappan, 1957, U.S. Natl. Mus. Bull. 215, p. 217, pl. 68, fig. 13 .

Test free, elongate, fusiform in ontline, circular in section; chambers added $180^{\circ}$ apart, in a biserial arrangement, much overlapping, increasing rapidly in size, final chamber extending back about three-fourths the distance to the base on one side, only about onethird the distance on the opposite side; sutures strongly oblique, flush; wall calcareous, finely perforate, surface smooth; aperture terminal, radiate.

Length of holotype $0.94 \mathrm{~mm}$, greatest breadth 0.42 $\mathrm{mm}$. Paratypes range from 0.60 to $1.12 \mathrm{~mm}$ in length.

Remarks.-Pyrulinoides thurrelli differs from $P$. obesa Marie in the larger size, more regularly fusiform outline, greater chamber overlap, more oblique sutures, and fewer, larger chambers.

The species occurs in the Grandstand and Topagoruk formations, and was named in honor of R. F. Thurrell, geologist, formerly with U.S. Geological Survey.

Types and occurrence.-Holotype (USNM P4553) from a core at $466-476$ feet, in the Grandstand formation, in Skull Cliff core test 1.

Unfigured paratype (USNM P $455 \pm$ ) from a core at 523-533 feet, in the Grandstand formation, and unfigured paratype (USNM P4555) from well cuttings at $3160-3170$ feet, in the Topagoruk formation, both from Simpson test well 1.

\section{Genus Globulina d'Orbigny, 1839 \\ Globulina exserta (Berthelin) \\ Plate 47, figures 20-23}

Polymorphina exserta Berthelin, 1880, Soc. Geol. France, Mém. ser. 3, v. 1, no. 5, p. 57, pl. 4, figs. 22, 23.

Polymorphina bucculenta Berthelin, 1880, Soc. geol. France, Mém. ser. 3 , v. 1 , no. 5 , p. 58 , pl. 4 , figs. 16,17 .

Globulina exserta (Berthelin). Cushman and Ozawa, 1930, U.S. Natl. Mus. Proc., v. 77, art. 6, p. 78, pl. 19, figs. 5-7; Tappan, 1943, Jour. Paleontology, v. 17, no. 5, p. 504, pl. 80, figs. 36, 37; Frizzell, 1954, Bur. Econ. Geol. Rept. Invest. 22, p. 104, pl. 14, fig. 19.
Test free, small, ovate, initial end acute to apiculate; chambers much overlapping, slightly inflated, in a roughly triserial arrangement; sutures oblique, flush; wall calcareous, finely perforate, surface smooth; aperture terminal, radiate.

Hypotypes range from 0.21 to $0.41 \mathrm{~mm}$ in length.

Remarks.-Orginally described from the Albian of France, this species has also been reported from the Lower Cretaceous of England and the Gulf Coast of the United States. Somewhat variable in size and proportions, it is characterized by the great amount of chamber overlap.

Types and occurrence.-Figured hypotypes (USNM P6651 a, b) from a core at 1070-1080 feet, in the Topagoruk formation, and unfigured hypotype (USNM P6652) from cuttings at 5520 to 5530 feet, in the Torok formation, in Simpson test well 1.

Figured hypotype (USNM P6653) from a core at 465-470 feet, in the Grandstand formation, and unfigured hypotypes (USNM P6654) from a core at 4610 to 4620 feet, in the Topagoruk formation, both from Umiat test well 2.

Figured hypotype (USNM P6655) from Seismograph Shot point 31 , party 46 , line $10-48$, at a depth of 70 feet, in the Grandstand formation.

Unfigured hypotype (USNM P6656) from field sample $47 \mathrm{~A} \mathrm{Ba} \mathrm{90,} \mathrm{in} \mathrm{the} \mathrm{Kukpowruk} \mathrm{formation.}$

Unfigured hypotypes (USNM P6657) from a core at 2012 to 2022 feet, and unfigured hypotype (USNM P6658) from a core at 2022 to 2032 feet, in the Topagoruk formation, in East Topagoruk test well 1.

Globulina lacrima Reuss subspecies canadensis Mellon and Wall Plate 47, figures 18, 19

Globulina sp. Wickenden, 1951, Geol. Survey Canada, Paper 51-16, p. 40, pl. IA, fig. 27.

Globulina lacrima canadensis Mellon and Wall, 1956, Research Council Alberta, Rept. 72, p. 16, pl. 2, fig. 6.

Test free, tiny, ovate in outline, with circular crosssection, broadly rounded base and slightly produced apertural end; chambers few in number, rapidly enlarging, overlapping; sutures flush, oblique, commonly relatively obscure so that the species might be mistaken at first glance for a Lagena; wall calcareous, finely perforate, surface smooth; aperture terminal, radiate.

Hypotypes range from 0.21 to $0.52 \mathrm{~mm}$ in length.

Remarks.-Similar in most respects to the German Globulina lacrima, this form was considered to be a "variety" because of its consistently smaller size, the Canadian (and Alaskan) specimens being about one third the size of the German species.

Globulina lacrima canadensis differs from $G$. $l a$ crima subspherica (Berthelin) which occurs in the 
Lower Cretaceous of Europe and the American Gulf Coast, in being more ovate in outline, rather than nearly spherical.

Types and occurrence.-Figured hypotype (USNM P6659) from well cuttings at 3760 to 3770 feet, in the Topagoruk formation, in Umiat test well 2.

Figured hypotype (USNM P6660) and unfigured hypotypes (USNM P6661) from a core at 2530 to 2535 feet, unfigured hypotype (USNM P6662) from cuttings at 1040 to 1050 feet, unfigured hypotype (USNM P6663) from cuttings at 1760 to 1770 feet, unfigured hypotypes (USNM P6664) from a core at 2024 to 2026 feet, unfigured hypotype (USNM P6665) from cuttings at 2160 to 2170 feet, and unfigured hypotypes (USNM P6666) from a core at 2235 to 2245 feet, all in the Topagoruk formation, in Simpson test well 1.

Unfigured hypotype (USNM P6667) from a core at 466 to 476 feet, in the Grandstand formation, in Skull Cliff core test 1.

Unfigured hypotype (USNM P6668) from field sample $49 A \operatorname{Tr} 611$, in the Fortress Mountain formation.

Unfigured hypotype (USNM P6669) from seismograph party 47 , line $27-48$, shot hole 2 , at 60 to 70 feet depth, in the Topagoruk formation.

Unfigured hypotype (USNM P6670) from seismograph party 46 , line $6-48$, shot point 15 , at 70 feet depth, in the Grandstand formation.

Unfigured hypotype (USNM P6671) from cuttings at 380 to 390 feet, and unfigured hypotype (USNM P6672) from cuttings at 3000 to 3010 feet, both in the Topagoruk formation, and unfigured hypotypes (USNM P6673) from a core at 3341 to 3346 feet, in the Torok formation, in South Barrow test well 1.

\section{Globulina prisca Reuss \\ Plate 47 , figures 25,26}

Globulina prisca Reuss, 1863, Akad. Wiss. Wien., Sitz., v. 46, pt. 1, p. 79, pl. 9, fig. 8; Cushman and Ozawa. 1930, U.S. Nat. Mus. Proc. v. 77 , art. 6 , p. 73 , pl, 12, figs. $6 a-c$ : Cushman, 1946, U.S. Geol. Survey Prof. Paper 206, p. 97, pl. 40, figs. 15-17; Frizzell, 1954, Bur. Econ. Geol. Rept. Invest. 22, p. 104, pl. 14, fig. 24; Bartenstein, 1956, Senckenb. leth., v. 37, nos. 5, 6, p. 529 .

Test free, elongate-ovate, with somewhat acutely angled base, and produced apertural region; chambers overlapping toward the base; sutures strongly oblique, flush; wall calcareous, finely perforate, surface smooth; aperture terminal, radiate.

Length of hypotypes ranges from 0.37 to $0.55 \mathrm{~mm}$.

Remarks.-Orginally deseribed from the Albian of Germany, this species also occurs in the Gault of England, and has been widely reported from Cretaceous strata elsewhere. It is narrower and more elongate than the other Alaskan species of Globulina, i.e., $G$. lacrima canadensis Mellon and Wall and $G$. exserta (Berthelin), and is also somewhat larger.

Types and occurrence.-Figured hypotype (USNM P6674) from a core at 1,080 to 1,087 feet, in the Topagoruk formation, unfigured hypotype (USNM P6675) from a core at 293 to 303 feet, and unfigured hypotype (USNM P6676) from a core at 523 to 533 feet, both in the Grandstand formation, all in Simpson test well 1.

Figured hypotype (USNM P6677) from cuttings at 1,780 to 1,790 feet, in the Topagoruk formation, in Umiat test well 2.

Unfigured hypotype (USNM P6678) from cuttings at 4,430 to 4,440 feet in the Topagoruk formation, in Umiat test well 1 .

\section{Family TURRILINIDAE Cushman, 1927 \\ Genus Neobulimina Cushman and Wickenden, 1928 Neobulimina albertensis (Stelck and Wall) Plate 48, figures 3-6}

Gümbelitria cretacea Cushman var. albertensis Stelck and Wall, 1954, Research Council Alberta, Rept. 68, p. 23, pl. 2, fig. 19 .

Gümbelitria cretacea Cushman var. spiritensis Stelck and Wall, 1955, Research Council Alberta, Rept. 70, p. 44, pl. 2, fig. 11.

Test free, tiny, elongate, somewhat flaring from the rounded base, early portion triserial, later somewhat irregularly biserial in adult specimens; chambers subglobular, increasing gradually in size; sutures distinct, constricted; wall finely perforate, calcareous, surface smooth; aperture a high and narrow loop extending up the face of the final chamber.

Hypotypes range from 0.13 to $0.31 \mathrm{~mm}$ in length and from 0.06 to $0.11 \mathrm{~mm}$ in breadth.

Remarks.-Originally this species was regarded as belonging to Guembelitria, because of the triserial development of the young specimens, most commonly observed, and the inflated nature of the chambers. It was described from the "Lower Speckled Shale horizon of the Kaskapau formation", but was also reported (Stelck and Wall, 1954, p. 24) to range "down into the lower Kaskapau beds."

A second variety was described (var. spiritensis) by Stelck and Wall $(1955$, p. 44$)$, which was reported to occur in "the central Kaskapau formation, with one isolated occurrence . . . in the . . lower Kaskapau." This "variety" showed a biserial later stage by which it was separated from $G$. cretacea albertensis. In Alaska both the more common triserial stage and the less frequent well developed specimen with biserial derelopment occur together in the Seabee formation, 
which is a near age equivalent (Turonian) of the "central Kaskapau."

SteIck and Wall $(1955$, p. 45$)$ noted also that this form might better be referred to Neobulimina, but tentatively had placed it with Guembelitria. The aperture is not typical of the latter genus however, as it is higher and more narrow. The genus Guembelitria does not develop a biserial later stage and does not show the twisted axis found in the present species.

Neobulimina albertensis is similar to $N$. irregularis Cushman and Parker, from the Austin chalk of Texas, but the latter species is larger, and has a more prominently developed biserial stage.

Types and occurrence.-Figured hypotypes (USNM P6646 a-d) and unfigured hypotypes (USNM P6647) from a core at 614 to 624 feet, in the Seabee formation, in Umiat test well 1.

Unfigured hypotype (USNM P6648) from a core at 719 to 729 feet in the Seabee formation, in Umiat test well 11.

Unfigured hypotypes (USNM P6506) from a core at 2170 to 2180 feet, unfigured hypotypes (USNM $\mathrm{P} 6507)$ from a core at 2180 to 2190 feet, unfigured hypotype (USNM P6508) from a core at 2190 to 2200 feet, unfigured hypotypes (USNM P66t9) from a core at 3363 to 3368 feet and unfigured hypotypes (USNM P6650) from a core at 3368 to 3380 feet, all in the Seabee formation, in Gubik test well 2.

\section{Neobulimina canadensis Cushman and Wickenden}

Plate 48, figures $18-27$

Noobulimina canadensis Cushman and Wickeuden, 1928, Cushman Lab. Foram. Research, Contr., v. 4. p. 13, pl. 1, figs. 1-2 ; Cushman, 1946. I.S. Geol. Survey Prof. Paper 206, 1. 125, pl. 52, figs. 11, 12; Cushman and Parker. 1947, U.S. Geol. Survey Prof. Paper 210-D, p. 132, pl. 29, figs. 32, 33; Nauss, 1947, Jour. Paleontologv. v. 21, no. 4, p. 340, pl. 48, figs. 5a-b; Tappan, 19.5, Cushman Found. Foram. Research, Contr., v. 2, pt. 1, p. 5, pl. 1, figs. 21 a-b; Bolin, 1952, South Dakota Geol. Survey Rept. Inv. 70, p. 44, pl. 3 , fig. 6; Tappan, 1951, in Payne and others, I.S. Geol. Survey Oil and Gas Inv. Map OM-126, sheet 3, fig. 21 (6) ; Frizzell, 1954, Bur. Econ. Geol., Rept. Inv. 22, p. 116, pl. 17. fig. 11.

Test free, tiny, elongate, narrow, early portion triserial, later biserial; chambers inflated, subglobular; sutures distinct, depressed; wall calcareous, hyaline, surface smooth; aperture loop-shaped, extending from the base of the final chamber about one-half the height of the chamber. Length ranges from 0.18 to $0.31 \mathrm{~mm}$, greatest breadth is between 0.08 and $0.13 \mathrm{~mm}$.

Remarks.-The species is said to have a very restricted range in the type area in Canada, for Nauss $(1947$, p. 340$)$ states that it ranges from 200 ) feet below the top to 200 feet above the base of the Lea Park for- mation. In northern Alaska, it is restricted to the Rogers Creek and Sentinel Hill members of the Schrader Bluff formation, Colville group. In other areas it has been reported to have a much wider geologic range, as for example in the Gulf Coastal region of the United States, where it has been recorded from beds ranging from Eagle Ford through Navarro in age. It seems probable that more than one species may have been thus included, hence certain of these records which may be questioned are not included in the above synonymy.

Types and occurrence.-Figured hypotypes (USNM $106504,106505 \mathrm{a}-\mathrm{c}$ ) and unfigured hypotypes (USNM P6793) from seismograph shot hole, Umiat shot point 15 , at a depth of 20 feet, in the Rogers Creek member of the Schrader Bluff formation.

Figured hypotype (USNM P6730) from cuttings at 120 to 130 feet, figured hypotype (USNM 106507) and unfigured hypotype (USNM 106506) from 280 to 290 feet, and figured hypotypes (USNM P6514 a, b) and unfigured hypotypes (USNM 106508) from 390 to 400 feet, all in the Sentinel Hill member of the Schrader Bluff formation, in Simpson core hole 11.

Figured hypotypes (USNM P6729 a, b) from field sample 47A Dt 360, unfigured hypotypes (USNM P6509) from field sample $47 \mathrm{~A}$ Dt 348, and unfigured hypotypes (USNM P6513) from field sample $47 \mathrm{~A} \mathrm{Dt}$ 284, all from the Sentinel Hill member of the Schrader Bluff formation.

\section{Neobulimina cf. canadensis Cushman and Wickenden}

Plate 48 , figures 16,17

Neobutimina canadensis Cushman and Wickenden, 1928, Cushman Lab. Foram. Research, Contr., v. 4, p. 13, pl. 1, figs. $1-2$.

Remarks.-The specimens here figured are somewhat larger than usual for this species, and about twice as large as the usual Alaskan specimen here referred. Length of figured specimens 0.39 and $0.55 \mathrm{~mm}$, greatest breadth $0.21 \mathrm{~mm}$.

Types and occurrence.-Figured specimen (USNM P6686) from well cuttings at 410 to 420 feet in the Sentinel Hill member of the Schrader Bluff formation, in Fish Creek test well 1.

Figured specimen (USNM P6687) from field sample $46 \mathrm{~A}$ Gr 144, in the Barrow Trail member of the Schrader Bluff formation.

\section{Neobulimina cf. primitiva (Cushman)}

Plate 48, figures 1, 2

?'irgulina primitiva Cushman, 1936, Cushman Lab. Foram. Res. Spec. Publ. 6, p. 46, pl. 7, fig. 1; Cushman, 1937, Cushman Lab. Foram. Res. Spec. Publ. 9, p. 2, pl. 1, figs. 
1-3 ; Frizzell, 1954, Bur. Econ. Geol. Rept. Invest. 22, p. 117, pl. 17, fig. 19.

Test free, tiny, narrow, elongate; chambers in a twisted biserial arrangement, enlarging gradually as added; sutures slightly depressed, oblique; wall calcareous, finely perforate, surface smooth; aperture an elongate slit extending up the face of the final chamber.

Length of hypotypes ranges from 0.19 to $0.37 \mathrm{~mm}$.

Remarks.-This species has heretofore been known only from the Goodland and Kiamichi formations of the Gulf Coast. The Alaskan specimens have more oblique sutures than is typical, but are referred here due to their similarity in other respects. The rarity of the species in the Alaskan material makes impossible a true evaluation of the consistency or importance of this feature.

Types and occurrence-Figured hypotype (USNM P6731) from a core at 3355 to 3360 feet, in the Torok formation, in South Barrow test well 1.

Figured hypotype (USNM P6732) from a core at 1570 to 1575 feet in the Topagoruk formation, in Simpson test well 1.

\section{Neobulimina subcretacea (Cushman) \\ Plate 48, figures 7-10}

Virgulina subcretacea Cushman. 1936, Cushman Lab. Foram. Research, Spec. Publ. 6, p. 46, pl. 7, fig. 2 ; Cushman, 1937, Cushman Lab. Foram. Research, Spec. Publ. 9, p. 2, pl. 1, figs. 4,5 .

Test free, elongate, flaring, numerous rounded inflated chambers in a twisted triserial arrangement, the latest chambers biserially arranged; sutures distinct, depressed; wall calcareous, finely perforate; aperture large, a broad and high loop-shaped opening extending up the face of the final chamber. Hypotypes range from 0.19 to $0.41 \mathrm{~mm}$ in length.

Remarks.-This species was originally described from the Goodland limestone (Lower Cretaceous) of Texas and has not previously been reported elsewhere. It differs from Neobulimina minima Tappan in being larger and more robust, with less twisted test, rounder and more inflated chambers and more constricted sutures.

Types and occurrence.-Figured hypotypes (USNM P6696 a-c) from the Grandstand formation, in Umiat Shot point 37 , at a depth of 65 feet, Seismograph party 46 , line $1-46$.

Figured hypotype (USNM P6697) from the Topagoruk formation, in well cuttings at 4180 to 4190 feet in Umiat test well 1.

Tnfigured hypotypes (USNM P6698) from the upper part of the Torok formation, field sample 52 A Wh 32.

\author{
Genus Praebulimina Hofker, 1951 \\ Praebulimina carseyae (Plummer) \\ Plate 48, figures 11-15
}

Buliminella carseyae Plummer, 1931, Univ. Texas Bull. 3101, p. 179 , pl. 8 , fig. 9 ; Loetterle, 1937, Nebraska Geol. Survey Bull. 2nd ser., Bull. 12, p. 37, pl. 5, fig. 10; Cushman and Parker, 1947, U.S. Geol. Survey Prof. Paper 210-D, p. 58, pl. 15, fig. 8.

Butimina venusae Nauss. Tappan, 1951 (part, not Nauss, 1947), Cushman Found. Foram. Research, Contr., v. 2, pt. 1, p. 6, pl. 1, fig. 24 (not figs. 23, 25, 26).

Butiminella carseyae Plummer var. carseyae Plummer. Frizzell, 1954, Bur. Econ. Geol. Rept. Invest. 22, p. 114, pl. 16, figs. 37, 38.

Test free, small, tapering gradually to the bluntly rounded base, chambers increasing gradually in size, final whorl occupying about half the length of the test; sutures distinct, depressed; wall calcareous, hyaline, finely perforate, surface smooth; aperture a narrow slit-like opening extending up the face of the final chamber.

Hypotypes range from 0.21 to $0.44 \mathrm{~mm}$ in length.

Remarks.-Originally described from Texas, where it occurs in the Austin chalk and Taylor group, this species also occurs in the Fort Hays limestone member of the Niobrara formation in Nebraska, and has been reported also from the Upper Cretaceous of England and Germany. It occurs in the Schrader Bluff formation in northern Alaska.

Types and occurrence,-Figured hypotypes (USNM 106513 and USNM P6503 a, b) from the Barrow Trail member of the Schrader Bluff formation, field sample 46 A Gr 144. The first mentioned specimen (USNM 106513) was erroneously included (Tappan, 1951, p. 6, pl. 1, fig. 24) with Bulimina venusae Nauss, and was recorded as occurring in the Tuluga member, now renamed Barrow Trail member (Whittington, 1956, p. 250,251 ).

Figured hypotypes (USNM P6682 a, b) from the Sentinel Hill member of the Schrader Bluff formation, field sample $49 \mathrm{~A}$ Gr 15.

Unfigured hypotype (USNM P6683) from the Sentinel Hill member of the Schrader Bluff formation, field sample $47 \mathrm{~A}$ St 39.

Unfigured hypotypes (USNM P6684) from the Sentinel Hill member of the Schrader Bluff formation, in a core at 425 to 435 feet, in Fish Creek test well 1.

Unfigured hypotypes (USNM P6685) from the Sentinel Hill member of the Schrader Bluff formation, in a core at 719 to 724 feet, in Sentinel Hill core test 1 . 
Praebulimina cushmani (Sandidge)

Plate 49, figures 1-5

Buliminella cushmani Sandidge, 1932, Jour. Paleontology, v. 6, p. 280, pl. 42, figs. 18, 19 ; Cushman, 1946, U.S. Geol. Survey Prof. Paper 206, p. 119, pl. 50, fig. 15; Cushman and Parker, 1947, U.S. Geol. Survey Prof. Paper 210-D, p. 58, pl. 15, figs. 10, 11 ; Frizzell, 1954, Bur. Econ. Geol., Rept. Inv. 22, p. 114, pl. 16, fig. 40 .

Test free, relatively short and robust, flaring; chambers inflated, about three to a whorl in the early stage, but with 4 per whorl in the adult, enlarging rapidly; sutures distinct, depressed; wall calcareous, distinctly but finely perforate, surface smooth; aperture a relatively broad and loop-shaped opening, extending up the flattened face of the final chamber.

Hypotypes range from 0.13 to $0.33 \mathrm{~mm}$ in length.

Remarks.-This species may be separated from the associated Praebulimina carseyae (Plummer) and $P$. venusae (Nauss) by its much shorter, broader and more rapidly flaring test.

Types and occurrence.-Figured hypotypes (USNM P6686 a-e) from the Rogers Creek member of the Schrader Bluff formation, in seismograph shot hole, Umiat shot point 15 , party 46 , line $1-46$, at a depth of 20 feet.

Unfigured hypotypes (USNM P6687) from the Sentinel Hill member of the Schrader Bluff formation, field sample $47 \mathrm{~A}$ Dt 360 .

Unfigured hypotypes (USNM P6688) from the Rogers Creek member of the Schrader Bluff formation, in cuttings at 760 feet, in Gubik test well 2.

Unfigured hypotypes (USNM P6689) from the Barrow Trail member of the Schrader Bluff formation, in the base of a core at 825 to 835 feet in Fish Creek test well 1.

Praebulimina nannina (Tappan)

Plate 49 , figures $6-9$

Bulimina nannina Tappan, 1940, Jour. Paleontology, v. 14, no. 2, p. 116, pl. 19, fig. 4 ; Cushman and Parker, 1947, U.S. Geol. Survey Prof. Paper 210-D, p. 78, pl, 19, fig. 10; Loeblich and Tappan, 1950, Univ. Kansas Paleont. Contr., Protozoa, art. 3, p. 13, pl. 2, fig. 20 ; Frizzell, 1954, Bur. Econ. Geol. Rept. Invest. 22, p. 115, pl. 16, fig. 53.

Test free, small, flaring; subglobular chambers in a slightly twisted triserial arrangement, increasing rapidly in size; sutures distinct, constricted; wall calcareous, hyaline, finely perforate, surface smooth; aperture an elongate loop-shaped opening extending up the face of the final chamber.

Length of hypotypes ranges from 0.18 to $0.24 \mathrm{~mm}$.

Remarks.-This species was originally described from the Grayson formation (Washita group) of Texas. It also occurs in the subsurface Maness shale member of South Tyler formation (Bailey, Evans, and Adkins, 1945) of northern Texas, and in the Kiowa shale of Kansas.

Types and occurrence.-Figured hypotypes (USNM P6692 a, b) from a core at 864 to 874 feet, and unfigured hypotypes (USNM P6693) from a core at 874 to 885 feet, in the Grandstand formation in Simpson core test 25 .

Figured hypotype (USNM P6694) from well cuttings at 4670 to 4680 feet, and figured hypotype (USNM P6695) from well cuttings at 5110 to 5120 feet, both from the Topagoruk formation, in Umiat test well 2.

\section{Praebulimina seabeensis Tappan}

Plate 49, figures $10-18$

Praebulimina seabeensis Tappan, 1957, U.S. Natl. Mus. Bull. 215 , p. 217 , pl. 69 , figs. 14-16.

Test free, elongate, flaring, chambers in a high spiral, triserially arranged, low, somewhat inflated, increasing gradually in size, those of final whorl somewhat higher and subglobular; sutures distinct, depressed, horizontal; wall calcareous, finely perforate, surface smooth; aperture loop-shaped, at the inner margin of the final chamber, extending up into the chamber face.

Length of holotype $0.26 \mathrm{~mm}$, breadth $0.18 \mathrm{~mm}$. Paratypes range from 0.10 to $0.42 \mathrm{~mm}$ in length.

Remarks.-Praebulimina seabeensis differs from $P$. venusae (Nauss) in the larger size, more bluntly rounded base, less flared test, and lower final whorl of chambers.

The specific name refers to the Seabee formation, in which this species is found.

Types and occurrence.-Holotype (USNM P4564) and figured paratypes (USNM P4565 a-c) from a core at 591 to 601 feet, figured paratype (USNM P4566) and unfigured paratype (USNM P4567) from a core at 519-529 feet, and figured paratype (USNM P4568) and unfigured paratypes (USNM P4569) from a core at $584-591$ feet, all from the Seabee formation, in Umiat test well 1 .

Unfigured paratypes (USNM P6501) from a core at 1030 to 1050 feet and unfigured paratypes (USNM P6502) from a core at 1670 to 1680 feet, in the Seabee formation, in Umiat test well 11.

Figured paratype (USNM P6510) and unfigured paratype (USNM P6511) from the Seabee formation, field sample 46 A Fi $80 \mathrm{~A}$.

Figured paratypes (USNM P6733 a, b) from the lower member of the Seabee formation, field sample $47 \mathrm{~A}$ Dt 78. 


\section{Praebulimina venusae (Nauss)}

Plate 49 , figures $19-21$

Bulimina venusae Nauss, 1947, Jour. Paleontology, v. 21. no. 4, p. 334, pl. 48, fig. 10 ; Tappan. 1951 (part) Cushman Found. Foram. Research, Contr.. v. 2, pt. 1, p. 6, pl. 1, figs. 23, 25, 26 (not fig. 24) ; Tappan, 1951, in Payne and others, U.S. Geol. Survey Oil and Gas Invest. Map OM-126, sheet 3, fig. 21 ( 7) .

Test free, tiny, triserial; early chambers low, those of the last two whorls inflated and increasing rapidly in height; sutures distinct, depressed; wall calcareous, hyaline, distinctly perforate, surface smooth; aperture loop-shaped, at the base of the final chamber.

Length ranges from 0.13 to $0.31 \mathrm{~mm}$, greatest breadth between 0.10 and $0.16 \mathrm{~mm}$.

Remarks.-Nauss (1947) records this species as common in the marine clay shales of the Vanesti tongue of the Belly River, and the upper part of the Lea Park shale. It occurs in the Schrader Bluff formation in northern Alaska.

Types and occurrence.-Figured hypotype (USNM 106509) and unfigured hypotypes (USNM 106510) from well cuttings at 280 to 290 feet in the Barrow Trail member of the Schrader Bluff formation, in Simpson core hole 11 (recorded by Tappan, 1951, as from the Colville formation, which was later elevated to group status).

Figured hypotypes (USNM 106511 a, b) and unfigured hypotypes (USNM 106512) from 260 feet below the top of the Sentinel Hill member of the Schrader Bluff formation, field sample $47 \mathrm{~A}$ Dt 360 .

Unfigured hypotype (USNM 10651t) from Umiat seismograph shot point 15 , at a depth of 20 feet, in the Rogers Creek member of the Schrader Bluff formation.

Unfigured hypotype (USNM P6504) from Umiat seismograph party 46 , line $1-46$, Shot point 14 at $15-$ 20 feet, in the Rogers Creek member of the Schrader Bluff formation.

Unfigured hypotypes (UTSNM P6505) from well cuttings at 760 feet, in the Rogers Creek member of the Schrader Bluff formation, in Gubik test well 2.

The figured specimen regarded as belonging to this species by Tappan (1951, pl. 1, fig. 24, USNM 106513) from the Barrow Trail member of the Schrader Bluff formation, field sample $46 \mathrm{~A}$ Gr 144, is now believed to belong to Praebulimina Carseyae (Plummer).

Family CAUCASINIDAE Bykova, 1959

Genus Lacosteina Marie, 1945

Lacosteina gouskovi Marie

Plate 49, figure 22

Lacosteina Goushovi Marie, 1945, Soc. Géol. France, Bull. ser. 5, v. 13, p. 296, text figs. 1-6.
Test free, elongate, early portion in a nearly planispiral coil, later portion triserial, with few chambers, sutures in early stage radial and flush, later ones slightly depressed; wall calcareous, finely perforate, surface smooth; aperture loop shaped, extending up the face of the final chamber.

Length of figured hypotype $0.33 \mathrm{~mm}$, greatest breadth $0.19 \mathrm{~mm}$. Other hypotypes range from 0.16 to $0.29 \mathrm{~mm}$ in length.

Remarks.-This species was originally described from the Upper Cretaceous of French Morocco, where it occurred with Nonionella cretucea Cushman $(=N$. taylorensis Hofker) a species also associated with it in the Alaskan material. This form is easily identified by the large planispiral early portion, and relatively few triserially arranged chambers.

Types and occurrence.-Figured hypotype (USNM P6690) from field sample $47 \mathrm{~A}$ St 39 , in the Sentinel Hill member of the Schrader Bluff formation.

Unfigured hypotypes (USNM P6691) from field sam-

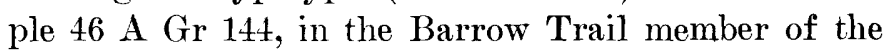
Schrader Bluff formation.

\section{Genus Caucasina Khalilov, 1951 \\ Caucasina vitrea (Cushman and Parker) \\ Plate 49 , figures $23-25$}

Buliminella vitrea Cushman and Parker, 1936. Cushman Lab. Foram. Research, Contr., v. 12, p. 7, pl. 2, fig. 4 ; Cushman, 1946, U.S. Geol. Survey Prof. Paper 206. p. 119, pl. 50, fig. 14; Cushman and Parker, 1947, U.S. Geol. Survey Prof. Paper 210-D, p. 59, pl. 15, fig. 12 ; Frizzell, 1954. Bur. Econ. Geol. Rept. Invest. 22 , p. 114 , pl. 16, fig. 42.

Aeolostreptis vitrea (Cushman and Parker). Loeblich and Tappan, 1957, U.S. Natl. Mius. Bull. 215, p. 227, pl. 72, fig. 20.

Test free, base bluntly rounded, early portion in a low discorbine coil with 6 chambers per whorl, later reduced in number to 3 chambers per whorl and becoming high spired; early chambers low, later ones of about equal breadth and height; sutures distinct, depressed; wall calcareous, finely perforate, granular in structure, surface smooth; aperture loop shaped, at the inner margin of the final chamber, perpendicular to the suture, and with a narrow lip at the forward margin.

Hypotypes range from 0.15 to $0.26 \mathrm{~mm}$ in length.

Remarks.-Originally described from the Upper Cretaceous Selma chalk of Mississippi, this species also occurs in the Austin chalk of Texas. In Alaska it occurs in the Sentinel Hill member of the Schrader Bluff formation.

Types and occurrence.-Figured hypotype (USNM P6680) from a core at 550.6 feet and figured hypotypes 
(USNM P6681a, b) from a core at 719 to 724 feet, all in the Sentinel Hill member of the Schrader Bluff formation, all in Sentinel Hill core test 1.

\section{Family CHILOSTOMELIIDAE Brady, 1881 \\ Genus Pallaimorphina Tappan, 1957 \\ Pallaimorphina ruckerae Tappan \\ Plate 50, figures 1-9}

Pallaimorphina ruckerae Tappan, 1957, U.S. Natl. Mus. Bull. 215, p. 221, pl. 71, figs. 1-9.

Test free, small, trochoid, rotund, and biconvex, periphery broadly rounded; four or five inflated chambers per whorl, increasing gradually in height and rapidly in length as added, so that chambers of final whorl are crescentic in spiral view, about twice as long as high; sutures distinct, slightly depressed, curved and oblique on the spiral side, nearly straight and radial on the umbilical side; wall calcareous, finely perforate, surface smooth; aperture a low sutural slit, extending from the umbilicus about half the distance to the periphery, bordered above by a narrow lip.

Greatest diameter of holotype $0.21 \mathrm{~mm}$, thickness $0.16 \mathrm{~mm}$. Paratypes range from 0.13 to $0.36 \mathrm{~mm}$ in diameter.

Remarks.-Pallaimorphina ruckerce differs from Quadrimorphina allomorphinoides (Reuss) in lacking an extremely broad spatulate apertural flap, having instead only a very narrow one. It is also much smaller and the chambers are subglobular, increasing gradually in size, without developing the extremely radial elongate final chamber characteristic of Quadrimorphina allomorphinoides. Very small young specimens of Reuss" species tend somewhat to resemble the present species, suggesting that this genus may be ancestral to Quadrimorphina.

Quadrimorphina albertensis Mellon and Wall, from the Clearwater formation of Canada, apparently has higher and more inflated chambers than does the Alaskan species and the aperture is nearly peripheral. It is undoubtedly closely related to the present species, however.

P. ruckerce occurs in the Grandstand, Topagoruk, Torok and Fortress Mountain formations. The species was named in honor of Florence Rucker, geologist, U.S. Geological Survey.

Type and occurrence.-Holotype (USNM P4664) and figured paratype (USNM P4665) from a core at 533-543 feet, figured paratypes (ISNM P4666a, b) and unfigured paratypes (TSNM P4667) from a core at 206-211 feet, unfigured paratypes (USNM P4668) from a core at $238-256$ feet, figured paratype (USNM P4669) and unfigured paratypes (USMN P4670) from a core at 256-266 feet, figured paratypes (USNM P4671a, b) from a core at 273-283 feet, unfigured paratypes (USNM P4672) from a core at 338-348 feet, figured paratype (CSNM P4673) from a core at 358-368 feet, unfigured paratypes (USNM P 4674 ) from a core at $438-443$ feet, unfigured paratypes (USNM P4675) from a core at 503-513 feet, unfigured paratypes (USNM P4676) from a core at 533-543 feet, unfigured paratypes (USNM P4677) from a core at 565-578 feet, unfigured paraytpes (USNM P4678) from a core at 663-673 feet, all from the Grandstand formation, and unfigured paratypes (USNM P4679) from a core at 1000-1010 feet, in the Topagoruk formation, all from Simpson test well 1.

Figured paratype (USNM P4680) from a core at $4641 / 2$ feet, in the Grandstand formation, in Umiat test well 2 .

Unfigured paratypes (USNM P4681) from a core at 256-26t feet and unfigured paratypes (USNM P4682) from a core at 461-466 feet, all from the Grandstand formation, in Skull Cliff core test 1.

Unfigured paratypes (USNM P4683) from a core at 558-568 feet, in the Topagoruk formation, in Arcon Point Barrow core test 1.

Unfigured paratype (USNM P4684) from well cuttings at $2545-2550$ feet, in the Grandstand formation, and unfigured paratype (USNM P4685) from well cuttings at $4820-1830$ feet, in the Topagoruk formation, all in Umiat test well 1.

Unfigured paratypes (USNM P4686) from the Kukpowruk formation, field sample $47 \mathrm{~A}$ Ba 83 .

Unfigured paratype (USNM 4687) from the upper part of the Torok formation ('Topagoruk formation equivalent), field sample $47 \mathrm{~A} \operatorname{Tr} 161$.

Unfigured paratypes (USNM P4688) from the Topagoruk formation, field sample $48 \mathrm{~A} \mathrm{~Wb} 24$.

Unfigured paratype (USNM P4689) from field sample 49A Pa 90, unfigured paratype (USNM P4690) from field sample 49A $\mathrm{Pa}$ 94, unfigured paratypes (USNM P4691) from field sample 49A Pa 561 and unfigured paratypes (USNM P4692) from field sample 49A Pa 56t, all from the Fortress Mountain formation.

Unfigured paratypes (USNM P4693) from the Fortress Mountain formation, field sample $49 \mathrm{~A}$ Tr 611.

Unfigured paratypes (USNM P6515) from field sumple $52 \mathrm{~A}$ Wh 33 , and unfigured paratypes (USNM P6516) from field sample 52A Wh 34 , both from the upper part of the Torok formation. 


\section{Family NONIONIDAE Schultz, 1854}

Genus Nonionella Cushman, 1926

Nonionella taylorensis Hofker

Plate 50, figures 10-12

Nonionella cretacea Cushman, 1931 (not Operculina cretacea Reuss, 1862) Tennessee Div. Geol. Bull. 41, p. 42, pl. 7, fig. 2; Cushman 1939, U.S. Geol. Survey Prof. Paper 191, p. 28, pl. 7, fig. 5; Cushman, 1946, U.S. Geol. Survey Prof. Paper 206, p. 101, pl. 43, fig. 24 ; Frizzel1, 1954, Bur. Econ. Geol. Rept. Inv. no. 22, p. 107, pl. 15, fig. 9 .

Nonionella taylorensis Hofker, 1955, Over. Natuurhist. Maandblad, Jg. 44, no. 9-10, p. 99.

Test free, small, enrolled, much compressed, auriculate in outline, all chambers may be visible on the spiral side, the overhanging umbilical chamber margin obscuring those of the earlier whorls on the opposite side; early chambers of nearly equal breadth and height, later one relatively broader, with breadth nearly twice the chamber height, 8 to 10 chambers in the final whorl; sutures gently curved, slightly depressed; wall calcareous, surface smooth, finely perforate; aperture interiomarginal, extending from the peripheral margin somewhat onto the umbilical side.

Hypotypes range from 0.16 to $0.36 \mathrm{~mm}$ in length.

Remarks.-This species is widely distributed in the Gulf Coastal Plain of the United States, occurring in beds of Navarro and Taylor age. In Alaska, it is very limited in occurrence, having been observed only in the Schrader Bluff formation, but occurs in relative abundance where present.

Recorded in the United States as $N$. cretacea Cushman, this species was renamed by Hofker (1955) as it is a junior homonym of Operculina cretacea Reuss, 1862, which also belongs to Nonionella, according to Hofker.

The species is characteristically somewhat compressed, but this feature is accentuated in the Alaskan material by a considerable degree of additional compression, most of the larger specimens thus being crushed and distorted in preservation.

Types and occurrence.-Figured hypotypes (USNM P6637a-c) and unfigured hypotypes (USNM P6638) from field sample $47 \mathrm{~A}$ St 38, and unfigured hypotypes (USNM P6639) from field sample 47 A St 39, all from the Sentinel Hill member of the Schrader Bluff formation.

\section{Family ALABA MINIDAE Hofker, 1951 \\ Genus Globorotalites Brotzen, 1942 \\ Globorotalites alaskensis Tappan \\ Plate 55, figures 6-9}

Globorotalites alaskensis Tappan, 1957, U.S. Natl. Mus. Bull. 215 , p. 220 , pl. 69, figs. 11-13.
Test free, trochoid, flat to slightly convex on the spiral side, strongly convex and centrally umbilicate on the opposite side, periphery subacute; chambers increasing rapidly in size and becoming more oblique spirally, extending back along the periphery, the six to eight chambers of the final whorl may be slightly less elevated than the peripheral keel, presenting an almost collapsed appearance; sutures distinct, oblique on the spiral side and those of final whorl somewhat thickened and elevated, on the umbilical side radial and flush or slightly depressed; wall calcareous, finely perforate, surface smooth; aperture interiomarginal, a low slit extending from the umbilicus almost to the periphery.

Greatest diameter of holotype $0.31 \mathrm{~mm}$, thickness $0.13 \mathrm{~mm}$. Paratypes range from 0.16 to $0.36 \mathrm{~mm}$ in diameter.

Remarks.-Globorotalites alaskensis differs from $G$. multisepta (Brotzen) in being one-third as large, in being less elevated on the umbilical side, in having fewer chambers per whorl, and in the chambers being broader and the sutures less oblique.

It occurs in the Grandstand and Topagoruk formations.

Types and occurrence.-Holotype (USNM P4649) and unfigured paratypes (USNM P4650) from a core at 680-690 feet, in the Grandstand formation, unfigured paratypes (USNM P4651) from a core at 1,429-1,439 feet and figured paratype (USNM P4652) from well cuttings at 1,770-1,780 feet, in the Topagoruk formation, in Umiat test well 2.

Figured paratype (USNM P4653) and unfigured paratypes (USNM P4654) from a core at 206-211 feet, unfigured paratype (USNM P4655) from a core at 211-221 feet, unfigured paratype (USNM P4656) from a core at 555-565 feet, all from the Grandstand formation, in Simpson test well 1.

Figured paratype (USNM P6739) from a core at 342 to 352 feet, in the Grandstand formation, in Simpson core hole 8 .

Unfigured paratypes (USNM P4657) from well cuttings at 190-200 feet, in the Grandstand formation, in Simpson core hole 10.

Unfigured paratypes (USNM P4658) from a core at 874-885 feet, in the Grandstand formation in Simpson core test 25 .

Unfigured paratype (USNM P6742) from well cuttings at 2290 to 2300 feet, in the Torok formation, in South Barrow test well 2. 


\section{Family EPONIDIDAE Hofker, 1951 \\ Genus Eponides Montfort, 1808 \\ Eponides morani Tappan}

Plate 51, figures 1-7

Eponides morani Tappan, 1957, U.S. Natl. Mus. Bull. 215, p. 219 , pl. 70, figs. $1-7$.

Test free, trochoid, biconvex, periphery subacute, all chambers of the $11 / 2$ to $21 / 2$ whorls visible on the spiral side, only the 6 to 8 chambers of the final whorl visible on the umbilicate side, chambers relatively narrow, extending backward at the periphery; sutures distinct, thickened, flush spirally, on the umbilical side nearly radial although slightly curved; wall calcareous, hyaline, relatively coarsely perforate, surface smooth; aperture broad and low, an interiomarginal shit, extending from the umbilical region almost to the peripheral margin.

Greatest diameter of holotype $0.47 \mathrm{~mm}$, thickness 0.18 . Paratypes range in diameter from 0.26 to 0.49 $\mathrm{mm}$.

Remarks.-Eponides morani differs from $E$. repandus (Fichtel and Moll) in being much smaller, with a lower spire, in having six to eight chambers rather than five or six in the final whorl, in lacking a keel, and in having a lower, more slitlike aperture.

The specimen selected as holotype was obtained from well cuttings, but it was selected as type because it was the most complete and best preserved specimen found; its true stratigraphic age is inferred from the occurrence of other specimens in core samples.

This species is found in the Grandstand and Topagoruk formations; its appearance in older rocks is probably due to contamination of the well cuttings. It was named for P. F. Moran, administrative assistant, U.S. Geological Survey.

Types and occurrence.-Holotype (USNM P4638) from well cuttings at $5670-5680$ feet, probably from the Topagoruk formation, found as contamination in the underlying Jurassic rocks, figured paratypes (USNM P4639a-c) and unfigured paratypes (USNM $\mathrm{P} 4640$ ) from a core at 2235-2245 feet, unfigured paratype (USNM P4641) from a core at 2275-2285 feet, all from the Topagoruk formation, unfigured paratype (ISNM P4644) from well cuttings at 3760-3770 feet, unfigured paratype (USNM P4642) from well cuttings at 4180-4190 feet, and figured paratype (USNM P4643) from well cuttings at 5190-5200 feet, all of Topagoruk age but found as contamination in older beds, all from Simpson test well 1.

Figured paratype (USNM P4645) and unfigured paratype (USNM P4646) from the upper part of the Torok formation (Topagoruk formation equivalent), field sample 47A Wh 543, and figured paratype (USNM P4647) and unfigured paratype (USNM $\mathrm{P} 4648)$ from the upper part of the Torok formation (Topagoruk formation equivalent), field sample $47 \mathrm{~A}$ Wh 541.

Unfigured paratypes (USNM P4659) from a core at 2789-2797 feet, in the Grandstand formation, in Oumalik test well 1.

Unfigured paratype (USNM P6738) from a core at 3349-3355 feet, in the Torok formation; in South Barrow test well 1.

Unfigured paratypes (USNM P6741) from the Torok formation, field sample $50 \mathrm{~A}$ Sa 5 .

A specimen (USNM 560391) erroneously listed in the original description (Tappan, 1951, p. 4) as an unfigured paratype of Gavelinella stictata, from cuttings at 3090 to 3100 feet, in the Torok formation, in South Barrow test well 1, also belongs to Eponides morani.

\section{Family CONORBOIDIDAE Hofker, 1951}

This family was described by Hofker as the family Conorbidae based on the type genus Conorbis Hofker, 1951. As the name of the type genus was a junior homonym, the new name Conorboides was proposed by Hofker (in Thalmann, 1952). According to the International Rules of Zoological Nomenclature (Copenhagen Decisions, 1953, p. 36)

where the name of the type genus of a taxon belonging to the Family Group has to be changed because it is found to be a junior homonym, the name of that taxon is to be replaced by a name based upon the changed name of the type genus.

The family name was thus changed to Conorboididae, by Thalmann, 1952, but is credited to Hofker, 1951.

\section{Genus Conorbina Brotzen, 1936 \\ Conorbina species \\ Plate 53, figure 1}

Discorbis norrisi Mellon and Wall, 1956 (part, not the holotype), Research Council Alberta, Rept. 72, p. 15, pl. 2, figs. 9-11.

not Discorbis norrisi Mellon and Wall. Stelck, Wall, Bahan, and Martin, 1956, Research Council Alberta, Rept. 75, p. 30, pl. 2, figs. 4-6.

Test free, small, planoconvex, periphery subacute; all of the two to three whorls visible on the convex spiral side, only the five to six chambers of the final whorl visible on the umbilical side, chambers of greater breadth than height on the spiral side; sutures gently curved backwards at the periphery on the spiral side, radial and slightly curved on the umbilical side; wall calcareous, finely perforate, surface smooth; aperture on the umbilical side, beneath the umbilical chamber margin. 
Greatest diameter ranges from 0.16 to $0.36 \mathrm{~mm}$.

Remarks.-This species is quite rare in Alaska, only a few poorly preserved specimens occurring in the Torok and Fortress Mountain formations. The paratype of Discorbis norrisi Mellon and Wall, figured in 1956 (pl. 2, figs. 9-11), is of the present species. The holotype of $D$. norrisi was first figured in the later publication of Stelck, Wall, Bahan, and Martin (1956, pl. 2, figs. 4-6) and is distinct from the above-mentioned paratype. The holotype of $D$. norrisi (and thus the nominal species) belongs to Gavelinella stictata (Tappan). It is a larger species, coarsely perforate, thicker, with a distinctive brownish color, and an aperture characteristic of Gavelinella.

Possibly the specimen figured by Mellon and Wall (1956, pl. 1, figs. 18-20) as Conorbina sp. B. may also belong to the present species. That figured as Conorbina sp. A by Mellon and Wall (1956, pl. 1, figs. 2224) appears to be Conorbina conica Lozo, which was originally described from the Glen Rose and Goodland formations of Texas.

Conorbina conica Lozo differs from the present form in being larger and higher spired, with chambers much lower, broader and more overlapping on the spiral side.

Types and occurrence-Figured specimen (USNM P6780) from a core at 1388 to 1396 feet in the Torok formation, in South Barrow test well 3.

Unfigured specimens (USNM P6781) from field sample $49 \mathrm{~A} \operatorname{Tr} 575$, in the Fortress Mountain formation.

\section{Genus Conorboides Hofker, 1952 \\ Conorboides umiatensis (Tappan)}

Plate 52, figures 1-10

Nanushukella umiatensis Tappan, 1957, C.S. Natl. Mus. Bull. 215 , p. 219, pl. 69, figs. 1-10.

Test free, trochoid, planoconvex, with a low rounded spire of about $21 / 2$ volutions, periphery rounded; chambers increasing rapidly in size, semilunate on the spiral side, about six in the early whorls and commonly only four in the final whorl, last chamber occupying about one-third of the umbilical side; sutures distinct, flush on the spiral side and may be somewhat limbate, depressed and nearly radial on the umbilical side; wall calcareous, coarsely perforate, surface smooth; aperture a low arch at the umbilical margin of the final chamber extending over much of the length of this margin, bordered above by a narrow apertural flap that has a fimbriate edge, apertures of earlier chambers of the final whorl all remaining open and visible, radiating from the open umbilicus.
Greatest diameter of holotype $0.29 \mathrm{~mm}$, height 0.16 $\mathrm{mm}$. Paratypes range from 0.18 to 0.34 in diameter.

Remarks.-This species was originally described as the type species for the genus Nanushukella Tappan. Specimens of Conorboides mitra (Hofker), from the Netherlands, obtained through the courtesy of Dr. J. $H$. van Voorthuysen, were later determined to be congeneric, hence Nanushukella becomes a synonym. The present species differs from $C$. mitra, from the Albian of the Netherlands, in being smaller, and lower spired. In $C$. mitra the periphery is more angular, the chambers are broader and lower, and the final chamber occupies a larger proportion of the umbilical side.

Conorboides umiatensis differs from Conorbina conica Lozo in having higher and less arcuate chambers as seen from the spiral side, a lower, more rounded spire, less oblique sutures, the characteristic umbilical aperture with serrated lip, and the earlier apertures remaining open throughout later development.

Types and occurrence.-Holotype (USNM P4619), figured paratype (USNM P4620), and unfigured paratypes (USNM P4621) from a core at 565-578 feet, unfigured paratypes (USNM P4622) from a core at 206-211 feet, figured paratypes (USNM P4623 a-c) and unfigured paratypes (USNM P4624) from a core at 238-256 feet, unfigured paratypes (USNM P4625) from a core at 338-348 feet, figured paratypes (USNM $\mathrm{P} 4626 \mathrm{a}, \mathrm{b}$ ) and unfigured paratypes (USNM P4627) from a core at 348-358 feet, unfigured paratypes (USNM P4628) from a core at $438-443$ feet, figured paratype (USNM P4629) and unfigured paratypes (USNM P4630) from a core at 513-523 feet, and unfigured paratypes (USNM P4631) from a core at 543545 feet, all from the Grandstand formation, Nanushuk group; unfigured paratype (USNM P4632) from a core at 1758-1768 feet and unfigured paratype (USNM P4633) from well euttings at 1990-2000 feet, both from the Topagoruk formation, in Simpson test well 1.

Figured paratype (USNM P4570a) and unfigured paratypes (USNM P4570b, P4571) from the Kukpowruk formation, field sample $47 \mathrm{~A}$ Tm 10.

Figured paratype (USNM P6743a) and unfigured paratype (USNM P6743b) from cuttings at 2980 to 2990 feet.

Unfigured paratype (USNM P6733) from a core at 3341 to $33 \pm 6$ feet, and unfigured paratype (USNM $\mathrm{P} 6734$ ) from a core at $3355-3360$ feet, all in the Torok formation, in South Barrow test well 1.

Unfigured paratypes (USNM P6735, P6736) from a core at 2030 to 2040 feet, and unfigured paratypes (USNM P6737) from a core at 2050 to 2060 feet, all in the Torok formation, in South Barrow test well 2. 
Unfigured paratype (USNM 106138) from well cuttings at 1560-1570 feet, unfigured paratypes (USNM 106137) from a core at 1850-1855 feet, unfigured paratype (USNM 106136) and unfigured paratype (USNM P4634) from well cuttings at 2610-2620 feet, from the Topagoruk formation, in Umiat test well 2.

Unfigured paratypes (USNM P4635) from the Fortress Mountain formation, field sample $49 \mathrm{~A} \operatorname{Tr} 611$.

Cnfigured paratype (USNM P4572) from the lower part of the Fortress Mountain formation, field sample $49 \mathrm{~A} \mathrm{~Pa} 81$, and unfigured paratype (USNM P4636) from the middle part of the Fortress Mountain formation, field sample $49 \mathrm{~A} \mathrm{~Pa} 468$.

Unfigured paratype (USNM P4637) from seismograph party 47 test hole, line $14 \mathrm{~A}-48$, shot hole 37 , at a depth of 190-200 feet, in the Grandstand formation.

\section{Genus Eurycheilostoma Loeblich and Tappan, 1957 \\ Eurycheilostoma grandstandensis Tappan}

Plate 53, figures 6-12

Eurycheilostoma grandstandensis Tappan, 1957, U.S. Natl. Mus. Bull. 215, p. 217, pl. 68, figs. 19-25.

Test free, trochoid, extremely high spired, all whorls visible spirally, only the final whorl visible on the concave, widely umbilicate opposite side, triserial throughout, chambers increasing gradually in size in the early portion, forming a gradually enlarging spire, later chambers enlarging rapidly and becoming inflated, so that there may be a distinct change in the diameter of the test with the final whorl, the final chamber occupying one-half to two-thirds of the umbilical side of the test; sutures distinct, flush in the early spire, depressed in the later portion; wall calcareous, finely but distinctly perforate, surface smooth, aperture an arch at the inner margin of the final chamber opening into the umbilicus, partly covered by an extensive although narrow flap which has a serrate border in all well preserved specimens, with an apertural reentrant occurring at both extremities of this flap.

Greatest diameter of holotype $0.16 \mathrm{~mm}$, height of spire $0.31 \mathrm{~mm}$. Paratypes range from 0.13 to $0.26 \mathrm{~mm}$ in diameter.

Remarks.-This species differs from E. altispira Loeblich and Tappan in being larger and extremely high spired and in having the conical early portion commonly followed by an abrupt flaring of the final whorl. It differs from $E$. robinsonae Tappan in being much higher spired, with a pointed apex and nearly flush sutures in the early development.

E. grandstandersis occurs in the Grandstand and Topagoruk formations.

Types and occurrence-Holotype (USNM P4595), figured paratypes (USNM P4596 a, b), and unfigured paratype (USNM P4597) from a core at 555-565 feet, unfigured paratypes (USNM P4598) from a core at 433-438 feet, unfigured paratypes (USNM P4599) from a core at 543-545 feet, all from the Grandstand formation; unfigured paratypes (USNM P4600) from a core at 1030-1040 feet, unfigured paratypes (USNM $\mathrm{P} 4601$ ) from a core at 1070-1080 feet, unfigured paratypes (USNM P4602) from a core at 1247-1267 feet, figured paratype (USNM P4603) and unfigured paratypes (USNM P4604) from a core at 1360-1370 feet, figured paratype (USNM P4605) and unfigured paratypes (USNM P4606) from well cuttings at 1580-1590 feet, unfigured paratypes (USNM P4607) from well cuttings at $1760-1770$ feet, unfigured paratypes (USNM P4608) from well cuttings at 1870-1880 feet, unfigured paratypes (USNM P4609) from a core at 1967-1977 feet, unfigured paratypes (USNM P4610) from a core at 2024-2026 feet, and figured paratypes (USNM P4611 a, b) from well cuttings at 2390-2395 feet, all from the Topagoruk formation, from Simpson test well 1.

Unfigured paratypes (USNM P4612) from well cuttings at $4180-4190$ feet, unfigured paratypes (USNM P4613) from well cuttings at $4220-4230$ feet, unfigured paratypes (USNM P4614) from well cuttings at 43404350 feet, all from the Topagoruk formation, in Umiat test well 1.

Unfigured paratypes (USNM P4615) from well cuttings at $4140-4150$ feet and unfigured paraytpes (USNM P4616) from a core at 5585-5595 feet, in the Topagoruk formation in Umiat test well 2.

Unfigured paratypes (USNM P4617) from 2390 feet below the top of the Grandstand formation, field sample $47 \mathrm{~A}$ Dt 227.

Unfigured paratypes (USNM P4618) from the lower part of a 50-foot section of the Topagoruk formation, field sample $47 \mathrm{~A}$ Tr 167.

\section{Eurycheilostoma robinsonae Tappan \\ Plate 53, figures 2-5}

Eurycheilostoma robinsonae Tappan, 1957, U.S. Natl. Mus. Bull. 215, p. 218, pl. 70, figs. 8-11.

Test free, trochoid, conical, with a much elevated spire of about four volutions, umbilical side concave with open and extensive umbilicus, periphery rounded; chambers inflated, increasing rapidly in size, later ones becoming semilunar in spiral view but relatively high as seen in edge view, final whorl with only three chambers, the last chamber occupying about three-fifths the area of the umbilical side; sutures distinct, slightly depressed; wall calcareous, finely but distinctly perforate, surface smooth; aperture an arch at the inner 
margin of the final chamber, opening into the umbilicus and partly covered by an umbilical flap of the chamber, which has a serrated border and an apertural reentrant into the chamber face at each extremity of the flap.

Greatest diameter of holotype $0.29 \mathrm{~mm}$, height of spire $0.31 \mathrm{~mm}$. Paratypes range from 0.13 to 0.29 $\mathrm{mm}$ in diameter.

Remarks.-Eurycheilostoma robinsonae differs from the associated $E$. grandstandensis Tappan in the much lower spire and more regular increase in chamber size. It differs from E. altispira Loeblich and Tappan in being about twice as large and higher spired.

This species is found in the Grandstand and Topagoruk formations, and was named in honor of Florence Robinson, geologist, U.S. Geological Survey.

Types and occurrence--Holotype (USNM P4584) and unfigured paratypes (USNM P4585) from a core at 651-661 feet, in the Topagoruk formation, in Arcon Point Barrow core test 1.

Figured paratype (USNM P4586) from a core at 264 feet, in the Grandstand formation, in Skull Cliff core test 1 .

Figured paratype (USNM P4587) and unfigured paratypes (USNM P4588) from a core at 2024-2026 feet, unfigured paratypes (USNM P4589) from well cuttings at 1760-1770 feet, and unfigured paratypes (USNM P4590) from well cuttings at 1840-1850 feet, all from the Topagoruk formation, in Simpson test well 1.

Figured paratype (USNM P4591) and unfigured paratypes (USNM P4592) from a marine zone at the base of a 640-foot section of the Kukpowruk formation, field sample $47 \mathrm{~A} \mathrm{Ba} 67$.

\section{Family VALVULINERIIDAE Brotzen, 1942 \\ Genus Valvulineria Cushman, 1926 \\ Valvulineria loetterlei (Tappan) \\ Plate 54, figures 1-4}

Pulvinulina sp. Margaret Carpenter, 1925, Texas Univ. Bull. 2544 , p. 17, figs. 11, 12.

Gyroidina nitida (Reuss). Plummer 1931 (not Rotalina nitida Reuss, 1841), Texas Univ. Bull. 3101, p. 191, pl. 14, fig. 5.

Gyroidina loetterlei Tappan, 1940, Jour. Paleontology, v. 14, no. 2, p. 120, pl. 19, fig. $10 ; 1943$, Jour. Paleontology, v. 17, no. 5, p. 512, pl. 82, fig. 9; Frizzell, 1954, Bur. Econ. Geol. Rept. Invest. 22, p. 124, pl. 18, fig. 41.

Valvulineria loetterlei (Tappan). ten Dam and Schijfsma, 1944, Soc. Géol. France, C. R. Sommaire, p. 143.

Gyroidina sp. A. Wickenden, 1951, Geol. Survey Canada Paper 51-16, p. 41, pl. IA, fig. 30 .

Gyroidina (f. G. nitida (Reuss). Stelck, Wall, Bahan and Martin, 1956 (not Rotalina nitida Reuss, 1844, and not Gyroidina nitida (Reuss) Cushman, 1946), Research Council Alberta, Rept. 75, p. 33, pl. 1, figs. 11-13, pl. 2, figs. 7-9.
Test free, small, robust, periphery broadly rounded, peripheral outline slightly lobulate; chambers inflated, 5 to 7 in the final whorl, with from 2 to $2 \frac{1}{2}$ whorls present, the early whorls comprising only a small portion of the spiral side, final chamber with a relatively large umbilical flap which covers the umbilicus and the flaps of preceding chambers; sutures distinct, radial, gently curved, slightly depressed; wall calcareous, finely perforate, surface smooth; aperture a low equatorial arch extending somewhat onto the umbilical side.

Hypotypes range from 0.16 to $0.39 \mathrm{~mm}$ in diameter.

Remarks.-This species has the large umbilical flap characteristic of Valvulineria, and does not show the numerous apertural lips of Gyroidinoides Brotzen, of which Rotalina nitida Reuss is the type. True Gyroidina has an open umbilicus surrounded by many small umbilical flaps, and a more restricted aperture. This species was originally described from the Grayson formation (lower Cenomanian) of Texas and also occurs in older formations of the Washita group (of Albian age). It differs from Valvutineria gracillima ten Dam, from the Albian of the Netherlands, France and England, in being smaller and more robust, with more broadly rounded periphery and larger umbilical flap.

Valvulineria loetterlei occurs in the Spirit River, Loon River, Moosebar and Clearwater formations, in Alberta and British Columbia, Canada, and is common in the Grandstand and Topagoruk formations and rare in the Torok formation in northern Alaska. Stelck, Wall, Bahan and Martin (1956, p. 34) considered it as "a good index of Middle Albian age in northwest Canada". In both Alaska and the type area of the Gulf Coast, it ranges from middle Albian upward into late Albian and early Cenomanian. Possibly the more restricted range in Canada is due to less favorable local conditions during this later time.

Types and occurrence.-Figured hypotype (USNM P6767) and unfigured hypotypes (USNM P6794) from a core at 1152 to 1162 feet, and unfigured hypotype (USNM P6795) from a core at 447 to 457 feet, all in the Topagoruk formation, in Arcon Point Barrow core test 1.

Figured hypotype (USNM P6768) and unfigured hypotypes (USNM P6796) from a core at 1967 to 1977 feet, unfigured hypotypes (USNM P6797) from a core at 1070 to 1080 feet, unfigured hypotypes (USNM P6798) from a core at 1570 to 1575 feet and figured hypotype (USNM P6769) from a core at 2535 to 2540 feet, all from the Topagoruk formation, unfigured hypotype (USNM P6799) from a core at 533 to 543 feet and unfigured hypotypes (USNM P6770) 
from a core at 743 to 753 feet, both from the Grandstand formation, in Simpson test well 1.

Figured hypotype (USNM P6771) from a core at 2145 to 2150 feet, and unfigured hypotype (USNM P6800) from a core at 1850 to 1855 feet, both in the Topagoruk formation, in Umiat test well 2.

Unfigured hypotype (USNM P6772) from a core at 2030 to 2040 feet, in the Torok formation, in South Barrow test well 2.

Unfigured hypotype (USNM P6773) from a core at 2094 to 2103 feet, in the Topagoruk formation, in East Topagoruk test well 1.

Unfigured hypotype (USNM P6774) from field sample $47 \mathrm{~A}$ Wh 542 , in the Topagoruk formation.

Unfigured hypotype (USNM P6801) from a core at 3046 to 3069 feet, in the Torok formation, in South Barrow test well 1.

Unfigured hypotype (USNM P6802) from cuttings at 4140 to 4150 feet, and unfigured hypotype (USNM P6803) from cuttings at 5280 to 5290 feet, both from the Topagoruk formation in Umiat test well 1.

Unfigured hypotypes (USNM P6804) from the Grandstand formation, in Seismograph shot hole, Party 47, line $14-\mathbf{A}-48$, shot hole 38 , at 120 to 130 feet.

Unfigured hypotype (USNM P6805) from field sample 47A Dt 227, in the Grandstand formation.

\section{Family ASTERIGERINIDAE d'Orbigny, 1839 \\ Genus Eoeponidella Wickenden, 1949 \\ Eoeponidella linki Wickenden \\ Plate 54, figures 9, 10}

Eoeponidella linki Wickenden, 1949, Royal Soc. Canada, Trans. 3rd ser., v. 42, sec. 4 , p. 81 , text fig. 1 .

Test free, small, planoconvex, convex spiral side with two or three volutions, five or six semilunar chambers in each whorl, only the chambers of the final whorl visible on the umbilical side, with small supplementary chambers covering their inner margin around the umbilicus; sutures distinct, oblique and flush on the spiral side, moderately depressed, straight and radial on the umbilical side; wall calcareous, finely perforate, surface smooth; aperture a small interiomarginal arch.

Hypotypes range from 0.23 to $0.31 \mathrm{~mm}$ in diameter.

Remarks.-This species was described from the Upper Cretaceous of Saskatchewan, Canada, in beds equivalent to the upper part of the Lea Park formation, and possibly the equivalent of the Grizzly Bear member. It occurs in the Sentinel Hill member of the Schrader Bluff formation in Alaska.

Types and occurrence.-Figured hypotype (USNM 106139) from the Sentinel Hill member of the Schrader Bluff formation, field sample 47A Dt 360.
Figured hypotype (USNM 106140) from cuttings at 380 to 390 feet, in the Sentinel Hill member of the Schrader Bluff formation, Simpson core hole 11.

Unfigured hypotypes (USNM P6740) from a core at 765 to 769 feet, in the Sentinel Hill member of the Schrader Bluff formation, in Sentinel Hill core test 1.

\section{Eoeponidella strombodes Tappan}

Plate 54, figures 5-8

Eoeponidella strombodes Tappan, 1951, Cushman Found. Foram. Research, Contr., v. 2, pt. 1, p. 6, pl. 1, figs. 22a-c ; Tappan, 1951, in Payne and others, U.S. Geol. Survey Oil and Gas Inv. Map OM-126, sheet 3, fig. 21 (4a-c).

Test free, small, biconvex, trochoid, umbilicate, periphery subacute; all whorls visible on the spiral side, only the seven or eight chambers of the final whorl visible on the umbilical side, chambers of approximately equal breadth and height, stellar chambers of the umbilical side somewhat inflated, small, reaching slightly more than half the distance from the umbilicus to the periphery and alternating in position with the larger primary chambers, outer margin of the stellar chambers angular, each chamber forming an acute angle; sutures distinct, slightly curved backwards at the periphery on the spiral side, straight and radiate on the umbilical side, sutures of the stellate portion slightly depressed; wall calcareous, with rather large perforations, surface smooth; aperture an arch at the umbilical side of the final chamber, adjacent to the preceding stellate chamber.

Greatest diameter of holotype $0.36 \mathrm{~mm}$, least diameter $0.29 \mathrm{~mm}$, greatest thickness $0.10 \mathrm{~mm}$. Other specimens are between 0.16 and $0.39 \mathrm{~mm}$ in diameter.

Remarks.-This species differs from Eoeponidella linki Wickenden in being more lenticular in shape and in having more chambers per whorl, with 7 to 8 primary chambers in the final whorl, instead of only 5 to 6 . The supplementary umbilical chambers have a more stellate arrangement in the present species, appearing to alternate with the primary chambers rather than paralleling them. The Alaskan species is also about one-third larger. Eoeponidella strombodes occurs throughout only about 200 feet of stratigraphic section, from 800 to 1,000 feet above the base of the Sentinel Hill member of the Schrader Bluff formation in northern Alaska.

Types and occurrence.-Holotype (USNM 560392), and figured paratypes (USNM $560393 \mathrm{a}, \mathrm{b}$ ) from a core at 719 to 724 feet, in the Sentinel Hill member of the Schrader Bluff formation, in Sentinel Hill core test 1.

Figured paratype (USNM 560394) and unfigured paratypes (USNM P6749) from the Sentinel Hill 
member, Schrader Bluff formation, field sample $47 \mathrm{~A}$ St 39.

\section{Family HETEROHELICIDAE Cushman, 1927}

\section{Subfamily HETEROHELICINAE Cushman, 1927}

Genus Heterohelix Ehren berg, 1841

Heterohelix globulosa (Ehrenberg)

Plate 55, figures 1, 2

Textularia globulosa Ehrenberg, 1834, K. preuss. Akad. Wiss. Berlin Abh., p. 135, pl. 4, fig. 4B.

Gümbelina globulosa (Ehrenberg) Egger, 1899, K. Bayer. Akad. Wiss. Math. naturh. Abt., Abh. Kl. 2, v. 21, pt. 1, p. 32, pl. 14, fig. 43 ; Carman, 1929, Jour. Paleontology, v. 3, p. 312, pl. 34, figs. 10-20; Morrow, 1934, Jour. Paleontology, v. 8, p. 194, pl. 29, fig. 18; Loetterle, 1937, Nebraska Geol. Survey Bull., 2nd ser., Bull. 12, p. 34 , pl. 5, fig. 3 ; Cushman, 1946, U.S. Geol. Survey Prof. Paper 206, p. 105, pl. 45, figs. 9-15; Young, 1951, Jour. Paleontology, v. 25, no. 1, p. 63, pl. 14, figs. $12,23-26$; Loeblich, 1951, Cushman Found. Foram. Research, Contr., v. 2, pt. 3, p. 108, pl. 12, figs. 4, 5; Stelck and Wall, 1954, Research Council Alberta, Rept. 68, p. 22, pl. 2, fig. 20; Frizzell, 1954, Bur. Econ. Geol. Rept. Inv. 22, p. 109, pl. 15, figs. 24-27.

Heterohelix globulosa (Ehrenberg) Montanaro Gallitelli, 1957, U.S. Natl. Mus. Bull. 215, p. 137, pl. 31, figs. 12-15.

Test free, small, biserial, flaring, with 5 to 7 pairs of nearly globular chambers, rapidly enlarging in size; sutures distinct, constricted; wall calcareous, finely perforate, surface smooth; aperture a broad low symmetrical arch at the inner margin of the final chamber.

Hypotypes range from 0.15 to $0.26 \mathrm{~mm}$ in length, and from 0.10 to $0.13 \mathrm{~mm}$ in breadth.

Remarks.-As shown by Montanaro Gallitelli (1957) the genus Guembelina is a synonym of Heterohelix, the degree of development of the early coil being a variable characteristic, which may be restricted to the microspheric generation. The present species is extremely rare in northern Alaska, where it occurs in a restricted zone within the Seabee formation. Probably because of its rarity and extremely small size, no specimens with an early coil have been observed in the Alaskan material.

Types and occurrence.-Figured hypotypes (USNM P6643 a, b) and unfigured hypotypes (USNM P6644) from a core at 655 feet, in the Seabee formation, in Simpson core test 13.

Unfigured hypotypes (USNM P6645) from a core at 153 to 162 feet, in the Seabee formation, in Simpson core test 30 .

\section{Family ROTALIPORIDAE, 1958}

Genus Hedbergella Bronnimann and Brown, 1958

Hedbergella loetterlei (Nauss)

Plate 55, figures $3-5$

Globigerina loetterli Nauss, 1947, Jour. Paleontology, v. 21, no. 4 , p. 336 , pl. 49 , figs. $11 a-c$.
Globigerina loetterlei Nauss. Tappan, 1951, Cushman Found. Foram. Research Contr., v. 2, pt. 1, p. 4, pl. 1, figs. 19a-c; Tappan, 1951, in Payne and others, U.S. Geol. Survey Oil and Gas Inv. Map OM-126, sheet 3, fig. 21 (8), not Globotruncana (Rugoglobigerina) loetterli loetterli (Nauss). Gandolfi, 1955, Bull. Am. Paleontology, v. 36, no. 155, p. 35, pl. 1, fig. 15.

Test free, small, trochospiral, with wide umbilicus; chambers globular, increasing rapidly in size in the early stages, later ones increasing very gradually in size, about six in the final whorl; sutures distinct, depressed; wall calcareous, hyaline, distinctly perforate; aperture interiomarginal, an extraumbilical-umbilical arch.

The species ranges in diameter from 0.18 to 0.29 $\mathrm{num}$, and is $0.10 \mathrm{~mm}$ in thickness.

Remarks.-According to Nauss (1947, p. 336) "Floods of this species are characteristic of the central part of the Lloydminster shale where the species is associated with a few specimens of Gümbelina globulosa (Ehrenberg). It has been encountered in this zone in wells in the Vermilion area, in southern Alberta and in an outcrop at Green Lake 112 miles northeast of Lloydminster". In northern Alaska, it occurs in the Seabee formation and the Rogers Creek member of the Schrader Bluff formation, Colville group, but is most characteristic of the Seabee formation, where it is also associated with Heterohelix (= Guembelina). Both genera are rare elsewhere in the Alaskan Cretaceous, and are present in abundance only locally in the Seabee formation. The Alaskan specimens are smaller than those from the type area in Canada.

Recent revisions of planktonic genera (Bronnimann and Brown, 1956, and Bolli, Loeblich, and Tappan, 1957) have restricted the genus Globigerina to the species with simple umbilical aperture. The extraumbilical aperture of this species precludes such assigiment. The species was placed in Rugoglobigerina by Gandolfi $(1955$, p. 35) but an examination of the holotype of this species, from Canada, and the specimens from Alaska, shows no indication of the apertural tegilla or coverplate characteristic of that genus. The species in Colombia is apparently distinct. The globular chambers, trochospiral coil, extraumbilical aperture and lack of umbilical tegilla or accessory or supplementary apertures places this species in the genus Hedbergella Bronnimann and Brown, 1958.

Types and occurrence.-Figured hypotype (USNM No. 106498) and unfigured hypotypes (USNM No. 106499) from a core at 655 feet in the Seabee formation in Simpson core test 13.

Unfigured hypotypes (USNM P6500) from a core at 153 to 162 feet in the Seabee formation in Simpson core test 30 . 
Unfigured hypotype (USNM P6512) from a core at 1,030 to 1,050 feet in the Seabee formation, in Umiat test well 11.

Figured hypotypes (USNM $106500 \mathrm{a}, \mathrm{b}$ ) from the lower member of the Seabee formation, field sample $47 \mathrm{~A} \mathrm{~Wb} 213$.

\section{Family GAVELINELIIDAE Hofker, 1956 \\ Genus Gavelinella Brotzen, 1942 \\ Gavelinella ammonoides (Reuss) \\ Plate 56, figures 8,9}

Rosalina ammonoides Reuss, 1846, verstein böhmischen Kreideform.. Stuttgart, pt. 1, p. 36, pl. 8, fig. 53, pl. 13, fig. 66 .

Anomalina ammonoides (Reuss). Franke, 1928. Abh. Preuss. Geol. Landesanst., n. ser., v. 111, p. 180, pl. 16, fig. 8.

Garelinella ammonoides (Reuss). Brotzen, 1942, Sveriges geol. Undersökning, ser. C., no. 451, Årsbok 36, no. 8, p. 47, text fig. 16.

Test small, trochospiral, planoconvex, with flattened spiral side of about two whorls, umbilical side elevated, with central area filled by a large, clear umbilical boss through which earlier whorls may be seen; 12 to 13 chambers in the final whorl, broad and low; sutures flush to slightly depressed, gently curved; wall calcareous, finely perforate, surface smooth; aperture not observable on the Alaskan specimens, due to the poor state of preservation.

Hypotypes range from 0.15 to $0.19 \mathrm{~mm}$ in diameter.

Remarks.-The rare Alaskan specimens are somewhat smaller than is typical for the species, but as much of the associated fauna is quite small this may be environmentally caused. The specimens are otherwise similar in appearance.

Types and occurrence.-Figured hypotypes (USNM P6750 a, b) and unfigured hypotype (USNM P6751) from cuttings at 290 to 300 feet, in the Sentinel Hill member of the Schrader Bluff formation, in Simpson core hole 11.

\section{Gavelinella awunensis Tappan}

Plate 56, figures $1-7$

Gavelinella awunensis Tappan, 1960, Am. Assoc. Petroleum Geologists Bull., v. 44, no. 3, p. 296. pl. 2. figs. 15-16.

Test free, trochospiral, planoconvex, with whorls partially overlapping on both sides, spiral side flattened, only partly evolute, umbilical side convex, umbonate; chambers increasing gradually in size, 8 to 12 in the final whorl; sutures distinct, gently curved, somewhat thickened and flush on the spiral side, depressed on the umbilical side; wall calcareous, distinctly perforate, surface smooth; aperture a low interiomarginal slit extending from the peripheral margin onto the umbilical side, beneath the umbilical chamber flaps.
Greatest diameter of holotype $0.36 \mathrm{~mm}$, thickness $0.15 \mathrm{~mm}$. Paratypes range from 0.18 to $0.41 \mathrm{~mm}$ in greatest diameter.

Remarks.-Gavelinella intermedia (Berthelin) from the Albian of France differs from the present species in being larger, more compressed and more equally biconvex. Gavelinella tormarpensis Brotzen from the Gault (Albian) of Sweden, has fewer chambers per whorl and is more nearly equally biconvex. The associated Alaskan species, Gr. stictata (Tappan) differs in being larger, more robust, more coarsely perforate, has a convex rather than flattened umbilical side and has fewer chambers in the final whorl.

Types and occurrence--Holotype (USNM P6752) from a core at 2040 to 2050 feet, figured paratype (USNM P6753) and unfigured paratypes (USNM P6806) from a core at 2000 to 2010 feet, and figured paratypes (USNM P6754 a, b) and unfigured paratypes (USNM P6807) from a core at 2030 to 2040 feet, all in the Torok formation, in South Barrow test well 2.

Figured paratype (USNM P6755) from well cuttings at 3110 to 3120 feet, in the Torok formation, in South Barrow test well 1.

Figured paratypes (USNM P6756 a, b) from well cuttings at 2160 to 2170 feet, in the Topagoruk formation, in Simpson test well 1.

\section{Gavelinella intermedia (Berthelin)}

Plate 58, figure 1

Anomalina intermedia Berthelin, 1880, Soc. Geol. France, Mém. ser. 3 , v. 1, mém. 5, p. 67, pl, 4, fig. 14.

Anomalina ammonoides (Reuss). Chapman, 1898 (not Rosalina ammonoides Reuss, 1845), Roval Micr. Soc. Jour., p. 4 , pl. 1, fig. 5 .

Gavelinella intermedia (Berthelin). Brotzen, 1942, Sveriges Geol. Undersök, ser. C, no. 451, Års. 36, no. 8 , p. 52, text fig. 18; Hofker, 1957, Beih. Geol. Jb., v. 27, p. 285, 303, text figs. 336, 337 .

Test free, small, coiled, nearly planispiral, but with earlier whorls also visible on umbilical side, spiral side umbonate, periphery subacute; chambers increasing gradually in size as added, 9 to 11 in the final whorl, early ones broad and low, later ones relatively higher; sutures slightly depressed, moderately to strongly curved; wall calcareous, perforate, smooth; aperture a low arch on the periphery, extending back on umbilical side beneath the successive umbilical flaps.

Hypotypes range from 0.18 to $0.28 \mathrm{~mm}$ in diameter. Remurks.-Originally described from the Albian of France, this species has also been recorded in equivalent strata in England and the Netherlands. It is rare in Alaska. 
Type and occurrence.-Figured hypotype (USNM $\mathrm{P} 6757$ ) from a core at 3,349 to 3,352 feet, in the Torok formation, in South Barrow test well 1.

\section{Gavelinella stictata (Tappan)}

Plate 57, figures 1-10

Discorbis stictata Tappan, 1951, Cushman Found. Foram. Research, Contr., v. 2, pt. 1, p. 4, pl. 1, figs. 18a-c; Tappan, 1951, in Payme and others, U.S. Geol. Survey Oil and Gas Invest. Map OM-126, sheet 3, fig. 21 (10-a-c).

?Discorbis norrisi Mellon and Wall, 1956 (part), Research Council Alberta, Rept. 72, p. 15 (not pl. 2, figs. 9-11) ; Stelck, Wall, Bahan, and Martin, 1956, Research Council Alberta, Rept. 75, p. 30, pl. 2, figs. 4-6.

Test free, large, biconvex, trochoid, umbilicate, periphery subacute; all chambers of the $21 / 2$ whorls visible on the spiral side, only the six to eight of the final whorl visible on the umbilical side, chambers increasing gradually in size as added; sutures distinct, thickened, especially in the umbilical region, flush or slightly depressed, oblique and reaching backwards at the periphery on the spiral side, gently curved and more radiate on the umbilical side; wall calcareous, very coarsely perforate, commonly with a distinctive brownish color; aperture an arch at the base of the final chamber near the periphery on the umbilical side, extending backward as a slit along the basal margin of the chamber.

Greatest diameter of holotype $0.47 \mathrm{~mm}$, least diameter $0.39 \mathrm{~mm}$, greatest thickness $0.16 \mathrm{~mm}$. Other specimens range between 0.31 and $0.73 \mathrm{~mm}$ in diameter.

Remarks.-Originally described as a species of Discorthis, recent studies of the type species of many of the trochospirally coiled calcareous genera have shown that the present species must be reassigned. Because of the apertural characters, it is here placed in Gavelinella Brotzen.

Discorbis norrisi Mellon and Wall, 1956, appears to be identical with the present species. The holotype was figured in a later paper (Stelck, Wall, Bahan and Martin, 1956), the originally figured paratype apparently representing a distinct species. The holotype of $D$. norrisi was from the Wilrich member of the Spirit River formation, in Alberta, Canada. The species was also reported from the upper part of the Loon River formation and the lower part of the Clearwater formation.

Types and occurrence.-Holotype (USNM 560385), figured paratype (USNM P6741) and unfigured paratypes (USNM 560386) from a core at 1010 to 1020 feet, figured paratypes (USNM $560388 \mathrm{a}, \mathrm{b}$ ) and unfigured paratypes (USNM P6809) from a core at 1030 to 1040 feet, all in the Topagoruk formation, and unfigured paratypes (USNM 560387) from a core at 293 to 303 feet, in the Grandstand formation, all in Simpson test well 1.

Figured paratype (USNM P6742) and unfigured paratypes (USNM P6810) from a core at 366 to 376 feet, and unfigured paratypes (USNM 560389) from a core at 466 to 476 feet, all in the Grandstand formation, in Skull Cliff core test 1.

Unfigured paratypes (USNM 560390) from a core at 236 to 246 feet, in the Topagoruk formation in Arcon Point Barrow core test 1.

Figured paratype (USNM P6743) and unfigured paratypes (USNM P6811) from a core at 853 to 864 feet, and figured paratype (USNM P6744) and unfigured paratypes (USNM P6812) from a core at 864 to 874 feet, all in the Grandstand formation in Simpson core test 25 .

Unfigured paratypes (USNM P6745) from a core at 520 to 529 feet, in the Grandstand formation, in Umiat test well 3.

Unfigured paratype (USNM P6746) from a core at 1630 to 1635 feet, in the Grandstand formation in Umiat test well 1.

Unfigured paratypes (USNM P6747) from a core at 680 to 690 feet, in the Grandstand formation, in Umiat test well 2.

Figured paratype (USNM P6022) from cuttings at 2940 to 2950 feet, figured paratype (USNM P6782) from a core at 3125 to 3133 feet, and figured paratype (USNM P6758) from a core at 3349 to 3352 feet, all from the Torok formation, in South Barrow test well 1. The specimen listed as an unfigured paratype (USNM 560391) of this species, by Tappan (1951, p. 4), from cuttings at 3090 to 3100 feet, in the Torok formation, in South Barrow test well 1, belongs to Eponides morani Tappan.

Unfigured paratypes (USNM P6748) from field sample $49 \mathrm{~A} \mathrm{~Pa} \mathrm{81,} \mathrm{in} \mathrm{the} \mathrm{Fortress} \mathrm{Mountain} \mathrm{forma-}$ tion.

\section{Gavelinella tumida Brotzen}

Plate 57, figures 11-13

Gavelinella tumida Brotzen, 1942, Sveriges geol. Undersökning, ser. C, no. 451, Årsbok 36, no. 8, p. 47, text fig. 15.

Test free, trochospiral, robust, spiral side flattened, with about 2 whorls visible, umbilical side convex, umbilicus small, periphery broadly rounded; chambers increasing gradually in size, later ones about equal in height and breadth, 6 or 7 chambers in the final whorl; sutures distinct, depressed, radial; wall calcareous, finely perforate, surface smooth; aperture an arch extending from the peripheral margin onto the umbilical side. 
Hypotypes range from 0.16 to $0.36 \mathrm{~mm}$ in diameter. Remarks.-Orginally described from the Senonian of Sweden, this species occurs in the Schrader Bluff formation in northern Alaska.

It differs from $G$. ammonoides (Reuss) in having fewer chambers per whorl, less curved sutures, and a more convex spiral side and in being larger.

Types and occurrence.-Figured hypotypes (USNM P6759 a, b) from the Rogers Creek member, Schrader Bluff formation, seismograph party 46 , line $1-46$, shot point 15 at a depth of 20 feet, Umiat area.

Unfigured hypotype (USNM P6760) from the Sentinel Hill member, Schrader Bluff formation, field sample 47A St 30.

Figured hypotype (USNM P6761) and unfigured hypotypes (USNM P6762) from the Barrow Trail member, Schrader Bluff formation, field sample $48 \mathrm{~A}$ Dt 421.

Unfigured hypotypes (USNM P6808) from a core at 1140 to 1150 feet in the Schrader Bluff formation, in Sentinel Hill core test 1.

\section{Family ANOMALINIDAE Cushman, 1927 \\ Genus Anomalinoides Brotzen, 1942 \\ Anomalinoides pinguis (Jennings) \\ Plate 58, figures 2-5}

Anomalina grosserugosa (Gümbel). Carsey, 1926 (Not Truncatulina grosserugosa Gümbel, 1868), Texas Univ. Bull. 2612, p. 46, pl. 3, fig. 3; Plummer, 1931, Texas Univ. Bull. 3101 , p. 201, pl. 14, fig. 9.

Anomalina pinguis Jennings, 1936, Bull. Am. Paleontology, v. 23, no. 78, p. 37, pl. 5, fig. 1 ; Cushman 1946, U.S. Geol. Survey Prof. Paper 206, p. 156.

Anomalinoides plummerae Brotzen, 1942, Sveriges Geol. Undersökning, ser. C, no. 451, Årsbok 36, no. 8, p. 23, text fig. 7 (3).

Anomalinoides pinguis (Jennings). Brotzen, 1948, Sveriges Geol. Undersökning, ser. C, no. 493, Årsbok 42, no. 2, p. 86 ; Frizzell, 1954, Bur. Econ. Geology Rept. Invest. 22, p. 131, pl. 21, fig. 8 .

Test free, robust, nearly planispiral, partially evolute on both sides, with broadly rounded periphery; nine to eleven chambers in the final whorl, earlier whorls obscured by umbonal thickening; sutures distinct, straight, radial, slightly depressed; wall calcareous, coarsely perforate, surface smooth; aperture an equatorial arch, bordered by a narrow lip and extending back laterally beneath successive umbilical flaps of earlier chambers.

Hypotypes range from 0.26 to $0.65 \mathrm{~mm}$ in diameter.

Remarks.-Originally described from the Cretaceous of Texas, where it occurs in the Taylor and Navarro groups, this species has also been reported from New Jersey. In Alaska, it occurs in the Rogers Creek and
Sentinel Hill members of the Schrader Bluff formation.

Types and occurrence.-Figured hypotype (USNM P6775) from a core at 699 to 709 feet, in the Sentinel Hill member of the Schrader Bluff formation, in Sentinel Hill core test 1 .

Figured hypotype (USNM P6776) from field sample $47 \mathrm{~A} \mathrm{~Wb} 456$, and figured hypotypes (USNM P6777 a, b) from field sample $47 \mathrm{~A} \mathrm{~Wb} 460$, all from the Rogers Creek member of the Schrader Bluff formation.

Unfigured hypotype (USNM P6813) from the Sentinel Hill member of the Schrader Bluff formation, field sample 47A Dt 366.

Unfigured hypotypes (USNM P6814) from Umiat Seismograph shot holes, party 46, line 1-46, shot hole 14, at 25 to 30 feet, in the Rogers Creek member of the Schrader Bluff formation.

Unfigured hypotypes (USNM P6815) from field sample $47 \mathrm{~A}$ Dt 349 , in the Sentinel Hill member of the Schrader Bluff formation.

\section{Anomalinoides solis (Nauss) \\ Plate 58, figures 11, 12}

Anomalina solis Nauss, 1947, Jour. Paleontology, v. 21, no. 4, p. 333 , pl. 49 , fig. 9 .

Test free, nearly planispiral, convex and umbonate spiral side with early whorls almost completely overlapped by the final whorl, opposite side flattened and umbilicate, periphery broadly rounded, chambers about twice as broad as high, 10 or 11 in the final whorl; sutures gently curved, thickened; wall calcareous, distinctly perforate, surface smooth, aperture an interiomarginal equatorial arch, extending onto the umbilical side and continuing beneath early chambers at the umbilical margin.

Hypotypes range from 0.31 to $0.37 \mathrm{~mm}$ in diameter. Remarks.-This species was originally described from the Lea Park shale of Alberta, Canada. It is rare in Alaska, occurring in the Sentinel Hill member of the Schrader Bluff formation and in the Ignek formation. It differs from Gavelinella ammonoides (Reuss) in being larger, with more numerous cham. bers, and is nearly completely planispiral. It differs from Anomalinoides henbesti (Plummer) in being thicker, with rounded instead of keeled periphery and with broader and lower chambers.

Types and occurrence.-Figured hypotype (USNM P6778) from a core at 699 to 709 feet, in the Sentinel Hill member of the Schrader Bluff formation, in Sentinel Hill core test 1. 
Figured hypotype (USNM P6779) from field sample $46 \mathrm{~A} \mathrm{Gr} 98$, in the Ignek formation.

\section{Anomalinoides talaria (Nauss)}

Plate 58, figures 6-10

Anomalina talaria Nauss, 1947, Jour. Paleontology, v. 21, no. 4 , p. 334, pl. 48, figs. $11,12$.

Test free, relatively small, nearly planispiral, periphery rounded; 8 or 9 chambers in the final whorl, earlier whorls partially visible at the center of the spiral side, opposite side with a narrow umbilicus; sutures thickened, radial, straight to moderately curved, slightly depressed; wall calcareous, coarsely perforate, smooth; aperture a low arch at the periphery, extending onto the umbilical side beneath the umbilical flaps of the preceding chambers.
Hypotypes range in greatest diameter from 0.13 to $0.39 \mathrm{~mm}$.

Remarks.-Originally described from the Lea Park shale of Canada, this species occurs in the Barrow Trail and Sentinel Hill members of the Schrader Bluff formation in Alaska.

Types and occurrence.-Figured hypotypes (USNM P6764a-c) from the Sentinel Hill member of the Schrader Bluff formation, field sample $47 \mathrm{~A}$ St 30.

Figured hypotypes (USNM P6765 a, b) from the Sentinel Hill member of the Schrader Bluff formation. field sample $47 \mathrm{~A}$ Dt 360 .

Unfigured hypotype (USNM P6766) from the Barrow Trail member of the Schrader Bluff formation, field sample $48 \mathrm{~A}$ Dt 417.

\section{REFERENCES}

Ager, D. V., 1956, Geographical factors in the definition of fossil species, in The species concept in paleontology : Systematics Assoc. Pub. 2, p. 105-109.

Applin, E. R., 1933, A microfossiliferous Upper Cretaceous section from South Dakota: Jour. Paleontology, v. 7, no. 2, p. 215-220.

Bailey, T. L., Evans, F. G., and Adkins, W. S., 1945, Revision of stratigraphy of part of Cretaceous in Tyler Basin, northeast Texas: Am. Assoc. Petroleum Geologists Bull., v. 29 , no. 2 , p. $176-178$.

Bartenstein, Helmut and Brand, Erich, 1951, Mikropaläontologische Untersuchungen zur Stratigraphic des nordwestdeutschen Valendis: Abh. Senckenberg. naturf. Ges., no. 485, Festschrift Rudolf Richter, p. 239-336, pls. 1-25.

Bergquist, H. R., 1956. Paleontology of test wells and core tests in the Onmalik area, Alaska, in Robinson, F. M. Core tests and test wells, Oumalik area, Alaska: U.S Geol. Survey Prof. Paper 305-A, p. 65-68.

- 1958a, Micropaleontologic study of the Umiat field, northern Alaska, in Collins, F. R., Test wells, Uniat area, Alaska: U.S. Geol. Survey Prof. Paper 305-B, p. 199-204.

- 1958b. Micropaleontologic study of the Gubik test wells, northern Alaska, in Robinson. F. MI., Test wells, Gubik area, Alaska: U.S. Geol. Survey Prof. Paper 305-C, p. 259-261.

- 1958c, Micropaleontologic study of the Topagoruk test wells, northern Alaska, in Collins, F, R., Test wells, Topagoruk area, Alaska: U.S. Geol. Survey Prof. Paper 305-D, p. 311-314.

- 1958d, Micropaleontologic study of Grandstand test well 1, northern Alaska, in Robinson. F. M., Test well, Grandstand area, Alaska: U.S. Geol. Survey Prof. Paper 305-E, p. $337-338$.

1958e, Micropaleontology of Meade test well 1 and Kaolak test well 1, northern Alaska, in Collins, F. R., Test wells, Meade and Kaolak areas, Alaska: U.S. Geol. Survey Prof. Paper 305-F, p. 373-374.

- 1959a, Micropaleontologic stidy of test wells in the Titaluk and Knifeblade areas, northern Alaska, in Robinson, F. M., Test wells, Titaluk and Knifeblade areas, Alaska : U.S. Geol. Survey Prof. Paper 305-G, p. $417-419$.
$1959 \mathrm{~b}$, Micropaleontology of Square Lake test well 1 and the Wolf Creek test wells, northern Alaska, in Collins, F. R., Test wells, Square Lake and Wolf Creek areas, Alaska : U.S. Geol. Survey Prof. Paper 305-H, p. 479-482.

Berthelin, M., 1880, Mémoire sur les foraminiféres fossiles de l'Etage Albien de Moncley (Doubs): Soc. Géol. France, Mém., ser. 3, v. 1, no. 5, p. 1-84, pls. 1-4.

Bolin, E. J., 1952, Microfossils of the Niobrara formation of southeastern South Dakota; South Dakota Geol. Survey, Rept. Inv. 70, p. 1-74 (Mimeographed), pls. 1-5, text fig. 1.

1956, Upper Cretaceous Foraminifera, Ostracoda and Radiolaria from Minnesota: Jour. Paleontology, v. 30, p. 278-298, pls. 37-39, 5 text figs.

Bolli, H. M., Loeblich, A. R.. Jr., and Tappan, Helen, 1957, Planktonic foraminiferal families Hantkeninidae, Orbulinidae, Globorotaliidae, and Globotruncanidae: U.S. Natl. Mus. Bull. 215, p. 3-50, text figs. 1-9, pls. 1-11.

Bramlette, M. N., 1946, The Monterey formation of California and the origin of its siliceous rocks; U.S. Geol. Survey Prof. Paper 212, 57 pp., 19 pls., 1 map.

Bronnimann, P., and Brown, N. K., Jr., 1956, Taxonomy of the Globotruncanidae: Eclog. Geol. Helvetiae, v. 48 (1955), no. 2, 1. 503-531, pls. 20-24.

- 1958, Hedbergella, a new name for a Cretaceous planktonic foraminiferal genus; Washington Acad. Sci., Jour., v. 48 , no. 1, p. $15-17$.

Campbell, A. S., and Clark, B. L., 1944, Radiolaria from Upper Cretaceous of middle California: Geol. Soc. America, Spec. Paper 57, 61 pp., 8 pls.

Carman, Katharine, 1929, Some Foraminifera from the Niobrara and Benton formations of Wyoming: Jour. Paleontology. v. 3, no. 3, p. 309-315, pl. 34 .

Carsey, D. O., 1926, Foraminifera of the Cretaceous of central Texas: Texas Univ. Bull. 2612, p. 1-56, pls. 1-8.

Chapman, Frederick, 1893. The Foraminifera of the Gault of Folkestone, pt. 4: Roy. Micros. Soc. Jour., p. 579-595, pls. 8,9 .

- 1894, The Foraminifera of the Gault of Folkestone, pt. 5 : Roy. Micros. Soc. Jour., p. 153-163, pls. 3-4. 
Cobban, W. A., and Reeside, J. B., Jr., 1952, Correlation of the Cretaceous formations of the western interior of the United States: Geol. Soc. America Bull., v. 63, p. 10111044, 2 figs., $1 \mathrm{pl}$.

Collins, F. R., 1958a, Test wells, Umiat area, Alaska: U.S. Geol. Survey Prof. Paper 305-B, p. 71-206.

1958b, Test wells, Topagoruk area, Alaska: U.S. Geol. Survey Prof. Paper 305-D, p. 265-316.

— 1958c, Test wells. Meade and Kaolak areas, Alaska: U.S. Geol. Survey Prof. Paper 305-F, p. 341-376.

- 1959, Test wells, Square Lake and Wolf Creek areas, Alaska: U.S. Geol. Survey Prof. Paper 305-H, p. 423-484.

Cushman, J. A., 1927, Some Foraminifera from the Cretaceous of Canada : Royal Soc. Canada, Trans., 3rd ser., v. 21, sec. 4 , p. $127-132,1$ pl.

_ 1937, A monograph of the foraminiferal family Valvulinidae: Cushman Lab. Foram. Research, Spec. Publ. 8, p. 1-210, 24 pls.

- 1943, Gaudryina canadensis, new name: Cushman Lab. Foram. Research. Contr., v. 19, pt. 2, p. 27-28, pl. 6.

1946, Upper Cretaceous Foraminifera of the Gulf Coastal region of the United States and adjacent areas: U.S. Geol. Survey Prof. Paper 206, p. 1-241, pls. 1-66.

1948, Foraminifera, their classification and economic use, ed. 4: Harvard Univ. Press, Cambridge, Mass., p. 1-605, pls. 1-55.

—_ and Wickenden, R. T. D., 1928, A new foraminiferal genus from the Upper Cretaceous: Cushman Lab. Foram. Research, Contr., v. 4, pt. 1, p. 12-13, pl. 1 .

Detterman, R. L., 1956a, New and refined nomenclature of Nanushuk group, in Gryc, George and others, Mesozoic sequence in Colville River region, northern Alaska: Am. Assoc. Petroleum Geologists Bull., v. 40, no. 2, p. 233-244.

$1956 \mathrm{~b}$, New member of Seabee formation, Colville group, in Gryc, George, and others, Mesozoic sequence in Colville River region, northern Alaska: Am. Assoc. Petroleum Geologists Bull. v. 40, no. 2, p. 253-254.

Eichenberg, W., 1933. Die Erforschung der Mikroorganismen insbesondere der Foraminiferen der norddeutschen Erdolfelder. Teil I. Die Foraminiferen der Unterkreide, Folge 2. Foraminiferen aus dem Barrême von Wenden am Mittellandkanal : Niedersächs geol. Ver. zu Hannover, Jahresber. 25, p. 167-200, pls. 17-23.

- 1934, Foraminiferen aus dem Hauterive von Wenden am Mittellandkanal, Die Foraminiferen der Unterkreide: Niedersächs geol. ver. zu Hannover, Jahresber. 26, p. 150-196, 8 pls.

Fox, S. K., Jr., 1954, Cretaceous Foraminifera from the Greenhorn, Carlile and Cody formations, South Dakota, Wyoming: U.S. Geol. Survey Prof. Paper 25t-E, p. 97124, pls. 24-26.

Galloway, J. J., 1933, A manual of the Foraminifera: Bloomington, Ill., Principia Press, p. $1-483$, pls. $1-42$.

Gandolfi, Rolando, 1955, The genus Globotruncana in northeastern Colombia: Bull. Amer. Paleontology, v. 36, no. 155, p. 1-118, 10 pls., 12 text figs.

George, T. N., 1956, Biospecies, chronospecies and morphospecies, in The species concept in paleontology: Systematics Assoc. Publ. 2, p. 123-137.

Geroch. S., 1957, Utigerinammina jankói Majzon (Foraminifera) in the Carpathian flysch: Soc. Geol. Pologne, Ann. v. 25 , fasc. 3 , p. $231-244$, pls. 14-15.
Gryc, George, Patton, W. W., Jr., and Payne, T. G., 1951, Present Cretaceous stratigraphic nomenclature of northern Alaska: Washington Acad. Sci. Jour., v. 41, no. 5, p. 159167,1 table, 3 text figs.

Gryc, George, and others, 1956, Mesozoic sequence in Colville River region, northern Alaska: Am. Assoc. Petroleum Geologists Bull. v. 40, no. 2, p. 209-25t, 6 text figs.

Haldane, J. B. S., 1956, Can a species concept be justified? in The species concept in palaeontology: Systematics Assoc. Publ. 2, p. 95-96.

Hatch, M. H., 1941, The logical basis of the species concept: Am. Naturalist v. 75, p. 193-212.

Hecht, F. E., 1938, Standart-Gliederung der nordwestdeutschen Interkreide nach Foraminiferen: Senckenberg Naturforsch. Ges. Abh. no. 443, p. 1-42, pls. 1-24.

Henderson, W. R. S., 1954, Cretaceous and some Triassic beds of northeastern British Columbia, Canada: Am. Assoc. Petroleum Geologists Bull. v. 38, no. 11, p. 2269-2289, 6 text figs.

Hofker, Jan, 1951, The Foraminifera of the Siboga expedition: Siboga Expeditie, pt. 3, p. 1-513.

1955, Foraminifera from the Cretaceous of southern Limburg, Netherlands, VII : Overdruk Natuurhist. Maandblad, Jg. 44, no. 9-10, p. 99-102, text figs.

Imlay, R. W., and Reeside, J. B., Jr., 1954, Correlation of the Cretaceous formations of Greenland and Alaska: Geol. Soc. America Bull. v. 65, p. 223-246, 2 figs., 1 pl.

Joysey, K. A., 1956, The nomenclature and comparison of fossil communities, in The species concept in palaeontology: Systematics Assoc. Publ. 2, p. 83-94.

Leffingwell, E. de K., 1919, The Canning River region, northern Alaska: U.S. Geol. Survey Prof. Paper 109, 251 pp., 33 figs., 35 pls.

Loeblich, A. R., Jr., and Tappan, Helen, 1950, Foraminifera of the type Kiowa shale, Lower Cretaceous, of Kansas: Univ. Kansas Paleon. Contr. Protozoa, Art. 3, p. 1-15, pls. 1-2. 1953. Studies of Arctic Foraminifera: Smithsonian Misc. Coll., v. 121, no. 7, p. 1-150, pls. 1-24.

1954, Emendation of the foraminiferal genera Ammodiscus Reuss, 1862 and Involutina Terquem, 1862: Washington Acad. Sci. Jour., v. 44, no. 10, p. 306-310, figs. 1, 2. 1955, Revision of some Recent foraminiferal genera: Smithsonian Misc. Coll., v. 128, no. 5, 37 pp., 4 pls.

Loetterle, G. J., 1937. The micropaleontology of the Niobrara formation in Kansas. Nebraska and South Dakota: Nebraska Geol. Surv., 2nd ser., Bull. 12, 73 pp., 11 pls.

Lozo. F. E., Jr., 1944, Biostratigraphic relations of some North Texas Trinity and Fredericksburg (Comanchean) Foraminifera: Am. Midland Naturalist, v. 31, no. 3, p. 513-582, pls. 1-5.

Mellon, G. B. and Wall, J. H., 1956, Geology of the MeMurray formation. Part 1. Foraminifera of the upper McMurray and basal Clearwater formations: Research Council Alberta, Rept. 72, p. 1-29, pls. 1-2, 4 figs.

Montanaro Gallitelli, Eugenia, 1957, A revision of the foraminiferal family Heterohelicidae: U.S. Natl. Mus. Bull. 215, p. 133-154, pls. 31-34.

Morrow, A. L.. 1934, Foraminifera and Ostracoda from the Upper Cretaceous of Kansas: Jour. Paleontology, v. 8, no. 2 , p. $186-205$, pls. $29-31$.

Myers, E. H., 1943, Life activities of Foraminifera in relation to marine ecology: Am. Philos. Soc. Proc., v. 86, p. 439458, 1 pl., 7 text figs. 
Myers, E. H., and Cole, W. S., 1957, Foraminifera, in Treatise on Marine Ecology and Paleoecology: Geol. Soc. America Memoir 67, v. 1, p. 1075-1082.

Nauss, A. W., 1945, Cretaceous stratigraphy of Vermilion area, Alberta, Canada: Am. Assoc. Petroleum Geologists, Bull., v. 29 , no. 11 , p. $1605-1629,5$ figs.

1947, Cretaceous microfossils of the Vermilion area, Alberta: Jour. Paleontology, v. 21, no. 4, p. 329-343, pls. 48-49.

Newell, N. D., 1956, Fossil populations, in The species concept in palaeontology: Systematics Assoc. Publ. 2, p. 63-82.

Noth, R., 1951, Foraminiferen aus unter und oberkreide des osterreichischen anteils an Flysch, Helvetikum und vorlandvorkommen : Jb. GeoL. Bundesanstalt, v. 3, p. 1-91, pls. $1-9$.

Patton, W. W., Jr., 1956, New and redefined formations of early Cretaceous age, in Gryc, George and others, Mesozoic sequence in Colville River region, northern Alaska: Am. Assoc. Petroleum Geologists Bull., v. 40, no. 2, p. 219-223.

Payne, T. G., and others, 1951, Geology of the Arctic Slope of Alaska : U.S. Geol. Survey Oil and Gas Inv. Map OM 126,3 sheets.

Peterson, R. H., Gauger, D. J., and Lankford, R. R., 1953, Microfossils of the Upper Cretaceous of northeastern Utah and southwestern Wyoming: Utah Geol. and Mineral Survey, Bull. 47, Contr. Micropal. 1, 158 pp., 16 pls., 8 text figs., 4 tables.

Plummer, H. J., 1931, Some Cretaceous Foraminifera in Texas: Univ. Texas Bull. 3101, p. 109-203, pls. 8-15.

Reuss, A. E., 1863, Die Foraminiferen des norddeutsehen Hils und Gault: Akad. Wiss. Wien. Sitz, v. 46, p. 5-100, pls. 1-13.

Revelle, Roger, and Fairbridge, Rhodes, 1957, Carbonates and carbon dioxide, in Treatise on marine ecology and paleoecology : Geol. Soc. America, Memoir 67, v. 1, p. 239-296.

Rhodes, F. H. T., 1956, The time factor in taxonomy, in The species concept in palaeontology: Systematics Assoc. Publ. 2, p. 33-52.

Robinson, F. M., 1956, Core tests and test wells, Oumalik area, Alaska: U.S. Geol. Survey Prof. Paper 305-A, p. 1-70.

- 1958a, Test wells, Gubik area, Alaska : U.S. Geol. Survey Prof. Paper 305-C, p. 207-264.

1958b, Test well, Grandstand area, Alaska : U.S. Geol. Survey Prof. Paper 305-E, p. 317-339.

1959a, Test wells, Titaluk and Knifeblade areas, Alaska : U.S. Geol. Survey Prof. Paper 305-G, p. 377-422. - 1959b, Test wells, Simpson area, Alaska: U.S. Geol. Survey Prof. Paper 305-J, p. 523-568.

- - and Collins, F. R., Core test, Sentinel Hill area and test well, Fish Creek area, Alaska: U.S. Geol. Survey Prof. Paper 305-I, p. 485-521.

— Rucker, F. P., and Bergquist, H. R., 1956, Two subsurface formations of early Cretaceous age, in Grye, George and others, Mesozoic sequence in Colville River region, northern Alaska: Am. Assoc. Petroleum Geologists Bull., v. 40, no. 2, p. 223-233.

Roemer, F. A., 1841, Die Versteinerungen des norddeutschen Kreidegebirges: Hahnschen Hofbuchhandlung, Hannover, 145 pp., 16 pls.

Rüst, A., 1892, Radiolaria from the Pierre formation of northwestern Manitoba: Canada Geol. Survey Contr. Micropaleontology, pt. 4, p. 101-111.

Sable, E. G., 1956, New and redefined Cretaceous formations in western part of northern Alaska: Am. Assoc. Petroleum Geologists Bull. v. 40, no. 11, p. 2635-2643, 3 figs.

Schrader, F. C., 1902, Geological section of the Rocky Mountains in northern Alaska: Geol. Soc. America Bull. v. 13, p. 233-252.

1904, A reconnaissance in northern Alaska: U.S. Geol. Survey Prof. Paper 20, 139 pp., maps.

Skolnick, Herbert, 1958, Lower Cretaceous Foraminifera of the Black Hills area: Jour. Paleontology, v. 32, no. 2, p. 275-285, pls. 36-38, 1 text fig.

Smith, P. S., and Mertie, J. B., Jr., 1930, Geology and mineral resources of northern Alaska : U.S. Geol. Survey Bull. 815, 351 pp., 22 figs., 34 pls., incl. maps.

Stainforth, R. M., 1952, Ecology of arenaceous Foraminifera : The Micropaleontologist, v. 6, no. 1, p. 42-44.

Stelck, C. R. and Wall, J. H., 1954, Kaskapau Foraminifera from Peace River area of western Canada ; Research Council Alberta, Rept. 68, 38 pp., 2 pls., 5 text figs.

1955, Foraminifera of the Cenomanian Dunveganoceras zone from Peace River area of western Canada: Research Council Alberta, Rept. 70, p. 1-62, pls. 1-3.

Stelck, C. R., Wall, J. H., Bahan, W. G., and Martin, L. J., 1956, Middle Albian Foraminifera from Athabasca and Peace River drainage areas of western Canada: Research Council Alberta Rept. 75, 60 pp., 2 figs., 5 pls.

Stelek, C. R., Wall, J. H., and Wetter, R. E., 1958, Lower Cenomanian Foraminifera from Peace River area, western Canada: Research Council Alberta, Geol. Div., Bull. 2, pt. I, p. 5-35, pls. 1-4.

Sylvester Bradley, P. C., 1956, The new palaeontology, in The species concept in palaeontology: Systematics Assoc. Publ. 2, p. 1-8.

Tappan, Helen, 1940, Foraminifera from the Grayson formation of northern Texas: Jour. Paleontology, v. 14, no. 2, p. $93-126$, pls. $14-19$.

1943, Foraminifera from the Duck Creek formation of Oklahoma and Texas: Jour. Paleontology, v. 17, no. 5, p. 476-517, pls. 77-83.

1951a, Northern Alaska index Foraminifera: Cushman Found. Foram. Research Contr., v. 2, pt. 1, p. 1-8, pl. 1 . 1951b, Micropaleontology, in Payne, T. G. and others, Geology of the Arctic Slope of Alaska: U.S. Geol. Survey Oil and Gas Inv. Map. OM-126, sheets 1 and 3. 1951c, Foraminifera from the Arctic Slope of Alaska. General introduction and pt. 1. Triassic Foraminifera: U.S. Geol. Survey Prof. Paper 236-A, p. 1-20, pl. 1-5, 2 figs.

1955, Foraminifera from the Arctic Slope of Alaska. Part 2. Jurassic Foraminifera: U.S. Geol. Survey Prof. Paper 236-B, p. 21-90, pls. 6-28, text figs. 3-9, 1 chart.

1957, New Cretaceous index Foraminifera from northern Alaska : U.S. NatI. Mus. Bull. 215, p. 201-222, text fig. 29 , pls. $65-71$.

- 1960, Cretaceous biostratigraphy of northern Alaska: Am. Assoc. Petroleum Geologists, Bull., v. 44, no. 3, p. 273-297, text figs. 1-7, pls. 1, 2.

Thalmann, H. E., 1952, New names for foraminiferal homonyms: Cushman Found. Foram. Research Contr., v. 3, pt. 1, p. 14 .

Thomas, Gwyn, 1956, The species conflict-abstractions and their applicability, in The species concept in palaeontology: Systematics Assoc. Publ. 2, p. 17-31.

Whittington, C. L., 1956, Revised stratigraphic nomenclature 
of Colville group, in Gryc, George, and others. Mesozoic sequence in Colville River region, northern Alaska: Am. Assoc. Petroleum Geologists Bull. v. 40, no. 2, p. 244-253. Wickenden, R. T. D., 1932a, New species of Foraminifera from the Upper Cretaceous of the prairie provinces: Royal Soc. Canada, Trans. 3rd ser., v. 26, sect. 4, p. 85-91, 1 pl.

$1932 \mathrm{~b}$, A useful foraminiferal horizon in the Alberta shale of southern Alberta: Jour. Paleontology, v. 6, no. 2, p. 203-207, pl. 29.

1945, Mesozoic stratigraphy of the eastern plains, Manitoba and Saskatchewan: Canada Dept. Mines and Resources, Geol. Survey Mem. 239, 87 pp., 5 pls., 2 figs., 3 maps.

1948, Eoeponidella, a new genus from the Upper Cretaceous : Trans. Royal Soc. Canada, 3rd ser., v. 42, sect. 4, p. $81-82$, fig. 1
1949, Some Cretaceous sections along Athabaska River from the mouth of Calling River to below Grand Rapids, Alberta: Canada Dept. Mines Resources, Geol. Survey Canada Paper 49-15, 31 pp., fig.

1951, Some Lower Cretaceous sections on Peace River below the mouth of Smoky River, Alberta: Canada Dept. Mines Tech. Surveys, Geol. Survey Canada, Paper 51-16, $47 \mathrm{pp}$. and pl., fig.

Wood, Alan, 1949, The structure of the wall of the test in the Foraminifera; its value in classification: Geol. Soc. London Quart. Jour., v. 104, p. 229-255, pls. 13-15.

Young, Keith, 1951, Foraminifera and stratigraphy of the Frontier formation (Upper Cretaceous), southern Manitoba: Jour. Paleontology, v. 25, no. 1, p. 35-68, pls. 11-14, 6 text figs. 


\section{INDEX}

[Italic numbers indicate description.]

\section{A}

Page

Acknowledgments........................... 92 acuminata, Citharina_.................. 117, 180; pl. 47

Vaginulina acuta, Pseudoglandulina acuticostata, Marginulina ....................... 167 Aeolostreptis.............................. 111 vitrea.................................... 188

Ager, D. V., quoted....................... 121

Alabaminidae -................ 190 alaskensis, Globorotalites................ 112, 190; pl. 55 albertensis, Gümbelitria cretacea................ 184

Neobulimina........... 96, 112, 114, 184; pl. 48 Quadrimorphina....................... 189 Trochammina.......... 97, 113, 114, 152; pl. 39

alexanderi, Bathysiphon -...................... 128

Gaudryina............................... 146, 148 Spiroplectammina allomorphinoides, Quadrimorphina.............. 189 altispira, Eurycheilostoma Ammobaculites............... 115, 116, 119, 121, 136, 137 coprolithiforme........................... 136, 137 coprolithiformis ....................... 136, 137, 138 Jragmentaria.............................. 136 fragmentarius -....................... 94, 95, 96 , $112,113,120,124,127,136,138 ;$ pl. 32 humei-. tyrrelli_......................... 136, 137, 138, 139 wenonahae.............. 96, 124, 127, 137, 138; pl. 32

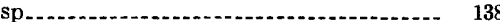

Ammobaculoides................................ 115

Ammodiscidae............................ 124, 130

Ammodiscus.............................. 96, 115, 130 cretaceus.... 97, 114, 116, 117, 130, 131, 132; pl. 30 gaultinus............................... 130 mangusi_............................. 131; pl. 30 rotalarius....................... 116, 181, 132; pl. 30 sp.................................... 138; pl. 30 ammonoides, Anomalina...................... 197 Gavelinella............ 97, 116, 117, 197, 199; pl. 56 Rosalina ammovitrea, Spiroplectammina... 94, 116, 139; pl. 33 ampulla, Frondicularia................. 117, 181; pl. 47 angulata, Bigenerina............................ 146 Gaudryina triangularis............................ 146

angusta, Vaginulina

angustissima, Citharina......................-.- 180

Anomalina ammonoides......................... 197 grosserugosa intermedia pinguis................................... 199 solis talaria

Anomalinidae . ........................... 199

Anomalinoides_.................................. 115, 199 henbesti................................. 199 pinguis........................ 97, 116, 199; pl. 58 plummerae.............................. 199 solis_._.......... 97, 98, 113, 114, 128, 199; pl. 58 talaria talarius apiculata, Lagena........................... 182 Oolina

Archicorythidae_.......................... 113

Arctica

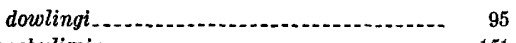

Arenobulimina............................... 151 chapmani_.............................. 151, 152
Page

paynei 151: pl. 36 torula $\ldots$. 97, 98, 112, 15\%; pl. 36

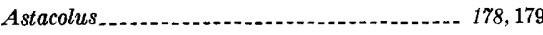
complanatus. gratus, Robulus......................... 179

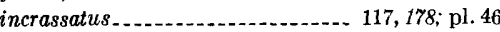
laevigatus................................... 178 perstriatus_.................... 116, 117, 178; pl. 46 schlönbachii, Lenticulina strombecki $\ldots$ Asterigerinidae............................... 195 athabaskensis, Inoceramus._._._._...... 95 athabascenis, Tritaxia......................... 144 Uvigerinammina........... 112, 113, 144; pl. 33 Aucella crassicollis........................... 93 Aucellina dowlingi.............................. 93 austinana, Nonionella_........................ 115 awunensis, Gavelinella.................. 197; pl. 57

Miliammina... 159,$160 ; p 1.36$

\section{B}

barksdalei, Hyperamminoides............... 129; pl. 29 barrowensis, Gaudryina $\ldots . . . .112,113,145,148$; pl. 34 basiplanata, Dentalina................ 116, $174:$ pl. 45 Bathysiphon . . . alexanderi.................................. 128 brosgei............................ 128; pl. 29 vitta $\ldots \ldots \ldots \ldots \ldots \ldots$ 111, $128 ;$ pl. 29 bayrocki, Lenticulina................... 113, 161; pl. 40 bearpawensis, Verneuilina.

Belemnitella mucronata....................... 169

Beudanticeras sp....... 93

Bigenerina angulata....................... 146

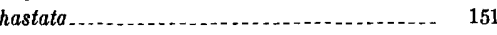
Biospecies, defined. . . . . . . . . . 118 bisobscura, Miliammina.............. 114,160; pl. 36 Bolivina elkensis............................... 128 Bolivinoides...................................... 111 honanzaense, Haplophragmoides............... 133 bonanzaensis, Haplophragmoides......... 96 $97,112,114,183,134 ;$ pl. 30

borealis, Verneulinoides....................... 94, 95, $112,113,120,122,126,127,142,144,149 ; \mathrm{pl} .34$ Borissiakoceras sp_.............. 96 bowsheri, Psam minopelta........... 157, 159; pl. 3 bronnii, Lenticulina (Saracenaria) bronni, Planularia $\ldots \ldots \ldots$ brosgei, Bathysiphon .................... 128; p!. 29 bucculenta, Polymorphina_................ 183

Bulimina nannina venusae............ 186, 188

Buliminella carseyae. carseyae carseyae........................... 186

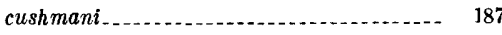
vitrea

Buliminidae_....................... 112, 123, 127, 186

colomorpha, Dentalina. Nodosaria (Nodosaria) _......................... 172

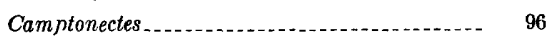
canadensis, Gaudryina.................... 95, $96,113,126,137,146 ; \mathrm{pl} .35$
Page

Globulina lacrima ............ 113, 183, 184; pl. 47 Neobulimina_.....97, 112,114,116, 128, 18.5; pl. 48 cardissoides, Inoceramus carlilensis, Haplophragmoides. . . . . carseyae, Buliminella.............. 186 Buliminella carseyae............... 186 Praebulimina ...... 97, 116, 117, 186, 187; pl. 48 carseyae, Buliminella................... 186

Caucasina vitrea $\ldots \ldots \ldots$ 116, 188; pl. 49 cephalotes, Cristellaria..................... 168 Marginulina ..................... 117, 168; pl. 43 Vaginulinopsis

Chandler formation, description fauna contained ........................ 95 Killik tongue............................ 95 Niakogon tongue chandlerensis, Dorothia . . . Marginulinopsis _................ 166; pl. 44 chapmani, Arenobulimina................ 151, 152 Flabellammina............. 198; pl. 33 charoides corona, Glomospira............... 130 Chilostomellidae. ...................... 93,189 Chronospecies, defined ................... 121 Citharina acuminata _... 117, 180; pl. 47 angustissima $\ldots \ldots \ldots$ complanata perstriata $\ldots . . . . . . . . . .178$ rudocostata . . . .

Citharinella tarrantensis. . . Clavulina............................ 137 clearwaterensis, Pseudonodosaria............. 171 Cleoniceras ................................. 94,95 collinsi, Marginulinopsis_. _. 113, 166, 167, 179; pl. 42 collyra, Haplophragmoides ................... 135 Colville group communis, Dentalina complanati, Pelosina..................... 129 perstriata, Citharina.................... 178 Vaginulina................................... 178 complanatus, Astacolus .................. 178 concinna, Nodosaria................. 117, 172; pl. 45 conica, Conorbina..............................

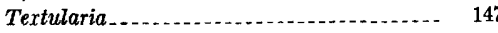
Conorbidae Conorbina...................................... 191 conica............................ 192 sp sp A sp B $\ldots \ldots 2$

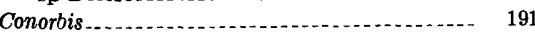
Conorboides .......... 191,192 mitra umiatensis. . . . . Conorboididae coprolithiforme, Ammobaculites........... 136, 137 coprolithıformis, Ammobaculites _........ 136, 137, 138 cordai, Frondicularia $\ldots \ldots \ldots$. Cornuspira cretacea......................... 131 corona, Glomospira Glomospira charoides................... 130 Correlation between Alaska and Canada.... 113, 114,115

Alaska and Europe................. 116,117, 118 Alaska and United States. . . Corwin formation. ........ 96 crassicollis, Aucella.......................... 93 


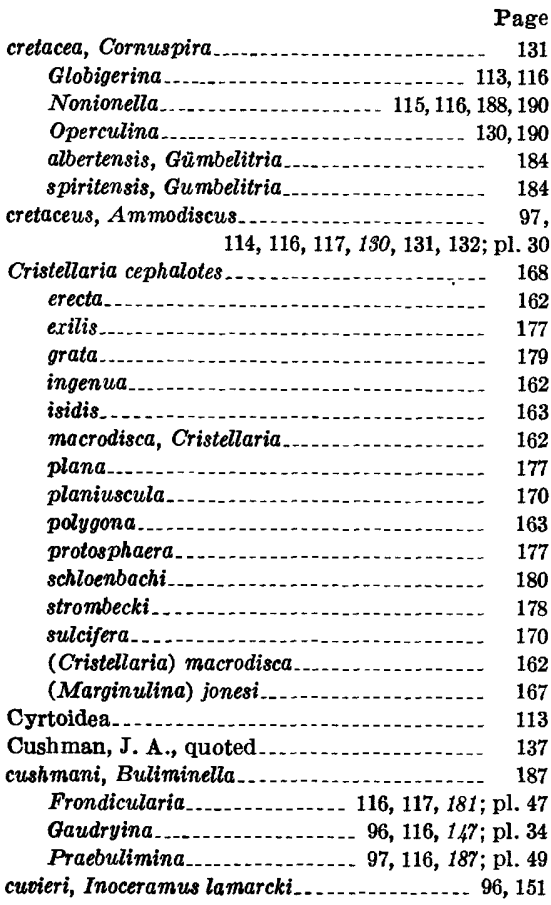

D

delicatulus, Scaphites................ 96 Dentalina................... 170, 173, $174,175,176$ basiplanata .................... 116, 174; pl. 45

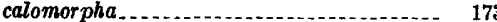
communis......... 176 dettermani................ $175 ;$ pl. 45

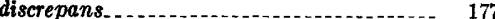
distincta.................. 117, 175, 177; pl. 45 doliiformis, Nodosaria.................... 173

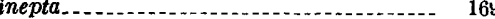

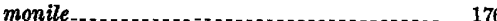

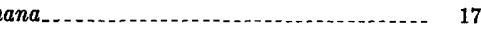
Nodosaria........................... 174 paupercula............ 169 Nodosaria praecommunis........... siliqua.................................. 176 soluta strangulata............... 116, 117, 176; pl. 45

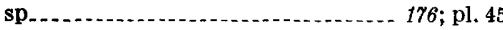
dettermani, Dentalina diagonis, Haplophragmoides................ 153 Trochammina _._ 97, 112, 116, 15s, 156, 157; pl. 38 dichotomiana, Frondicularia microdisca

Dictyomitra Discorbidea. . . . . Discorbis. norrisi..._. stictata. . . discrepans, Dentalina. distincta, Dentalina................ 117, 175, 177; pl. 45 Ditrupa ... diversitatus, Haplophragmoides.......... 134 doliformis, Nodosaria ................. 117, 17s; pl. 45 Nodosaria (Dentalina)

Dorothia.............. 150 chandlerensis . . . . . . dorsata, Marginulina_..._._._. 97, 116, 166, 169; pl. 44 dowlingi, Arctica. Aucellina............... 93 dunveganensis, Inoceramus............... 95 Panope dutroi, Sarcenaria................... 164, 165; pl. 41
$\mathbf{E}$

Page

eggeri, Haplophragmoides...-............. 135 eilete, Trochammina............ 93, 112,15s; pl. 38 elegans, Hyperamminoides................. 129 elkensis, Bolivina elongata, Glandulina........................ 171 Marginulina............................... 177

Enantiodentalina

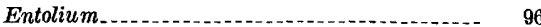
Eoeponidella linki_.............. 97, 113, 114, 195; pl. 54 strombodes _..._..._._._. $97,113,195 ;$ pl. 54 Epistomina fax............................. 128

Eponides.......... 191 morani_... repandus. ................... 191

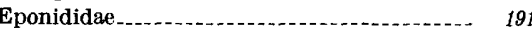
erecta, Cristellaria Lenticulina _....... 117, 162; pl. 40

Eurycheilostoma altispira $\ldots$. . grantstandensis.......... 94, 95, 112,199, 194; pl. 53

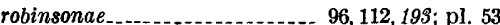
Euryhaline organisms, defined........ 123 exilis, Cristellaria $\ldots . . . . . . . . . . . . . . . .177$ Vaginulina exserta, Globulina........ 96,116,117,183,184; pl. 47 Polymorphina 183

Faunal group, Haplophragmoides topagorukensis- $H$. gigas .

Faunal zone, Gaudryina irenensis-Trochammina rutherfordi............. 112

Gaudryina tailleuri

Pseudoclavulina hastata-Arenobulimina torula

Pseudoclamulina-Arenobulimina.

Trochammina ribetonensis - Neobulimina

canadensis...
Verneuilinoides borealis.............

$95,96,108,112,125$

fax, Epistomina_............... 128 fitiformis, Nodosaria

fischeri, Verneuilinoides........ 97, 98, 126, 149; pl. 32

Flabellammina 199 chapmani........... $139 ;$ pl. 33 rugosa.

flexocarinata, Nodosaria..........117, 179, 174; pl. 45 Nodosaria fontannesi............... 173 Jontannesi, Nodosaria .................... 174 flexocarinata, Nodosaria $\ldots . . . \ldots \ldots \ldots . . . . . . . .173$

Fortress Mountain formation, correlation.-.- 93 description.............................. 93 fauna contained.

fragmentaria, Ammobaculites............... 136 fragmentarius, Ammobaculites ......94, 95, 96, 112, $113,120,124,127,136,138 ;$ pl. 32

frankei, Lenticulina........... 162

Frondicularia $\ldots \ldots \ldots$ 172, 181, 182 ampulla..................... 117, 181; pl. 47 cordai ........... 181, 182 cushmani._._. guestphalica loryi microdisca dichotomiana perovata pseudoconcinna. . . ungeri $\mathrm{sp} \ldots \ldots \ldots \ldots$

fusula, Nodosaria _..._._._... 97, 116, 117, 173; pl. 45 Nodosaria (Nodosaria) . ................ 173

G

Gastroplites
gatesi, Marginulina.
Page

Gaudryina $96,119,122,145,150$ alexanderi............................ 146, 148 angulata barrowensis _............ 112, 113, 145, 148; pl. 34 canadensis_...... 95, 96,113,126, 137, 146; pl. 35 cushmani_..._._._._... 96, 116, 147; pl. 34 hectori _... irenensis ...... 95, 97, 112, 113, 114, 126, 147; pl. 35 nanushukensis........................ 94 $95,112,113,146,148,149 ;$ pl. 34 subretacea tailleuri _._._._._._. 93, 112, $149 ;$ pl. 35

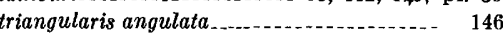
sp A . sp B $\mathrm{B}$ Gaudryinella irregularis . . . . . gaultina, Glomospirella........... 116,117,130; pl. 29 Paleopolymorphina $\ldots \ldots \ldots$........ 117, 189; vl. 47 Polymorphina.......... 182 gaultinus, Ammodiscus................... 130

Gavelinella a mmonoides. ........ 97,116,117, 197, 199; pl. 56 awunensis........... 197; pl. 57 intermedia _................ 117, 197; pl. 58 tictata $\ldots . . . .94,95,112,113,191,192,197,198 ;$ pl. 57 tormarpensis_.......... 197 tumida_._........ 97, 117, 198; pl. 57 Gavelinellidae............................. 197 George, T. N., quoted....... 118, 120 gigas, Haplophragmoides. 112.113, 116, 127, 134, 135; pl. 33

glabra, Morginulina Glandulina elongata................ 171

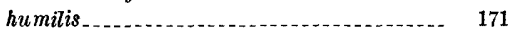
Nodosaria mutobilis. ......... 171

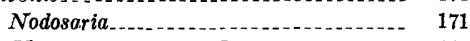
gleddiei, Verneuilinoides perplexa ............ 143 Globigerina cretacea

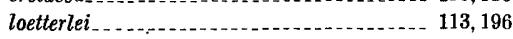
globigeriniformis, Trochammina Globorotaliidae........................... 196

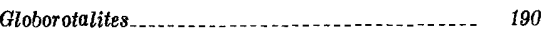
alaskensis...................... 112,190; pl. 55 multisepta 190

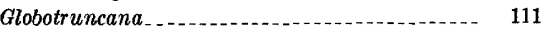
(Rugoglobigerina) loetterli loetterli _....... 196

Clobulina exserta $96,116,117,183,184 ;$ pl. 47

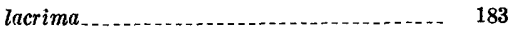
canadensis subspherica ............ 183 prisca. sp globulosa, Gümbelina.................... 196 Heterohelix......... 96,112, 113, 116, 196; pl. 55

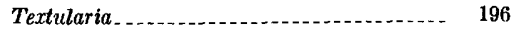

Glomospira charoides corona....................... 130 corona _. _ _. . . .

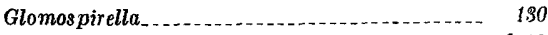
gaultina glutinosa, Massilina_.................... 159 gouskovi, Lacosteina gracillima, Valvulineria................. 194

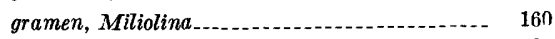
Grandstand anticline....................... 95 formation.................. 95 grandstandensis, Eurycheilostoma.......... 94, $95,112,19.3,194 ;$ pl. 53 Saracenaria.................. 113, 164; pl. 41 grota, Cristellaria. Vagınulinopsis _. grotus, Robulus (Astacolus) gravenori, Textularia......... 96, 112, 114, 141 ; pl. 33 
Page

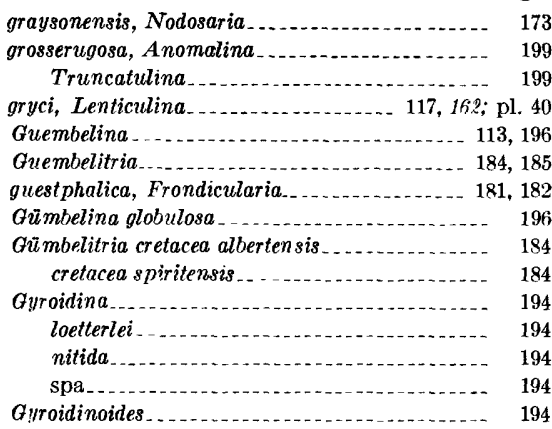

II

H aldane, J. B. S., quoted _ _..

Haplophragmoides....... 93, 96, 115, 121, 193 bonanzaense . . . . . . bonanzaensis .... 96, 97, 112, 114, 133, 134; pl. 30 carlilensis............................... 116 collyra..................................... 135 diagonis _........... 153 diversitatus................................. 134 eggeri....................................... 135 gigas _...... 98, 112,113, 116, 127, 134, 135; pl. 30 linki rota. $116,126,133,134 ;$ pl. 31 topagor ukensis_.. $95,112,113,127,134,135 ;$ pl. 31 hastata, Bigenerina...................... 151 Pseudoclavulina........ 95, 112, 114, 151; pl. 36 Hatch, M. H., quoted.......... 118 hauteriviana, Lagena................... 175 hectori, Gaudryina.............. 146, 147 Hedbergella.......................... 196 loetterlei _.......... 96, 112, 113, 116, 196: pl. 55 henbesti, Anomalinoides............... 199 Heterohelicidae. Heterohelicinae

Heterohelix globulosa humei, Ammobaculites................. 136, 137, 138 humilis, Glandulina Nodosaria ................................ 170, 171 (Glandulina) Pseudoglandulina..................... 171 Rectoglandulina ............ 117, 170, 172; pl. 44

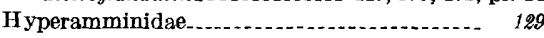
Hyperamminoides.............................. 129 barksdalei.......................... 129; pl. 29

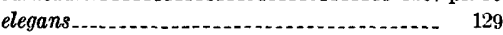

Ignek formation. 97,98 incrassata, Vaginulina..................... 178 incrassatus, Astacolus................ 117, 178; pl. 46 inepta, Dentalina............................. 169 Marginulina ingenua, Cristellaria Lenticulina. .................... 117, 162; pl. 41 Inoceramus ... athabaskensis............................... 95 cardissoides................................ 97

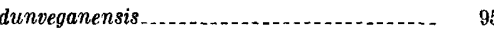

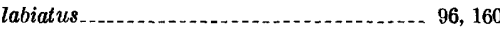
lamarcki cuvieri___............. 96, 151 lundbreckensis......................... 97 sp........ 93 ntermedia, Anomalina.................... 197 Gavelinella_...................... 117, 197; pl. 58 International Rules of Zoological Nomenclature, cited..................... 191

Involutina mangusi.......................... 131 irenensis, Gaudryina. $97,112,113,114,126,147 ;$ pl. 35 irregularis, Gaudryinella.......... 96, 116, 150; $\mathrm{\rho l} .35$
Page

ischnia, Miliammina_._._............ 95, 160; pl. 37 isidis, Cristellaria

Robulus. 163

$\mathbf{J}$

Jonesi, Cristellaria (Marginulina) Lenticulina (Marginuliuopsis) robusta..... 167 Marginulinopsis.................... 117, 167; pl. 42 Nodosaria._............................... 171 Joysey, K. A., quoted

\section{K}

kirschner', Rectoglandullna........ 117, 171, 172; pl. 44 koveri, Spiroplectammina............. 118, 141, 142 Kukpowruk formation, correlation . ........... 96 Kukpowruk formation, description .......... 95,93 fauna contained

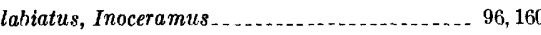
Lacosteina ................ 111, 188 gouskoni..................... 97, 118, 188; pl. 49 lacrima, Globulina.............. 183 canadensis, Globulina....... 113,183, 184; pl. 47 subspherica, Globulina

laevigatus, Astacolus _._._................... 178

Lagena. ............... 183 apiculata............................... 182 hauteriviana lamarcki cuvieri, Inoceramus _._._. lathrami, Saccammina _................. 95, 126, 129 Lemuroceras $\mathrm{sp}$ Lenticulina. ......................... 161, 166, 17 bayrocki....................... 113,161; pl. 40 erecta_....................... 117, 162; pl. 40 frankei. gryci.............. 117, 162; pl. 40 ingenua......................... 117, 162; pl. 41 macrodisca................... 117,162; pl. 40 polygona _... . . . _... . . . . 117, 168; pl. 40 secans................................. 161 topagorukensis.................... 168; pl. 40 sp ..- 161

Lenticulina (Astacolus) schlōnbachii_......... 180 (Marginulinopsis) robusta jonesi........... 167 (Saracenaria) bronnii_.................... 165 valanginiana (Vaginulinopsis) pachynota planiuscula lepida, Nodosaria $\ldots \ldots \ldots$......... 97, 117, 174; pl. 45

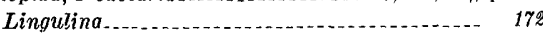
loryi ......... 117,178; pl. 44 redivina...................... 117, 179; pl. 44 sp $3 \ldots \ldots \ldots$. linki, Eoeponidella $a_{\text {. }} \ldots$ Haplophragmoides . . . . . . . . . . . . . . 133 Liosphaeridae .

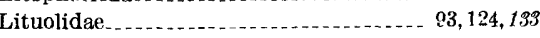
loeblichae, Nodosaria. . ....................... 176

loetterlei, Globigerina Gyroidina ........ 194 Hedhergella $a . \ldots . .25,112,113,116,196 ;$ pl. 55 I'alvulineria ..................... 113, 194; pl. 54 loetterli, Globotruncana (Rugoglobigerina) loet-

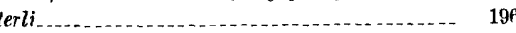
loetterli, Glohotruncana (Rugoolobigerina) _. 196 Lophosphaeridae Loryi, Frondicularia Lingulina lundbreckensis, Inoceramus

\section{$\mathbf{M}$}

macrodisca, Cristellaria (Cristellaria) ........... 162 Lenticulina _...................... 117, 162; pl. 40 mangusi, Ammodiscus._................. 131; pl. 30 Involutina................................ 131
Page

manitobensis, Miliammina.................... 94 $95,113,124,126,127,159,160 ; \mathrm{pl} .36$ Tritaxia............. 145

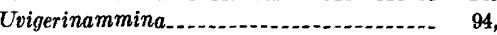
$96,112,113,124,126,127,144,145 ;$ pl. 33

Marginulina__. 168, 170

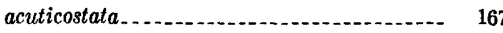
cephalotes . . . . . dorsata................... 97, 116, 166, 169 ; pl. 44 elongata gatesi . . . . . . . glabra inepta jonesi, Cristellaria........................ 167

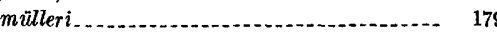
planiuscula ...................... 117, $170 ;$ pl. 43 radiata

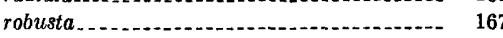
sulcifera trinitatensis.

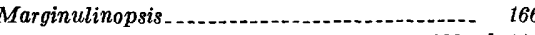
chandlerensis........ 166; pl. 144 collinsi_................ 113,166,167,179; pl. 42 jonesi_............................. 117, 167; pl. 42 reiseri robusta jonesi, Lenticulina................... 167 umiatensis...................... 167, 168; pl. 43

Massilina glutinosa......................... 159

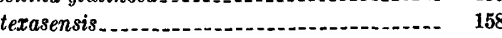
mcmurrayensis, Trochammina...........- 155 microdisca dichotomiana, Frondicularia........ 181 Miliammina_._._........... 96,159 awunensis......................... 159, 160; pl. 36 bisobscura _........................ 114, 160; pl. 36 ischnia_._........... 95, 160; pl. 37 manitobensis.............................. 94 $95,113,124,126,127,159,160 ;$ pl. 36

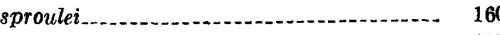
valdensis_._.

Miliolidae

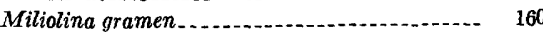

minima, Neobulimina.............. 186

Minimusthon minuta, Reophax................ 116,132: pl. 30 mitra, Conorbnides.......................... 192 monile, Dentalina............................... 176

Nodosaria morani, Eponides. mordenensis, Spiroplectammina _... 97,114,140; pl. 33 Morphospecies, defined........................ 118 mucronata, Belemnitella muelleri, V aginulinopsis............. 117, 179; $\mathrm{pl} .47$ muilleri Marginulina............................ 179 multisepta, Globorotalites ................... 190 mutabilis, Glandulina........................ 17 Nodosaria (Glandulina) .................- 171

Myers, E. H., quoted...................... 124 $\mathbf{N}$

nana, Dentalina.............................. 176 Nodosaria (Dentalina) nannina, Bulimina......................... 187 Praebulimina. _............ 116, 187; pl. 49 Nanushuk group Nanushukella_............................... 192 umiatensis nanushukensis, Gaudryina............... 94 $95,112,113,146,148,149 ;$ pl. 34

Nasellaria_. . . . . . . . . . .

Neobulimina _........ 184, 185 albertensis_................ 96,112,114,184; pl. 48 canadensis_........ 97,112,114,116,128,185; pl. 48 irregularis. . . .

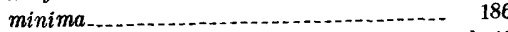

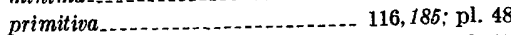
subcretacea . ........................ 116, 186; pl. 48

Neofiabellina............................ 111 
Page

netrona, Rectoglandulina Newell, N. D., quoted.................... 119, 12

Ninuluk formation, description........... fauna contained............................... 95 nitida, Gyroidina Rotalina

Nodosarella

Nodosaria calomor pha _..._....................... 172, 173 Nodosaria concinna_...................... 117, 172; pl. 45 doliiformis_._._._................ 117,178; pl. 45 filiformis.................................... 176

flexocarinata fontannesi.................................. 17 flexocarinata $\ldots . . . \ldots \ldots$

fusula

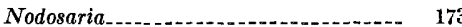
(Glandulina) humilis mutabilis........................ 171 graysonensis.............................. 173 humilis . . jonesi_..................................... 17

lepida..._............ 97, 117, 174; pl. 45 loeblichae................................ 176 monile

nana

(Nodosaria) calomorpha................... 172 fusula paupercula................................. 169 radicula, jonesi_............................. 171 regularis__. sp

(Dentalina) dolifformis nana... paupercula $\ldots$................................ 169 Nodosariidae.... 91, 93, 94, 112, 116, 117, 123, 127, 161 Nonionella.................................... 115, 190 austinana............. 115 cretacea_...................... 115, 116, 188, 190 taylorensis.... 97, 113, 115, 116, 118, 188, 190; pl. 50 Nonionidae.

norrisi, Discorbis $191,192,198$

obesa, Pyrulinoides.............. fauna contained........................... 93 oligostegia, Saracenaria

Oolina................................. 180 apiculata......... 116, 117, 182; pl. 47 Operculina.............. 131

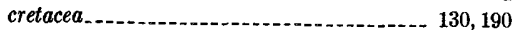

ozawaii, Paleopolymor phina

\section{$\mathbf{P}$}

pachynota, Lenticulina (Vaginulinopsis) _...... 180 Vaginutinopsis............. 93, 117, 180; pl. 47

Paleopolymorphina.................. 182

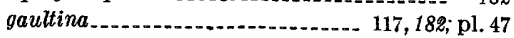
gaultina
ozawaii $\ldots \ldots \ldots$

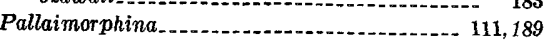
ruckerae ..................... 96, 112, 189; pl. 50

Palmula tarrantensis._._................... 181

Panope dunveganensis......................... $\quad 95$

parallela, Verneuilina............... 144

paupercula, Dentalina.

Nodosaria

(Dentalina) ............................. 169

paynei, Arenobulimina.... 169

Pelosina_... 129 complanata.......... $\quad 129$ pepperensis, Reophax . . . . . 30 perovata, Frondicularia.................... 181 perplexa gleddiei, Verneuilinoides............ 143 perstriata, Citharina complanata.......... 178

Vaginulina complanata................. 178 perstriatus, Astacolus $\ldots . . . . . . .116,117,178$; pl. 46
Page

vinguis, Anomalina..................... 199 Anomalinondes........... 97, 116, 199; pl. 58 plana, Cristellaria Vaginulina. .............. 117, 177; pl. 46 planiuscula, Cristellaria............. 170 Lenticulina (Vaginulinopsis) _.............. 170 Marginulina. .................... 117, 170; pl. 43 Planularia bronn plummerae, Anomalinoides................. 199 polygona, Crnstellaria....................... 163 Lenticulina..................... 117, 168; pl. 40 Polymorphina bucculenta..._._._._._._. 183 exserta gaultina 182 Polymorphinidae

Praebulimina ........................... 115, 186 carseyae _........ 97,116, 117, 186, 187; pI, 48 cushmani_.................. 97,116,187; pl. 49 nannina... . .

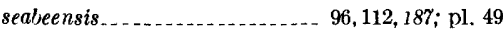
venusae $\ldots \ldots .97,113,114,187,188 ; \mathrm{pl}, 49$ praecommunis, Dentalina _.............. 175; pl. 45 Previous studies............ 98 primitiva, Nesbulimina_..._._._._. 116, 185; pl. 48 I irgulina ... . . . 185 Prince Creek formation. prisca, Globulina ................... 117,18;; pl. 47 projectura, Saracenaria.............. 113, 164; pl. 41 prolongata, Tritaxia spiritensis_........... 150 protesphaera, Cristellaria

Psamminopelta bowsheri....................... 157,159; pl. 37 subcircularis _...

Pseudoclavilina_.................. 151 hastata............... 96,112,114, 15t; pl. 36 pseudoconcinna, Frondicularia ............. 181 Pseudoglandulina acuta................. 172 humilis 171

Pseudonodosaria clearwaterensis ............ 171

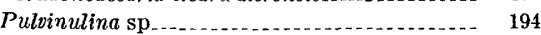

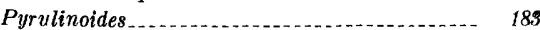
obesa_._. thurrelli

Q

Muadrimorphina $\ldots \ldots$ albertensis........................................ 189 allomorphinoides....................... 189

Ouinqueloculina. sphaera $\ldots . . . . .114,15 \%$; pl. 37

R

radiata, Marginulina radiculo jonesi, Nodosaria Radiolaria........................ 7,34, 115, 124, 127 Radiolarian faunas, correlation of ........ 112,113 rainwateri, Trochammina rayi, Siphotertularia .................. 95, 142; pl. 34

Rectoglandulina $\ldots . . . . . . .170,172$ humilis........ 117, 170,172; pl. 44 kirschneri. ................ 117, 171, 172; pl. 44 netrona.............. 171; pl. 44 rediviva, Lingulina...... 117.172; pl.44 regularis, Nodosaria reiser, Marginulinopsis _. _........ 113, 167, 168; pl. 43 Reophacidae $\ldots . . . . . . . . . . . . . . . . . . . . .124,132$ Reophax minuta $\ldots \ldots \ldots$ 116, 132; pl. 30 pepperensis . . . . 116, 133; pl. 30 texana

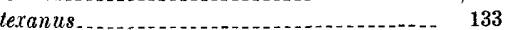
troyeri repandus, Eponides Rhizamminidae ....... 124, 128 Rhodes, F. H. T., quoted......... 119 ribstonensis rutherfordi, Trochammina......... 95, $112,113,126,155 ;$ pl. 39 Trochammina $112,114,121,126,152,154,155 ;$ pl. 39
Page

robinsonnae, Eurycheilostoma.......96, 112, 193; pl. 53 Robulus isidis........................... 163 (Astacolus) gratus..................... 179

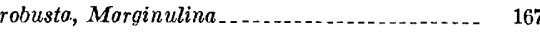
jonesi, Lenticulina (Marginulinopsis) _.... 167 rollaensts, Textularia

Rosalina ammonoides ..................... 197 rota, Haplof,hragmoides.............. 96 $97,98,112,113,114,116,126,133,134 ;$ pl. 31 rotalarius, Ammodiscus.......... 116, 131, 132; pl. 30

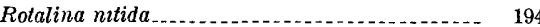
Rotaliporo.............................. 111 ruckerae, Pallaimorphina ....... 96, 112, 189; pl. 50 rudocostxta, Citharina

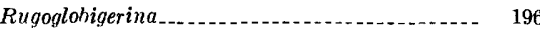
loetterli loetterli, Globotruncana........ 196 rugosa, Flabellammina.................... 139 rutherfordı, Trochammina _..._._._._. 121, 154, 155 Trocham mina ribstonensis.............. 95, $112,113,126,155 ;$ pl. 39

Rzehakinidae S

sablei, Trochammina.......................... 153 Saccammina. Saccarnminidae_........................... 129 Sample locality register $100,101,102,103,104,105,106,107$ saratogana, Saracenaria._.-. 164 Saracenaria bronnii, Lenticulina dutroi........................... 164, 165; pl. 41 grandstandensis ................... 113,164; pl. 41 oligostegia projectura $a_{\ldots} \ldots \ldots \ldots \ldots \ldots \ldots$................. 113, 164; pl. 41 saratogana.............................. 164

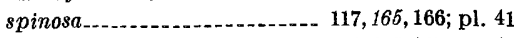
trollopei_............... 113, 164,165,167; pl. 41 valanginiana _.................... 117,166; pl. 42 Lenticulina_._.............. 166 sp _ _ sp C

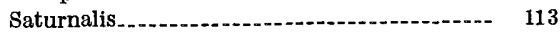
Scaphites delicatulus. Schackoina schlönbachii, Lenticulina (Astacolus) _........-.- 180 schloenbachi, Cristellaria................... 180 Vaginulinopsis..................... 117, 180; pl. 46 Schrader Bluff formation, Barrow Trail member

correlation.

description...

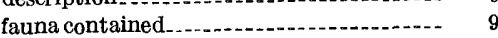

Rogers Creek member

Sentinel Hill member................... 97 schraderensis, Vaginulina_..._............ 177; pl. 46 scotti, Spiroplectammina_................. 140 Seabee formation, correlation............... 96 description . . fauna contained............... 96, 97 lower member............................. $\quad 96$ upper (Ayiyak) member.................. $\quad \mathbf{g}_{6}$ seabeensis, Praebulimina_._._._.... 96, 112,187; pl. 49 secans, Lenticulina........................... 161 Seismic shot hole samples, register .......... 110,111 siliqua, Dentalina ........................ 176 Siphotextularia rayi.............. 95, 142; pl, 34 washitensis solis, Anomalina Anomalinoides _..... 97, 98,113, 114, 128, 199; pl. 58 soluta, Dentalina___._. 172,173, 176 sphaera, Quinqueloculina _........... 114, 157; pl. 37 spinosa, Saracenaria ............. 117, 165, 166; pl. 41 spiritensis, Gumbelitria cretacea prolongata, Tritaxia 


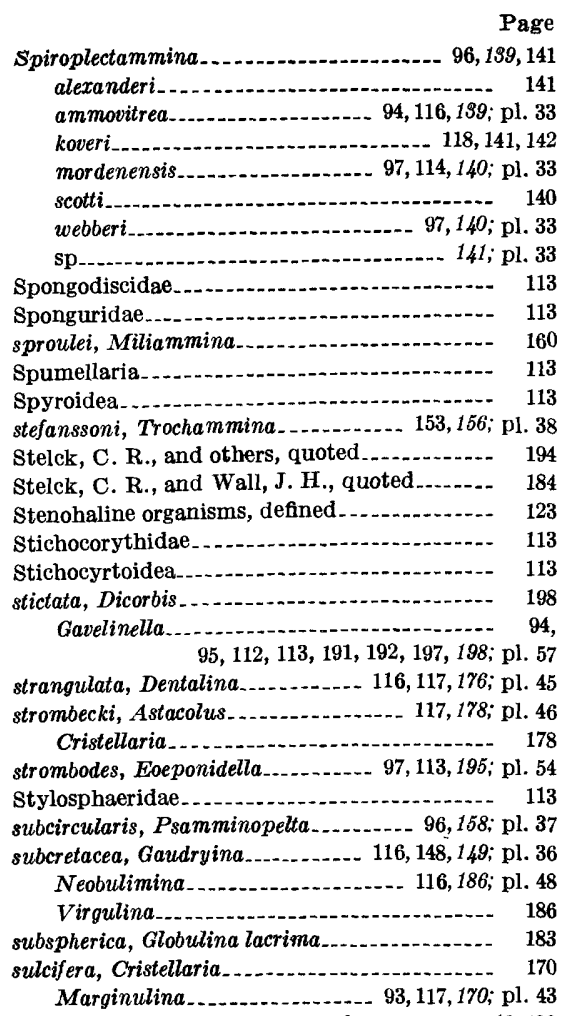

Sylvester-Bradley, P.C., quoted. .......... 118, 120

tailleuri, Gaudryina Verneuilinoides_.................... 118, 149, 150 talaria, Anomalina........................... 200 Anomalinoides ................ 97, 113,200; pl. 58 talarius, Anomalinoides....................... 114 Tancredia........... 96 tarrantensis, Citharinella............. 116,181; pl. 47 Palmula

Taxonomy, ecological criteria.............. 120, 121 evolutionary criteria...................... 121 genetic and physiological criteria . ....... 118 morphological criteria. ............. 118, 119, 120

taylorensis, Nonionella_.................... 97 , $113,115,116,118,188,190 ;$ pl. 50 texana, Reophax ... 136, 137 texanus, Reophax texasensis, Massilina__._._._._._._._....... 158 Textularia ............................ 119,141, 147 conica__._._._. 147 globulosa gravenori_................. 96, 112,114,141; pl. 33 rollaensis_............................... 142 topagorukensis..................... 118, 141 ; pl. 33
Textulariidae._._. 93,124,139

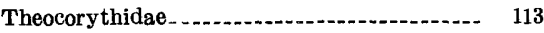

Thomas, Gwyn, quoted.................... 119

thurrelli, Pyrulinoides...................... 183; pl. 47

Topagotuk formation, correlation............. 93,94

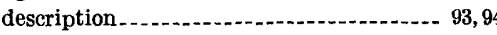
fauna contained ............................... 94 topagorukensis, Haplo phragmoides............ 95, $112,113,127,134,135 ;$ pl. 31 Lenticulina .. 163; pl. 40 Textularia tormárpensis, Gavelinella.................... 197 Torok formation, description................ 93 fauna contained.......................... 93 torula, Arenobulimina.......... 97,98, 112, 152; pl. 36 triangularis angulata, Gaudryina...........- 146 trinitatensis, Marginulina....................... 168

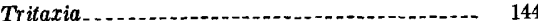
athabascensis............................... 144 manitobensis................................ 145 spiritensis prolongata............. 150

Trochammina_....... 93, 96,115, 116, 120,121, 122, 152 albertensis_................ 97, 113, 114, 152; pl. 39 diagonis. .......... 97,112,116,153,156,157; pl. 38 eilete _......................... 93, 112,153; pl. 38 globigeriniformis........................ 156 mcmurrayensis ............................. 155 rainwateri_................ 113, 116, 126, 153; pl. 39 ribstonensis. $112,114,126,152,154,155 ;$ pl. 39 rutherfordi $i_{-. . .} 95,112,113,121,126,155 ;$ pl. 39 rutherfordi_.......................... 121, 154,155

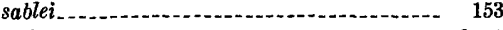
stefanssoni..................... 153, 156; pl. 38 umiatensis . _ _._. webbi_........ whittingtoni_.............. 97, 112, 153, 157; pl. 39 sp_._................ 155 Trochamminidae. trollopei, Saracenarix.......... 113, 164,165, 167; pl. 41 troyeri, Reophax.......................... 183; pl. 30 Truncatulina grosserugosa..._.............. 199

Tuktu formation, correlation.............. 95 description............................ 94,95 fauna contained......................... 95 tumida, Gavelinella_____._._._._._._. 97, 117,198; pl. 57 tyrrelli, Ammobaculites. $136,137,138,139$

\section{$U$}

umiatensis, Conorboides._._.... 94,96,112, 192; pl. 52 Marginulinopsis_.................. 167,168; pl. 43 Nanushukella ........................... 192

Trochammina............... 156; pl. 38 ungeri, Frondicularia ............ 116, 117, 188; pl. 47 Unio...- 126

Uvigerinammina_...................... 111, 124,144 athabascensis.................. 112, 113,144; pl. 33 manitobensis............................ 94 $96,112,113,124,126,127,144,145 ; \mathrm{pl} .33$
V

Page

Vaginulina.................................... 177

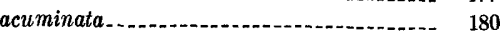
angusta............................ 177 complanata perstriata................ 178 exilis . . incrassata plana._._.................... 117, 17\%; pl. 46 schraderensis.......................... 177; pl. 46 vandenbroecki.......................... 178

Vaginulinopsis cephalotes _............ 168 grata. muelleri............................ 117, 179; pl. 47 pachynota.................... 93,117,180; pl. 47 Lenticulina pachynota............ 180 planiuscula, Lenticulina................ 170 schloenbachi .................... 117, 180; pl. 46 valanginiana, Lenticulina (Saracenaria) ....... 166 Saracenaria . ....................... 117,166; pl. 42 valdensis, Miliammina................. 159 Valvulineria.................................. 19 gracillima loetterlei............................ 113, 194: pl. 54

Valvulineriidae............................... 194

Valvulinidae .........

vandenbroecki, Vaginulina................. 178

venusae, Bulimina. ................ 186, 188 Praebulimina........ 97, 113, 114, 187, 188; pl. 49 Verneuilina.

bearpawensis .............................. 144 parallela-............. 144 sp A......... 145, 146

Verneuilinidae. ...................... 93, 124,142

Verneuilinoides......................... 96, 116,148 borealis................................ $94,95,112,113$, $120,122,126,127,142,144,149 ; \mathrm{pl} 34$

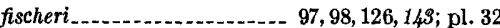
per plexa gleddiei........................... 143

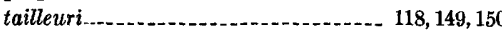
sp............................ 142, 143 Virgulina primitiva....................... 185 subcretacea

Virgulinidae............. 127, 18 vitrea, Aeolostreptis...................... 97, 116 Buliminella....................................... 188 Caucasina ......................... 116, 188; pl. 49 vitta, Bathysiphon .................. 111, 128; pl. 29

\section{W}

washitensis, Siphotextularia..................... 142 webberi, Spiroplectammina........... 97,140; pl. 33 webbi, Trochammina...................... 153,154 Well and core test locality register...... 108, 109, 110 wenonahae, A mmobaculites ................. $124,127,137,198 ;$ pl. 32 whittingtoni, Trochammina_... 97, 112, 153,157; pl, 39 Wickenden, R. T. D., quoted............ 148

Zygartidae 



\section{PLATES 29-58}




\section{PLATE 29}

Figures 1-5. Bathysiphon brosgei Tappan. 1, 5, Side views of paratypes (USNM P4224 a, b). 2, Holotype (USNM P4216). 3, 4, Paratypes (USNM P4217 a, b). Specimens show growth irregularities and surface wrinkles. All from the Topagoruk formation, $\times 30$. (p. 128).

6-8. Bathysiphon vitta Nauss. 6, Side view of hypotype (USNM P5912) from the Torok formation. 7, Hypotype (USNM P5906) and 8, hypotype (USNM P5907) from the Topagoruk formation. All $\times 30$. (p. 128).

9-12. Saccammina lathrami Tappan. 9a, Side view of paratype (USNM P5922) from the Topagoruk formation; 9b, top view. 10, Side view of paratype (USNM P5921) from the Grandstand formation. 11, Holotype (USNM P5920) from the Grandstand formation. 12, Paratype (USNM P5924) from the Topagoruk formation. Specimens show the usual lateral compression of this species. All $\times 55$. (p. 129).

13-16. Glomospira corona Cushman and Jarvis. 13, Hypotype (USNM P5931) from the Grandstand formation. $\times 120$. 14, Hypotype (USNM P5938) from the Torok(?) formation. 15, Hypotype (USNM P5932) from the Topagoruk formation. 16, Hypotype (USNM P5935) from the Fortress Mountain formation. Figs. 14-16, $\times 70$. (p. 130).

17-20. Glomospirella gaultina (Berthelin). 17, Hypotype (USNM P5942) from the Topagoruk formation. 18, Hypotype (USNM P5939) from the Grandstand formation. 19, 20, Hypotypes (USNM P5945 a, b) from the Fortress Mountain formation. All $\times 70$. (p. 130).

21-27. Hyperamminoides barksdalei Tappan. 21, Paratype (USNM P4227) from the Topagoruk formation. 22, Paratype (USNM P4226) from the Grandstand formation. 23, Large paratype (USNM P4389) from the Topagoruk formation. 24, Paratype (USNM P4229), with collapsed wall, from the Topagoruk formation. 25, Paratype (USN M P4390) from the Topagoruk formation. 26, Holotype (USNM P4386) from the Grandstand formation. 27a, Side view of paratype (USNM P4228) from the Topagoruk formation; 27b, edge view. Figs. 21, 22, 24, 27, all $\times 55$. Figs. $23,25,26$, all $\times 70$. (p. 129).

All figures are camera lucida drawings by Helen Tappan Loeblich. 


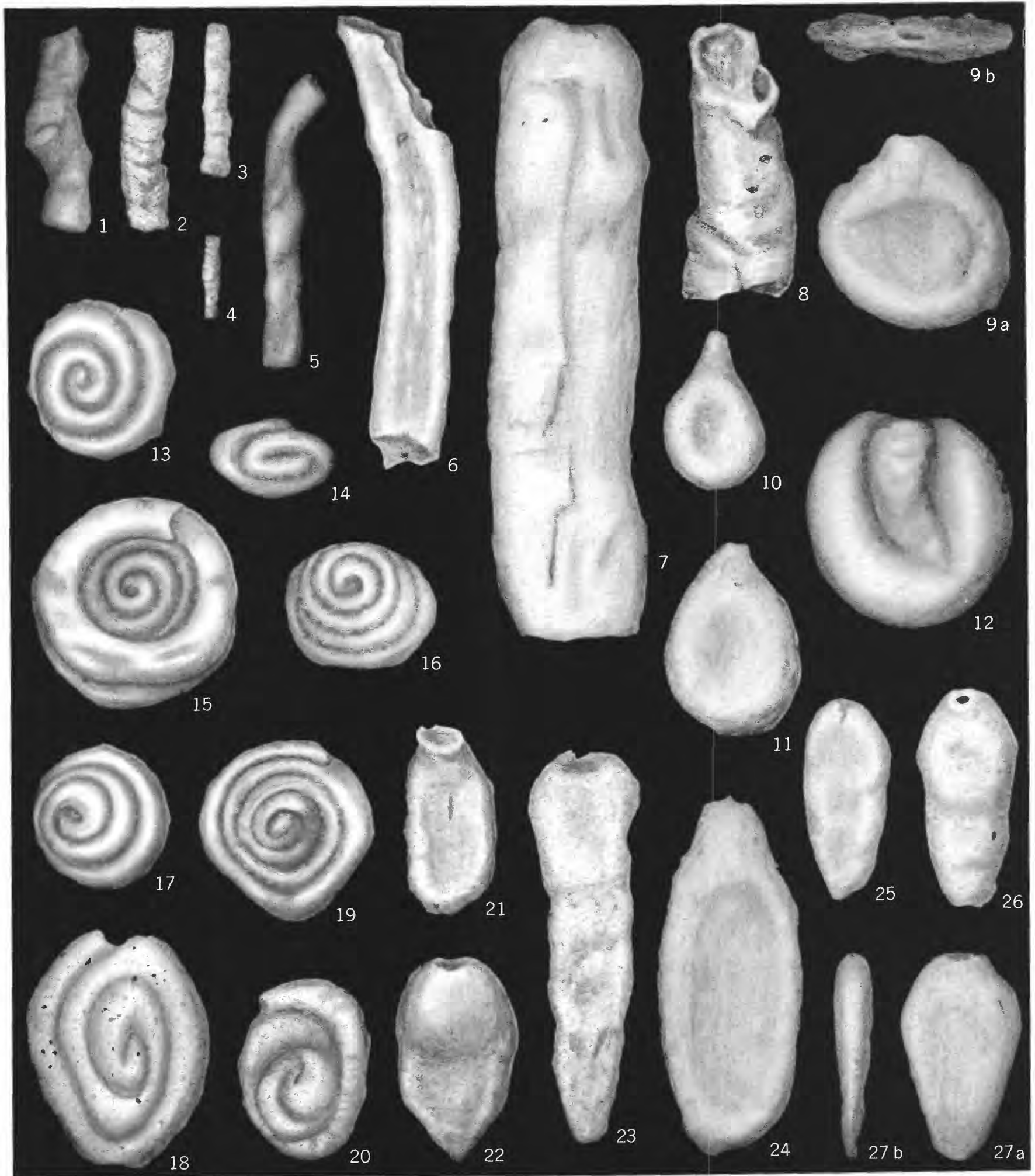

BATHYSIPHON, SACCAMMINA, HYPERAMMINOIDES, GLOMOSPIRA, AND GLOMOSPIRELLA 


\section{PLATE 30}

Figures 1, 2. Ammodiscus cretaceus (Reuss). Hypotypes (USNM P5953a, b) from the Schrader Bluff formation. $\quad \times 55 . \quad(p .130)$

3, 4. Ammodiscus mangusi (Tappan). 3, Paratype (USNM P4240) from the Chandler formation. 4, Holotype (USNM P4232) from the Topagoruk formation. $\times 70$. (p. 131)

5-8. Ammodiscus rotalarius Loeblich and Tappan. 5, Hypotype (USNM P5955) from the Topagoruk formation. 6, Hypotype (USNM P5960) from the Topagoruk formation. 7, Hypotype (USN M P5965) from the Kukpowruk formation. 8, Hypotype (USNM P5956) from the Topagoruk formation. All $\times 70$. (p. 131)

9. Ammodiscus sp. Small specimen (USNM P5980) from the Schrader Bluff formation, $\times 70$. (p. 132)

10. Reophax minuta Tappan. Hypotype (USNM P5986) from the Torok formation. $\times 70$. (p. 132)

11-13. Reophax troyeri Tappan. 11, Holotype (USNM P5992) showing rounded chambers. 12, Paratype (USNM P5996). 13, Paratype (USNM P5998). All from the Topagoruk formation, $\times 55$. (p. 133)

14. Reophax pepperensis Loeblich. Hypotype (USNM P5988) showing tiny tapering test, from the Seabee formation. $\times 70$. (p. 133)

15. Haplophragmoides gigas Cushman. Hypotype (USNM P6001) from the Ignek formation, showing large size and sinuate sutures. $\times 30$. (p. 134)

16-19. Haplophragmoides bonanzaensis Stelck and Wall. 16, Small hypotype (USNM P6005) from the Schrader Bluff formation, $\times 120$. 17, 19, Hypotypes (USNM P6009 a, b) from the Seabee formation, $\times 70$. 18, Hypotype (USNM P6004) from the Seabee formation, $\times 120$. (p. 133).

All figures are camera lucida drawings by Helen Tappan Loeblich. 


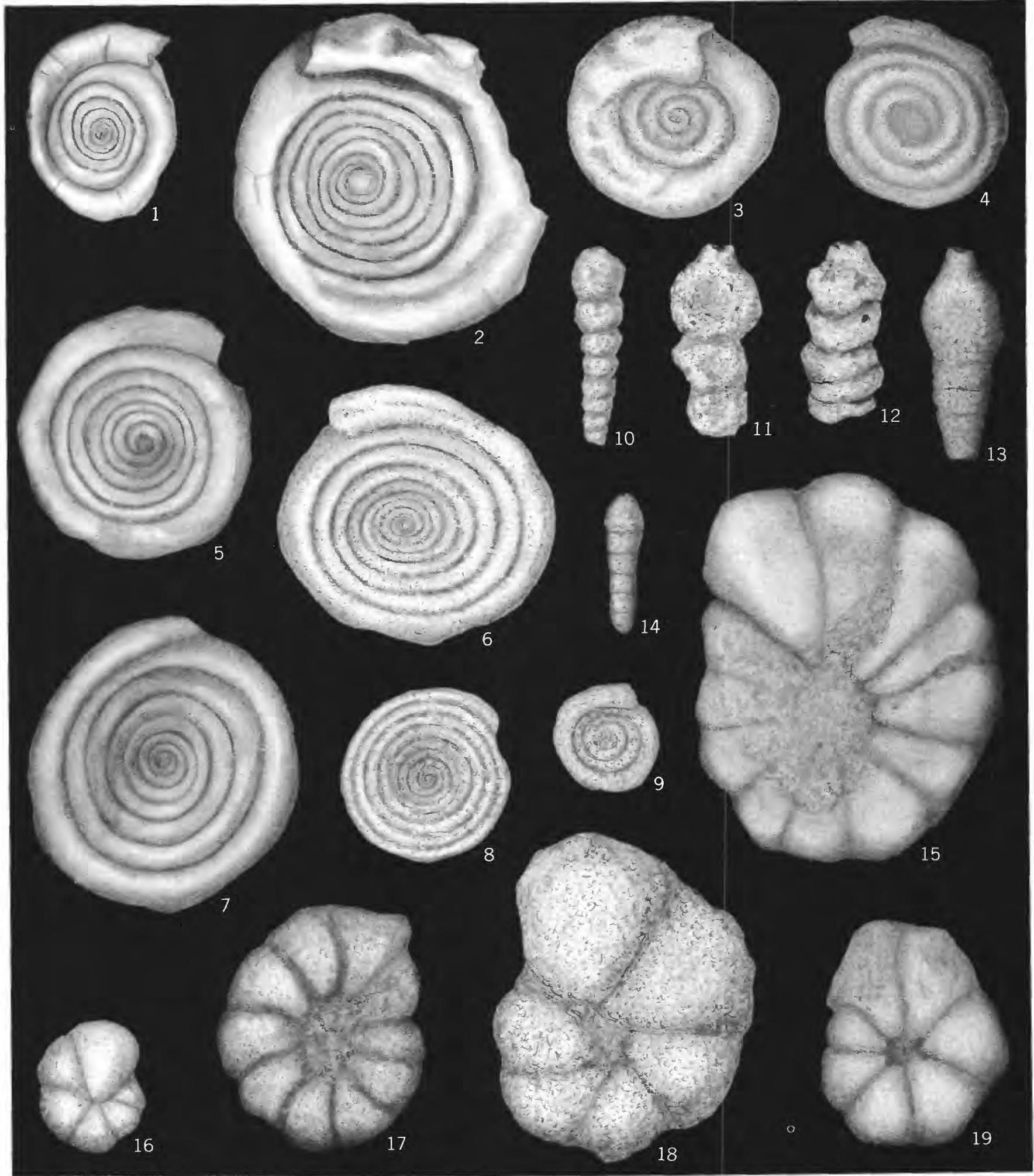

AMMODISCUS, REOPHAX, AND HAPLOPHRAGMOIDES 


\section{PLATE 31}

Figures 1-15. Haplophragmoides topagorukensis Tappan. 1, Paratype (USNM P4279). 2, Paratype (USNM P4270) showing oblique crushing. 3, Paratype (USNM P4277) crushed from the edge, perpendicular to the plane of coiling. 4, Paratype (USNM P4288). 5, Holotype (USNM P4242), 6, Paratype (USNM P4275), showing large size of some specimens. 7, Paratype (USNM P4257). 8, Paratype (USNM P4252). 9, Paratype (USNM P4254). 10, Paratype (USNM P6018). 11, Paratype (USNM P6025). 12, Paratype (USNM P6013). 13, 15, Paratypes (USN M P 4246a, b), showing lateral and oblique compression of different specimens. 14, Paratype (USNM P6023). Figs. 1-3, 5-9 from the Topagoruk formation, figs. 4, 12, 13, 15 from the Grandstand formation, figs. 10, 14 from the Torok formation and fig. 11 from the Fortress Mountain formation. Figs. 1, 4-6, 10-15, all $\times 70$; figs. $2,3,7-9, \times 30$. (p. 135)

16-18. Haplophragmoides rota Nauss. 16, Hypotype (USNM P6045) from the Seabee formation. 17, Hypotype (USNM P6031) from the Schrader Bluff formation. 18, Hypotype (USN M P6029) from the Seabee formation. Figs. 16, 18, $\times 70$. Fig. $17, \times 55$. (p. 134)

All figures are camera lucida drawings by Helen Tappan Loeblich. 


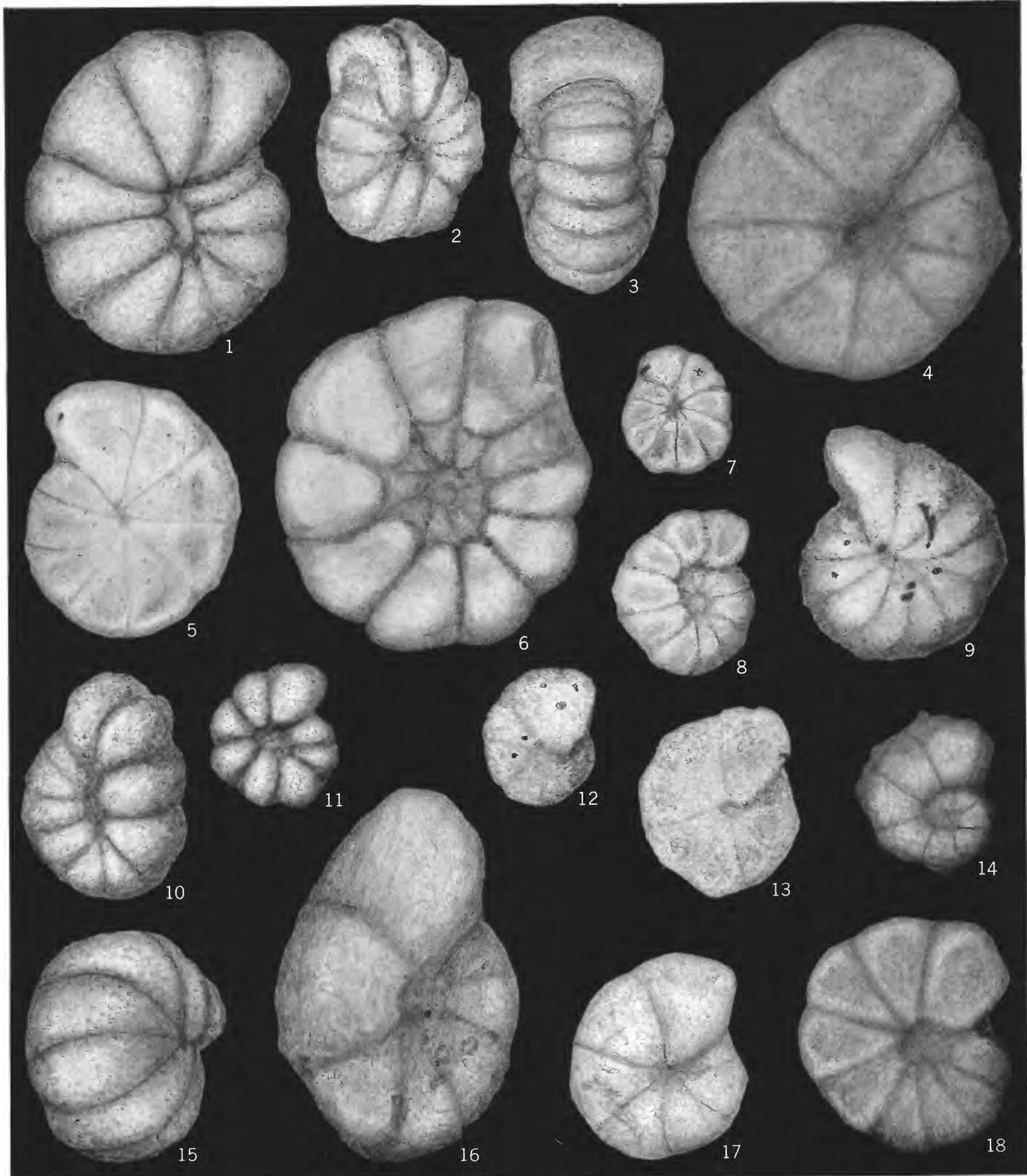

HAPLOPHRAGMOIDES 


\section{PLATE 32}

Figures 1-7. Ammobaculites wenonahae Tappan. 1a, Side view of paratype (USNM P6067); 1b, edge view. 2, Large paratype (USNM P6066). 3, Holotype (USNM 106127a). 4, Paratype (USNM P6082). 5, Paratype (USNM P6072). 6, Paratype (USNM 106129). 7, Paratype (USNM 106127b). Fi६s. 1, 2, 6 from Topagoruk formation, figs. $3-5,7$ from the Grandstand formation. All $\times 55$. (p. 138)

8-11. Ammobaculites fragmentarius Cushman. 8, 11a, Side views of hypotypes (USNM P6057a, b); 11b, edge view. 9, Hypotype (USNM P6059). All from the Grandstand formation. 10, Hypotype (USNM P6062) from the Topagoruk formation. All $\times 55$. (p. 136)

12-17. Verneuilinoides fischeri Tappan. 12, Paratype (USNM P4342) from the Ignek formation. 13, Paratype (USNM P4340) from the Seabee formation. Both $\times 70$. 14, Holotype (USNM P4356). 15, 16, Paratypes (USNM P4357a, b). Figs. 14-16 from the Ignek formation. 17, Paratype (USNM P4359) from the Schrader Bluff formation. Figs. 14-17, all $\times 55$. (p. 143)

All figures are camera lucida drawings by Helen Tappan Loeblich. 


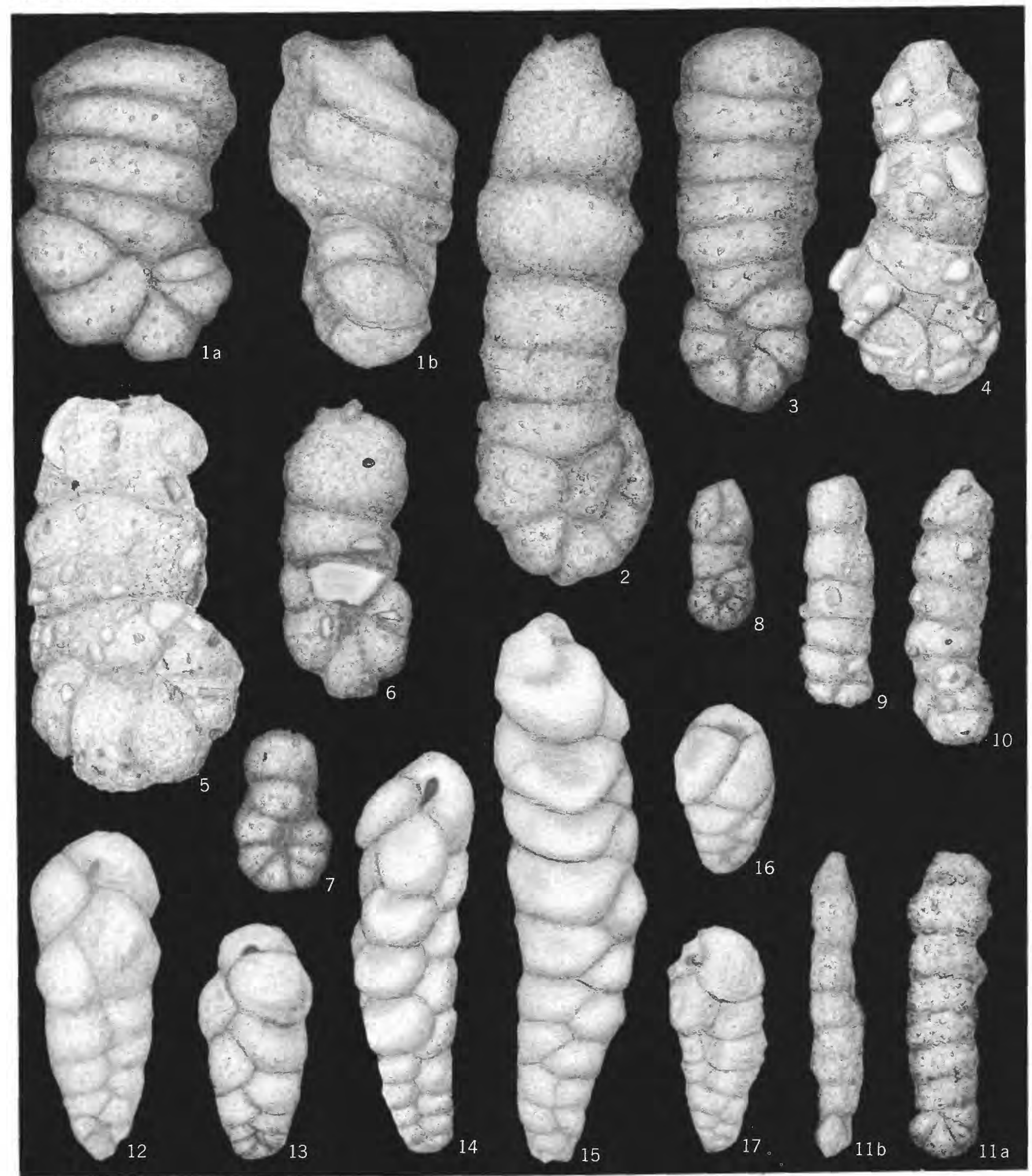




\section{PLATE 33}

Figures 1-3. Spiroplectammina webberi Tappan. 1, 2, Paratypes (USNM P4352 a, b) from the Schrader Bluff formation. 3a, Side view of holotype (USN M P4348) from the Seabee formation; $3 b$, edge view. $\times 115$. (p. 140)

4. Spiroplectammina ammovitrea Tappan. Hypotype (USNM P6095) from the Torok formation (probably contamination from the overlying Topagoruk formation). $\times 95 . \quad(p .139)$

5. Spiroplectammina sp. Specimen (USNM P6103) from the Topagoruk formation. $\times 95 . \quad$ (p. 141)

6. Spiroplectammina mordenensis Wickenden. 6a, Side view of hypotype (USNM 106501) from the Schrader Bluff formation; $6 \mathrm{~b}$, top view. $\times 95$. (p. 140)

7-11. Textularia topagorukensis Tappan. 7, Megalospheric paratype (USNM P4302). 8a, Side view of holotype (megalospheric), (USNM P4296); 8b, top view. 9a, Side view of holotype of Spiroplectammina koveri Tappan (USNM P4290); 9b, edge view. 10, Paratype (USNM P6097) of S. koveri, from the Torok formation. 11, Paratype (USNM P4292) of S. koveri. Figs. 9-11 formerly referred to S. koveri, now regarded as microspheric specimens of T. topagorukensis. Figs. 7-9, 11 from the Topagoruk formation. All $\times 95$. (p. 141)

12. Uvigerinammina athabascensis (Mellon and Wall). Side view of hypotype (USNM P6783) from the Torok formation. $\times 70 . \quad($ p. 139)

13-15. Flabellammina chapmani Tappan. 13, 14, Paratypes (USNM P6093 a, b) from the Schrader Bluff formation, $\times 40$. 15a, Side view of holotype (USNM P4355) from the Seabee formation; $15 \mathrm{~b}$, top view, $\times 70$. (p. 139)

16-17. Textularia gravenori Stelck and Wall. Hypotypes (USNM P6105 a, b) from the Seabee formation. $\times 160 . \quad(p$. 141)

18-23. Uvigerinammina manitobensis (Wickenden). 18, Hypotype (USNM P6230) 19a, Side view of hypotype (USNM) 106490 ); 19b, top view. Both from the Topagoruk formation, $\times 95.20,21$, Hypotypes (USNM 106489 a, b) from the Tuktu formation. 22, 23, Hypotypes (USNM P6233 a, b) from the Torok formation. Figs. 20-23, $\times 70$. (p. 145)

All figures are camera lucida drawings by Helen Tappan Loeblich. 

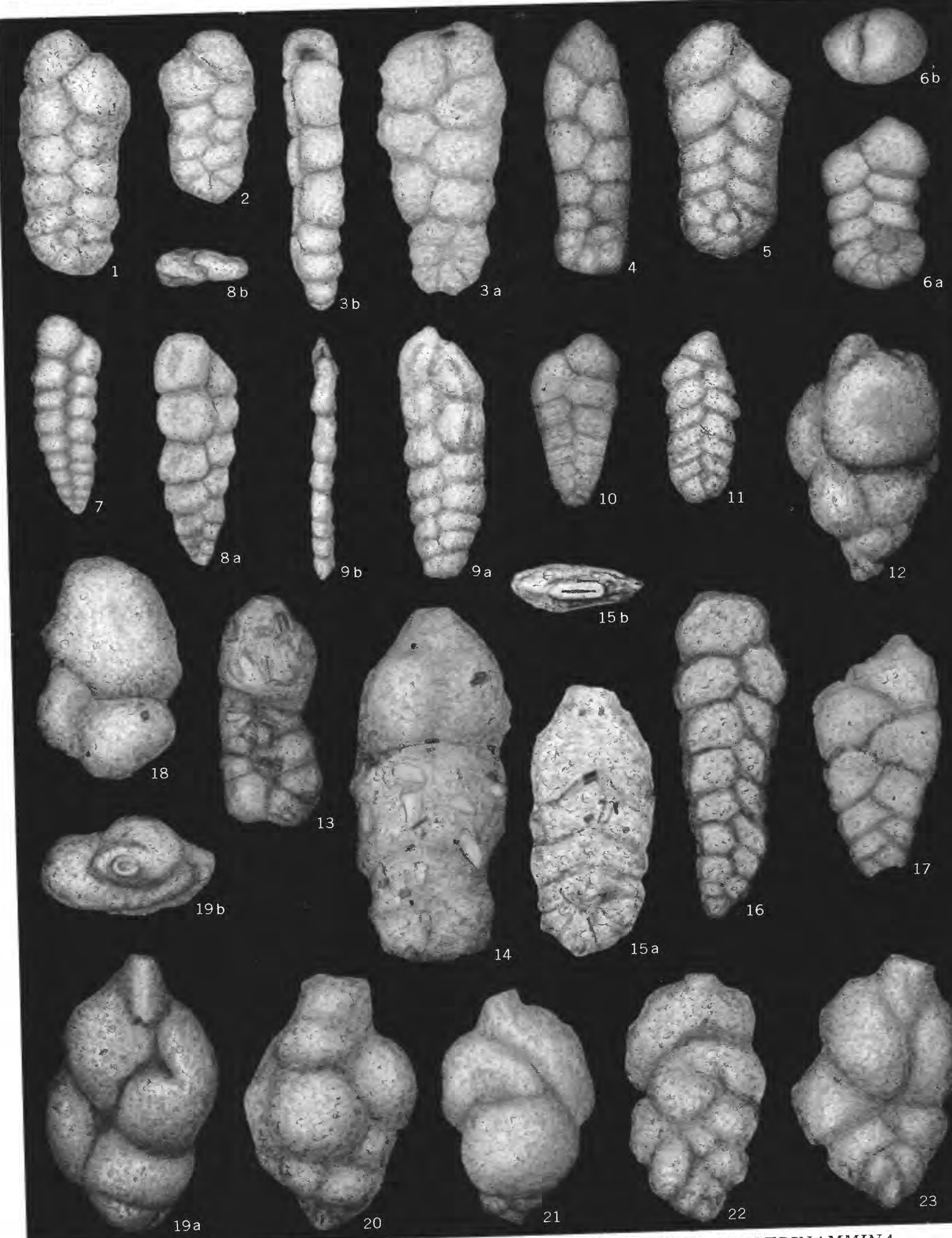

SPIROPLECTAMMINA, TEXTULARIA, FLABELLAMMINA, AND UVIGERINAMMINA 


\section{PLATE 34}

Figures 1-9. Verneuilinoides borealis Tappan. 1, 2, 7, 9, Paratypes (USNM P4329a-d) showing variation in size and proportions. 3, Paratype (USNM P4326). 4, Paratype (USNM P4317). 5, Paratype (USNM 106132). 6, Holotype (USNM 106131). 8, Small paratype (USN M P4319). All from the Grandstand formation. Figs. 1-3, $\times 70$; figs. $4-6,8, \times 120$; figs. $7,9, \times 55$. (p. 142)

10. Gaudryina cushmani Tappan. Hypotype (USNM P6165) from the Torok formation. $\times 70$. (p. 147)

11-15. Gaudryina nanushukensis Tappan. 11a, Side view of holotype (USNM 106120); 11b, top view. 12, Paratype (USNM 106121) 13, Paratype (USNM P6183). 14, 15, Paratypes (USNM 106124 a, b). Figs. 11, 12, 14, 15 from the Topagoruk formation, $\times 55$; fig. 13 from the Tuktu formation, $\times 70$. (p. 148)

16-18. Gaudryina barrowensis Tappan. 16, Paratype (USNM P6134) 17, Paratype (USNM P6141). 18, Holotype (USNM P6131), showing angularity of triserial portion. All from the Torok formation, $\times 70$. (p. 145)

19-22. Siphotextularia? rayi Tappan. 19, Paratype (USNM P6122) from the Kukpowruk formation. 20, Paratype (USNM P6108) from the Topagoruk formation. Both $\times 55$. 21a, Side view of holotype (USNM P4304); $21 \mathrm{~b}$, edge view. 22, Paratype (USNM P4306). Both from the Topagoruk formation, $\times 70$. (p. 142)

All figures are camera lucida drawings by Helen Tappan Loeblich. 


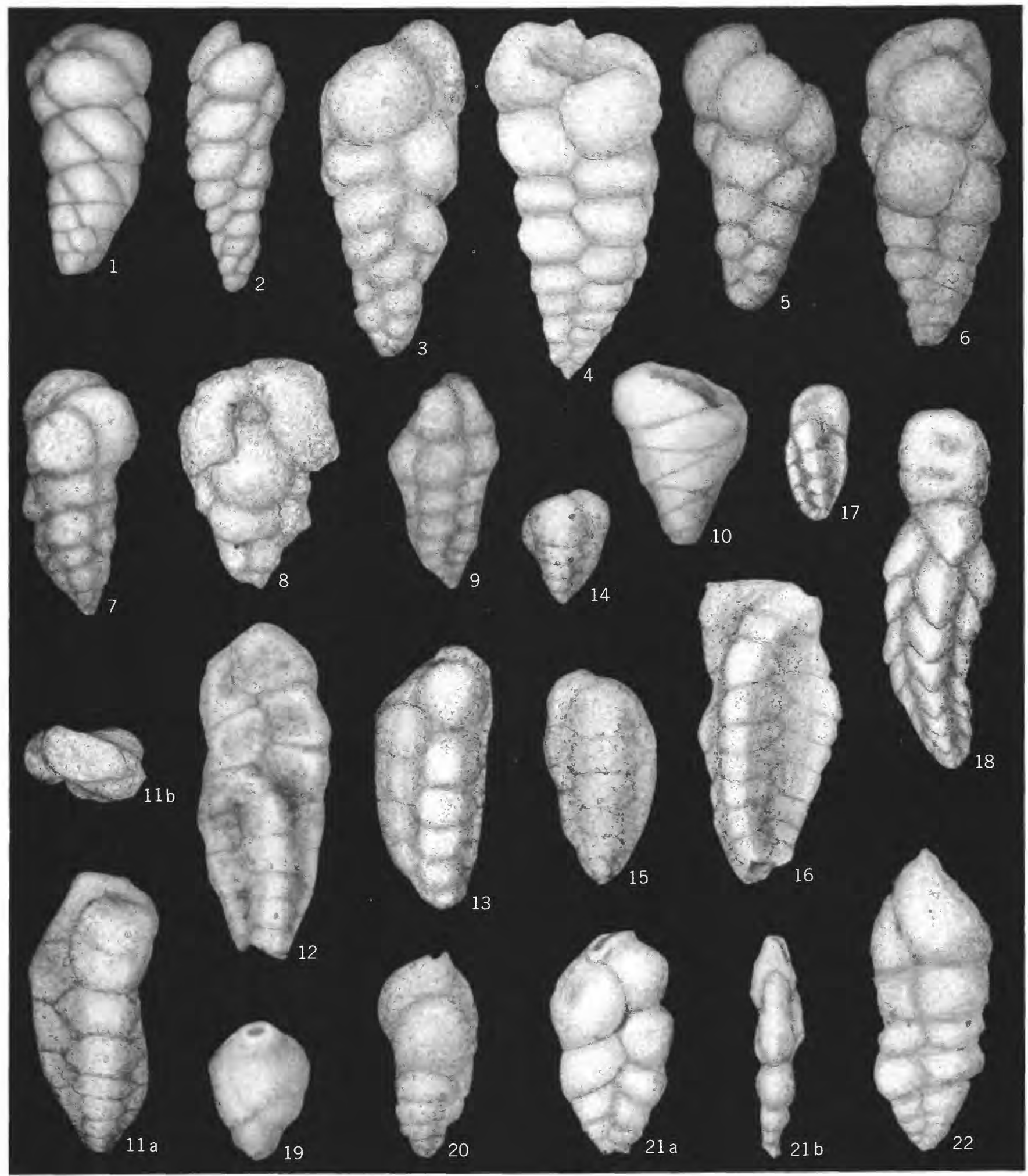

VERNEUILINOIDES, SIPHOTEXTULARIA, AND GAUDRYINA 
PLATE 35

Figures 1-7. Gaudryina canadensis Cushman. 1, 7, Hypotypes (USNM P6144 a, b) from the Grandstand formation. 2, Hypo type (USNM P6158), from the Tuktu formation. 3, Hypotype (USNM P6151) from the Topagoruk formation. 4, Hypotype (USNM P6152) from the Topagoruk formation. 5, 6, Hypotypes (USNM P6146 a, b) from the Grandstand formation. Figs. 1, 7, ×70; figs. 2-4, $\times 95$; figs. 5, 6, × 160. (p. 146)

8-16. Gaudryina tailleuri (Tappan). 8, Paratype (USNM P4368). 9, Paratype (USNM P4365). 10a, Side view of holotype of Dorothia chandlerensis Tappan (USNM P4401), now regarded as probably the microspheric generation of G. tailleuri; 10b, edge view. 11, Paratype (USNM P4404) of D. chandlerensis. 12, Paratype (USNM P4373). 13, Paratype (USNM P6118). 14a, Side view of holotype (USNM P4367); 14b, top view. 15a, Side view of paratype (USNM P6763); 15b, top view. 16, Paratype (USNM P6112). Figs. 8, 9, 12, 14, from the Fortress Mountain formation, figs. 10, 11, 13, 15, 16, from the Torok formation. Figs. 8, 9, 12, 14, $\times 115$; figs. 10, 11, $13,15,16, \times 95$. (p. 149)

17-21. Gaudryina irenensis Stelck and Wall. 17, 19, 20, Hypotypes (USNM P6160a-c) from the Ninuluk formation. 18, Hypotype (USNM P6189) from the Seabee formation. 21, Hypotype (USN M P6193) from the Seabee formation. All $\times 95$. (p. 147)

22-24. Gaudryinella irregularis Tappan. 22, Hypotype (USNM P6209). 23, Hypotype (USNM P6212). 24, Hypotype (USN M P6214). All from the Torok formation. All $\times 95$. (p. 150).

All figures are camera lucida drawings by Helen Tappan Loeblich. 


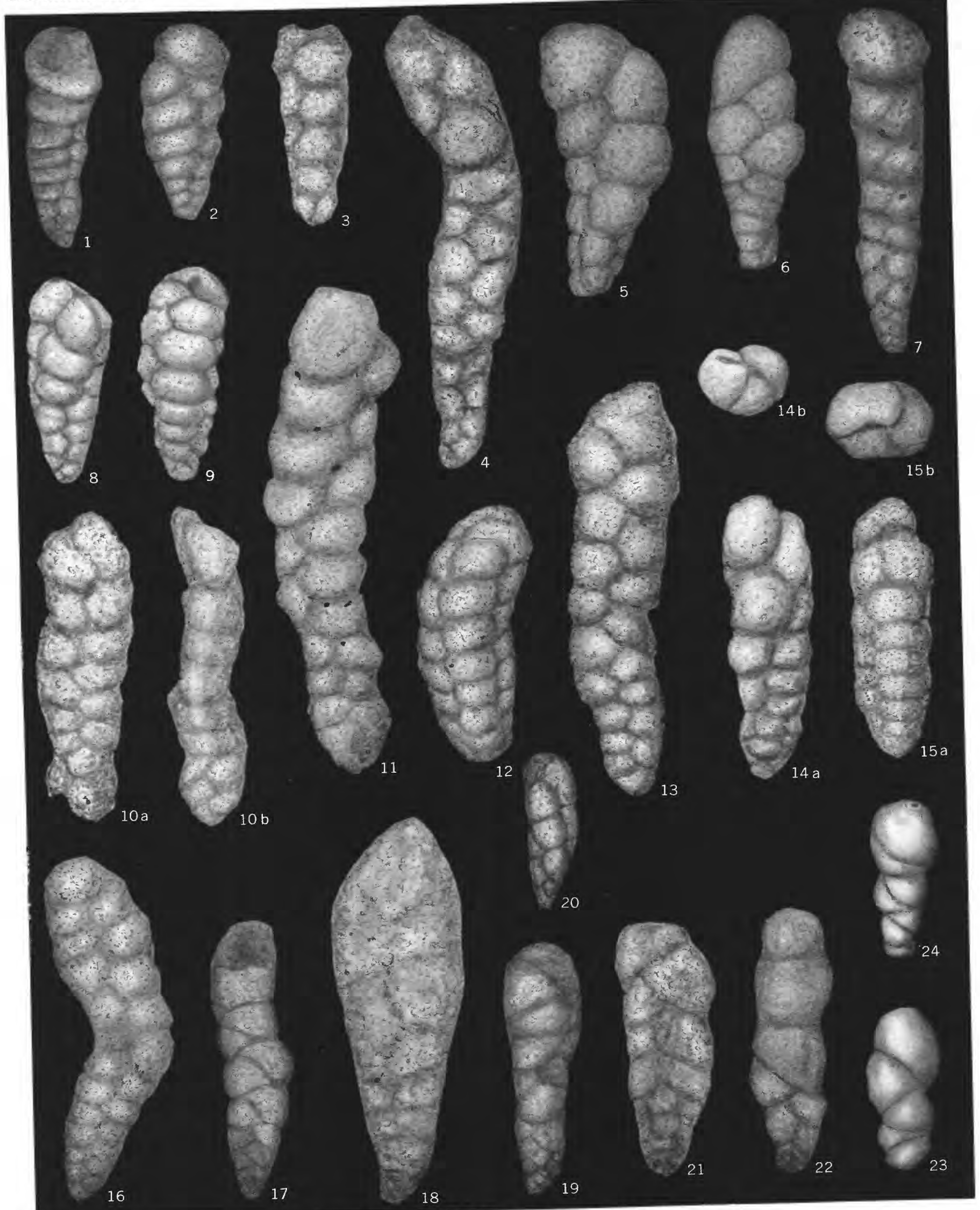




\section{PLATE 36}

Figures 1-4. Arenobulimina paynei Tappan. 1, 4, Pyritized paratypes (USNM P4384 a, b) from the Topagoruk formation. 2, Holotype (USNM P4375) from the Topagoruk formation. 3, Crushed paratype (USNM P4379) from the Grandstand formation. All $\times 70$. (p. 151)

5, 6. Gaudryina subcretacea Cushman. 5, Hypotype (USNM P6204) 6, Hypotype (USNM P6205). Both from the Topagoruk formation. $\times 55 . \quad($ p. 149)

7-9. Arenobulimina torula Tappan. 7, 9, Paratypes (USNM P4396 a, b) crushed in different planes. 8, Holotype (USNM P4393), pyritized, thus preserving the original form. All from the Ignek formation. $\times 70$. (p. 152)

10, 11. Pseudoclavulina hastata (Cushman). Hypotypes (USNM P6241 a, b) from the Seabee formtaion. $\times 55$. (p. 151 )

12-18. Miliammina manitobensis Wickenden. 12, Hypotype (USNM P6355) 13, 16, Hypotypes (USNM P6342 a, b). 14, Hypotype (USNM P6349). 15, Hypotype (USNM P6358). 17, Hypotype (USNM P6352). 18, Hypotype (USNM P6351). Figs. 12, 14, 15, 18 from the Topagoruk formation. Figs. 13, 16, 17 from the Grandstand formation. Figs. 12-17, $\times 70$; fig. 18, $\times 30$. (p. 160)

19. Mitiammina bisobscura Stelck and Wall. Hypotype (USNM P6329) from the Seabee formation. $\quad \times 70 . \quad(\mathrm{p} .160)$

20-24. Miliammina awunensis Tappan. 20, Paratype (USNM P6325) from the Torok formation. 21, Paratype (USNM) P6324) from the Topagoruk formation. 22, Paratype (USNM P4409) from the Chandler formation. 23, Paratype (USNM P4415) from the Grandstand formation. 24, Holotype (USNM P4407) from the Chandler formation. All $\times 70$. (p. 159)

All figures are camera lucida drawings by Helen Tappan Loeblich. 


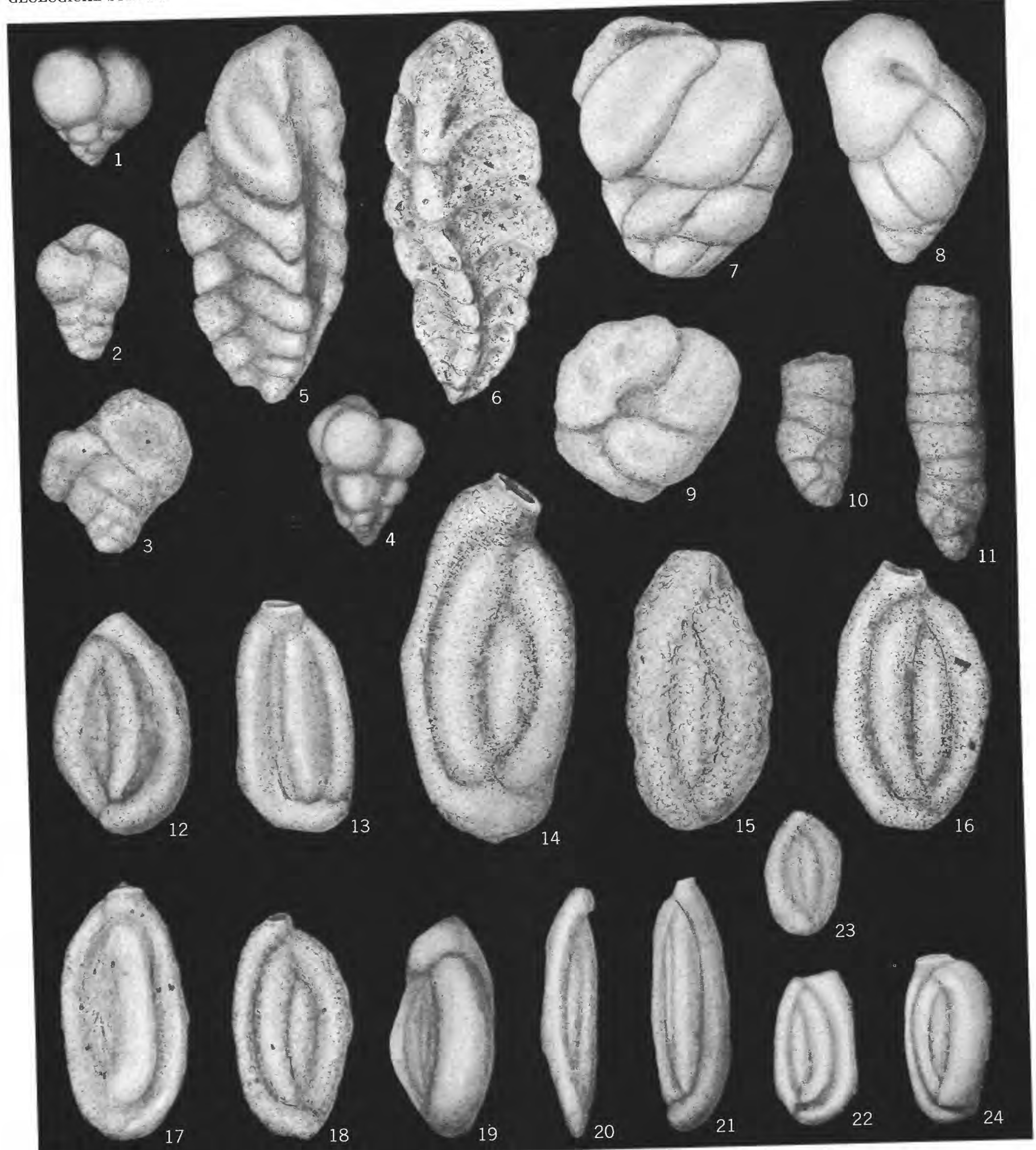

GAUDRYINA, ARENOBULIMINA, PSEUDOCLAVULINA, AND MILIAMMINA 


\section{PLATE 37}

Figures 1-5. Miliammina ischnia Tappan. 1, 2, 4, Paratypes (USNM P6355a-c). 3, Paratype (USNM P4421). 5, Holotype USNM P4419). All from the Grandstand formation, $\times 95$. (p. 160)

6. Quinqueloculina sphaera Nauss. 6a, b, Opposite sides of hypotype (USNM P6315) from the Schrader Bluff formation; 6c, top view, $\times 150$. (p. 157)

7-10. Psamminopelta subcircularis Tappan. 7, Paratype (USNM P4454). 8, Paratype (USNM P6317). 9, Paratype (USNM P4453). 10, Holotype (USNM P4452). All from the Grandstand formation. $\times 95 . \quad$ (p. 158)

11-22. Psamminopelta bowsheri Tappan. 11, Paratype (USNM P4436) from the Chandler formation. 12, Paratype (USNM P4462) from the Grandstand formation. 13, 14, 16, 21, Paratypes (USNM P4430a-d) from the Grandstand formation. 15, Paratype (USNM P4426) from the Topagoruk formation. 17, Holotype (USNM P4424) from the Grandstand formation. 18, Paratype (USNM P4429) from the Grandstand formation. 19, Paratype (USNM P4443) from the Torok formation. 20, Paratype (USNM P4434) from the Grandstand formation. 22, Paratype (USNM P6367) from the Torok formation. Figs. 11, 12, 15, 17, 18, ×40. Figs. 13, 14, 16, 19-22, $\times 95$. (p. 157)

All figures are camera lucida drawings by Helen Tappan Loeblich. 


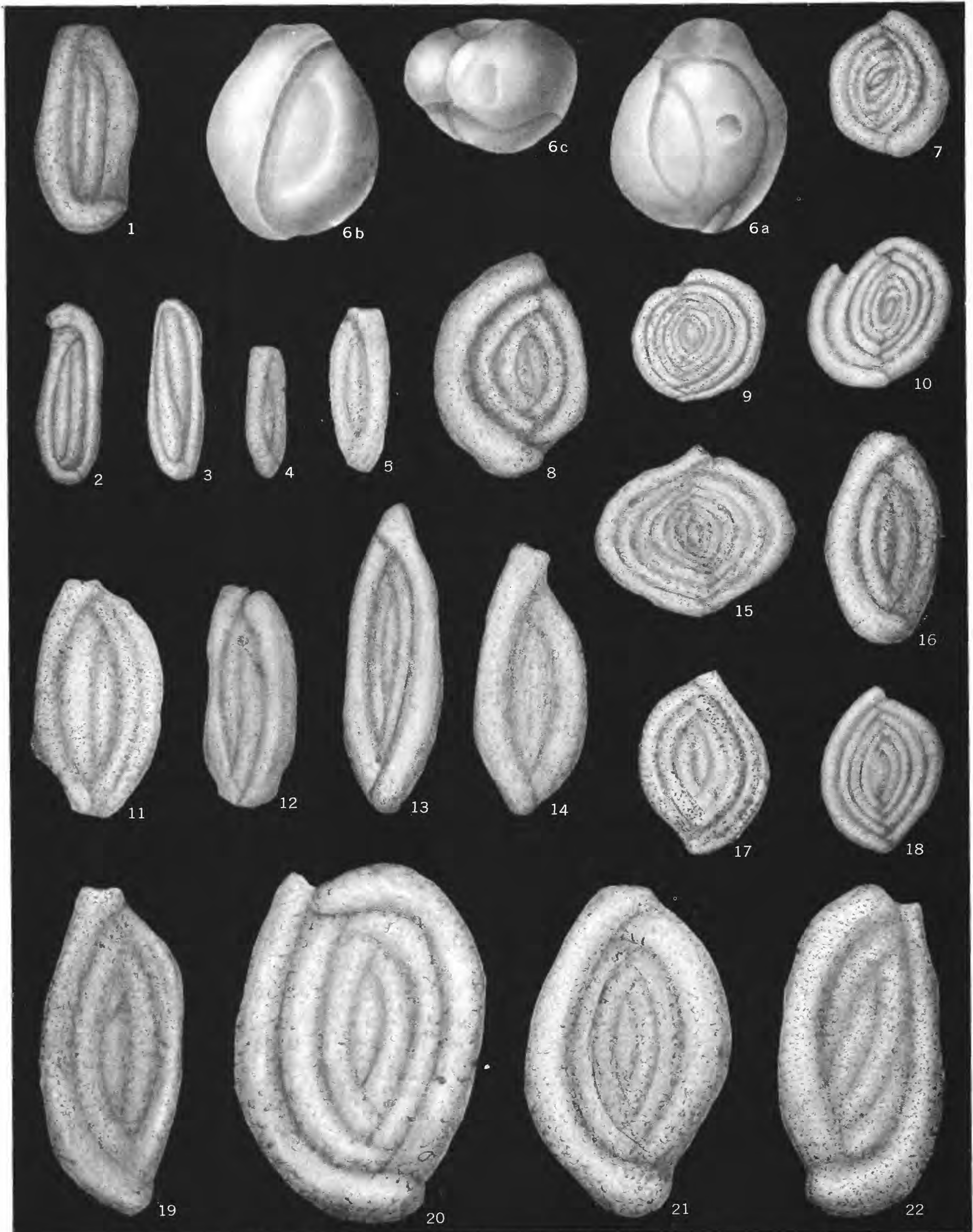

MILIAMMINA, QUINQUELOCULINA, AND PSAMMINOPELTA 


\section{PLATE 38}

Figures 1-4. Trochammina diagonis (Carsey). 1, 2, Hypotypes (USNM P6251 a, b) from the Seabee formation, $\times 55$. 3 , 4 , Hypotypes (USNM P6256 a, b) from the Seabee formation. $\times 70 . \quad$ (p. 153)

5-8. Trochammina umiatensis Tappan. 5a, Spiral view of holotype (USNM P4495) from the Grandstand formation; $5 \mathrm{~b}$, umbilical view; $5 \mathrm{c}$, edge view. $\times 70.6,7$, Paratypes (USNM P4502 a, b) from the Grandstand formation. $\times 55$. 8, Paratype (USNM P6021) from the Topagoruk formation. $\times 70$. (p. 156)

9, 10. Trochammina eilete Tappan. 9a, Spiral view of holotype (USNM P4483) from the Torok formation; 9b, umbilical view; 9c, edge view. 10, Paratype (USNM P4487) from the Fortress Mountain formation. $\times 70$. (p. 153)

11-14. Trochammina stefanssoni Tappan. 11, 13, 14, Paratypes (USNM P4492a-c), showing crushing and distortion in various planes. 12a, Spiral view of holotype (USNM P4490); 12b, umbilical view. All from the Schrader Bluff formation $\times 70$. (p. 156)

All figures are camera lucida drawings by Helen Tappan Loeblich. 


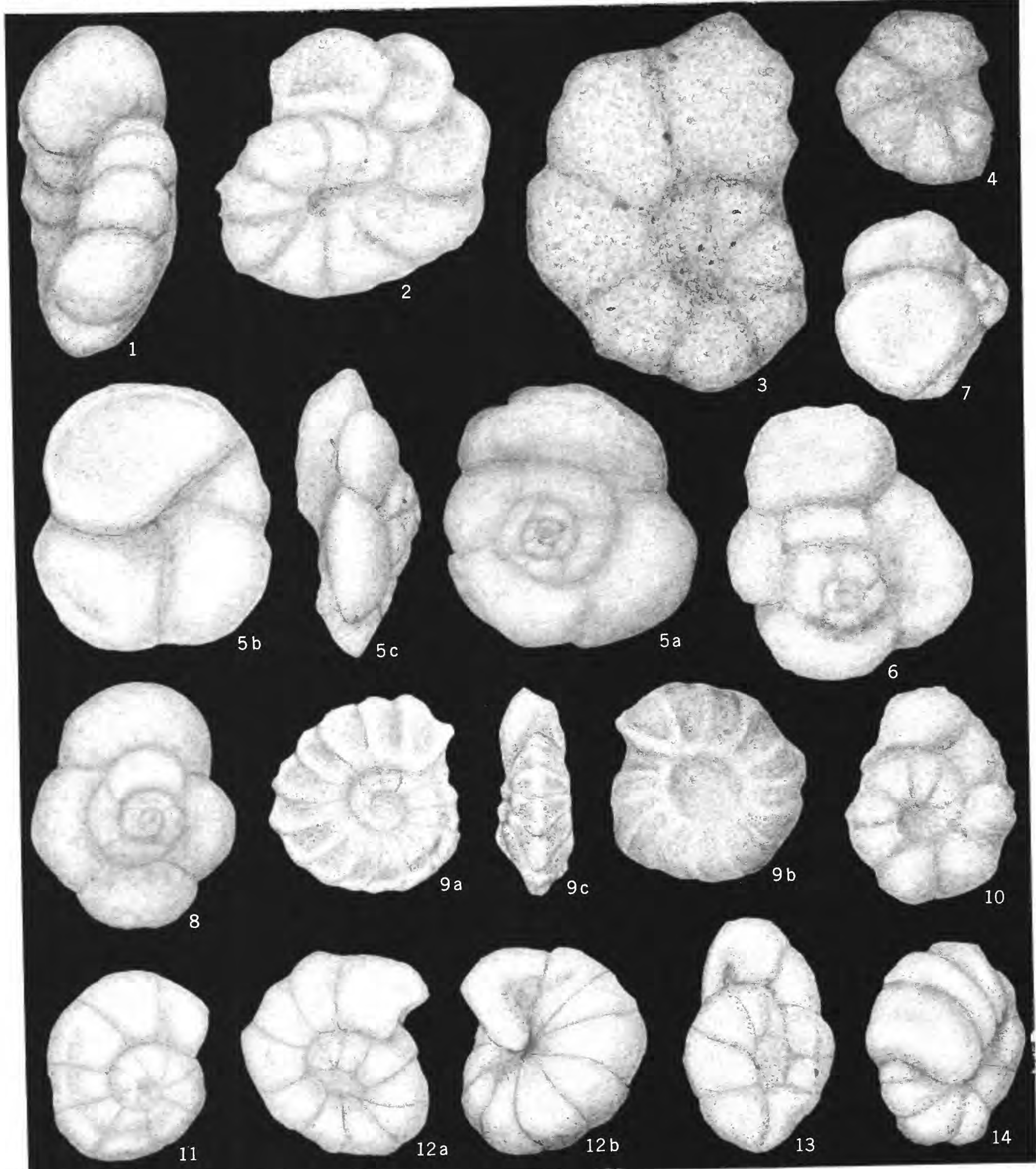

TROCHAMMINA 


\section{PLATE 39}

FigUres 1-6. Trochammina whittingtoni Tappan. 1, Umbilical view of paratype (USNM P4508). 2, Spiral view of paratype (USNM P6277). 3a, Spiral view of holotype (USNM P4505); 3b, umbilical view; 3c, edge view, showing typical crushing of this species. 4, Small paratype (USNM P4506). 5, Paratype (USNM P4514). 6, Paratype (USNM P6281). Figs. 1-4, 6, from the Seabee formation, fig. 5 from the Schrader Bluff formation. All $\times 70$. (p. 157)

7-12. Trochammina rainwateri Cushman and Applin. 7a, Spiral view of somewhat distorted hypotype (USNM P6257) from the Topagoruk formation; 7b, umbilical view. 8, Hypotype (USNM P6266), from the Grandstand formation. 9, Hypotype (USNM P6268) from the Tuktu formation. 10, Hypotype (USNM P6261) from the Grandstand formation. 11, 12, Hypotypes (USNM P6263 a, b) from the Topagoruk formation. All $\times 70$. (p. 153)

13, 14. Trochammina albertensis Wickenden. 13a, 14a, Spiral views of hypotypes (USNM P4516 a, b) from the Sehrader Bluff formation; 13b, umbilical view; 13c, edge view. $\times 70$. (p. 152)

15-17. Trochammina ribstonensis Wickenden. 15a, Spiral view of small hypotype (USNM P6286) from the Schrader Bluff formation; 15b, umbilical view; 15c, edge view. $\times 120.16$, Hypotype (USNM P6289) from the Tuluvak tongue of the Prince Creek formation. $\times 70 . \quad 17$, Hypotype (USNM P6291) from the Seabee formation. $\times 70$. (p. 154)

18-20. Trochammina ribstonensis Wickenden subspecies rutherfordi Stelck and Wall. 18a, 20, Spiral views of hypotypes (USNM P6300 a, b) ; 18b, umbilical view; 18c, edge view. $\times 120.19$, Spiral view of hypotype (USNM P6296), $\times 70$. All from the Ninuluk formation. (p. 155)

All figures are camera lucida drawings by Helen Tappan Loeblich. 


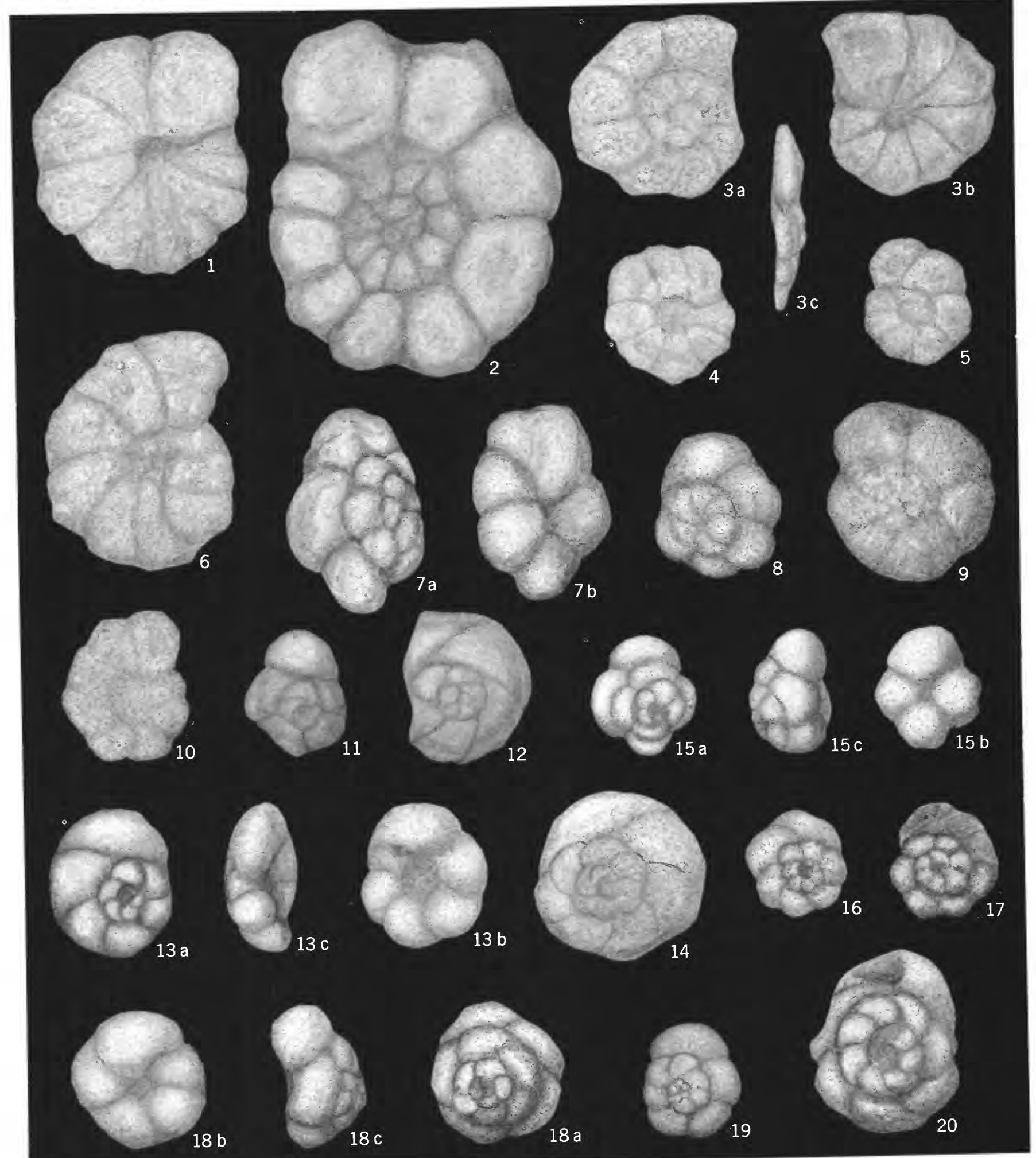

TROCHAMMINA 


\section{PLATE 40}

FigURe 1. Lenticulina polygona (Perner). Hypotype (USNM P6408) from the Torok formation. $\times 70 . \quad(p .163)$

2, 3. Lenticulina bayrocki Mellon and Wall. 2a, Side view of hypotype (USNM P6412) from the Topagoruk formation; $2 \mathrm{~b}$, face view. $\times 70$. 3a, Side view of hypotype (USNM P6411) from the Grandstand formation; $3 \mathrm{~b}$, face view. $\times 55$. (p. 161)

4. Lenticulina gryci Tappan. 4a, Side view of hypotype (USNM P6409) from the Schrader Bluff formation; $4 \mathrm{~b}$, face view. $\times 70 . \quad(p .161)$

5-8. Lenticulina macrodisca (Reuss). 5, Hypotype (USNM P6385). ×55. 6, Hypotype (USNM P6394). $\times 70 . \quad 7$, Small hypotype (USNM P6398). $\times 70$. 8a, Side view of hypotype (USNM P6396); 8b, face view. $\times 70$. All from the Topagoruk formation. (p. 162)

9-12. Lenticulina topagorukensis Tappan. 9a, Side view of holotype (USNM P6415); 9b, face view. $\times 70 . \quad 10 \mathrm{a}$, Side view of paratype (USNM P6416); 10b, face view, $\times 70$. 11, Paratype (USNM P6417), $\times 120$. All from the Topagoruk formation. 12, Paratype (USNM P6418) from the Torok formation. $\times 70 . \quad(p .163$ )

13-14. Lenticulina erecta (Perner). 13a, Side view of hypotype (USNM P6379); 13b, face view. 14, Hypotype (USNM P6375). Both from the Topagoruk formation. $\times 55 \quad$ (p. 162)

All figures are camera lucida drawings by Helen Tappan Loeblich. 


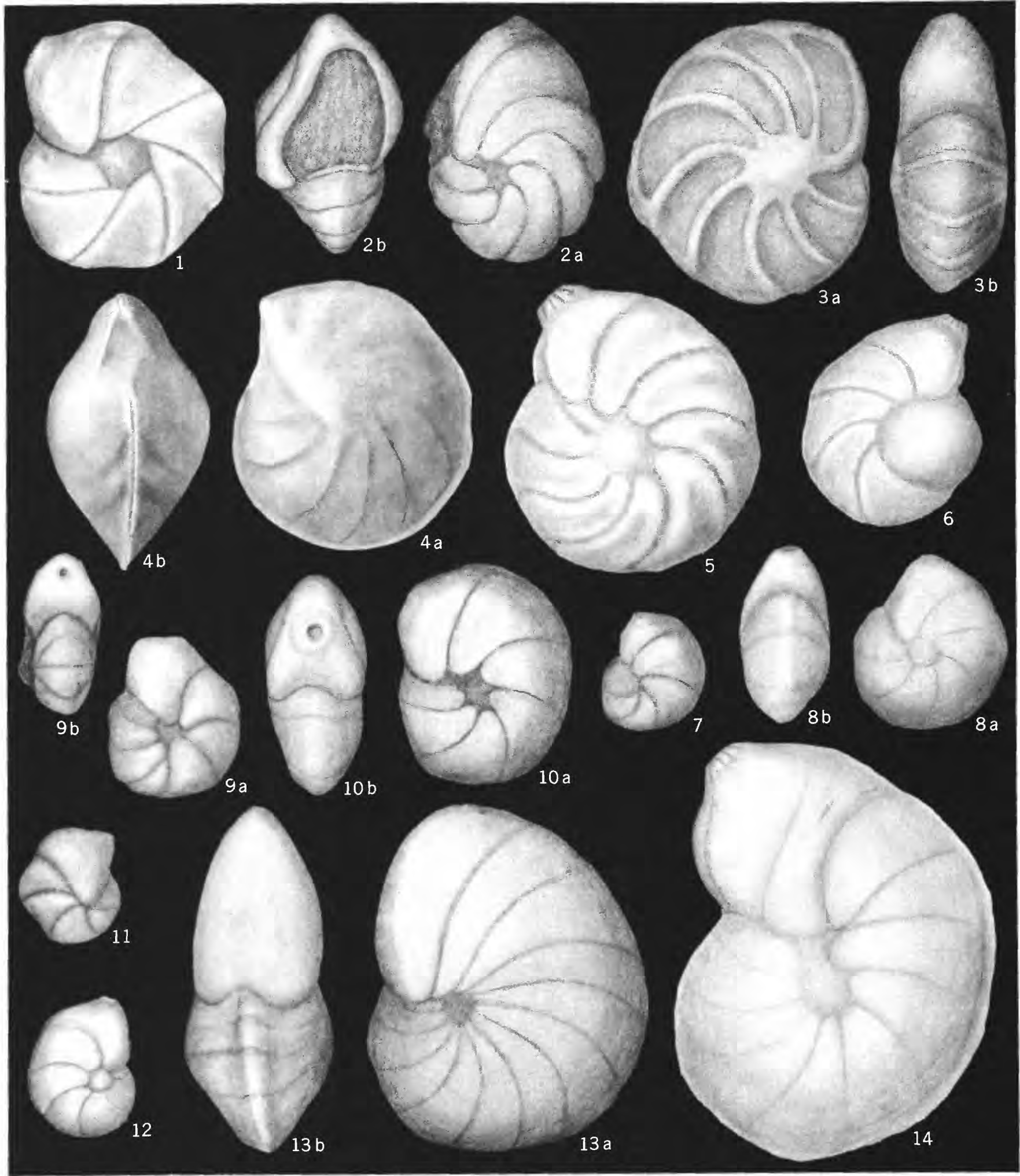




\section{PLATE 41}

Figures 1, 2. Lenticulina ingenua (Berthelin). 1, Hypotype (CSNM P6422), ×70. 2, Hypotype (USNM P6384), $\times 55$. Both from the Torok formation. (p. 162)

3-5. Saracenaria grandstandensis Táppan. 3a, Side view of holotype (USNM P6442); 3b, face view. $\times 70$. 4a, Side view of paratype (USNM P6443); 4b, face view. $\times 120$. 5, Paratype (USNM P6444), $\times 70$. All from the Grandstand formation. (p. 164)

6-8. Saracenaria trollopei Mellon and Wall. 6a, Side view of hypotype (USNM P6438) from the Torok formation; 6b, face view. 7, Hypotype (USNM P6441) from the Topagoruk formation. 8, Hypotype (USNM P6439) from the Torok formation. All $\times 70$. (p. 165)

9-14. Saracenaria projectura Stelck and Wall. 9a, 13, Side views of hypotypes (USNM P6423 a, b); 9b, face view. 10, Hypotype (USNM P6425). 11a, Side view of hypotype (USNM P6427); 11b, face view. 12a, Side view of hypotype (USNM P6434); 12b, face view. 14, Hypotype (USNM P6431). Fig. 12 from the Grandstand formation, others from the Torok formation. All $\times 70$. (p. 164)

15-17. Saracenaria dutroi Tappan. 15a, Side view of holotype (USNM P4533); 15b, face view. 16, Paratype (USNM P4540). 17a, Side view of paratype (USNM P4537); 17b, face view. All from the Topagoruk formation, $\times 70$. (p. 164)

18, 19. Saracenaria spinosa Eichenberg. 18a, Side view of hypotype (USNM P6451) from the Topagoruk formation; 18b, face view. 19, Hypotype (USNM P6448) from the Grandstand formation. Both $\times 120$. (p. 165)

All figures are camera lucida drawings, figs. 15-17 by Patricia Isham, others by Helen Tappan Loeblich. 


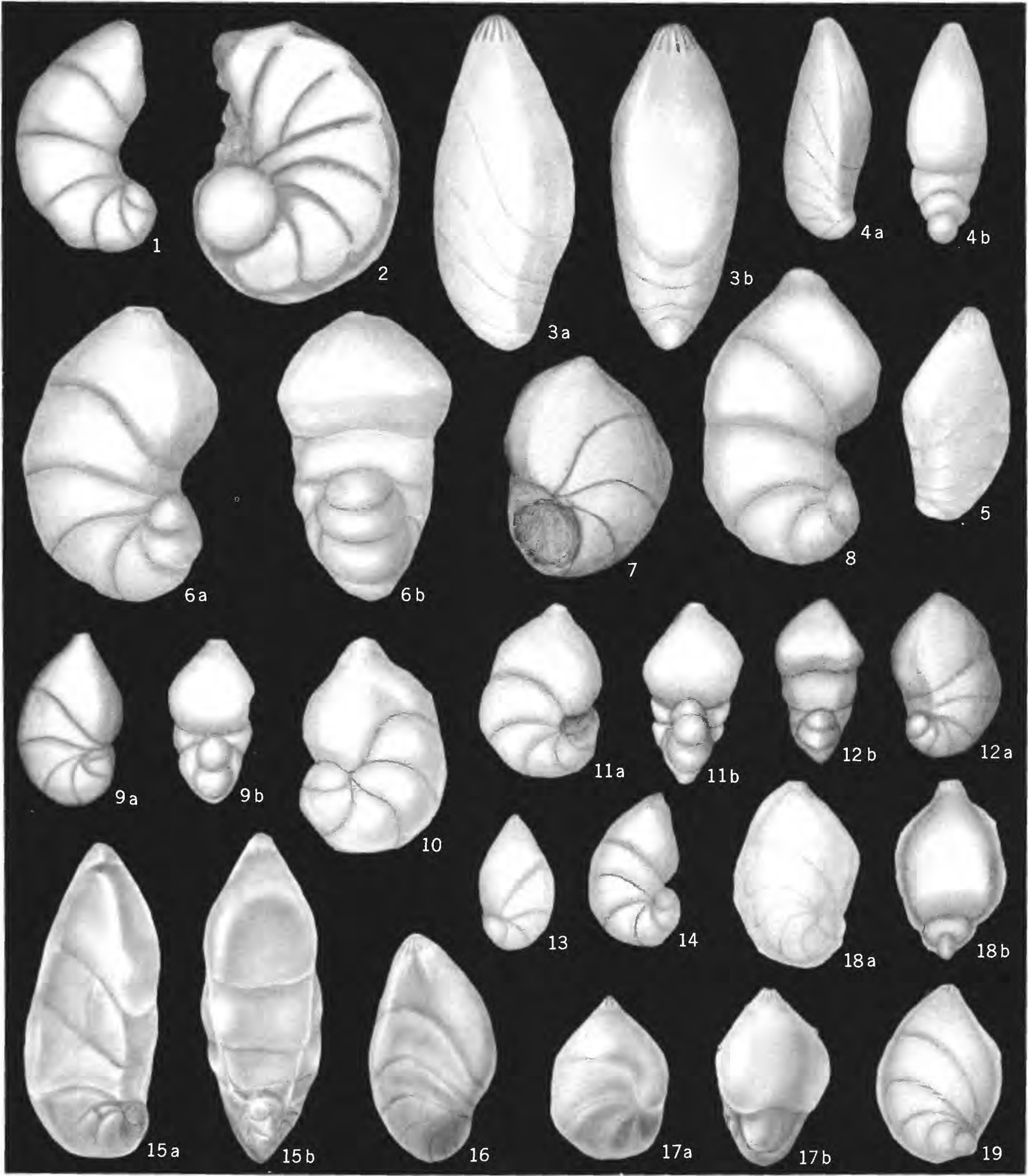

LENTICULINA AND SARACENARIA 


\section{PLATE 42}

FIgures 1-6. Marginulinopsis jonesi (Reuss). 1, 2, Hypotypes (USNM P6475 a, b), X95. 3, Hypotype (USNM P6474), $\times 70$. 4, Hypotype (USNM P6473), $\times 95$. 5, Hypotype (USNM P6472), $\times 70$. All from the Topagoruk formation. 6a, Side view of hypotype (USN M P6469) from the Grandstand formation; 6b, edge view, $\times 95$. (p. 167)

7, 8. Saracenaria valanginiana Bartenstein and Brand. 7a, Side view of hypotype (USN M P6452); 7b, face view. 8a, Side view of hypotype (USNM P6453); 8b, face view. Both from the Torok formation, $\times 95$. (p. 166)

9. Saracenaria sp. 9a, Side view of specimen (USNM P6456) from the Topagoruk formation; $9 \mathrm{~b}$, face view. $\times 95$. (p. 166)

10-15. Marginulinopsis collinsi Mellon and Wall. 10a, Side view of hypotype (USNM P6461) from the Torok formation; 10b, face view. 11, Hypotype (USNM P6467) from the Topagoruk formation. 12, Hypotype (USNM P6464) from the Topagoruk formation. 13, Hypotype (USNM P6468) from the Grandstand formation. 14, Hypotype (USNM P6460) from the Torok formation. 15, Hypotype (USNM P6463) from the Topagoruk formation. Fig. 11, $\times 160$; other figs. $\times 95$. (p. 166)

All figures are camera lucida drawings, fig. 7 by Patricia Isham, other figures by Helen Tappan Loeblich. 

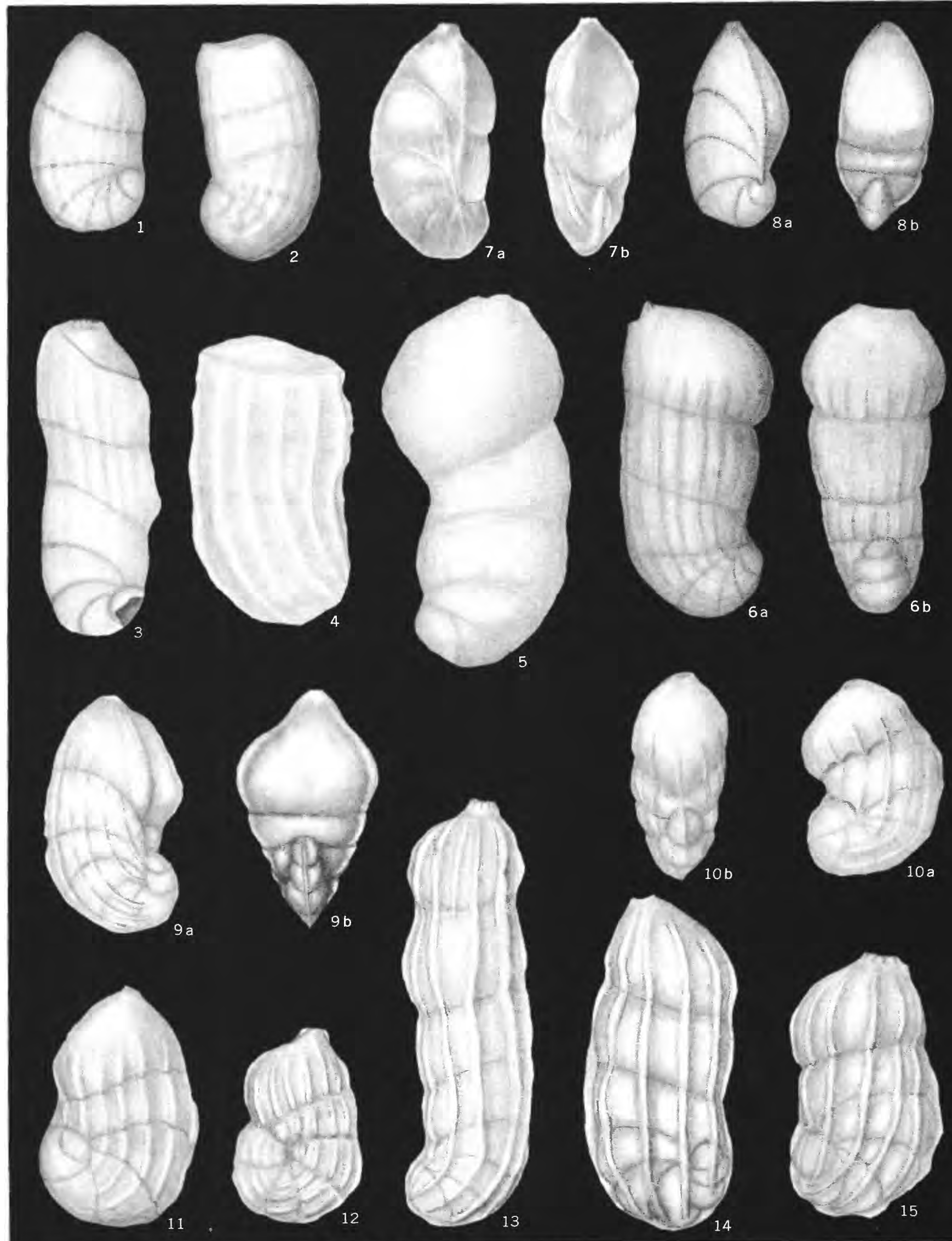

SARACENARIA AND MARGINULINOPSIS 


\section{PLATE 43}

Figures 1-4. Marginulinopsis reiseri Tappan. 1a, Side view of holotype (USNM P6476); 1b, face view, $\times 70$. 2a, Side view of paratype (USNM P6486); 2b, face view, $\times 95$. 3, Large paratype (USNM P6483), $\times 95$. All from the Topagoruk formation. 4, Paratype (USNM P6484) from the Grandstand formation, $\times 70$. (p. 167)

5-7. Marginulinopsis umiatensis Tappan. 5a, Side view of paratype (USNM 106126); 5b, face view. 6, Holotype (USNM 106125). 7, Paratype (USNM P6457). Ali from the Topagoruk formation, $\times 95$. (p. 168)

8-11. Marginulina planiuscula (Reuss). 8, 9, Hypotypes (USNM P6525 a, b). 10 Hypotype (USNM P6534). 11, Hypotype (USNM P6527). All from the Grandstand formation, $\times 95$. (p. 170)

12, 13. Marginulina gatesi Tappan. 12, Paratype (USNM P4527). 13, Holotype (USNM P4522). Both from the Grandstand formation, $\times 95$. (p. 169)

14-17. Marginulina cephalotes (Reuss). 14, Hypotype (USNM P6521). 15, Hypotype (USNM P6518). 16, Hypotype (USNM P6519). All from the Torok formation. 17, Hypotype (USNM P6524) from the Fortress Mountain formation. All $\times 95$. (p. 168)

18, 19. Marginulina sulcifera (Reuss). 18, Hypotype (USNM P6544) from the Torok formation, $\times 95$. 19, Hypotype (USNM P6546) from the Fortress Mountain formation, $\times 160$. (p 170.)

All figures are camera lucida drawings by Helen Tappan Loeblich. 


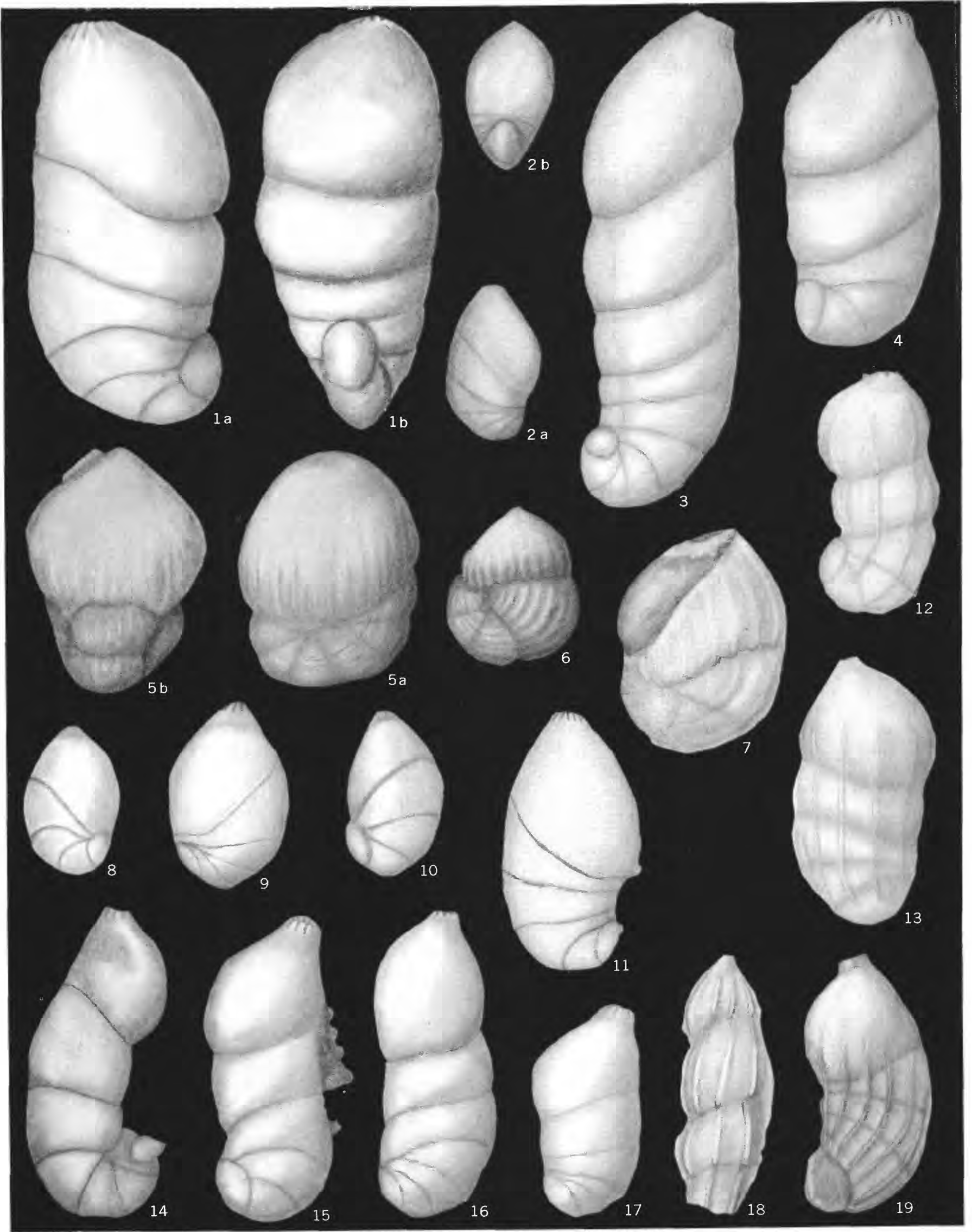




\section{PLATE 44}

Figures 1-3. Marginulinopsis chandlerensis Tappan. 1a, Side view of paratype (USNM P6542); 1b, face view. 2, Holotype (USNM P6538). 3, Paratype (USNM P6539). All from the Schrader Bluff formation, $\times 70$. (p. 166)

4, 5. Marginulina dorsata Cushman. Hypotypes (USN M P6499a, b) from the Schrader Bluff formation, $\times 55$. (p. 169)

6, 7. Marginulina inepta (Reuss). 6, Hypotype (USNM P6719) from the Torok formation. 7a, Side view of hypotype (USNM P6720) from the Topagoruk formation; 7b, top view. $\times 70 . \quad$ (p. 169)

8-10. Rectoglandulina humilis (Roemer). 8, Hypotype (USNM P6623) from the Topagoruk formation. 9, Hypotype (USN M P6624) from the Grandstand formation. 10, Hypotype (USNM P6625) from the Topagoruk formation. $\times 55$. (p. 170)

11, 12. Rectoglandulina netrona Tappan. 11a, Side view of holotype (USNM P6627); 11b, top view. 12, Paratype (USNM P6628). Both from the Topagoruk formation. $\times 120 . \quad$ (p. 171)

13-18. Rectoglandulina kirschneri Tappan. 13, Paratype (USNM P4548) from the Torok formation. 14a, Side view of holotype (USNM P4546) from the Topagoruk formation; 14b, top view. 15, Paratype (USNM P6611) from the Topagoruk formation. 16, Paratype (USNM P6610) from the Grandstand formation. 17, Paratype (USNM P6603) from the Torok formation. 18, Paratype (USNM P4549) from the Grandstand formation. Figs. 13, 18, $\times 55$; figs. 14-17, $\times 70$. (p. 171)

19-21. Lingulina loryi (Berthelin). 19, Juvenile megalospheric hypotype (USNM P6613) from the Topagoruk formation. 20, Hypotype (USNM P6614) from the Fortress Mountain formation. 21a, Side view of hypotype (USNM P6612) from the Topagoruk formation; $21 \mathrm{~b}$, edge view; $21 \mathrm{c}$, top view. $\times 120 . \quad$ (p. 172)

22. Lingulina rediviva Berthelin. 22a, Side view of hypotype (USNM P6615) from the Grandstand formation; 22b, top view. $\times 120$. (p. 172)

All figures are camera lucida drawings; figs. 1-3, 8, 9, 13-17 by Patricia Isham, other figures by Helen Tappan Loeblich. 


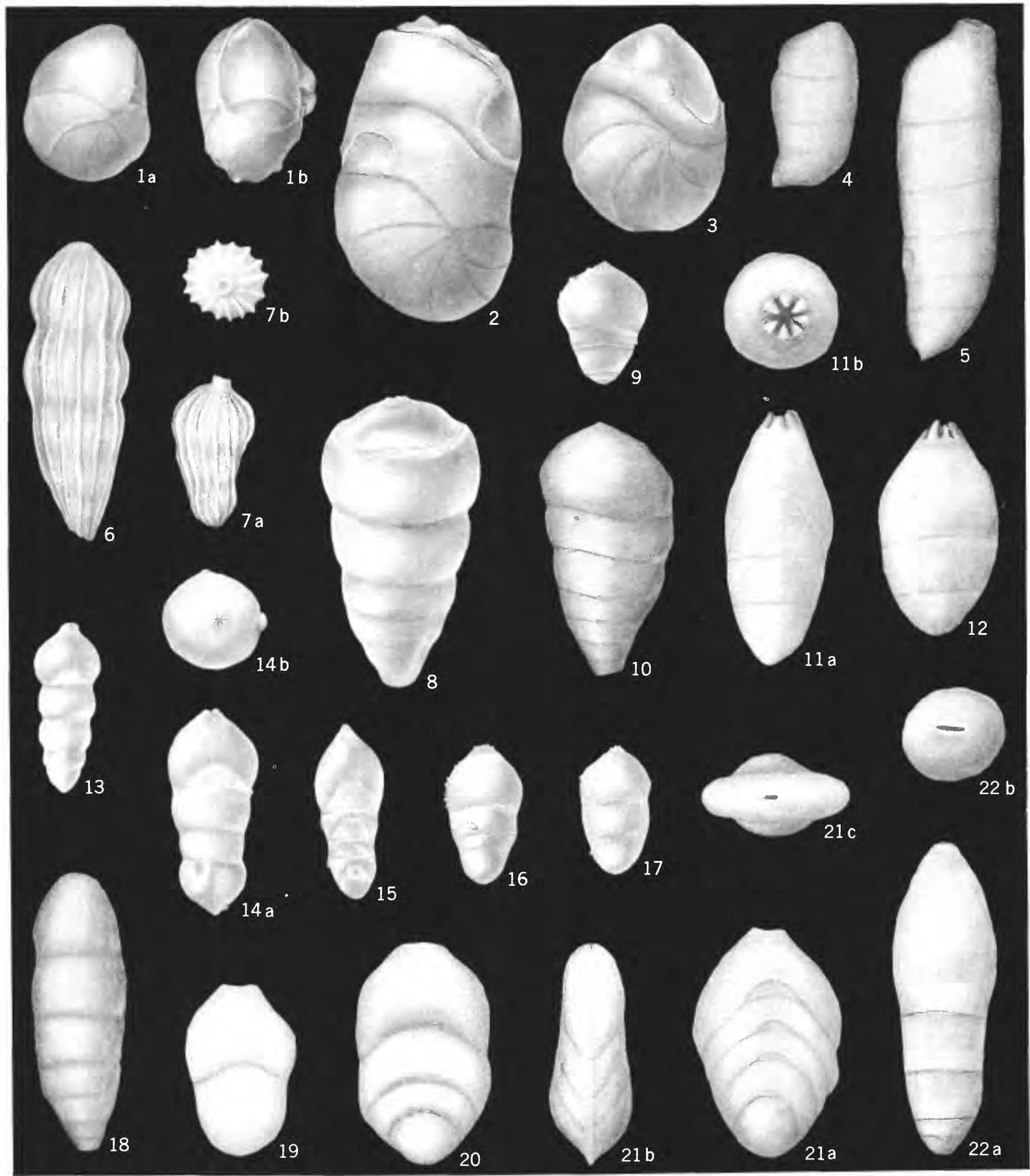

MARGINULINOPSIS, MARGINULINA, RECTOGLANDULINA, AND LINGULINA 


\section{PLATE 45}

Figure 1. Nodosaria nana Reuss. Hypotype (USNM P6708) from the Torok formation. $\times 95$. (p. 174)

2. Nodosaria fusula Reuss. Hypotype (USNM P6706) from the Schrader Bluff formation, $\times 220$ (p. 173)

3, 4. Nodosaria flexocarinata Khan. 3, Hypotype (USNM P6723). 4, Hypotype (USNM P6722). Both from the Grandstand formation. $\times 160 . \quad$ (p. 173)

5, 6. Nodosaria ef. concinna Reuss. 5, Hypotype (USNM P6711) 6, Hypotype (USNM P6710). Both from the Torok formation, $\times 95$. (p. 172)

7, 8. Nodosaria lepida Reuss. Hypotypes (USNM P6712a,b) from the Schrader Bluff formation. $\quad \times 95 . \quad(p .174)$

9-12, 22. Dentalina? dettermani Tappan. 9, Paratype (USNM P4561) from the Fortress Mountain formation. 10, Paratype (USNM P4559) from the Topagoruk formation. 11, Paratype (USNM P4557) from the Grandstand formation. 12, Holotype (USNM P4556), a large single chamber, with terminal aperture and broken connecting neck, from the Grandstand formation. 22, Paratype (USNM P6701) from the Topagoruk formation. All $\times 95$. (p. 175)

13, 14. Nodosaria doliiformis Eichenberg. 13, Hypotype (USNM P6641) 14a, Side view of hypotype (USNM P6640); $14 \mathrm{~b}$, top view. Both from the Torok formation. $\times 95$. (p. 173)

15, 16. Dentalina praecommunis Tappan. 15, Holotype (USNM P6715). 16, Paratype (USNM P6716). Both from the Topagoruk formation, $\times 70$. (p. 175)

17. Dentalina basiplanata Cushman. Hypotype (USNM P6633) from the Schrader Bluff formation, $X 70 . \quad$ (p. 174)

18. Dentalina distincta Reuss. Hypotype (USN M P6707) from the Topagoruk formation, $\times 160$. (p. 175)

- 19. Dentalina sp. Specimen (USNM P6705) from the Schrader Bluff formation. $\times 95$. (p. 176)

20-21. Dentalina strangulata Reuss. 20, Hypotype (USNM P6700) from the Torok formation. 21, Hypotype (USNM P6699) from the Grandstand formation. $\times 95 . \quad(p .176)$

All figures are camera lucida drawings by Helen Tappan Loeblich. 


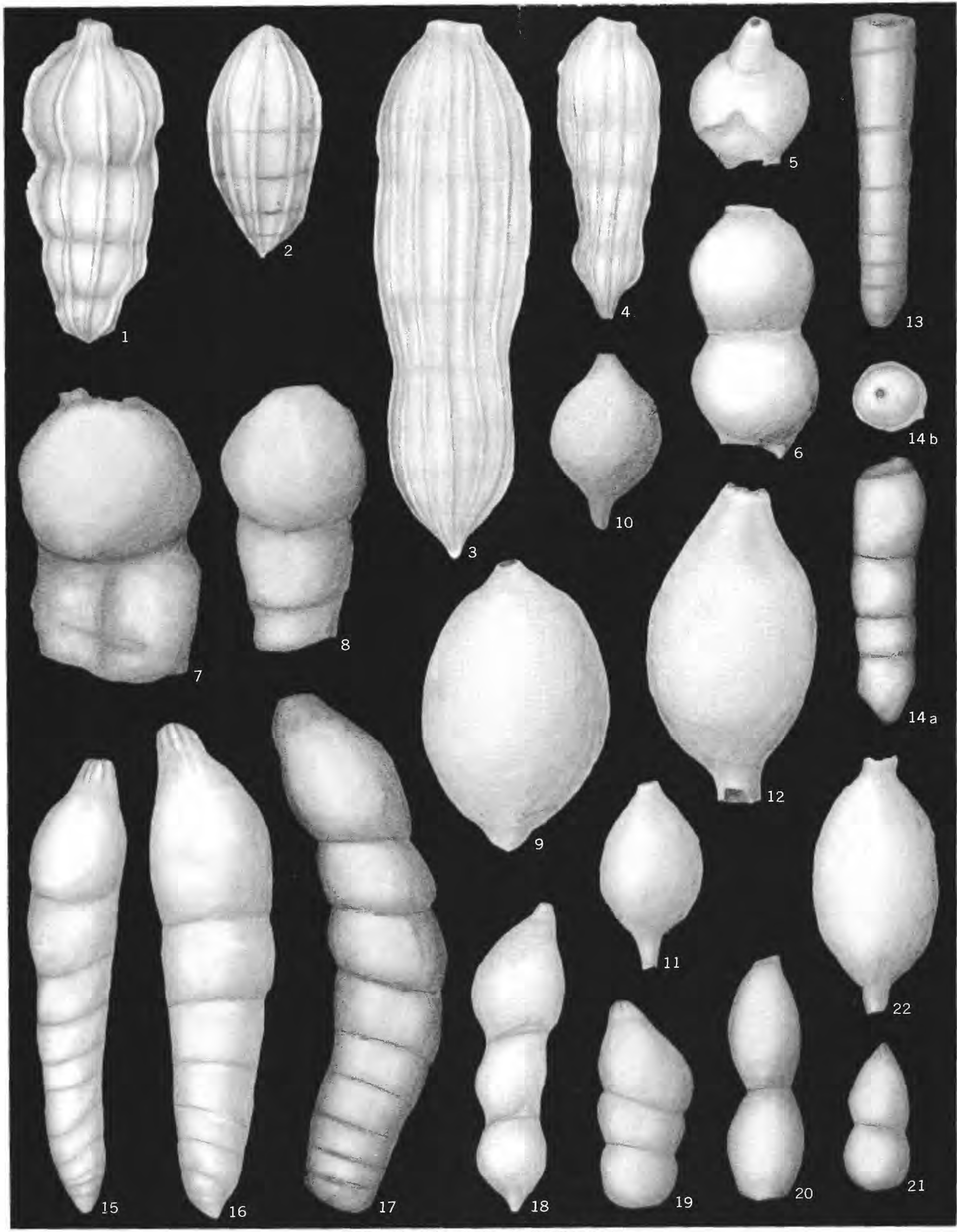




\section{PLA'TE 46}

Figures 1-3. Vaginulina exilis (Reuss). 1, Hypotype (USNM P6548) from the Torok formation. 2, Hypotype (USNM P6549) from the Topagoruk formation, $\times 160$. 3, Hypotype (USNM P6551) from the Togagoruk formation, $\times 95$. (p. 177)

4, 5. Vaginulina schraderensis Tappan. 4, Paratype (USNM P6618). 5a, Side view of holotype (USNM P6617); 5b, face view, $\times 95$. (p. 177)

6, 7. Vaginulinopsis grata (Reuss). 6a, Side view of hypotype (USNM P6590); 6b, face view. 7a, Side view of hypotype (USNM P6598); 7b, face view. Both from the Topagoruk formation. $\times 95$. (p. 179)

8-10. Astacolus incrassatus (Reuss). 8, Hypotype (USNM P6556) from the Torok formation, $\times 70$. 9a, Side view of hypotype (USNM P6555); 9b, face view. 10a, Side view of hypotype (USNM P6557); 10b, face view. Both from the Topagoruk formation, $\times 95$. (p. 178)

11. Vaginulina ef. plana (Reuss). 11a, Side view of hypotype (USNM P6547) from the Torok formation. 11b, face view. $\times 95$. (p. 180)

12, 13. Vaginulinopsis schloenbachi (Reuss). 12, Hypotype (USNM P6585). 13, Hypotype (USNM P6586). Both from the Topagoruk formation, $\times 95$. (p. 178)

14, 15. Astacolus strombecki (Reuss). 14a, Side view of hypotype (USNM P6558) from the Grandstand formation; 14b, face view. 15, Hypotype (USNM P6559) from the Torok formation. $\times 95 . \quad$ (p. 178)

16, 17. Astacolus perstriatus (Tappan). 16, Hypotype (USNM P6552) from the Torok formation. 17a, Side view of hypotype (USNM P6553) from the Topagoruk formation; 17b, face view. $\times 95 . \quad$ (p. 178)

All figures are camera lucida drawings, figs. 4, 6-8, 10, by Patricia Isham, other figures by Helen Tappan Loeblich. 


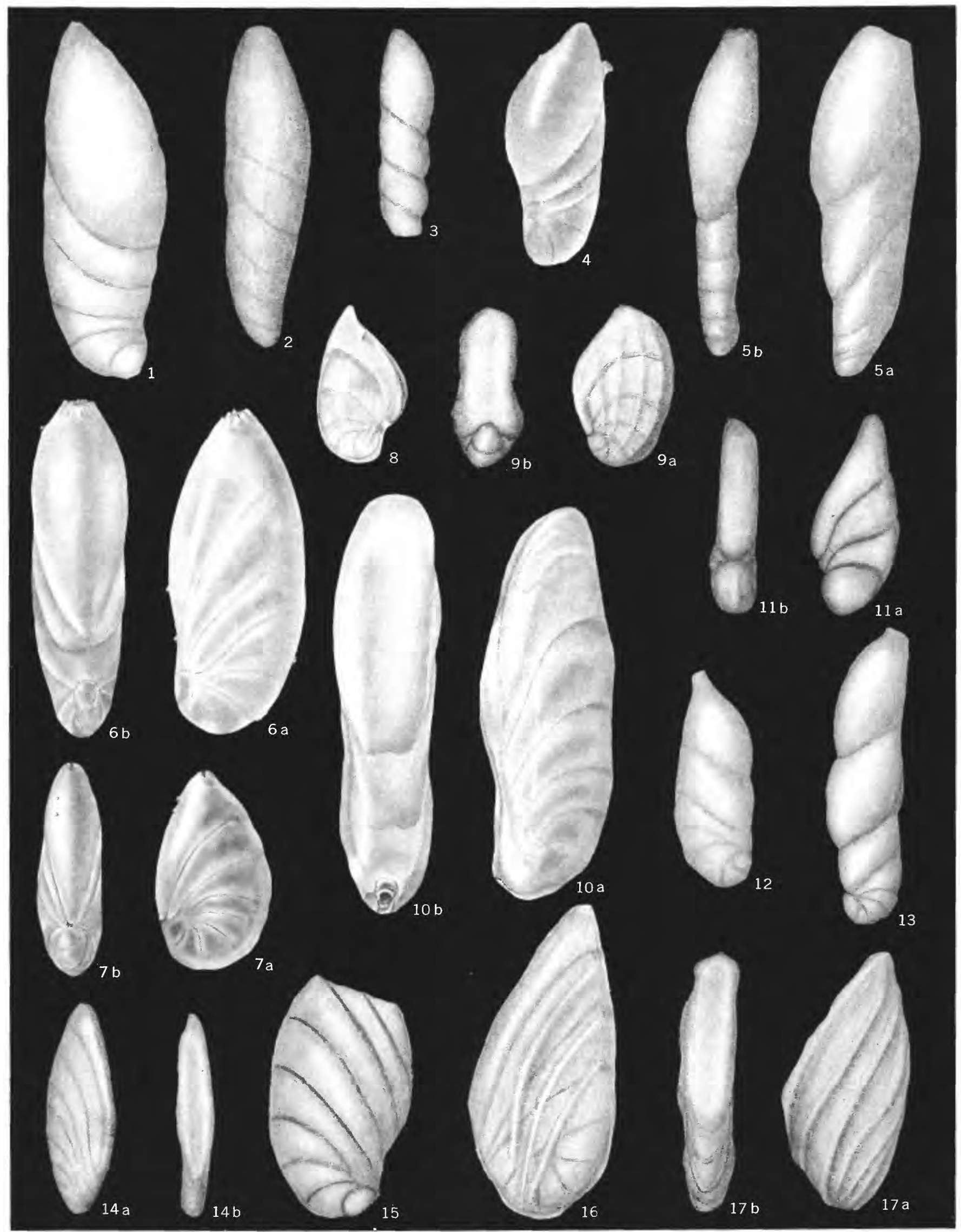

VAGINULINA, ASTACOLUS, AND VAGINULINOPSIS 


\section{PLATE 47}

Figures 1-5. Vaginulinopsis muelleri (Reuss). 1a, Side view of hypotype (USNM P6564), from the Grandstand formation; 1b, face view. 2, Hypotype (USNM P6567). 3, Hypotype (USNM P6570). Both from the Topagoruk formation. 4, Hypotype (USNM P6575) from the Torok formation. 5a, Side view of hypotype (USNM P6568) from the Topagoruk formation; $5 \mathrm{~b}$, face view. All $\times 70$. (p. 179)

6. Vaginulinopsis pachynota ten Dam. 6a, Side view of hypotype (USNM P6582) from the Torok formation; 6b, face view. $\times 70 . \quad(p .180)$

7, 8. Citharina ef. acuminata (Reuss). 7, Hypotype (USNM P6608) from the Torok formation. 8a, Side view of hypotype (USNM P6607) from the Topagoruk formation; 8b, face view. $\times 55 . \quad$ (p. 180)

9, 10. Frondicularia cushmani Loeblich and Tappan. 9, Hypotype (USNM P6702) from the Grandstand formation. 10, Hypotype (USNM P6703) from the Topagoruk formation. $\times 70 . \quad$ (p. 181)

11, 12. Frondicularia ampulla Hucke. 11, Juvenile hypotype (USNM P6727). 12, Juvenile hypotype (USNM P6726). Both from the Topagoruk formation, $\times 55$. (p. 181)

13. Frondicularia ungeri Reuss. Hypotype (USNM P6704) from the Grandstand formation. Specimen is split longitudinally, so that only the interior is visible, the remainder embedded in rock. A fragment of the exterior is visible at the left central part of the test. $\times 25 . \quad$ (p. 182)

14. Frondicularia sp. Figured specimen (USNM P6728) from the Torok formation. $\times 70$. (p. 182)

15. Citharinella cf. tarrantensis (Loeblich and Tappan). Hypotype (USNM P6714) from the Grandstand formation. $\times 70$. (p. 181)

16. Oolina apiculata Reuss. Hypotype (USNM P6631) from the Torok (?) formation. $\quad \times 70 . \quad$ (p. 182)

17. Paleopolymorphina gaultina (Berthelin). Hypotype (USNM P6679) from the Grandstand formation. $\times 70$. (p. 182)

18, 19. Globulina lacrima Reuss subspecies canadensis Mellon and Wall. 18, Hypotype (USNM P6660). 19, Hypotype (USNM P6659). Both from the Topagoruk formation, $\times 70$. (p. 183)

20-23. Globulina exserta (Berthelin). 20, Hypotype (USNM P6653). 21, Hypotype (USNM P6655). Both from the Grandstand formation. 22, 23, Hypotypes (USNM P4553) from the Topagoruk formation. $\times 70$. (p. 183)

24. Pyrulinoides thurrelli Tappan. Holotype (USNM P4553) from the Grandstand formation, $\times 70$. (p. 183)

25, 26. Globulina prisca Reuss. 25, Hypotype (USNM P6674). 26, Hypotype (USNM P6677). Both from the Topagoruk formation, $\times 70$. (p. 184)

All figures are camera lucida drawings; figures 1, 2 by Patricia Isham, other figures by Helen Tappan Loeblich. 


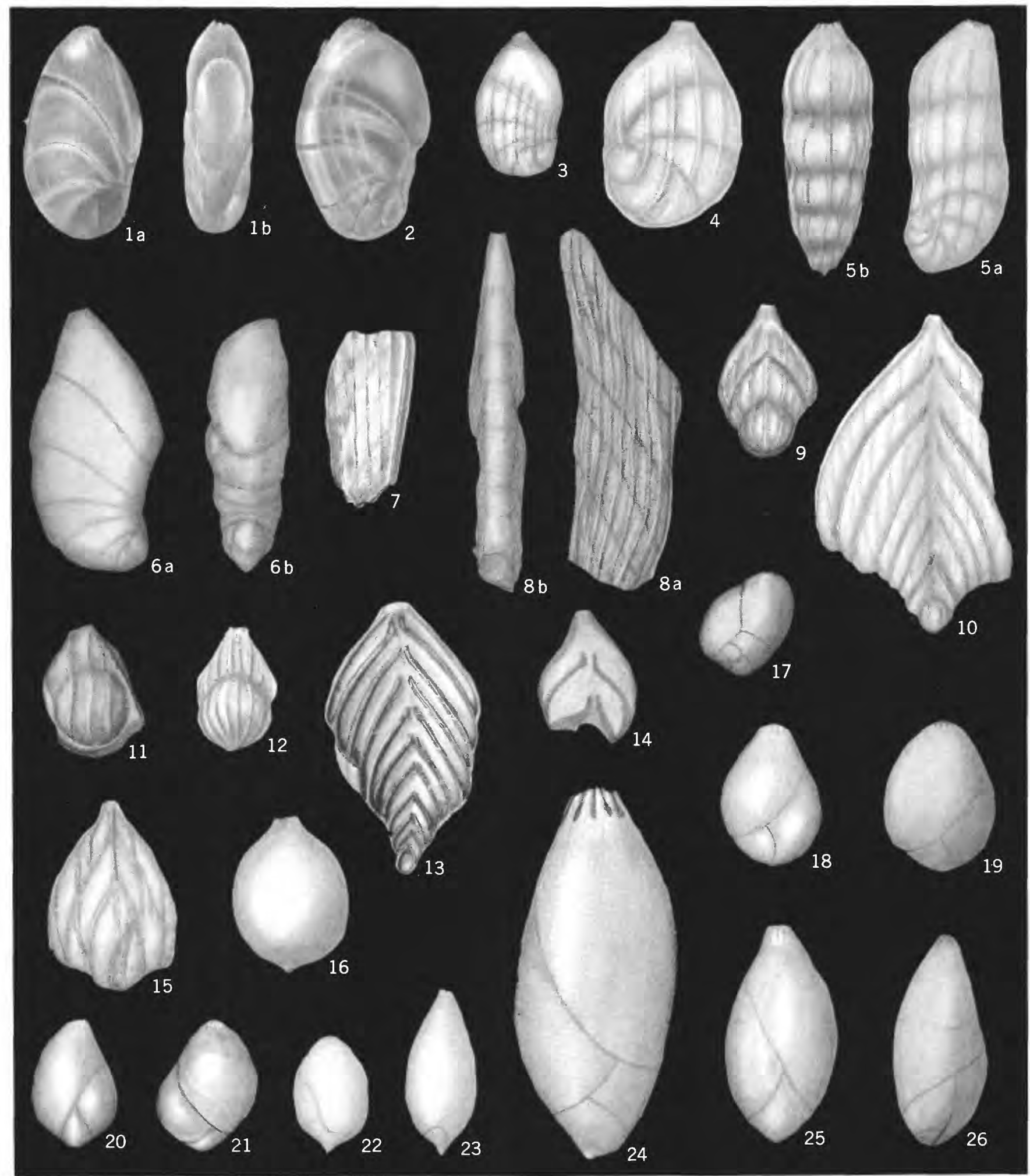

VAGINULINOPSIS, CITHARINA, CITHARINELLA, FRONDICULARIA, OOLINA, PALEOPOLYMORPHINA, PYRULINOIDES, AND GLOBULINA 


\section{PLATE 48}

Figures 1, 2. Neobulimina cf. primitiva (Cushman). 1a, Side view of hypotype (USNM P6731) from the Torok formation; 1b, top view. 2a, Side view of hypotype (USNM P6732) from the Topagoruk formation; $2 b$, top view. $\times 120$ (p. 185)

3-6. Neobulimina albertensis (Stelck and Wall). 3a, 4-6, Side views of hypotypes (USNM P6646 a-d) from the Seabee formation; $3 \mathrm{~b}$, top view. $\times 160$. (p. 184)

7-10. Neobulimina subcretacea (Cushman). 7a, 9, 10, Side views of hypotypes (USNM P6696 a-c) from the Grandstand formation; 7b, top view. 8, Hypotype (USNM P6697) from the Topagoruk formation. All $\times 120$. (p. 186)

11-15. Praehulimina carseyae (Plummer). 11, 14, Hypotypes (USNM P6503 a, b). 12, Hypotype (USNM 106513). 13, 15, Hypotypes (USNM P6682 a, b). All from the Schrader Bluff formation, $\times 120$. (p. 186)

16, 17. Neobulimina cf. canadensis Cushman and Wickenden. 16a, Side view of hypotype (USNM P6686); 16b, top view. 17, Hypotype (USNM P6687). Both from the Schrader Bluff formation. $\times 120$. (p. 185)

18-27. Neobulimina canadensis Cushman and Wickenden. 18, 20, Hypotypes (USNM P6514 a, b). 19a, Side view of hypotype (USNM 106504); 19b, top view. 21, 25, 27, Hypotypes (USNM 106505 a-c). 22, Hypotype (CSNM 106507). 23, 26, Hypotype (USNM P6729 a, b). 24, Hypotype (USNM P6730). All from the Schrader Bluff formation. Fig. 19, $\times 120$; other figures, $\times 160$ (p. 185)

All figures are camera lucida drawings, figures $8,12,19,20 \mathrm{~b}$ by Helen Tappan Loeblich; other figures by Patricia Isham. 


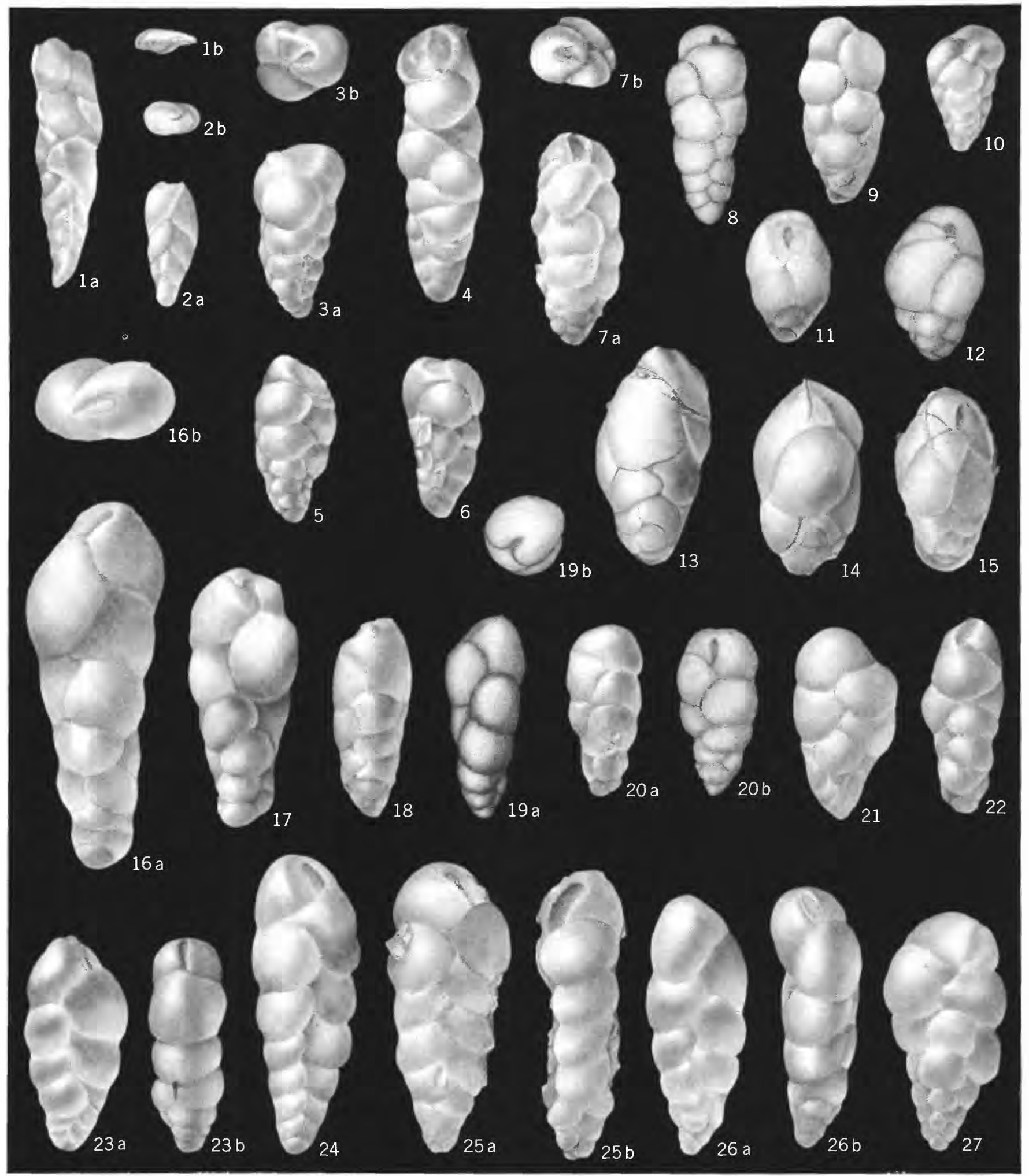

NEOBULIMINA AND PRAEBULIMINA 


\section{PLATE 49}

Figures 1-5. Praebulimina cushmani (Sandidge). 1a, 2a, 3-5a, Side views of hypotypes (USNM P6686 a-e) from the Schrader Bluff formation; $1 \mathrm{~b}, 2 \mathrm{~b}, 5 \mathrm{~b}$, top views. $\times 115$. (p. 187)

6-9. Praebulimina nannina (Tappan). All figs., a, side view, b, top view. 6, Hypotype (USNM P6694). 7, Hypotype (USNM P6695). Both from the Topagoruk formation. 8, 9, Hypotypes (USNM P6692 a, b) from the Grandstand formation. All $\times 115$. (p. 187)

10-18. Praebulimina seabeensis Tappan. a, side view; b, top. 10, Holotype (USNM P4564). 11, 12, 18, Paratypes (USNM P4565 a-c). 13, Paratype (USNM P6510). 14, Paratype (USNM P4566). 15, 16, Paratypes (USNM P6733 a, b). 17, Paratype (USNM P4568). All from the Seabee formation. Figs. 10, 14-17, $\times 115$; figs. 11-13, 18, $\times 160$. (p. 187)

19-21. Praebulimina venusae (Nauss). 19a, 21, Side views of hypotypes (USNM $106511 \mathrm{a}, \mathrm{b}$ ); $19 \mathrm{~b}$, top view; $\times 120$. 20, Hypotype (USNM 106509), ×160. All from the Schrader Bluff formation. (p. 188)

22. Lacosteina gouskovi Marie. 22, b, Opposite sides of hypotype (USNM P6690) from the Schrader Bluff formation; 22c, top view, $\times 115$. (p. 188)

23-25. Caucasina vitrea (Cushman and Parker). 23a, 24, Side views of hypotypes (USNM P6681 a, b); 23b, basal view; 23c, top view. 25, Hypotype (USNM P6680). All from the Schrader Bluff formation, $\times 165$ ( $p$. 188)

All figures are camera lucida drawings, figures 19-21, 23b, by Helen Tappan Loeblich, other figures by Patricia Isham. 


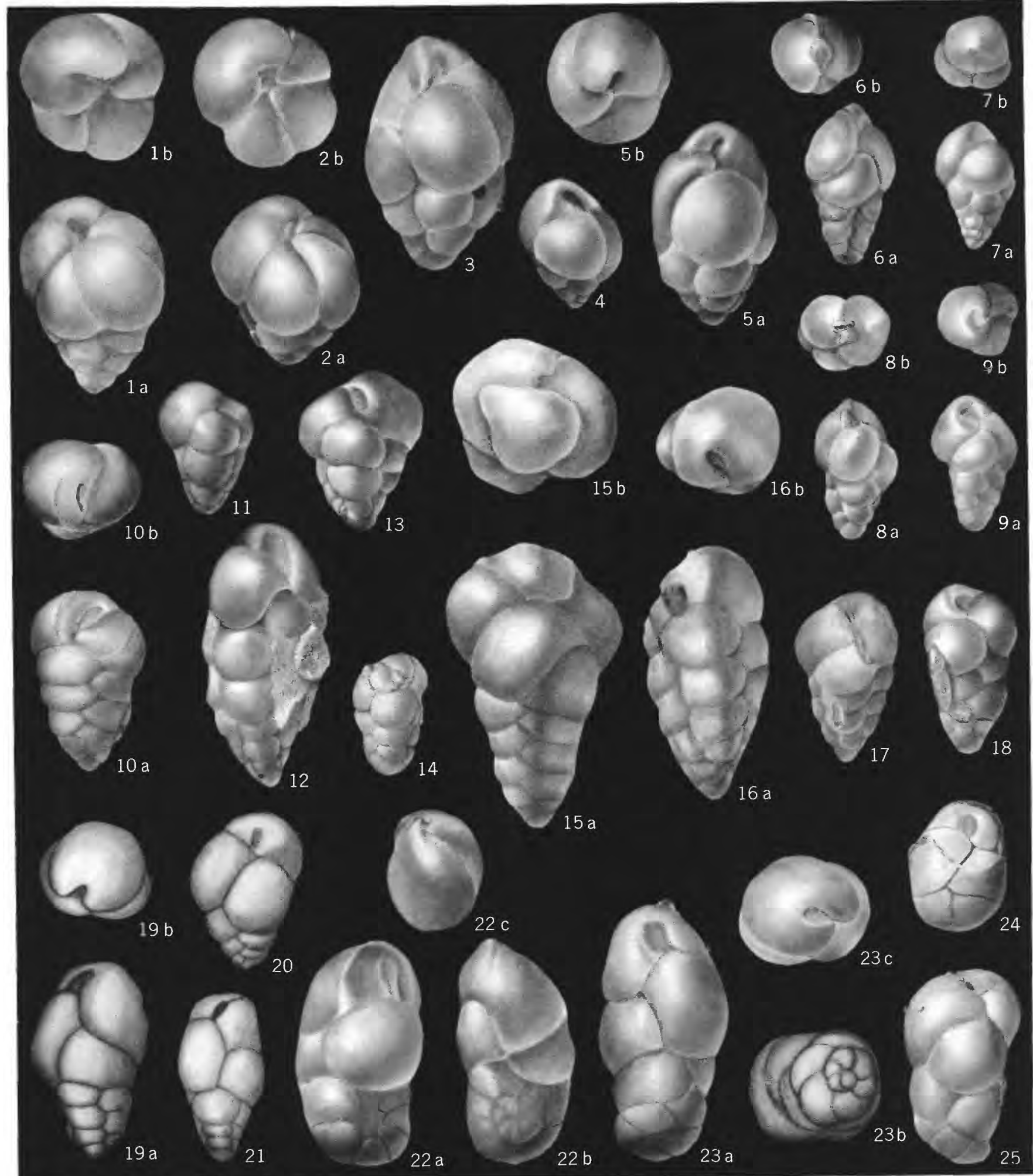

PRAEBULIMINA, CAUCASINA, AND LACOSTEINA 


\section{PLA'TE 50}

Figures 1-9. Pallaimorphina ruckerae Tappan. All figures a, spiral side; b, umbilical side; c, edge. 1, Paratype (USNM P4669). 2, 6, Paratypes (USNM P4666 a, b). 3, 8, Paratypes (USNM P4671 a, b). 4, Holotype (USNM P4664). 5, Paratype (USNM P4665). 7, Paratype (USNM P4680). 9, Paratype (USNM P4673). All from the Grandstand formation. Figs. 4, 5, $\times 200$. Other figures $\times 150$. (p. 189)

10-12. Nonionella taylorensis Hofker. Hypotypes (USNM P6637 a-c) from the Schrader Bluff ormation. 10a, Side view; 10b, edge view. All $\times 150$. (p. 190)

All figures are camera lucida drawings by Patricia Isham. 


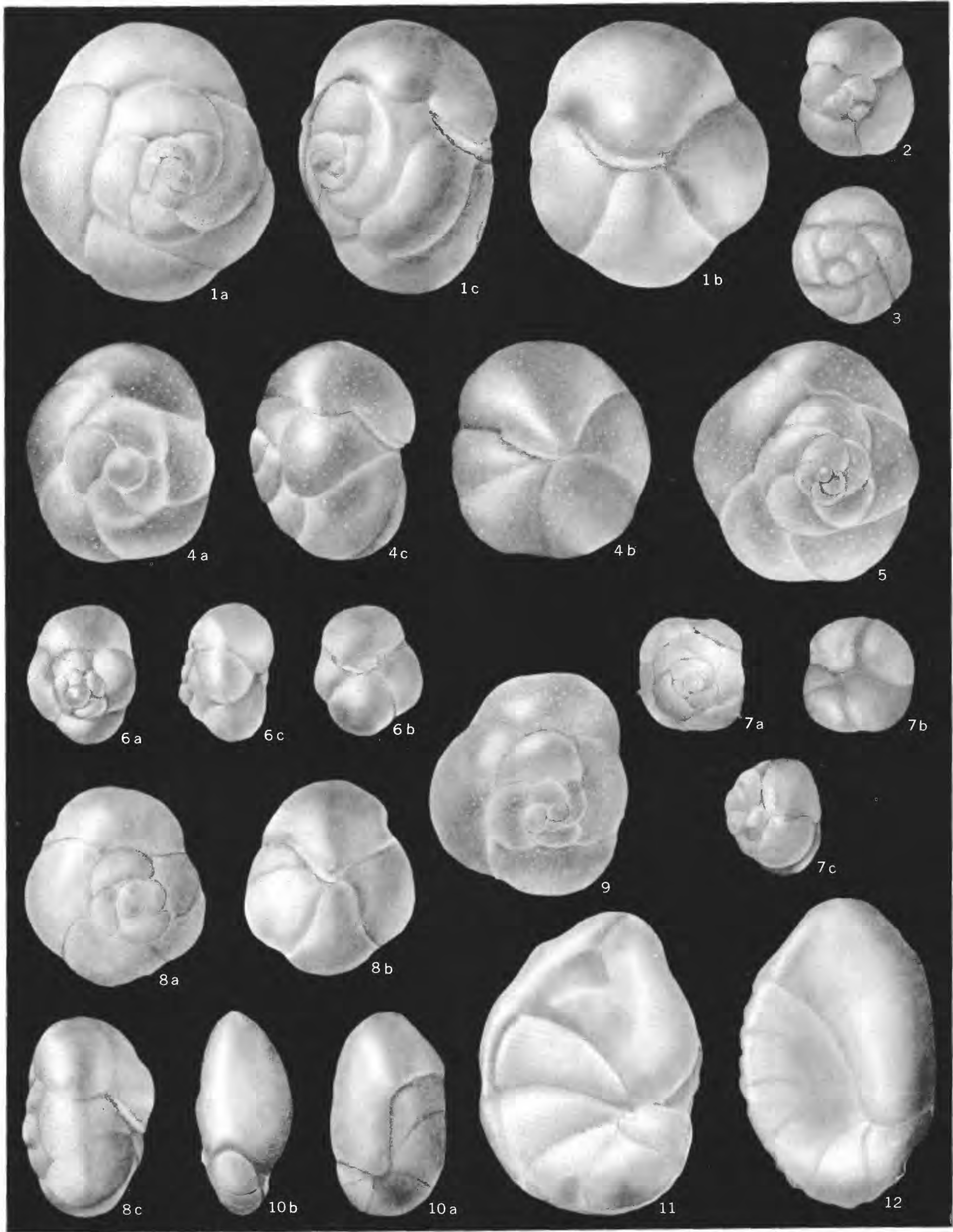

PALLAIMORPHINA AND NONIONELLA 


\section{PLATE 51}

Figures 1-7. Eponides morani Tappan. All figures a, spiral side; b, umbilical side; c, edge. 1, Holotype (USNM P4638). 2, 4, 5, Paratypes (USNM P4639 a-c). 3, Paratype (USNM P4645). 6, Paratype (USNM P4647). 7, Paratype (USNM P4643). Figs. 3, 6 from the Torok formation, $\times 75$. Other figs. from the Topagoruk formation, $\times 110$. (p. 191)

All figures are camera lucida drawings by Patricia Isham. 


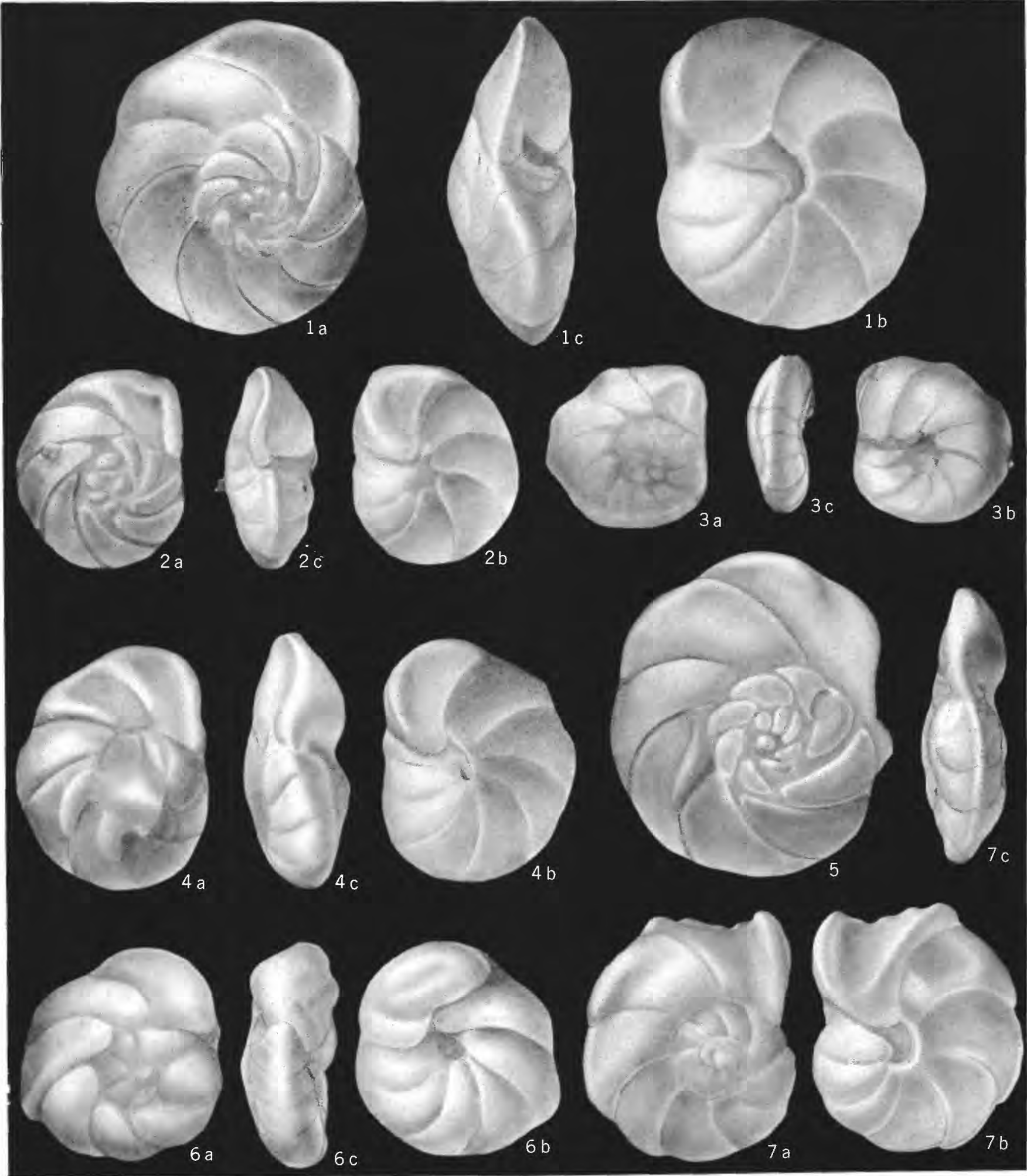




\section{PLA'TE 52}

Figures 1-10. Conorboides umiatensis (Tappan). All figures a, spiral side; b, umbilical side; c, edge. 1, Paratype (USNM P6743a) from the Torok formation. 2, 6, Paratypes (USNM P4626a, b) from the Grandstand formation. 3, Paratype (USNM P4570a) from the Kukpowruk formation. 4, 5, 7, Paratypes (USNM P4623a-c) from the Grandstand formation. 8, Paratype (USNM P4620) from the Grandstand formation. 9, Holotype (USNM P4619) from the Grandstand formation. 10, Paratype (USNM P4629) from the Grandstand formation. All $\times 115 . \quad$ (p. 192) All figures are camera lucida drawings by Patricia Isham. 


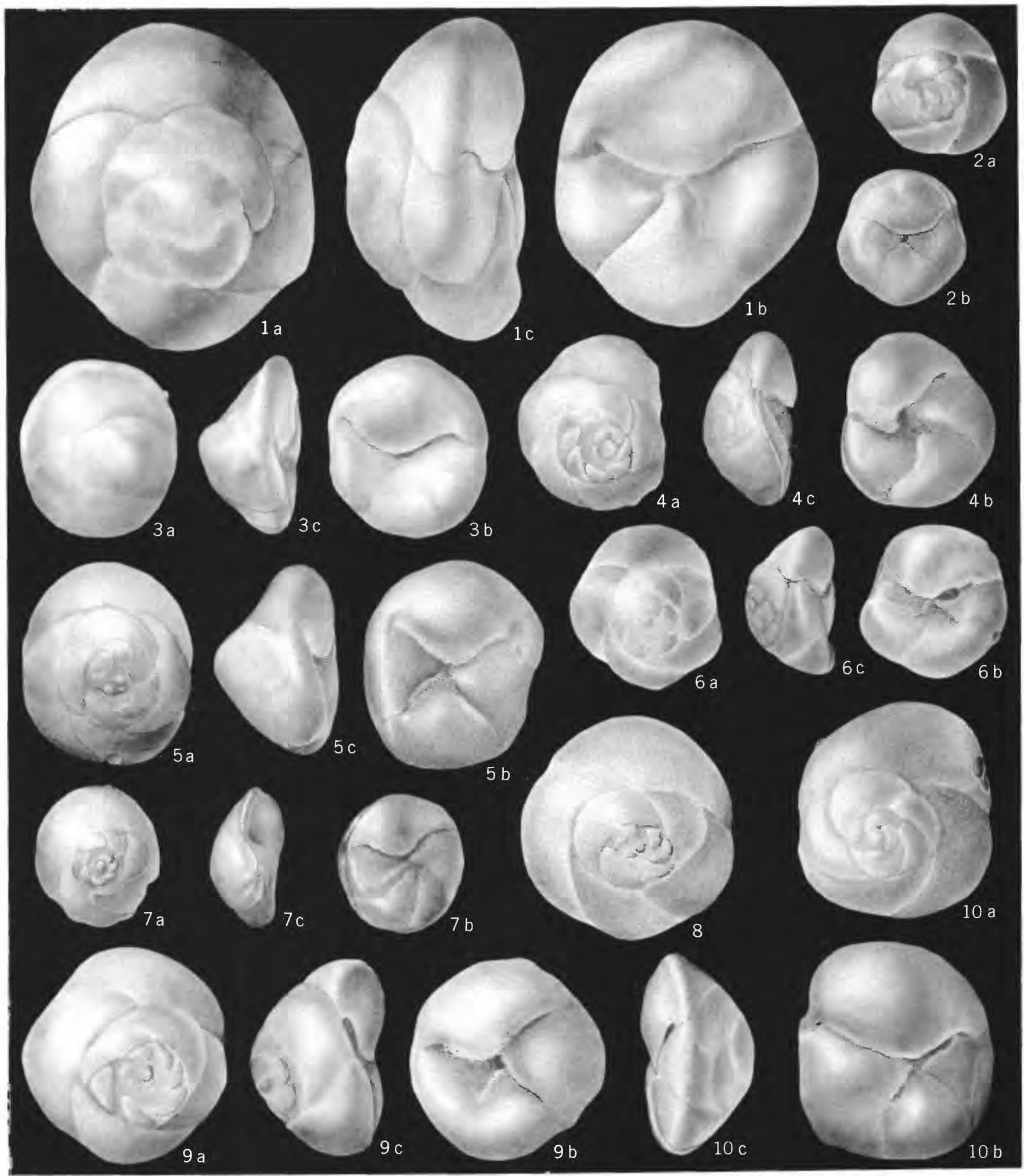


PLATE 53

FiguRe 1. Conorbina sp. 1a, Spiral view of specimen (USNM P6780) from the Torok formation; 1b, umbilical side; 1c, edge view. $\times 115$. (p. 191)

2-5. Eurycheilostoma robinsonae Tappan. 2a, Spiral side of paratype (USNM P4591) from the Kukpowruk formation; 2b, umbilical side; 2c, edge. 3a, Spiral side of holotype (USNM P4584) from the Topagoruk formation; 3b, umbilical side; 3c, edge. 4a, Edge view of paratype (USNM P4587) from the Topagoruk formation, showing relatively high spire; $4 \mathrm{~b}$, umbilical side. 5a, Spiral side of paratype (USNM P4586) from the Grandstand formation; 5 b, umbilical view; $5 \mathrm{c}$, edge. All $\times 115 . \quad$ (p. 193)

6-12. Eurycheilostoma grandstandensis Tappan. 6, 7, Paratypes (USNM P4596a, b), showing extremely high spire. 8a, Side view of holotype (USNM P4595); 8b, umbilical view. Figs. 6-8 from the Grandstand formation. 9a, Side view of paratype (USNM P4605); 9b, umbilical view. 10a, 11a, Side views of paratypes (USNM P4611a, b); $10 \mathrm{~b}, 11 \mathrm{~b}$, umbilical views. 12a, Side view of paratype (USNM P4603); 12b, umbilical view. Figs. 9-12 from the Topagoruk formation. All figs. $\times 115$ (p. 193)

All figures are camera lucida drawings by Patricia Isham, except fig. 1c by Helen Tappan Loeblich. 


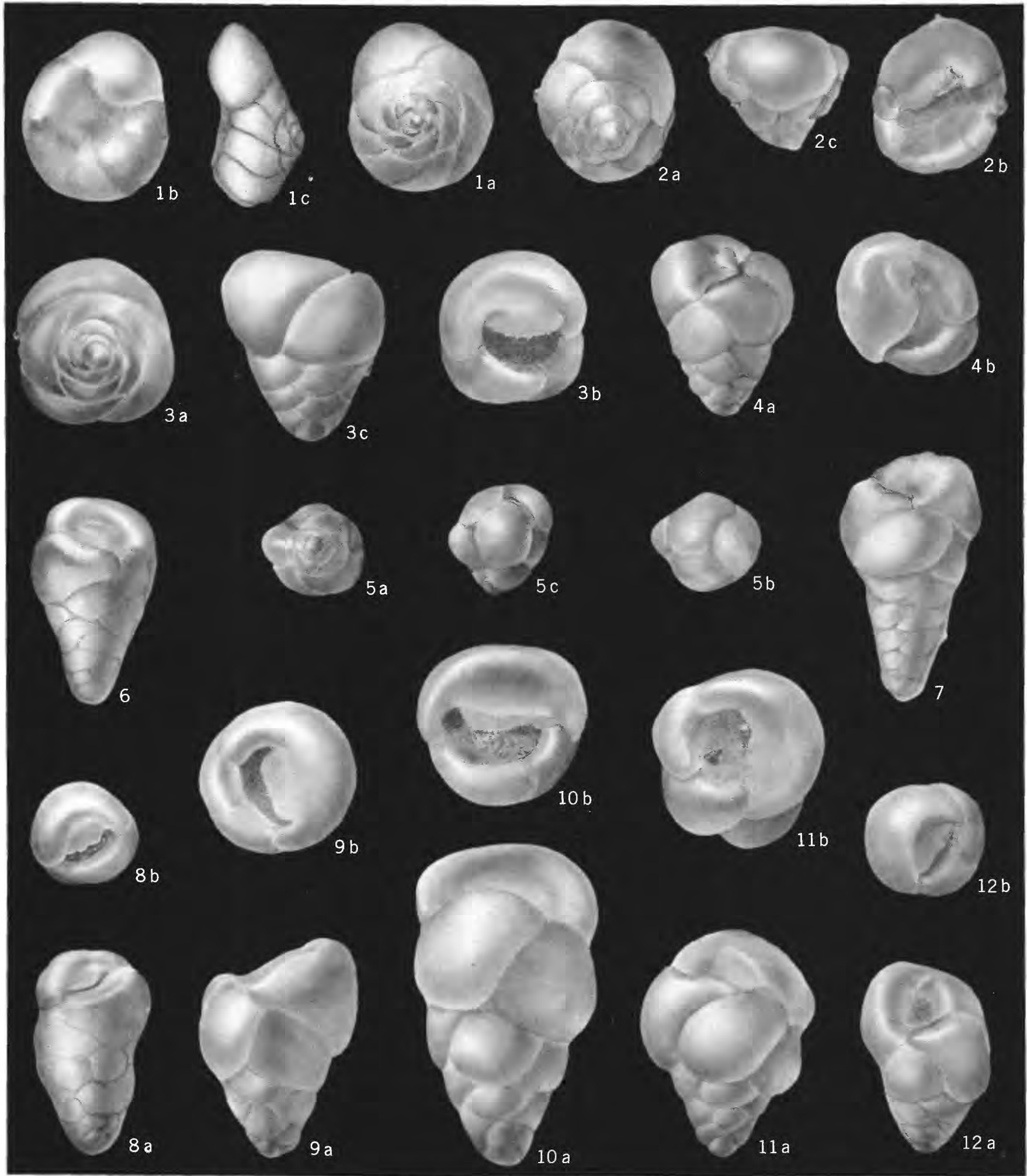

CONORBINA AND EURYCHEILOSTOMA 


\section{PLATE 54}

Figures 1-4. Valvulineria loetterlei (Tappan). a, spiral side; b, umbilical side; c, edge. 1, Hypotype (USNM P6768). 2, Hypotype (USNM P6767). 3, Hypotype (USNM P6771). 4, Hypotype (USNM P6769). All from the Topagoruk formation, $\times 115$. (p. 194)

5-8. Eoeponidella strombodes Tappan. 5a, Spiral side of holotype (USNM 560392); 5b, umbilical side; $5 \mathrm{c}$, edge; $\times 120$. 6, 8, Paratypes (USNM 560393a, b) ; 6a, spiral side; 6b, 8, umbilical sides; 6c, edge. 7, Umbilical side of paratype (USNM 560394). Figs. 6-8, $\times 115$. All from the Schrader Bluff formation (p. 195).

9, 10. Eoeponidella linki Wickenden. 9a, Spiral side of hypotype (CSNM 106139); 9b, umbilical side; 9c, edge. 10, Hypotype (USNM 106140). Both from the Schrader Bluff formation, $\times 165$. (p. 195).

All figures are camera lucida drawings; figs. 1-4, 6-8 by Patricia Isham; figs. $5,9,10$ by Helen Tappan Loeblich. 


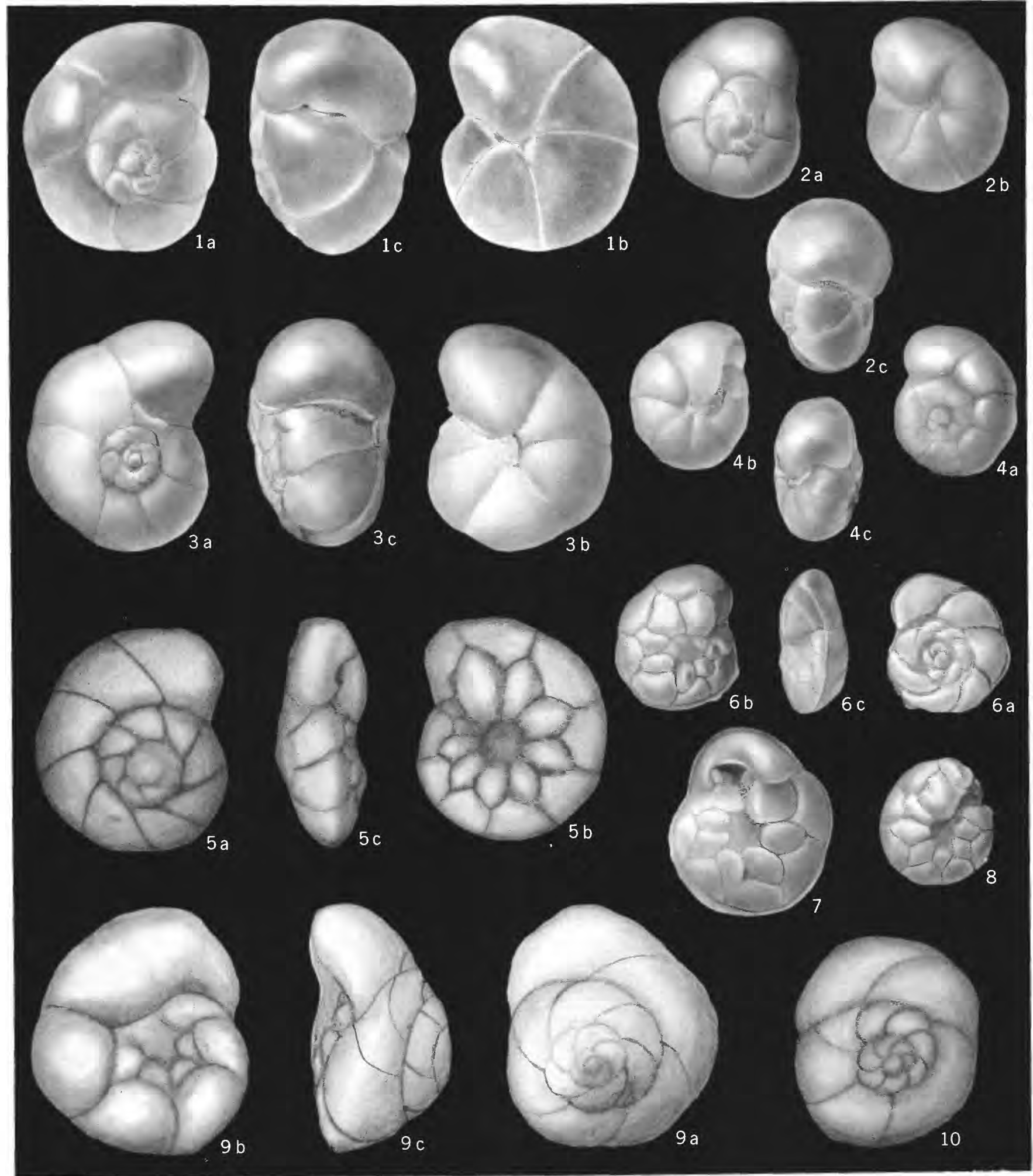

VALVULINERIA AND EOEPONIDELLA 


\section{PLATE 55}

Figures 1, 2. Heterohelix globulosa (Ehrenberg). Hypotypes (USNM P6643a, b) from the Seabee formation. $\quad \times 220 . \quad(p .196)$. 3-5. Hedbergella loetterlei (Nauss). 3a, Spiral view of hypotype (USNM 106498) from the Seabee formation; $3 \mathrm{~b}$, umbilical view; 3c, edge, $\times 160$. 4, 5, Hypotypes (USNM $106500 \mathrm{a}$, b) from the Seabee formation, $\times 150$. (p. 196). 6-9. Globorotalites alaskensis Tappan. All figures a, spiral side; $b$, umbilical side; c, edge. 6, Paratype (USNM P4653). 7, Paratype (USNM P6739). 8, Holotype (USNM P4649). All from the Grandstand formation. 9, Paratype (USNM P4652) from the Topagoruk formation. All $\times 160$. (p. 190).

All figures are camera lucida drawings; figs. 3, 9a by Helen Tappan Loeblich, other figs. by Patricia Isham. 

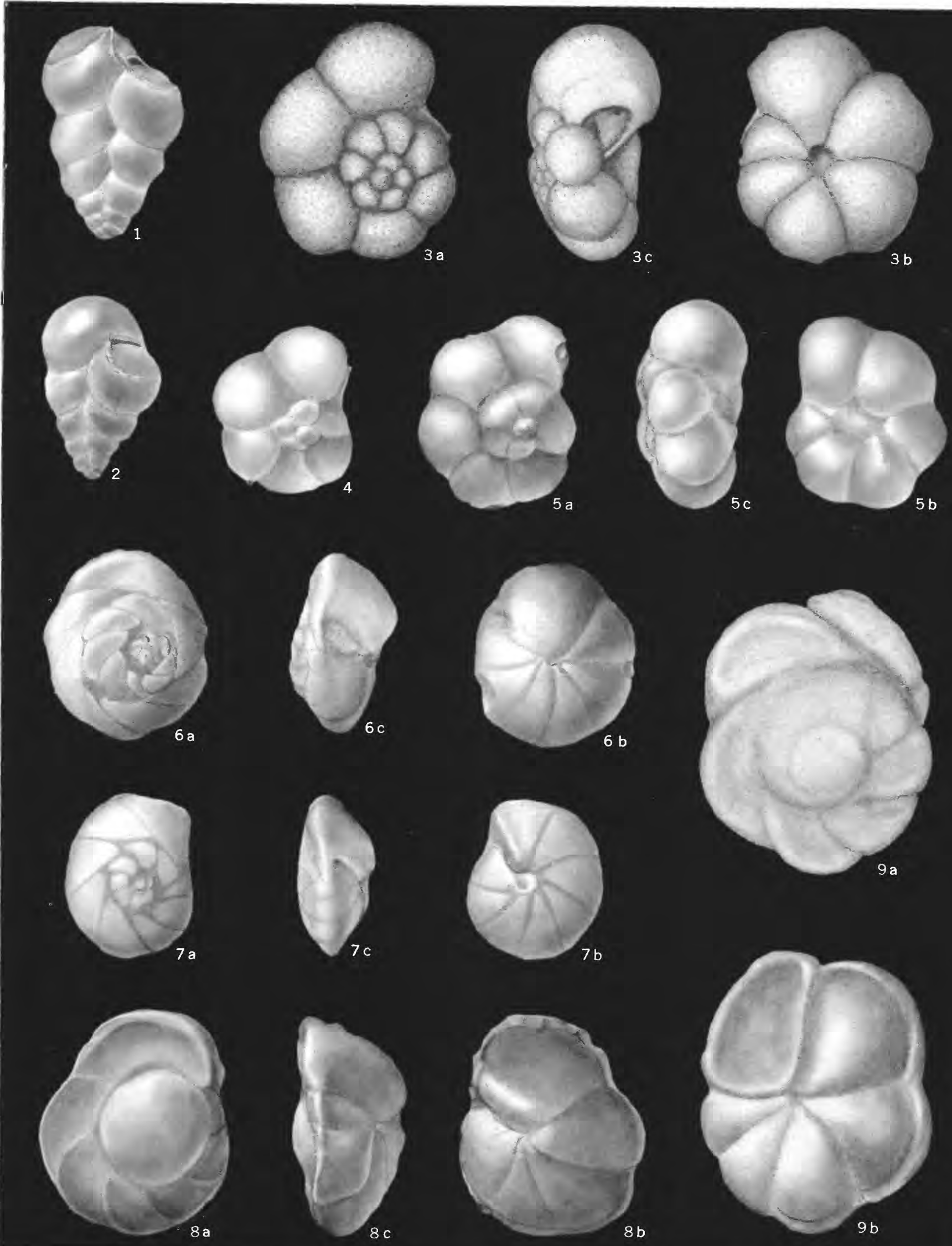

HETEROHELIX, HEDBERGELLA, AND GLOBOROTALITES 


\section{PLA'TE 56}

Figures 1-7. Gavelinella awunensis Tappan. All figs. a, spiral side; b, umbilical side; c, edge. 1, Paratype (USNM P6755), $\times$ 150. 2, Paratype (USNM P6753), $\times 95$. Both from the Torok formation. 3, Crushed paratype and 4, paratype (USNM P6756 a, b) from the Topogoruk formation, $\times 150$. 5, 6, Paratypes (USNM P6754a, b) from the Torok formation, $\times 95$. 7, Holotype (USNM P6752) from the Torok formation, $\times 95$. (p. 197).

8, 9. Gavelinella ammonoides (Reuss). Hypotypes (USNM P6750a, b) from the Schrader Bluff formation. a, spiral side; b, umbilical side; c, edge; $\times 220$. (p. 197).

All figures are camera lucida drawings; figs. 1-7 by Patricia Isham, figs. 8, 9 by Helen Tappan Loeblich. 


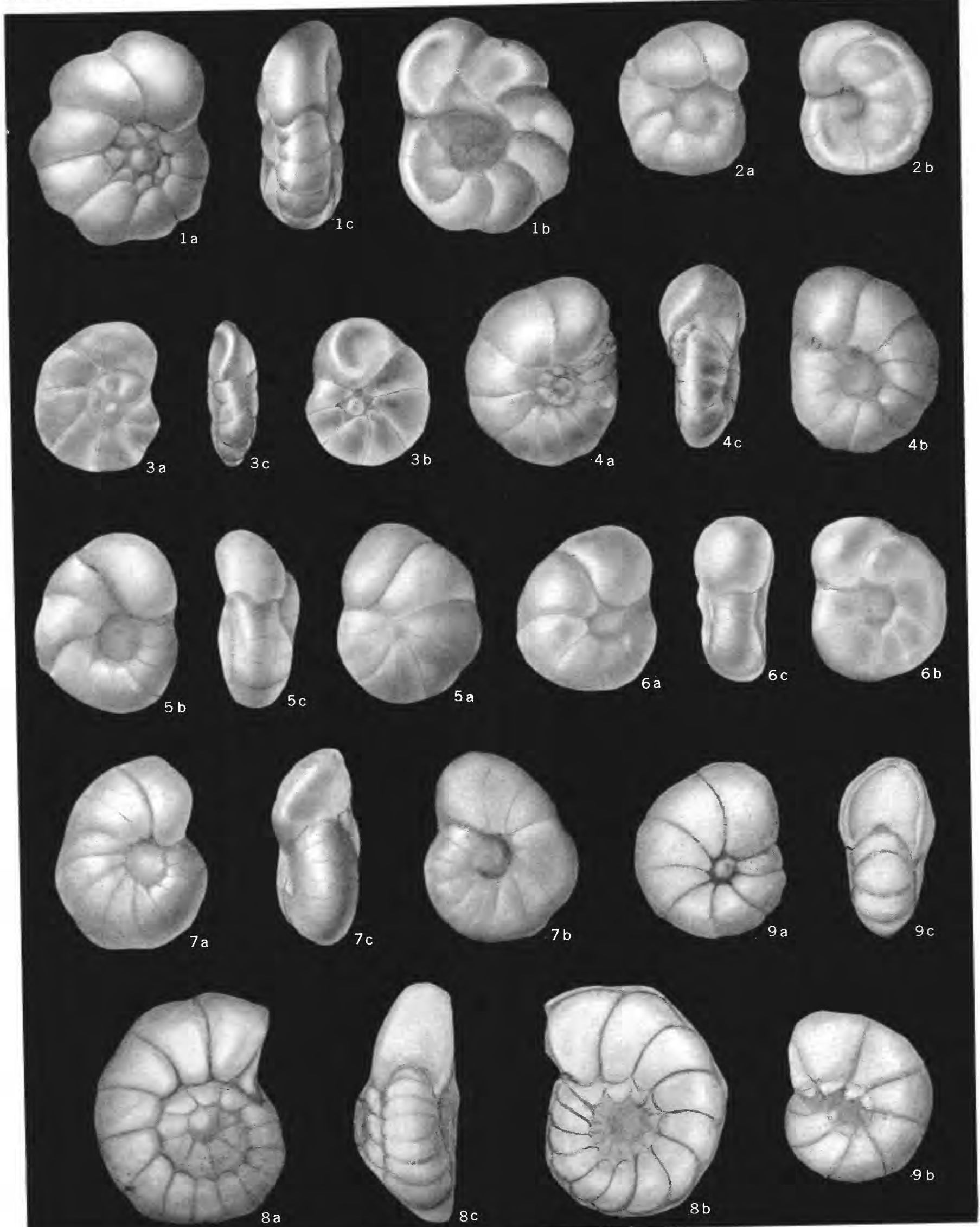




\section{PLATE 57}

Figures 1-10. Gavelinella stictata (Tappan). All figures, a, spiral side; b, umbilical side; c, edge. 1, 6, Paratypes (USNM $560388 \mathrm{a}, \mathrm{b})$ from the Topagoruk formation, $\times 70$. 2, Paratype (USN M P6022), and 3, paratype (CSNM P6782), both from the Torok formation. 4, 5, Paratypes (USNM P6743, 6744) both from the Grandstand formation. Figs. 2-5, $\times 110$. 7, Paratype (USNM P6742) from the Grandstand formation, $\times 70$. 8, Paratype (USNM P6741) from the Topagoruk formation, $\times 70$. 9, Paratype (USNM P6758) from the Torok formation, $\times 110$. 10, Holotype (USNM 560385) from the Topagoruk formation, $\times 70$. (p. 198).

11-13. Gavelinella tumida Brotzen. a, spiral side; b, umbilical side; c, edge. 11, 13, Hypotypes (USNM P6759 a, b). 12, Hypotype (USNM P6761). All from the Sehrader Bluff formation, $\times 120$. (p. 198).

All figures are camera lucida drawings; figs. 1-9 by Patricia Isham; figs. 10-13 by Helen Tappan Loeblich. 


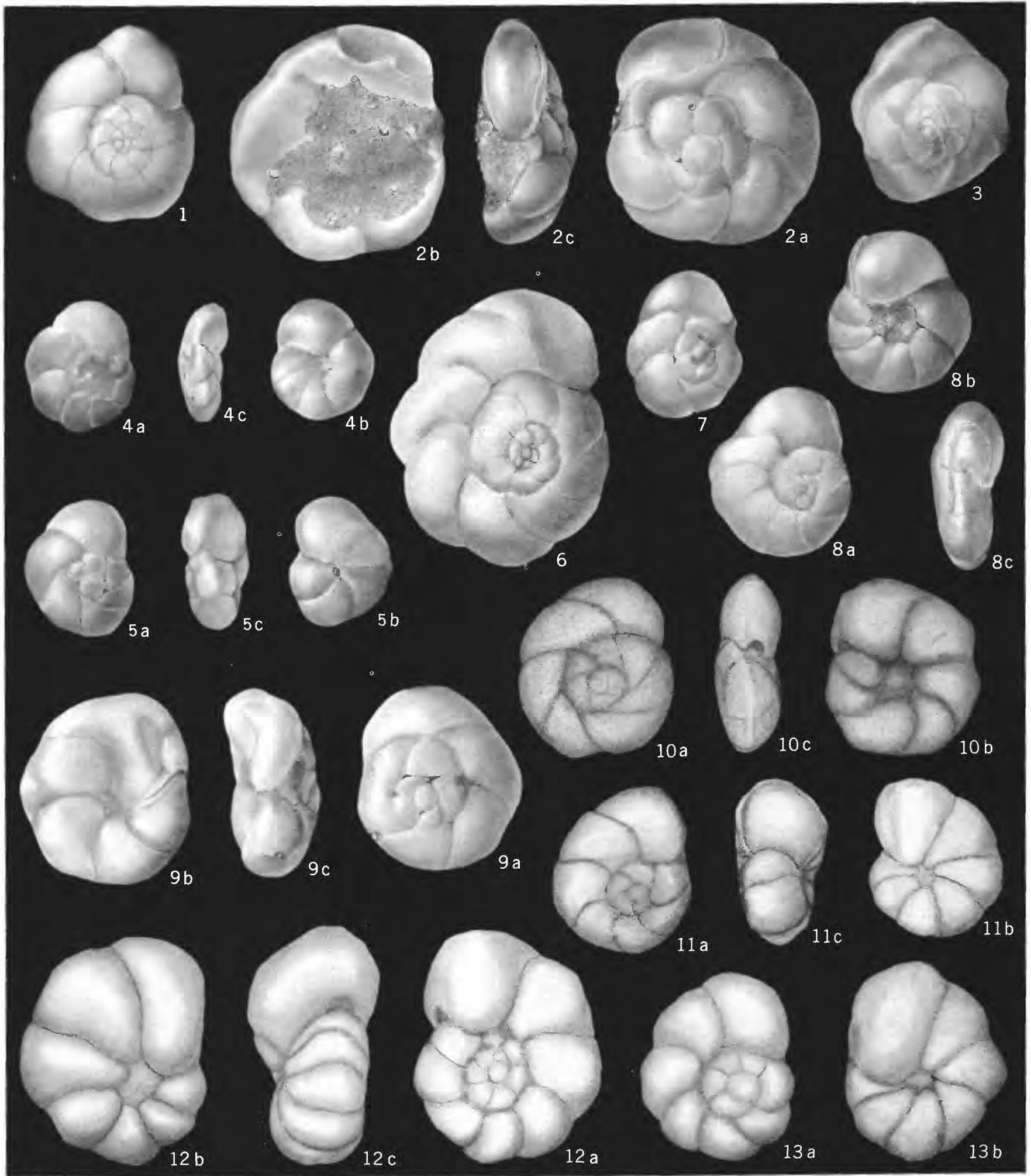

GAVELINELLA 


\section{PLATE 58}

Figure 1. Gavelinella intermedia (Berthelin). 1a, Spiral side of hypotype (USNM P6757); 1b, umbilical side; 1c, edge view, from the Torok formation, $\times 115$. (p. 197).

2-5. Anomalinoides pinguis (Jennings). a, Spiral side; b, umbilical side; c, edge. 2, Hypotype (USNM P6776). 3, Hypotype (USNM P 6775). 4, 5, Hypotypes (USNM P6777 a, b). All from the Schrader Bluff formation, $\times 70$. (p. 199).

6-10. Anomalinoides talaria (Nauss). a, Spiral view; b, umbilical view; c, edge. 6-8, Hypotypes (USNM P6764 a-c). 9, 10, Hypotypes (USNM P6765 a, b). All from the Schrader Bluff formation, $\times 120$. (p. 200).

11, 12. Anomalinoides solis (Nauss). a, Spiral view; b, umbilical view; c, edge. 11, Hypotype (USNM P6779) from the Ignek formation, $\times 115$. 12, Hypotype (USNM P6778) from the Schrader Bluff formation, $\times 70$. (p. 199).

All figures are camera lucida drawings; figures 9,10 by Helen Tappan Loeblich, others by Patricia Isham. 


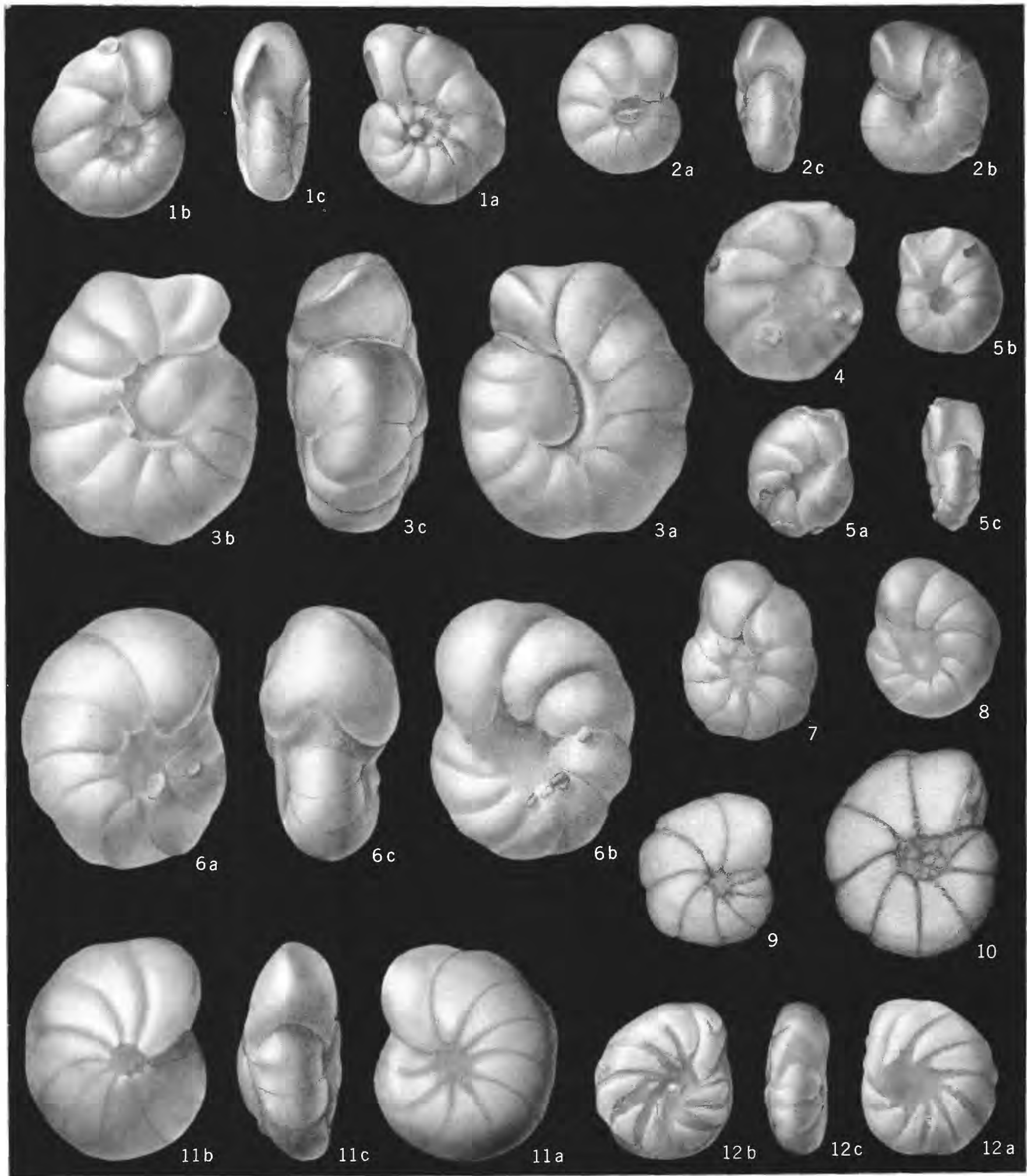

GAVELINELLA AND ANOMALINOIDES 
